

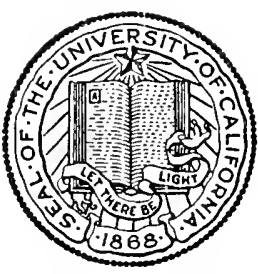

\section{THE LIBRARY}

OF

\section{THE UNIVERSITY \\ OF CALIFORNIA \\ LOS ANGELES}

SCHOOL OF LAW 








\title{
THE ACT
}

TO

\section{Regulate Commerce}

CONSTRUED BY

\section{THE SUPREME COURT}

\author{
By \\ HUBERT BRUCE FULLER, A.M., LL.M. \\ of the Cleveland, Ohio, Bar
}

Author of

"The Law of Accident and Employers' Liability Insurance"

WASHINGTON, D. C.

JOHN BYRNE \& COMPANY

1915 
COPYRIGHT, 1915

BY

Hubert Bruce Fulle, 
To

My Daughter

Harriet Lois Fuller. 



\section{INTRODUCTION}

The Commerce Clause contains one of the most important grants of power to the United States to be found in the Federal Constitution. Adopted merely for the purpose of preventing disputes among the states which had recently formed the Confederation, it has been the source of varied and potent legislation governing the intricate problems of interstate traffic incident to a complicated and highly developed industrial and social life. Framed to suit the inconsequential problems offered by a traffic handled by stage coach, ox cart and sailing vessel, it has served as the vehicle to govern the important questions arising from an enormous volume of traffic handled by the railroad, the steamer, and other agencies of commerce. A preliminary chapter has been included to trace at least in outline the genesis and development of legislation under the Commerce Clause.

The literature of the subject, both political and economic as well as legal, appears to be well nigh inexhaustible. Yet there has seemed room for a further discussion of certain features of the Act to Regulate Commerce. The findings of the Interstate Commerce Commission to date fill some thirty large volumes. The decisions of the lower Federal courts upon this act are only less voluminous. On the other hand, the decisions of the Supreme Court which constitute the last word on the question, and from which no appeal can be taken, have often not been treated by writers on this subject with the measure of importance which should be accorded them. Many of the most important of these decisions have been handed down by that court since the appearance of any treatise on this act. It has seemed desirable, therefore, to collate these decisions, to include an exhaustive discussion of them within the confines of a single volume and to bring them down to the latest possible date. Such a volume could be of particular value to the lawyer who does not have at his disposal a large legal library. It would constitute the law of the Act to Regulate Commerce so far as that law has been finally determined. Decisions of the lower courts, subject to review and, therefore, to being overruled, have been omitted from discussion in this work. It is hoped that the volume will fill a place hitherto unoccupied in the bibliography of the Act to Regulate Commerce. 
The author welcomes this opportunity to acknowledge his debt of gratitude to those who have by suggestion, advice or otherwise assisted in the preparation of this work. To detail the list might not be possible, and to hold the individuals responsible for the statements in the volume might be unfair to them. For the statements the author accepts responsibility. He is under more particular obligations to Mr. Frank Bright, of Washington, D. C. ; Hon. George Carroll Todd, Assistant to the Attorney General of the United States; Mr. Granville W. Mooney, of Austinburg, O., and Mr. Thomas H. Fuller, of Washington, D. C., for many kindly and welcome suggestions; to Mr. Alfred Holmead, Assistant Secretary of the Interstate Commerce Commission, and to the attaches of the office of the Clerk of the United States Supreme Court for many courtesies always graciously extended. And particularly does the author feel that a recognition is due to the faithful services of his wife, Florence D. Fuller, for assistance in the difficult and arduous task of reading proof, verifying citations and preparing the index of the volume.

HUBERT BRUCE FULL,ER.

Cleveland, Ohio, March 25, 1915. 


\section{TABLE OF CONTENTS}

Page.

The Commerce Clause of the Constitution, ............... 5

The Act to Regulate Commerce.

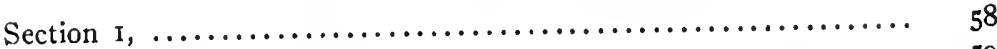

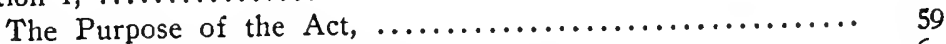

Intrastate Traffic Controlled by the States, .............. 6 I

Police Power of the States, ....................... 73

Goods Shipped Between Points Within a State to be Transported to or from a Foreign Country, ............... 74

Alaska within the Terms of the Act to Regulate Commerce, ... 83

Regulation in States Formerly under Territorial Organization, . 83

Commerce Included under the Act, $\ldots \ldots \ldots \ldots \ldots \ldots \ldots \ldots \ldots .64$

Commerce to or from Foreign Countries, ............. 88

Transportation Partly by Railroad and Partly by Water, .... 89

Common Control, Management or Arrangement for a Continu-

ous Carriage or Shipment, ..................... 90

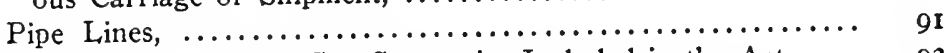

Express and Sleeping Car Companies Included in the Act, .... 93

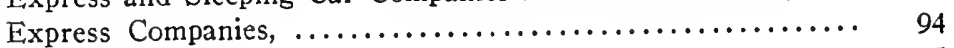

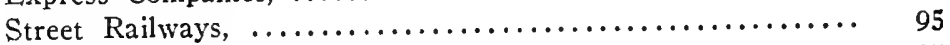

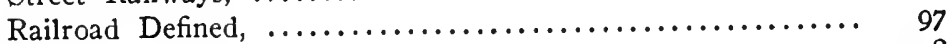

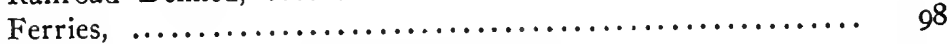

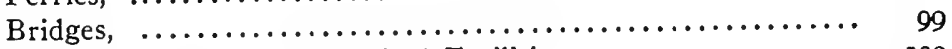

Switches, Tracks and Terminal Facilities, ............. I00

Transportation, ............................... 102

Receipt and Delivery of Freight, .................. 103

Stock Yards and Terminal Facilities for Live Stock, ........ I I0

Stock Yard Charges, ......................... I18

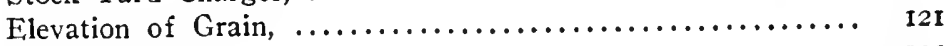

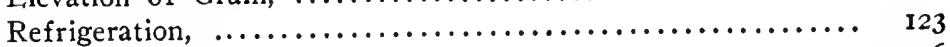

Railroad Charges, ............................ 126

Charges Must be Just and Reasonable, ............... 127

Decision as to Reasonableness of Rates, ............... I30

Reasonableness of Rates for Intrastate Traffic, .......... 133

Federal Control of Intrastate Rates, ................. 138

Reasonableness of Rates, ...................... 139

Charging of Depreciation and Improvements, ........... 146

Through Rates Compared with Local Rates, ............ I47

Presumption of Reasonableness of Rates, .............. I48

Free Transportation and Passes Prohibited, ............. I49

Passes, ..................................... I5I

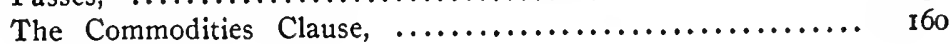

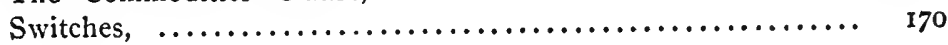


Section 2. Discriminations Forbidden, .................. ${ }_{178}$

History of the Section, ......................... 178

The Elkins Act, ............................... 180

Through and Local Traffic, $\ldots \ldots \ldots \ldots \ldots \ldots \ldots \ldots \ldots \ldots$ I $8 \mathrm{I}$

Competition under Section $2, \ldots \ldots \ldots \ldots \ldots \ldots \ldots \ldots \ldots \ldots$. 183

Party Rates, ................................ ${ }_{184}$

Special Services Entitled to Particular Rates, ............. I89

Rates Based upon Ownership of Goods Transported, ........ I90

Types of Discrimination, ........................ 192

Section 3. Forbidding Undue or Unreasonable Preference or Ad-

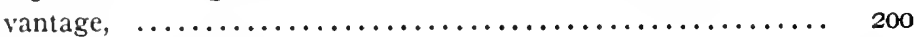

History of the Section, ............................ 200

Relation of Section 3 to Sections 1 and $2, \ldots \ldots \ldots \ldots \ldots \ldots \ldots$. 201

Preferences to Localities, ............................ 202

Basing Points, ................................. ${ }_{205}$

Federal Control of Intrastate Rates, .................. 206

State Regulations, ............................. 209

Natural or Artificial Differences Permitting Discriminations, .. 2 II

Discriminations in Wharfage Rights and Facilities, ......... 216

Rates on Manufactured and Unmanufactured Articles, ....... 217

Discrimination in Car Service, ........................ 218

Railroad Shipments, ........................... 220

Demurrage Charges, ............................. ${ }_{222}$

Transit Charges and Privileges, ...................... 222

Preferences in Through Routing, .................... 222

I. ighterage Allowances, $\ldots \ldots \ldots \ldots \ldots \ldots \ldots \ldots \ldots \ldots \ldots \ldots . .224$

Use of Track and Terminal Facilitics, .................. 224

Classification of Property, ......................... 225

Section 4. The Long and Short Haul Clause, ............... 227

History of the Section, .......................... 227

Over the Same Line or Route, ....................... 247

Amendment of June $18,1910, \ldots \ldots \ldots \ldots \ldots \ldots \ldots \ldots . . . \ldots \ldots$

State Legislation on Long and Short Haul, .............. 258

Water Competition, .............................. 259

Section 5. Pooling of Freight and Division of Earnings, ......... 260

Competing Water Carriers Not to be Owned by Railroads, .... 266

Section 6. Printing, Posting and Filing of Rates and Schedules, .. 269

History of the Section, ............................ 275

Conclusiveness of the Published Rate, ................. 277

Posting of Rates in Railroad Stations, .................. 282

Absence of Filed and Published Rate, .................. 285

Charges to be Included in the Filed and Published Schedules,.. 288

Through Rates, .............................. 300

Section 7. Continuous Carriage, .......................... 301

Section 8. Liability of Common Carriers for Damages, .......... 304

Liability for Damages, ............................ 304

Equity Jurisdiction Under the Commerce Act, ........... 316 
Section 9. Choice of Complaint to the Commission or Suit in

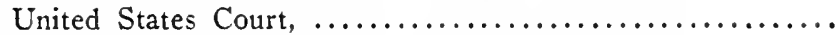

Rights of Private Action before Judicial Tribunals, ..........

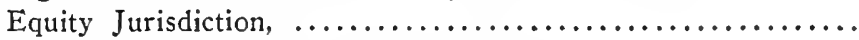

Actions for Damages in Courts of Law,$\ldots \ldots \ldots . . . . . . . . .$.

Furnishing Testimony and Production of Books, ............

Section 10. Penalties for Violations of the Act, ...............

History of the Section, ..............................

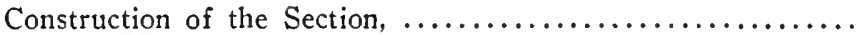

Section Ir. Method of Appointment and Terms of Members of the Interstate Commerce Commission, ................... 337

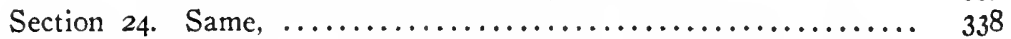

Section 12. Powers of Interstate Commerce Commission to Conduct Investigations, .......................... 340

Incriminatory Testimony, $\ldots \ldots \ldots \ldots \ldots \ldots \ldots \ldots \ldots \ldots . \quad 342$

Compulsory Testimony Act of February II, I893, .......... 345

Court Process to Aid Inquiries before the Commission, ...... 350

Section 13. Complaints to the Commission, ................ 362

History of the Section, ............................ ${ }_{363}$

Procedure, .................................. 364

Section I4. Annual Reports of the Commission, .............. 366

History of the Section, ........................... 366

The Commission and the Courts. ..................... 367

Published Reports of the Decisions, .................. 371

Section 15. Control of Rates by the Commission, ............. 372

History of the Section, ......................... 377

Regulation of Rates, ........................... 378

Regulation of Car Distribution, ..................... 386

Control of Through Routes, ........................ 389

Regulation of Allowances to Shippers. ................ 392

Control Exercised by Commission under Section 15, ....... 396

Powers of Commission in Regulation of Rates, etc., ........ 397

Two Year Limitation Upon Orders of the Commission, ...... 400

Court Review of Orders of the Interstate Commerce Commis-

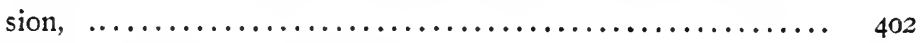

Section 16. Orders of the Commission, .................. 410

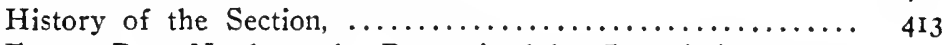

Future Rate Need not be Determined by Commission before

Order of Reparation, ............................

Jurisdiction in Reparation Actions, .....................

Attorney's Fee, ............................... 423

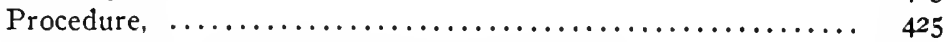

Orders of the Commission and Their Finality, ............ 426

Limitation of Court Actions, ....................... 427

Section I6a. Rehearings by the Commission, ............... 428

Section 17. Practise and Procedure, .................... 429

Section 18. Salaries of Commissioners and Expenses of Commis-

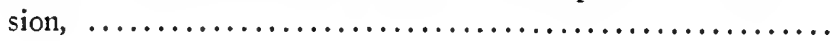


Section 19. Principal Office of the Interstate Commerce Commis-

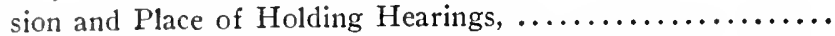

Section 19a. Physical Valuation of the Property of Common Car-

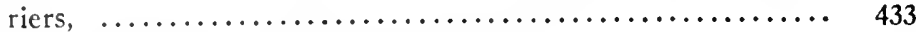

Section 20. Reports and Liabilities of Carriers, ............ 440

History of the Section and Amendments, ............. 445

Reports of Carriers and Systems of Accounting, ........ 445

Right to Examine Papers of Railroad Companies, ........ 455

Writs of Mandamus for the Enforcement of Reports, ....... 457

The Carmack Amendment, Liability of the Primary Carrier, ... 460

State Legislation and Regulation Superseded, ............ 469

Limitation of Time for Bringing Action, ............ 473

Liability of Carrier Measured by Rate Charged for Shipment,.. 475

I iability of Carrier to Suit in Foreign District, ........... 488

Section 2I. Annual Reports of the Interstate Commerce Commis-

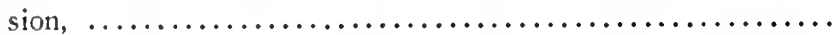

Section 22. Persons and Property Carried Free or at Reduced Rates, ................................. 492

History of the Section, ...................... 493

Scope and Purposes of the Section, ................ 494

Free Passes and Franks, ...................... 498

Cumulative Remedies and Common Law Rights, ......... 500

Section 23. Jurisdiction of Federal Courts to Issue Writs of Man-

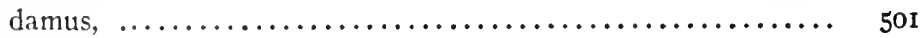

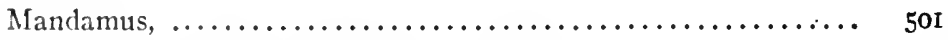

The Elkins Act, Approved February 19, 1903,............ 505

History of the Act, .......................... 510

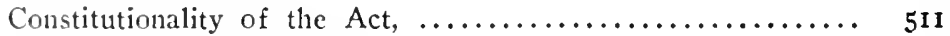

Participants in Joint Rates, .................... 518

Lack of Intent to Rcbate not a Defense, .............. 5 I9

Unit of Offense and When Offense Complete, .......... 52 I

What May Constitute Rebates, ................. 522

Sufficiency of the Indictment, .................. 526

Effect of Hepburn Act on Prosecutions under Elkins Act, .... 528 APPENDIX.

Rules of Practise Before the Commission, ............... 533

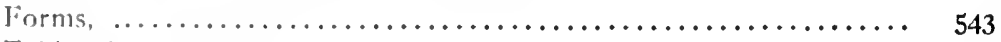

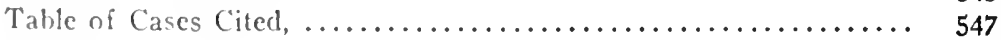

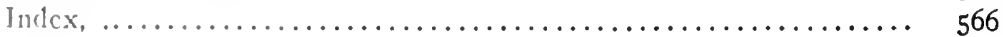




\section{The Commerce Clause of the Constitution}

During the war of the American Revolution the different states of the Union were leagued together in a common causethat of securing their independence of Great Britain. The central authority was represented in the Articles of Confederation which at best amounted to but little more than a league of friendship. The colonies were extremely averse to subjecting themselves to the exercise of any authority which they feared might become as onerous to them as that from which they had taken up arms to free themselves. The Confederation was in reality more a league than a national government. The Continental Congress was in truth merely a nominal legislature. There was no federal executive, no federal judiciary and there existed no power of enforcing obedience either by states or individuals to the dictates and enactments of the legislature. The common danger from the enemy and the single purpose which animated the states of securing their independence of the mother country alone held them together and induced them to lay aside for the moment the consideration of those deeper questions which at best were but dormant. Mutual interests and common sympathies rather than the power of a central government furnished the cohesive power during the years of armed strife.

These conditions changed with the termination of the war and the signature of the Treaty of Paris in 1783 . Mutual jealousies and the determination to assert and enforce local interests-which had been repressed with difficulty during the previous years-became alarmingly apparent. Immediately the several states began to adopt conflicting and retaliatory trade regulations and restrictions born primarily of jealousies and animosities between the different states. The seaboard states were unwilling to grant to the Confederation the power to raise revenues or assess duties on imports. On the contrary they burdened the commerce of inland states by levying duties on imported goods which were intended for those states which had no seaports. Moreover this lack of power to regulate or control the commerce of the states proved a serious source of embarrassment to the Confederation in its exercise of the treaty making power and served to advertise to the world the inefficiency of the new government. Indeed the very 
principles which had inspired the war of the Revolution seriously threatened the Confederation of States with anarchy and ruin. The commercial power of the so-called nation was subject to all the diverse municipal laws and regulations of the thirteen several states.

Futile efforts were made by Congress to secure from the several states authority to regulate the foreign commerce of the country. Difficulties between the states concerning the regulation of commerce among themselves became increasingly frequent. In particular the dispute growing out of the uncertain jurisdiction in the waters of the Potomac River and Chesapeake Bay, between Maryland and Virginia, became acrimonious. A preliminary meeting of a joint-commission of these two states at Mt. Vernon in 1785 led to a convention at Annapolis the following year in which participated delegates from five states. The commercial situation had grown rapidly more demoralizing and had inspired the gravest concern among the statesmen of the time. They realized that a uniform system of trade regulations was essential to the common interests and permanent harmony of the states and that these could be secured and enforced only through a strong central authority fortified by uniform laws.

The demoralization of the four years which succeeded the declaration of peace was proving quite as desolating and quite as destructive to the thirteen states as had the preceding years of war. The appeal for relief from all sides became so insistent that a resolution adopted by Congress recommending the revision of the Articles of Confederation was approved by the various states and in 1787 the Constitutional Convention met in Philadelphia. It remains then a historical fact that our present Constitution and our system of government had their origin in the perplexities and cmbarrassments attending the regulation of foreign and interstate conmerce luring the era of the Confederation.

As finally evolved paragraph three, of section eight, of Article one of the Constitution grants to Congress the power "To regulate commerce with foreign nations, and among the several States, and with the Indian tribes." This clause was not one of those provisions of the Constitution which inspired acrimonious debate. To the contrary it met with the approval of all the public men of the day regardless of political and sectional distinctions. In bricf, the design of the framers of the Constitution in these few words was to provide uniformity in intercourse with 
foreign nations and between the several states, to prevent discriminatory commercial legislation and regulations by the different states, to stop unjust distinctions born of local jealousies and animosities, to make it impossible for certain states to build up a commercial supremacy at the expense of the prosperity of other states, to forestall the commercial conflicts which would arise if one state might prevent the importation of the property of another state into its territory and to insure so far as possible economic and commercial equaliy throughout the Union.

The members of the Constitutional Convention for the most part did not realize the potential power of this paragraph. In I79I, while Attorney General of Washington's cabinet, Edmund Randolph, one of the framers of the Constitution and one of the drafters of this very provision, declared to the President that the powers conferred by it "are little more than to establish the forms of commercial intercourse between the States, and to keep the prohibitions which the Constitution imposed on that intercourse undiminished in their operations; that is to prevent taxes on imports or exports; preferences to one port over another, by any regulation of commerce and revenue; and duties upon the entering or clearing of the vessels of one state in the ports of another." On the other hand, Hamilton, an earnest exponent of the theory of implied powers and a persistent advocate of a strongly centralized government, declared the provision a substantial and extensive grant of power.

This then is the commerce clause as it was adopted by the Constitutional Convention and ratified by the States one hundred and twenty-five years ago and as it has endured during that enttire interval to the present day. That clause was framed by our fathers to meet the abuses incident to the insignificant trade of a scattered population conducted by ox-carts, stage coaches and sailing vessels. To-day it serves to furnish the grant of power through which Congress may regulate an almost inconceivable volume of trade moved by steam and electricity over land and water-and even through the air-in an age of the most complex and diversified industrial development known to civilization. Even when the methods of communication which had existed for centuries were revolutionized in the United States by the importation from England of the Stourbridge Lion-the first locomotive ever operated in this country-which was set up on the rails prepared for it by the Delaware and Hudson Canal Company, the 
real significance of the railroad was little comprehended nor did any one dream of the expansion of the succeeding eighty years. By a process, then, of judicial construction the powers granted in the age of the stage coach and packet boat of the eighteenth century have been gradually adapted to serve the era of the Pullman car and the turbine steamer of the twentieth century. The interim has been marked by an evolution in legal construction as well as in physical science.

For a better understanding and clearer conception of this evolution it is well to keep constantly in mind the elemental fact that ours is a government of enumerated powers and that all functions except those specifically granted to the federal government by the Constitution remain in and can be exercised only by the separate states. In the earlier days of our history the courts in construing the various provisions of the constitution were wont to give marked weight to the views and purposes of the framers of that instrument in order to determine their nature and the extent of their operation; but as our civilization became more complex and our industries more diversified the courts have gradually come to ignore this process of inquiry until at the present time it is judicially declared in even the highest courts that such considerations do not affect or define the extent of those powers.

Not for more than thirty years did any cases of importance arise for determination under the commerce clause of the Constitution. In 1824 we find the real beginning of the construction of this clause in the famous case of Gibbons v. Ogden. ${ }^{1}$ The decision of the Supreme Court of the United States in this case set forth general principles which have stood the test of nearly a century and which formed the basis for the hundreds of decisions which have since been rendered by our courts under this clause inrl also for the statutory legislation which has been enacted in that interval to regulate our interstate commerce.

The New York legislature granted to Robert R. Livingstone and Robert Fulton the exclusive right of navigation of the waters within the jurisdiction of the State of New York with boats propelled ly fire or steam, for a term of years. By assignments from these grantees Ogden acquired the exclusive right to navigate vescels propelled by steam from various New Jersey ports to the rity of $\mathrm{New}$ York. Gibbons, on the other hand, controlled cer-

I 9 Wheaton 1, 6 L. Ed. 23. 
tain steamboats engaged in carrying passengers and transporting freight from New York to Elizabethtown, New Jersey, which were duly licensed and enrolled under an Act of Congress regulating the enrollment and licensing of vessels employed in the coasting trade. The vessels belonging to Gibbons were manifestly operating in violation of the exclusive grant conferred by the New York legislature upon Livingstone and Fulton and their assigns. Ogden thereupon obtained an injunction in the New York courts against Gibbons and the case was carried to the United States Supreme Court. This court unanimously reversed the New York court and declared that the licenses granted to Gibbons pursuant to the Act of Congress gave his vessels full right and authority to navigate the waters of the United States by steam and that the law of the New York legislature prohibiting other vessels than those which derived their rights from Livingstone and Fulton and their assigns from navigating the waters by steam was repugnant to this Act of Congress which had been passed pursuant to the power granted by the commerce clause of the Constitution and was thereby void. The general principles which were enunciated by the Supreme Court speaking through Chief Justice Marshall formed the basis for all decisions since rendered under this clause. They have been constantly acted upon and the later decisions have merely adapted them to the progress of commerce and thus evolved the present system.

These principles, briefly summarized, are:

In construing the powers granted under the Constitution to the general government the courts must avoid the narrow construction which would only serve to cripple the government, and on the other hand must be watchful so as not to import to words a meaning which they do not possess and which would improperly enlarge their effect, but they must endow them with their usual and accepted meaning considered in connection with the purposes for which the powers were conferred. Commerce is a more generic term than traffic-it is intercourse between nations and states and comprises every form of commercial relation including navigation and the commerce which passes between the various states. While this power does not extend to commerce conducted entirely within a state-jurisdiction over which is specifically reserved to the state-it nevertheless does not halt at the state line when applied to foreign and interstate intercourse, but invades the state wherever and by whatever agencies the commerce is 
carried into the confines of the state. This power over interstate commerce is vested in Congress as absolutely and as completely as though there existed no state government and there is no limitation beyond that which Congress in its own volition may exercise. The power to regulate commerce is wholly apart from and does not include the power to levy duties and collect taxes. Such legislation as quarantine laws, health laws and inspection laws of all descriptions which indirectly affect interstate and foreign commerce are included in the general category of police powers and are not surrendered to the general government, but like laws governing intra-state commerce belong to the states. These propositions herein set forth were at once accepted and have remained since the maxims of the law on interstate and intrastate commerce. One point alone remained undecided-and that was the most strongly contested point in the case-whether the federal power to regulate interstate commerce was exclusive of any power in the different states over the subject.

A very considerable portion of the litigation of the ensuing years has turned upon the differentiation between the scope of the police powers of the individual states and the exclusiveness of the power over interstate commerce vested in Congress. An act of the New York legislature requiring the masters of vessels arriving in New York to report to the mayor of the city within twenty-four hours after arrival a list of passengers, with name, place of nativity and last residence, together with their age and occupation, was upheld by the Supreme Court in 1837 as an inspection and quarantine law within the police power of the state. ${ }^{2}$ On the other hand in 1849 a case came before the court involving the validity of statutes of New York and Massachusetts which imposed taxes upon alien passengers arriving in the ports of these states. $^{3}$ 'These acts were properly declared void and the court pointed out the fundamental distinction betwcen this statute and that under consideration in the former case-that in the earlier case no tax was levied upon the passengers or the vessels, but only on the master after his arrival for his omission in failing to report the passengers whom he had carried.

In $185 \mathrm{I}$, in the famous Port Wardens case, the Supreme Court at length settled the acrimonious and long standing controversy

2 New York v. Miln, it Peters 102, 9 L. Ed, 648.

3 The Passenger Cases, 7 Howard 283, 12 L. Ed. 702. 
over concurrent and exclusive power. ${ }^{4}$ An Act of the Pennsylvania legislature declared that any vessel which neglected or refused to take a pilot should pay to a society for the relief of aged and distressed pilots and their widows and dependent orphans a sum equal to one-half of the prescribed amount of pilotage.

The court said :

"Whatever subjects of this power are in their nature national, or admit only of one uniform system or plan of regulation, may justly be said to be of such a nature as to require exclusive regulation by Congress. * * Can we say that by the mere grant of power to regulate commerce, the States are deprived of all power to legislate on the subject, because from the nature of the power the legislation of Congress must be exclusive. This would be to affirm that the nature of the power is, in any case, something different from the nature of the subject to which, in such case, the power extends, and that the nature of the power necessarily demands, in all cases, exclusive legislation by Congress, while the nature of one of the subjects of that power not only does not require such exclusive legislation but may be best provided for by many different systems enacted by the States, and in conformity with the circumstances of the ports within their limits."

The court upheld the Pennsylvania statute and the construction then placed upon the commerce clause has stood the test of the intervening years of constant and manifold application.

In I894, the Supreme Court of the United States tersely analyzed and classified the nature of the respective powers of the states and the national government under the commerce clause in the case of Covington and Cincinnati Bridge Co. v. Kentucky, in passing upon the validity of an Act of the State of Kentucky authorizing the plaintiffs above to construct a bridge across the Ohio River at Cincinnati. ${ }^{5}$ The court said:

4 Cooley v. Port Wardens of Philadelphia, 12 Howard 299, I3 L. Ed. 996.

5154 U. S. 204,38 L. Ed. 962, I4 Sup. Ct. 1087. In the very recent Minnesota Rate Cases, 230 U. S. 352, 57 L. Ed. I5II, 33 Sup. Ct. 729, the Supreme Court has discussed extensively the line of demarcation between national and state jurisdiction. To quote at length the court there said :

"If a state enactment imposes a direct burden upon interstate commerce, it must fall regardless of Federal legislation. The point of such an objection is not that Congress has acted, but that the state has directly restrained that which in the absence of Federal regulation should be free. If the Acts of Minnesota constitute a 
"The adjudications of this court with respect to the power of the States over the general subject of commerce are divisible into three classes. First, those in which the power of the state is exclusive; second, those in which the States may act in the absence of legislation by Congress; third, those in which the action of Congress is exclusive and the States cannot interfere at all.

"The first class, including all those wherein the States have plenary power, and Congress has no right to interfere, concern the strictly internal commerce of the state, and while the regulations of the state may affect interstate commerce indirectly, their bearing upon it is so remote that it cannot be termed in any just sense an interference. Under this power, the States may authorize the construction of highways, turnpikes, railways, and canals between points in the same state, and regulate the tolls for the use of the

direct burden upon interstate commerce, they would be invalid without regard to the exercise of Federal authority touching the interstate rates said to be affected. On the other hand, if the state, in the absence of Federal legislation, would have had the power to prescribe the rates here assailed, the question remains whether its action is void as being repugnant to the statute which Congress has enacted.

"Prior to the passage of the Act to Regulate Commerce carriers fixed their interstate rates free from the actual exertion of Federal control; and under that Act, as it stood until the amendment of June 29, 1906, the Interstate Commerce Commission had no power to prescribe interstate rates. (Interstate Commerce Commission v. C., N. O. \& T. P. Ry. Co., 167 U. S. 479, 5II, 42 L. Ed. 243 , 17 Sup. Ct. 896.) The states, however, had long exercised the power to establish maximum rates for intrastate transportation Was this power, apart from Federal action, subject to the limitation that the state could not fix intrastate rates, reasonable as such, generally throughout the state, but only as to such places and in such circumstances that the interstate business of the carriers would not be thereby affected? 'That is, was the state debarred from fixing reasonable rates on traffic, wholly internal, as to all state points so situated that as a practical consequence the carriers would have to reduce the rates they had made to competing points without the state, in order to maintain the volume of their interstate business or to continue the parity of rates or the relation between rates as it had previously existed? Was the state, in prescribing a general tariff of reasonable intrastate rates otherwise within its authority hound not to go below a minimum standard established by the interstate rates made by the carriers within competitive districts? If the state power, independently of Federal legislation, is thus limited, the inquiry need proceed no further. Otherwise it must be determined whether Congress has so acted as to create such a restriction upon the state authority theretofore existing.

"The general principles governing the excrcise of state authority when interstate commerce is affected are well established. The power of Congress to regulate commerce among the several states is supreme and plenary. It is 'complete in itself, may be exercised to its utmost extent, and ackrowledges no limitations, other than are prescribed in the Constitution.' (Gibbons v. Ogden, 9 Wheat. 1, 11). 6 I. 1.d. 23.) The conviction of its necessity sprang from 
same, Railroad v. Maryland, 2I Wall. 456; and may authorize the building of bridges over non-navigable streams, and otherwise regulate the navigation of the strictly internal waters of the state-such as do not, by themselves or by connection with other waters, form a continuous highway over which commerce is or may be carried on with other states or foreign countries. Veazie v. Moor, I4 How. 568,

the disastrous experiences under the Confederation when the states vied in discriminatory measures against each other. In order to end these evils, the grant in the Constitution conferred upon Congress an authority at all times adequate to secure the freedom of interstate commercial intercourse from state control and to provide effective regulation of that intercourse as the national interest may demand. The words 'among the several states' distinguish between the commerce which concerns more states than one and that commerce which is confined within one state and does not affect other states. *** This reservation to the states manifestly is only of that authority which is consistent with and not opposed to the grant to Congress. There is no room in our scheme of government for the assertion of state power in hostility to the authorized exercise of Federal power. The authority of Congress extends to every part of interstate commerce and to every instrumentality or agency by which it is carried on; and the full control by Congress of the subjects committed to its regulation is not to be denied or thwarted by the commingling of interstate and intrastate operations. This is not to say that the nation may deal with the internal concerns of the state as such, but that the execution by Congress of its constituional power to regulate interstate commerce is not limited by the fact that intrastate transactions may have become so interwoven therewith that the effective government of the former incidentally controls the latter. This conclusion necessarily results from the supremacy of the national power within its appointed sphere. * * *

The grant in the Constitution of its own force, that is, without action by Congress, established the essential immunity of interstate commercial intercourse from the direct control of the states with respect to those subjects embraced within the grant which are of such a nature as to demand that if regulated at all their regulation should be prescribed by a single authority. It has repeatedly been declared by this court that as to those subjects which require a general system or uniformity of regulation the power of Congress is exclusive. In other matters, admitting of diversity of treatment according to the special requirements of local conditions, the states may act within their respective jurisdictions until Congress sees fit to act, and when Congress does act the exercise of its authority overrides all conflicting state legislation.

"Our system of government is a practical adjustment by which the national authority as conferred by the Constitution is maintained in its full scope without unnecessary loss of local efficiency. Where the subject is peculiarly one of local concern, and from its nature belongs to the class with which the state appropriately deals in making reasonable provision for local needs, it can not be regarded as left to the unrestrained will of individuals because Congress has not acted, although it may have such a relation to interstate commerce as to be within the reach of the Federal power. In such case Congress must be the judge of the necessity of Federal action. Its paramount authority always enables it to intervene at its discretion for the complete and effective government of that which has been committed to its care, and, for this purpose, and to this extent, 
I4 L. Ed. 545; The Montello, I I Wall. 4I I, 20 L. Ed. I9I ; S. C., 20 Wall. 430, 22 L. Ed. I9I. 'This is true notwithstanding the fact that the goods of passengers carried or travelling over such highway between points in the same state may ultimately be destined for other states, and, to a slight extent, the state regulations may be said to interfere with interstate commerce. *** Congress has no power to interfere with police regulations relating exclusively to the

in response to a conviction of national need, to displace local laws by substituting laws of its own. The successful working of our constitutional system has thus been made possible. * * *

"Again, it is manifest that when the legislation of the state is limited to internal commerce to such degree that it does not include even incidentally the subjects of interstate commerce, it is not rendered invalid because it may affect the latter commerce indirectly. In the intimacy of commercial relations, much that is done in the superintendence of local maatters may have an indirect bearing upon interstate commerce. The development of local resources and the extension of local facilities may have a very important effect upon communities less favored and to an appreciable degree alter the course of trade. The freedom of local trade may stimulate interstate commerce, while restrictive measures within the police power of the state enacted exclusively with respect to internal business, as distinguished from interstate traffic, may in their reflex or indirect influence diminish the latter and reduce the volume of articles transported into or out of the state. It was an objection of this sort that was urged and overruled in Kidd v. Pearson (128 U. S. I, 32 L... Ed. 346, 9 Sup. Ct. 6), to the law of Iowa prohibiting the manufacture and sale of liquor within the state, save for limited purposes. When, however, the state in dealing with its internal commerce undertakes to regulate instrumentalities which are also used in interstate commerce, its action is necessarily subject to the exercise by Congress of its authority to control such instrumentalities so far as may be necessary for the purpose of enabling it to discharge its constitutional function. (Southern Railway Co. v. United States, 222 U. S. 20, 56 L. Ed. 72, 32 Sup. Ct. 2; Baltimore \& Ohio Railroad Co. v. Interstate Commerce Commission, 22 I U. S. 612,55 L. Ed. 878, 31 Sup. Ct. 621.) ** *

"And, wherever as to such matters, under these establislied principles, Congress may be entitled to act, by virtue of its power to secure the complete government of interstate commerce, the state power nevertheless continues until Congress does act and by its valid interposition limits the exercise of the local authority.

"These principles apply to the authority of the state to prescribe reasonable maximum rates for intrastate transportation.

"It became a frequent practice for the states to create commissions as agencies of state supervision and regulation, and in many instances the rate-making power was conferred upon these bodies. A summary of such legislation is given in Interstate Commerce Commission v. C., N. O. \& T. P. Ry. Co. (I67 U. S. 479, 495, 496, 42 L. Ed. 243, 17 Sup. Ct. 896.) * * *

"In Wabasli etc. Railway Co. v. Illinois (I18 U. S. 557, 30 L. Ed. 24.7 Sup. Ct. 4), it was finally determined that the authority of the state did not extend to the regulation of charges for interstate transportation. There the statute was aimed at discrimination. It was said to have been violated by the railroad company in the case of shipments from points within Illinois to the city of New York. The state court had construed the statute to be binding as to that part 
internal trade of the States. United States v. Dewitt, 9 Wall. 4I. * * *

"Within the second class of cases-those of what may be termed concurrent jurisdiction-are embraced laws for the regulation of pilots; *** quarantine and inspection laws and the policing of harbors; $* * *$ the improvement of navigable channels; $* * *$ the regulation of wharfs, piers, and docks; $* * *$ the construction of dams and bridges across the navigable waters of a state;

of the interstate haul which was within the state, although inoperative beyond the boundary. So applied, this court held the Act to be invalid. But no doubt was entertained of the state's authority to regulate rates for transportation that was wholly intrastate. ${ }^{*} *$ *

"The doctrine was thus fully established that the state could not prescribe interstate rates, but could fix reasonable intrastate rates throughout its territory. The extension of railroad facilities has been accompanied at every step by the assertion of this authority on the part of the states and its invariable recognition by this court. It has never been doubted that the state could, if it saw fit, build its own highways, canals, and railroads. Railroad Company v. Maryland, 2 I Wall. 456, 470, 22 L. Ed. 678. It could build railroads traversing the entire state and thus join its border cities and commercial centers by new highways of internal intercourse to be always available upon reasonable terms. Such provision for local traffic might indeed alter relative advantages in competition, and by virtue of economic forces those engaged in interstate trade and transportation might find it necessary to make readjustments extending from market to market through a wide sphere of influence; but such action of the state would not for that reason be regarded as creating a direct restraint upon interstate commerce and as thus transcending the state power. Similarly, the authority of the state to prescribe what shall be reasonable charges of common carriers for intrastate transportation, unless it be limited by the exertion of the constitutional power of Congress, is state wide.

"As a power appropriate to the territorial jurisdiction of the state, it is not confined to a part of the state, but extends throughout the state-to its cities adjacent to its boundaries as well as to those in the interior of the state. To say that this power exists, but that it may be exercised only in prescribing rates that are on an equal or higher basis than those that are fixed by the carrier for interstate transportation, is to maintain the power in name while denying it in fact. It is to assert that the exercise of the legislative judgment in determining what shall be the carrier's. charge for the intrastate service is itself subject to the carrier's will. But this state-wide authority controls the carrier and is not controlled by it, and the idea that the power of the state to fix reasonable rates for its internal traffic is limited by the mere action of the carrier in laying an interstate rate to places across the state's border, is foreign to our jurisprudence.

"If this authority of the state be restriated it must be by virtue of the paramount power of Congress over interstate commerce and its instruments, and, in view of the nature of the subject, a limitation may not be implied because of a dormant Federal power-that is, one which has not been exerted, but can only be found in the actual exercise of Federal control in such measure as to exclude this action by the state which otherwise would clearly be within its province.

"The question we have now before us, essentially, is whether after 
* * * and the establishment of ferries; * * * Under this power the States may also tax the instruments of interstate commerce as it taxes other similar property, provided such tax be not laid upon the commerce itself.

"But wherever such laws, instead of being of a local nature and not affecting interstate commerce but incidentally, are national in their character, the non-action of Congress indicates its will that such commerce shall be free and untrammelled, and the case falls within the third class-of those laws wherein the jurisdiction of Congress is exclusive. Brown v. Houston, II U. S. 622, 29 L. Ed. 257, 5 Sup. Ct. IO9I ; Bowman v. Chicago, etc. Railway Co., I 25 U. S. 465,3 I L. Ed. 700, 8 Sup. Ct. 689. Subject to the exceptions above specified, as belonging to the first and second classes, the States have no right to impose restrictions, either

the passage of the interstate Commerce Act, and its amendment, the state continued to possess the state-wide authority which it formerly enjoyed to prescribe reasonable rates for its exclusively internal traffic. That, as it plainly appears, was the nature of the action taken by Minnesota, and the attack, however phrased, upon the rates here involved as an interference with interstate commerce, is in substance a denial of that authority.

"Having regard to the terms of the Federal statute, the familiar range of state action at the time it was enacted, the continued exercise of state authority in the same manner and to the same extent after its enactment, and the decisions of this court recognizing and upholding this authority, we find no foundation for the proposition that the Act to regulate commerce contemplated interference therewith.

"Congress did not undertake to say that the intrastate rates of interstate carriers should be reasonable or to invest its administrative agency with authority to determine their reasonableness. Neither by the original Act nor by its amendment did Congress seek to establish a unified control over interstate and intrastate rates; it did not set up a standard for intrastate rates, or prescribe, or authorize the Commission to prescribe either maximum or minimum rates for intrastate traffic. It can not be supposed that Congress sought to accomplish by indirection that which it expressly disclaimed, or attempted to override the accustomed authority of the states without the provision of a substitute. On the contrary, the fixing of reasonable rates for intrastate transportation was left where it had been found; that is, with the states and the agencies created by the states to deal with that subject. Missouri Pacific Railway Co. v. Larabee Mills, 21 I U. S. 612, 620, 621, 53 L. Ed. 352, 29 Sup. Ct. 214.

"The interblending of operations in the conduct of interstate and local business by interstate carriers is strongly pressed upon our attention. It is urged that the same right of way, terminals, rails, bridges and stations are provided for both classes of traffic; that the proportion of each sort of business varies from year to year, and indeed, from day to day; that no division of the plant, no apportionment of it between interstate and local traffic, can be made today which will hold to-morrow; that terminals, facilities, and connections in one state aid the carriers' entire business and are an element of value with respect to the whole property and the business in other states; that securities are issued against the entire line of 
by way of taxation, discrimination, or regulation, upon commerce between the States. 'That, while the States have the right to tax the instruments of such commerce as other property of like description is taxed, under the laws of the several States, they have no right to tax such commerce itself, is too well settled even to justify the citation of authorities. The proposition was first laid down in Crandall v. Nevada, 6 Wall. 35, I8 L. Ed. 745, and has been steadily adhered to since. That such power of regulation as they possess is limited to matters of a strictly local nature, and does not extend to fixing tariffs upon passengers or merchandise from one state to another, is also settled by more recent decisions, although it must be admitted that cases upon this point have not always been consistent."

In any consideration of the commerce clause of the Constitution one of the most interesting and yet troublesome questions is that presented by the so-called police powers of the States and by the exercise by the different states of that authority which may be said to rest in the states subordinate only to such legislation as Congress shall at any time enact under its constitutional authorization. Unfortunately the term "police power" is generally loosely and inaccurately used in confusion with the class of municipal regulations. The word comes to us from the Greek polis, meaning

the carrier and can not be divided by states; that tariffs shauld be made with a view to all the traffic of the road and should be fair as between through and short-haul business; and that, in substance, no regulation of rates can be just which does not take into consideration the whole field of the carrier's operations, irrespective of state lines. The force of these contentions is emphasized in these cases, and in others of like nature, by the extreme difficulty and intricacy of the calculations which must be made in the effort to establish a segregation of intrastate business for the purpose of determining the return to which the carrier is properly entitled therefrom.

"But these considerations are for the practical judgment of Congress in determining the extent of the regulation necessary under existing conditions of transportation to conserve and promote the interests of interstate commerce. If the situation has become such, by reason of the interblending of the interstate and intrastate operations of interstate carriers, that adequate regulation of their interstate rates can not be maintained without imposing requirements with respect to their intrastate rates which substantially affect the former, it is for Congress to determine, within the limits of its constitutional authority over interstate commerce and its instruments the measure of the regulation it should supply. It is the function of this court to interpret and apply the law already enacted, but not under the guise of construction to provide a more comprehensive scheme of regulation than Congress has decided upon. Nor, in the absence of Federal action, may we deny effect to the laws of the state enacted within the field which it is entitled to occupy until its authority is limited through the exertion by Congress of its paramount constitutional power." 
state or commonwealth, and if used in its derivative sense conveys the proper meaning. The term refers to the inherent powers of sovereignty which belong to any autonomous state. In the "License Cases" Chief Justice Taney discussed these powers in the following words:

"What are the police powers of a state? They are nothing more or less than the powers of government inherent in every sovereignty to the extent of its dominions. And whether a state passes a quarantine law, or a law to punish offences, or to establish courts of justice, or requiring certain instruments to be recorded, or to regulate commerce within its own limits, in every case it exercises the same power; that is to say, the power of sovereignty, the power to govern men and things within the limits of its dominions. It is by virtue of this power that it legislates; and its authority to make regulations of commerce is as absolute as its power to pass health laws, except in so far as it has been restricted by the Constitution of the United States."

In a much later case the Supreme Court said:

"Generally it may be said in respect to laws of this character (a state statute making it unlawful for a railroad company in Texas to charge and collect a greater sum for transporting frieight than is specified in the bill of lading) that, though resting upon the police power of the state, they must yield whenever Congress, in the exercise of the powers granted to it, legislates upon the precise subject-matter, for that power, like all other reserved powers of the States, is subordinate to those in terms conferred by the Constitution upon the nation. "No urgency for its use can authorize a state to exercise it in regard to a subject-matter which has been confided exclusively to the discretion of Congress by the Constitution.' Henderson v. New York, 92 U. S. 259, 27I, 23 L. Ed. 543. 'Definitions of the police power must, however, be taken, subject to the condition that the state cannot, in its exercise, for any purpose whatever, encroach upon the powers of the general government, or rights granted or secured by the supreme law of the land.' New Orleans Gas Co. v. Louisiana Light Co., I15 U. S. 650, 66r, 29 L. Ed. 516. "While it may be a police power in the sense that all provisions for the health, comfort, and security of the citizens are police regulations, and an exercise of the police power, it has been said more than once in this court that, where such powers are so exercised as to come within the domain of Federal authority as defined by the Constitu-

6 Pierce v. New Hampshire, 5 Howard 504 at 583, 12 L. Ed. 256. 
tion, the latter must prevail.' Morgan v. Louisiana, I 8 U. S. $455,464,30$ L. Ed. 237, 6 Sup. Ct. I I I 4." 7

The power of a state to protect the lives, health and property of its citizens and to also preserve good order and the public morals- "the power to govern men and things within the limits of its domain"-is a power originally and always belonging to the States, is essentially exclusive, is not surrendered by them to the national government and is not directly restrained by the Federal Constitution. In order, however, to preserve their validity these statutes must not directly interfere with or restrain interstate commerce. In Cleveland, Cincinnati, Chicago \& St. Louis Railway Co. v. Illinois, the Supreme Court said:

"Few classes of cases have become more common of recent years than those wherein the police power of the state over the vehicles of interstate commerce has been drawn in question. That such power exists and will be enforced, notwithstanding the constitutional authority of Congress to regulate such commerce, is evident from the large number of cases in which we have sustained the validity of local laws designed to secure the safety and comfort of passengers, employees, persons crossing railway tracks, and adjacent property owners, as well as other regulations intended for the public good." 8

State laws have been sustained by the Supreme Court requiring locomotive engineers to be examined and licensed by the state authorities ; requiring such engineers to be examined from time to time regarding their ability to distinguish colors; ${ }^{10}$ requiring telegraph companies to receive dispatches and to transmit and deliver them with due diligence, as applied to messages from outside the state $;^{11}$ requiring railway companies to fix their rates annually for the transportation of passengers and freight, and also requiring them to post a printed copy of such rates at all their stations $;{ }^{12}$ forbidding the consolidation of parallel or com-

7 Gulf, Colorado \& Santa Fe Railway Co. v. Hefley, 158 U. S. 98 at 104, 39 L. Ed. 910 , I5 Sup. Ct. 802.

8 I77 U. S. 514, 44 L. Ed. 868, 20 Sup. Ct. 722.

9 Smith v. Alabama, I24 U. S. 465, 31 L. Ed. 508, 8 Sup. Ct. 564.

Io Nashville, etc. Railway Co. v. Alabama, 128 U. S. 96, 32 L. Ed. 352, 9 Sup. Ct. 28.

II Western Union Telegraph Co. v. James, I62 U. S. 650, 40 L. Ed. I 105, I6 Sup. Ct. 934.

I2 Railway Company v. Fuller, i7 Wall. 560, 21 L. Ed. 710. 
peting lines of railway ${ }^{13}$ regulating the heating of passenger cars, and directing guards and guard posts to be placed on railroad bridges and trestles and the approaches thereto ${ }^{14}$ providing that no contract shall exempt any railroad corporation from the liability of a common carrier or a carrier of passengers, which would have existed if no contract had been made; ${ }^{15}$ forbidding the running of freight trains on Sunday $;^{16}$ declaring that when a common carrier accepts for transportation anything directed to a point of destination beyond the terminus of his own line or route, he shall be deemed thereby to assume an obligation for its safe carriage to such point of destination, unless at the time of such acceptance such carrier be released or exempted from such liability by contract in writing, signed by the owner or his agent. ${ }^{17}$

While the state may not impose a duty on tonnage it may regulate wharfage charges and exact tolls for the use of artificial facilities provided under its authority. ${ }^{18}$ The power of the state extends to the regulation of vessels while in port and the state may prescribe rules for their anchorage and mooring and may designate the wharves at which they may receive and discharge passengers and freight and thus prevent the danger of confusion and collision. ${ }^{19}$

A very interesting line of decisions may be found based on

I3 Louisville and Nashville Railroad v. Kentucky, I6r U. S. 677, 40 L. Ed. 849 , I6 Sup. Ct. 714.

I4 N. Y., N. H. \& H. Railroad Co. v. New York, 165 U. S. 628,4 I L. Ed. 853 , 17 Sup. Ct. 418 .

I5 Chicago, Milwaukee, etc. Railway Co. v. Solan, I69 U. S. 133, 42 L. Ed. 688, 18 Sup. Ct. 289.

I6 Hennington v. Georgia, I63 U. S. 299, 41 L. Ed. I66, I6 Sup. Ct. 1086. In sustaining the Statute of Georgia in this case Mr. Justice Harlan declared that "local laws of the character mentioned have their source in the powers, which the States reserved and never surrendered to Congress, of providing for the public health, the public morals, and the public safety and are not $* * *$ regulations of interstate commerce simply because for a limited time or to a limited extent they cover the field occupied by those engaged in such commerce."

I7 Richmond \& Allegheny Railroad v. Patterson Tobacco Co., I69 U. S. 3 II, 42 L. Ed. 759, I8 Sup. Ct. 335.

I8 Ouachita Packet Co. v. Aiken, I2I U. S. 444, 30 L. Ed. 976, 7 Sup. Ct. 907 ; Sands v. Manistee River Improvement Co., 123 U. S. 288, 31 L. Ed. I 49,8 Sup. Ct. II3, and cases cited.

19 Gloucester Ferry Co. v. Pennsylvania, I14 U. S. 196, 29 L. Ed. I58, 5 Sup. Ct. 826. 
statutes of different states regulating the points at which trains must stop for accepting and discharging passengers in the States. A state statute requiring every railroad to stop all its regular passenger trains running wholly within the State of Minnesota at its stations in all county seats long enough to take on and discharge passengers with safety was held to be a reasonable exercise of the police power even as applied to a train connecting with a train of the same company running into another state and carrying some interstate passengers as well as the mail. ${ }^{20}$ But the statute expressly provided that it should not apply to through trains entering the state from any other state or to transcontinental trains of any railroad. Here the Supreme Court said of police regulations for the government of railroads: "They are not in themselves regulations of interstate commerce; and it is only when they operate as such in the circumstances of their application and conflict with the express or presumed will of Congress exerted upon the same subject, that they can be required to give way to the paramount authority of the Constitution of the United States."

The leading case on this question is that of Lake Shore \& Michigan Southern Railway v. Ohio, where the court passed upon a statute of the State of Ohio requiring that every railroad company should cause three of its regular trains carrying passengers, if so many are run daily, Sundays excepted, to stop at a station, city or village containing over three thousand inhabitants, for a time sufficient to receive and let off passengers. ${ }^{21}$ The court held that, in the absence of legislation by Congress upon the subject, this statute was consistent with the Constitution of the United States even when applied to trains engaged in interstate commerce through the State of Ohio. The court through Justice Harlan said :

"The statute does not stand in the way of the railroad company running as many trains as it may choose between Chicago and Buffalo without stopping at intermediate points, or only at very large cities on the route, if in the contingency named in the statute the required number of trains stop at each place containing three thousand inhabitants long enough to receive and let off passengers. It seems from the evidence that the average time required to stop a train and re-

20 Giadson v. Minnesota, 166 U. S. 427, 4I L. Ed. 1064, 17 Sup. Ct. 627.

$21 \quad 173$ U. S. 285,43 L. Ed. 702 , 19 Sup. Ct. 465. 
ceive and let off passengers is only three minutes. Certainly the State of Ohio did not endow the plaintiff in error with the rights of a corporation for the purpose simply of subserving the convenience of passengers traveling through the state between points outside of its territory. $* * *$ It was for the state to take into consideration all the circumstances affecting passenger travel within its limits, and as far as practicable make such regulations as were just to all who might pass over the road in question. It was entitled, of course, to provide for the convenience of persons desiring to travel from one point to another in that state on domestic trains. But it was not bound to ignore the convenience of those who desired to travel from places in the state to places beyond its limits, or the convenience of those outside of the state who wished to come into it. Its statute is in aid of interstate commerce of that character. It was not compelled to look only to the convenience of those who wished to pass through the state without stopping."

On the other hand an Illinois statute was declared to interfere with the Constitution which recited that "all regular passenger trains shall stop a sufficient length of time at the railroad stations of county seats to receive and let off passengers with safety." The court maintained that this statute imposed an unreasonable restriction upon interstate traffic. ${ }^{22}$

The question broadly considered is this: Whether a state statute is valid which requires every passenger train, regardless of the number of trains passing daily and regardless of the character

22 This statute first came before the Supreme Court of the United States in the case of Illinois Central Railroad v. Illinois, 163 U. S. 142, 41 L. Ed. I07, 16 Sup. Ct. I096. It was held to be an unreasonable restriction to require a fast mail train from Chicago to places south of the Ohio River, over an interstate highway established by authority of Congress, to delay the transportation of its interstate passengers and United States mail, by turning aside from its direct route and running to a station (Cairo) three and a half miles away from a point on that route, and back again to the same point before proceeding on its way; and to do this for the purpose of discharging and receiving passengers at that station, for whom the railroad company furnished other and ample accommodation. The court said: "The state may doubtless compel the railroad company to perform the duty imposed by its charter of carrying passengers and goods between its termini within the state. But so long, at least, as that duty is adequately performed by the company, the state cannot, under the guise of compelling its performance, interfere with the performance of paramount duties to which the company has been subjected by the Constitution and laws of the United States." 
of the traffic carried by them, to stop at any and all stations through which such trains may pass, and regardless of whether another train designated especially for local traffic may stop at the same station within a few minutes of the trains in question. If the state can compel all passenger trains to stop at county seats there is no valid reason why the state could not compel them to stop at every station-a requirement which would be practically destructive of through travel. The Supreme Court, in passing upon this statute in the case of Cleveland, Cincinnati, Chicago and St. Louis Ry. Co. v. Illinois, said: "After all local conditions have been adequately met, railways have the legal right to adopt special provisions for through traffic, and legislative interference therewith is unreasonable, and an infringement upon that provision of the Constitution which we have held requires that commerce between the states shall be free and unobstructed." ${ }_{23}$ In another case the court said of an analagous statute: "While it purports only to control the carrier when engaged within the state, it must necessarily influence his conduct, to some extent, in the management of his business throughout his entire voyage. *** If each state was at liberty to regulate the conduct of carriers while within its jurisdiction, the confusion likely to follow could not but be productive of great inconvenience and unnecessary hardship. Each state could provide for its own passengers and regulate the transportation of its own freight regardless of the interests of others." 24

On the other hand the courts have without exception upheld the validity of state regulations requiring passenger trains to stop at railroad crossings and drawbridges, and to reduce their speed when running through crowded thoroughfares; requiring signal

23177 U. S. 514, 44 L. Ed. 868, 20 Sup. Ct. 722.

24 Hall v. DeCuir, 95 U. S. 485,24 L. Ed. 547.

Cases involving the validity of state statutes and orders of state railroad commissions directing the stoppage of through interstate trains have frequently of late years been before the courts. The earlier cases are collected and referred to in Mississippi Railroad Commission v. Illinois Central Railroad Company, 203 U. S. 335. 5 I L. Ed. 209, 27 Sup. Ct. go. See also Atlantic Coast Line Co. v. North Carolina Commission, $206 \mathrm{U}$. S. I, 5 I L. Ed. 933, 27 Sup. Ct. 585: Atlantic Coast Line v. Wharton, 207 U. S. 328. 52 L. Ed. 230,28 Sup. Ct. 121 ; Missouri Pacific Railway Co. v. Kansas, 216 U. S. 262,54 L. Ed. 472, 30 Sup. Ct. 330 ; Herndon v. Chicago, Rock Island \& Pacific Railway Co., 218 U. S. 135, 54 L. Ed. 970 , 30 Sup Ct. 633. 
lights to be carried at night, tracks to be fenced within the state, an efficient bell and whistle to be attached to all engines, tariffs and time-tables to be posted at proper places-in short, all enactments will be enforced which contribute to the safety, comfort and convenience of the patrons of the roads. ${ }^{25}$

"The states may under their police powers enact inspection laws, quarantine laws and health laws of every description. These laws are designed to protect the health, safety and morals of the people of the various states and so long as they have been enacted in good faith for those purposes and do not conflict with national legislation enacted under the authority of the Federal Constitution they have been quite generally upheld. Naturally they are of a very wide scope. Among such enactments have been upheld a statute prohibiting the importation into a state except for immediate slaughter cattle from certain sections of the country which have not been passed as healthy by the proper state officials or by the authorities of the national Department of

25 Erb v. Morasch, 177 U. S. 584, 44 L. Ed. 897, 20 Sup. Ct. 819; Cleveland, etc. Railway Co. v. Illinois, I77 U. S. 514, 44 L. Ed. 868, 20 Sup. Ct. 722; Railroad Company v. Richmond, 96 U. S. 521, 24 L. Ed. 734; Southern Railway v. King, 217 U. S. 524, 54 L. Ed. 868, 30 Sup. Ct. 594. In the Railroad Commission Cases, II6 U. S. 307 at 334, 29 L. Ed. 636, 6 Sup. Ct. 334, the court said: "This company is not relieved entirely from state regulation or state control in Mississippi simply because it has been incorporated by, and is carrying on business in, the other states through which its road runs. While in Mississippi it can be governed by Mississippi in respect to all things which have not been placed by the Constitution of the United States within the exclusive jurisdiction of Congress, that is to say, using the language of this court in Cardwell v. Bridge Co., II3 U. S. 205, 210, 28 L. Ed. 959, 5 Sup. Ct. 423, 'when the subjects on which it is exerted are national in their character, and admit and require uniformity of regulations affecting alike all the states.' Under this rule nothing can be done by the government of Mississippi which will operate as a burden on the interstate business of the company or impair the usefulness of its facilities for interstate traffic. It is not enough to prevent the state from acting that the road in Mississippi is used in aid of interstate commerce. Legislation of this kind to be unconstitutional must be such as will necessarily amount to or operate as a regulation of business without the state as well as within. $* * *$ The line between the exclusive power of Congress and the general powers of the state in this particular is not evcrywhere distinctly marked, and it is always easier to determine when a case ariscs whether it falls on one side or the other, than to settlc in advance the boundary, so that it may be in all respects strictly accurate." 
Agriculture; ${ }^{26}$ a statute forbidding the sale of oleomargarine which was artificially colored; ${ }^{27}$ a statute prohibiting the sale of adulterated food and drugs, although this affected interstate commerce, on the ground that they were a fraud on the public. ${ }^{28}$ And on this theory the states may regulate the sale of cigarettes within their territory. ${ }^{29}$

The line of distinction between the commercial power vested in Congress by the Federal Constitution and the police power of the state is often extremely hard to distinguish. Indeed it may be said that some cases almost seem to draw a distinction without a difference. The Supreme Court has well said that these powers "though quite distinguishable when they do not approach each other may yet, like the intervening colors between white and black, approach so nearly as to perplex the understanding, as colors perplex the vision in marking a distinction between them." The general restriction always resting upon state legislation is that it must not substantially prohibit or unnecessarily burden or directly affect either foreign or interstate commerce. In its last analysis the final test of legislation of this character is its reasonableness.

The Supreme Court of the United States has held that a tax upon freight transported from one state to another is a regulation of interstate commerce and cannot be imposed by a state; ${ }^{30}$ so also a statute imposing a burdensome condition on shipmasters as a prerequisite to the landing of passengers; ${ }^{31}$ a statute prohibiting the driving or conveying of any Texas, Mexican or Indian cattle, whether sound or diseased, into a state between the

26 Asbell v. State of Kansas, 209 U. S. 251, 52 L. Ed. 778, 28 Sup. Ct. 485 .

27 Plumley v. Massachusetts, 155 U. S. 46r, 39 L. Ed. 223, I5 Sup. Ct. I54. Here the court said: "We are of opinion that it is within the power of a state to exclude from its market any compound manufactured in another state which has been artificially colored, or adulterated, so as to cause it to look like an article of food in general use, and the sale of which may, by reason of such coloration or adulteration, cheat the public into purchasing that which they may not intend to buy. The constitution of the United States does not secure to any one the privilege of defrauding the public."

28 Crossman v. Lurman, I92 U. S. I89, 48 L. Ed. 40 I, 24 Sup. Ct. 234.

29 Austin v. Tennessee, I79 U. S. 343, 45 L. Ed. 225, 21 Sup. Ct. I32.

30 Case of the State Freight Tax, 15 Wall. 232, 21 L. Ed. 146.

3I Henderson v. Mayor of New York, 92 U. S. 259, 23 L. Ed. 543. 
first day of March and the first day of November each year ; ${ }^{32}$ a statute requiring every auctioneer to collect and pay into the state treasury a tax on his sales, when applied to imported goods in the original packages by him sold for the importer ; ${ }^{33}$ a statute intended to regulate or tax, or impose any other restriction upon, the transmission of persons or property, or telegraphic messages, from one state to another; ${ }^{34}$ a statute levying a tax upon nonresident drummers offering for sale or selling goods, wares or mercliandise by sample, manufactured by or belonging to citizens of other states. $^{35}$ Likewise the court has held unconstitutional and roid a statute of a state requiring those engaged in the transportation of passengers among the states to give all persons traveling within that state upon ressels or other vehicles equal rights and privileges in all parts of such vessels or cars without distinction on account of race or color, and subjecting to an action for damages exemplary as well as actual, the owner of any vessel who should exclude colored passengers, on account of their color, from the cabin set apart for the use of whites during the passage. ${ }^{36}$ The court declared the statute a regulation of interstate commerce.

32 Railroad Company v. Husen, 95 U. S. 465, 24 L. Ed. 527.

33 Cook v. Pennsylvania, 97 U. S. 566, 24 L. Ed. IoI5.

34 Wabash, St. Louis, etc. Railway v. Illinois, II8 U. S. 557, 30 L. Ed. 244, 7 Sup. Ct. 4.

35 Robbins v. Shelby Taxing District, 120 U. S. 489, 30 L. E.d. 694, 7 Sup. Ct. 592 .

36 Hall v. DeCuir, 95 U. S. 485,24 L. Ed. 547. The court said: "The line which separates the powers of the States from this exclusive power of Congress is not always distinctly marked, and oftentimes it is not casy to determine on which side a particular case belongs. Judges not unfrequently differ in their reasons for a decision in which they concur. Under such circumstances it would be a useless task to undertake to fix an arbitrary rule by which the line must in all cases be located. It is far better to leave a mattcr of such delicacy to be settled in each case upon a view of the particular rights involved. But we think it may safely be said that state legislation which seeks to impose a direct burden upon interstate commercc, or to interfere directly with its freedom, does encroach upon the exclusive power of Congress. The statute now under consideration, in our opinion, occupies that position. It does not act upon the business through the local instruments to be employed after coming within the state, but directly upon the business as it comes into the state from without or goes out from within. While it purports only to control the carrier when cngaged within the state, it must necessarily influence his conduct to some cxtent in the management of his business throughout his 
In construing cases which have come before the courts the difficulty has not arisen from any question as to the existence of the exclusive power conferred upon Congress to regulate commerce among the several states, but as to what is to be deemed an encroachment upon it. For, as the court has said, "legislation may in a great variety of ways affect commerce and persons en-

entire voyage. His disposition of passengers taken up and put down within the state, or taken up within to be carried without, cannot but affect in a greater or less degree those taken up and put down without. A passenger in the cabin set apart for the use of whites without the state must, when the boat comes within, share the accommodations of that cabin with such colored persons as may come on board afterwards, if the law is enforced.

"It was to meet just such a case that the commercial clause in the Constitution was adopted. The river Mississippi passes through or along the borders of ten different states, and its tributaries reach many more. The commerce upon these waters is immense, and its regulation clearly a matter of national concern. If each state was at liberty to regulate the conduct of carriers while within its jurisdiction, the confusion likely to follow could not but be productive of great inconvenience and unnecessary hardship. Each state could provide for its own passengers and regulate the transportation of its own freight, regardless of the interests of others. Nay more, it could prescribe rules by which the carrier must be governed within the state in respect to passengers and property brought from without. On one side of the river or its tributaries he might be required to observe one set of rules, and on the other another. Commerce cannot flourish in the midst of such embarrassments. No carrier of passengers can conduct his business with satisfaction to himself, or comfort to those employing him, if on one side of a state line his passengers, both white and colored, must be permitted to occupy the same cabin, and on the other be kept separate. Uniformity in the regulations by which he is to be governed from one end to the other of his route is a necessity in his business, and to secure it Congress, which is untramelled by state lines, has been invested with the exclusive power of determining what such regulations shall be. If this statute can be enforced against those engaged in interstate commerce, it may be as well against those engaged in foreign; and the master of a ship clearing from New Orleans for Liverpool, having passengers on board, would be compelled to carry all, white and colored, in the same cabin during his passage down the river, or be subject to an action for damages, 'exemplary as well as actual,' by any one who felt himself aggrieved because he had been excluded on account of his color.

"This power of regulation may be exercised without legislation as well as with it. By refraining from action, Congress, in effect, adopts as its own regulations those which the common law or civil law, where that prevails, has provided for the government of such business, and those which the states, in the regulation of their domestic concerns, have established 
gaged in it without constituting a regulation of it within the meaning of the Constitution." 37

The Constitution is an instrument of enumeration and not of definition. No effort was made to define the word "commerce" in that instrument. That was left to the determination of the courts. In the first great case decided under this clause commerce was held to be not alone traffic but also intercourse. ${ }^{38}$ The court there said that commerce "describes the commercial intercourse between nations and parts of nations in all its branches and is regulated by prescribing rules for carrying on that intercourse." In a more recent case the court declared that commerce among the states was not a technical legal conception but a practical one drawn from the course of business. ${ }^{39}$ The indispensable element or test of interstate commerce is that of importation into one state from another. In Henderson v. Mayor, the Supreme Court declared that commerce meant trade or intercourse. "It means commercial intercourse between nations and parts of nations in all of its branches. It includes navigation as the principal means by which foreign intercourse is carried on. To regu-

affecting commerce, but not regulating it within the meaning of the Constitution. In fact, congressional legislation is only necessary to cure defects in existing laws, as they are discovered, and to adapt such laws to new developments of trade. As was said by Mr. Justice Field, speaking for the court in Welton v. The State of Missouri, 91 U. S. 282, 23 L. Ed. 349 , 'inaction (by Congress)) $* * *$ is equivalent to a deciaration that interstate commerce shall remain free and untrammelled.' Applying that principle to the circumstances of this case, congressional inaction left Benson at liberty to adopt such reasonable rules and regulations for the disposition of passengers upon his boat, while pursuing her voyage within Louisiana or without, as seemed to him most for the interest of all concerned. The statute under which this suit is brought, as construed by the state court, seeks to take away from him that power so long as he is within Louisiana; and while recognizing to the fullest extent the principle which sustains a statute, unless its constitutionality is clearly established, we think this statute, to the extent that it requires those engaged in the transportation of passengers among the states to carry colored passengers in Louisiana in the same cabin with whites, is unconstitutional and void. If the public good requires such legislation, it must come from Congress and not from the states."

See also Chiles v. Chesapeake \& Ohio Ry. Co., 218 U. S. 7I, 54 L. Ed. 936, 30 Sup. Ct. 667.

37 Sherlock v. Alling, 93 U. S. I03, 23 L. Ed. 819.

38 Gibbons v. Ogden, 9 Wheaton, I, 6 L. Ed. 23.

39 Swift and Co. v. U. S., 196 U. S. 375, 49 L. Ed. 518, 25 Sup. Ct. 276. 
late this trade and intercourse is to prescribe the rules by which it should be conducted." 40 Under such a construction of the word commerce Florida was not permitted to confer upon a local telegraph company the exclusive right to establish and maintain lines of telegraph in certain counties of that state. This was based upon the congressional control both of commerce and the postal service. ${ }^{41}$ Similarly the commerce clause has been held very naturally to apply to communication by means of the telephone. ${ }^{42}$ And a bridge across a river connecting two states is a highway of commerce and so any regulation by either state of a toll for passing over the bridge is unconstitutional as an unauthorized interference with interstate commerce. ${ }^{43}$ Lottery tickets are subjects of commerce and their transportation from one state to another is interstate commerce which may be prohibited by Congress under the commerce clause $;^{44}$ but policies of insurance are not articles of commerce within any legal or ordinary meaning of that term. ${ }^{45}$ Many of the most perplexing and interesting questions which have arisen under the commerce clause have related to interstate liquor shipments, and the efforts of the various states to prevent the sale of liquor shipped from other states into terri-

40 Henderson v. Mayor of New York, 92 U. S. 259, 23 L. Ed. 543.

4 I Pensacola Tel. Co. v. Western Union, 96 U. S. I, 24 L. Ed. 708. Here the court said: "The powers thus granted (to the national government) are not confined to the instrumentalities of commerce or the postal service, known or in use when the Constitution was adopted, but they keep pace with the progress of the country and adapt themselves to the new developments of time and circumstances. They extend from the horse with its rider to the stage coach, from the sailing vessel to the steam boat, from the coach and steamboat to the railroad, as these new agencies are successively brought into use to meet the demands of increasing population and wealth."

42 Muskogee Nat. Tel. Co. v. Hall, i18 Fed. 382.

43 Covington, etc. Bridge Co. v. Kentucky, 154 U. S. 204, 38 L. Ed. 962, I4 Sup. Ct. 1087. Here the court said: "The thousands of people who daily pass and repass over this bridge may be as truly said to be engaged in commerce as if they were shipping cargoes of merchandise from New York to Liverpool. While the bridge company is not of itself a common carrier, it affords a highway for such carriage and a toll upon such bridge is as much a tax upon commerce as a toll upon a turnpike is a tax upon the traffic of such turnpike."

44 Lottery Cases, Champion v. Ames, I88 U. S. 32I, 47 L. Ed. 492, 23 Sup. Ct. 32 I.

45 Paul v. Virginia, 8 Wall. 168, ig L. Ed. 357; Hooper v. California, 155 U. S. 648, 39 L. Ed. 297 , I5 Sup. Ct. 207. 
tory called "dry." The leading case on this question held that a state statute prohibiting the sale of liquors in the state, except for certain purposes, was unconstitutional and void under the commerce clause of the Constitution, as applied to a sale in the original packages or kegs, unbroken and unopened, of liquors brought in from another state. ${ }^{46}$

One of the most important and interesting phases of this question of the relation of the state and national government in the control of commerce is involved in the question of taxation. Generally speaking the transportation of freight, or the subjects of commerce, is a constituent part of commerce itself. Therefore a tax upon freight, transported from one state to another, is a regulation of commerce among the states. The Supreme Court has repeatedly held that no state has the right to lay a tax on interstate commerce in any form, whether by way of duties on the transportation of the objects of commerce, or on the receipts derived therefrom, or on the occupation of carrying it on, since such taxation is a burden on commerce and thus amounts to a regulation of it. ${ }^{47}$ But this exemption of foreign and interstate commerce from state regulation does not prevent the state from taxing the property of those engaged in such commerce located

46 Leisy v. Hardin, I35 U. S. 100, 34 L. Ed. I28, 1o Sup. Ct. 68I. The court here held that these were subjects of exchange, barter and traffic and that since Congress had not legislated on the subject that was equivalent to a declaration on its part that commerce in that matter should be free. See also: Bowman v. Chicago, etc. Ry Co., I25 U. S. 465, 508, 31 L. Ed. 700,8 Sup. Ct. 689; In re Rahrer, i40 U. S. 545, 35 L. Ed. 572, II Sup. Ct. 865; Rhodes v. Iowa, I70 U. S. 412, 42 L. Ed. 1088, 18 Sup. Ct. 664; Vance v. Vandercook, 170 U. S. 438, 42 L. Ed. 1100,18 Sup. Ct. 674; Brown v. Maryland, I2 Wheat. 419, 6 L. Ed. 678.

47 Case of State Tax on Gross Receipts, 15 Wall. 284, 21 L. Ed. I64; Telegraph Co. v. Texas, I05 U. S. 460, 26 L. Ed. I067; Robbins v. Shelby Taxing District, 120 U. S. 489 , 30 L. Ed. 694, 7 Sup. Ct. 592; Fargo v. Michigan, 121 U. S. 230, 30 L. Ed. 888, 7 Sup. Ct. 857; Lyng v. Michigan, I35 U. S. I61, 34 L. Ed. I30, io Sup. Ct. 725; Postal Telegraph Co. v. Adams, I55 U. S. 688, 39 L. Ed. 31 I, I5 Sup. Ct. 360 ; Galveston, Harrisburg \& San Antonio Railroad Co. v. Texas, 210 U. S. 217, 52 L. Ed. I03I, 28 Sup. Ct. 638; Ludwig v. Western Union Telegraph Co., 216 U. S. I46, 54 L. Ed. 423, 30 Sup. Ct. 280; Western Union Telegraph Co. v. Kansas, 216 U. S. I, 54 I. Ed. 355, 30 Sup. Ct. I90; Oklahoma v. Wells Fargo and Co., 223 U. S. 298, 56 L. Ed. 445, 32 Sup. Ct. 2I8; United States Express Co. v. Minnesota, 223 U. S. 335,56 L. Ed. 459, 32 Sup. Ct. 211 ; Bacon v. Illinois, 227 U. S. 504, 57 L. Ed. 615, 33 Sup. Ct. 399. 
within the state as the property of other citizens is taxed, nor from regulating matters of local concern which, like wharfage and pilotage, may incidentally affect interstate commerce. ${ }^{48}$ The rule is well stated in Fargo v. Hart, where the court said:

"A state cannot tax the privilege of carrying on commerce among the states. Neither can it tax property outside of its jurisdiction belonging to persons domiciled elsewhere. On the other hand, it can tax property permanently within its jurisdiction although belonging to persons domiciled elsewhere and used in commerce among the states. And when that property is part of a system and has its actual uses only in connection with other parts of the system, that fact may be considered by the state in taxing, even though the other parts of the system are outside of the state. The sleepers and rails of a railroad, or the posts and wires of a telegraph company, are worth more than the prepared wood and the bars of steel or coils of wire, from their organic connection with other rails or wires and the rest of the apparatus of a working whole. This being clear, it is held reasonable and constitutional to get at the worth of such a line in the absence of anything more special, by a mileage proportion. The tax is a tax on property, not on the privilege of doing the business, but it is intended to reach the intangible value due to what we have called the organic relation of the property in the state to the whole system." 49

For the first forty or fifty years of railway transportation conditions did not seem to demand the exercise of any control by legislative authority. But certain evils gradually became apparent, more especially the people felt that through the advantage gained by a monopoly of transportation facilities excessive and unwarranted rates were charged for services rendered. The first serious effort towards railway regulation in this country originated in the so-called Granger movement in the early seventies. The plan adopted generally involved the establishment of a commission endowed by the state legislature with authority to fix the rate, either absolute or maximum, which the railway might charge.

48 Leloup v. Port of Mobile, I27 U. S. 640, 32 L. Ed. 3II, 8 Sup. Ct. 1380 .

49 Fargo v. Hart, 193 U. S. 490,48 L. Ed. 76I, 24 Sup. Ct. 498 , and cases cited. See also Atlantic and Pacific Telegraph Co. v. Philadelphia, 190 U. S. I60, 47 L. Ed. 995, 23 Sup. Ct. 817; Pittsburgh, Cincinnati, Chicago \& St. Louis Railway Co. v. Backus, I54 U. S. 42I, 38 L. Ed. I03I, I4 Sup. Ct. 1114; Cleveland, Cincinnati, Chicago \& St. Louis Railway Co. v. Backus, 154 U. S. 439, 38 L. Ed. 1041, 14 Sup. Ct. I122. 
In the earliest cases the Supreme Court declared that the reasonableness of rates for public service should be determined by the various state legislatures and that they were not subject to court review. By a gradual process of judicial evolution the court has to-day taken the opposite ground and it now holds the more equitable view that the action of the legislatures is subject to review by the courts of competent jurisdiction.

The leading case holding to the earlier view is that of Munn v. Illinois, decided in 1876 , which involved the validity of a statute of the State of Illinois fixing maximum rates which might be charged for services by warehouses. In a most exhaustive decision the court said, inter alia:

"In countries where the common law prevails, it has been customary from time inmemorial for the legislature to declare what shall be a reasonable compensation under such circumstances, or, perhaps more properly speaking, to fix a maximum beyond which any charge made would be unreasonable. Undoubtedly, in mere private contracts, relating to matters in which the public has no interest, what is reasonable must be ascertained judicially. But this is because the legislature has no control over such a contract. So, too, in matters which do affect the public interest, and as to which legislative control may be exercised, if there are no statutory regulations upon the subject, the courts must determine what is reasonable. The controlling fact is the power to regulate at all. If that exists, the right to establish the maximum of charge, as one of the means of regulation, is implied. In fact, the common law rule, which requires the charge to be reasonable, is itself a regulation as to price. Without it the owner could make his rates at will, and compel the public to yield to his terms, or forego the use. *** Rights of property which have been created by the common law cannot be taken away without due process; but the law itself, as a rule of conduct, may be changed at the will, or even at the whim, of the legislature, unless prevented by constitutional limitations. Indeed the great office of statutes is to remedy defects in the common law as they are developed, and to adapt it to the changes of time and circumstances. To limit the rate of charge for services rendered in a public employment, or for the use of property in which the public has an interest, is only changing a regulation which existed before. It establishes no new principle in the law, but only gives a new effect to an old one.

"We know that this is a power which may be abused; but that is no argument against its existence. For protection 
against abuses by legislatures the people must resort to the polls, not to the courts.

"We come now to consider the effect upon this statute of the power of Congress to regulate commerce. It was very properly said in the case of the State Tax on Railway Gross Receipts, I5 Wall. 293, that 'it is not everything that affects commerce that amounts to a regulation of it, within the meaning of the Constitution.' The warehouses of these plaintiffs in error are situated and their business carried on exclusively within the limits of the State of Illinois. They are used as instruments by those engaged in state as well as those engaged in interstate commerce, but they are no more necessarily a part of commerce itself than the dray or the cart by which, but for them, grain would be transferred from one railroad station to another. Incidentally they may become connected with interstate commerce, but not necessarily so. Their regulation is a thing of domestic concern, and, certainly, until Congress acts in reference to their interstate relations, the State may exercise all the powers of government over them, even though in so doing it may indirectly operate upon commerce outside its immediate jurisdiction. We do not say that a case may not arise in which it will be found that a state, under the form of regulating its own affairs has encroached upon the exclusive domain of Congress in respect to interstate commerce, but we do say that, upon the facts as they are represented to us in this record, that has not been done." 50

At this same session of the Supreme Court in 1876 a series of cases was decided involving the validity of railway rates fixed by the legislatures of Iowa, Minnesota and Wisconsin. In the case of Chicago, Burlington \& Quincy Railway Co. v. Iowa, it was contended that maximum transportation rates fixed by an Iowa statute amounted to a confiscation of property without due process of law guaranteed by the Constitution. ${ }^{51}$ The court in effect decided that the action of the legislature amounted to the due process contemplated by that instrument. The court said:

"In the absence of any legislative regulation upon the subject, the courts must decide for it, as they do for private persons, when controversies arise, what is reasonable. But when the legislature steps in and prescribes a maximum of charge, it operates upon this corporation the same as it does upon individuals engaged in a similar business. It was within the power of the company to call upon the legislature 
to fix permanently this limit, and make it a part of the charter; and, if it was refused, to abstain from building the road and establishing the contemplated business. If that had been done, the charter might have presented a contract against future legislative interference. But it was not; and the company invested its capital, relying upon the good faitl of the people and the wisdom and impartiality of legislators for protection against wrong under the form of legislative regulation. ***

"The objection that the statute complained of is void because it amounts to a regulation of commerce among the States, has been sufficiently considered in the case of Munn v. Illinois. This road, like the warehouse in that case, is situated within the limits of a single state. Its business is carried on there, and its regulation is a matter of domestic concern. It is employed in state as well as interstate commerce, and, until Congress acts, the state must be permitted to adopt such rules and regulations as may be necessary for the promotion of the general welfare of the people within its own jurisdiction, even though in so doing those without may be indirectly affected."

In the case of Peik v. Chicago and Northwestern Railway Company, another of the Granger cases, the complainants sought to restrain the enforcement of a Wisconsin statute fixing maximum rates for the transportation of passengers and freight. . It was contended that the rates named in the statute would destroy the value of the railway securities, that the railway was entitled to charge a reasonable compensation for its services and that what constituted a reasonable compensation was a question not for the legislature but for the courts. The court, in answer to this contention, declared:

"In Munn v. Illinois, 94 U. S. I I3, and Chicago, Burlington \& Quincy Railroad Co. v. Iowa, 94 U. S. 155, 24 L. Ed. 94, we decided that the state may limit the amount of charges by railroad companies for fares and freights, unless restrained by some contract in the charter, even though their income may have been pledged as security for the payment of obligations incurred upon the faith of the charter. So far this case is disposed of by those decisions. * * *

"As to the claim that the courts must decide what is reasonable, and not the legislature. This is not new to this case. It has been fully considered in Munn v. Illinois. Where property has been clothed with a public interest, the legislature may fix a limit to that which shall in law be reasonable for its use. This limit binds the courts as well as the people. 
If it has been improperly fixed, the legislature, not the courts, must be appealed to for the change." ${ }^{2}$

It is to be particularly noticed that even these Granger cases did not declare that a railroad must continue to do business against its will under rates determined by statute-the railroad had the alternative of ceasing business. Nor did the Granger cases declare that property used in public service could be taken without due process of law-but that statutory enactments determining the rates which might be charged for such services constituted due process of law.

The Supreme Court adhered for some years to the principle which it had laid down in the Granger cases of $1876 . .^{53}$ Gradually various members of the Supreme Court came to alter their position as to the power of the state to exercise control over rates for public service and the finality of the action of state legislatures on the subject. In the Railroad Commission Cases (Stone et al. v. Farmers' Loan \& Trust Company) decided in 1886 this attitude became apparent for the first time in the majority opinion of the court. Speaking through the Chief Justice, the court there said :

"It is now settled in this court that a state has power to limit the amount of charges by railroad companies for the transportation of persons and property within its own jurisdiction, unless restrained by some contract in the charter, or unless what is done amounts to a regulation of foreign or interstate commerce. *** From what has been said it is not to be inferred that this power of limitation or regulation is itself without limit. This power to regulate is not a power to destroy, and limitation is not the equivalent of confiscation. Under pretence of regulating fares and freights, the state cannot require a railroad corporation to carry persons or property without reward: neither can it do that which in law amounts to a taking of

5294 U. S. 164, 24 L. Ed. 97. See also Chicago, Milwaukee \& St. Paul Railroad Company v. Ackley, 94 U. S. I79, 24 L. Ed. 99; Winona \& St. Peter Railroad Company v. Blake, 94 U. S. 189, 24 L. Ed. 995; Stone v. Wisconsin, 94 U. S. 181, 24 L. Ed. 102.

53 Ruggles v. Illinois, 108 U. S. 526, 27 L. Ed. 812, 2 Sup. Ct. 832. Here the court said: "Since in the absence of some restraining contract, the state may establish a maximum of rates to be charged by railroad companies for the transportation of persons and property, it follows that when a maximum is so established the rates fixed by the directors must conform to its requirements, otherwise the by-laws will be repugnant to the laws." 
private property for public use without just compensation, or without due process of law." ${ }_{54}$

In 1890 a majority of the Supreme Court had adopted the theory of judicial review for rate regulation. In that year the court handed down its decision in a case involving a statute of the State of Minnesota providing for a railroad commission and authorizing it to establish rates for the transportation of persons and property which should be final and conclusive. The commission thus organized reduced the rate for carrying milk between certain points within the state from 3 cents to 2.5 cents per gallon and the Minnesota courts refused to admit evidence offered by the railroad that the lower rate was unreasonable and confiscatory. The courts maintained that under the statute the findings of the commission were conclusive and exempt from review. The question then went to the United States courts on the theory that the denial of a judicial hearing and determination as to the reasonableness of the rates involved would deprive the railroad of property without due process of law as guaranteed by the Constitution. The Supreme Court said:

"The construction put upon the statute by the Supreme Court of Minnesota must be accepted by this court, for the purposes of the present case, as conclusive and not to be reexamined here as to its propriety or accuracy. The Supreme Court authoritatively declares that it is the expressed intention of the legislature of Minnesota, by the statute, that the rates recommended and published by the Commission, if it proceeds in the manner pointed out by the Act are not simply advisory, nor merely prima facie equal and reasonable, but final and conclusive as to what are equal and reasonable charges; that the law neither contemplates nor allows any issue to be made or inquiry to be had as to their equality or reasonableness in fact; that, under the statute, the rates published by the Commission are the only ones that are lawful, and, therefore, in contemplation of law the only ones that are equal and reasonable, and that, in a proceeding for a mandamus under the statute, there is no fact to traverse except the violation of the law in not complying with the recommendations of the Commission. In other words, although the railroad company is forbidden to es-

54 I16 U. S. 307, 29 L. Ed. 636, 6 Sup. Ct. 334 . See also Dow v. Beidelman, I25 U. S. 680, 3I L. Ed. 84I, 8 Sup. Ct. 1028, where it was plainly intimated that the courts might review the action of the legislature to determine its reasonableness. 
tablish rates that are not equal and reasonable, there is no power in the courts to stay the hands of the Commission, if it chooses to establish rates that are unequal and unreasonable.

"This being the construction of the statute by which we are bound in considering the present case, we are of opinion that, so construed, it conflicts with the Constitution of the United States in the particulars complained of by the railroad company. It deprives the company of its right to a judicial investigation by due process of law, under the forms and with the machinery provided by the wisdom of successive ages for the investigation judicially of the truth of a matter in controversy, and substitutes therefor, as an absolute finality, the action of a railroad commission which, in view of the powers conceded to it by the state court, cannot be regarded as clothed with judicial functions or possessing the machinery of a court of justice. * * *

"The question of the reasonableness of a rate of charge for transportation by a railroad company, involving as it does the element of reasonableness both as regards the company and as regards the public, is eminently a question for judicial investigation, requiring due process of law for its determination. If the company is deprived of the power of charging reasonable rates for the use of its property, and such deprivation takes place in the absence of an investigation by judicial machinery, it is deprived of the lawful use of its property, and thus, in substance and effect, of the property itself, without due process of law and in violation of the Constitution of the United States; and in so far as it is thus deprived, while other persons are permitted to receive reasonable profits upon their invested capital, the company is deprived of the equal protection of the laws." 55

The advent of new judges on the court and the gradual change in its complexion marked this evolution in its position on this important question of rate regulation. The support of the fundamental doctrine of the Granger cases gradually diminished. By the case of Chicago, Milwaukee \& St. Paul Railway v. Minnesota, just cited, the Granger cases were practically overruled. The action of the legislatures in fixing rates could no longer be translated into due process of law-that was to be derived from the investigations and decisions of the courts as to what was fair and

55 Chicago, Milwaukee \& St. Paul Railway Co. v. Minnesota, I34 U. S. 418, 33 L. Ed. 970, ro Sup. Ct. 462. A strong dissenting opinion was filed based on the judgment of the court in the Granger cases. See also Minneapolis Eastern Railway Co. v. Minnesota, I34 U. S. 467, 33 L. Ed. 985 , 10 Sup. Ct. 473. 
reasonable. Thus in the last analysis the courts may determine just what control over railroad rates the legislatures may exercise. This control should be subject to judicial review. Since this Minnesota case deciding in favor of the paramount authority of judicial investigation, suits to invalidate rates fixed by state legislatures have multiplied and the decisions of the court have tended to decrease rather than increase the scope of the power of the states. ${ }^{56}$

In Chicago \& Grand Trunk Railway Company v. Wellman, the Supreme Court in its opinion on the validity of a statute regulating railway rates, said:

"The legislature has power to fix rates, and the extent of judicial interference is protection against unreasonable rates. * * * Surely, before the courts are called upon to adjudge an Act of the legislature fixing the maximum passenger rates for railroads to be unconstitutional, on the ground that its enforcement would prevent the stockholders from receiving any dividends on their investments, or the bondholders any interest on their loans, they should be fully advised as to what is done with the receipts and earnings of the company; for if so advised, it might clearly appear that a prudent and honest management would, within the rates prescribed, secure to the bondholders their interest, and to the stockholders reasonable dividends. While the protection of vested rights of property is a supreme duty of the courts, it has not come to this, that the legislative power rests subservient to the discretion of any railroad corporation which may, by exorbitant and unreasonable salaries, or in some other improper way, transfer its earnings into what it is pleased to call 'operating expenses.' " 57

Here the principle is clearly announced that rates must be proven to be unreasonable before the courts will declare legislation fixing then void on that ground. These principles are set forth at length in the exhaustive opinion of the court in Reagan $v$. Farmers' Loan \& Trust Co., where the following occurs:

"It is not to be supposed that the legislature of any state, or a commission appointed under the authority of any state, will ever engage in a deliberate attempt to cripple or de-

56 In this connection see, however, an obiter dictum in Budd v. New York, 143 U. S. 517,36 L. Ed. 247, 12 Sup. Ct. 468 . This case in reality, however, declared that the unreasonableness of rates must be proved before the courts would hold them void on that ground.

57 I 43 U. S. 339, 30 L. Ed. I76, 12 Sup. Ct. 400. 
stroy institutions of such great value to the community as the railroads, but will always act with the sincere purpose of doing justice to the owners of railroad property as well as to other individuals; and also that no legislation of a state, as to the mode of proceeding in its own courts can abridge or modify the powers existing in the Federal courts, sitting as courts of equity. *** The province of the courts is not changed, nor the limit of judicial inquiry altered, because the legislature instead of the carrier prescribes the rates. The courts are not authorized to revise or change the body of rates imposed by a legislature or a commission; they do not determine whether one rate is preferable to another, or what under all circumstances would be fair and reasonable as between the carriers and the shippers; they do not engage in any mere administrative work; but still there can be no doubt of their power and duty to inquire whether a body of rates prescribed by a legislature or a commission is unjust and unreasonable, and such as to work a practical destruction to rights of property, and if found so to be, to restrain its operation. *** These cases all support the proposition that while it is not the province of the courts to enter upon the merely administrative duty of framing a tariff of rates for carriage, it is within the scope of judicial power and a part of judicial duty to restrain anything which, in the form of a regulation of rates, operates to deny to the owners of property invested in the business of transportation that equal protection which is the constitutional right of all owners of other property. There is nothing new or strange in this. It has always been a part of the judicial function to determine whether the act of one party (whether that party be a single individual, an organized body, or the public as a whole) operates to divest the other party of any rights of person or property. In every constitution is the guarantee against the taking of private property for public purposes without just compensation. $* * *$ As we have seen, it is not the function of the courts to establish a schedule of rates. It is not, therefore, within our power to prepare a new schedule or rearrange this. Our inquiry is limited to the effect of the tariff as a whole, including therein the rates prescribed for all the several classes of goods, and the decree must either condemn or sustain this act of quasi-legislation. If a law be adjudged invalid, the court may not in the decree attempt to enact a law upon the same subject which shall be obnoxious to no legal objections. It stops with simply passing its judgment on the validity of the act before it. The same rule obtains in a case like this.

"And now, what deductions are fairly to be drawn from all the facts before us? Is there anything which de- 
tracts from the force of the general allegation that these rates are unjust and unreasonable? This clearly appears. The cost of this railroad property was $\$ 40,000,000$; it cannot be replaced to-day for less than $\$ 25,000,000$. There are $\$ 15,000,000$ of mortgage bonds outstanding against it, and nearly $\$ 10,000,000$ of stock. These bonds and stock represent money invested in the construction of this road. The owners of the stock have never received a dollar's worth of dividends in return for their investment. The road was thrown into the hands of a receiver for default in payment of the interest on the bonds. The earnings for the last three years prior to the establishment of these rates was insufficient to pay the operating expenses and the interest on the bonds. In order to make good the deficiency in interest the stockholders have put their hands in their pockets and advanced over a million of dollars. The supplies for the road have been purchased at as cheap a rate as possible. The officers and employees have been paid no more than is necessary to secure men of the skill and knowledge requisite to suitable operation of the road. By the voluntary action of the company the rate in cents per ton per mile has decreased in ten years from 2.03 to 1.30 . The actual reduction by virtue of this tariff in the receipts during the six or eight months that it has been enforced amounts to over \$150,000. Can it be that a tariff which under these circumstances has worked such results to the parties whose money butilt this road is other than unjust and unreasonable? Would any investment ever be made of private capital in railroad enterprises with such as the proffered results?

"It is unnecessary to decide, and we do not wish to be understood as laying down as an absolute rule, that in every case a failure to produce some profit to those who have invested their money in the building of a road is conclusive that the tariff is unjust and inreasonable. And yet justice demands that every one should receive some compensation for the use of his money or property, if it be possible without prejudice to the rights of others. There may be circumstances which would justify such a tariff: there may have been extravagance and a needless expenditure of money; there may be waste in the management of the road; enormous salaries, unjust discrimination as between individual shippers, restlting in general loss. 'The construction may have been at a time when material and labor were at the highest price, so that the actual cost far exceeds the present value; the road may have been unwisely built, in localities where there is no sufficient business to sustain a road. Doubtless, too, there are many other matters affecting the 
rights of the community in which the road is built as well as the rights of those who have built the road."58

Such cases as this established the general principle that railroads properly conducted are entitled to earn interest on their bonds and a return for their stockholders besides paying operating expenses. And that where the tariff of rates established by the legislatures is so unreasonable as to practically destroy the value of the property of companies engaged in transporting freight and passengers the courts may be appealed to. Just what return the stockholders should be entitled to was not decided nor was any general criterion established. ${ }^{59}$ By inference, at least, the proposition was laid down that where a failure to earn returns sufficient to pay dividends on stock and interest on bonds was due to unwise investments, faulty and extravagant management, or to competition to whose benefits the public was entitled, railroads and other public service corporations might not be protected from the action of state legislatures in fixing a maximum rate for services. ${ }^{60}$

58154 U. S. 362, 38 L. Ed. 1014, 14 Sup. Ct. 1047. See also Reagan v. Mercantile Trust Co., 15t U. S. 413, 38 L. Ed. 1028, I4 Sup. Ct. 1060.

59 St. Louis and San Francisco Railway v. Gill, 156 U. S. 649, 39 L. Ed. 567, 15 Sup. Ct. 484. Here the court said:

"Given the case of a general law prescribing rates to all companies, can the courts inquire whether such rates are reasonable. and may they find that as to one company the prescribed rates permit it to do business at a profit, and as to another, whose facilities are inferior, or where expenditures are greater, the rates afford no profit? And will the fate of the law, as to its validity, depend, in each case, on the result of such an inquiry? This court has declared, in several cases, that there is a remedy in the courts for relief against legislation establishing a tariff of rates which is so unreasonable as to practically destroy the value of property of companies engaged in the carrying business, and that especially may the courts of the United States treat such a question as a judicial one, and hold such acts of legislation to be in conflict with the Constitution of the United States, as depriving the companies of their property without due process of law, and as depriving them of the equal protection of the laws."

60 Covington and Lexington Turnpike Road Company v. Sandford, I64 U. S. 578, 4 I L. Ed. 560, I7 Sup. Ct. 198. Here an Act of the Kentucky legislature reduced the rate of toll which might be charged on the turnpike owned by the company. The company declared that the proposed rate would so diminish its earnings as to make it impossible for it to maintain its road, meet its ordinary expenses and earn any dividends on its stock. The court said:

"It cannot be said that a corporation is entitled, as of right, and without reference to the interests of the public, to realize a given per cent. upon its capital stock. When the question arises whether the legislature has exceeded its constitutional power in prescribing 
The pronouncement of the court thus far as to the basis of value on which a fair return should be allowed to carrying corporations in the matter of determining rates had been entirely negative. The rates ought not to be so low as to render it impossible for the corporations to pay the interest on their bonds or a fair dividend on their stock. For such a rate amounts to taking property without due process of law. The next step was for the court to formulate a basis for the proper calculation of the reasonableness of rates to be charged for services to be rendered. In a word this was declared to be "the fair value of the property being used by it for the convenience of the public." In order to arrive at that value the court suggested certain items which should be taken into account-the original cost of construction, the investments in permanent improvements, the amount of bonds and stock outstanding and their value, the operating expenses, the

rates to be charged by a corporation controlling a public highway, stockholders are not the only persons whose rights or interests are to be considered. The rights of the public are not to be ignored. It is alleged here that the rates prescribed are unreasonable and unjust to the company and its stockhloders. But that involves an inquiry as to what is reasonable and just for the public. If the establishing of new lines of transportation should cause a diminution in the number of those who need to use a turnpike road, and, consequently, a diminution in the tolls collected, that is not, in itself a sufficient reason why the corporation, operating the road, should be allowed to maintain rates that would be unjust to those who must or do use its property. The public cannot properly be subjected to unreasonable rates in order simply that stockholders may earn dividends.

"If a corporation cannot maintain such a highway and carn dividends for stockholders, it is a misfortune for it and them, which the constitution does not require to be remedied by imposing unjust burdens upon the public. So that the right of the public to use the defendant's turnpike upon payment of such tolls as in view of the nature and value of the service rendered by the company are reasonable, is an element in the general inquiry whether the rates established by law are unjust and unreasonable. That inquiry also involves other considerations, such, for instance, as the reasonable cost of maintaining the road in good condition for public use, and the amount that may have been really and necessarily invested in the enterprise. In short, each case must depend upon its special facts. ***

"The circumstances of each turnpike company must determine the rates if toll to be properly allowed for its use. Justice to the public and to the stockholders may require, in respect of one road, rates clifferent from those prescribed for other roads. Rates on one road may be reasonable and just to all concerned, while the same rates wonld be exorbitant on another road. The utmost that any corporation, operating a public highway, can rightfully demand at the hands of the legislature when exerting its general powers is that it recrive what, under all the circumstances, is such compensation for the use of its property as will be just both to it and to the public." 
condition of the rolling stock, the earning capacity of the properties, etc. ${ }^{61}$ It is to be noted that in the leading case which set forth these criteria, that of Smyth v. Ames, no mention is made of franchise valuations and that element is not to be taken into consideration in determining the amount upon which the rates allowed are to be calculated. In short the court limits this to the tangible, physical property.

In view of the fact that a state legislature could exercise con-

6I Smyth v. Ames, 169 U. S. 466, 42 L. Ed. 8I9, I8 Sup. Ct. 418 . Here the court rendered a unanimous opinion which constituted a landmark in the history of railroad rate regulation, from which the following is quoted:

"We hold, however, that the basis of all calculations as to the reasonableness of rates to be charged by a corporation maintaining a highway under legislative sanction must be the fair value of the property being used by it for the convenience of the public. And in order to ascertain that value, the original cost of construction, the amount expended in permanent improvements, the amount and market value of its bonds and stock, the present as compared with the original cost of construction, the probable earning capacity of the property under particular rates prescribed by statute, and the sum required to meet operating expenses, are all matters for consideration, and are to be given such weight as may be just and right in each case.

"We do not say that there may not be other matters to be regarded in estimating the value of the property. What the company is entitled to ask is a fair return upon the value of that which it employs for the public convenience. On the other hand, what the public is entitled to demand is that no more be exacted from it for the use of a public highway than the services rendered by it are reasonably worth. But even upon this basis, and determining the probable effect of the Act of 1893 by ascertaining what could have been its effect if it had been in operation during the three years immediately preceding its passage, we perceive no ground on the record for reversing the decree of the circuit court. On the contrary, we are of opinion that as to most of the companies in question there would have been, under such rates as were established by the Act of 1893 , an actual loss in each of the years ending June 30 , 1891, I892, and I893; and that, in the exceptional cases above stated, when two of the companies would have earned something above operating expenses, in particular years, the receipts or gains, above operating expenses, would have been too small to affect the general conclusion that the Act, if enforced, would have deprived each of the railroad companies involved in these suits of the just compensation secured to them by the Constitution.

"If a railroad corporation has bonded its property for an amount that exceeds its fair value, or if its capitalization is largely fictitious, it may not impose upon the public the burden of such increased rates as may be required for the purpose of realizing profits upon such excessive valuation or fictitious capitalization; and the apparent value of the property and franchises used by the corporation, as represented by its stocks, bonds and obligations, is not alone to be considered when determining the rates that may be reasonably charged." 
trol over rates only within the limits of the state the question naturally arose in this connection whether in ascertaining the condition of a railroad and its profits consideration should be given only to that portion of its business which would be called domestic as distinguished from interstate or foreign, or whether a railroad might be compelled to submit to a low maximum rate within the state, which would not permit a profit upon its intrastate business considered as a unit, provided the losses incurred thereby were more than neutralized by the earnings of its through or interstate business. In passing upon this point the Supreme Court clearly enunciated its view in the Smyth v. Ames case, as follows:

"In our judgment, it must be held that the reasonableness or unreasonableness of rates prescribed by a state for the transportation of persons and property wholly within its limits must be determined without reference to the interstate business done by the carrier, or to the profits derived from it. The state cannot justify unreasonably low rates for domestic transportation considered alone, upon the ground that the carrier is earning large profits on its interstate business, over which, so far as rates are concerned, the state has no control. Nor can the carrier justify unreasonably high rates on domestic business upon the ground that it will be able only in that way to meet losses on its interstate business. So far as rates of transportation are concerned domestic business should not be made to bear the losses on interstate business, nor the latter the losses on domestic business. It is only rates for the transportation of persons and property between points within the state that the state can prescribe; and when it undertakes to prescribe rates not to be exceeded by the carrier, it must do so with reference exclusively to what is just and reasonable, as between the carrier and the public, in respect of domestic business. The argument that a railroad line is an entirety; that its income goes into, and its expenses are provided for, out of a common fund; and that its capitalization is on its entire line, within and without the state, can have no application where the state is without authority over rates on the entire line, and can only deal with local rates and make such regulations as are necessary to give just compensation on local business." 62

62169 U. S. 466, 42 L. Ed. 819, 18 Sup. Ct. 418. See also the very illuminating case of San Diego Land Co. v. National City, 174 U. S. 739, at pages 754 and 757, 43 L. Ed. 1 154, 19 Sup. Ct. 804. See also Smyth v. Ames, 171 U. S. 361, 365, 43 L. E.d. 197, 18 Sup. Ct. 888. 
Thus it becomes apparent that an Act of the legislature fixing maximum rates might be constitutional as to one road and yet unconstitutional as to other roads. It might permit one road to earn a reasonable income beyond its expenses, while it would entail a deficit upon other railroads. Another element was added in the case of Cotting $v$. Kansas City Stock Yards Co., where the court said:

"The state's regulation of his charges is not to be measured by the aggregate of his profits, determined by the volume of business, but by the question whether any particular charge to an individual dealing with him is, considering the service rendered, an unreasonable exaction. In other words, if he has a thousand transactions a day and his charges in each are but a reasonable compensation for the benefit received by the party dealing with him, such charges do not become unreasonable because by reason of the multitude the aggregate of his profits is large. The question is not how much he makes out of his volume of business, but whether in each particular transaction the charge is an unreasonable exaction for the services rendered. He has a right to do business. He has a right to charge for each separate service that which is reasonable compensation therefor, and the legislature may not deny him such reasonable compenstion, and may not interfere simply because out of the multitude of his transactions the amount of his profits is large." ${ }^{3}$

In the Cotting case the court declared that rates which yielded a profit which amounted to 10.9 per cent. on the investment were not unreasonable, while an Act of the legislature which prescribed rates which would reduce the profit to 5.3 was unconstitutional. Thus the court had now reached the point of determining positively what percentage of profit was reasonable and a point below which the percentage should not fall without subjecting rate fixing legislation to the likelihood of being declared confiscatory and unconstitutional.

The most comprehensive decision of the Supreme Court on the question of the reasonableness of rates fixed by legislative action is found in the Minnesota Rate Cases, decided by the court in I9I3. The court declared that while the rate making power is essentially a legislative function, yet that it must be exercised with due regard for the rights of private property which must not be placed at the mercy of legislative caprice. The court carefully

63 I83 U. S. 79, 46 L. Ed. 92, 22 Sup. Ct. 30. 
analyzed different methods which had been pursued in arriving at a valuation of the railroad properties in order to determine whether rates were or were not confiscatory. It declared that the burden of proof that rates are confiscatory is on the railroads but it insisted that the public cannot be taxed to make excessive returns on good will, franchise values, or any artificial or unjustifiable valuation. Charters granted by the public, no matter how valuable they might since have become, could not be set up as an asset upon which the public should be asked to make a profitable return. "Water" represented by inflated stock issues and overcapitalization is not an investment entitled to any place on an inventory of railroad property. Nor could the special purposes to which railroad property is devoted be assumed to make a special valuation for that property. The court declared that the fair valuation of the property should be the basis for determining the reasonableness of any rates which might be fixed but held that it was not the business of the court to make rules for such computations-that this was the business of the legislatures. With reference to the question of the reasonableness of rates, and the consequent constitutionality of acts of the legislature in determining them, the court said:

"The rate-making power is a legislative power and necessarily implies a range of legislative discretion. We do not sit as a board of revision to substitute our judgment for that of the legislature or of the commission lawfully constituted by it as to matters within the province of either. The case falls within a well-defined category. Here we have a general schedule of rates involving the profitableness of the intrastate operations of the carrier taken as a whole, and the inquiry is whether the state has overstepped the constitutional limit by making the rates so unreasonably low that the carriers are deprived of their property without due process of law and denied the equal protection of the laws.

"The property of the railroad corporation has been devoted to a public use. There is always the obligation springing from the nature of the business in which it is engagedwhich private exigency may not be permitted to ignorethat there shall not be an exorbitant charge for the service rendered. But the state has not seen fit to undertake the service itself; and the private property embarked in it is not placed at the mercy of legislative caprice. It rests secure under the constitutional protection which extends not merely to the title but to the right to receive just compensation for the service given to the public. $* * *$ In de- 
termining whether that right has been denied. each case must rest upon its special facts. But the general principles which are applicable in a case of this character have been set forth in the decisions. (I) The basis of calculation is the 'fair value of the property' used for the convenience of the public. (Smyth v. Ames, I6g U. S. 466.) * * *

"(2) The ascertainment of that value is not controlled by artificial rules. It is not a matter of formulas, but there must be a reasonable judgment having its basis in a proper consideration of all relevant facts.

"(3) Where the business of the carrier is both interstate and intrastate, the question whether a scheme of maximum rates fixed by the state for intrastate transportation affords a fair return, must be determined by considering separately the value of the property employed in the intrastate business and the compensation allowed in that business under the rates prescribed. (Smyth v. Ames, supra.)

"It is manifest that an attempt to estimate what would be the actual cost of acquiring the right of way, if the railroad were not there, is to indulge in mere speculation. * * * The assumption of its nonexistence, and at the same time that the values that rest upon it remain unchanged, is impossible and can not be entertained. The conditions of ownership of the property and the amounts which would have to be paid in acquiring the right of way, supposing the railroad to be removed, are wholly beyond reach of any process of rational determination. The cost of reproduction method is of service in ascertaining the present value of the plant, when it is reasonably applied and when the cost of reproducing the property may be ascertained with a proper degree of certainty. But it does not justify the acceptance of results which depend upon mere conjecture. It is fundamental that the judicial power to declare legislative action invalid upon constitutional grounds is to be exercised only in clear cases. The constitutional invalidity must be manifest, and if it rests upon disputed questions of fact the invalidating facts must be proved. And this is true of asserted value as of other facts.

"It is clear that in ascertaining the present value we are not limited to the consideration of the amount of the actual investment. If that has been reckless or improvident, losses may be sustained which the community does not underwrite. As the company may not be protected in its actual investment, if the value of its property be plainly less, so the making of a just return for the use of the property involves the recognition of its fair value if it be more than its cost. The property is held in private ownership and it is that property, and not the original cost of it, of which the owner may not be deprived without due process of law. But still it is prop- 
erty employed in a public calling, subject to governmental regulation, and while under the guise of such regulation it may not be confiscated; it is equally true that there is attached to its use the condition that charges to the public shall not be unreasonable. And where the inquiry is as to the fair value of the property, in order to determine the reasonableness of the return allowed by the rate-making power, it is not admissible to attribute to the property owned by the carriers a speculative increment of value over the amount invested in it and beyond the value of similar property owned by others solely by reason of the fact that it is used in the public service. That would be to disregard the essential conditions of the public use and to make the public use destructive of the public right.

"We therefore hold that it was error to base the estimates of value of the right of way, yards and terminals upon the so-called railway value of the property. The company would certainly have no ground of complaint if it were allowed a value for these lands equal to the fair average market value of similar land in the vicinity, without additions by the use of multipliers, or otherwise, to cover hypothetical outlays. The allowances made below for a conjectural cost of acquisition and consequential damages must be disapproved; and in this view we also think it was error to add to the amount taken as the present value of the lands the further sums calculated on that value, which were embraced in the items of 'engineering, superintendence, legal expenses,' 'contingencies,' and 'interest during construction.' * * *

"We are of opinion that on an issue of this character involving the constitutional validity of state action, general estimates of the sort here submitted, with respect to a subject so intricate and important (the relative amount and cost of intrastate and interstate business), should not be accepted as adequate proof to sustain a finding of confiscation. While accounts have not been kept so as to show the relative cost of interstate and intrastate business, giving particulars of the traffic handled on through and local trains, and presenting data from which such extra cost, as there may be, of intrastate business may be suitably determined, it would appear to have been not impracticable to have had such accounts kept or statistics prepared at least during test periods properly selected. It may be said that this would have been a very difficult matter, but the company having assailed the constitutionality of the state acts and orders was bound to establish its case, and it was not entitled to rest on expressions of judgment when it had it in its power to present accurate data which would permit the court to draw the right conclusion." "64

64230 U. S. 352,57 L. Fd. 1511, 33 Sup. Ct. 729. 
To summarize then, forty years have transferred from the opinions of state legislatures to the judgment of the courts the test of the reasonableness of railroad rates. In the Granger cases the court denied its authority to interfere with the action of the legislatures in fixing local rates even where the rates were so low as to destroy all profits. After a number of cases, with strong dissenting opinions, after various adverse dicta this doctrine was fully repudiated in the case of Chicago, Milwaukee \& St. Paul Railroad Co. v. Minnesota, decided in $1889 .{ }^{65}$ From the date of that decision until the case of Covington, etc., Turnpike Co. v. Sandford, in 1896 , the court went no farther than to declare that the rates fixed by legislatures must be sufficiently high to afford some income above operating expenses. ${ }^{66}$ Then in the case of Smyth v. Ames, the court undertook to more specifically indicate what might be considered a sufficient net profit to render valid a tariff of rates determined by legislative action. ${ }^{67}$ In I90I in Cotting v. Kansas City Stock Yards Co., the court specifically declared that rates yielding a profit of I I per cent. on the investment were not unreasonable but that rates which would reduce this profit to 5.3 per cent. were unconstitutional. ${ }^{63}$ The Minnesota Rate Cases unqualifiedly sustain these latter decisions and place on a solid foundation the doctrine of judicial review as to the reasonableness of all rate legislation.

The doctrine was thus laid down in the very earliest decisions that the states had full and plenary power to control intrastate traffic and with limtiations as to their reasonableness to fix maximum rates for intrastate transportation, provided only that such action did not interfere directly with interstate commerce whose control was vested by the Constitution in the national Congress. The validity of state legislation along these lines was not defeated if it merely indirectly affected interstate commerce. ${ }^{69}$ But any direct effect that it might have upon interstate commerce rendered it unconstitutional.

65 I34 U. S. 418, 33 L. Ed. 970 , ro Sup. Ct. 462.

66164 U. S. 578,4 I L. Ed. 560,17 Sup. Ct. 198.

67169 U. S. 466,42 L. Ed. 819 , 18 Sup. Ct. 418.

68 183 U. S. 79, 46 L. Ed. 92,22 Sup. Ct. 30.

69 See Field v. Barber Asphalt Co., 194 U. S. 618, 48 L. Ed. 1142, 24 Sup. Ct. 784, where the court said: "It is only direct interferences with the freedom of such commerce (interstate) that bring the case within the exclusive domain of Federal legislation." 
The first serious effort towards railway regulation in the United States had been the Granger movement in the early seventies. This revolved about the fixing of rates either absolute or maximum and as to purely intrastate business was sustained by the Supreme Court in the long line of decisions which have been cited. But in these decisions it was unqualifiedly maintained that it was not within the power of the states to regulate the conduct of carriers for the benefit of interstate travelers and shippers. The Supreme Court finally declared that with respect to interstate traffic the state could exercise no control even over that part of the hat1 entirely within the state, since that authority had been bestowed tupon Congress by the commerce clause of the Constitution. This was the decision in the celebrated case of Wabash, St. Louis \& Pacific Railway Co. v. Illinois, which became a monument in the history of railway regulation. ${ }^{70}$ This was the culmination of a series of cases asserting the independence of all interstate commerce of state legislation even as to that part of the business which might be wholly within the state. The court had under consideration a statute of the State of Illinois providing a penalty on the ground of unjust descrimination in any case where a railroad company should, within the state, charge or receive for transporting passengers or freight of the same class, the same or a greater sum for a short distance than it did for a longer distance. The defendant in the case at bar had charged more for transporting the same class of goods from Gilman, Illinois, to New York than from Peoria to New York, although Gilman was eightysix miles nearer New York, the difference being in the length of the line within Illinois. The court held that the statute must be construed to include a transportation of goods under one contract and by one voyage from the interior of the State of Illinois to New York and that such a transportation is "commerce among the states," even as to that part of the voyage which lies within the State of Illinois, although it was not denied that there might be a transportation of goods which is begun and ended within its limits, and disconnected with any carriage outside of the state, which is not commerce among the states. The court therefore held that a statute of a state intended to regulate or to impose any restriction upon the transmission of property or persons or telegraphic messages from one state to another is void even as to

70 118 U. S. 557,30 L. Ed. 244,7 Sup. Ct. 4. 
that part of such transmission which may be within the state. Speaking through Mr. Justice Miller, the court said:

"If the Illinois statute could be construed to apply exclusively to contracts for a carriage which begins and ends within the state, disconnected from a continuous transportation through or into other states, there does not seem to be any difficulty in holding it to be valid. $* * *$ The reason for this is that both the charge and the actual transportation in such cases are exclusively confined to the limits of the territory of the state, and is not commerce among the states, or interstate commerce, but is exclusively commerce within the state. So far, therefore, as this class of transportation, as an element of commerce, is affected by the statute under consideration, it is not subject to the constitutional provision concerning commerce among the states. It has often been held in this court, and there can be no doubt about it, that there is a commerce wholly within the state which is not subject to the constitutional provision, and the distinction between commerce among the states and the other class of commerce between the citizens of a single state, and conducted within its limits exclusively, is one which has been fully recognized in this court, although it may not be always easy, where the lines of these classes approach each other, to distinguish between the one and the other.

"It is not the railroads themselves, that are regulated by this Act of the Illinois legislature so much as the charge for transportation, and if each one of the states through whose territories these goods are transported can fix its own rules for prices, for modes of transit, for times and modes of delivery, and all the other incidents of transportation to which the word 'regulation' can be applied, it is readily seen that the embarrassments upon interstate transportation, as an element of interstate commerce, might be too oppressive to be submitted to. * * * It cannot be too strongly insisted upon that the right of continuous transportation from one end of the country to the other is essential in modern times to that freedom of commerce from the restraints which the state might choose to impose upon it, that the commerce clause was intended to secure. This clause, giving to Congress the power to regulate commerce among the states and with foreign nations, as this court has said before, was among the most important of the subjects which prompted the formation of the Constitution. Cook v. Pennsylvania, 97 U. S. 566, 574, 24 L. Ed. I015; Brown v. Maryland, I2 Wheat. 419, 446, 6 L. Ed. 678. And it would be a very feeble and almost useless provision, but poorly adapted to secure the entire freeedom of commerce among 
the states which was deemed essential to a more perfect union by the framers of the Constitution, if, at every stage of the transportation of goods and chattels through the country, the state within whose limits a part of this transportation must be done could impose regulations concerning the price, compensation, or taxation, or any other restrictive regulation interfering with and seriously embarrassing this commerce.

"We must therefore hold that it is not, and never has been, the deliberate opinion of a majority of this court that a statute of a state which attempts to regulate the fares and charges by railroad companies within its limits, for a transportation which constitutes a part of commerce among the states, is a valid law.

"Of the justice or propriety of the principle which lies at the foundation of the Illinois statute it is not the province of this court to speak. As restricted to a transportation which begins and ends within the limits of the state it may be very just and equitable, and it certainly is the province of the state legislature to determine that question. But when it is attempted to apply to transportation through an entire series of states a principle of this kind, and each one of the states shall attempt to establish its own rates of transportation, its own methods to prevent discrimination in rates, or to permit it, the deleterious influence upon the freedom of commerce among the states and upon the transit of goods through those states cannot be overestimated. 'That this species of regulation is one which must be, if established at all, of a general and national character, and cannot be safely and wisely remitted to local rules and local regulations, we think is clear from what has already been said. And if it be a regulation of commerce, as we think we have demonstrated it is, and as the Illinois court concedes it to be, it must be of that national character, and the regulation can only appropriately exist by general rules and principles, which demand that it should be done by the Congress of the United States under the commerce clause of the Constitution."

The Wabash case demonstrated clearly the necessity for Federal legislation on the question. With the constantly increasing incorporation of separate roads into great systems stretching thousands of miles, the combinations of these systems through associations, the suppression of competition through pooling, rate agreements, and otherwise, and the rapidly growing disposition of the roads to favor large and powerful shippers to the disadvantage of the smaller ones, there arose a general and increasing demand for relief against the cvil effects of unjust rates and discrimina- 
tion. This demand had been given a fresh impetus by the decision in this case. And Congress responded in the enactment of the Cullon-Reagan Bill, approved February 4, I887, and now generally known as the Interstate Commerce Act.

By the very nature of things this Act was largely tentative and experimental although it was based upon most exhaustive examination and investigation. Generally speaking the fundamental principles written into the statutes by this Act were that rates, regulations and practices affecting interstate traffic should be just and reasonable and also free from undue and improper discriminations. These general principles having been declared the law undertook to provide proper machinery for giving effect to these substantive requirements.

While the Interstate Commerce Act as passed in 1887 denounced rebates and unjust discriminations it prescribed penalties only against carriers for granting rebates. No penalty was provided for shippers who might seek or accept such unlawful concessions. Two years later the Act was amended so as to provide penalties against shippers also. Shippers then refused to testify before the Interstate Commerce Conmission concerning discriminations by railroads, invoking the doctrine of constitutional protection against self-incrimination, although the Act had declared that while a witness should not be excused under such circumstances from testifying his testimony should not be employed against him in any criminal prosecution. Congress then passed another amendatory Act in I893, protecting a witness altogether from prosecution on account of any matter about which he should be required to testify. In 1897 an important decision of the Supreme Court declared that the Commission was not empowered to prescribe a future rate, no matter how unreasonable the existing rate might be deemed. ${ }^{71}$

However, in its essentials the Interstate Commerce Act was not enlarged until the passage of the Elkins Act of 1903. By that law the scope of the original Act was extended and several new features were added. This bill was based upon the results of a general investigation by the Commission which revealed wholesale rebating on important shipments, despite the efforts of that body through the courts to enjoin carriers engaged in such prac-

71 Interstate Commerce Commission v. Alabama Midland Railway Co., I68 U. S. I44, 42 L. Ed. 414, 18 Sup. Ct. 45. 
tices. The Elkins Act strengthened the law by specifically authorizing such injunctions and prescribing increased penalties for discriminations and departures from the published tariffs of rates. Under the original law the courts had held that a corporation was not indictable and that proof of a departure from published tariffs did not establish an offense as it did not prove discrimination in itself-since the shippers might have been given the same unpublished or secret rates without inequality.

A series of exposures and investigations disclosed the most intimate relations between the railroads and the producers of such commodities as coal and oil, revealed the most extensive and flagrant discriminations and rebates, and the violation of the spirit of the Interstate Commerce Act through the medium of private-car lines. As a result thereof Congress passed the socalled Hepburn Bill, approved June 29, 1906. This Act increased in many respects the power of the Interstate Conmerce Commission to regulate interstate commerce and conferred upon it at1thority upon complaint and proper hearings to prescribe for the future just and reasonable rates and regulations in place of those which might be found unjust and unreasonable. It defined transportation so as to include refrigeration, ventilation, elevation and other similar services which had hitherto not been regarded as a part of transportation, and conferred upon the Commission jurisdiction over pipe lines, and sleeping car and express companies. This Act contained likewise the so-called Commodities Clause forbidding railroads to carry any commodity, other than timber and its manufactures, in which they had a financial interest except only so much as miglit be intended and necessary for their own use. This feature of the Act was aimed at those railroads which owned and operated coal mines and oil fields and the discriminations which had been practiced by them under cover of such ownership.

The Mann Act, approved June I8, 1910, created the Commerce Court conferring upon it the general jurisdiction theretofore enjoyed by the United States Circuit Courts with reference to orders of the Interstate Commerce Conmission. It also empowered the Commission to suspend the operation of tariffs providing for increased rates subject to investigation to determine their reasonableness and propriety. This provision was a recognition of the necessity for the injunction of transportation wrongs before they should be committed, since complete reparation for damages 
for injuries already suffered is manifestly impossible. Jurisdiction and authority over telegraph and telephone lines were conferred upon the Commission which was empowered to make suitable orders in the same manner as if formal complaint had been made by shippers. The powers of the Commission were also increased over the establishment of joint rates and through routes.

The Act of March I, I9I3, provided for the physical valuation of railroad properties and the Act of October 22, 1913, abolished the recently formed Commerce Court. Other acts passed by Congress akin to the Act to Regulate Commerce have included legislation to promote the safety of employees and travelers upon interstate railroads by compelling interstate carriers to equip their cars with automatic couplers and brakes and their locomotives with driving wheel brakes, known as the Safety Appliance Law $; 2$ to require interstate carriers to report to the Interstate Commerce Commission each month all accidents upon their lines; to provide for the arbitration of disputes between employers and employees; to compel and regulate the inspection of boilers; to limit the hours of service of employees of interstate railroads; $;^{73}$ to prevent cruelty to animals while in transit by requiring that at stated intervals they be unloaded, fed, watered and rested. $^{74}$

72 These include the Acts of March 2, 1893, April I, 1896, and March 2, 1903. See among others St. Louis, Iron Mountain, etc. Ry. v. Taylor, 210 U. S. 281, 52 L. Ed. 1061, 28 Sup. Ct. 616; Johnson v. Southern Pacific Co., 196 U. S. 1, 49 L. Ed. 872, 25 Sup. Ct. 158; Schlemmer v. Buffalo, R. \& P. Ry., 205 U. S. I, 5I L. Ed. 68I, 27 Sup. Ct. 407 ; Chicago Burlington \& Quincy Ry. v. United States, 220 U. S. 559. 55 L. Ed. 582, 3 I Sup. Ct. 612; Delk v. St. Louis \& San Francisco R. R., 220 U. S. 580, 55 L. Ed. 590, 31 Sup. Ct. 617; Schlemmer v. Buffalo, R. \& P. Ry., 220 U. S. 590, 55 L. Ed. 596, 3I Sup. Ct. 56I ; Southern Ry. v. United States, 222 U. S. 20, 56 L. Ed. 72, 32 Sup. Ct. 2; Brinkmeier v. Missouri Pacific Ry., 224 U. S. 268, 56 L. Ed. 758, 32 Sup. Ct. 412 ; Chicago, R. I. \& Pac. Ry. v. Brown, 229 U. S. 317,57 L. Ed. 204. 33 Sup. Ct. 840 . Southern Ry. Co. v. Indiana R. R. Commission, decided Feb. 23, 1915.

73 Act of March 4, I907. See among others: Baltimore and Ohio R. R. v. Interstate Commerce Commission, 22I U. S. 6I2, 55 L. Ed. 878, 3I Sup. Ct. 62I ; United States v. Atchison, Topeka and Santa Fe Ry., 220 U. S. 37, 55 L. Ed. 36r, 31 Sup. Ct. 362; St. Louis, Iron Mountain, etc. Ry. v. McWhirter, 229 U. S. 265, 57 L. Ed. I179, 33 Sup. Ct. 858; Missouri, K. \& T. Ry. v. United States, 23 I U. S. I12, 58 L. Ed. I44, 34 Sup. Ct. 26; Erie Railroad Co, v. Williams, 233 U. S. 685, 58 L. Ed. I 155, 34 Sup. Ct. 76 r.

74 The Act of June 29, 1906. See Baltimore and Ohio Southwestern Railroad v. United States, 220 U. S. 94,55 L. Ed. 384, 3I Sup. Ct. 368. 
Other legislation includes the Employers' Liability Act, ${ }^{75}$ and the Mann White Slave Act to prevent the interstate transportation of women for immoral and illicit purposes. ${ }^{76}$

In this connection it may not be amiss to call attention to the anomaly of the Interstate Commerce Commission as an institution under our theory of government. The delegation to the Commission of the power to regulate commerce by controlling interstate rates, while not considered by the courts a delegation of legislative power, undoubtedly is closely related to the legislative power. The right vested in the Commission to determine the reasonableness of existing rates makes it a judicial body. Its authority to see that the Act to regulate commerce is enforced makes it to that extent an executive body. The Commission therefore in its different functions combines the legislative, judicial and executive, which under our scheme of government are intended to be separate and distinct.

Apart from the Act to Regulate Commerce and the kindred Acts already enumerated Congress has enacted much legislation

75 Howard v. Illinois Central Railroad, 207 U. S. 463, 52 L. Ed. 297 , 28 Sup. Ct. 14I, declaring unconstitutional the Employers Liability Act of July I1, 1906. The subsequent Act of April 22, 1908, amended April 5, I9I0, was declared constitutional in Mondou v. New York, New Haven and Hartford Railroad Co., 223 U. S. I, 56 L. Ed. 327, 32 Sup. Ct. I69. See also: Missouri Pacific Railway Co. v. Castle, 224 U. S. 54I, 56 L. Ed. 875. 32 Sup. Ct. 60I; Philadelphia, Baltimore \& Washington R. R. v. Schubert, 224 U. S. 603,56 L. Ed. 911,32 Sup. Ct. 589; Gulf, Colorado \& S. F. Ry. v. McGinnis, 228 U. S. 173,57 L. Ed. 785, 33 Sup. Ct. 426; St. Louis, Iron Mountain, etc. Ry. v. Hesterly, 228 U. S. 702, 57 L. Ed. I03I, 33 Sup. Ct. 703; Norfolk and Western Railway Co. v. Earnest, 229 U. S. II4, 57 L. Ed. 1096, 33 Sup. Ct. 654; Michigan Central R. R. v. Vreeland, 227 U. S. 59, 57 L. Ed. 417, 33 Sup. Ct. 192; North Carolina R. R. v. Zachary, 232 U. S. 248,58 L. Ed. 59I, 34 Sup. Ct. 305; Pederson v. Delaware, L. \& W. R. R., 229 U. S. 146, 57 L. Ed. I125, 33 Sup. Ct. 648; Seaboard Air Line v. Horton, 233 U. S. 492, 58 L. Ed. 1062, 34 Sup. Ct. 635; Illinois Central R. R. v. Behrens, 233 U. S. 473, 58 L. Ed. I05I, 34 Sup. Ct. 646; Grand Trunk Western Ry. v. Lindsay, 233 U. S. 42, 58 L. Ed. 838, 34 Sup. Ct. 58I ; Southern Ry. Co. v. Gadd, 233 U. S. 572, 58 L. Ed. 1099, 34 Sup. Ct. 696. Toledo, St. Louis \& Western R. R. Co. v. Slavin, decided Feb. 23, 1915 .

76 The Act of Junc 25, 1910. See also: Hoke v. United States, 227 U. S. 308,57 L. Ed. 523, 33 Sup. Ct. 28I ; Athanasaw v. United States, 227 U. S. 326,57 L. E.d. 528,33 Sup. Ct. 285 ; Bennett v. United States, 227 U. S. 333, 57 L. Ed. 531, 33 Sup. Ct. 288; Harris v. United States, 227 U. S. 340; Wilson v. United States, 232 U. S. 563, 58 L. Ed. 728, 34 Sup. Ct. 347; United States v. Holte, 236 U. S. 140. 
under the authority of the Commerce Clause of the Constitution. Most important of all was the Sherman Anti-Trust Act of July 2, 1890 , to prevent combinations in restraint of trade. ${ }^{77}$ This has been followed by the recent Federal Trade Commission Act and the Clayton Anti-Trust Act. Acts have also been passed to prevent the interstate transportation of obscene literature, lottery tickets, game killed in violation of state laws, dairy and food products and drugs falsely labeled or branded and to prevent the carriage of liquor into territory which under state laws prohibits its sale or consumption.

Interstate commerce has acquired a volume and importance never conceived by the authors of the Constitution. To-day interstate transactions comprise a very large proportion of the business of the country. Although the power to regulate commerce was granted chiefly as a means of protection against commercial hostilities and reprisals between the various states of the Union it remained practically dormant until comparatively recent years. It has, however, now come to be recognized as a most potent affirmative and constructive power constitutionally capable of effective development along many lines. Indeed it may be said to be the greatest power lodged in the national government, with almost unlimited possibilities of expansion in the constantly growing field of commercial and industrial intercourse. The latest decisions of the Supreme Court point to the conclusion that whenever the Federal authority is ready to undertake the entire regulation of transportation rates, it will have the power to do so, so closely interrelated are intrastate and interstate traffic. 'The signs point to a not distant date of unified control of the whole subject.

77 See among others: Minnesota v. Northern Securities Co., 194 U. S. 48, 48 L. Ed. 870, 24 Sup. Ct. 598; Harriman et al. v. Northern Securities Co., 197 U. S. 244, 49 L. Ed. 739, 25 Sup. Ct. 493; Standard Oil Co. v. United States, 22 I U. S. I. 55 L. Ed. 6I9, 3I Sup. Ct. 502; United States v. Reading Company, 226 U. S. 324, 57 L. Ed. 243, 33 Sup. Ct. 90. 


\section{The Act to Regulate Commerce}

Be it enacted by the Senate and House of Representatives of the United States of America in Congress assembled,

SEc. I. (As amended June 29, I9o6, April I3, Carriers and 1908, and June I8, 1910.) That the provisions of subject to the this Act shall apply to any corporation or any person
Act. or persons engaged in the transportation of oil or other commodity, except water and except natural or artificial gas, by means of pipe lines, or partly by pipe lines and partly by railroad, or partly by pipe Telegraph lines and partly by water, and to telegraph, teletelephone, and
cable compa-phone, and cable companies (whether wire or wirenies. less) engaged in sending messages from one State, Territory, or District of the United States, to any other State, Territory, or District of the United States, or to any foreign country, who shall be considered and held to be common carriers within the meaning and purpose of this Act, and to any common carrier or carriers engaged in the transportation of passengers or property wholly by railroad (or partly by railroad and partly by water when both are used under a common control, management, or arrangement for a continuous carriage or shipment), from one State or Territory of the United States or the District of Columbia to any other State or Territory of the United States or the District of Columbia, or from one place in a Territory to another place in the same Territory, or from any place in the United States to an adjacent foreign country, or from any place in the United States through a foreign country to any other place in the United States, and also to the transportation in like manner of property shipped from any place in the United States to a foreign country and carried from such place to a port of transshipment, or shipped from a foreign country to any place in the United States and carried to such 
Act does not apply to transportation wholly within one state.

place from a port of entry either in the Cnited States or an adjacent foreign country: Provided, however, That the provisions of this Act shall not apply to the transportation of passengers or property, or to the receiving, delivering, storage, or handling. of property wholly within one State and not shipped to or from a foreign country from or to any State or Territory as aforesaid, nor shall they apply to the transmission of messages by telephone, telegraph, or cable wholly within one State and not transmitted to or from a foreign country or to any S.ate or Territory as aforesaid.

The Purpose of the Act.-In order to comprehend the significance and the spirit of this Act we must know something of the purposes which inspired Congress to its enactment and as well some of the conditions which had theretofore prevailed and which it was anticipated this legislation would remedy. Its meaning becomes clearer if the purposes which it sought to accomplish are borne in mind and if the discrepancies which had come to attend the operation of the railroads are considered. Before the passage of the Act to Regulate Commerce railway traffic in the United States was regulated only under the general principles of common law applicable to common carriers, which at best provided that the railroads should carry for all persons who desired to make shipments, that goods should be shipped in the order of their delivery at the particular station of their initiation, and that the charges for the service of transportation should be reasonable. Although the weight of authority in this country favored the rule that charges must be equal to all persons for the same services it was at least doubtful whether the railroads were bound to this course and whether they might not charge one person more than another for either a similar or exactly the same service. The evils which were naturally incident to a policy of unrestricted competition accumulated and suggested the necessity of some measure of legislative control. In the words of the Supreme Court, "these evils ordinarily took the shape of inequality of charges made, or of facilities furnished, and were usually dictated by or tolerated for the promotion of the interests of the officers of the corporation or of the corporation itself, or for the benefit of some favored persons at the expense of others, or of some par- 
ticular locality, or community, or of some local trade or commercial connection, or for the destruction or crippling of some rival or hostile line." 1 In many of the different states acts had been passed by the Legislatures for the purpose of preventing such unreasonable and unjust discriminations. The inefficiency of these laws beyond the confines of the states because of constitutional limitations, the manifest impossibility of securing concerted action by all legislatures toward the regulation of traffic between and among the various states, and the growing abuses in railroad management and railroad transportation, all combined to demonstrate the necessity for legislation by Congress to control the problem under its constitutional power to regulate commerce among the several states. Similar legislation had been meanwhile adopted by the English Parliament and the English act furnished the basis for our Interstate Commerce Act.

The history of the legislation, the language of the act, and the decisions of our own and the English courts, all show that the purpose of the act was to compel the railroads as common carriers and therefore as public agents to give equal treatment to all, to secure equality of rates for all shippers and to forbid undue and unreasonable preferences or discriminations and thus destroy favoritism, while at the same time seeking to prevent unjust and unreasonable rates. ${ }^{2}$ The various amendments to the Act have

I Interstate Commerce Commission v. Baltimore \& Ohio Railroad Co., I 45 U. S. 263, 36 L. Ed. 699, 12 Sup. Ct. 844.

2 In Interstate Commerce Commission v. Baltimore \& Ohio Railroad Co., I45 U. S. 263,36 L. Ed. 699, I2 Sup. Ct. 844, the Supreme Court said:- "The principal objects of the Interstate Commerce Act were to secure just and reasonable charges for transportation; to prohibit unjust discriminations in the rendition of like services under similar circumstances and conditions; to prevent undue or unreasonable preferences to persons, corporations or localities; to inhibit greater compensation for a shorter than for a longer distance over the same line; and to abolish combinations for the pooling of freights. It was not designed, however, to prevent competition between different roads, or to interfere with the customary arrangements made by railway companies for reduced fares in consideration of increased mileage, where such reduction did not operate as an unjust discrimination against other persons traveling over the road."

See also Armour Packing Co. v. United States, 209 U. S. 56, 52 L. Ed. 681, 28 Sup. Ct. 428; Interstate Commerce Commission v. Cincinnati, New Orleans \& Texas Pacific Railway, I67 U. S. 479, 42 L. Ed. 243, I7 Sup. Ct. 896; New York, New Haven \& Hartford Railroad Co. v. Inter- 
been adopted in furtherance of these same objects and for the purpose of remedying abuses which have developed in spite of the legislation intended to prevent them.

Intrastate Traffic Controlled by the States.-In the first place in matters of commerce which pertain only to the several states and whose operations are conducted within the confines of those states the Federal Constitution gives Congress no control or authority. In the field wherein the states are primarily concerned but where legislation or regulations may indirectly affect interstate commerce or communication between different states national legislation is supreme, but until such time as Congress does act the control remains vested in the states. The demand for federal legislation and the inspiration of the Act to Regulate Commerce of 1887 both arose from the fact that beyond the limits of state control there remained an enormous field of unregulated activity in the conduct of interstate transportation which could not otherwise be reached. In order, however, that there might be no question of the intended scope of its legislation and the regulation which it sought to enforce, Congress carefully defined the limitations of the act and expressly provided that it should not extend to purely intrastate traffic. This proviso of paragraph one of Section One thus declared the intention of Congress to exclude from the provisions of the act that transportation which is "wholly within one state," with the specified qualification where its subject was going to or coming from a foreign country or going to or coming from another state or territory. Thus the regulation and control of intrastate commerce and the fixing of rates for intrastate transportation were left by this act with the states and their agencies created to deal with the subject. ${ }^{3}$ Under the present

state Commerce Commission, 200 U. S. 36r, 50 L. Ed. 515, 26 Sup. Ct. 272; Southern Railway Co. v. Reid, 222 U. S. 424, 56 L. Ed. 257, 32 Sup. Ct. I40; Texas \& Pacific Railway Co. v. Interstate Commerce Commission, 162 U. S. 197, 40 L. Ed. 940, I6 Sup. Ct. 666.

3 Minnesota Rate Cases, 230 U. S. 352, 57 L. Ed. I5II, 33 Sup. Ct. 729. In the course of a lengthy and extremely comprehensive opinion, the court said:- "The general principles governing the exercise of state authority when interstate commerce is affected are well established. The power of Congress to regulate commerce among the several states is supreme and plenary. * * * The reservation to the states manifestly is only of that authority which is consistent with and not opposed to the (constitutional) grant to Congress. There is no room in our scheme of govern- 
highly developed system of transportation in the United States the interblending of operations renders it increasingly difficult to differentiate between interstate and intrastate traffic and, there-

ment for the assertion of state power in hostility to the authorized exercise of federal power. The authority of Congress extends to every part of interstate commerce and to every instrumentality or agency by which it is carried on; and the full control by Congress of the subjects committed to its regulation is not to be denied or thwarted by the commingling of interstate and intrastate operations. This is not to say that the nation may deal with the internal concerns of the state as such, but that the execution by Congress of its constitutional power to regulate interstate commerce is not limited by the fact that intrastate transactions may have become so interwoven therewith that the effective government of the former incidentally controls the latter. This conclusion necessarily results from the supremacy of the national power within its appointed sphere. ***

"It is manifest that when the legislation of the state is limited to internal commerce to such degree that it does not include even incidentally the subjects of interstate commerce, it is not rendered invalid because it may affect the latter commerce indirectly. In the intimacy of commercial relations, much that is done in the superintendence of local matters may have an indirect bearing upon interstate commerce. *** If this authority of the state be restricted it must be by virtue of the paramount power of Congress over interstate commerce and its instruments, and, in view of the nature of the subject, a limitation may not be implied because of a dormant federal power-that is, one which has not been exerted, but can only be found in the actual exercise of federal control in such measure as to exclude this action by the state which otherwise would clearly be within its province.

"When Congress, in the year 1887, enacted the Act to Regulate Commerce (24 Stat. 379), it was acquainted with the course of the development of railroad transportation and with the exercise by the states of the rate-making power. *** Congress carefully defined the scope of its regulation, and expressly provided that it was not to extend to purely intrastate traffic. In the first section of the Act to Regulate Commerce there was inserted the following proviso:

"'Provided, however, That the provisions of this Act shall not apply to the transportation of passengers or property, or to the receiving, delivering, storage, or handling of property, wholly within one state, and not shipped to or from a foreign country from or to any state or territory as aforesaid.'

"When in the year 1906 (Act of June 29, 1906, ch. 3591, 34 Stat. 584), Congress amended the Act so as to confer upon the Federal Commission power to prescribe maximum interstate rates, the proviso in section I was re-cnacted. Again in 1910, when the act was extended to embrace telegraph, telephone, and cable companies engaged in interstate business, the proviso was once more re-enacted, with an additional clause, so as to 
fore, more and more perplexing to legislate concerning one class of traffic without imposing restrictions or regulations upon the other class.

exclude intrastate messages from the operation of the statute. (Act of June 18 , I910, ch. 309,36 Stat. 545 .) ***

"There was thus excluded from the provisions of the act that transportation which was 'wholly within one state,' with the specified qualification where its subject was going to or coming from a foreign country.

***

"The question we have now before us, essentially, is whether after the passage of the Interstate Commerce Act, and its amendment, the state continued to possess the state-wide authority which it formerly enjoyed to prescribe reasonable rates for its exclusively internal traffic. That, as it plainly appears, was the nature of the action taken by Minnesota, and the attack, however phrased, upon the rates here involved as an interference with interstate commerce, is in substance a denial of that authority.

"Having regard to the terms of the federal statute, the familiar range of state action at the time it was enacted, the continued exercise of state authority in the same manner and to the same extent after its enactment, and the decisions of this court recognizing and upholding this authority, we find no foundation for the proposition that the act to regulate commerce contemplated interference therewith.

"Congress did not undertake to say that the intrastate rates of interstate carriers should be reasonable or to invest its administrative agency with authority to determine their reasonableness. Neither by the original Act nor by its amendment did Congress seek to establish a unified control over interstate and intrastate rates; it did not set up a standard for intrastate rates, or prescribe, or authorize the Commission to prescribe either nuaximum or minimum rates for intrastate traffic. It can not be supposed that Congress sought to accomplish by indirection that which it expressly disclaimed, or attempted to override the accustomed authority of the states without the provision of a substitute. On the contrary, the fixing of reasonable rates for intrastate transportation was left where it had been found; that is. with the states and the agencies created by the states to deal with that subject. (Mis:ouri Pacific Railway Co. $v$. Larabee Mills, 211 U. S. 612, 620, 621, 53 L. Ed. 352, 29 Sup. Ct. 2I4.)

"How clear was the purpose not to occupy the field thus left to the exercise of state power is shown by the clause uniformly inserted in the numerous Acts passed by Congress to authorize the construction of railways across the Indian Territory.

"The decisions of this court since the passage of the Act to Regulate Commerce have uniformly recognized that it was competent for the state to fix such rates, applicable throughout its territory. If it be said that in the contests that have been waged over state laws during the past twenty. five years the question of interference with interstate commerce by the establishment of state-wide rates for intrastate traffic has seldom been 
The proviso of the first paragraph of Section One relating to traffic wholly within one state has been amended from its original form in but one particular. By the Act of June 18, 1910, the Act

raised, this fact itself attests the common conception of the scope of state authority. And the decisions recognizing and defining the state power wholly refute the contention that the making of such rates either constitutes a direct burden upon interstate commerce or is repugnant to the federal statute. ***

"To suppose, however, from a review of these decisions, that the exercise of this acknowledged power of the state may be permitted to create an irreconciliable conflict with the authority of the nation, or that through an equipoise of powers an effective control of interstate commerce is rendered impossible, is to overlook the dominant operation of the Constitution which, creating a nation, equipped it with an authority, supreme and plenary, to control national commerce and to prevent that control, exercised in the wisdom of Congress, from being obstructed or destroyed by any opposing action. But, as we said at the outset, our system of government is a practical adjustment by which the national authority as conferred by the Constitution is maintained in its full scope without unnecessary loss of local efficiency. It thus clearly appears that, under the established principles governing state action, the state of Minnesota did not transcend the limits of its authority in prescribing the rates here involved, assuming them to be reasonable intrastate rates. It exercised an authority appropriate to its territorial jurisdiction and not opposed to any action thus far taken by Congress.

"The interblending of operations in the conduct of interstate and local business by interstate carriers is strongly pressed upon our attention. It is urged that the same right of way, terminals, rails, bridges, and stations are provided for both classes of traffic; that the proportion of each sort of business varies from year to year and indeed from day to day; that no division of the plant, no apportionment of it between interstate and local traffic, can be made to-day which will hold to-morrow; that terminals, facilities and connections in one state aid the carrier's entire business and are an element of value with respect to the whole property and the business in other states; that securities are issued against the entire line of the carrier and can not be divided by states; that tariffs should be made with a view to all the traffic of the road and should be fair as between through and short-haul business; and that, in substance, no regulation of rates can be just which does not take into consideration the whole ficld of the carrier's operations, irrespective of state lines. The force of these contentions is emphasized in these cases, and in others of like nature, by the extreme difficulty and intracacy of the calculations which must be made in the effort to establish a segregation of intrastate business for the purpose of determining the return to which the carrier is properly entitled therefrom.

"But these considerations are for the practical judgment of Congress in determining the extent of the regulation necessary under existing con- 
to Regulate Commerce was extended to embrace telegraph, telephone and cable companies engaged in interstate business and a clause was added to the proviso so as to exclude intrastate messages from the operation of the statute. ${ }^{4}$

While cases are easily conceived wherein there can be no possible question of identification of commerce as either intrastate or

ditions of transportation to conserve and promote the interests of interstate commerce. If the situation has become such, by reason of the interblending of the interstate and intrastate operations of interstate carriers, that adequate regulation of their interstate rates cannot be maintained without imposing requirements with respect to their intrastate rates which substantially affect the former, it is for Congress to determine, within the limits of its constitutional authority over interstate commerce and its instruments the measure of the regulation it should supply. It is the function of this court to interpret and apply the law already enacted, but not under the guise of construction to provide a more comprehensive scheme of regulation than Congress has decided upon. Nor, in the absence of federal action, may we deny effect to the laws of the state enacted within the field which it is entitled to occupy until its authority is limited through the exertion by Congress of its paramount constitutional power."

See also Missouri Pacific Railway v. Larabee Flour Mills, 2 I I U. S. 612, 53 L. Ed. 352, 29 Sup. Ct. 2I4, where the court said:- "The roads are therefore engaged in both interstate commerce and that within the state. In the former they are subject to the regulation of Congress; in the latter to that of the state, and to enforce the proper relation between Congress and the state the full control of each over the commerce subject to its dominion must be preserved. Fairbank v. United States, I $8 \mathrm{r}$ U. S. 283. 45 L. Ed. 862, 2I Sup. Ct. 648. How the separateness of control is to be accomplished it is unnecessary to determine. Its existence is recognized in the first section of the Interstate Commerce Act of February 4, I887.

4 The proviso in question was a part of the Act to Regulate Commetce as originally enacted February 4, I887; it was re-enacted June 29, 1906, ch. $359 \mathrm{I}, 34$ Stat. 584, when Congress amended the act so as to confer upon the Federal Commission power to prescribe maximum interstate rates; again in 1910 when the Act was extended to embrace telegraph, telephone and cable companies engaged in interstate business, the proviso was once more re-enacted with an additional clause so as to exclude intrastate messages from the operation of the statute (Act of June I8, I9ro, ch. 309,36 Stat. 545). This amendment consisted of adding the following clause to the proviso as before enacted:-

"Nor shall they apply to the transmission of messages by telephone, telegraph, or cable wholly within one state and not transmitted to or from a foreign country from or to any state or territory as aforesaid." 
interstate the fact remains that in the present highly developed and extremely complex state of industrial life and transportation in the United States it is either very difficult or entirely impossible to differentiate between commerce which is interstate and that which is intrastate. A train made up of cars running merely between two points within the same state and loaded with goods shipped from one point to the other is of course engaged purely and entirely in intrastate commerce and therefore subject only to the laws and regulations of the state in question. On the other hand a train made up of cars some of which come from points without the state to points within the state, others from a point in the state to a point out of the state and still others being carried from one town to another town both in the state is engaged in both interstate and intrastate commerce. Both classes of traffic are frequently loaded in the same car and even when they are carried in separate cars these cars are a part of the same train and are moved under equal or similar circumstances at terminals, switch yards, etc. With rare exceptions cars are used interchangeably for both classes of traffic and are seldom set apart to be used entirely either for traffic within the state or traffic destined for outside of the state. Both classes of cars are operated by the same train crews-the same locomotives driven by the same firemen and engineers, with the same conductors, brakemen, flagmen, etc. They are run over the same tracks, across the same bridges and through the same tunnels. In brief they are interdependent. In this connection it must be remembered that while Congress has no power to regulate intrastate commerce as such, its power to regulate interstate commerce is plenary. ${ }^{5}$

5 Southern Railway Company v. United States, 222 U. S. 20, 56 L. Ed. 72, 32 Sup. Ct. 2. Here the court said:- "Speaking only of railroads which are highways of both interstate and intrastate commerce, these things are of common knowledge: Both classes of traffic are at times carried in the same car and when this is not the case the cars in which they are carried are frequently commingled in the same train and in the switching and other movements at terminals. Cars are seldom set apart for exclusive use in moving either class of traffic, but generally are used interchangeably in moving both; and the situation is much the same with trainmen, switchmen and like employees, for they usually, if not necessarily, have to do with both classes of traffic."

In the Minnesota Rate Cases, 230 U. S. 352, 57 L. Ed. I5I I, 33 Sup. Ct. 729, Justice Hughes said:- "The interblending of operations in the conduct of interstate and local business by interstate carriers is strongly 
But where purely intrastate rates between points within the same state when taken in conjunction with interstate rates produce discriminations and thus affect interstate traffic Congress may directly or through its proper agency exercise a control over such intrastate rates. ${ }^{6}$ Congress possesses the power to protect

pressed upon our attention. It is urged that the same right of way, terminals, railroad bridges, and stations are provided for both classes of traffic; that the proportion of each sort of business varies from year to year, and, indeed, from day to day; that no division of the plant, no apportionment of it between interstate and local traffic, can be made to-day which will hold to-morrow; that terminals, facilities and connections in one state aid the carrier's entire business and are an element of value with respect to the whole property and the business in other states; that cecurities are issued against the entire line of the carrier and cannot be divided by states."

6 Houston, East and West Texas Railway Co. $v$. United States (The Shreveport Case), 234 U. S. 342,58 L. Ed. 1341, 34 Sup. Ct. 833 . Hero intrastate rates between points in the state of Texas as fixed by the Texas Railroad Commission were much smaller than those charged for interstate traffic from points in Louisiana to points in Texas of the same distance and such intrastate rates produced discriminations in violation of the third section of the act to regulate commerce. The Interstate Commerce Commission directed the carriers to desist from charging higher rates for the transportation of any commodity from Shreveport to Dallas and Houston respectively, and intermediate points, than were contemporaneously charged for the carriage of such commodity from Dallas and Houston toward Shreveport for equal distances. as the commission found that relation of rates to be reasonable. The Supreme Court said:- "The point of the objection to the order is that, as the discrimination found by the commission to be unjust arises out of the relation of intrastate rates. maintained under state authority, to interstate rates that have been upheld as reasonable, its correction was beyond the commission's power. Manifestily the order might be complied with, and the discrimination avoided, either by reducing the interstate rates from Shreveport to the level of the competing intrastate rates, or by raising these intrastate rates to the level of the interstate rates, or by such reduction in the one case and increase in the other as would result in equality. But it is urged that, so far as the interstate rates were sustained by the commission as reasonable. the commission was without authority to compel their reduction in order to equalize them with the lower intrastate rates. The holding of the commerce court was that the order relieved the appellants from further obligation to observe the intrastate rates and that they were at liberty to comply with the commission's requirements by increasing these rates sufficiently to remove the forbidden discrimination. The in. validity of the order in this respect is challenged upon two grounds:

(I) That Congress is impotent to control the intrastate charges of an 
interstate commerce from destruction or injury by local or state governments and it may therefore control the intrastate charges of an interstate carrier whenever that becomes necessary to prevent discrimination against interstate traffic. The following language of the Supreme Court in the Shreveport Case is particularly pertinent:- "Wherever the interstate and intrastate transactions of carriers are so related that the government of the one involves the control of the other, it is Congress, and not the State, that is

interstate carrier even to the extent necessary to prevent injurious discrimination against interstate traffic; and

(2) That, if it be assumed that Congress has this power, still it has not been exercised, and hence the action of the commission exceded the limits of the authority which has been conferred upon it.

"First. It is unnecessary to repeat what has frequently been said by this court with respect to the complete and paramount character of the power confided to Congress to regulate commerce among the several states. It is of the essence of this power that, where it exists, it dominates. Interstate trade was not left to be destroyed or impeded by the rivalries of local governments.

"Congress is empowered to regulate-that is, to provide the law for the government of interstate commerce; to enact 'all appropriate legislation' for its 'protection and advancement' (The Daniel Ball, Io Wall. 557, 564, 19 L. Ed. 999); to adopt measures 'to promote its growth and insure its safety' (County of Mobile v. Kimball, I02 U. S. 691, 26 L. Ed. 238) ; 'to foster, protect, control and restrain' (Second Employers' Liability Cases, 223 U. S. I, 56 L. Ed. 327,32 Sup. Ct. I69). Its authority extending to these interstate carriers as instruments of interstate commerce, necessarily embraces the right to control their operations in all matters having such a close and substantial relation to interstate traffic that the control is essential or appropriate to the security of that traffic, to the efficiency of the interstate service, and to the maintenance of conditions under which interstate commerce may be conducted upon fair terms and without molestation or hindrance. As it is competent for Congress to legislate to these ends, unquestionably it may seek their attainment by requiring that the agencies of interstate commerce shall not be used in such manner as to cripple, retard or destroy it. The fact that carriers are instruments of intrastate commerce, as well as of interstate commerce, does not derogate from the complete and paramount authority of Congress over the latter or preclude the federal power from being exerted to prevent the intrastate operations of such carriers from being made a means of injury to that which has been confided to federal care. Wherever the interstate and intrastate transactions of carriers are so related that the government of the one involves the control of the other, it is Congress and not the state, that is entitled to prescribe the final and dominant rule, for otherwise Congress would be denied the exercise of its constitutional authority and the state, and not the nation, would be su- 
entitled to prescribe the final and dominant rule, for otherwise Congress would be denied the exercise of its constitutional authority and the State, and not the Nation, would be supreme within the national field. $* * *$ This is not to say that Congress possesses the authority to regulate the internal commerce of a State, as such, but that it does possess the power to foster and protect interstate commerce, and to take all measures necessary or ap-

preme within the national field. Baltimore \& Ohio Railroad Co. v. Interstate Commerce Commission, 221 U. S. 612, 618, 55 L. Ed. 878, 31 Sup. Ct. 621; Southern Railway Co. v. Linited States, 222 L. S. 20, 26, 27, 56 L. Ed. 72,32 Sup. Ct. 2 ; Second Employers' Liability Cases, supra, pp. 48, 5I ; Interstate Commerce Commission v. Goodrich Transit Co., 224 U. S. 194, 205, 213. 56 L. Ed. 729, 32 Sup. Ct. 436: Minnesota Rate Cases, 230 U. S. 352, 431. 57 L. Ed. 1511, 33 Sup. Ct. 729; Illinois Central Railroad Co. v. Behrens, 233 Č. S. 473.58 L. Ed. 105I, 34 Sup. Ct. 646. ***

"While these decisions sustaining the federal power relate to measures adopted in the interest of the safety of persons and property, they illustrate the principle that Congress in the exercise of its paramount power may prevent the common instrumentalities of interstate and intrastate commercial intercourse from being used in their intrastate operations to the injury of interstate commerce. This is not to say that Congress possesses the authority to regulate the internal commerce of a state, as such, but that it does possess the power to foster and protect interstate commerce, and to take all measures necessary or appropriate to that end although intrastate transactions of interstate carriers may thereby be controlled.

"This principle is applicable here. We find no reason to doubt that Congress is entitled to keep the highways of interstate communication open to interstate traffic upon fair and equal tcrms. That an unjust discrimination in the rates of a common carricr. by which one person or locality is unduly farored as against another under substantially similar conditions of traffic, constitutes an evil is undeniable; and where this evil consists in the action of an interstate carrier in unreasonably discriminating against interstate traffic orer its line, the authority of Congress to prevent it is equally clear. It is inmaterial, so far as the protecting power of Congress is concerned. that the discrimination arises from intrastate rates as compared with interstate rates. The use of the instrument of interstate commerce in a discriminatory manner so as to inflict injury upon that commerce, or some part thereof, furnishes abundant ground for federal intervention. Nor can the attempted exercise of state authority alter the matter, where Congress has acted, for a state may not authorize the carrier to do that which Congress is entitled to forbid and has forbidden. It is also to be noted-as the government has well said in its argument in support of the commission's order-that the power to deal with the relation between the two kinds of rates, as a relation, lies exclusively with Congress. It is manifest that the state cannot fix the 
propriate to that end, although intrastate transactions of interstate carriers may thereby be controlled. $* * *$ It is immaterial, so far as the protecting power of Congress is concerned, that the discrimination arises from intrastate rates as compared with interstate rates. The use of the instrument of interstate commerce in a discriminatory manner so as to inflict injury upon that commerce, or some part thereof. furnishes abundant ground for Federal intervention. *** Undoubtedly-in the absence of a

relation of the carrier's interstate and intrastate charges without directly interfering with the former, unless it simply follows the standard set by federal authority.

"It is for Congress to supply the needed correction where the relation between intrastate and interstate rates presents the evil to be corrected, and this it may do completely by reason of its control over the interstate carrier in all matters having such a close and substantial relation to interstate commerce that it is necessary or appropriate to exercise the control for the effective government of that commerce. It is also clear that, in removing the injurious discriminations against interstate traffic arising from the relation of intrastate to interstate rates, Congress is not bound to reduce the latter below what it may deem to be a proper standard fair to the carrier and to the public. Otherwise, it could prevent the injury to interstate commerce only by the sacrifice of its judgment as to interstate rates. Congress is entitled to maintain its own standard as to these rates and to forbid any discriminatory action by interstate carriers which will obstruct the freedom of movement of interstate traffic over their lines in accordance with the terms it establishes. Having this power, Congress could provide for its execution through the aid of a subordinate body; and we conclude that the order of the commission now in question cannot be held invalid upon the ground that it exceeded the authority which Congress could lawfully confer.

"The opposing argument rests upon the proviso in the first section of the act which in its original form was as follows:-'Provided, however, that the provisions of this Act shall not apply to the transportation of passengers or property, or to the receiving, delivering, storage or handling of property. wholly within one state, and not shipped to or from a foreign country from or to any state or territory as aforesaid.' * * * Congress thus defined the scope of its regulation and provided that it was not to extend to purely intrastate traffic. It did not undertake to authorize the commission to prescribe intrastate rates and thus to establish a unified control by the exercise of the rate-making power over both descriptions of traffic. Undoubtedly-in the absence of a finding by the commission of unjust discrimination-intrastate rates were left to be fixed by the carrier and subject to the authority of the states or of the agencies created by the states. This was the question recently decided by this court in the Minnesota Rate Cases, supra. * * * The present question, however, was reserved, the court saying (230 U. S., p. 
finding by the Commission of unjust discrimination-intrastate rates were left to be fixed by the carrier and subject to the authority of the States or of the agencies created by the States. * * * These words of the proviso have appropriate reference to exclusively intrastate traffic, separately considered; to the regulation of domestic commerce, as such. The powers conferred by the act are not thereby limited where interstate commerce itself is involved."

Traffic to be intrastate must not only originate and also terminate within the state but it must be at all times, during its shipment between these two points, within the state and under the jurisdiction of the state. For example, where commerce shipped from one point within a state to another point within the same state must go outside that state in order to reach the point designated it loses its character as intrastate traffic and by virtue of crossing the limits of the state becomes interstate traffic. In order that traffic may be within the control of a state, as intrastate

4I9):- 'It is urged, however, that the words of the proviso' (referring to the proviso above mentioned) 'are susceptible of a construction which would permit the provisions of section three of the act, prohibiting carriers from giving an undue or unreasonable preference or advantage to any locality, to apply to unreasonable discriminations between localities in different states, as well when arising from an intrastate rate as compared with an interstate rate as when due to interstate rates exclusively. If it be assumed that the statute should be so construed, and it is not necessary now to decide the point, it would ineritably follow that the controlling principle governing the enforcement of the act should be ap. plied to such cases as might thereby be brought within its purview; and the question whether the carrier, in such a case, was giving an undue or unreasonable preference or advantage to one locality as against another, or subjecting any locality to an undue or unreasonable prejudice or disadvantage, would be primarily for the investigation and determination of the Interstate Commerce Commission and not for the courts.'

"Here the commission expressly found that unjust discrimination existed under substantially similar conditions of transportation and the inquiry is whether the commission had power to correct it. We are of the opinion that the limitation of the proviso in section one does not apply to a case of this sort. The commission was dealing with the relation of rates injuriously affecting. through an unreasonable discrimination, traffic that was interstate. The question was thus not simply one of transportation that was 'wholly within one state.' These words of the proviso have appropriate reference to exclusively intrastate traffic, separately considered; to the regulation of domestic commerce, as such. The powers conferred by the act are not thereby limited where interstate 
or domestic traffic, the subject transported must be under the exclusive jurisdiction of the state throughout the entire voyage. ${ }^{7}$

commerce itself is involved. This is plainly the case when the commission finds that unjust discrimination against interstate trade arises from the relation of intrastate to interstate rates as maintained by a carrier subject to the act. Such a matter is one with which Congress alone is competent to deal, and, in view of the aim of the act and the comprehensive terms of the provisions against unjust discrimination, there is no ground for holding that the authority of Congress was unexercised and that the subject was thus left without governmental regulation."

7 Hanley v. "Kansas City Southern Railway Company, I87 U. S. 617, 47 L. Ed. 333, 23 Sup. Ct. 2r4. In this case the issue involved the right of the state railroad commissioners of the state of Arkansas to fix and enforce rates on a shipment of goods in a through bill of lading from Fort Smith, Arkansas, to Grannis, Arkansas, over the defendant's railroad by way of Spiro in the then Indian Territory. The distance by this route between Fort Smith and Grannis was II6 miles of which 52 miles was in Arkansas and the remaining 64 miles in the Indian Territory. The Supreme Court said:- "The transportation of these goods certainly went outside of Arkansas and we are of opinion that in its aspect of commerce it was not confined within the state. Suppose that the Indian Territory were a state and should try to regulate such traffic, what would stop it? Certainly not the fiction that the commerce was confined to Arkansas. If it could not interfere the only reason would be that this was commerce among the states. But if this commerce would have that character as against the state supposed to have been formed out of the Indian Territory, it would have it equally as against the state of Arkansas. If one could not regulate it the other could not.

"No one contends that the regulation could be split up according to the jurisdiction of state or territory over the track, or that both state and territory may regulate the whole rate. There can be but one rate fixed by one authority, whether that authority be Arkansas or Congress. Wabash, St. Louis and Pacific Railway Co. v. Illinois, I 8 U. S. 557, 30 L. Ed. 244, 7 Sup. Ct. 4 ; Covington and Cincinnati Bridge Co. v. Kentucky, I54 U. S. 204, 38 L. Ed. 962, I4 Sup. Ct. 1087; Hall v. De Cuir, 95 U. S. 485,24 L. Ed. 547. But it would be more logical to allow a division according to the jurisdiction over the track than to declare that the subject for regulation is indivisible, yet that the indivisibility does not depend upon the commerce being under the authority of Congress, but upon a fiction which attributes it wholly to Arkansas, although that fiction is quite beyond the power of Arkansas to enforce.

"It is decided that navigation on the high seas between ports of the same state is subject to regulation by Congress, Lord v. Steamship Company, I02 U. S. 54I, 26 L. Ed. 224, and is not subject to regulation by the state, Pacific Coast Steamship Company v. Railroad Commissioners, 9 Sawyer 253, and although it is argued that these decisions are not conclusive, the reason given by Mr. Justice Field for his decision in the last 
Police Power of the States.-Notwithstanding the exclusive nature of the power of Congress to control interstate commerce, the various states may, in exercise of what is termed their police power make reasonable rules and regulations with regard to the manner of carrying on interstate business within their borders. They may legislate concerning the precautions which shall be used to avoid danger, the facilities for the comfort of passengers and the safety and protection of freight carried, and, within reasonable limitations, they may regulate the towns at which trains shall stop. Naturally such regulations are void and inoperative if they directly burden interstate commerce and if they conflict with regulations upon the same subject enacted by the national Congress. They can be valid only when they indirectly affect interstate conmerce and when consistent with the general requirement that interstate commerce shall be free and unolsstructed. The power of the states is recognized over such incidental matters indirectly affecting interstate commerce as contribute to the safety, comfort and convenience of the patrons of the railroads. In the Minnesota Rate Cases, the Supreme Court has said:- "The legislation of the state safeguarding life and property and promoting comfort and convenience within its jurisdiction may extend incidentally to the operations of the carrier in the conduct of interstate business, provided it does not subject that business to unreasonable demands and is not opposed to Federal legislation."

cited case disposes equally of the case at bar. To bring the transportation within the control of the state, as part of its domestic commerce, the subject transported must be within the entire voyage under the exclusive jurisdiction of the state."

8 This subject of the police powers of the state as they affect interstate commerce is treated more in detail at pages 17 to 26 . See Minnesota Rate Cases, 230 U. S. 352, 57 L. Ed. I5I1, 33 Sup. Ct. 729. In Cleveland, Cincinnati, Chicago and St. Louis Railway Co. v. Illinois, 177 U. S. 514 , 44 L. Ed. 868, 20 Sup. Ct. 722, the court said :-

"Few classes of cases have become more common of recent years than those wherein the police power of the state over the vehicles of interstate commerce has been drawn in question. That such power exists and will be enforced, notwithstanding the constitutional authority of Congress to regulate such commerce, is evident from the large number of cases in which we have sustained the validity of local laws designed to secure the safety and comfort of passengers, employees, persons crossing railway tracks and adjacent property owners, as well as other regulations intended for the public good. 
Goods Shipped Between Points Within a State to be Transported to or from a Foreign Country.-Commerce takes its character as intrastate, interstate or foreign when it is actually started in the course of transportation,- - whether, as the case may be, it is to a point within the same state, to a point in another state, or to a point in a foreign country,-or when it is delivered to a carrier for transportation. ${ }^{9}$ This character it retains from the

"We have recently applied this doctrine to state laws requiring locomotive engineers to be examined and licensed by the state authorities (Smith v. Alabama, 124 U. S. 465,31 L. Ed. 508, 8 Sup. Ct. 564) ; requiring such engineers to be examined from time to time with respect to their ability to distinguish colors (Nashville, etc., Railway Co. v. Alabama, 128 U. S. 96, 32 L. Ed. 352, 9 Sup. Ct. 28) ; requiring telegraph companies to receive dispatches and to transmit and deliver them with due diligence, as applied to messages from outside the state (Western Union Tel. Co. v. James, I62 U. S. 650 , 40 L. Ed. I 105, I6 Sup. Ct. 934); forbidding the running of freight trains on Sunday (Hennington v. Georgia, I63 U. S. 299, 4 I L. Ed. I66, I6 Sup. Ct. I086); requiring railway companies to fix their rates annually for the transportation of passengers and freight, and also requiring them to post a printed copy of such rates at all their stations (Railway Co. v. Fuller, 17 Wall. 560. 21 L. Ed. 710) ; forbidding the consolidation of parallel or competing lines of railway (Louisville \& Nashville R. R. v. Kentucky, I6I U. S. 677, 40 L. Ed. 849, I6 Sup. Ct. 7I4); regulating the heating of passenger cars and directing guards and guard posts to be placed on railroad bridges and trestles and the approaches thereto (N. Y., N. H. \& H. R. R. v. New York, I65 U. S. 628, 4I L. Ed. 853 , I7 Sup. Ct. 418); providing that no contract shall exempt any railroad corporation from the liability of a common carrier or a carrier of passengers which would have existed if no contract had been made (Chicago, Milwaukee, etc., Railway Co. v. Solan, I69 U. S. 133, 42 L. Ed. 688, 18 Sup. Ct. 289; and declaring that when a common carrier accepts for transportation anything directed to a point of destination beyond the terminus of his own line or route he shall be deemed thereby to assume an obligation for its safe carriage to such point of destination, unless at the time of such acceptance such carrier be released or exempted from such liability by contract in writing, signed by the owner or his agent (Richmond \& Allegheny R. R. v. Patterson Tobacco Co., I69 U. S. 3II, 42 L. Ed. 759, I8 Sup. Ct. 335). In none of these cases was it thought that the regulations were unreasonable or operated in any just sense as a restriction upon interstate commerce."

See also Houston and Texas Railroad v. Mayes, 20I U. S. 321, $50 \mathrm{~L}$. Ed. 772, 26 Sup. Ct. 49I ; Mississippi Railroad Commission v. Illinois Central Railroad, 203 U. S. 335, 5I L. Ed. 209, 27 Sup. Ct. 90; Missouri Pacific Railway v. Larabee Flour Mills, 211 U. S. 612, 53 L. Ed. 352, 29 Sup. Ct. 2 I4.

9 Coe v. Errol, I16 U S. 5 17, 20 L. Ed. 715, 6 Sup. Ct. 475. 
beginning to the end of its transportation. The test of through billing is not necessarily determinative. The continuity of a shipment as a movement in intrastate or foreign commerce does not terminate with nor is its character affected by being transported on local bills of lading. In short it is the essential character of the commerce which determines the question of federal or state control, and not the mere accident or device, artificial in its nature, of local or through bills of lading. As the Supreme Court has said- "It is the nature of the traffic and not its accidents which determines its character." ${ }^{10}$ For example, commerce shipped on a local bill of lading from a point within a state to a seaport of the same state but intended for further foreign or export shipment is foreign commerce within the meaning and contemplation of the Interstate Commerce Act and the mere fact that it may be billed to an intrastate point and be again handled under the artifice of a separate shipment from such seaport, does not constitute this intrastate commerce so as to deprive the Interstate Commerce Commission of its jurisdiction over the shipment or so as to subject it to the control of state legislation or regulations. ${ }^{11}$

Io Texas and New Orleans Railroad Company $v$. Sabine Tram Co., 227 U. S. II 57 L. Ed. 442, 33 Sup. Ct. 229. In Illinois Central Railroad Co. v. De Fuentes (La. R. R. Com.), 236 U. S. 157, the Supreme Court said:"When freight actually starts in the course of transportation from one state to another it becomes a part of interstate commerce. The essential nature of the movement and not the form of the bill of lading determines the character of the commerce involved. And generally when this interstate character has been acquired it continues at least until the load reaches the point where the parties originally intended that the movement should finally end."

II Louisiana Railroad Commission v. Texas and Pacific Railway, 229 U. S. 336, 57 L. Ed. 1215, 33 Sup. Ct. 837. Here certain logs and staves were transported from various points within the state of Louisiana to the city of Alexandria and there delivered to the Texas and Pacific Railway which transported them to New Orleans to the consignees who were engaged in the business of exporting staves to foreign countries. The bills of lading provided for the delivery of the freight in question from the initial point to New Orleans to the order of the shipper or consignee. Despite this the staves and logs were intended by the shippers to be exported to foreign countries and were treated by the shippers and carriers accordingly. The shipments were in the physical custody of the railroad company until their arrival at New Orleans and thereafter in the physical custody of the steamships, which issued bills of lading therefor to the shippers of the cargo. The Louisiana Railroad Commission had promul- 
Where goods are shipped from a point in one state to a desig nated point in another state by way of a junction point in the second state and the second portion of the carriage-that between

gated certain rates or tariffs for all intrastate commerce and the question involved in the case was whether the shipments in dispute were intrastate and thus subject to such rates or whether they came under federal jurisdiction. After citing certain cases hereinafter quoted, the Supreme Court said:- "In those cases there was necessarily a local movement of freight, and it necessarily terminated at the seaboard. But it was decided that its character and continuity as a movement in foreign commerce did not terminate, nor was it affected by being transported on local bills of lading. The principle enunciated in the cases was that it is the essential character of the commerce, not the accident of local or through bills of lading which determines federal or state control over it. And it takes character as interstate or foreign commerce when it is actually started in the course of transportation to another state or to a foreign country. The facts of the case at bar bring it within the ruling. The staves and logs were intended by the shippers to be exported to foreign countries, and there was no interruption of their transportation to their destination except what was necessary for transshipment at New Orleans."

In Ohio Railroad Commission v. Worthington, 225 U. S. IoI, 56 L. Ed. 1087, 32 Sup. Ct. 653, coal was shipped from the Ohio mines to Huron, Ohio, where the Wheeling and Lake Erie Railroad owned large docks and unloading machinery for transferring coal from the cars to the lake vessels. The coal is marked "Lake Coal" and is consigned to the operator or some office employee as a matter of convenience in designating the grade of coal. The operator notified the railroad, according to the plan pursued, that at a certain time a vessel would be at Huron to load a certain number of tons of a particular grade of coal; the railroad then would pick up so many of the coal company's cars as were necessary to fill the cargo, moving them on to the dock by the side of the waiting vessel. The coal shipped at this lake-cargo rate would remain in the cars until unloaded into a vessel; and when the coal leaves the mines it is not known in what vessel it will be loaded nor to what particular ultimate destination it would go, the coal frequently being actually sold and vessels arranged for after the coal is at Huron. With inconsiderable exceptions, all the coal thus loaded in vessels was carried to points either in Canada or in other states than Ohio. The railroad charged a higher tariff for coal carried merely to Huron and to be distributed and consumed there. The lake-cargo rate also included, besides the transportation to Huron, placing it on vessels and trimming it for the continuance of its journey. Even the lake-cargo coal was carried to Huron on bills of lading to that point. The Ohio Railroad Commission contended that the shipment from the mines to Huron was an intrastate shipment, not within the power or control of the Act to Regulate Commerce or the Interstate Commerce Commission, and that it had the power to regulate the freight 
the junction point and the point of destination in that state-is entirely within a state and the shipment is charged a local rate for that portion of the carriage it is none the less, even as to this

tariffs to that point. The Supreme Court said:- "By every fair test the transportation of this coal from the mine to the upper lake ports is an interstate carriage, intended by the parties to be such, and the rate fixed by the (state) commission which is in controversy here is applicable alone to coal which is thus, from the beginning to the end of its transportation, in interstate carriage, and such rate is intended to and does cover an integral part of that carriage, the transportation from the mine to the Lake Erie port, the placing upon the vessel and the trimming or distributing in the hold, if required, so that the vessel may complete such interstate carriage. * * * A rate is fixed on that part of an interstate carriage which includes the actual placing of the coal into vessels ready to be carried beyond the state destination. That the test of through billing is not necessarily determinative is shown in the late case of Southern Pacific Terminal Co. v. Interstate Commerce Commission and Young, 219 U. S. 498, 55 L. Ed. 310, 3I Sup. Ct. 279."

Southern Pacific Terminal Co. v. Interstate Commerce Commission and Young, 219 U. S. 498, 55 L. Ed. 310, 3I Sup. Ct. 279, presents a case of similar import. In this case Young was engaged in the business of buying cotton seed cake and having it ground into meal at one of the wharves of the Southern Pacific Terminal Company, one of the constituents of the Southern Pacific Company. He was in the habit of buying cotton seed cake at points in the interior of Texas, shipping it to himself in carload lots at the pier in question at Galveston, there grinding it into meal, sacking it and loading it into steamships berthed there for export. It was declared that Young was given certain preferences over other manufacturers and shippers in wharfage and shipping privileges and the Interstate Commerce Commission issued an order on the terminal company to desist from granting such preferences. It was contended that the order of the Commission transcended its jurisdiction since it referred to commerce purely state and intrastate and also purely foreign. The court declared:- "In other words, the manufacture or concentration on the wharves of the terminal company are but incidents, under the circumstances presented by the record, in the transshipment of the products in export trade and their regulation is within the power of the Interstate Commerce Commission. To hold otherwise would be to disregard, as the Commission said, the substance of things and make evasions of the Act of Congress quite easy. It makes no difference, therefore, that the shipments of the products were not made on through bills of lading or whether their initial point was Galveston or some other place in Texas. They were all destined for export and by their delivery to the Galveston, Harrisburg and San Antonio Railway they must be considered as having been delivered to a carrier for transportation to their foreign destination, the terminal company being a part of the railway for such purpose. The case, therefore, comes under Coe v. Errol, II6 U. S. 517, 29 L. Ed. 715, 
part, interstate commerce and within the purview of the Act to Regulate Commerce. No such artificial device as an apparent independent shipment or a local bill of lading or the division of the charges into interstate and local rates will defeat the operation of

6 Sup. Ct. 475 , where it is said that goods are in interstate, and necessarily as well in foreign, commerce when they have 'actually started in the course of transportation to another state, or been delivered to a carrier for transportation.' In Gulf, Colorado and Santa Fe Railway Co. v. Texas, 204 U. S. 403,5 I L. Ed. 540,27 Sup. Ct. 360 , the facts are different and the case is not apposite."

A very similar case is presented in Texas and New Orleans Railroad Co. v. Sabine Tram Co., 227 U. S. III, 57 L. E.d. 442, 33 Sup. Ct. 229. Here the Sabine Tram Company shipped from its mills at Ruliff, Texas, to Sabine, Texas, a large quantity of lumber on the order of W. A. Powell Company, a concern engaged in the exportation of lumber. The bills of lading read "for delivery at Sabine to the Sabine Tram Company, 'notify W. A. Powell Company, Limited.'” The action was brought to recover the difference in freight rates between Ruliff and Sabine as fixed by the Texas Railroad Commission and the rates charged by the railroad as established and filed with the Interstate Commerce Commission as pertaining to foreign commerce. The court said:- "If we may regard the essential character of the shipments we can have no hesitation in pronouncing them to have been in interstate commerce. *** The shipments having the character of foreign commerce when they passed 'out through the port of Sabine,' when did they acquire it? We have had occasion to express at what point of time a shipment of goods may be ascribed to interstate or foreign commerce and decided it to be when the goods have actually started for their destination in another state or to a foreign country, or been delivered to a carrier for transportation. Coe v. Errol, 116 U. S. 517 ; Southern Pacific Terminal Co. v. Interstate Commerce Commission, 219 U. S. 498, 527. * * * That there must be continuity of movement we may concede, and to a foreign destination intended at the time of the shipment. $* * *$ The determining circumstance is that the shipment of the lumber to Sabine was but a step in its transportation to its real and ultimate destination in foreign countries. In other words, the essential character of the commerce, not its mere accidents, should determine. It was to supply the demand of foreign countries that the lumber was purchased, manufactured and shipped, and to give it a various character by the steps in its transportation would be extremely artificial. Once admit the principle and means will be afforded of evading the national control of foreign commerce from points in the interior of a state. There must be transshipment at the seaboard, and if that may be made the point of ultimate destination by the device of separate bills of lading the commerce will be given local character, though it be essentially foreign. That it is the nature of the traffic and not its accidents which determines its character is illustrated by Ohio Railroad 
the act where it is to all intents and purposes a single shipment between an initial point in one state and a final point in another state. ${ }^{12}$

But where a shipment of goods has been made from a point in one state to a point in a second state and after such interstate shipment has been completed in good faith, a new and independent contract of shipment is made from the point of initial destination to a second point within that same state this latter shipment is intrastate commerce and is not affected by the interstate

Commission v. Worthington, 225 U. S. 10I, 56 L. Ed. 1087, 32 Sup. Ct. 653. * * Nor was there a break, in the sense of the interstate commerce law and the cited cases, in the continuity of the transportation of the lumber to foreign countries by the delay and its transshipment at Sabine. Swift and Company v. United States, I96 U. S. 375, 49 L. Ed. 518,25 Sup. Ct. 276. Nor, as we have seen, did the absence of a definite foreign destination alter the character of the shipments."

12 United States v. Union Stock Yards Company, 226 U. S. 286, 57 L. Ed. 226, 33 Sup. Ct. 83. The court here said:- "That the service is performed wholly within one state can make no difference if it is a part of interstate carriage. *** It is the character of the service rendered, not the manner in which goods are billed, which determines the interstate character of the service."

Baer Brothers Mercantile Company $\because$ Denver and Rio Grande Railroad Company, 233 U. S. 479, 58 L. Ed. 1055, 34 Sup. Ct. 64I. Here the Baer Brothers Mercantile Company was engaged in the liquor business at Leadville, Colorado, and purchased its beer from a brewing company at $\mathrm{St}$. Louis, Missouri. The beer was shipped from St. Louis in carload lots by the Missouri Pacific "to be delivered to the Baer Brothers Company at Leadville, Colorado, via the Denver and Rio Grande." No through bill of lading was issued as the companies had not established a through rate. Each shipment was waybilled to Pueblo, Colorado, where the car was delivered to the Denver and Rio Grande with an expense bill and this company forwarded the beer to Leadville at its local rate naming the Missouri Pacific as the consignor and the Baer Brothers as the consignee. In a complaint based on the rates charged by the Denver and Rio Grande the defense was asserted that that portion of the shipment was intrastate commerce and not within the control of the Act to Regulate Commerce. The court as to this, said:- "The Denver and Rio Grande claimed in the record in the Court of Appeals that the order was void on its face for the reason that the commission was without jurisdiction to pass upon the reasonableness of the rate from Pueblo, Colorado, to Leadville, Colorado. But while there was no through-rate and no through-route there was in fact, a through-shipment from St. Louis, Missouri, to Leadville, Colorado. Its interstate character could not be destroyed by ignoring the points of origin and destination, separating the rate into its com- 
classification of the first shipment. ${ }^{13}$ It is clearly settled that the character of a shipment, be it local or interstate, is not altered by a transfer of title during the course of the transportation. The control of goods in process of shipment is an entirely different

ponent parts and by charging local rates and issuing local waybills, attempting to convert an interstate shipment into intrastate transportation. For 'where goods shipped from a point in one state to a point in another are received in transit by a state common carrier, under a conventional division of the charges, such a carrier must be deemed to have subjected its road to an arrangement for the continuous carriage or shipment within the meaning of the Act to Regulate Commerce.' Cincinnati, etc., Railway Co. v. Interstate Commerce Commission, I62 U. S. 184, 40 L. Ed. 935, I6 Sup. Ct. 700. This common arrangement does not depend upon the establishment of a through-route or the issue of a through bill of lading, but may be otherwise manifested. Ibid. That there was a common arrangement between the two carriers here was shown by the long-continued course in dealing, and the division of the freight, with the knowledge that it had been paid as compensation for the single haul."

See also Cincinnati etc., Railway Co. v. Interstate Commerce Commission, 162 U. S. 184, 40 L. Ed. 935, I6 Sup. Ct. 700.

I3 Gulf, Colorado \& Santa Fe Railway v. Texas, 204 U. S. 403, 5 I L. Ed. 540, 27 Sup. Ct. 360. This case presents a most interesting state of facts. In order to understand the ruling of the court and to differentiate it from the cases cited in the preceding note it is necessary that they be stated somewhat at length. The Hardin Grain Company, located at Kansas City having contracted with parties at Goldthwaite, Texas, for the delivery of two car loads of corn at that place, contracted to purchase of the Harroun Commission Company, also of Kansas City, and with an agent at Texarkana, Texas, the same quantity of corn to be delivered at the latter point. The corn with which the Harroun Company proposed to fill their contract was shipped from Hudson, South Dakota, to Texarkana, Texas. It was delivered at Texarkana, Texas, to the Hardin Grain Company who five days thereafter shipped it in the same cars, without breaking bulk from Texarkana to its correspondent at Goldthwaite, Texas. The question arose whether the shipment from Texarkana to Goldthwaite should be paid for at the rates prescribed by the Texas Railroad Commission or whether this was a portion of an interstate transportation which was under the control of the national government.

In deciding that the transportation from Texarkana was an independent shipment and therefore intrastate commerce, the Supreme Court said:"The first contract of shipment in this case was from Hudson (South Dakota) to Texarkana (Texas). *** When the Hardin Company accepted the corn at Texarkana the transportation contracted for ended. The carrier was under no obligations to carry it further. It transferred the corn, in obedience to the demands of the owner, to the Texas \& 
matter from the transportation itself, which follows the contract of shipment until that is changed by the agreement of owner and carrier.

Pacific Railway Company, to be delivered by it, under its contract with such owner. Whatever obligations may rest upon the carrier at the terminus of its transportation to deliver to some further carrier, in obedience to the instructions of the owner, it is acting not as a carrier, but simply as a forwarder. No new arrangement having been made for transportation the corn was delivered to the Hardin Company at Texarkana. Whatever may have been the thought or purpose of the Hardin Company in respect to the further disposition of the corn, was a matter immaterial so far as the completed transportation was concerned. In this respect there is no difference between an interstate passenger and an interstate transportation. If Hardin, for instance, had purchased at Hudson a ticket for interstate carriage to Texarkana, intending all the while after he reached Texarkana to go on to Goldthwaite, he would not he entitled on his arrival at Texarkana to a new ticket from Texarkana to Goldthwaite at the proportionate fraction of the rate prescribed by the Interstate Commerce Commission for carriage from Hudson to Goldthwaite. The one contract of the railroad companies having been finished he must make a new contract for his carriage to Goldthwaite, and that would be subject to the law of the state within which that carriage was to be made.

"The question may be looked at from another point of view. Supposing a carload of goods was shipped from Goldthwaite to Texarkana under a bill of lading calling for only that transportation, and supposing that the laws of Texas required, subject to penalty, that such goods should be carried in a particular kind of car, can there be any doubt that the carrier would be subject to the penalty, although it should appear that the shipper intended after the goods had reached Texarkana to forward them to some other place outside the state? To state the question in other words, if the only contract of shipment was for local transportation, would the state law in respect to the mode of transportation be set one side by a federal law in respect to interstate transportation on the ground that the shipper intended after the one contract of shipment had been completed to forward the goods to some place outside the state? Coe 1 . Errrol, 116 U. S. 517-527, 29 L. Ed. 715, 6 Sup. Ct. 475. Again it appeared that this corn remained five days in Texarkana. The Hardin Company was under no obligation to ship it further. It could in any other way it saw fit have provided corn for delivery to Saylor \& Burnett, and unloaded and used that car of corn in Texarkana. It must be remembered that the corn was not paid for by the Hardin Company until its receipt in Texarkana. It was paid for on receipt and delivery to the Hardin Company. Then, and not till then, did the Hardin Company have full title to and control of the corn, and that was after the first contract of transportation had been completed.

"It must further be remembered that no bill of lading was issued from Texarkana to Goldthwaite until after the arrival of the corn at Tex- 
Where the consignee of coal, shipped from another state to a distributing point in a second state to which the original consignment was made, holds the cars still loaded with the coal on a sidetrack until sales thereof were made, and pays the original carrier for the interstate transportation, and then after the sale of the coal tenders bills of lading to another carrier for a shipment to another point within the second state the continuity of the through traffic has been broken and the second shipment is purely intrastate. $^{14}$

arkana, the completion of the first contract for transportation, the acceptance and payment by the Hardin Company. In many cases it would work the grossest injustice to a carrier if it could not rely on the contract of shipment it has made, know whether it was bound to obey the state or federal law, or, obeying the former, find itself mulcted in penalties for not obeying the law of the other jurisdiction, simply because the shipper intended a transportation beyond that specified in the contract. It must be remembered that there is no presumption that a transportation when commenced is to be continued beyond the state limits and the carrier ought to be able to depend upon the contract which it has made and must conform to the liability imposed by that contract."

In distinguishing this case from that of Ohio Railroad Commission v. Worthington, 225 U. S. 10I, 56 L. Ed. 1087, 32 Sup. 653, the Supreme Court in the latter case said:- "The facts showed that the corn was carried upon a bill of lading from Hudson (South Dakota) to Texarkana and that afterwards, some five days later, it was shipped from T'exarkana to Goldthwaite, both points in the state of Texas. This was held to be an intrastate shipment, unaffected by the fact that the shipper intended to reship the corn from Texarkana to Goldthwaite, for, as this court held, the corn had been carried to Texarkana upon a contract for interstate shipment, and the reshipment after five days upon a new contract, was an independent intrastate shipment. It is evident from this statement of facts that the case is quite different from the one under consideration. There a new and independent contract for intrastate shipment was made, the interstate transportation having been completely performed; here a rate is fixed on that part of an interstate carriage which includes the actual placing of the coal into vessels ready to be carried beyond the state destination."

In that case, and also in the cases of Texas and New Orleans Railroad v. Sabine Tram Company, 227 U. S. III, 57 L. Ed. 442, 33 Sup. Ct. 229, and in Louisiana Railroad Commission v. Texas and Pacific Railway, 229 U. S. 336,57 L. Ed. 1215, 33 Sup. Ct. 837, it is apparent that while there was of necessity a local movement of the freight yet that the coal, the lumber and the staves were in each case intended for export and that there was no such break in the continuity of their shipment.

I4 Chicago, Milwaukee and St. Paul Railway Company v. Iowa, 233 U. S. $334,5^{8}$ L. Ed. 988,34 Sup. Ct. 592. The court said:-"It is un- 
Alaska within the Terms of the Act to Regulate Commerce. -The term Territory as it occurs in the Act wherein are defined the classes of shipment contemplated thereby refers not to an area of land or a landed possession but rather to a political unit which governs and is governed as such. The amendment of the Act of June 29, 1906, clearly extended the provisions of the Act to intraterritorial commerce and made the act completely comprehensive of the whole subject, so as to include transportation from and in Alaska to the United States. ${ }^{15}$

\section{Regulation in States Formerly under Territorial Organiza-} tion.-Under the Commerce clause of the Constitution, Congress has full control and authority over railroads in the Territories of

doubtedly true that the question whether commerce is interstate or intrastate must be determined by the essential character of the commerce, and not by mere billing or forms of contract. * * * But the fact that commodites received on interstate shipments are reshipped by the consignees in the cars in which they are received, to other points of destination, does not necessarily establish a continuity of movement, or prevent the reshipment to a point within the same state from having an independent and intrastate character. $* * *$ The question is with respect to the nature of the actual movement in the particular case; and we are unable to say upon this record that the state court has improperly characterized the traffic in question here."

15 Interstate Commerce Commission v. Humboldt Steamship Company, 224 U. S. 474,56 L. Ed. 729.32 Sup. Ct. 436 . Here the question was considered as to whether Alaska is a Territory of the United States within the meaning of the Interstate Commerce Act as amended. The case was based upon the petition of the Humboldt Steamship Company to the Interstate Commerce Commission to require certain railroads in Alaska to print and keep for public inspection schedules showing their rates between points in Alaska and Canada and other places; to require them to establish through routes and joint rates with the petitioner, etc. The court referred to the case of The Steamer Coquitlam $v$. United States, I63 U. S. 346,4 I L. Ed. $18_{4}, 16$ Sup. Ct. III7, as determining the point that Alaska constitutes one of the Territories of the United States. The court in the Humboldt Steamship Company case said:-"The power to prescribe a rate was conferred by the amendment of June 29, 1906, and that amendment extended the provisions of the Act for the first time to intraterritorial commerce. The amendment made the Act completely comprehensive of the whole subject ***. As said by the minority of the Commission:'There is no suggestion of doubt that the ends of justice require as much the application of the same principle and regulation in Alaska as in New Mexico or Arizona.' The two latter at the time this was said were Territories." 
the United States, and its power over them is exclusive and paramount, but when these Territories are organized into States and as such admitted into the Union the whole subject of rates in domestic or local business passes under the full control of the State in its corporate capacity, subject, of course, to the fundamental condition that it should authorize only such rates as were legal and not inconsistent with the constitutional rights of the railway company. ${ }^{16}$

Commerce Included under the Act.-In general terms the Act to Regulate Commerce was enacted to control and govern interstate transportation. But by its definition and specifications in the first paragraph of the first section it manifestly does not include certain varieties of interstate commerce-such for example as commerce between different states conducted by wagons moved by horses or propelled by gasoline. By direction the Act is declared to relate only to transportation between different states in persons or property when conducted entirely by railroad or partly by railroad and partly by water. This therefore excludes commerce between states when conducted entirely by water. This Act was aimed avowedly to correct certain conditions governing railroad transportation-Congress having frequently legislated in other ways and at other times regarding transportation between states by boats.

Manifestly a railroad situated entirely within a state, which carries freight, even from another state, only on local bills of lading specifying points within the state and on an agreement limited to its own line, and not on foreign through bills of lading, and which is not a participant with such other lines in through rates and charges or traffic arrangements, does not come within the purport of the Act to Regulate Commerce and is not engaged in interstate transportation. ${ }^{17}$ In order that the transportation may be im-

I6 Oklahoma v. Atchison, Topeka and Sante Fe Railway, 220 U. S. 277, 55 L. Ed. 465, 31 Sup. Ct. 434; Oklahoma v. Chicago, Rock Island and Pacific Railway, 220 U. S. 302, 55 L. Ed. 474, 3I Sup. Ct. 442.

I7 Cincinnati, New Orleans and Texas Pacific Railway Co. v. Interstate Commerce Commission (The Social Circle Case), I62 U. S. I84, 40 L. Ed. 935, I6 Sup. Ct. 700. This case involved rates on shipments from Cincinnati, Ohio, to points in Georgia including Atlanta, Augusta and Social Circle. Social Circle was situated on the Georgia Railroad some 52 miles from Atlanta and its rate from Cincinnati was reached by adding the local Social Circle to Atlanta rate of 30 cents to the Cincinnati to At- 
mune from the control and jurisdiction of the act to regulate commerce the railroad should be wholly within the state, the service to be performed should be within the state and the carriage or commerce should be purely intrastate. ${ }^{18}$

Within certain general limits interstate transportation may be defined with ease. The beginning and termination of the transit which constitutes interstate commerce may be determined without

lanta rate; and it was claimed that the carriage over the Georgia Railroad was not under an arrangement for a continuous shipment or carriage but was the local haul of that road and was not within the purview of the Act to Regulate Commerce. The Supreme Court denying this contention, proceeded to say:- "It may be true that the Georgia Railroad Company, as a corporation of the state of Georgia, and whose entire road is within that state, may not be legally compelled to submit itself to the provisions of the Act of Congress, even when carrying, betwcen points in Georgia, freight that has been brought from another state. It may be that if, in the present case, the goods of the James and Mayer Buggy Company had reached Atlanta, and there and then, for the first time, and independently of any existing arrangement with the railroad companies that had transported them thither, the Georgia Railroad Company was asked to transport them, whether to Augusta or to Social Circle, that company could undertake such transportation free from the control of any supervision except that of the state of Georgia. But when the Georgia Railroad Company enters into the carriage of foreign freight, by agreeing to receive the goods by virtue of foreign through bills of lading, and to participate in through rates and charges, it thereby becomes part of a continuous line, not made by a consolidation with the foreign companies, but made by an arrangement for the continuous carriage or shipment from one state to another, and then becomes amenable to the Federal act, in respect to such inter state commerce. We do not perceive that the Georgia Railroad Company escaped from the supervision of the Commission by requesting the foreign companies not to name or fix any rates for that part of the transportation which took place in the state of Georgia when the goods were shipped to local points on its road. It still left its arrangement to stand with respect to its terminus at Augusta and to other designated points. *** All we wish to be understood to hold is, that when goods shipped under a through bill of lading, from a point in one state to a point in another, are received in transit by a state common carrier, under a conventional division of the charges, such carrier must be deemed to have subjected its road to an arrangement for a continuous carriage or shipment within the meaning of the Act to regulate commerce. When we speak of a through bill of lading we are referring to the usual method in use by connecting companies, and must not be understood to imply that a common control, management or arrangement might not be otherwise manifested."

18 United States v. Union Stock Yards, 226 U. S. 286, 57 L. Ed. 226, 33 Sup. Ct. 83 . 
difficulty. The first may be designated as that point of time when an article is delivered to a carrier for transportation to the place of its destination in another state-that is when it is started on its ultimate journey. ${ }^{19}$ The ending of interstate commerce is then by comparison the point of time at which it reaches that destination-that is when the goods in question have been unloaded and delivered or offered to be delivered to the consignee. ${ }^{20}$ But intermediate between these points many and varied questions may arise. We have seen, for instance, that goods shipped between points in the same state on local bills of lading but intended for transshipment to points beyond the state constitute interstate commerce within the meaning of the Act. ${ }^{21}$ And on the other hand where goods are shipped into a state from another state and are intended to be later transshipped, if they are held at such point not in necessary delay or accommodation to the means of transportation, but for purposes of business or profit, even though it is intended that they shall be later transshipped, the act of interstate commerce is concluded as far as the first shipment is concerned and a new shipment becomes a separate and distinct incident. Conversely delay not exceeding the time necessary for the convenience of transshipment or transportation to its real or ultimate destination does not constitute a termination of the first act of interstate commerce or divide the transaction into two distinct operations. $^{22}$ The determining element is the character of the

19 Coe v. Frrol, i16 U. S. 517, 29 L. Ed. 715, 6 Sup. Ct. 475.

20 Brown v. Houston, 114 U. S. 622,29 L. Ed. 257,5 Sup. Ct. 1091 ; Covington Stock Yards Co. v. Keith, 139 U. S. 128, 35 L. Ed. 73. I I Sup. Ct. 416; Southern Pacific Terminal Co. v. Interstate Commerce Commission, 219 U. S. 498, 55 L. Ed. 310, 31 Sup. Ct. 279.

2I Louisiana Railroad Commission v. Texas \& Pacific Railway, 229 U. S. 336, 57 L. Ed. 1215, 33 Sup. Ct. 837; Texas and New Orleans R. R. v. Sabine Tram Co., 227 U. S. II I, 57 L. Ed. 442, 33 Sup. Ct. 229.

22 This question has frequently arisen in connection with the matter of state taxation of goods which have been a feature of interstate commerce. For example, see General Oil Company v. Crain, 209 U. S. 2 II, 52 L. Ed. 754, 28 Sup. Ct. 475, where oil was shipped from different states to a distributing center at Memphis, Tennessee. Here the oil was stored in tanks, part to supply orders already received from without the state and intended to be transshipped and part to fill orders which it was anticipated would later be received. The court said:--"In State v. Engle, Receiver, 5 Vroom (N. J.) 435, coal mined in Pennsylvania and sent by rail to Elizabethport, in New Jersey, where it was deposited on the wharf for 
service rendered which naturally must be ascertained by the elements of each individual case rather than by any hard and pre-

separation and assortment for the purpose of being shipped by water to other markets for the purpose of sale, it was held that the property was not subject to taxation in New Jersey. The court said:-'Delay within the state, which is no longer than is necessary for the convenience of transshipment for its transportation to its destination, will not nake it property within the state for the purpose of taxation.' * * * The (General Oil) company was doing business in the state and its property was receiving the protection of the state. Its oil was not in movement through the state. It had reached the destination of its first shipment, and it was held there, not in necessary delay or accommodation to the means of transportation, as in State $v$. Engle, but for the business purposes and profit of the company. It was only there for distribution, it is said, to fulfill orders already received. But to do this required that the property: be given a locality in the state beyond a mere halting in its transportation. It required storage there-the maintenance of the means of storage, of putting it in and taking it from storage. The bill takes pains to allege this. 'Complainant shows that it is impossible, in the coal oil business. such as complainant carries on, to fill separately each of these small orders directly from the railroad tank ears. because of the great delay and expense in the way of freight cliarges incident to sueh a plan, and for the further reason that an extensive plant and apparatus is necessary, in order to properly and conveniently unloar and receive the oil from said tank cars, and it would be impracticable if not impossible, to have such apparatus and machinery at every point to which complainant ships said oil.' This certainly describes a business-describes a purpose for which the oil is taken from transportation, brought to rest in the state and for which the protection of the state is necessary. a purpose outside the mere transportation of the oil. The case, therefore, comes under the principle announced in American Steel \& Wire Co. $r$ Speed, 192 L. S. 500. 48 L. Ed. 538, 24 Sup. Ct. 365."

See also Susquehanna Coal Co. $v$. South Amboy, 228 C. S. 665, 57 L. Ed. 1015, 33 Sup. Ct. 712, where was involved a tax on coal shipped to that point and there unloaded and stored but destined to further and later transshipment. The court here said:- "The coal, therefore, was not in actual movement through the state; it was at rest in the state, and was to be handled and distributed from there. Therefore the principles expressed in Ceneral Oil Co. v. Crain. 209 C. S. 2 II, 52 L. Ed. 754, 28 Sup. Ct. 475 , and Bacon v. Illinois. 227 U. S. 504,57 L. Ed. 6r5, 33 Sup. Ct. 299 , are applicable to it. The products in neither of those cases were destined for sale in the states where stored; the delay there was to be temporary -a postponement of their transportation to their destinations. There was. however, a business purpose and advantage in the delay which was availed of, and while it was arailed of, the products secured the protection of the state. In both cases it was held that there was a cessation of interstate commerce and subjection to the dominion of the state." 
conceived or artificial rules. Of whatever nature, the shipment must be bona fide and not a mere pretence for the purpose of avoiding certain obligations or securing certain advantages.

Manifestly telegraph messages from one state to another constitute a branch of interstate commerce. The Act to Regulate Commerce, as originally passed and approved February 4, I887, made no mention of this subject but the amendment of June 18 , I9Io, bestowed upon the Interstate Commerce Commission the control and regulation of this phase of interstate commerce. ${ }^{23}$

Commerce to or from Foreign Countries.-The Act to Regulate Commerce by its terms includes traffic "from any place in the United States to an adjacent foreign country," and "from any place in the United States through a foreign country to any other place in the United States" and also "from any place in the United States to a foreign country and carried from such place to a port of transshipment," and as well "from a foreign country to any place in the United States and carried to such place from a port of entry either in the United States or an adjacent foreign country." By its scope this language includes the whole field of commerce-excepting only that wholly within a state-both between the various states and territories of the United States and that which is embraced within our export and import trade. The jurisdiction of the Commission under the scope of the act is limited naturally, however, to only that part of the export or import rate and shipment belonging to and conducted by the carrier in the United States. ${ }^{24}$ But the Act has thus included in its scope

23 In Western Union Telegraph Co. v. Crovo, 220 U. S. 364, 55 L. Ed. 498, 3I Sup. Ct. 399, the court said:-"That companies engaged in the telegraph business, whose lines extend from one state to another, are engaged in interstate commerce and that messages passing from one state to another constitute such commerce is indisputable. Such companies and such messages come, therefore, under the regulating power of Congress." See also Western Union Telegraph Co. v. Commercial Milling Co., 2 is U. S. 406, 54 L. Ed. I088, 3I Sup. Ct. 59, and cases therein cited.

24 Texas and Pacific Railway Company v. Interstate Commerce Commission, (The Import Rate Case) I62 U. S. 197, 40 L. Ed. 940, I6 Sup. Ct. 666. Here the shipment involved consisted of goods from Liverpool and London to San Francisco via New Orleans on a through rate. The court said:- "It would be difficult to use language more unmistakably signifying that Congress had in view the whole field of commerce (excepting commerce wholly within a state) as well that between the states and territories as that going to or coming from foreign countries." 
the entire commerce of the United States foreign and interstate and subjected to its regulations all carriers so engaged in the transportation of people or property whether by railroads or by combinations of railroads and water lines.

\section{Transportation Partly by Railroad and Partly by Water.-} Under this section "common carriers engaged in the transportation of passengers or property $* * *$ partly by railroad and partly by water when both are used under a common control, management, or arrangement for a continuous carriage or shipment" are within the terms of the Act and under the control of the Interstate Commerce Commission. Such common carriers are subject to the provisions of the Act in the same terms and manner as the other companies named in the legislation. It is doubtless true that certain provisions of the act by their nature relate to some carriers and not to others but within the broad terms of section I carriers partly by railroad and partly by water under a common arrangement for a continuous carriage or shipment are as specifically included as carriers entirely by railroad..$^{25}$

25 Interstate Commerce Commission $v$. Goodrich Transit Co., $224 \mathrm{U}$. S. 194, 56 L. Ed. 729. 32 Sup. Ct. 436. The Goodrich Transit Company was engaged in carrying on traffic, both passenger and freight, on the Great Lakes by joint rates with the railroads. Here the court said:- "The first section makes the act apply alike to common carriers engaged in the transportation of passengers or property wholly by railroad or partly by railroad and partly by water under an arrangement for a continuous carriage or shipment. It is conceded that the carriers filing the bills in these cases were common carriers engaged in the transportation of passengers and property partly by railroad and partly by water under a joint arrangement for a continuous carriage or shipment. Such common carriers are declared to be subject to the provisions of the Act in precisely the same terms as those which comprehend the other companies named in the act. Carriers partly by railroad and partly by water under a common arrangement for a continuous carriage or shipment are as specifically within the terms of the Act as any other carrier named therein. It may be that certain provisions of the Act are in their nature applicable to some carriers and not to others; but we are only concerned to inquire in this case whether the carricrs thus broadly brought within the terms of the Act by section I thereof are subject to the provisions of the statute by the authority of which the Commission undertook to require the system of accounting. etc. * * * " In Wilmington Transportation Co. v. California Railroad Commission, 236 U. S. I5I, the Supreme Court said:-"The Interstate Commerce Commission has not been authorized to prescribe rates for water transportation unconnected with transportation by railroad." 


\section{Common Control, Management or Arrangement for a Con-} tinuous Carriage or Shipment.-The evidences and the proof of a common control, management or arrangement for a continuous carriage or shipment may vary with specific cases but the usual tests approved by the Supreme Court include a through routing of the freight in interstate commerce, the acceptance of the goods by connecting carriers by virtue of through bills of lading, and the participation in through rates and charges therefor. Nor is it essential that there should be an agreement for a through rate, since the receipt and forwarding of shipments in the usual manner by carriers engaged in interstate commerce under through bills of lading, amount to a common arrangement such as is contemplated by the statute. And a railroad which lies wholly within a state which participates in the carriage of an interstate shipment by making an arrangement for its continuous carriage under a through bill of lading and with an agreement for participating in through rates, becomes to the extent of that shipment at least subject to the jurisdiction of the Interstate Commerce Commission. ${ }^{26}$

26 Cincinnati, New Orleans and Texas Pacific Railway Company v. Interstate Commerce Commission (The Social Circle Case), 162 U. S. 184, 40 L. Ed. 935, 16 Sup. Ct. 700. Here a charge of $\$ 1.07$ per hundred pounds was made on shipments from Cincinnati to Atlanta and an additional charge of 30 cents (the local rate from Atlanta to Social Circle) or $\$ 1.37$ on the same shipment from Cincinnati to Social Circle. It was clained that the 30-cent charge from Atlanta to Social Circle was purely the local charge between those two points over the Georgia Railroad, that it was not under a common control or an arrangement for continuous shipment and therefore not within the provisions of the Act to regulate commerce. The Supreme Court as to this contention said:- "It may be true that the Georgia Railroad Company, as a corporation of the state of Georgia, and whose entire road is within that state, may not be legally compelled to submit itself to the provisions of the Act of Congress, even when carrying. between points in Georgia, freight that has been brought from another state. * * * But when the Georgia Railroad Company enters into the carriage of foreign freight, by agreeing to receive the goods by virtue of foreign through bills of lading, and to participate in through rates and charges, it thereby becomes part of a continuous line, not made by a consolidation with the foreign companies, but made by an arrangement for the continuous carriage or shipment from one state to another, and thus becomes amenable to the Federal Act, in respect to such interstate commerce. We do not perceive that the Georgia Railroad Company escaped from the supervision of the Commission, by requesting the foreign companies not to name or fix any rates for that part of the transportation which took place in the state of Georgia when the goods were shipped to 
Where one of the railroads with its portion of the carriage is entirely within a state it is immaterial that it receives the entire benefit of the rate on its own line provided there is a through bill of lading and a through routing under and by virtue of which there is a continuous carriage rather than an entirely separate and distinct shipment and contract of carriage evidenced in part by a local bill of lading. ${ }^{27}$

Pipe Lines.-By the Act of June 29, 1906, section I was amended so as to include in the act to regulate commerce interstate pipe lines except those used to carry water or natural or artificial gas, and to make those engaged, for instance, in the trans-

local points on its road. It still left its arrangement to stand with respect to its terminus at Augusta and to other designated points. Having elected to enter into the carriage of interstate freights and thus subjected itseli to the control of the Commission, it would not be competent for the company to limit that control, in respect to foreign traffic, to certain points on its road and exclude other points."

27 Louisville and Nashville Railroad Company $\checkmark$ Behlmer, 175 U. S. 648,44 L. Ed. 309, 20 Sup. Ct. 20\%. This case involved rates on hay and grain transported from Memphis to Summerville, South Carolina,the rate being reached by adding to the through rate from Memphis to Charleston, the local rate from Charleston back over the same line to Summerville. The benefit of this additional local rate was received wholly by the local road on which Summerville was situated. and it was contended that under these conditions the carriers did not constitute a continuous line bringing them within section I of the Act to regulate commerce. "The conceded facts," said the court, "from which it was deduced as a matter of law that the carriers were operating "under a common control, management or arrangement for a continuous carriage or shipment' were as follows: The several carriers transported hay from Memphis under through bills of lading, by continuous carriage to Summerville and Charleston. The several roads shared in an agreed rate on traffic to Charleston and in a precisely equal in amount rate on traffic to Summerville. On shipments to Summerville, however, there was added to the Charleston rate the amount of the local rate from Charleston to Summerville, the benefit of which additional exaction was solely received by the local road on which Summerville was situated. The contention that under this state of facts the carriers did not constitute a continuous line. bringing them within the control of the Act to regulate commerce, is no longer open to controversy in this court. In Cincinnati, New Orleans and Texas Pacific Railway v. Interstate Commerce Commission, 162 C. S. 184, 40 L. Ed. 935, I6 Sup. Ct. 700 , decided since the case in hand was before the Commission and the Circuit Court, it was held under a state of facts substantially similar to that here found that the carriers were thereby subject to the Act to regulate commerce." 
portation of oil common carriers. Such pipe lines are required upon the payment of proper charges to carry oil for all who may apply for such transportation and they cannot as a condition precedent thereto compel such shippers to sell the oil to the owners of the pipe lines. The Supreme Court has declared this a proper and constitutional regulation of such business. ${ }^{28}$ But a pipe line

28 United States v. Ohio Oil Co., $23+$ U. S. 548, 58 L. Ed. I 459,34 Sup. Ct. 956. The court in construing this feature of the law said:- "The provisions of the Act are to apply to any person engaged in the transportation of oil by means of pipe lines. The words 'who shall be considered and held to be common carriers within the meaning and purpose of this Act' obviously are not intended to cut down the generality of the previous declaration to the meaning that only those shall be held common carriers within the Act who were common carriers in a technical sense, but an injunction that those in control of pipe lines and engaged in the transportation of oil shall be dealt with as such. If the Standard Oil Company and its co-operating companies were not so engaged no one was. It not only would be a sacrifice of fact to form but would empty the Act if the carriage to the seaboard of nearly all the oil east of California, were held not to be transportation within its meaning, because by the exercise of this power the carriers imposed as a condition to the carriage a sale to themselves. As applied to them, while the amendment does not compel them to continue in operation it does require them not to continue except as common carriers. That is the plain meaning as has been held with regard to other statutes similarly framed. Atlantic Coast Line Railroad Co. v. Riverside Mills, 219 U. S. I86, I95, 203. 55 L. Ed. I67, 3I Sup. Ct. I64. Its evident purpose was to bring within its scope pipe lines that although not technically common carriers yet were carrying all oil offered, if only the offerers would sell at their price.

"The only matter requiring much consideration is the constitutionality of the Act. That the transportation is commerce among the states we think clear. That conception cannot be made wholly dependent upon technical questions of title, and the fact that the oils transported belonged to the owner of the pipe line is not conclusive against the transportation being such commerce. Rearick v. Pennsylvania, 203 U. S. 507 and 5I2, 5 I L. Ed. 295, 27 Sup. Ct. 159. See Texas and New Orleans Railroad Co. v. Sabine Tram Co., 227 U. S. III, 57 L. Ed. 442, 33 Sup. Ct. 229. The situation that we have described would make it illusory to deny the title of commerce to such transportation beginning in purchase and ending in sale, for the same reasons that make it transportation within the Act.

"The control of Congress over commerce among the states cannot be made a means of exercising powers not entrusted to it by the Constitution, but it may require those who are common carriers in substance to become so in form. So far as the statute contemplated future pipe lines and prescribes the conditions upon which they may be established there can be no doubt that it is valid. So the objection is narrowed to the fact that it ap- 
used merely for drawing its own oil from the company's well to its refinery does not come within the provisions of this act merely because it happens to cross a state line, the transportation being there merely an incident to its use.

Express and Sleeping Car Companies Included in the Act.-The term "common carrier" as used in this Act shall include express companies and sleeping car companies. The term "railroad" as used "r in this act shall include all bridges and ferries used or operated in connection with any railroad, and also all the road in use by any corporation operating a railroad, whether owned or operated under a contract, agreement, or lease, and shall also include all switches, spurs, tracks, and terminal facilities of every kind used or necessary in the transportation of the persons or property designated herein, and also all freight depots, yards, and grounds used or necessary in the transportation or delivery of any of said property; and the term "transportation" shall include cars and other vehicles and all instrumentalities and facilities of shipment or carriage, irrespective of ownership or of any contract, express or implied, for the use thereof and all services in connection with the receipt, delivery, elevation, and transfer in transit, ventilation, refrigeration or icing, storage, and handling of property transported; and it shall be the duty of every carrier subject to the provisions of this Act to provide and furnish such transportation upon reasonable request therefor, and to establish through routes and just and reasonable rates applicable thereto; and to provide reasonable facilities for operating such through routes and to make reasonable rules and regulations with respect to the exchange, interchange, and return of cars used therein, and for the operation of such through routes, and providing for reasonable compensation to those entitled thereto.

plies to lines already engaged in transportation. But, as we already have intimated, those lines that we are considering are common carriers now in everything but form. They carry everybody's oil to a market, although they compel outsiders to sell it before taking it into their pipes. The an- 
Express Companies.-By the Hepburn Rate Act of June 29, 1906 the Act to regulate Commerce was amended by the inclusion in Section I of the sentence: "The term 'common carrier' as used in this Act shall include express companies and sleeping car companies." Thus for the first time this class of companies was brought within the terms of the Act and under the jurisdiction and control of the Interstate Commerce Commission. By this enactment Congress has exercised its authority over interstate express business and has provided its own scheme of regulation in order to secure the discharge of the public duties and obligations involved therein. Thereby Congress has asserted its exclusive control with regard to the obligations to be assumed by interstate express carriers. ${ }^{29}$ The Act includes express com-

swer to their objection is not that they may give up the business, but that as applied to them, the statute practically means no more than they must give up requiring a sale to themselves before carrying the oil that they now receive. The whole case is that the appellees if they carry must do it in a way that they do not like. There is no taking and it does not become necessary to consider how far Congress could subject them to pecuniary loss without compensation in order to accomplish the end in view. Hoke v. United States, 227 U. S. $308,323,57$ L. Ed. 523, 33 Sup. Ct. 28I ; Lottery Case, I88 U. S. 321, 357, 47 L. Ed. 492, 23 Sup. Ct. 321.

"There remains to be considered only the Uncle Sam Oil Company. This company has a refinery in Kansas and oil wells in Oklahoma, with a pipe line connecting the two which it has used for the sole purpose of conducting oil from its own wells to its own refinery. It would be a perversion of language considering the sense in which it is used in the statute, to say that a man was engaged in the transportation of water whenever he pumped a pail of water from his well to his house. So as to oil. When, as in this case, a company is simply drawing oil from its own wells across a state line to its own refinery for its own use, and that is all, we do not regard it as falling within the description of the act, the transportation being merely an incident to use at the end."

29 Barrett v. City of New York, 232 U. S. 14, 58 L. Ed. 483, 34 Sup. Ct. 203. By a municipal ordinance express companies in New York City were required to obtain local licenses for their various wagons and drivers. The court held that as far as interstate business is concerned no such annual license fee could be exacted, and declared:-"But if the abovementioned sections are to be deemed to require that a license must be obtained as a condition precedent to conducting the interstate business of an express company, we are of the opinion that, so construed, they would be clearly unconstitutional. It is insisted that, under the authority of the state, the ordinances were adopted in the exercise of the police power. But that does not justify the imposition of a direct burden upon interstate commerce. *** The right of public control, in requiring such a li- 
panies which are organized as joint stock associations as well as companies which are in reality partnerships or corporations. The nature of their business rather than the form of their artificial organization determines the question. ${ }^{30}$

Street Railways.-The Supreme Court has held that the term "railroad" as defined in Section I of the Act was not broad enough to include within its scope street railroads carrying passengers between cities divided by a state line. The court insisted that the Act contemplated the regulation of the operation and traffic of railroads which in their nature were so connected with other railroads as to be able to ship freight across the continent without the necessity for breaking bulk, railroads intended to furnish

cense, is asserted by virtue of the character of the employment; but while such a requirement may be proper in the case of local or intrastate business, it cannot be justified as a prerequisite to the conduct of the business that is interstate. Not only is the latter protected from the action of the state, either directly or through its municipalities, in laying direct burdens upon it, but, in the present instance, Congress has exercised its authority and has provided its own scheme of regulation in order to secure the discharge of the public obligations that the business involves.

As applied to the company's business of interstate transportation, it must fall with the provision regarding the license, and, further, it must be regarded as repugnant to the exclusive control asserted by Congress in occupying the field of regulation with regard to the obligations to be assumed by interstate express carriers."

See also United States v. Adams Express Company, 229 U. S. 38I, 57 I. E.d. 1237,33 Sup. Ct. 878 ; Adams Express Company v. Croninger, 226 U. S. 491, 57 L. Ed. 31 4,33 Sup. Ct. 148; American Express Company v. United States, 212 U. S. 522, 53 L. Ed. 635, 29 Sup. Ct. 315; Wells Fargo Company $v$. Neiman-Marcus Company, 227 U. S. 469,57 L. Ed. 600, 33 Sup. Ct. 267.

30 United States v. Adams Express Company, 229 U. S. 38I, 57 L. Ed. 1237, 33 Sup. Ct. 8;8. The court here said:--"It has been notorious for many years that some of the great express companies are organized as joint stock associations, and the reason for the amendment hardly could be seen unless it was intended to bring these associations under the Act. As suggested in the argument for the Government, no one, certainly not the defendant, seeins to have doubted that the statute now imposes upon them the duty to file schedules of rates. American Express Company $v$. United States, 212 U. S. 522, 53 L. Ed. 635, 29 Sup. Ct. 315. (The American Express Company is a joint stock association.) But if it imposes upon them the duties under the words common carrier as interpreted, it is reasonable to suppose that the same words are intended to impose upon them the penalty inflicted on common carriers in case those duties are not performed." 
channels of intercourse between widely separated communities and not within a single community, eren thongh that community be divided by state lines; that the act contemplated railroads which connected different states and cities rather than different streets or suburbs-railroads which were required to post their schedules of rates and tariffs at their various stations and depots where passengers and freight are accepted, and not at every street corner where a passenger may hail a car. It is manifest that under the original act to regulate commerce of February 4,1887 , electric railroads even in interurban traffic where they crossed state lines were not included though by an amendment of June 18, 1910, to Section 15 of the Act the Commission is apparently endowed with jurisdiction over such street electric passenger railways as transport freight in interstate commerce. ${ }^{31}$

3I Omaha Street Railway Company v. Interstate Commerce Commission, 230 U. S. 324, 57 L. Ed. 1501, 33 Sup. Ct. 890. The railroad in question operated cars between Council Bluffs, Iowa, and Omaha, Nebraska, and complaint was made to the Interstate Commerce Commission of the unreasonableness of certain fares charged by that company. The question in the Supreme Court turned on the point of whether the provisions of the Commerce Act as to railroads applied to street railroads. The court said: - "The statute in terms applies to carriers engaged in the transportation of passengers or property by railroad. But, in 1887 , that word had no fixed and accurate meaning, for there was then, as now, a conflict in the decisions of the state courts as to whether street railroads were embraced within the provisions of a statute giving rights or imposing burdens on railroads. The appellants cite decisions from twelve states holding that in a statute the word 'railroad' does not mean 'street railroad.' The defense cite decisions to the contrary from an equal number of states. The present record discloses a similar disagreement in Federal tribunals. For not only did the Commerce Court and the Circuit Court differ, but it appears that the members of the Commission were divided on the subject when this case was decided and also when the question was first raised in Willson v. Rock Creek Railroad, 7 I. C. C. 83. * * * But all the decisions hold that the meaning of the word is to be determined by construing the statute as a whole. If the scope of the Act is such as to show that both classes of companies were within the legislative contemplation, then the word railroad will include street railroad. On the other hand, if the Act was aimed at railroads proper, then street railroads are excluded from the provisions of the statute. Applying this universally accepted rule of construing this word, it is to be noted that ordinary railroads are constructed on the companies' own property. The tracks extend from town to town and are usually connected with other railroads, which themselves are further connected with others, so that freight may be shipped, without breaking bulk, across the continent. Such railroads are channels of 
Railroad Defined.-As originally enacted February 4, I887, this clause read merely:- "The term 'railroad' as used in this Act shall include all bridges and ferries used or operated in connection with any railroad, and also all the road in use by any corporation operating a railroad, whether owned or operated under a contract, agreement or lease." By the Act of June 29, I906, Congress amended the clause by adding thereto:-"and shall also include all switches, spurs, tracks and terminal facilities of every

interstate commerce. Street railroads, on the other hand, are local, are laid in streets as aids to street traffic, and for the use of a single community, even though that community be divided by state lines, or under different municipal control. When these street railroads carry passengers across a state line they are, of course, engaged in interstate commerce, but not the commerce which Congress had in mind when legislating in 1887. Street railroads transport passengers from street to street, from ward to ward, from city to suburbs, but the commerce to which Congress referred was that carried on by railroads engaged in hauling passengers or freight 'between states,' 'between states and territories,' 'between the United States and foreign countries.' The act referred to railroads which were required to post their schedules-not at street corners where passengers board street cars but in 'every depot, station or offle where passengers or freight are received for transportation.' The railroads referred to in the Act were not those having separate, distinct and local street lines, but those of whom it was required that they should make joint and reasonable facilities for interchange of traffic with connecting lines, so that freight might be easily and expeditiously moved in interstate commerce.

***

"But it is said that since 1887 , when the Act was passed, a new type of interurban railroad has been developed which, with electricity as a motive power, uses larger cars and runs through the country from town to town, enabling the carrier to haul passengers, freight, express and the mail for long distances at high speed. We are not dealing with such a case, but with a company chartered as a street railroad, doing a street railroad business and hauling no freight. * * * The company used such cars and did a street passenger business only. It laid its tracks in crowded thoroughfares of those cities and their suburbs and it is manifest that Congress did not intend that these tracks should be connected with railroads for hauling freight cars and long trains through and along the streets of Omaha and Council Bluffs.

"It is contended, however, that the amendment of June $18,1910,(36$ Stat. 553), shows that Congress considered that street railroads were under the jurisdiction of the Commission inasmuch as it then provided that the Commission shall not establish any through route, classification or rate between street electric passenger railways not engaged in ${ }^{*} *$ transporting freight * * * and railroads of a different character.' It is contended on the other hand that in that statute Congress distinctly rec- 
kind used or necessary in the transportation of the persons or property designated herein, and also all freight depots, yards, and grounds used or necessary in the transportation or delivery of any of said property."

Ferries.-Thus by the terms of the Act railroad ferries are brought within the purview of Federal legislation and subjected to the control and jurisdiction of the Interstate Commerce Commission. But where ferries are operated on streams between two or more states and thus engage in interstate commerce the mere fact that they carry persons other than railroad passengers does not affect the situation since by reason of this legislation the whole business comprehended in such ferriage is immune from control by the State. This is in harmony with the general rule that where interstate commerce is involved and Congress has legislated concerning it the authority of Congress will be treated as having been exercised over the whole question to the entire exclusion of any form of State control. This necessarily follows since were Congress to divide its authority over the elements of interstate commerce, intermingled with the complex activities of other features of commerce, the national authority would be rendered nugatory by reason of the very confusion and conflict it would inspire. $^{32}$

ognized that a street electric road was 'a different character of railroad,' and apprehending that the broad language of the amendment of 1910 might be construed to take in street railroads, this provision was inserted out of abundant caution to prevent that result, as in the case of establishing routes wholly by water, which certainly were not within the terms of the original Act. This section of the Act of 1910, however, having been passed after the order was made by the Commission, November 27, 1909, is not before us for construction and, manifestly, cannot be given a retrospective operation, though the Government insists that it should be given a prospective operation. *** There being nothing to show that Congress attempted an express ratification and it being open whether the amendment was intended to confer a jurisdiction not previously given, the motion of the Government to make the order of November 27, 1909, effective from June 18 , 1910, cannot prevail."

32 New York Central and Hudson River Railroad v. Hudson County, 227 U. S. 248,57 L. Ed. 499, 33 Sup. Ct. 269. The tracks of the West Shore Railroad Company extend from upper New York state to the terminus of the road at Weehawken, New Jersey. From Weehawken steam ferries are opcrated to various terminal points in New York City for the purpose of carrying railroad passengers and traffic between thosc two points. Although operated as railroad ferries they are not limited to 
Bridges.-That bridges used by railroads engaged in interstate commerce are included within the scope of the act admits of no doubt. A bridge becomes under such conditions as much an instrumentality of commerce as the rails or the roadbed of which it is in reality a part and it is as essential to the operation of a rail-

the use of railroad passengers coming in or intending to go over the West Shore Railroad, but they are patronized freely by persons who have business in New York and Weehawken respectively. The Board of Chosen Freeholders of Hudson County, New Jersey, adopted ordinances fixing the rate for foot passengers ferried from New Jersey to New York and the action here was undertaken to prevent the enforcement of the ordinance in question. The court said:- "The inclusion of railroad ferries within the text (of the Act to Regulate Commerce) is so certain and so direct as to require nothing but a consideration of the text itself. Indeed, this inevitable conclusion is not disputed in the argument for the defendant in error, but it is insisted that as the text only embraces railroad ferries and the ordinances were expressly decided by the court below only to apply to persons other than railroad passengers, therefore the action by Congress does not extend to the subject embraced by the ordinances. But as all the business of the ferries between the two states was interstate commerce within the power of Congress to control and subject in any event to regulation by the state as long only as no action was taken by Congress, the result of the action by Congress leaves the subject, that is, the interstate commerce carried on by means of the ferries, free from control by the state. We think the argument by which it is sought to limit the operation of the Act of Congress to certain elements only of the interstate commerce embraced in the business of ferriage from state to state is wanting in merit. In the absence of an express exclusion of some of the elements of interstate commerce entering into the ferriage, the assertion of power on the part of Congress must be treated as being coterminous with the autthority over the subject as to which the purpose of Congress to take control was manifested. Indeed, this conclusion is inevitable since the assumption of a purpose on the part of Congress to divide its authority orer the elements of interstate commerce intermingled in the movement of the regulated interstate ferriage would be to render the national authority inefficacious by the confusion and conflict which would result. The conception of the operation at one and the same time of both the power of Congress and the power of the states over a matter of interstate commerce is inconceivable, since the exertion of the greater power necessarily takes possession of the field, and leaves nothing upon which the lesser power may operate. To concede that the right of a state to regulate interstate ferriage exists 'only in the absence of Federal legislation' and at the same time to assert that the state and federal power over such subject is concurrent is a contradiction in terms. But this view has been so often applied as to cause the subject to be no longer open to controversy." 
road as the engines and cars in which the traffic is carried. ${ }^{33}$ The fact that a bridge may be used both by trains engaged in intrastate commerce and by those engaged in interstate commerce makes it none the less an instrumentality of the latter.

\section{Switches, Tracks and Terminal Facilities.-The Act to Regu-} late Commerce extends to and covers all terminal facilities which, though entirely within a state, are used wholly or partly in the operations of interstate commerce. ${ }^{34}$ The Supreme Court has held that Congress has not so taken over the whole question of terminals, switching tracks, sidings, etc, of interstate railroads as

33 The decision of the Supreme Court in Pedersen v. Delaware, Lackawanna and Western Railroad Company, 229 U. S. 146, 57 L. Ed. I125, 33 Sup. Ct. 648 , is of particular interest in this connection. This was a case brought under the Employers Liability Act of 1908 . The railroad employee in question was killed while carrying a sack of bolts or rivets to be used in repairing a bridge regularly in use by both interstate and intrastate trains. The court declaring that the man was engaged in interstate commerce within the meaning of the Employers Liability Act, continued to say:- "Tracks and bridges are as indispensable to interstate commerce by railroad as are engines and cars; and sound economic reasons unite with settled rules of law in demanding that all of these instrumentalities be kept in repair. The security, expedition and efficiency of the commerce depends in large measure upon this being done. *** But independently of the statute, we are of opinion that the work of keeping such instrumentalities in a proper state of repair while thus used is so closely related to such commerce as to be in practice and in legal contemplation a part of it. The contention to the contrary proceeds upon the assumption that interstate commerce by railroad can be separated into its several elements, and the nature of each determined regardless of its relation to others or to the business as a whole. But this is an erroneous assumption. The true test always is: Is the work in question a part of the interstate commerce in which the carrier is engaged? * * Of course we are not here concerned with the construction of tracks, bridges, engines or cars which have not as yet become instrumentalities in such commerce, but only with the work of maintaining them in proper condition after they have become such instrumentalities and during their use as such. True, a track or bridge may be used in both interstate and intrastate commerce, but when it is so used it is none the less an instrumentality of the former; nor does its double use prevent the employment of those who are engaged in its repair or in keeping it in suitable condition for use from being an employment in interstate commerce."

34 United States v. Union Stock Yards \& Transit Co., 226 U. S. 286, 57 L. Ed. 226, 33 Sup. Ct. 83 . 
to invalidate all state regulations relative to the interchange of traffic. $^{35}$

35 Grand Trunk Railway v. Michigan Railroad Commission, 23I U. S 457, 58 L. Ed. 310, 34 Sup. Ct. 152. Suit was here brought as the result of an order by the Michigan Railroad Commission to compel the interchange of railway traffic centering in and about the city of Detroit. One defense interposed was that such an order amounted to state interference with interstate commerce concerning which Congress had already legislated and that it was therefore void. The court said:- "It is contended that the order is an interference with interstate commerce. The contention is premature if not without foundation. * * * We will not dwell on the contention of appellants that Congress has taken over the whole subject of terminals. team tracks, switching tracks, sidings, etc. We need make no other comment than it cannot be asserted as a matter of law that Congress has done so; and where the accommodation between intrastate and interstate commerce shall be made. we are not called upon to say on this record." Illinois Central R. R. v. De Fuentes (La. R. R. Com.), 236 U. S. 157.

An interesting line of decisions construing the scope of interstate commerce are to be found under the Employers Liability Act. Where a freight train was engaged in hauling two freight cars loaded with lumber destined for a port in the same state there to be loaded and shipped by boat to another state and the train was propelled by a switching engine it was engaged in interstate commerce. Seaboard Air Line Railway $v$. Moore, 228 U. S. 433, 57 L. Ed. 907, 33 Sup. Ct. 580 . Also the hauling of empty cars from one state to another is interstate commerce. North Carolina Railroad Co. צ. Zachary. 232 U. S. 248, 58 L. Ed. 59 I, 34 Sup. Ct. 305; Johnson v. Southern Pacific Co., I96 L. S. I, 49 L. Ed. 872. 25 Sup. Ct. 158. Inspecting, oiling and firing an engine preparatory to a movement of interstate freight has been held to be a part of interstate commerce under the Employers Liability Act. In this case the court said:"It is argued that because, so far as appears. deceased has not previously" participated in any movement of interstate ireight, and the through cars had not as yet been attached to his engine, his employment in interstate commerce was still in futuro. It seems to us, however, that his acts in inspecting. oiling, firing, and preparing his engine for the trip to Selma were acts performed as a part of interstate commerce and the circumstance that the interstate freight cars had not as yet been coupled up is legally insignificant." North Carolina Railroad Company v. Zachary, 232 U. S. 248, 58 L. Ed. 591, 34 Sup. Ct. 305.

On the other hand where a switching crew were moving several cars loaded with freight wholly intrastate and then intended to switch several cars loaded with interstate commerce the fact that it was the intention then to perform an act of interstate commerce was immaterial and did not alter the fact that the first switching was an act purely of intrastate commerce. The Supreme Court declared:- "Here, at the time of the fatal injury the intestate was engaged in moving several cars, all loaded with intrastate freight, from one part of the city to another. That was not a 
Transportation.-In the original Act of February 4, I887, this clause read merely- "and the term 'transportation' shall include all instrumentalities of shipment or carriage." By the Act of June 29, 1906, the clause "cars and other vehicles and" was inserted before the words "all instrumentalities," and after those words the two words "and facilities" were inserted; at the end of the original clause the Act of June 29, 1906, added the following

service in interstate commerce and so the injury and resulting death were not within the statute. That he was expected, upon the completion of that task, to engage in another which would have been a part of interstate commerce is immaterial under the statute. for by its terms the true test is the nature of the work being done at the time of the injury." Illinois Central Railroad Co. v. Behrens, 233 U. S. 473, 58 L. Ed. 105I, 34 Sup. Ct. 646. And a yard clerk who was killed while proceeding through a railway yard to meet an incoming interstate freight train in order to take down the numbers of the cars, inspecting the seals, checking and labeling them was employed at the time in interstate commerce. The court in an interesting decision said:- "The deceased was employed by the defendant as a yard clerk in that yard and his principal duties were those of examining incoming and outgoing trains and making a record of the numbers and initials on the cars, of inspecting and making a record of the seals on the car doors, of checking the cars with the conductor's lists, and of putting cards or labels on the cars to guide switching crews in breaking up incoming and making up outgoing trains. His duties related to both intrastate and interstate traffic, and at the time of his injury and death he was on his way through the yard to one of the tracks therein to meet an incoming freight train composed of several cars, ten of which were loaded with freight. The purpose with which he was going to the train was that of taking the numbers of the cars and otherwise performing his duties in respect to them. While so engaged he was struck and fatally injured by a switch engine, which, it is claimed, was being negligently operated by other employees in the yard. * * * The train from Oklahoma was not only an interstate train, but was engaged in the movement of interstate freight; and the duty which the deceased was performing was connected with that movement, not indirectly or remotely, but directly and immediately. The interstate transportation was not ended merely because that yard was a terminal for that train, nor even if the cars were not going to points beyond. Whether they were going further or were to stop at that station, it still was necessary that the train be broken up and the cars taken to the appropriate tracks for making up outgoing trains or for unloading and delivering freight, and this was as much a part of the interstate transportation as was the movement across the state line. MeNeill v. Southern Railway Co., 202 U. S. 543, 50 L. Ed. II 42,26 Sup. Ct. 722. See also Johnson v. Southern Pacific Company. 196 U. S. I, 49 L. Ed. 872 , 25 Sup. Ct. 158." St. Louis, San Francisco and Texas Railway Co. v Seale, 229 U. S. 156, 57 L. Ed. 1129, 33 Sup. Ct. 651. 
- "irrespective of ownership or of any contract, express or implied, for the use thereof and all services in connection with the receipt, delivery, elevation, and transfer in transit, ventilation, refrigeration or icing, storage and handling of property transported; and it shall be the duty of every carrier subject to the provisions of this Act to provide and furnish such transportation upon reasonable request therefor, and to establish through routes and just and reasonable rates applicable thereto." The Act of June I8, I9Io, added to the foregoing the clause- "and to provide reasonable facilities for operating such through routes and to make reasonable rules and regulations with respect to the exchange, interchange, and return of cars used therein, and for the operation of such through routes, and providing for reasonable compensation to those entitled thereto."

The Act therefore specifically includes all manner of cars which are used by railroads for transporting passengers and freight between states-sleeping cars, chair cars, dining cars, day coaches, etc., freight cars, flat cars, box cars, gondola cars, etc., and locomotives, steam and electric. ${ }^{36}$

Receipt and Delivery of Freight.-Transportation includes something more than the mere carriage or movement of traffic. It includes, for instance, what is a condition precedent to carriage -that is the receipt of the goods in question-and it includes as well their delivery or offer to the party for whom they are intended. The Supreme Court has declared that transportation begins with the delivery of the articles in question to the carrier to be loaded upon its cars, and ends only after they are unloaded and delivered, or offered to be delivered, to the consignee at such a place as will permit him to take them into his possession. Under the general law and even before the enactment of the Act to Regu-

36 Decisions of the Supreme Court under the Safety Appliance Act of March 2, 1893 , as amended, are interesting by way of suggestion. In Johnson v. Southern Pacific Co., 196 U. S. 1, 49 L. Ed. 8;2, 25 Sup. Ct. 158, the court said:- "Tested by context, subject matter and object, "any car' meant all kinds of cars running on the rails, including locomotives." In Schlemmer v. Buffalo, Rochester and Pittsburgh Railway Co., $205 \mathrm{U}$. S. I, 51 L. Ed. 681, 27 Sup. Ct. 407, the term was held to cover shovel cars. In Southern Railway Company v. United States, 222 U. S. 20, 56 L. Ed. 72, 32 Sup. Ct. 2, the Employers Liability Act as amended was declared "to embrace all locomotives, cars and similar vehicles used on any railroad which is a highway of intcrstate commerce." 
late Commerce a common carrier from the very nature of its employment was under the legal obligation to furnish suitable and necessary facilities for receiving property of all kinds offered to it for shipment over its road and connections and also for discharging the property after it shall have reached the place of consignment. And moreover such carriers were not entitled to assess or collect an extra or special charge for merely receiving or delivering goods through its freight depots or plants or stock yards even, any more than they could make a special charge for the use of passenger depots by passengers proceeding to or coming from trains. Such facilities the carriers are bound to furnish and such services they are bound to render without any other or further compensation than the customary charges for transportation. $^{37}$ This rule, however, does not prevent a carrier from making a charge, additional to that for transportation, for special services rendered to the shipper or consignce besides the mere receipt

37 North Pennsylvania Railroad Co. v. Commercial Bank of Chicago, 123 U. S. 727,31 L. Ed. 287,8 Sup. Ct. 266 . Here the court said:-"The duty of a common carrier is not merely to carry safely the goods intrusted to him, but also to deliver them to the party designated by the terms of the shipment, or to his order, at the place of destination. There are no conditions which would release him from this duty except such as would release him from the safe carriage of the goods. The undertaking of the carrier to transport goods necessarily includes the duty of delivering them. * * * He cannot release himself from responsibility by abandoning the goods or turning them over to one not entitled to receive them."

In Covington Stock Yards v. Keith, 139 U. S. 128, 35 L. Ed. 73, II Sup. Ct. 416, the court said:- "The carrier must at all times be in proper condition both to receive from the shipper and to deliver to the consignee, according to the nature of the property to be transported, as well as to the necessities of the respective localities in which it is received and delivered. A carrier of live stock has no more right to make a special charge for merely receiving or merely delivering such stock, in and through stock yards provided by itself, in order that it may properly receive and load, or unload and deliver, such stock, than a carrier of passengers may make a special charge for the use of its passenger depot by passengers when proceeding to or coming from its trains, or than a carrier may charge the shipper for the use of its general freight depot in merely delivering his goods for shipment, or the consignee of such goods for its use in merely receiving them there within a reasonable time after they are unloaded from the cars."

See also Interstate Commerce Commission v. Atchison, Topeka and Sante Fe Railway Company, (Los Angeles Switching Case), 234 U. S. 294, 58 L. Ed. 1319, 34 Sup. Ct. 814. 
and delivery of the goods-as, for instance, for storage in a warehouse where the goods are not accepted and removed within a reosonable time by the consignee or his agents. In this regard the Act to Regulate Commerce amounted to a statutory declaration of the common law obligations of common carriers and did not impose upon the carriers any new or burdensome duties or obligations regarding the receipt or delivery of traffic. But the obligation of a carrier to accept shipments offered or tendered at its station is a reasonable one and does not contemplate that it must accept cars offered to it at an arbitrary point near its terminus by a competing railroad for the obvious and manifest purpose of securing the use of the terminal facilities of the first road. ${ }^{38}$ Such

38 Louisville and Nashville Railroad Company v. Central Stock Yards, 212 U. S. 132, 53 L. Ed. 441, 29 Sup. Ct. 246. The Central Stock Yards Company had equipped excellent facilities for the handling of live stock to and from Louisville on the Southern Railway. The Louisville and Nashville Raitroad by a similar arrangement has made the Bourbon Stock Yards its live stock depot at Louisville. The two railroads had physical connections at a point between the two stock yards in question. Suit was brought by the Central Stock Yards Company against the Louisville and Nashville road to compel it to receive live stock tendered to it outside the state of Kentucky for the Central Stock Yards station and to deliver the same at a point of physical connection between its road and the Southern Railway, for ultimate delivery to or at the Central Stock Yards. The Constitution of Kentucky required railroad companies organized under that state to receive, move, load. unload. etc., freight tendered by other connecting roads without delay or discrimination. The Supreme Court said:- "There remains for consideration only the third division of the judgment, which requires the plaintiff in error to receive at the connecting point, and to switch, transport and deliver all live stock consigned from the Central Stock Yards to any one at the Bourbon Stock Yards. This also is based upon the sections of the Constitution that have been quoted. If the principle is sound, every road into Louisville, by making a physical connection with the Louisville and Nashrille, can get the use of its costly terminals and make it do the switching necessary to that end, upon simply paying for the service of carriage. The duty of a carrier to accept goods tendered at its station does not extend to the acceptance of cars offered to it at an arbitrary point near its terminus by a competing road, for the purpose of reaching and using its terminal station. To require such an acceptance from a railroad is to take its property in a very effective sense, and cannot be justified, unless the railroad holds that property subject to greater liabilities than those incident to its calling alone. The Court of Appeals did not put its decision upon any supposed special liability, but upon the broad ground that the state constitution requires it and law fully may require it of a common carrier by rail. Therefore the judgment must be reversed." 
a requirement would in fact amount to a taking of the property of the first railroad company without due process of law in violation of the constitutional guarantee.

As a result of the provisions thus expressly inserted in Section one of the Act to Regulate Commerce by the Hepburn Act, with reference to the provision and delivery of cars for interstate shipments, all state legislation on that subject is superseded. ${ }^{39}$ Con-

39 Chicago, Rock Island and Pacific Railway Co. v. Hardwick Farmers' Eilevator Co., 226 U. S. 426, 57 L. Ed. 284, 33 Sup. Ct. 174. The statute here in question was known as the Minnesota Reciprocal Demurrage Law which sought to make it the duty of a railway company subject to its provisions, on demand by a shipper, to furnish cars for transportation of freight, at terminal points on its line of road in Minncsota within fortyeight hours and at intermediate points within seventy-two hours after such demand, Sundays and legal holidays excepted. For failure to comply with these requirements penalties were defined. The Supreme Court in passing upon this statute said:- "We are not called upon to test the merits of these conflicting contentions, since we are of opinion that by the Act of June 29, 1906, known as the Hepburn Act, amendatory of the Act to Regulate Commerce, Congress has legislated concerning the deliveries of cars in interstate commerce by carriers subject to the Act. In the original Act to regulate commerce the term 'transportation' was declared to embrace all instrumentalities of shipment or carriage. By the Hepburn Act it was declared that the term transportation (italics ours)-

"shall include cars and other vehicles and all instrumentalities and
facilities of shipment or carriage, irrespective of ownership or of
any contract, express or implied, for the use thereof and all services
in connection with the receipt, delivery, elevation, and transfer in
transit, ventilation, refrigeration or icing, storage and handling of
property transported; and it shall be the duty of every carrier sub-
ject to the provisions of this act to provide and furnish such trans-
portation upon reasonable request therefor, and to establish through
routes and just and reasonable rates applicable thereto.'

"The purpose of Congress to specifically impose a duty upon a carrier in respect to the furnishing of cars for interstate traffic is of course by these provisions clearly declared. That Congress was specially concerning itself with that subject is further shown by a proviso inserted to supplenent section I of the original act imposing the duty under certain circumstances to furnish switch connections for interstate traffic, whereby it is specifically declared that the common carrier making such connections 'shall furnish cars for the movement of such traffic to the best of its ability without discrimination in favor of or against any such shipper.' Not only is there then a specific duty imposed to furnish cars for interstate traffic upon reasonable request therefor, but other applicable sections of the Act to Regulate Commerce give remedies for the violation of that duty. ** As legislation concerning the delivery of cars for the carriage of interstate traffic was clearly a matter of interstate commerce 
gress thus declared clearly its purpose to regulate the delivery of cars in interstate commerce by carriers coming within the purview of that Act. Thus statutes of the various states assessing penalties for delay or failure to furnish cars for shipments, fixing

regulation, even if such subject was embraced within that class of powers concerning which the state had a right to exert its authority in the absence of legislation by Congress, it must follow in consequence of the action of Congress to which we have referred that the power of the state over the subject matter ceased to exist from the moment that Congress exerted its paramount and all embracing authority over the subject. We say this because the elementary and long-settled doctrine is that there can be no divided authority over interstate commerce and that the regulations of Congress on that subject are supreme. It results, therefore, that in a case where from the particular nature of certain subjects the state may exert authority until Congress acts under the assumption that Congress by inaction has tacitly authorized it to do so, action by Congress destroys the possibility of such assumption, since such action, when exerted, covers the whole field and renders the state impotent to deal with a subject over which it had no inherent but only permissive power. Southern Railway Co. v. Reid, 222 U. S. 424, 56 L. Ed. 257, 32 Sup. Ct. I40."

The so-called Demurrage Statute of April 19, 1907, of Arkansas, was considered in St. Louis, Iron Mountain and Southern Railway v. Edwards, 227 U. S. 265, 57 L. Ed. 506, 33 Sup. Ct. 262. This statute aimed at imposing a penalty on carriers for delay in giving notice to consignees of the arrival of shipments of freight. The court said:- "As applied to interstate commerce, we think such penalties were not enforceable because of a want of power in the state to impose them in view of the legislation of Congress existing at the time the alleged duty to give notice arose. Recently in Chicago, Rock Island and Pacific Railway Co. v. Hardwick Farmers' Elevator Company, 226 U. S. 426, 57 L. Ed. 284, 33 Sup. Ct. I74, a regulation of the state of Minnesota enacted after the passage of the Hepburn Act imposing penalties on carriers for failing on demand to furnish a supply of cars for the movement in interstate traffic was held invalid because of the absence of power in a state in consequence of the Hepburn Act to provide for such penalties. While the case before us concerns the power of a state over the delivery of cars in consummation of an interstate shipment, we nevertheless think that the Hardwick case is controlling because the legislation of Congress as clearly excludes the right of a state to penalize for failure to deliver interstate freight at the termination of an interstate shipment as it was found to prevent a state from penalizing for failure to furnish cars for the initiation of the movement of interstate traffic. This conclusion is necessary since the amendment to section I of the Act to regulate commerce by which a definition is given to the term transportation and which in the Hardwick case was held to exclude the right of a state to penalize for the non-delivery of cars to initiate the movement of an interstate shipment, by its very terms embraces the obligation of a carrier to deliver to the consignee, and 
demurrage charges for delays in the delivery of freight, regulating the interchange of traffic between railroads having physical connections within the state are void. This is true because the state at best had no inherent but only a permissive power and when the

therefore by the same token excludes the right of a state to penalize on that subject. ***We are referred in argument to no other provision of the Act tending in the slightest degree to indicate that the duties which were united by the provisions of one section of the Act were divorced by another and were made therefore subject to the possibility of varying and it may be conflicting state penalties. On the contrary, in this instance as in the one considered in the Hardwick case, the context of the Act adds strength to the conviction produced by the definition of the first section, and therefore gives rise to the conviction that the context of the statute, not only as was held in the Hardwick case, excludes the right of a state to regulate by penalties or demurrage charges the obligation of furnishing the means of interstate transportation, but also excludes power in a state to impose penalties as a means of compelling the performance of the duty to promptly deliver in consummation of such transportation."

See also Yazoo and Mississippi Valley Railroad Company v. Greenwood Grocery Co., 227 U. S. I, 57 L. Ed. 389, 33 Sup. Ct. 213, where in considering delayage charges the court said:- "Approaching the subject from this point of view, we think the rule of the state commission upon which the right to all the so-called 'delayage penalties' was based constituted an unreasonable burden upon interstate commerce within the decision in Houston R. R. Co. v. Mayes, 201 U. S. 321, 50 L. Ed. 772, 26 Sup. Ct. 491, since the requirement as to the delivery of cars within the short period fixed in the rule is absolute, and makes no allowance whatever for any justifiable and unavoidable cause for the failure to deliver." And see Louisville and Nashville Railroad Co. v. Central Stock Yards Co., 212 U. S. 132, 53 L. Ed. 441, 29 Sup. Ct. 246.

In McNeill v. Southern Railway Co., 202 U. S. 543, 50 L. Ed. I142, 26 Sup. Ct. 722, the issue involved an order of the North Carolina Railroad Commission to the railroad requiring it to make delivery of certain cars, from points in other states, beyond its right of way and on the siding of the consignee. The court said:- "The cars of coal not having been delivered to the consignee, but remaining on the tracks of the railway company in the condition in which they had been originally brought into North Carolina from points outside of that state, it follows that the interstate transportation of the property had not been completed when the corporation Commission made the order complained of. *** Without at all questioning the right of the state of North Carolina in the exercise of its police authority to confer upon an adminstrative agency the power to make many reasonable regulations concerning the place, manner and time of delivery of merchandise moving in the channels of interstate commerce, it is certain that any regulation of such subject made by the state or under its authority which directly burdens interstate commerce is a regulation 
national government acted that power was nullified and all permissive legislation enacted under it avoided. The courts have

of such commerce and repugnant to the Constitution of the United States. (Houston \& Texas Rwy. Co. v. Mayes, 20I U. S. 321, 5o L. Ed. 772, 26 Sup. Ct. 49I.) Not being called upon to do so, we do not pass upon all the general regulations formulated by the Commission on the subject stated, but are clearly of opinion that the court below rightly held that the particular application of those regulations with which we are here concerned was a direct burden upon interstate commerce and void. Viewing the order which is under consideration in this case as an assertion by the corporation Commission of its general power to direct carriers engaged in interstate commerce to deliver all cars containing such commerce beyond their right of way and to a private siding, the order manifestly imposed a burden so direct and so onerous as to leave no room for question that it was a regulation of interstate commerce. On the other hand, treating the order as but the assertion of the power of the corporation Commission to so direct in a particular case, in favor of a given person or corporation, the order not only was in its very nature a direct burden and regulation of interstate commerce, but also asserted a power concerning a subject directly covered by the Act of Congress to regulate commerce and the amendments to that Act, which forbid and provide remedies to prevent unjust discrimination and the subjecting to undue disadvantages by carriers engaged in interstate commerce."

Houston and Texas Central Railroad Company v. Mayes, 201 U. S. 32I, 50 L. Ed. 772, 26 Sup. Ct. 49I, involved the constitutionality of certain statutes of the state of Texas which undertonk to assess penalties on railroads which failed to furnish cars to shippers as requested in written notices. The court declared:- "While there is much to be said in favor of laws compelling railroads to furnish adequate facilities for the transportation of both freight and passengers. and to regulate the general subject of speed, length and frequency of stops, for the heating, lighting and ventilation of passenger cars, the furnishing of food and water to cattle and other live stock, we think an absolute requirement that a railroad shall furnish a certain number of cars at a specified day, regardless of every other consideration except strikes and other public calamities, transcends the police power of the state and amounts to a burden upon interstate commerce. It makes no exception in cases of a sudden congestion of traffic, an actual inability to furnish cars by reason of their temporary and unavoidable detention in other states, or in other places within the same state. It makes no allowance for interference of traffic occasioned by wrecks or other accidents upon the same or other roads, involving a detention of traffic, the breaking of bridges, accidental fires, washouts or other unavoidable consequences of heavy weather. *** Although it may be admitted that the statute is not far from the line of proper police regulation, we think that sufficient allowance is not made for the practical difficulties in the administration of the law, and that, as applied to interstate commerce, it transcends the legitimate powers of the legislature." 
suggested, however, that a state statute which merely sought to prevent any discrimination against demands for cars for interstate shipments, or forbidding an unequal distribution of cars by a carrier for the benefit of interstate to the detriment of local commerce might be upheld. ${ }^{40}$

Stock Yards and Terminal Facilities for Live Stock.-Generally speaking transportation per se terminates when the goods in question are received at the station or warehouse of the town to which the consignment is made. ${ }^{41}$ And for services rendered in addition to and beyond that, further charges may be made beside those for the mere transportation. But the carrier must provide suitable facilities for the delivery of all classes of freight in keeping with the nature and demands which they suggest.

40 St. Louis Southwestern Railway Co. v. Arkansas, 217 U. S. 136,54 L. Ed. 698,30 Sup. Ct. 476 . Here the question at issue turned upon a statute requiring railroad companies to deliver cars to shippers with penalties for violations. The court in concluding said:- "We think it needs but statement to demonstrate that the ruling of the court below involved necessarily the assertion of power in the state to absolutely forbid the efficacious carrying on of interstate commerce, or, what is equivalent thereto, to cause the right to efficiently conduct such commerce to depend upon the willingness of the company to be subjected to enormous pecuniary penalties as a condition of the exercise of the right. It is to be observed that there is no question here of a regulation of a state forbidding an unequal distribution of cars by a carrier for the benefit of interstate to the detriment of local commerce. * * * In the nature of things, as the rules and regulations of the (American Railway) Association concern matters of interstate commerce inherently within federal control, the power to determine their sufficiency we think was primarily vested in the body upon whom Congress has conferred authority in that regard." See also Hampton v. St. Louis and Iron Mountain Railway Co., 227 U. S. 456, 57 L. Ed. 596, 33 Sup. Ct. 263, where also an Arkansas statute was under consideration-forbidding discrimination between shippers and requiring cars to be furnished on application of shippers. The court said:- "Coming first to the clause in the 17th section which the court below held invalidated the whole Act: That clause probably means no more than that there shall be no discrimination aginst demands for cars for interstate shipments. If, however, it be construed as extending the Act so as to regulate the furnishing of cars for interstate shipments, it would be invalid by reason of the provisions of the Hepburn amendment to the Act to regulate commerce of June 29, 1906."

4I Interstate Commerce Commission v. Detroit, Grand Haven and Milwaukee Railway Co. (known as the Grand Haven Cartage Case), 167 U. S. 633, 42 L. Ed. 310, 17 Sup. Ct. 957. 
The same facilities will not meet the requirements of all classes of traffic. An enclosed depot or warehouse while serving for the receipt or delivery of inanimate though perishable goods would not be proper or sufficient for handling live stock. From the very nature of its employment a carrier of live stock must provide the not only necessary but also suitable facilities for receiving such stock as is offered for shipment and for discharging and caring for such stock as may be received for consignees at that point. In Covington Stockyards v. Keith, the Supreme Court said-"The duty to receive, transport and deliver live stock will not be fully discharged, unless the carrier makes such provision, at the place of loading, as will enable it to properly receive and load the stock, and such provision, at the place of unloading, as will enable it to properly deliver the stock to the consignee."42 From the very"

42139 U. S. 128, 35 L. Ed. 73, 1 I Sup. Ct. 4 I6. In a complete discussion of the matter of terminal facilities for the receipt and delivery of different classes of freight the Supreme Court said:- "The railroad company, holding itself out as a carrier of live stock, was under a legal obligation, arising out of the nature of its employment, to provide suitable and necessary means and facilities for receiving live stock offered to it for shipment over its road and connections, as well as for discharging such stock after it reaches the place to which it is consigned. * * When animals are offered to a carrier of live stock it is its duty to receive them; and that duty cannot be efficiently discharged, at least in a town or city, without the aid of yards in which the stock offered for shipment can be received and handled with safety and without inconvenience to the public while being loaded upon the cars in which they are to be transported. So, when live stock reach the place to which they are consigned, it is the duty of the carrier to deliver them to the consignee; and such delivery cannot be safely or effectively made except in or through inclosed yards or lots, convenient to the place of unloading. In other words, the duty to receive, transport and deliver live stock will not be fully discharged, unless the carrier makes such provision, at the place of loading, as will enable it to properly receive and load the stock, and such provision, at the place of unloading, as will enable it to properly deliver the stock to the consignee."

To the same effect the court in North Pennsylvania Railroad Co. v. Commercial Bank of Chicago, I23 U. S. 727, 31 L. Ed. 287, 8 Sup. Ct. 266, said:- "The duty of a common carrier is not merely to carry safely the goods intrusted to him, but also to deliver them to the party designated by the terms of the shipment, or to his order, at the place of destination. There are no conditions which would release him from this duty except such as would release him from the safe carriage of the goods. The undertaking of the carrier to transport goods necessarily includes the duty of delivering them. ** If the consignee is absent from the place of 
nature of the case a carrier of live stock is not charged with all the responsibilities that distinguish a carrier of goods. This is due to the nature of the traffic, the apparent difficulties in its safe transportation, the necessity of providing food, water, light, air and exercise for the animals as well as the obligation to protect them not only from injuries from without but also to keep them from injuring each other-all of these are considerations which suggest the widely different duties devolving upon a carrier of live stock from a carrier of goods merely which require none of those special attentions. And though these obligations may be different the carrier is charged with the same duty and the same obligation as in the carriage of goods-of providing suitable facilities for receipt and delivery. And these facilities must be adapted to the character of the traffic which they are required to accommodate, and also to the necessities of the localities where the stock is to be received or delivered. For the mere receipt or delivery of this stock, including the process of loading and unloading, the carrier was held to be no more entitled to make an extra charge than for the use of its general freight depots for loading and unloading ordinary shipments of goods or the use of its passenger depots for receiving and discharging its passengers. ${ }^{43}$ At

destination, or cannot, after reasonable inquiries, be found, and no one appears to represent him, the carrier may place the goods in a warehouse or store with a responsible person to be kept on account of and at the expense of the owner. He cannot release himself from responsibility by abandoning the goods or turning them over to one not entitled to receive them. If the freight consist, as in this case, of live stock, the carrier will not, under the circumstances mentioned, that is, when the consignee is absent or cannot after reasonable inquiries be found, and no one appears to represent him, relieve himself from responsibility by turning the animals loose. He must place them in some suitable quarters where they can be properly fed and sheltered, under the charge of a competent person as his agent, or for account and at the expense of the owner. Turning them loose without a keeper or delivering them to one not entitled to receive them would equally constitute a breach of duty for which he could be held accountable. These principles are firmly established by the adjudged cases and rest upon obvious grounds of justice."

43 North Pennsylvania Railroad Co. v. Commercial Bank of Chicago, 123 U. S. 727,31 L. Ed. 287,8 Sup. Ct. 266, supra. The court further declared:- "A railroad company, it is true, is not a carrier of live stock with the same responsibilities which attend it as a carrier of goods. The nature of the property, the inherent difficulties of its safe transportation, and the necessity of furnishing to the animais fnod and water, light and air, and 
the same time the railroad company is required to furnish only reasonable facilities and only at proper places and it could not be required to provide appliances for receiving or delivering stock at every point on its line, within or without a city, where persons might live or transact business and desire to establish a stock yard. ${ }^{4 t}$

protecting them from injuring each other, impose duties in many respects widely different from those devolving upon a mere carrier of goods. The most scrupulous care will not always secure the carrier from loss. But notwithstanding this difference in duties and responsibilities, the railroad company, when it undertakes generally to carry such freight, becomes subject, under similar conditions, to the same obligations so far as the delivery of the animals which are safely transported is concerned, as in the case of goods. They are to be delivered at the place of destination to the party designated to receive them if he presents himself, or can with reasonable efforts be found, or to his order. No obligation of the carrier, whether the freight consists of goods or of live stock, is more strictly enforced."

In Covington Stock Yards Company v. Keith, 139 U. S. 128, 35 L. Ed. 73, II Sup. Ct. 416, the court said further:-"There are recognized limitations upon the duty and responsibility of carriers of inanimate property that do not apply to carriers of live stock. These limitations arise from the nature of the particular property transported. * * * The same principle (as to rules governing delivery) necessarily applies to the receiving of live stock by the carrier for transportation. The carrier must at all times be in proper condition both to receive from the shipper and to deliver to the consignee, according to the nature of the property to be transported, as well as to the necessities of the respective localities in which it is received and delivered. A carrier of live stock has no more right to make a special charge for merely receiving or merely delivering such stock, in and through stock yards provided by itself, in order that it may properly receive and load, or unload and deliver, such stock, than a carrier of passengers may make a special charge for the use of its passenger depot by passengers when proceeding to or coming from its trains, or than a carrier may charge the shipper for the use of its general freight depot in merely delivering his goods for shipment, or the consignee of such goods for its use in merely receiving them there within a reasonable time after they are unloaded from the cars. If the carrier may not make such special charges in respect to stock yards which itself owns, maintains or controls, it cannot invest another corporation or company with authority to impose burdens of that kind upon shippers and consignees. The transportation of live stock begins with their delivery to the carrier to be loaded upon its cars, and ends only after the stock is unloaded and delivered, or offered to be delivered, to the consignees, if to be found, at such place as admits of their being safely taken into possession."

44 Covington Stock Yards Co. v. Keith, 139 U. S. 128, 35 L. Ed. 73, I 1 Sup. Ct. 416. The court here declared:- "We must not be understood 
It is not to be assumed in the concrete, whatever the situation may be as to theory, that the carriers gratuitously furnish these terminal facilities or gratuitously perform these terminal services. The presumption is that the through rate includes adequate compensation for the services rendered at both the point of delivery and shipment. For years the carriers had delivered carloads of cattle to the various stockyards throughout the country without making any charge other than that specified for transportation in the through rate, though that rate is presumed to have provided in and of itself compensation for services rendered in making delivery at stock yards. There was no division of the rate into "rate charge" and "terminal charge." But with the addition of services performed by the railroads in connection with such terminal facilities as stock yards which were in many cases located at a distance from their own lines, separate or so-called "terminal charges" were made. Apparently these were not arrived at by dividing their previous charges or by setting apart the alleged treminal charge embraced in the through rate so as to segregate it from that rate,-making one distinct "terminal charge" and another distinct "through rate."

While it is true that the receipt and delivery of traffic to the consignee or his order is as much a part of the transportation as the actual physical carriage of the goods for which the carrier is not entitled to make any extra charge, yet for services that the railroad may render or procure to be rendered off its own line, or outside the real matter of transportation over its line, it is entitled to charge and receive proper compensation. ${ }^{45}$ In actual practice it is not essential that the terminal properties and facilities should be actually owned or directly leased by a railroad company in order to bring them within the jurisdiction of the Interstate Commerce Commission. The jurisdiction of the Commis-

as holding that the railroad company, in this case, was under any legal obligation to furnish, or cause to be furnished, suitable and convenient appliances for receiving and delivering live stock at every point on its line in the city of Covington where persons engaged in buying, selling or shipping live stock, chose to establish stock yards. *** It was not within the power of the railroad company *** by agreement in any form, to burden appellees with charges for services it was bound to render without any other compensation than the customary charges for transportation."

45 Interstate Commerce Commission v. Stickney, 215 U. S. 98, 54 L. Ed. I12, 30 Sup. Ct. 66. 
sion will not be defeated by a mere artificial device. Where the terminal is a portion of a system engaged in the transportation of interstate commerce the Commission has jurisdiction to supervise and control it within the proper statutory limitations. And so where a railroad company and a terminal company which is in fact a wharfage company are both operated by a dominating holding company, the railroad and wharfage companies being nominally independent each of the other, this artificial relation is but an incident which will not be permitted to serve as a cover to the real relations which subject them to the control of the Interstate Commerce Commission. ${ }^{4}$ The law and the courts will deal

46 Southern Pacific Terminal Company $\therefore$. Interstate Commerce Commission, 219 U. S. 498, 55 L. Ed. 310, 31 Sup. Ct. 279. Here the Southern Pacific Terminal Company owning wharves and terminals at Galveston, and the Southern Pacific railroads including the Galveston, Harrisburg and San Antonio Railway Company, are controlled by the Southern Pacific Company owning ninety-nine per cent. of their stock. Import and export traffic passing through Galveston passes over the wharves of the terminal company and the only track facilities are those owned by the terminal company on its own lands. The Galveston, Harrisburg and San Antonio Railway is the only road having physical connection with the tracks of the terminal company. The terminal company own no cars or locomotives and issues no bills of lading but carries on a wharfage business and publishes a schedule of charges for such business which, however, is not filed with the Interstate Commerce Commission. Its charges are shown as wharfage charges in the tariffs of the Galveston, Harrisburg and San Antonio Railroad and the other railways entering Galveston. The court, in discussing these various relations and their effect upon the jurisdiction of the Interstate Commerce Commission, said:- "There is a separation of the companies if we regard only their charters; there is a union of them if we regard their control and operation through the Sonthern Pacific Company. This control and operation are the important facts to shippers. It is of no consequence that by mere charter declaration the terminal company is a wharfage company or the Southern Pacific a holding company. Verbal declarations cannot alter facts. The control and operation of the Southern Pacific Company of the railroads and the terminal company have united them into a system of which all are necessary parts, the terminal company as well as the railroad companies. As said by the Interstate Commerce Commission, 'the terminal company was organized to furnish terminal facilities for the system at the port of Galveston,' and it is further said that 'through shipments on the railroad lines from and to points in different states of the Union pass and repass over the docks of the terminal company. It forms a link in this chain of transportation. It is necessary to complete the avenue through which move shipments over these lines owned by a single corporation.' * * * And 
with the system as a whole and not with its various constituent elements.

surely a system so constituted and used as an instrument of interstate commerce may not escape regulation as such because one of its constituents is a wharfage company and its dominating power a holding company. As well said by the Interstate Commerce Commission, 'a corporation such as this terminal company, which has 'competing lines,' should not be permitted to defeat the jurisdiction of this Commission by showing that it is not in fact owned by any railroad company, *** The terminal com. pany is part and parcel of the system engaged in the transportation of commerce, and to the extent that such commerce is interstate the Commission has jurisdiction to supervise and control it within statutory limits. To hold otherwise would in effect permit carriers generally, through the organization of separate corporations, to exempt all of their terminals from our regulating authority.'

"The reasoning of the Commission is justified by the statute. It includes in the term 'railroad' 'all bridges and ferries used or operated in connection with any railroad, and also all the roads in use by any corporation operating a railroad, whether owned or operated under a contract, agreement, or lease, and shall also include all switches, spurs, tracks, and terminal facilities of every kind used or necessary in the transportation of the persons or property designated herein, and also all freight depots, yards, and grounds used or necessary in the transportation or delivery of any of said property.' The property of the terminal company is 'necessary in the transportation or delivery' of the interstate and foreign freight transported by the lines of the Southern Pacific system. It is the only terminal for freight moving over the lines of such system, the rails of one of those lines, the Galveston, Harrisburg and San Antonio Railway Company, connecting with tracks upon the docks of the terminal company. That the latter collects a trackage charge from the former and it a switching charge from the terminal company are, to quote the Commission, "but incidents of the separate corporations.' In opposition to these views appellants urge the legal individuality of the different railroads and the terminal company and cite cases which establish, it is contended, that stock ownership simply or through a holding company does not identify them. We are not concerned to combat the proposition. The record does not present a case of stock ownership merely or of a holding company which was content to hold. It presents a case, as we have already said, of one actively managing and uniting the railroads and the terminal company into an organized system. It is with the system that the law must deal, not with its elements. Such elements may, indeed, be regarded from some standpoints as legal entities; may have, in a sense, separate corporate operation; but they are directed by the same paramount and combining power and made single by it. In all transactions it is treated as single. *** And, we have seen, the terminal facilities which the terminal company was authorized to maintain were for the system, not for the corporate elements considered separately." 
When in addition to the mere delivery of traffic something is done by the railroads which inures in some manner to the benefit of the shipper and which involves some service rendered by and expense borne by the railroad company the carrier is entitled to make a charge in addition to that assessed merely for the transportation. But the service rendered must be of some actual benefit to the shipper or his consignee and involve some added burden upon the carrier, and it must not be a mere subterfuge or cloak for an extra or unwarranted charge. And where such an actual service is rendered the carrier is not limited in its charge to the bare cost of performing the act in question. It is warranted in receiving some compensation in addition thereto and in securing a reasonable profit out of its operations. ${ }^{47}$ The Supreme Court has declared the situation analagous to the case of furnishing sleeping accommodations for its passengers-that the railroads are under no obligation to provide such accommodations but if they do so they are not limited in their charges to the mere cost therof but are entitled to make a measure of profit. Especially is the carrier entitled to make such charges when the privilege extended to the shipper or the consignee is in no sense a part of the transportation but is outside thereof.

47 Southern Railway Co. v. St. Louis Hay and Grain Co., 214 U. S. 297, 53 L. Ed. 1004, 29 Sup. Ct. 678. In this case the question arose concerning the custom of the hay and grain company to ship hay to its warehouses, there unload it and inspect and reload it for southern markets. This is called a reconsigmment. This practice involved the use of the cars for a longer time than otherwise and involved additional expense for hauling cars and the railroad company made a charge per car therefor. The hay and grain company sought to have the charge limited to the actual cost of this additional service rendered. The court said:"If the stopping for inspection and reloading is of some benefit to the shipper and involves some service by and expense to the railway company, we do not think that the latter is limited to the actual cost of that privilege. It is justified in receiving some compensation in addition thereto. A carrier may be under no obligations to furnish sleeping or other accommodations to its passengers, but if it does so it is not limited in its charges to the mere cost, but may rightfully make a reasonable profit out of that which it does furnish. Especially is this true when, as here, the privilege is in no sense a part of the transportation, but outside thereof. Whether the conclusion of the Commission that the carrier is under no obligations to permit the interruption of the transit is right, and whether it is or is not under such obligation, it is entitled to receive some compensation beyond the mere cost for that which it does." 
Stock Yard Charges.-As we have seen the carriers of live stock were charged with the duty of providing suitable facilities for delivering as well as receiving this class of traffic which could be properly handled only by the erection and use of suitable yards properly enclosed and fenced. And for the mere delivery of stock within such enclosures when forming a part of the ordinary terminal facilities of the railroads no extra charge could be exacted. ${ }^{48}$ The charge for transportation was deemed to include the item of the use of the yards thus provided. But with the development of an intricate and complex system of stock yards in the large cattle sections of the country as well as the beef killing and packing centers, added services were performed for the shippers in the shape of hauling cars beyond the lines of the carriers proper and furnishing other special facilities, and the custom was adopted in about the year 1894 of making terminal charges for such services and publishing and declaring them as separate, and distinct and in addition to the regular transportation charges for merely hauling the stock. It became apparent that the terminal services thus rendered embraced some character of service not by operation of law included in the mere contract of carriage considered by itself. In the first case decided by the Supreme Court on this question of terminal charges for stock yard services a charge of $\$ 2$ per car was deemed not to be unreasonable. And the court there held that the services thus rendered being distinct from the mere transportation the carriers had the legal right to divide the charges into terminal and transportation, and further that each charge should be considered in and of itself and that if the terminal charge was reasonable the carrier could not be forced to reduce that charge because it had in the meantime reduced the transportation charge with which the other had been joined. ${ }^{49}$

48 North Pennsylvania Railroad Company v. Commercial National Bank of Chicago, 123 U. S. 727, 31 L. Ed. 287, 8 Sup. Ct. 266; Covington Stockyards Co. v. Keith, 139 U. S. 128, 35 L. Ed. 73, i Sup. Ct. 416.

49 Interstate Commerce Commission v. Chicago, Burlington and Quincy Railroad Company, I86 U. S. 320, 46 L. Ed. II82, 22 Sup. Ct. 824. Here the court declared:- "As the right of the defendant carriers to divide their rates and thus to make a distinct charge from the point of shipment to Chicago and a separate terminal charge for delivery to the stock yards, a point beyond the lines of the respective carriers, was conceded by the Commission and was upheld by the Circuit Court of Appcals, no conten- 
Where the terminal charge is in itself reasonable it will not be condemned because the prior charges of connecting roads make the total of the transportation and terminal rates unreasonable. Not the terminal charge but the prior transportation charge must under those circumstances be altered..$^{50}$ Each is a separate charge

tion on this subject arises. If, despite this concurrence of opinion, controversy was presented on the subject we see no reason to doubt. under the facts of this case, the correctness of the rule as to the right to divide the rate, admitted by the Commission and announced by the court below. This is especially the case in view of the sixth section of the Act to Regulate Commerce, wherein it is provided that the schedules of rates to be filed by carriers shall 'state separately the terminal charges and any rules or regulations which could in anywise change, affect or determine any part or the aggregate of said aforesaid rates and fares and charges.' Whether the rule which we approve as applied to the facts in this case would be applicable to terminal serrices by a carrier on his own line which he was obliged to perform as a necessary incident of his contract to carry, and the performance of which was demanded of him by the shipper, is a question which does not arise on this record, and as to which we are. therefore, called upon to express no opinion." Sce also United States $x$ Union Stock Yards Company. 226 U. S. 286.

50 Interstate Commerce Commission v. Stickney, $2 I_{5}$ U. S. 98.54 L. Ed. II2, 30 Sup. Ct. 66. This case turned upon the reasonableness of stock yard terminal charges which constituted a distinct item from carriage charges. The court as to these points said:- "The carrier is entitled to have a finding that any particular charge is unreasonable or unjust before it is required to change such charge. For services that it may render or procure to he rendered off its own line. or outside the mere matter of transportation over its line, it may charge and receive compensation. Southern Railway Co. $v$ St. Louis Hay and Grain Co., $2 I_{4}$ U. S. 297.53 L. Ed. I004. 29 Sup. Ct. 678. If the terminal charge be in and of itself just and reasonable it cannot be condemned or the carrier required to clange it on the ground that it, taken with prior charges of transportation over the lines of the carrier or of connecting carriers. makes the total charge to the shipper unreasonable. That which must be corrected and condemned is not the just and rcasonable terminal charge, but those prior charges which must of themselves be unreasonable in order to make the aggregate of the charges from the point of shipment to that of delivery unreasonable and unjust. In order to avail itself of the benefit of this rule the carrier must separately state its terminal or other special charges complained of. for if many matters are lumped in a single charge it is impossible for either shipper or Commission to determine how much of the lump cliarge is for the terminal or special services. The carrier is under no obligations to clarge for terminal services. Business interests may justify it in waiving any such charge, and it will be considered to have waived it unless it makes plain to both shipper and Commission that it is insisting upon it. *** The Union Stock Yards 
and each must stand or fall on its merits. The carrier is moreover entitled to a finding on each one. The fact that connecting carriers own the stock of the terminal company does not in any way affect the reasonableness of the rates charged for such service nor will that fact make the terminal company a part of the lines or property of the connecting carricrs. And stock yard companies with their locomotives, and tracks and employees engaged in hauling live stock for hire over their tracks to and from their pens or sheds come within the classification of railroads under the first section of the Act to regulate commerce and their operations are manifestly within the comprehension of the term "transportation." Although their property and their tracks lie wholly within a state they are engaged in a portion of the actual shipment between different states and they are therefore engaged in interstate commerce. ${ }^{51}$

Company is an independent corporation and the fact, if it be a fact, that most or even all of its stock is owned by the several railroad companies entering into Chicago does not make its lines or property part of the lines or property of the separate railroad companies. *** If any shipper is wronged by the aggregate charge from the place of shipment to the Union Stock Yards it would seem necessarily to follow that the wrong was done in the prior charges for transportation, and, as we have already stated, should be corrected by proper proceedings against the companies guilty of that wrong, otherwise injustice will be done. If this charge, reasonable in itself, be reduced the Union Stock Yards Company will suffer loss while the real wrongdoers will escape. It may be that it is more convenient for the Commission to strike at the terminal charge, but the convenience of Commission or court is not the measure of justice."

5I United States v. Union Stock Yard and Transit Company, $226 \mathrm{U}$. S. 286, 57 L. Ed. 226, 33 Sup. Ct. 83. In discussing this phase of the question the Supreme Court said:- "We think that these companies, because of the character of the service rendered by them, their joint operation and division of profits and their common ownership by a holding company, are to be deemed a railroad within the terms of the Act of Congress to Regulate Commerce, and the services which they perform are included in the definition of transportation as defined in that Act. It is the manifest purpose of the Act to include interstate railroad carriers, and by its terms the Act excludes transportation wholly within a state. In view of this purpose and so construing the Act as to give it force and effect, we think the stock yard company did not exempt itself from the operation of the law by leasing its railroad and equipment to the Junction Company, for it still receives two-thirds of the profits of that company and both companies are under a common stock ownership with its consequent control. We therefore think the Commerce Court was right in holding that the Junction Company should file its rates with the Interstate Commerce Com- 
Elevation of Grain.-Under the Act of June 29, I906, the Act to regulate commerce was amended to include "elevation and transfer in transit" as well as "storage" under the general classification of "transportation." "52 Under the terms of the Act charges were contemplated by the carriers as against the shippers of grain but as a matter of practice the carriers have con. tracted with the shippers to render such services themselves upon the payment of certain allowances by the railroads. In order to expedite the return of cars to their own lines and prevent their continued absence on through trips to the east, it became necessary to shift the grain to other cars at certain of the eastern termini of the large grain carrying roads of the 11 est. In order tc make this change it is commercially necessary to pass the grain through an elevator, where also it is weighed and graded, the former in particular being a step in the transportation. And thus to accomplish these purposes as well as to save the financial burden of building expensive elevators the custom grew up among the railroads of contracting with the large shippers of grain to provide the elevators themselves and perform these elevation services in return for certain payments. The grain which passed through these elevators was either the property of the owners of the elevators or else was handled by them as agents of the railroads interested in performing the contract of transportation. The railroads then instead of being paid for services thus rendered in fact contracted with others to perform these functions. Apart from the mere transfer of the grain from car to car and also of weighing it. the shippers were able to perform other

mission and that it should also have held the stock yard company subject to the provisions of the Interstate Commerce Acts."

52 Union Pacific Railroad Company v. Updike Grain Company, 222 U. S. 215, 56 L. Ed. I7I, 32 Sup. Ct. 39. The court here said:-"The longmooted question as to whether eleration was such a part of transportation as to bring it within the jurisdiction of the Interstate Commerce Commission was answered by the Act of June 29. I906, (34 Stat. L. 584, 590), in which Congress declared that the term 'transportation' 'shall include *** all $* * *$ facilities of shipment $* * *$ irrespective of ownership *** and all services in connection with the $* * *$ elevation and transfer in transit $* * *$ and handling of property transported.' Carriers were required 'to provide and furnish such transportation upon reasonable request therefor.' The Act recognized that the shipper himself might own the elevator or other facility included within the definition of transporta. tion." 
services during the process of the elevation-such as grading, cleaning, sorting, clipping and mixing the grain-which, although not paid for by the railroads, constitute a valuable convenience to the shippers in enabling them to perform these functions at one and the same time with weighing and transferring the conmodity. The Supreme Court therefore in consideration of the fact that the carrier is required to furnish this part of the transportation upon request and can hire the instrumentality instead of owning it, approved an allowance for elevation equal to the cost of the service and confined such allowances to grain reshipped within ten days. ${ }^{53}$ But in the shipment of hay which is taken to warehouses in the cars in which shipped, there unloaded, inspected and reloaded for other markets-under the name of reconsignment - the service is rendered by the railroads in the shape of hauling the cars an extra distance and detaining them for a longer time. And for such services, covered by the general term

53 Interstate Commerce Commission v. Diffenbaugh, et al., $222 \mathrm{U}$. S. 42, 56 L. Ed. 83, 32 Sup. Ct. 22. Here the Union Pacific Railroad contracted to pay Peavey and Company, large grain shippers, ccrtain elevation allowances in return for furnishing the facilities therefor in order that the carrier might secure the release of its cars for its own road and with the least possible delay. The court declared:- "Congress clearly recognized that services such as those rendered by Peavey and Company were services in trausportation and were to be paid for notwitlistanding the possibility that some advantage might be gained as a result. *** The Act of Congress in terms contemplates that if the carrier reccives services from an owner of property transported, or uses instrumentalities furnished by the latter, he shall pay for them. This is taken for granted in section I5; the only restriction being that he shall pay no more than is reasonable. *** As the carrier is required to furnish this part of the transportation upon request he could not be required to do it at his own expense, and there is nothing to prevent his hiring the instrumentality instead of owning it." See also Union Pacific Railway Company v. Updike Grain Company, 222 U. S. 2I5, 56 L. Ed. I7I, 32 Sup. Ct. 39, where the court said:- "The Union Pacific's desire to have cars promptly unloaded so that they might be returned to its own line may lave been the principal motive which induced it to agree to pay elevator charges. But the consideration, moving between the carrier and the elevator, was the service performed by the latter in unloading grain at terminal points. This relieved the carrier of the expense of building similar structures and avoided the delay of having the grain transferred from one car to another by the slow process of shovelling. When the service was rendered, the carrier received value for which it was bound to pay. whether performed by the owner of the grain or some other person hired for the same purpose." 
of transportation though not strictly a feature of the actual carriage the railroads have been authorized to charge an amount equal to the actual cost of the privilege together with a moderate compensation therefor. This is based upon the general theory that the cost of a particular service is not a proper test of the reasonableness of the charge for it when it constitutes a part of a larger transaction. ${ }^{54}$

Refrigeration.-It is the duty of a common carrier accepting goods for transportation to provide the necessary facilities for their carriage in a proper manner. Therefore, it is the duty of a railroad to furnish adequate facilities for the proper handling of perishable goods. This is a common law duty irrespective of any statutory obligation. ${ }^{55}$ The Act to regulate commerce gives form and letter to this rule. But common carriers are not compelled to perform such special services merely as an incident of the transportation and for the rate charged for the carriage. By the amendment of June 29, 1906, these various charges for "ventilation," "refrigeration," or "ice" must be separately published by the railroads the same as other special charges incident to transportation. The railroads are required to furnish refrigeration cars, whether through personal ownership or by lease. And whatever transportation facility or service the law requires carriers to furnish they have a right to supply. For example, they

54 In Southern Railway Company v. St. Louis Hay and Grain Company, 214 U. S. 297,53 L. Ed. 1004, 29 Sup. Ct. 678, the court said:-"If the stopping for inspection and reloading is of some benefit to the shipper and involves some service by and expense to the railway company, we do not think that the latter is limited to the actual cost of that privilege. It is justified in receiving some compensation in addition thereto. A carrier may be under no obligations to furnish sleeping or other accommodations to its passengers, but if it does so it is not limited in its charges to the mere cost, but may rightfully make a reasonable profit out of that which it does furnish. Especially is this true when, as here, the privilege is in no sense a part of the transportation, but outside thereof. Whether the conclusion of the Commission that the carrier is under no obligations to permit the interruption of the transit is right and whether it is or is not under such obligation it is entitled to receive some compensation beyond the mere cost for that which it does."

55 The Southwark, 19I U. S. I, 48 L. Ed. 65, 24 Sup. Ct. I, where proper refrigeration was declared to be an incident of seaworthiness under a bill of lading for the transportation of dressed beef. See also Covington Stock Yards Company v. Keith, I39 U. S. 128, 35 L. Ed. 73, I I Sup. Ct. $4 \mathrm{I} 6$. 
can use their own cars and cannot be compelled to accept those tendered by the shipper and so also they can furnish all the ice needed in refrigeration. ${ }^{50}$ Otherwise the railroads will be de-

56 Atchison, Topeka and Santa Fe Railway Company v. United States, 232 U. S. 199, 58 L. Ed. 568, 34 Sup. Ct. 29I. This case revolved about the freight and refrigeration charges on citrus fruit shipped from California to eastern points. The court in its decision discussed the question of icing, pre-cooling and refrigeration as a feature of transportation under the Act to Regulate Commerce. The court said:- "This ruling (of the Commission) is attacked by the appellants, who contend that icing is a part of refrigeration, which section I of the Hepburn Bill makes a part of the transportation they are bound to furnish upon reasonable request. They insist that in order to meet the duty, thus imposed by statute, they have been compelled at great expense to erect immense plants where trainloads of fruit can be cooled and where an enormous quantity of ice is manufactured for refrigeration purposes. They argue that, being bound to furnish all necessary icing and re-icing and having at great cost prepared to furnish the supply, it is not only just, but a right given by statute, that they should be allowed to provide all needed icing or refrigeration at a rate to be approved by the Commission.

"Whatever transportation service or facility the law requires the carrier to supply they have the right to furnish. They can therefore use their own cars, and cannot be compelled to accept those tendered by the shipper on condition that a lower freight rate be charged. So, too, they can furnish all the ice needed in refrigeration, for this is not. only a duty and a right under section I of the Hepburn Bill, but an economic necessity due to the fact that the carriers cannot be expected to prepare to meet the demand and then let the use of their plants depend upon haphazard calls, under which refrigeration can be demanded by all shippers at one time and by only a few at another. This contention was sustained by the Commission, which recognized that 'the shipper has no right to provide refrigeration himself to-day and call upon the railroad company for that service to-morrow. To permit such a course is to demoralize the service of the defendants and to prevent them from discharging their duty with economy and efficiency. *** It is the duty of the carrier to furnish refrigeration upon reasonable demand, and in so far as the furnishing of that refrigeration is a part of the service rendered by the carrier, the carrier may insist upon its right to furnish that service exclusively.'

"But of course this does not mean, that because the carriers have ice on hand, they can compel the shipper to have his fruit refrigerated, when, on account of the state of the weather or for other cause, he prefers to have it forwarded under ventilation only. When, however, ice is actually needed and is actually used, the question arises as to whether icing is a part of preparation which can be done by the shipper; or a part of refrigeration (transportation) which, by statute the carrier has the exclusive right to furnish.

"To this question no answer can be given that will apply in all cases. 
moralized by reason of an irregular demand for such services and be forced to depend upon haphazard calls under which refrigeration can be demanded by all shippers at one time and by only a few at another time. This does not, however, mean that because the carriers have ice on hand or possess proper refrigeration facilities, they can compel shippers to have their fruit re-

For in the shipment of fruit, as in that of other articles, it is impossible to lay down a rule which definitely fixes what loading includes and by whom it must be done. Nor is there any consistent practise on this subject, since from reported cases it appears that the claims of the parties are based rather on interest than on some definite principle. Sometimes the shipper, as here, insists on the right to load and provide necessary appliances. At other times he demands that such service and appliances be furnished by the railroad company. Conversely the carriers sometimes claim, as here the right to furnish service and facilities, while in other cases insisting that one or both must be supplied by the consignor. ***

"These inconsistent and conflicting demands serve to emphasize the fact that, before the haul actually begins, the right or duty of each party, where not absolutely fixed by statute, must be decided with reference to the special facts of each case.

"But loading may involve more than the mere placing of the freight on the cars, since the character of the shipment may be such as to require the furnishing and placing of stakes, racks, blocks and binders needed to make the transportation safe; or, the freight may be such as to require special covering, packing, icing or heating, in order to preserve the merchandise in condition fit for use at the end of the journey. Who is to furnish these needed facilities, may be quite as uncertain as who is to place the freight on the car, and can only be determined by considering the character of the shipment, the place where the loading begins and who can most economically perform the service required. Neither party has a right to insist upon a wasteful or expensive service for which the consumer must ultimately pay. The interest of the public is to be considered as well as that of the shippers and carriers-their rights in turn having been adjusted by a reduction in the rate, if the loading is done in whole or in part by the shipper; and by an increase in the rate where the loading is done in whole or in part by the carrier. But, by whomsoever done, the loading must be such as to fit the freight for shipment, and when-by statutory requirement, by valid order of the Commission, or by the carrier's voluntary act-the car is placed at the consignor's warehouse to be loaded by the shipper, he may not only put the freight on the car but may do all other acts required to fit the freight for its proper shipment-at least, until under a tariff regularly filed, the carrier offers to do what is necessary to secure or preserve what has thus been placed on its car for transportation. The refrigeration and pre-cooling offered by the carrier to shippers of pre-cooled fruit was found not to be the equivalent of the method adopted by the shipper." 
frigerated if they prefer to ship it ventilated only, by reason of the weather or other causes. No fixed rule can be laid down that will apply inflexibly and serve to distinguish those functions which may be claimed by the shipper as a part of the preparation for shipment and those which may be claimed by the carrier as a part of the service of transportation. The rights and duties of each party, when not definitely fixed by statute, must, therefore, be decided with reference to the special facts of each case. And the shipper may perform these services if the methods and facilities provided by the carriers are insufficient or inferior.

Charges must be just and reasonable.

Classifications, regulations, and practices must be $\mathrm{just}$ and rea. snnable.
Railroad Charges.-All charges made for any service rendered or to be rendered in the transportation of passengers or property and for the transmission of messages by telegraph, telephone, or cable, as aforesaid, or in connection therewith, shall be just and reasonable; and every unjust and unreasonable charge for such service or any part thereof is prohibited and declared to be unlawful: Provided, That messages by telegraph, telephone, or cable, subject to the provisions of this Act, may be classified into day, night, repeated, unrepeated, letter, commercial, press, government, and such other classes as are just and reasonable, and different rates may be charged for the different classes of messages: And provided further, That nothing in this Act shall be construed to prevent telephone, telegraph, and cable companies from entering into contracts with common carriers, for the exchange of services.

And it is hereby made the duty of all common carriers subject to the provisions of this Act to establish, observe, and enforce just and reasonable classifications of property for transportation, with reference to which rates, tariffs, regulations, or practises are or may be made or prescribed, and just and reasonable regulations and practises affecting classifications, rates, or tariffs, the issuance, form, and substance of tickets, receipts, and bills of lading, the manner and method of presenting, marking, packing, and delivering property for transportation, the facilities for transportation, the carrying of personal, sample, and excess baggage, and all other 
matters relating to or connected with the receiving, handling, transporting, storing, and delivery of property subject to the provisions of this Act which may be necessary or proper to secure the safe and prompt receipt, handling, transportation, and delivery of property subject to the provisions of this Act upon just and reasonable terms, and every such unjust and unreasonable classification, regulation, and practise with reference to commerce between the States and with foreign countries is prohibited and declared to be unlawful.

Charges must be just and reasonable.-This section of the Act to regulate commerce was adopted as a portion of the law of February 4, 1887, and was not altered until the Act of June I8, I910, when telegraph, telephone and cable companies were also included within the provisions of the Act and placed under the jurisdiction of the Interstate Commerce Commission. ${ }^{5 i}$

It is to be noted that in this section at least no power is conferred by Congress upon the Interstate Commerce Commission to fix rates, either maximum, minimum or absolute. The fixing of rates is left in the hands of the carriers subject only to the inhibitions that they must be both just and reasonable. And this was the common law obligation applying to common carriers. The provision here under discussion was merely a statutory affirmation of this common law rule which demanded that roads should carry for all persons, in the order in which they applied, and that their charges be reasonable leaving common carriers free to make their contracts, classify their traffic and adjust and apportion their rates to harmonize with the demands of commerce under the same general principles recognized in all lines of trade. ${ }^{59}$

57 As originally enacted this section read as follows:-"All charges made for any service rendered or to be rendered in the transportation of passengers or property as aforesaid, or in connection therewith, or for the receiving, delivering, storage, or handling of such property. shall be reasonable and just; and every unjust and unreasonable charge for such service is prohibited and declared to be unlawful."

58 Cincinnati. New Orleans and Texas Pacinc Railway Co. v. Interstate Commerce Commission, (known as the Social Circle Case), I62 U. S. I84, 40 L. Ed. 935, 16 Sup. Ct. 700. Here the court said:- "Whether Congress intended to confer upon the Interstate Commerce Commission the power to fix rates, was mooted in the courts below and is discussed in the briefs of the counsel. We do not find any provision of the Act that expressly, 
This principle had prevailed in England and legislation declaratory thereof had already been enacted in many of the states of the Union which during the so-called Granger movement had undertaken the task of curbing the power and activities of the railroads. A fundamental distinction is to be noted in the character of the power to prescribe rates and the power to inquire and determine whether the rates which have been adopted and

or by necessary implication, confers such a power. It is argued on behalf of the Commission that the power to pass upon the reasonableness of existing rates implies a right to prescribe rates. This is not necessarily so. The reasonableness of the rate, in a given case, depends on the facts. and the function of the Commission is to consider these facts and give them their proper weight. If the Commission, instead of withholding judgment in such a matter until an issue shall be made and the facts found, itself fixes a rate, that rate is prejudged by the Commission to be reasonable.

"We prefer to adopt the view expressed by the late Justice Jacksnn, when circuit judge, in the case of Interstate Commerce Commission $v$. Baltimore and Ohio Railroad Company, 43 Fed. 37 , and whose judgment was affirmed by this court, I45 U. S. 263,36 L. Ed. 699, I2 Sup. Ct. 844: -'Subject to the two leading prohibitions that their charges shall not be unjust or unreasonable, and that they shall not unjustly discriminate, so as to give undue preference or disadvantage to persons or traffic similarly circumstanced, the Act to regulate commerce leaves common carriers as they were at the common law, free to make special contracts looking to the increase of their business, to classify their traffic, to adjust and apportion their rates so as to meet the necessities of commerce, and generally to manage their important interests upon the same principles which are regarded as sound, and adopted in other trades and pursuits.'"

Interstate Commerce Commission v. Baltimore and Ohio Railroad, I45 U. S. 263,36 L. Ed. 699, I2 Sup. Ct. 844. In discussing this phase of the question the court here declared:- "Prior to the enactment of the Act of February 4, 1887, commonly known as the Interstate Commerce Act, railway traffic in this country was regulated by the principles of the common law applicable to common carriers, which demanded little more than that they should carry for all persons who applied, in the order in which the goods were delivered at the particular station, and that their charges for transportation should be reasonable. It was even doubted whether they were bound to make the same charge to all persons for the same service; though the weight of authority in this country was in favor of an equality of charge to all persons for similar services. In several of the states Acts had been passed with the design of securing the public against unreasonable and unjust discriminations. * * The principal objects of the Interstate Commerce Act were to secure just and reasonable charges for transportation; to prohibit unjust discriminations in the rendition of like services under similar circumstances and conditions." 
charged are reasonable. The first is a legislative act while the second is a judicial act. ${ }^{59}$ And in this section of the Act at least no power is given to the Commission to positively establish a rate. Manifestly a rate may be unjust and unreasonable from being too low as well as from being too high. In the first case the injustice is to the carrier and in the second instance the injustice is to the shipper. The reasonableness of a rate must of necessity depend upon the facts in each case, and the Interstate Commerce Commission is endowed with the function only of ascertaining and considering the facts and giving them proper weight. But this function is negative in its character. It is confined to ascertaining whether the given rate is unreasonable and of enjoining the carrier from enforcing it if it is so found. The Commission cannot assert a power by indirection which it is not given directly. It could not by determining what in reference to the past was a reasonable and just rate,-whether as maximum, minimum or absolute-obtain a peremptory order in the shape of a writ of mandamus that in the future the railroads should adhere to the rate thus determined to have been reasonable and just in the past. ${ }^{80}$ But this discussion, while germane to the sec-

59 Interstate Commerce Commission v. Cincinnati, New Orleans and Texas Pacific Railway Co., (known as the Maximum Rate Case), $167 \mathrm{U}$. S. 479, 42 L. Ed. 243, I7 Sup. Ct. 896. The court, discussing this question at length, said:- "The question debated is whether it (Congress) vested in the Commission the power and the duty to fix rates; and the fact that this is a debatable question, and has been most strenuously and earnestly debated, is very persuasive that it did not. The grant of such a power is never to be implied. The power itself is so vast and comprehensive, so largely affecting the rights of carrier and shipper, as well as indirectly all commercial transactions, the language by which the power is given had been so often used and was so familiar to the legislative mind and is capable of such definite and exact statement, that no just rule of construction would tolerate a grant of such power by mere implication. * * * It is one thing to inquire whether the rates which have been charged and collected are reasonable-that is a judicial act; but an entirely different thing to prescribe rates which shall be charged in the future-that is a legislative act. * * The power given is the power to execute and enforce, not to legislate. The power given is partly judicial, partly executive and administrative, but not legislative."

60 Interstate Commerce Commission v. Cincinnati, New Orleans and Texas Pacific Railway Co., I67 U. S. 479, 42 L. Ed. 243, I7 Sup. Ct. 896. Here the court said:- "Our conclusion then is that Congress has not conferred upon the Commission the legislative power of prescribing rates either maximum or minimum or absolute. As it did not give the express 
tion at issue is largely academic and historical because of subsequent amendments in the Acts of June 29, 1906, and June 18, I9I0, which enlarged the powers of the Interstate Commerce Commission in the determination and enforcement of rates. The question of a recovery of any payment made by shippers on rates charged by the railroads which are determined to be unjust and unreasonable by the Commission will be treated in the discussion of a later section (section 9) of the Act.

Decision as to Reasonableness of Rates.-Under the common law when a carrier declined to receive goods offered for transportation or to deliver goods shipped except upon the payment of an unreasonable and excessive sum, the shipper had a right of action in damages. It became settled that under such conditions an action could be maintained to recover the overcharge. Manifestly it was difficult, in the very nature of the question, to demonstrate what constituted an unreasonable rate since it could be ascertained only by first proving what would be a reasonable charge for the service rendered-the first being of necessity dependent upon the second. Moreover, being a question for judicial decision, the standard of reasonableness was bound to be variable. The courts being numerous and juries of different minds a rate held reasonable in one court or by one jury might be deemed unreasonable in a different jurisdiction or by a different jury in the same jurisdiction. And similarly the degree of

power to the Commission it did not intend to secure the same result indirectly by empowering that tribunal to determine what in reference to the past was reasonable and just, whether as maximum, minimum or absolute, and then enable it to obtain from the courts a peremptory order that in the future the railroad companies should follow the rates thus determined to have been in the past reasonable and just."

See also Interstate Commerce Commission v. Alabama Midland Railway Co., I68 U. S. I44, 42 L. Ed. 4I4, 18 Sup. Ct. 45, where the court said :- "Discussion of these assignments is rendered unnecessary by recent decisions of this court, wherein it has been held, after elaborate argument, that Congress has not conferred upon the Interstate Commerce Commission the legislative power of prescribing rates, either maximum or minimum, or absolute; and that, as it did not intend to give the express power to the Commission, it did not intend to secure the same result indirectly by empowering that tribunal, after having determined what, in reference to the past, were reasonable and just rates to obtain from the courts a peremptory order that in the future the railroad companies should follow the rates thus determined to have been in the past reasonable and just" 
unreasonableness was equally bound to vary. This difficulty was inherent in the nature of the controversy since it was of necessity a question of fact and thus subject to the differing judgments and caprices of variant juries. It became, therefore, necessary for the legislative power to establish some one body with the power to determine the reasonableness of rates in order to do away with this confusion and to establish a uniform standardpossessed of a jurisdiction broad enough to comprehend all such controversies which might arise. This became an essential element in the very purpose of the Act to Regulate Commerce-name$1 \mathrm{y}$, to prevent discriminations and preferences between shippers by carriers. These were without doubt among the principal reasons for this Act. And in order to firmly establish this prin. ciple it was a prerequisite that all questions as to the reasonableness of rates should first of all be passed upon by the Interstate Commerce Commission. Until the Commission then has declared a rate to be reasonable the courts are without power to grant redress to shippers who have, by that standard, been charged an unreasonable rate. ${ }^{61}$ Furthermore the power of the courts to

6I Texas and Pacific Railway $\therefore$ Abilene Cotton Oil Co., 204 U. S. 426, 5I L. Ed. 553, 27 Sup. Ct. 350. Here the court in discussing this phase of the question said:- "If it be that the standard of rates fixed in the mode provided by the statute could be treated on the complaint of a shipper by a court and jury as unreasonable, without reference to prior action by the Commission, finding the established rate to be unreasonable and ordering the carrier to desist in the future from violating the Act, it would come to pass that a shipper might obtain relief upon the basis that the established rate was unreasonable, in the opinion of a court and jury, and thus such shipper would receive a preference or discrimination not enjoyed by those against whom the schedule of rates was continued to be enforced. This can only be met by the suggestion that the judgment of a court, when based upon a complaint made by a shipper without previous action by the Commission would give rise to a change of the schedule rate and thus cause the new rate resulting from the action of the court to be applicable in future as to all. This suggestion, however, is manifestly without merit, and only serves to illustrate the absolute destruction of the Act and the remedial provisions which it created which would arise from a recognition of the right asserted. For if, without previous action by the Commission, power might be exerted by courts and juries generally to determine the reasonableness of an established rate, it would follow that unless all courts reached an identical conclusion a uniform standard of rates in the future would be impossible, as the standard would fluctuate and vary. dependent upon the divergent conclusions reached as to reasonableness by the various courts called upon to consider the subject as an 
award damages or relief to those injured is exhausted when a decree has been issued for the amount of money involved in the particular wrong charged and does not embrace the power to direct the carrier to abstain in the future from similar unreasonable charges.

original question. Indeed the recognition of such a right is wholly inconsistent with the administrative power conferred upon the Commission and with the duty, which the statute casts upon that body, of seeing to it that the statutory requirement as to uniformity and equality of rates is observed. Equally obvious is it that the existence of such a power in the courts, independent of prior action by the Commission, would lead to favoritism, to the enforcement of one rate in one jurisdiction and a different one in another, would destroy the prohibitions against preferences and discriminations, and afford, moreover, a ready means by which, through collusive proceedings, the wrongs which the statute was intended to remedy could be successfully inflicted. Indeed no reason can be perceived for the enactment of the provision endowing the administrative tribunal, which the Act created with power, on due proof, not only to award reparation to a particular shipper, but to command the carrier to desist from violation of the Act in the future, thus compelling the alteration of the old or the filing of a new schedule, conformably to the action of the Commission, if the power was left in courts to grant relief on complaint of any shipper, upon the theory that the established rate could be disregarded and be treated as unreasonable, without reference to previous action by the Commission in the premises. This must be, because, if the power existed in both courts and Commission to originally hear complaints on this subject, there might be a divergence between the action of the Commission and the decision of a court. In other words, the established schedule might be found reasonable by the Commission in the first instance and unreasonable by a court acting originally, and thus a conflict would arise which would render the enforcement of the act impossible. * * *

"And this becomes particularly cogent when it is observed that the power of the courts to award damages to those claiming to have been injured, as provided in the section (9), contemplates only a decree in favor of the individual complainant, redressing the particular wrong asserted to have been done, and does not embrace the power to direct the carrier to abstain in the future from similar violations of the Act; in other words, to command a correction of the established schedules, which power, as we have shown is conferred by the Act upon the Commission in express terms. In other words we think that it inevitably follows from the context of the Act that the independent right of an individual originally to maintain actions in courts to obtain pecuniary redress for violations of the Act conferred by the ninth section must be confined to redress of such wrongs as can consistently with the context of the Act, be redressed by courts without previous action by the Commission, and, therefore, does not imply the power in a court to primarily hear complaints concerning wrongs 
Reasonableness of Rates for Intrastate Traffic.-The states, under the Constitution, retaining the power to regulate essentially intrastate transportation have for the most part enacted legislation corresponding more or less closely to the Federal Act to regulate commerce and have also established railroad commissions based upon the fundamental ideas of the Interstate Commerce Commission and endowed with powers relating to local traffic similar to that possessed by the Federal Commission in its relation to interstate traffic. The legislatures in many of the states have enacted statutes fixing maximum rates of transportation for passenger traffic and clothing the state commissions with the power to either declare freight rates unreasonable or else to designate rates which shall be deemed reasonable. The Federal Supreme Court has been called upon to review the action of these state commissions and also to pass upon the legislation of these states, and in a large number of decisions certain general principles have been laid down which would apply to the determination of the reasonableness of railroad rates. In principle these decisions have declared that the interests of two general classes were involved-the public as represented in the person of the shippers who were entitled to receive services from common carriers at rates which were fair and commensurate with the services rendered, and the railroads, consisting of the stockholders, bondholders, etc., who were entitled to receive a fair return upon their investments and whose property should not be seized in violation of the $5^{\text {th }}$ amendment to the Constitution without due process of law under the guise of being forced to accept rates which did not permit a fair return upon the value of their property. There must be on the one hand a fair value for the services rendered and on the other regard for the fair value of the property used in performing the service. The court has expressly stated that this value cannot be reached by so simple a calculation as the

of the character of the one here complained of. Although an established schedule of rates may have been altered by a carrier voluntarily or as the result of the enforcement of an order of the Commission to desist from violating the law, rendered in accordance with the provisions of the statute, it may not be doubted that the power of the Commission would nevertheless extend to hearing legal complaints of and awarding reparation to individuals for wrongs unlawfully suffered from the application of the unreasonable schedule during the period when such schedule was in force." 
computation of the sum of the operating expenses of the railroad, interest on its obligations and reasonable dividends for its stockholders. For a railroad may have bonded its property for an amount in excess of its fair value, or its capitalization may be largely fictitious - and it will not be permitted by such expedients to impose upon the public the burden of such increased or inflated rates as may be required for the purpose of realizing profits upon this excessive valuation of fictitious capitalization; the apparent value of the property and franchises used by the railroad, as indicated by its stocks, bonds and similar obligations, is not alone to be considered when determining the rates that may be reasonably charged. While on the one hand the public cannot properly be subjected to unreasonable rates in order simply that stockholders may earn dividends, on the other hand the railroads may not be required to use their property for the benefit of the public without receiving just compensation for the services rendered by them. Succinctly the court has said: "What the company is entitled to ask is a fair return upon the value of that which it employs for the public convenience. On the other hand, what the public is entitled to demand is that no more be exacted from it for the use of a public highway than the services rendered by it are reasonably worth." 62

States may regulate absolutely purely intrastate rates provided in discharging this function they do not violate any constitutional rights of railroads, among which may be mentioned that guaranteed by the $14^{\text {th }}$ amendment, which declares that property shall not be taken without due process of law. ${ }^{63}$ State railroad com-

62 Smyth v. Ames, 169 U. S. 466, 547, 42 L. Ed. 819, I8 Sup. Ct. 418.

63 Southern Pacific Company v. Campbell, 230 U. S. 537, 57 L. Ed. I6ro, 33 Sup. Ct. I027; Chesapeake and Ohio Railway Co. v. Conley, 230 U. S. 513, 57 L. Ed. 1597, 33 Sup. Ct. 985. Simpson v. Shepard, (The Minnesota Rate Cases), 230 U. S. 352, 57 L. Ed. 151 33 Sup. Ct. 729, where the court said:- "Congress did not undertake to say that the intrastate rates of interstate carricrs should be reasonable or to invest its administrative agency with authority to determine their reasonableness. Neither by the original Act nor by its amendment did Congress seek to establish a unified control over interstate and intrastate rates; it did not set up a standard for intrastate rates, or prescribe, or authorize the Commission to prescribe either maximum or minimum rates for intrastate traffic. It cannot be supposed that Congress sought to accomplish by indirection that which it expressly disclaimed, or attempted to override the accustomed authority of the states without the provision of a substitute. On the contrary, the fixing of reasonable rates for intrastate transporta- 
missions may be enjoined from issuing orders governing interstate shipments and whether traffic is interstate or intrastate must be determined by the facts in each case and not by general decrees rendered in advance. ${ }^{64}$ And states may prohibit unjust discrimination by domestic or intrastate railroads against localities on their lines within the states and state railroad commissions may determine whether rates are thus discriminatory. ${ }^{65}$ In

tion was left where it had been found; that is, with the states and the agencies created by the states to deal with that subject. (Missouri Pacific Ry. Co. v. Larrabee Mills, 21 I U. S. 612, 620, 621, 53 L. Ed. 352, 29 Sup. Ct. 2I4.)"

64 In Oregon Railroad and Navigation Co. v. Campbell, 230 U. S. 525, 57 L. Ed. 1604, 33 Sup. Ct. 1026, the court said:-"Whether the order governs particular shipments must depend on the facts of each case, that is, upon the question whether the traffic is interstate or intrastate. If it were sought to compel the application of the intrastate rate to goods which were properly to be regarded as moving in interstate commerce, the complainant would have its remedy. But it would be necessary to show the actual conditions and that the order, although valid in its proper operation, was being misapplied with respect to particular transactions. The bill failed to make a case of this sort. Upon this point the court below said :- If the order be valid, as it is held to be, then all shipments or commerce which are intrastate in character must be controlled by the order; all that are not are not affected by it. If question arises as to any particular shipment or any particular commodity to be moved, or in process of transportation, it might be settled by carrying the matter to the Commission; or if the Commission unlawfully exacts the state rate upon interstate traffic, I see no reason why it may not be enjoined in any court of competent jurisdiction. These special cases must necessarily be determined as they arise, as it is impossible by a general decree, to determine in advance what specific commodities and the transportation thereof constitute interstate and what intrastate commerce,' 177 Fed. 318, 320. We are of the opinion that the ruling was right."

65 In Portland Railway, Light and Power Co. v. Oregon Railroad Commission, 229 U. S. 397,57 L. Ed. 1248,33 Sup. Ct. 820, the court said: - "The authority of the states to control by appropriate legislation the rates of fare to be charged by street railway companies and other common carriers wholly within their borders and subject to their laws is unquestionable. In the legitimate exercise of such authority we see no reason why a state may not consistently with due process of law prohibit any unjust discrimination by a domestic railroad company against certain localities upon its lines. If the state may not thus legislate as to its domestic corporations they, by merely arbitrary action, may so exercise their rate-fixing power as to build up one community and destroy another, and prevent that equality of treatment which it has been the object of many statutes of this kind, passed under state and federal authority, to secure. 
this connection it must be understood that a rate may of itself be reasonable and lawful and yet be illegal as compared with other rates because discriminatory against some shipper or locality on its line.

Rates prescribed by state legislatures for intrastate traffic are presumptively valid though they are not conclusively so. To require by legislation that railroads shall cliarge rates which prevent them from obtaining a reasonable return constitutes a deprivation of property without due process of law in violation of the fourteenth amendment to the Constitution. 'Thus the power of the courts may be invoked to determine whether rates thus fixed are confiscatory. ${ }^{66}$

The difficulty of determining what are reasonable rates, what rates provide a proper compensation for services rendered based upon the cost of transportation, cannot be exaggerated. For example, the Supreme Court has held that the ratio of the total operating expenses of a railroad or of a railroad division to the entire receipts of the road or division, of itself, affords no sufficient basis, when testing the reasonableness of rates prescribed by a state, for ascertaining the cost of transportation of intrastate freight traffic moving on class rates between two points on such

The statute does not define unjust discrimination but leaves it to the Commission, upon hearing, to determine what rates are unjust and discriminatory, and to make orders for other fares, which in its judgment are not open to such objection. The statute expressly provides for a judicial review by the courts of the orders of the commission to test the lawfulness of the fares fixed and the reasonableness of regulations prescribed by the Commission. We find nothing in the fourteenth amendment which prevents a state from making provision for such relief to communities unjustly discriminated against by companies subject to the laws of the state in which they operate and from which they derive their powers as common carriers and public service corporations."

See also Same v. Same, 229 U. S. 414, 57 L. Ed. 1259, 33 Sup. Ct. 827.

66 Missouri Pacific Railway Co. v. Tucker, 230 U. S. 340, 57 L. Ed. 1507, 33 Sup. Ct. 96I, where the court said:- "Primarily it is to be observed that the rates prescribed by the legislature, while presumptively valid, are not conclusively so; that to require the company, in the operation of its road, to give effect to rates which prevent it from obtaining a reasonable return for the service rendered to the public is to deprive it of its property without due process of law; and that whether the prescribed rates are thus in excess of the state's power (See Atlantic Coast Line R. R. Co. v. North Carolina Corporation Commission, 206 U. S. 1, 24-26, 51 L. Ed. 933, 27 Sup. Ct. 585, and cases cited) is a question which the company is entitled to have determined in appropriate judicial proceedings." 
division. In the words of the Supreme Court, "Before such a ratio could properly be used in setting forth the cost of a specified portion of the traffic, it would be necessary to have evidence either justifying the conclusion that the cost in proportion to the revenue was substantially the same for that part of the traffic as for the whole, or, if there were a material difference, satisfactorily showing the nature and extent. * * * Local traffic may cost more per unit of freight movement than through traffic, but whether it costs more in proportion to revenue is another matter. That, of course, depends upon the rates charged and is a fact to be proved." 67

Rates are not confiscatory and thus illegal merely because they will result in certain specified losses in revenue. In order to be illegal they must be so unreasonably low as to be confiscatory. ${ }^{68}$ A state court may find that a rate named by a state railroad commission is not confiscatory and so refuse to enjoin its enforcement. But such a decree does not prejudice the right of a carrier to reopen the case if after an adequate and proper trial of the rate it can demonstrate that it is in fact confiscatory and does constitute a deprivation of property without due process of law in violation of the Constitution. ${ }^{69}$ And the right of a railroad to contest rates on the ground that they are confiscatory is not impaired by putting the rates into effect if upon trial they prove confiscatory. ${ }^{70}$

67 Wood v. Vandalia Railroad Co., 23I U. S. I, 58 L. Ed. 97, 34 Sup. Ct. 7 .

68 Louisville and Nashville Railroad Co. v. Garritt, 23 I U. S. 298, 58 L. Ed. 229, 34 Sup. Ct. 48. The court here said:- "If the Commission establishes rates that are so unreasonably low as to be confiscatory, an approprite mode of obtaining relief is by bill in equity to restrain the enforcement of the order. * * * But it may be supposed that a reduction in rates found to be excessive will always cause a loss in revenue; and the question is not simply as to the amount of reduction. but whether the rates as fixed would allow a fair return. The bill does not show the value of the property employed, the expenses of operation, or the return which would be permitted under the rates prescribed."

69 Northern Pacific Railway Co. v. North Dakota, 216 U. S. 579, 54 L. Ed. 624, 30 Sup. Ct. 423; Wilcox v. Consolidated Gas Co., 212 U. S. I9, 53 L. Ed. 382, 29 Sup. Ct. 192.

70 Allen v. St. Louís, Iron Mountain and Southern Railway Co., 230 U. S. 553, 57 L. Ed. I625, 33 Sup. Ct. I030, where the court said:- "We deem it to be clear that the right of the complainants to contest the validity of the rates, if, as applied to changed conditions, they were found 
Federal Control of Intrastate Rates.-While it is true that under the Constitution the states retain control of purely intrastate traffic, that traffic bears so close and intimate a relation to interstate commerce that for the proper control and protection of the latter the national government may be forced to and can exercise a certain control over the former. Thus, where rates, established by an interstate carrier for shipments between intrastate points by the authority of a state, produce discriminations when taken in conjunction with interstate rates the Federal government by reason of its dominant power over interstate commerce may assert itself and so regulate intrastate rates as to destroy and prevent such discrimination. In such cases the intrastate rates must yield to the superior power of interstate rates and to that extent be subject to the control of Congress. Wherever the interstate and intrastate operations of carriers are so related that the government of the one involves the control of the other, Congress and not the states prescribes the dominant rule. Otherwise the power of Congress over interstate commerce might be largely nullified by the different individual states in their manipulation and control of intrastate rates. ${ }^{71}$

to be confiscatory, was not impaired by their action in putting them into effect."

II Houston, East and West Texas Railway Co. v. United States (The Shreveport Case), 234 U. S. 342, 58 L. Ed. 1341, 34 Sup. Ct. 833 . The Supreme Court here said:- "The fact that carriers are instruments of intrastate commerce, as well as of interstate commerce, does not derogate from the complete and paramount authority of Congress over the latter or preclude the Federal power from being exerted to prevent the intrastate operations of such carriers from being made a means of injury to that which has been confided to federal care. Wherever the interstate and intrastate transactions of carriers are so related that the government of the one involves the control of the other, it is Congress, and not the state, that is entitled to prescribe the final and dominant rule, for otherwise Congress would be denied the exercise of its constitutional authority and the state, and not the nation, would be supreme within the national field. * * * This is not to say that Congress possesses the authority to regulate the internal commerce of a state, as such, but that it does possess the power to foster and protect interstate commerce, and to take all measures necessary or appropriate to that end, although intrastate transactions of interstate carriers may thereby be controlled. * * * That an unjust discrimination in the rates of a common carrier, by which one person or locality is unduly favored as against another under substantially similar conditions of traffic, constitutes an evil is undeniable; and where 
Reasonableness of Rates.-The same difficulties which are apparent in determining the reasonableness of intrastate rates apply as well to the determination of the propriety of interstate rates. For instance, the same right of way, the same terminals, rails, bridges and stations are used in the conduct of both classes of traffic; the same employees handle both kinds of shipments; and the same engines haul and the same cars carry both; securities are issued against the entire railroad system and not against its component parts as such. ${ }^{2}$ This difficulty of nature is based

this evil consists in the action of an interstate carrier in unreasonably discriminating against interstate traffic over its line the authority of Congress to prevent it is equally clear. It is immaterial, as far as the protecting power of Congress is concerned, that the discrimination arises from intrastate rates as compared with interstate rates. The use of the instrument of interstate commerce in a discriminatory manner so as to inflict injury upon that commerce, or some part thereof, furnishes abundant ground for federal intervention. Nor can the attempted exercise of state authority alter the matter, where Congress has acted, for a state may not authorize the carrier to do that which Congress is entitled to forbid and has forbidden."

Simpson v. Shepard (Minnesota Rate Cases), 230 U. S. 352, 57 L. Ed. I5II, 33 Sup. Ct. 729, where as to this feature the court said:- "If the situation has become such by reason of the interblending of the interstate and intrastate operations of interstate carriers, that adequate regulation of their interstate rates can not be maintained without imposing requirements with respect to their intrastate rates which substantially affect the former, it is for Congress to determine, within the limits of its constitutional authority over interstate commerce and its instruments the measure of the regulation it should supply. It is the function of this court to interpret and apply the law already enacted, but not under the guise of construction to provide a more comprehensive scheme of regulation than Congress has decided upon."

72 Simpson v. Shepard (Minnesota Rate Cases), 230 U. S. 352, 57 L. Ed. 151 I 33 Sup. Ct. 729. The court here said:-"The interblending of operations in the conduct of interstate and local business by interstate carriers is strongly pressed upon our attention. It is urged that the same right of way, terminals, rails, bridges, and stations are provided for both classes of traffic; that the proportion of each sort of business varies from year to year, and, indeed, from day to day; that no division of the plant, no apportionment of it between interstate and local traffic, can be made to-day which will hold to-morrow; that terminals, facilities, and connecions in one state aid the carrier's entire business and are an element of value with respect to the whole property and the business in other states; that securities are issued against the entire line of the carrier and can not be divided by states; that tariffs should be made with a view to all the traffic of the road and should be fair as between through and short 
upon the interblending of the local and interstate operations of railroads, the intricacy of their relations and the difficulty of determining a suitable and proper basis upon which to estimate the returns to which carriers are reasonably entitled. The determination of rates in futuro is a legislative rather than a judicial function although after such rates have been established by the proper legislative body they may be subject to judicial review to determine whether their enforcement is violative of the constitutional rights of the carriers. ${ }^{73}$ While the courts may not fix rates they may review rates already fixed with a view to determining whether they are reasonable. The Supreme Court has declared that there is no general rule by which it is possible to declare the reasonableness or unreasonableness of all rates, but that the legality of rates must be adjudged according to the circumstances of each case. But the Supreme Court has, however, in a somewhat extended line of decisions, laid down certain general criteria to be applied in the determination of this question.

First of all, the rights of the carrier as well as those of the shipper are to be consulted. A rate may be unreasonable to the shipper because too high, or if too low it may be unreasonable to the carrier and thus unfair to the stockholders and other owners

haul business; and that, in substance, no regulation of rates can be just which does not take into consideration the whole field of the carrier's operations, irrespective of state lines. The force of these contentions is emphasized in these cases, and in others of like nature, by the extreme difficulty and intricacy of the calculations which must be made in the effort to establish a segregation of intrastate business for the purpose of determining the return to which the carrier is properly entitled therefrom."

To the same effect see Knott v. Chicago, Burlington and Quincy Railroad Co., (Missouri Rate Cases), 230 U. S. 474, 57 L. Ed. 1571, 33 Sup. Ct. 975; Northern Pacific Ry. Co. v. North Dakota, decided March 8, 19r5; Norfolk \& Western Ry. Co. v. West Virginia, decided March 8, 1915.

73 Prentis v. Atlantic Coast Line R. R. (The Virginia Rate Case), 2 I I U. S. 210,53 L. Ed. 150,29 Sup. Ct. 67, where the court said:-"A judicial inquiry investigates, declares and enforces liabilities as they stand on present or past facts, and under laws supposed already to exist. That is its purpose and end. Legislation, on the other hand, looks to the future and changes existing conditions by making a new rule, to be applied thereafter to all or some part of those subject to its power. The establishment of a rate is the making of a rule for the future, and therefore is an act legislalative not judicial in kind."

See also discussion under Section 15, where this question is treated at length. 
of securities. ${ }^{74}$ But the public cannot be subjected to unreasonable rates merely that stockholders may earn dividends, for the community has certain rights which are not to be ignored. ${ }^{75}$

Nor can railroads charge exorbitant rates in order to pay operating expenses where with a view to future profits and business the lines have been built into new and undeveloped territory and where thus the condition of the country does not warrant or permit such rates. ${ }^{76}$

But the roads are entitled to demand a fair return upon the reasonable value of the property at the time it is being used for the public. ${ }^{77}$ The difficulty presented in determining the legal

74 Interstate Commerce Commission v. Cincinnati, New Orleans and Texas Pacific Railway (The Maximum Rate Case), I67 U. S. 479, 42 L. Ed. 243, 17 Sup. Ct. 896, where the court said:-“'The first section declares that the rates shall be reasonable and just and prohibits every unreasonable and unjust charge. Now the rate may be unreasonable because it is too low as well as because it is too high. In the former case it is unreasonable and unjust to the stockholder, and in the latter to the shipper."

75 Covington and Lexington Turnpike Road Co. v. Sanford, I64 U. S. 578, 4I L. Ed. 560, 17 Sup. Ct. 198. The court here said:-"It cannot be said that a corporation is entitled, as of right, and without reference to the interests of the public, to realize a given per cent. upon the capital stock. * * * The rights of the public are not to be ignored. * * * The public cannot properly be subjected to unreasonable rates in order simply that stockholders may earn dividends."

76 In Minneapolis and St. Louis Railway Co. v. Minnesota, I86 U. S. 257, 46 L. Ed. 115I, 22 Sup. Ct. 900, the court said:-"It sometimes happens that, for purposes of ultimate profit and of building up a future trade, railways carry both freight and passengers at a positive loss; and while it may not be within the power of the Commission to compel such a tariff, it would not upon the other hand be claimed that the railroads could in all cases be allowed to charge grossly exorbitant rates as compared with rates paid upon other roads, in order to pay dividends to stockholders. Each case must be determined by its own considerations, and while the rule stated in Smyth v. Ames is undoubtedly sound as a general proposition that the railways are entitled to a fair return upon the capital invested, it might not justfy them in charging an exorbitant mileage in order to pay operating expenses, if the conditions of the country did not permit it."

77 San Diego Land and Town Co. v. National City, I74 U. S. 739, 43 I. Ed. I154, I9 Sup. Ct. 804 . The court here said:-"What the company is entitled to demand, in order that it may have just compensation, is a fair return upon the reasonable value of the property at the time it is being used for the public. The property may have cost more than it ought to have cost, and its outstanding bonds for money borrowed and which went into the plant may be in excess of the real value of the property." 
propriety of rates centers about the question of ascertaining what is the "reasonable value of the property" thus used. In one of its earliest decisions upon this question the Supreme Court said: "In order to ascertain that value, the original cost of construction, the amount expended in permanent improvements, the amount and market value of its bonds and stock, the present as compared with the original cost of construction, the probable earning capacity of the property under particular rates prescribed by statute, and the sum required to meet operating expenses, are all matters for consideration, and are to be given such weight as may be just and right in each case." ${ }^{8}$ 'The court inti-

Cotting v. Godard (Kansas City Stockyards Case), I83 U. S. 79, 46 L. Ed. 92, 22 Sup. Ct. 30 : "The determination of the legislature is to be presumed to be just, and must be upheld unless it clearly appears to result in enforcing unreasonable and unjust rates." In Norfolk \& Western Ry. Co. v. West Virginia, decided March 8, 1915, the court said: "In making a reasonable adjustment of the carrier's charges, the State is under no obligation to secure the same rate of return from each of the two principal departments of business, passenger and freight; but the State may not select either of these departments for arbitrary control. Thus, it would not be contended that the State might require passengers to be carried for nothing, or that it could justify such action by placing upon the shippers of goods the burden of excessive charges in order to supply an adequate return for the carrier's entire service. And, on the same principle, it would also appear to be outside the field of reasonable adjustment that the State should demand the carriage of passengers at a rate so low that it would not defray the cost of their transportation, when the entire traffic under the rate was considered, or would provide only a nominal reward in addition to cost."

78 Smyth v. Ames (Nebraska Rate Case), I69 U. S. 466. In Northern Pacific Ry. Co. v. North Dakota, decided March 8, 1915, the court said: "It has repeatedly been assumed in the decisions of this court, that the state has no arbitrary power over the carrier's rates and may not select a particular commodity or class of traffic for carriage without reasonable reward...... It is presumed-but the presumption is a rebuttable onethat the rates which the state fixes for intrastate traffic are reasonable and just...... But this legislative power cannot be regarded as being without limit. The constitutional guaranty protects the carrier from arbitrary action and from the appropriation of its property to public purposes outside the undertaking assumed; and where it is established that a commodity, or a class of traffic, has been segregated and a rate imposed which would compel the carrier to transport it for less than the proper cost of transportation, or virtually at cost, and thus the carrier would be denied a reasonable reward for its service...... it must be concluded that the state has exceeded its authority." 
mated, however, that there might be other elements to be regarded in estimating this value.

While the capitalization of a carrier may be considered as an element in determining the reasonableness of rates it must have an honest value and represent a bona fide return. This is not the case where, for example, stock has been issued to contractors greatly in excess of the value of work done and services performed by them. ${ }^{i 9}$ The capitalization should bear a reasonable relation to the valuation of the property.

The cost of reproduction constitutes also a proper feature although it is not always a proper measure of the present value of a system or plant which has been in use for a considerable length of time. Some items, such as machinery, will depreciate in value, while others, such as real estate, are likely to increase in value. ${ }^{80}$

The Supreme Court has also declared that if the property which legally enters into the consideration of the rate question has increased in value since being acquired the corporation as a general rule is entitled to the benefit of such increase though this cannot be accepted where the property has increased so enormously in value as to render a rate guaranteeing a reasonable re-

79 Knoxville v. Knoxville Water Co., 212 U. S. I, 53 L. Ed. 371, 29 Sup. Ct. 148. The court said:- "The cost of reproduction is not always a fair measure of the present value of a plant which has been in use for many years. The items composing the plant depreciate in value from year to year in a varying degree. Some pieces of property, like real estate for instance, depreciate not at all, and sometimes, on the other hand, appre. ciate in value. *** Counsel for the company urge rather faintly that the capitalization of the company ought to have some infuence in the case in determining the valuation of the property. It is a sufficient answer to this contention that the capitalization is shown to be considerably in excess of any valuation testified to by any witness, or which can be arrived at by any process of reasoning. The cause for the large variation between the real value of the property and the capitalization in bonds and preferred and common stock is apparent from the testimony. All, or substantially all, the preferred and common stock was issued to contractors for the construction of the plant, and the nominal amount of the stock issued was greatly in excess of the true value of the property furished by the contracts. * * It perhaps is unnecessary to say that such contracts were made by the company with persons who, at the time, by stock ownership, controlled its action. Bonds and preferred and common stock issued under such conditions afford neither measure of nor guide to the value of the property."

80 Knoxville v. Knoxville Water Co., 2 I2 U. S. I, 53 L. Ed. 37I, 29 Sup. Ct. I48, supra. 
turn upon such increased value unjust to the public. ${ }^{81}$ Good will, however, is not under all conditions an element of valuation. ${ }^{82}$

Consideration must further be given to the fact that reduced rates frequently result in increased traffic above that carried under the higher rates. For that reason a reduction in rates may not always reduce net earnings, but may in fact increase them. This is a question which can be answered only by a practical test of the operation of such rates. ${ }^{83}$

The profits from or reasonableness of rates cannot be determined merely from the gross receipts of a railroad. Account must be taken of the expenses incurred in producing those receipts. Thus while the gross receipts may be large the expenses may be even larger and the business therefore unprofitable. ${ }^{84}$ As

81 Wilcox v. Consolidated Gas Co., 212 U. S. 19, 53 L. Ed. 382, 29 Sup. Ct. 192, where the court said:- "We are also of opinion that it is not a case for a valuation of good will. *** And we concur with the court below in holding that the value of the property is to be determined as of the time when the inquiry is made regarding the rates. If the property, which legally enters into the consideration of the question of rates, has increased in value since it was acquired, the company is entitled to the benefit of such increase. This is, at any rate, the general rule. We do not say there may not possibly be an exception to it, where the property may have increased so enormously in value as to render a rate permitting a reasonable return upon such increased value unjust to the public."

82 Wilcox v. Consolidated Gas Co., 212 U. S. 19, 53 L. Ed. 382, 29 Sup. Ct. 392, supra.

83 In Wilcox v. Consolidated Gas Co., 212 U. S. 19, 53 L. Ed. 382, 29 Sup. Ct. 392, supra, the court said:- "There is no particular rate of compensation which must in all cases and in all parts of the country be regarded as sufficient for capital invested in business enterprises.

Of course there is always a point below which a rate could not be reduced and at the same time permit the proper return on the value of the property, but it is equally true that a reduction in rates will not always reduce the net earnings, but on the contrary may increase them. The question of how much an increased consumpticn under a less rate will increase the earnings of complainant, if at all, at a cost not proportioned to the formet cost, can be answered only by a practical test."

84 Chicago, Milwaukee and St. Paul Railway Co. v. Tompkins, (South Dakota Rate Case), 176 U. S. 167, 44 L. Ed. 417, 20 Sup. Ct. 336. The court said:- "Now, it is obvious that the amount of gross receipts from any business does not of itself determine whether such business is profitable or not. The question of expenses incurred in producing those receipts must be always taken into account and only by striking the balance between the two can it be determined that the business is profitable. The gross receipts may be large, hut if the expenses are larger surely the busi- 
already intimated the reasonableness of rates is a question of fact and must be decided upon the circumstances of each particular case. ${ }^{85}$

Although prior to the passage of the Hepburn Act the Interstate Commerce Commission did not possess the power of fixing the rates to be charged by railroads that body has since its foundation been charged with the duty of determining the reasonableness of rates subject to the review of the courts upon the legal questions involved. But even where the Supreme Court has differed from the Commission in its construction of the law it has frequently remanded the case to the Commission for an investigation or re-investigation of the propriety of rates based upon a proper construction of the Act to regulate commerce. ${ }^{86}$

ness is not profitable. It cannot be said that the rates which a legislature prescribes are reasonable if the railroad company charging only those rates finds the necessary expenses of carrying on its business greater than its receipts."

85 Interstate Commerce Commission v. Louisville and Nashville Railroad Co., 227 U. S. 88, 57 L. Ed. 431, 33 Sup. Ct. 185, where the court said: - "But the statute gave the right to a full hearing, and that conferred the privilege of introducing testimony, and at the same time imposed the duty of deciding in accordance with the facts proved. A finding without evidence is arbitrary and baseless. *** In the comparatively few cases in which such questions have arisen it has been distinctly recognized that administrative orders, quasi-judicial in character, are void if a hearing was denied; if that granted was inadequate or manifestly unfair; if the finding was contrary to the "indisputable character of the evidence."

See also Illinois Central Railroad Co. v. Interstate Commerce Commission, 206 U. S. 44I, 5I L. Ed. I128, 27 Sup. Ct. 700.

86 Interstate Commerce Commission v. Clyde Steamship Co., I8I U. S. 29, 45 L. Ed. 729, 21 Sup. Ct. 512. The court here said:-"In the East Tennessee, Virginia and Georgia case, just decided, following the ruling made in Louisville and Nashville Railroad Co. v. Behlmer, I75 U. S. 648, 667 , and previous cases, we have held that, where the Commission by reason of its erroneous construction of the statute had in a case to it presented declined to adequately find the facts, it was the duty of the courts, on application being made to them, to enforce the erroneous order of the Commission, not to proceed to an original investigation of the facts which should have been passed upon by the Commission, but to correct the error of law committed by that body, and after doing so to remand the case to the Commission so as to afford it the opportunity of examining and finding the facts as required by law. The investigation which we have given the questions which arise in these cases and the consideration which we have bestowed on the issues which were involved in the case of the East Tennessee, Virginia and Georgia Railroad have served but to impress upon 
But the Interstate Commerce Commission will not be permitted to regulate and control the policy of railroads in fixing rates or to force then to substitute a lower rate for one that is just and reasonable. And if a new rate is reasonable the roads cannot be forced to desist from enforcing it merely because the former rate has been long in force and because the new rate would operate to the disadvantage of certain business interests which had developed because of the former rate. ${ }^{87}$

Charging of Depreciation and Improvements.-Before considering at all the question of profits a road is entitled to earn a sufficient return annually to provide not only for current repairs but also for making good the depreciation and replacing those portions of its property which each year cease to be of value. It is not compelled to see its property gradually waste or wear out without making suitable provision out of its earnings for its proper replacement. ${ }^{88}$ But expenditures for equipment and addi-

us the necessity of adhering to that rule, in order that the statute may be complied with both in letter and spirit. Acting in accordance with this requirement, whilst affirming the decree below which refused to enforce the order of the Commission, we shall do so without prejudice to the right of the Commission, if it so elects, to make an original investigation of the questions presented in these records."

See also Louisville and Nashville Railroad Co. v. Behlmer, I75 U. S. 648, 44 L. Ed. 309, 20 Sup. Ct. 209.

87 Southern Pacific Co. v. Interstate Commerce Commission, 2 I9 U. S. 433, 55 L. Ed. 283, 3I Sup. Ct. 288, where the court said: "We think when the opinion is considered as a whole-that it was based upon the belief by the Commission that it had the right under the law to protect the lumber interests of the Willamette Valley from the consequences which it was deemed would arise from a change of the rate, even if the change was from an unreasonable low rate which had prevailed for some time to a just and reasonable charge for the service rendered for the future." In Northern Pacific Ry. Co. v. North Dakota, decided March 8, 1915, the court said: "But, while local interests serve as a motive for enforcing reasonable rates, it would be a very different matter to say that the state may compel the carrier to maintain a rate upon a particular commodity that is less than reasonable, or-as might equally well be asserted-to carry gratuitously, in order to build up a local enterprise...... It does not aid the argument to urge that the state may permit the carrier to make good its loss by charges for other transportation."

88 Knoxville v. Knoxville Water Co., 21 2 U. S. I, 53 L. Ed. 37I, 29 Sup. Ct. 148. The court said:- “Before coming to the question of profit at all the company is entitled to earn a sufficient sum annually to provide not only for current repairs but for making good the depreciation and replacing the parts of the property when they come to the end of their life. The company is not bound to see its property gradually waste, without making provision out of earnings for its replacement. It is entitled to 
tions to construction must not be charged all against the revenues of the single year when made but should be distributed over a considerable period of time. ${ }^{83}$

In order to prevent abuses growing out of the charging of such items to operating expenses of a single year and in order to enable the Interstate Commerce Commission to judge more accurately of what may constitute reasonable and proper rates, the Act to Regulate Commerce by section 20 vests the Commission with authority to prescribe a uniform system of accounting and bookkeeping. ${ }^{90}$

Through Rates Compared With Local Rates.-The earlier claim that the sum of two reasonable local rates cannot constitute an unreasonable through rate has been expressly disavowed by the Supreme Court. Many items and considerations establish the fact that local business is per mile more costly than through business-for example, the additional fuel consumed, the increased wear upon machinery occasioned by frequent stops, the wages of added employees. So that, other considerations being

see that from earnings the value of the property invested is kept unimpaired, so that at the end of any given term of years the original investtnent remains as it was at the beginning."

89 Illinois Central Railroad Co. v. Interstate Commerce Commission, 206 U. S. 441, 51 L. Ed. 1128, 27 Sup. Ct. 700, where the court said:"The Commission finds that the net and gross earnings of the appellant have grown from year to year. and also that what they have reported as operating expenses have also grown. But in these operating expenses there were included 'expenditures for real estate, right of way, tunnels, bridges, and other strictly permanent improvements, and also for equipment such as locomotives and cars.' The Commission expressed the opinion that such expenditures should not be charged to a single year, but 'should be, so far as practicable and so far as rates exacted from the public are concerned,' projected proportionately over the future. *** He (the carrier) must pay a toll, but a toll measured by the reasonable value of the service. The elements of that value may be many and complex, not always determinable, as we have seen, with mathematical accuracy, but, we think, it is clear that instrumentalities which are to be used for years should not be paid for by the revenues of a day or year; and this is the principle of returns upon capital which exists in durable shape."

90 See discussion under section 20. Also Interstate Commerce Commission v. Goodrich Transit Co., 224 U. S. 194, 56 L. Ed. 729, 32 Sup. Ct. 436; Kansas City Southern Railway Co. v. United States, 231 U. S. 423, 58 L. Ed. 296, 34 Sup. Ct. 125. 
equal, a reasonable through rate is less than the aggregate of the local tariffs between the intermediate stations. ${ }^{91}$

Presumption of Reasonableness of Rates.-In the judicial review of rates complained of by a railroad the burden of proof naturally devolves upon the carrier to show that the legislature, state or national, or its duly organized agency, has set an unreasonable limitation upon its rates. If the complaint is made by a shipper the burden of proof rests upon him to show that the rates fixed by the carrier are unduly high. Of nature under the amendment of June I8, I9IO, upon objection to an advance of rates pro-

9 I Minneapolis and St. Louis Railroad Co. v. Minnesota, I86 U. S. 257, 46 L. Ed. I15I, 22 Sup. Ct. 900, where the court said:-"There is an underlying fallacy in the argument of the railroad company in this connection, that the sum of two reasonable local rates cannot be unreasonable. * * We cannot assent to this proposition. The practice of railways in this country is almost universally to the contrary, and a through tariff is almost always fixed at a less sum than the aggregate of local tariffs between nearby stations upon the same road. Doubtless the fixing of a lower through tariff is dictated largely by a desire of each road to get as much mileage as possible from its patrons, as well as by an effort to meet competition over other lines between the same termini; but in addition to this there is an increased cost of local business over through business in the additional fuel consumed and the increased wear upon the machinery of each train involved in stopping at every station." These facts were noticed by Mr. Justice Brewer in the opinion of the court in Chicago, Milwaukee and St. Paul Railway Co. v. Tompkins, I76 U. S. I67, 44 L. Ed. 4I7, 20 Sup. Ct. 336, in which he makes the following observation:- "Take a single line of 100 miles with ten stations. One train starts from one terminus with through freight and goes to the other without stop. A second train starts with freight for each intermediate station. The mileage is the same. The amount of freight hauled per mile may be the same; but the time taken by the one is greater than that taken by the other. Additional fuel is consumed at each station where there is a stop. The wear and tear of the locomotive and cars from the increased stops and in shifting cars from the main to side tracks is greater; there are the wages of the employees at the intermediate stations, the cost of insurance, and these elements are so varying and uncertain that it would seem quite out of reach to make any accurate comparison of the relative cost. And if this is true, when there are two separate trains, it is more so when the train carries both local and through freight. It is impossible to distribute between the two the relative cost of carriage. $* * *$ We think, therefore, there was error in the failure to find the cost of doing the local business, and that only by a comparison between the gross receipts and the cost of doing the business, ascertaining thus the net earnings, can the true effect of the reduction of rates be determined." 
posed by a carrier, the burden is placed on such carrier to show the reasonableness of the advance suggested.

The legal presumption is furthermore that the rates fixed by the legislature or its agency are reasonable and the burden of proof rests upon the railroad companies to show to the contrary, to demonstrate that they infringe the constitutional guarantee of protection to property. The case in behalf of the railroad must be clear, or the legislation of the states will be upheld by the courts. ${ }^{92}$

Furthermore the existence of a rate raises a presumption of reasonableness in its behalf. ${ }^{93}$ But the maintenance of a lower rate does not raise a legal presumption that a new and higher rate is unreasonable. ${ }^{.4}$

\section{Free Transportation and Passes Prohibited.-} No common carrier subject to the provisions of this Act shall, after January first, nineteen hundred and seven, directly or indirectly, issue or give any interstate free ticlet, free pass, or free transportation for passengers, except to its employees and their families, its officers, agents, surgeons, physicians, and attorneys at law; to ministers of religion, Excepted traveling secretaries of railroad Young Men's Christian Associations, inmates of hospitals and charitable and eleemosynary institutions, and persons exclusively engaged in charitable and eleemosynary work; to indigent, destitute, and homeless persons.

92 In Chicago, Milwaukee and St. Paul Railway Co. v. Tompkins, (South Dakota Rate Case), 176 L. S. 167, 44 L. Ed. 417, 20 Sup. Ct. 336, the court said:- "In approaching the consideration of a case of this kind we start with the presumption that the Act of the legislature is valid, and upon the company seeking to challenge its validity rests the burden of proving that it infringes the constitutional guarantee of protection to property: The case must be a clear one in behalf of the railroad company or the legislation of the state must be upheld."

See also Minneapolis and St. Louis Railroad Co. v. Minnesota, 186 U. S. 257, 46 L. Ed. II5I, 22 Sup. Ct. goo, in which the court said:- "The presumption is that the rates fixed by the Commission are reasonable, and the burden of proof is upon the railroad companies to show the contrary."

93 Interstate Commerce Commission v. Union Pacific Railroad Co., 222 U. S. 541, 56 L. Ed. 308, 32 Sup. Ct. 108.

94 Southern Pacific Co. v. Interstate Commerce Commission, 219 U. S. 433, 55 L. F.d. 283, 31 Sup. Ct. 288. 
and to such persons when transported by charitable societies or hospitals, and the necessary agents employed in such transportation; to inmates of the National Homes or State Homes for Disabled Volunteer Soldiers, and of Soldiers' and Sailors' Homes, including those about to enter and those returning home after discharge; to necessary care takers of live stock, poultry, milk, and fruit; to employees on sleeping cars, express cars, and to linemen of telegraph and telephone companies; to Railway Mail Service employees, post office inspectors, customs inspectors, and immigration inspectors; to newsboys on trains, baggage agents, witnesses attending any legal investigation in which the con1mon carrier is interested, persons injured in wrecks and physicians and nurses attending such persons: Interchange of Provided, That this provision shall not be construed authorized passes.

to prohibit the interchange of passes for the officers, agents, and employees of common carriers, and their families; nor to prohibit any common carrier from carrying passengers free with the object of providing relief in cases of general epidemic, pestilence, Extension of or other calamitous visitation: And provided furmeaning of "term "families." ther, That this provision shall not be construed to prohibit the privilege of passes or franks, or the exchange thereof with each other, for the officers, agents, employees, and their families of such telegraph, telephone, and cable lines, and the officers, agents, employees and their families of other con1mon carriers subject to the provisions of this Act: Provided further, That the term "employees" as used in this paragraph shall include furloughed, pensioned, and superannuated employees, persons who have become disabled or infirm in the service of any such common carrier, and the remains of a person killed in the employment of a carrier and exemployees traveling for the purpose of entering the service of any such common carrier; and the term "families" as used in this paragraph shall include the families of those persons named in this proviso, 
also the families of persons killed, and the widows during widowhood and minor cliildren during minority of persons who died while in the service of any such common carrier. Any common carrier violating this provision shall be deemed guilty of a misdemeanor, and for each offense, on conviction, Jurisdiction and penalty for shall pay to the United States a penalty of not less than one hundred dollars nor more than two thousand dollars, and any person, other than the persons excepted in this provision, who uses any such interstate free ticket, free pass, or free transportation shall be subject to a like penalty. Jurisdiction of offenses under this provision shall be the same as that provided for offenses in an Act entitled "An Act to further regulate commerce with foreign nations and among the States," approved February nineteenth, nineteen hundred and three, and any amendment thereof. (See section 22.)

Passes.-Under the Act to Regulate Commerce as originally enacted in 1887 there was no inhibition against the issuance of passes or giving of free transportation by common carriers. Although this practise had been condemned by the Interstate Commerce Commission as well as the United States Supreme Court as a practical violation of section 2 of the Act in that it amounted to an unjust discrimination between patrons of the roads, the fact remained that the custom of giving passes had continued and had become a well recognized abuse both to the railroads themselves and to the general public as well. By amendnents of March 2, I889, and February 8, I 895 , to section 22 of the Interstate Commerce Act the railroads were expressly forbidden to transport free of charge any property. And also recognition was given to the right of the railroads to carry without charge certain officials and certain classes of persons.

By the Act of June 29. 1906, Congress for the first time adopted an cxpress statutory inhibition against the issuance of passes by any carriers embraced by the terms of the Act to Regulate Commerce and forbade the giving of free transportation except to certain classes specifically designated. The purpose of the Hepburn Act was to entirely eliminate and uproot the whole practise of furnishing free transportation under any guise or pretense. 
This paragraph was enacted in pursuance of the evident purpose of Congress to establish uniform rates for transportation and to compel railroads to charge and patrons to pay therefore only in money. In this way alone it was felt that the doors could be closed to violations of the letter and intent of the law. And except for the classes expressly named no free transportation could be issued under any pretext. Even where prior to the enactment of this legislation railroad companies had entered into contracts, either indefinite or fixed in their length, for the issuance of free transportation such agreements now being in violation of the law were avoided. Thus, for example, where in satisfaction of a clain for damages a railroad had contracted to issue free transportation the contract was outlawed by virtue of this legislation. ${ }^{95}$

95 Louisville and Nashville Railroad Company v. Mottley, 2 I9 U. S. 467,55 L. Ed. 297, 3I Sup. Ct. 265. As a result of a collision of railroad trains on the line of the Louisville and Nashville Railroad one Mottley and his wife received serious personal injuries. A few days thereafter Mottley and his wife entered into a contract with the railroad company whereby the latter was released from all claims for the damages thus sustained in consideration of the issuance to them of annual passes over the railroad and its branches each year during the lives of the said Mottley and his wife or either of them. The railroad company adhered to this agreement for many years but finally refused further to perform it on the ground that the Act of Congress of June 29, I906, made its performance illegal. Thereupon Mottley and his wife brought suit to enforce the agreement. The Supreme Court in passing upon the question said:- "It is said, however, that as the contract of Mottley and wife with the railroad company was originally valid, it cannot be supposed that Congress intended by the Act of 1906 to annul or prevent its enforcement. But the purpose of Congress was to cut up by the roots every form of discrimination, favoritism and inequality, except in the cases of certain excepted classes to which Mottley and his wife did not belong and which exceptions rested upon peculiar grounds. Manifestly, from the face of the Commerce Act itself, Congress, before taking final action, considered the question as to what exceptions, if any, should be made in respect of the prohibition of free tickets, free passes and free transportation. It solved the question when, without making any exceptions of existing contracts, it forbade by broad, explicit words any carrier to charge, demand, collect or receive a 'greater or less or different compensation' for any services in connection with the transportation of passengers or property than was specified in its published schedules of rates. The court cannot add an exception based on equitable grounds when Congress forebore to make sucl an exception. Yyturbide v. United States, 22 How. 290, 293, I6 L. Ed. 342. The words of the Act, therefore, must be taken to mean that a carrier, engaged in interstate commerce, cannot charge, collect or receive for 
It is well to keep in mind the idea that this clause is based upon the intention of eliminating and preventing unjust discrimination by carrying certain classes of persons or traffic free of charge or at less than the declared and published rates. And only in those cases which are specifically excepted by Congress and related in the clause in question can passes be either allowed or accepted.

transportation on its road anything but money. In Armour Packing Company v. United States, 209 U. S. 56, 8I, 52 L. Ed. 681, 28 Sup. Ct. 428, this court said:- 'There is no provision excepting special contracts from the operation of the law. One rate is to be charged. and that the one fixed and published in the manner pointed out in the statute, and subject to change in the only way open by the statute. There is no provision for the filing of contracts with shippers and no inethod of making them public defined in the statute. If the rates are subject to secret alteration by special agreement then the statute will fail of its purpose to establish a rate duly published, known to all, and from which neither shipper nor carrier may depart.' So, in Adams Express Co. v. United States, 212 U. S. 522, 532-3, 53 L. Ed. 635, 29 Sup. Ct. 315. 'But the power of Congress over interstate transportation embraces all manner of carriage of that character - whether gratuitous or otherwise-and, in the absence of express exceptions, we think it was the intention of Congress to prevent a departure from the published rates and schedules in any manner whatsoever. If this be not so, a wide door is opened to favoritism in the carriage of property in the instances mentioned, free of charge. If it is lawful, in view of the provisions of the Interstate Commerce Act, to issue franks of the character under consideration in this case, then this right must be founded upon some exception incorporated in the Act.'

"It is further said that the passes contemplated by the parties were not strictly free passes; for, it is argued, the railroad company would receive a valuable consideration for each one issued by it. This view is more plausible than sound, and does not meet the difficulty. Suffice it to say, in this case, that such passes, when issued, would be illegal under the Act of Congress, by reason of their not being paid for in money, according to the company's schedule of rates, but in consideration only of the release by Mottley and wife of their claim for damages on account of the collision in question. *** The agreement between the railroad company and the Mottleys must necessarily be regarded as having been made subject to the possibility that, at some future time, Congress might so exert its whole constitutional power in regulating interstate commerce as to render that agreement unenforceable or to impair its value. That the exercise of such power may be hampered or restricted to any extent by contracts previously made between individuals or corporations, is inconceivable. The framers of the Constitution never intended any such state of things to exist.

"It is said that if Congress intended by the commerce Act to embrace such a case as this, then the Act is repugnant to the Constitution. * * * These authorities and principles condemn the proposition that the defend- 
To further insure the enforcement of this provision a penalty is nominated against both the carrier who may give and the person who may receive such free transportation or pass.

The issuance of franks by express companies to their employees, officers and others in order to secure the free transportation of packages is within the inhibitions of this section of the Interstate Commerce Act. This inhibition applies both to the officials and employees of the express companies themselves and to the issuance of such franks to the officials and employees and their families of other express or transportation companies. ${ }^{96}$

ants in error had the constitutional right, pursuant to or because of the agreement of $187 \mathrm{I}$ and during their respective lives, to accept and use free transportation for themselves, as passengers, on an interstate train, after Congress forbade, under penalty any interstate carrier to demand, collect or receive compensation for transportation, or any interstate passenger, not within the classes excepted by the Act, to use transportation tickets, except upon the basis fixed by the carrier's published schedule of rates. After the commerce Act came into effect no contract that was inconsistent with the regulations established by the Act of Congress could be enforced in any court. The rule upon this subject is thoroughly established. It is not determinative of the present question that the Commerce Act as now construed will render the contract of no value for the purposes for which it was made. $* * *$ They (the authorities) are numerous and are all one way. They support the view that, as the contract in question would have been illegal if made after the passage of the Commerce Act, it cannot now be enforced against the railroad company, even though valid when made. If that principle be not sound, the result would be that individuals and corporations could, by contracts between themselves, in anticipation of legislation, render of no avail the exercise by Congress, to the full extent authorized by the Constitution, of its power to regulate commerce. No power of Congress can be thus restricted. The mischiefs that would result from a different interpretation of the Constitution will be readily perceived." In Louisville and Nashville Railroad Company v. Mottley, 2 II U. S. 149, 53 L. Ed. I26, 29 Sup. Ct. 42, the question at issue was one of jurisdiction. U. S. v. Erie R. R., decided February 23, I9I 5 .

96 American Express Company v. United States, 212 U. S. 522, 53 L. Ed. 635, 29 Sup. Ct. 315. An injunction was issued to restrain express companies from issuing any frank for the free transportation of property to the officials and employees of the defendant and their families; to the officials and employees and their families of other express companies and the officials and employees and their families of any railroads or common carriers subject to the Act to Regulate Commerce. The facts were not in dispute and the question at issue was whether the interstate commerce law prohibited express companies from giving free transportation of personal packages to the officers and employees and members of their families and 
Beyond the exceptions specified in the section under consideration transportation companies cannot issue passes or free transportation under any guise or pretext. They will not even be permitted to issue free transportation in payment of advertising or other services rendered to them or on their account. And the mere fact that a state statute may seek to validate such methods

the officers of other transportation companies and members of their families in exchange for passes issued by the latter to the officers of the express companies. The court said:- "It is contended that such transportation is not within the terms of the Act, as it was not the purpose of Congress to regulate in these provisions gratuitous transportation. but the purpose was to prevent discriminations, rebating and so forth, where property has been carried by a common carrier for hire; that it is a departure from the rates charged for that class of transportation which is the evil to be remedied, and the only one covered by the terms of the Act. But the power of Congress over interstate transportation embraces all manner of carriage of that character-whether gratuitous or otherwise-and, in the absence of express exceptions, we think it was the intention of Congress to prevent a departure from the published rates and schedules in any manner whatsoever. If this be not so, a wide door is opened to favoritism in the carriage of property, in the instances mentioned, free of charge. If it is lawful, in view of the provisions of the Interstate Commerce Act, to issue franks of the character under consideration in this case, then this right must be founded upon some exception incorporated in the Act, and it is the contention of the learned counsel for the appellant that such exception is found in the proviso in section I of the Hepburn Act.

"Turning to section I of the Hepburn Act, it is apparent that all that immediately precedes the proviso appertains to the carriage of passengers, for common carriers are forbidden to issue or give any free pass or free transportation for passengers, except to its employees, etc. Until we come to the proviso, the Act is clearly thus limited. It is then enacted that this provision, that is, the previous part of the enactment, which refers only to the transportation of passengers, shall not be construed to prohibit the interchange of passes for the officers, agents and employees of common carriers and their families, or to prohibit any common carrier from carrying passengers free in certain cases. While it is true the language here used has reference to common carriers and by the terms of the Hepburn Act express companies are within that description, yet the proviso is as clearly limited to the carriage of passengers and the interchange of passes for officers, agents and employees of common carriers and their families, as is the body of the section itself.

"It is contended that this section if limited to the carriage of passengers was unnecessary in view of the concluding part of section 22 of the Act of February 4, I887, as amended by the Acts of March 2, 1889 and February 8, I 895 . which provides: 'Nothing in this Act shall be construed to pre- 
of payment for printing and advertising will not in any way alter the rule or limit the inhibition. ${ }^{97}$

vent railroads from giving free carriage to their own officers and employees, or to prevent the principal officers of any railroad company or companies from exchanging passes or tickets with other railroad companies for their officers and employees, etc.'

"But we are to consider the language which Congress has used in passing a given law, and when the language is plain and explicit our only province is to give effect to the Act as plainly expressed in its terms. We are clearly of the opinion that, without doing violence to the language used in section I-including the proviso-its terms cannot be held to include the transportation of goods. It is very likely that there is no substantial reason why Congress should not extend to express companies, their officers, agents and employees, corresponding privileges for free carriage of goods with those which are given to the officers, agents and employees of railroad companies in respect to transportation of persons, but -if the law is defective in this respect-the remedy must be applied by Congress and not by the courts."

97 Chicago, Indianapolis and Louisville Railway Company v. United States, 219 U. S. 486, 55 L. Ed. 305, 3I Sup. Ct. 272. The case arose out of a contract between the railroad in question and the publishers of Munsey's magazine whereby in return for certain advertising carried in the pages of that periodical the railroad agreed to issue free transportation aggregating an agreed amount to the publisher of the magazine and the members of his family and to his employees and the members of their families. The railroad company cited a statute of Indiana-it being an Indiana corporation-which prohibited railway companies from giving free tickets, free passes or free transportation, but which in express words authorized the company to issue transportation in payment for printing and advertising. The court said:- "The decisive question in this case is whether the contract between the railway company and the Munsey company is repugnant to the Acts of Congress regulating commerce. In other words, could the company, in return for the transportation which it agreed to furnish and did furnish to the Munsey publisher over its interstate lines, and to his employees and to the immediate members of his and their families, accept as compensation for such service anything else than money, the amount to be determined by its published schedule of rates and charges? Upon the authority of Louisville and Nashville R. R. Co. v. Mottley, 219 U. S. 467, 55 L. Ed. 297, 3I Sup. Ct. 265, and according to the principles announced in the opinion in that case, the answer to the above question must be in the negative. The acceptance by the railway company of advertising, not of money in payment of the interstate transportation furnished to the publisher of the Munsey magazine, his employees and the immediate members of his and their families, was for the reasons given in the Mottley case, in violation of the Commerce Act. The facts in the present case show how easily, under any other rule, the Act can be evaded and the object of Congress entirely defeated. The legislative department 
However the fact that one does accept free transportation in violation of the terms of the Act to regulate commerce and rides on a pass does not make him an outlaw nor deprive him of the benefit and protection of the laws of the states requiring railroad companies to use proper care and precautions in the transportation of passengers and traffic. Such a passenger does not forfeit his right to safety or such protection by accepting gratuitous carriage in violation of the law. ${ }^{98}$

intended that all who obtained transportation on interstate lines should be treated alike in the matter of rates, and that all who availed themselves of the services of the railway company (with certain specified exceptions) should be on a plane of equality. Those ends cannot be met otherwise than by requiring transportation to be paid for in money which has a certain value known to all and not in commodities or services or otherwise than in money.

"We need say but little about the Indiana statute upon which the defense is in part based. The transactions, in respect of which the government seeks relief, being interstate in their character, the Acts of Congress as to such transactions are paramount."

98 Southern Pacific Company v. Schuyler, 227 U. S. 60I, 57 L. Ed. 662, 33 Sup. Ct. 277. Schuyler was employed in the railway mail service of the United States and in line therewith was entitled to ride free, at least while on official business. Called to another city by the illness of a member of his family who later died he set out to return by a mail train using as evidence of his right to transportation the commission of his appointment. The train on which he was thus riding was derailed and Schuyler was killed. An action was brought for damages on account of his death and the railroad company set up the defense that Schuyler was riding upon his pass in violation of the Act to Regulate Commerce, not being on official business and that thus being a trespasser the railroad was under no legal duty to care for his safety. The Supreme Court did not pass upon the question of whether his riding on the pass while not on official business was a violation of the Act in question but declared that in any event this fact, if granted, did not make an outlaw of him or deprive him of the protection of the law and the right to proper protection and safety. The court declared:- "Neither the letter nor the spirit of the Act makes an outlaw of him who violates its prohibition by either giving or accepting gratuitous interstate carriage. The deceased no more forfeited his life, limb or safety, and no more forfeited his right to the protection accorded by the local law to a passenger in his situation, than the carrier forfeited its right of property in the mail car upon which the deceased rode. His right to safe carriage was not derived, according to the law of Utah, from the contract made between him and the carrier, and therefore was not deduced from the supposed violation of the Hepburn Act. It arose from the fact that he was a human being of whose safety the plaintiff in error had undertaken the charge. With its consent he had 
But where a pass is issued under the terms of the statute to one of the family of a railroad employee it is a gratuity and where such pass stipulates that the railroad issuing it will not be liable for injuries sustained by any one riding thereon, such a provision is valid and there can be no recovery. ${ }^{99}$

In constructing, improving or repairing its road or in building extensions or branches a railroad company in providing for the

placed his life in its keeping, and the local law thereupon imposed a duty upon the carrier, irrespective of the contract of carriage. The Hepburn Act does not deprive one who accepts gratuitous carriage, under such circumstances, of the benefit and protection of the law of the state in this regard. It results that the judgment under review must be affirmed, irrespective of the question whether the Hepburn Act forbids the giving of free interstate transportation to the employees of the railway mail service when not on duty."

99 Charleston and Western Carolina Railway Co. v. Thompson, 234 U. S. 576,58 L. Ed. 1476,34 Sup. Ct. 96.4 . The plaintiff, a woman, sued the railroad company to recover for personal injuries inflicted upon her while a passenger upon one of the trains of such road. The court said:"The railroad pleaded that she was traveling on a free pass that exempted the company from liability, the same having been issued to her gratuitously under the Hepburn Act of June 29, 1906, c. 3591, section I, as wife of an employee. *** The main question is whether when the statute permits the issue of a 'free pass' to its employees and their families it means what it says. The railroad was under no obligation to issue the pass. It may be doubted whether it could have entered into one, for then the services would be the consideration for the duty and the pass and by section 6 it was forbidden to charge 'a greater or less or different compensation' for transportation of passengers from that in its published rates. The antithesis in the statute is between the reasonable charges to be shown in its schedules and the free passes which it may issue only to those specified in the Act. To most of those enumerated the free pass obviously would be gratuitous in the strictest sense, and when all that may receive them are grouped in a single exception we think it plain that the statute contemplates the pass as gratuitous in the same sense to all. It follows, or rather is saying the same thing in othar words, that even on the improbable speculation that the possibility of getting an occasional free pass entered into the motives of the employee in working for the road, the law did not contemplate his work as a conventional inducement for the pass but on the contrary contemplated the pass as being what it called itself, free. As the pass was free under the statute, there is no question of the validity of its stipulations. This was conceded by the Court of Appeal, as we have stated, and is established by the decisions of this court. Northern Pacific Railway Co. v. Adams, I92 U. S. 440, 48 L. Ed. 513, 24 Sup. Ct. 408; Boering v. Chesapeake Beach Railway Co., I93 U. S. 442, 48 L. Ed. 742, 24 Sup. Ct. 515." 
transportation of men and supplies for the work in question is not acting as a common carrier and in transporting such employees or supplies necessary for the work without charge or at reduced rates the railroad does not violate this clause of the Act. ${ }^{100}$ This applies whether the work in question is done directly by the railroad company or indirectly through a contract with a third party. The arrangement or contract, however, must be entered into in good faith and not be a mere subterfuge or cloak for concealing a violation of the provisions of the law.

100 Santa Fe, Prescott and Phonix Railway Company v. Grant Brothers Construction Company, 228 U. S. 177,57 L. Ed. 787,33 Sup. Ct. 474. Here the railroad in question was engaged in building westerly from its main line a branch railroad and for this purpose entered into a contract with the construction company for the necessary grading. As a part of the contract the railroad company agreed to carry the supplies and employees of the construction company at reduced rates. The construction company agreed to assume all risk of accident and loss to person and baggage. The action grew out of a loss of certain materials by fire said to have been caused from sparks of a locomotive of the railroad. The court said:- "In constructing, improving or repairing its road, and in building its extensions and branches, the railroad company is providing facilities for its service as a common carrier, but of course is not acting as such. It may do the work itself, if it chooses, or it may make it the subject of contract with another. In the latter case it simply employs an appropriate agency. The haulage by the railroad company of the men, appliances and supplies, required by the contractor for the purpose of the construction or improvement, to or from the point on its line where the work is to be done, is merely incidental to the work itself. The cost of such haulage is obviously an item of expense which must be taken into acount in fixing the terms of the construction contract, and in providing for it over its own line the railroad company may adjust the matter with the contractor as it sees fit. If the railroad company did the work directly it would have to take its employees and the necessary outfit to the place of work, and it may undertake to do the like for the contractor, either free of charge or at reduced rates, as they may agree. * * * It is clear that in dealing with transportation of this character over its own road, in connection with construction or improvement, a railroad company is not acting in the performance of its duty as a common carrier, and the arrangement for free or reduced-rate carriage for the necessary materials and men used in the work, when it is a part of the contract, entered into in good faith and not as a subterfuge, is not obnoxious to the provisions of law prohibiting departures from the published tariffs, for the reason that such an agreement lies outside the policy of these provisions. See Matter of Railroad-Telegraph Contracts, I2 I. C. C. Rep. 10, 11. The parties then were free to make their own bargain as to this transportation and the liability which should attach to it." 
Commodities clause.

The Commodities Clause.-From and after May first, nineteen hundred and eight, it shall be unlawful for any railroad company to transport from any state, territory, or the District of Columbia, to any other state, territory, or the District of Columbia, or to any foreign country, any article or commodity, other than timber and the manufactured products thereof, manufactured, mined, or produced by it, or under its authority, or which it may own in whole or in part, or in which it may have any interest, direct or indirect, except such articles or commodities as may be necessary and intended for its use in the conduct of its business as a common carrier.

The Commodities Clause was inserted in the Act to regulate commerce by the Hepburn law, approved June 29, I906. Effective May I, 1908, its general purpose was to prohibit railroad companies engaged in interstate commerce from being at the same time manufacturers, producers, and owners of commodities which they carry-in short to confine interstate railroads to the business of transportation for the general public. Several railroad companies, by purchase, lease or otherwise, had become possessed of various mining and manufacturing and producing properties-particularly coal mines-whose products they transported on their own account from the place of production to other states where they were marketed. The abuses which grew out of this dual relation of producer and monopolizer of transportation facilities inspired the enactment of this clause by Congress. The case of New York, New Haven and Hartford Railroad Company v. Interstate Commerce Commission, decided February 19, I906, brought the situation to a focus. ${ }^{101}$ The Chesapeake and Ohio Railroad had contracted to sell to the New York, New Haven and Hartford Railroad Company coal to be carried from the Kanwaha district, West Virginia mines, to Newport News by rail and thence by water to Connecticut for delivery to the buyer at $\$ 2.75$ per ton; it was averred that the price of the coal at the mines and the cost of transportation from Newport News to Connecticut would aggregate $\$ 2.47$ per ton, thus leaving the Chesapeake and Ohio road only about $\$ .28$ per ton for 
carrying the coal from the Kanwaha district to Newport News, while the published tariff for like carriage for this distance was $\$ 1.45$ per ton. It was argued that this amounted to a rebate and a concession in favor of the New Haven road by the Chesapeake and Ohio. The New Haven road alleged that it was a mere purchaser of coal from the Chesapeake and Ohio, and not a shipper over that road, and that the coal was intended for its own use in operating its road. The evidence showed that the Chesapeake and Ohio bought the coal thus shipped from the mine operators in the West Virginia district. The Supreme Court held that a carrier could not legally stipulate to sell and carry the coal at a rate insufficient to yield the published and lawful freight rates, after the cost of purchasing the commodity and delivery beyond its own lines had been deducted-and that this could not be accomplished either directly or indirectly. ${ }^{102}$

I02 The court said:- "For here it is unquestioned that the Chesapeake and Ohio, as a result of its being a dealer, had become, long prior to the adoption of the interstate commerce law and continued to be thereafter, up to the passage of the West Virginia statute prohibiting a carrier from dealing in coal, virtually the sole purchaser and seller of all coal produced along the line of its road. That this result was not merely accidental, but was in effect engendered by the power of the carrier to deal in and transport a commodity, is illustrated by the case of the Attorney General v. The Great Northern Railway Company, (29 Law Journal [N. S. Equity] 794). *** We think it is established beyond doubt that, desiring to stimulate the production of coal along its line and thereby, as it conceived, to increase the carriage of that commodity and to benefit the railroad and those living along its line by the reflex prosperity which it was deemed would arise from giving a stimulus to an industry tributary to the railroad, the Chesapeake and Ohio bought and sold the coal without reference to whether the net result to it would realize its published rates. And it would seem that this means of stimulating the industry in question was resorted to instead of attempting to bring about the same result by a lowering of the published rates, because to have so done would have engendered disparity between coal rates and the tariff on all other articles contained in the same classification, and would besides have caused other and competing roads to make a similar reduction on the published rates and thereby would have frustrated the very advantages to itself and those along its lines which the Chesapeake and Ohio deemed it was bringing about by the method pursued.

"Because no express prohibition against a carrier who engages in interstate commerce becoming a dealer in commodities moving in such commerce is found in the Act, it does not follow that the provisions which are expressed in that Act should not be applied and be given their lawful 
The decision in the New Haven case was followed four months later by the enactment of the so-called Commodities Clause forbidding any railroad company to transport in interstate com-

effect. Even, therefore, if the result of applying the prohibitions as we have interpreted them will be practically to render it difficult, if not impossible, for a carrier to deal in commodities, this affords no ground for relieving us of the plain duty of enforcing the provisions of the statute as they exist. This conclusion follows, since the power of Congress to subject every carrier engaging in interstate commerce to the regulations which it has adopted is undoubted."

The court held that the railroad could not give a rebate on its own coal which it carried and declared that it was immaterial that the inadequacy of the price might have been caused in part or in whole by strikes or other means over which it had no control.

Earlier in the opinion, the court also said:- "If by the mere fact of purchasing and selling merchandise to be transported, a carrier is endowed with the power of disregarding the published rate, it becomes apparent that the carrier possesses the right to treat the owners of like commodities by entirely different rules. That is to say, the existence of such a power in its essence would enable a carrier, if it chose to do so, to select the favored persons from whom he would buy and the favored persons to whom he would sell, thus giving such persons an advantage over every other, and leading to a monopolization in the hands of such persons of all the products as to which the carrier chose to deal. Indeed the inevitable result of the possession of such a right by a carrier would be to enable it, if it chose to exercise the power, to concentrate in its own hands the products which were held for shipment along its line, and to make it, therefore, the sole purchaser thereof and the sole seller at the place where the products were to be marketed; in other words, to create an absolute monopoly. To illustrate: If a carrier may by becoming a dealer buy property for transportation to market and eliminate the cost of transportation to such market, a faculty possessed by no other owner of the commodity, it must result that the carrier would be in a position where no other person could ship the commodity on equal terms with the carrier in its capacity of dealer. No other person owning the commodity being thus able to ship on equal terms, it would result that the owners of such commodiy would not be able to ship, but would be compelled to sell to the carrier. And as by the departure from the tariff rates the person to whom the carrier might elect to sell would be able to buy at a price less than any other person could sell for, it would follow that such person so selected by the carrier would have a monopoly in the market to which the goods were transported. And that the result arising from an admission of the asserted power of the carrier as a dealer to disregard the published rates conduces immediately and not merely remotely to the production of the injurious results stated, is not only demonstrated by the very nature of things, but is established to be the case by the facts indisputably shown on this record." 
merce "any article or commodity" other than timber and its manufactured products in which it may have any interest, direct or indirect, except such as may be necessary and intended for its own use and consumption as a common carrier. In a word the purpose of Congress in enacting this provision was to divorce, in a real, substantial sense, production and transportation, and thereby to prevent the transporting company from doing injustice to other and independent owners of coal and coal mining properties. The clause was at once attacked as being unconstitutional because beyond the power granted to Congress in the commerce clause of the Constitution; as being in conflict with the due process clause of the fifth amendment of the Constitution, and as being repugnant to the Constitution because of the discrimination caused by the exception of timber and the manufactured products thereof. May 3, I909, the Supreme Court passed first upon this clause in the case of United States v. Delaware and Hudson Company. ${ }^{103}$ Summarizing its decision the court said: "We then construe the statute as prohibiting a railroad company engaged in interstate commerce from transporting in such commerce articles or commodities under the following circumstances and conditions: a. When the article or commodity has been manufactured, mined or produced by a carrier or under its authority, and at the time of transportation the carrier has not in good faith before the act of transportation dissociated itself from such article or commodity; b. When the carrier owns the article or commodity to be transported in whole or in part; c. When the carrier at the time of transportation has an interest, direct or indirect, in a legal or equitable sense in the article or commodity, not including, therefore, articles or commodities manufactured, mined, produced or owned, etc., by a bona fide corporation in which the railroad company is a stockholder." 104

103253 U. S. 366, 53 L. E.d. 836, 29 Sup. Ct. 527.

104 The court. in the course of its opinion further said:- "Recurring to the text of the commodities clause, it is apparent that it disjunctively applies four generic prohibitions, that is it forbids a railroad company from transporting in interstate commerce articles or commodities, 1 , which it has manufactured, mined or produced; 2 , which have been so mined, manufactured or produced under its authority; 3 , which it owns in whole or in part, and, 4 , in which it has an interest, direct or indirect. * * * In view of the far-reaching effect to arise from giving to the first two prohibitions a meaning wholly antagonistic to the remaining ones, we think our duty requires that we should treat the prohibitions as having a com- 
The Supreme Court thus declared the Commodities Clause constitutional and a proper exercise by Congress of its power under the commerce clause of the Constitution. Further it declared that the clause as thus construed was not in conflict with

mon purpose, that is, the dissociation of railroad companies prior to transportation from articles or commodities, whether the association resulted from manufacture, mining, production or ownership, or interest, direct or indirect. In other words, in view of the ambiguity and confusion in the statute we think the duty of interpreting should not be so exerted as to cause one portion of the statute which, as conceded by the government, is radical and far-reaching in its operation if literally construed, to extend and enlarge another portion of the statute which seems reasonable and free from doubt if also literally interpreted. Rather it seems to us our duty is to restrain the wider, and as we think, doubtful prohibitions so as to make them accord with the narrow and more reasonable provisions and thus harmonize the statute.

"Nor is there force in the contention that because the going into effect of the clause was postponed for a period of nearly two years, therefore the far-reaching and radical effects which the government attributes to the clause must have been contemplated by Congress. We think, on the contrary, it is reasonable to infer, in view of the facts disclosed in the statement which we have previously excerpted, that the delay accorded is entirely consistent with the assumption that it was so granted to afford the time essential to make the changes which would be required to conform to the commands of the clause as we have interpreted it, such as providing the facilities for dissociation by sale at the point of production before transportation or segregation by means of the organization of bona fide manufacturing, mining or producing corporations.

"It remains to determine the nature and character of the interest embraced in the words 'in which it is interested directly or indirectly.' The contention of the government that the clause forbids a railroad company to transport any commodity manufactured, mined or produced, or owned in whole or in part, etc., by a bona fide corporation in which the transporting carrier holds a stock interest, however small, is based upon the assumption that such prohibition is embraced in the words we are considering. The opposing contention, however, is that interest, direct or indirect, includes only commodities in which a carrier has a legal interest, and therefore does not exclude the right to carry commodities which have been manufactured, mined, produced or owned by a separate and distinct corporation, simply because the transporting carrier may be interested in the producing, etc., corporation as an owner of stock therein. If the words in question are to be taken as embracing only a legal or equitable interest in the commodities to which they refer they cannot be held to include commodities manufactured, mined, produced or owned, etc., by a distinct corporation merely because of a stock ownership of the carrier. Pullman Palace Car Co. v. Missouri Pacific R. R., I15 U. S. 587, 29 L. 
the due process clause of the fifth amendment and that there was no constitutional limitation requiring such a regulation as contemplated by the Act to be applied to all commodities alike, and that therefore the exception of timber and its manufactured products was valid and that the clause did not involve a discrimination between carriers.

Ed. 499, 6 Sup. Ct. 194; Conley v. Mathieson Alkali Works, igo U. S. 406, 47 L. Ed. 1113, 23 Sup. Ct. 728. And that this is well settled in the law of Pennsylvania is not questioned. It is unnecessary to pursue the subject in more detail, since it is conceded in the argument for the government that if the clause cmbraces only a legal interest in an article or commodity it cannot be held to include a prohibition against carrying a commodity simply because it had been manufactured, mined or produced, or is owned by a corporation in which the carrier is a stockholder. The contention of the government substantially rests upon the assumption that unless the words be given the meaning contended for they are without significance. That this is clearly not the case is well illustrated by the New Haven case (200 U. S. 36I).*** If it be that the mind of Congress was fixed on the transportation by a carrier of any commodity produced by a corporation in which the carrier held stock, then we think the failure to provide for such a contingency in express language gives rise to the implication that it was not the purpose to include it. At all events, in view of the far-reaching consequences of giving the statute such a construction as that contended for. as indicated by the statement taken from the answers and returns which we have previously inserted in the margin, and of the questions of constitutional power which would arise if that construction was adopted, we hold the contention of the government not well founded.

"We then construe the statute as prohibiting a railroad company engaged in interstate commerce from transporting in such commerce articles or commodities under the following circumstances and conditions: a. When the article or commodity has been manufactured, mined or produced by a carrier or under its authority. and at the time of transportation the carrier has not in good faith before the act of transportation dissociated itself from such article or commodity; b. When the carrier owns the article or commodity to be transported in whole or in part; c. When the carrier at the time of transportation has an interest, direct or indirect, in a legal or equitable sense in the article or commodity, not including, therefore, articles or commodities manufactured, mined, produced or owned, etc., by a bona fide corporation in which the railroad company is a stockholder.

"The question then arises whether, as thus construed, the statute was inherently within the power of Congress to enact as a regulation of commerce. That it was we think is apparent, and if reference to authority to so demonstrate is necessary it is afforded by a consideration of the ruling in the New Haven case, to which we have previously referred.

"We think it unnecessary to consider at length the contentions based 
Of particular interest was the ruling of the court upon the proper construction and effect of the phrase "interest, direct or indirect," possessed by a carrier in the article of transportation. The court declared that the bona fide ownership by a railroad of stock in a corporation manufacturing, mining, etc., the inhibited articles did not of itself constitute an "interest, direct or indirect, in a legal or equitable sense" in the commodity manufactured, mined, produced or owned, etc. ${ }^{105}$ In a subsequent decision, which was in fact a sequel to the Delaware and Hudson case, the Supreme Court discussed more at length the question of stock ownership by a carrier in a mining or producing company and declared that while the stock ownership by a carrier used for the

upon the due process clause of the fifth amendment. In form of statement these contentions apparently rest upon the ruinous consequences which it is assumed would be operated upon the property rights of the carriers by the enforcement of the clause interpreted as the government construed it. For the purpose of our consideration of the subject it may be conceded, as insisted on behalf of the United States, that these contentions proceed upon the mistaken and baleful conception that inconvenience, not power, is the criterion by which to test the constitutionality of legislation. When, however, mere forms of statement are put aside and the real scope of the argument at bar is grasped, we think it becomes clear that in substance and effect the argument really asserts that the clause as construed by the government is not a regulation of commerce, since it transcends the limits of regulation and embraces absolute prohibitions, which, it is insisted, could not be exerted in virtue of the authority to regulate. The whole support upon which the propositions and the arguments rest hence disappear as a result of the construction which we have given the statute. Through abundance of caution we repeat that our ruling here made is confined to the question before us. ***

"Without elaborating, we hold the contention that the clause under consideration is void because of the exception as to timber, and the manufactured products thereof, is without merit. Deciding, as we do, that the clause, as construed, was a lawful exercise by Congress of the power to regulate commerce, we know of no constitutional limitation requiring that such a regulation when adopted should be applied to all commodities alike. It follows that even if we gave heed to the many reasons of expedience which have been suggested in argument against the exception and the injustice and favoritism which it is asserted will be operated thereby, that fact can have no weight in passing upon the question of power. And the same reasons also dispose of the contention that the clause is void as a discrimination between carriers."

See also United States v. Louisiana and Pacific Railway Co., (The Tap Line Cases), 234 U. S. 1, 58 L. Ed. 1185,34 Sup. Ct. 74 I.

105 See dissenting opinion by Justice Harlan. 
purpose of a bona fide separate administration of the affairs of such a producing corporation in which it has this interest might not be denied, yet the use of such control of stock for the purpose of destroying the entity of a producing corporation and of commingling its affairs in administration with the affairs of the railroad company, so as to make the two corporations virtually one, was a distinct violation of the Commodities Clause. ${ }^{108}$

The inhibition of the Commodities Clause applies as well to merchandise transported from a market to a mine as from a mine to a market. A railroad was thus held to violate the Com-

106 United States v. Lehigh Valley Railroad Co., 220 U. S. 257, 55 L. Ed. 458, 31 Sup. Ct. 387. The court here said:-"While that decision (in the Delaware and Hudson case) expressly held that stock ownership by a railroad company in a bona fide corporation, irrespective of the extent of such ownership, did not preclude a railroad company from transporting the commodities manufactured, mined, produced or owned by such corporation, nothing in that conclusion foreclosed the right of the government to question the power of a railroad company to transport in interstate commerce a commodity manufactured, mined, owned or purchased by a corporation in which the railroad held stock and where the power of the railroad company as a stockholder was used to obliterate all distinctions between the two corporations. That is to say, where the power was exerted in such a manner as to so commingle the affairs of both as by necessary effect to make such affairs practically indistinguishable and therefore to cause both corporations to be one for all purposes. $* * *$

"Our duty is to enforce the statute, and not to exclude from its prohibitions things which are properly embraced within them. Coming to discharge this duty it follows, in view of the express prohibitions of the commodities clause, it must be held that while the right of a railroad company as a stockholder to use its stock ownership for the purpose of a bona fide separate administration of the affairs of a corporation in which it has a stock interest may not be denied, the use of such stock ownership in substance for the purpose of destroying the entity of a producing, etc., corporation and of commingling its affairs in administration with the affairs of the railroad company, so as to make the two corporations virtually one, brings the railroad company so voluntarily acting as to such producing, etc., corporation within the prohibitions of the commodities clause. In other words, that by operation and effect of the commodities clause there is a duty cast upon a railroad company proposing to carry in interstate commerce the product of a producing, etc., corporation in which it has a stock interest not to abuse such power so as virtually to do by indirection that which the commodities clause prohibits, a duty which plainly would be violated by the unnecessary commingling of the affairs of the producing company with its own, so as to cause them to be one and inseparable." 
modities Clause where it hauled hay purchased for the use of its horses and mules at its mines where three-fourths of the coal mined was sold for public consumption and the remaining onefourth produced was used as fuel for running its locomotives. There is, however, no violation of the Commodities Clause if the hay is bought from a dealer at its mines, the hay having first been transported by the railroad company, the title of the hay at the time of the transportation not being in the railroad company. ${ }^{107}$

107 Delaware, Lackawana and Western Railroad Co. v. United States, 23 I U. S. 363,58 L. E. 269,34 Sup. Ct. 65 . The railroad company was indicted for hauling over its lines between Buffalo, N. Y., and Scranton, Pa., twenty carloads of hay, belonging to the company, but not necessary for its use as a common carrier, but purchased for the use of animals cmployed in and about the mines at Scranton-all the coal taken therefrom being sold for use by the public, except the steam coal which was used as fuel for the company's locomotives. The railroad company contended that the commodity clause violated the fifth amendment, deprived the company of a right to contract, and prevented it from carrying its own property needed in a legitimate intrastate business conducted under a state charter granted before the adoption of the Hepburn Bill. The Supreme Court said:-"This contention must be overruled on the authority of United States ex rel. Attorney General v. Delaware and Hudson Co., 213 U. S. 366,53 L. Ed. 836,29 Sup. Ct. 527 . It is true that the decision in that case related to shipinents of coal from mine to market, while here the merchandise was transported from market to mine. But the statute relates to 'all commodities, except lumber, owned by the company,' and includes inbound as well as outbound shipments. Both classes of transportation are within the purview of the evil to be corrected, and therefore subject to the power of Congress to regulate interstate commerce. The exercise of that power is, of course, limited by the provisions of the fifth amendment, $* * *$ But the commodity clause does not take property, nor docs it arbitrarily deprive the company of a right of property. The statute deals with railroad companies as public carriers, and the fact that they may also be engaged in a private business does not compel Congress to legislate concerning them as carriers so as not to interfere with them as miners or merchants. If such carrier hauls for the public and also for its own private purposes, there is an opportunity to discriminate in favor of itself against other shippers in the rate charged, the facility furnished, or the quality of the service rendered. The commodities clause was not an unreasonable and arbitrary prohibition against a railroad company transporting its own useful property, but a constitutional exercise of a governmental power intended to cure or prevent the evils that might result if, in hauling goods in or out, the company occupied the dual and inconsistent position of public carrier and private shipper.

"It was suggested that the case is not within the statute because, as the 
It was the intention of Congress in enacting the Commodity Clause to exempt from the provisions thereof timber and its manufactured products and to permit railroads to haul such lumber and products although the carrying road owned them itself. The Supreme Court has held that Congress had the constitutional power to enact such exemption which was based upon the belief that railroads built and owned by the same persons who cut and owned the timber were regarded as essential to the development of the timber regions in the Sonthwest. And the court has held that such roads, also serving the general public along their lines, which constitute tap lines, may share in through rates from the point of shipment to the point of delivery-though such roads cannot, under the cloak of a division of joint rates, receive more than a just compensation for the service rendered and thus under such guise become the means of procuring rebates or discriminations in favor of the owners of the tap lines. ${ }^{108}$

company could buy, in Scranton, hay that had already been transported over its line, no possible harm would come to anyone if it bought the same liay at Buffalo, and then hauled it to Scranton for use at the mine, but not for sale in competition with other dealers in stock food. But the courts are not concerncd with the question as to whether, in a particular case, there has been any discrimination against shippers or harm to other dealers. The statute is general, and applies not only to those particular intances in which the carrier did use its power to the prejudice of the shipper, but to all shipments which, however innocent in themselves, come within the scope and probability of the evil to be prevented.

"In this case the hay was purchased for use in operating mines where 75 per cent. of the coal produced was 'assorted sizes' intended to be sold for domestic purposes. The remaining 25 per cent. was steam coal-all of which was used as fuel on the company's locomotives. This steam coal was in the nature of a by-product from a mine operated primarily for the purpose of obtaining coal for sale. Hay purchased for use in such mining cannot be said to have been necessary for the use of the company in the conduct of its business as a common carrier. *** As the hay belonged to the defendant and was intended for use in its private business of mining, the tranportation over its lines, in interstate commerce, was a violation of the commodity clause."

I08 United States v. Louisiana and Pacific Railway Company, (Tap Line Cases), 234 U. S. I, 58 L. Ed. I 85,34 Sup. Ct. 74I. Various lumber companies in the southwest built short lines of railroads from their logging camps to the nearby trunk lines and over these so-called tap lines and trunk lines shipped out their lumber products and received a portion of the joint rates charged for the haul to the point of delivery. These tap lines carried as well a small traffic composed of the property of others. These 
Switches.-Any common carrier subject to the provisions of this Act, upon application of any lateral, branch line of railroad, or any shipper tendering interstate traffic for transportation, shall con-

Switch con- struct, maintain, and operate upon reasonable terms
octions. a switch connection with any such lateral, branch line of railroad, or private side track which may be constructed to connect with its railroad, where such connection is reasonably practicable and can be put in with safety and will furnish sufficient business to justify the construction and maintenance of the same; and shall furnish cars for the movement of such traffic to the best of its ability without discrimination in favor of or against any such shipper. If any common carrier shall fail to install and operate any

logging roads were mill propositions at the outset but with the development of the communities along their tracks they engaged in other business to a certain, though limited extent, and they were treated as common carriers by connecting systems of other carriers. Their own engines and crews were engaged in hauling their cars over the tap lines to the trunk lines when they were taken up by these lines. The court said:--"While Congress in enacting the commodities clause amendment section I of the Act to Regulate Commerce (34 Stat. 584) sought to divorce transportation from production and manufacture and to make transportation a business of and by itself unallied with manufacture and production in which a carrier was itself interested, the debates, which may be resorted to for the purpose of ascertaining the situation which prompted this legislation, show that the situation in some of the states as to the logging industry and transportation was sharply brought to the attention of Congress and led to the exemption from the commodities clause of timber and the manufactured products thereof, thus indicating the intention to permit a railroad to haul such lumber and products although it owned them itself. And that Congress had the constitutional power to enact such exemption was held in United States v. Delaware and Hudson Company, 213 U. S. 366, 416-7, 53 L. Ed. 836,29 Sup. Ct. 527. This declaration of public policy which is now part of the Commerce Act cannot be ignored in interpreting the power and authority of the Commission under the Act. The discussion resulting in the action of Congress shows that railroads built and owned by the same persons who own the timber were regarded as essential to the development of the timber regions in the southwest and the necessity of such roads was dwelt upon and set forth with ample illustration by Commissioner Prouty in his concurring opinion in this case." See also United States v. Butler County Railroad Company, 234 U. S. 29, 58 L. Ed. I196, 34 Sup. Ct. 748. 
such switch or connection as aforesaid, on application therefor in writing by any shipper or owner of such lateral, branch line of railroad, such shipper or owner of such lateral, branch line of railroad may make complaint to the Commission, as provided in section thirteen of this Act, and the Commission shall hear and investigate the same and shall determine as to the safety and practicability thereof and justification and reasonable compensation therefor, and the Commission may make an order, as provided in section fifteen of this Act, directing the common carrier to comply with the provisions Switch con nections may be ordered by the Commission. of this section in accordance with such order, and such order shall be enforced as hereinafter provided for the enforcement of all other orders by the Commission, other than orders for the payment of money.

The original Act to regulate commerce of February 4, I887, contained no provision regulative of switch connections and the subject was first embraced in the so-called Hepburn Act of June 29, 1906, when the above provision was incorporated in the Interstate Commerce Act.

Before the enactment of the Hepburn Act and the inclusion of this provision in the Act to regulate commerce the Supreme Court had upheld the right of the states, acting through administrative bodies to require railroads to make reasonable track connections. ${ }^{109}$ The state laws, however, were strictly construed and

I09 Washington ex rel. Oregon Railroad and Navigation Co. v. Fairchild, 224 U. S. 510 at 528,56 L. Ed. 863,32 Sup. Ct. 535. Here the court said:"Since the decision in Wisconsin, Minnesota and Pacific Railroad v. Jacobson, 179 U. S. 287, 45 L. Ed. I194, 21 Sup. Ct. 124, there can be no doubt of the power of a state, acting through an administrative body, to require railroad companies to make track connections. But manifestly that does not mean that a Commission may compel them to build branch lines, so as to connect roads lying at a distance from each other; nor does it mean that they may be required to make connections at every point where their tracks come close together in city, town and country, regardless of the amount of business to be done, or the number of persons who may utilize the connection if built. The question in each case must be determined in the light of all the facts, and with a just regard to the advantage to be derived by the public and the expense to be incurred by the carrier. For while the question of expense must always be con- 
railroads under such legislation have only been compelled to make connections with other roads lying at a distance or to build connecting tracks with strict regard to the situation of the various railroads and the interests and communities to be served. Where the advantage to the public is great and the cost to the roads is not prohibitive or does not amount to the confiscation of property the track connection will be upheld though one or both of the roads may thereby be deprived of the revenue which it would otherwise have received for the longer haul. The Supreme Court has held that the states do not possess the power to direct

sidered (Chicago \&c. R. R. v. Tompkins, I76 U. S. 167, 174, 44 L. Ed. 417 , 20 Sup. Ct. 336), the weight to be given that fact depends somewhat on the character of the facilities sought. If the order involves the use of property needed in the discharge of those duties which the carrier is bound to perform, then, upon proof of the necessity, the order will be granted, even though 'the furnishing of such necessary facilities may occasion an incidental pecuniary loss.' But even then the matter of expense is 'an important criterion to be taken into view in determining the reasonableness of the order.' Atlantic Coast Line R. R. v. North Carolina Commission, 206 U. S. 1, 51 L. Ed. 933, 27 Sup. Ct. 585; Missouri Pacific Rwy. v. Kansas, 216 U. S. 262, 54 L. Ed 472, 30 Sup Ct. 330. Where, however, the proceeding is brought to compel a carrier to furnish a facility not included within its absolute duties, the question of expense is of more controlling importance. In determining the reasonableness of such an order the court must consider all the facts,- - the places and persons interested, the volume of business to be affected, the saving in time and expense to the shipper, as against the cost and loss to the carrier. On a consideration of such and similar facts the question of public necessity and the reaonableness of the order must be determined. This was done in Wisconsin R. R. v. Jacobson, in which for the first time, it was decided that a state Commission might compel two competing interstate roads to connect their tracks."

In Wisconsin, Minnesota and Pacific Railroad v. Jacobson, 179 U. S. 287, at p. 30I, 45 L. Ed. 1 194, 21 Sup. Ct. I24, the court said:-“In so deciding we do not at all mean to hold that under no circumstances could a judgment enforcing track connections between two railroad corporations be a violation of the constitutional rights of one or the other, or possibly of both such corporations. It would depend upon the facts surrounding the cases in regard to which the judgment was given. The reasonableness of the judgment with reference to the facts concerning each case must be a material, if not a controlling, factor upon the question of its validity. A statute, or a regulation provided for therein, is frequently valid, or the reverse, according as the fact may be, whether it is a reasonable or an unreasonable exercise of legislative power over the subject matter involved. And in many cases questions of degree are the controlling ones by which to determine the validity, or the reverse, of legislative action." 
carriers engaged in interstate commerce to deliver all cars containing such commerce beyond their right of way and to a private siding, on the ground that such an order imposes a burden upon interstate commerce so direct and so onerous as to leave no question that it is an unconstitutional regulation. ${ }^{110}$ Such an order

I Io McNeill v. Southern Railway Company, 202 U. S. 543, 50 L. Ed. I142, 26 Sup. Ct. 722. This case was decided May 28, 1906, before the adoption of this amendment to the Act to Regulate Commerce. The North Carolina Corporation Commission ordered the railroad company to deliver certain of its cars, containing shipments destined to the consignee, beyond its right of way and on the siding extending across the land of private persons to the establishment of the consignee, upon payment of the freight charges. The court said:- "Not being called upon to do so, we do not pass upon all the general regulations formulated by the Commission on the subject stated, but are clearly of opinion that the court below rightly held that the particular application of those regulations with which we are here concerned was a direct burden upon interstate commerce and void. Viewing the order which is under consideration in this case as an assertion by the Corporation Commission of its general power to direct carriers engaged in interstate commerce to deliver all cars containing such commerce beyond their right of way and to a private siding, the order manifestly imposed a burden so direct and so onerous as to leave no room for question that it was a regulation of interstate commerce. *** The direct burden and resulting regulation of interstate commerce operated by an alleged assertion of state authority similar in character to the one here involved was passed upon by the Circuit Court of Appeals for the Sixth Circuit in Central Stock Yards Co. v. Louisville and Nashville R. R. Co. (II8 Fed. Rep. II3). The court in that case was called upon to determine whether certain laws of Kentucky imposed a direct burden upon interstate commerce and were a regulation of such commerce, upon the assumption that those laws compelled a common carrier engaged in interstate commerce trasportation to deliver cars of live stock moving in the channels of interstate commerce at a particular place beyond its own line different from the general place of delivery established by the railway company. In pointing out that if the legislation in question was entitled to the construction claimed for it, it would amount to a state regulation of interstate commerce, it was aptly and tersely said (p. I20): 'It is thoroughly well settled that a state may not regulate interstate commerce, using the terms in the sense of intercourse and the interchange of traffic between the states. In the case at bar we think the relief sought pertains to the transportation and delivery of interstate freight. It is not the means of making a physical connection with other railroads that is aimed at, but it is sought to compel the cars and freight received from one state to be delivered to another at a particular place and in a particular way. If the Kentucky constitution could be given any such construction, it would follow it could regulate interstate commerce. 
comprehending only intrastate commerce would doubtless be sustained.

By its very nature this paragraph demands and has received a strict construction both by the Interstate Commerce Commission and by the Supreme Court. In its terms it is limited to a "lateral, branch line." 'This designation refers to what the applicant road is at the time of making the application for the connection and not to what it may become after such a connection has been secured. This is not a roving power conferred upon the Interstate Commerce Commission enabling it to order a switch connection wherever it may arbitrarily determine. It is limited to a somewhat narrow class of lines which are by their nature dependent upon and incident to the main line with which the connection is desired. They may be embraced in the generic term "feeders"roads such as may be built from mines, or forests or manufacturing plants to bring coal and ore, or lumber, or manufactured products to the main line for through shipment. It does not suffice that as a result of such a switch connection some shippers might be accommodated if the road which applies is not at the time of such application a branch of the trunk line carrier with which the union is desired. A road built independent of the trunk line, operated without regard to it, and parallel to it and thus in a measure in competition with it, manifestly would not constitute a "lateral, branch line." It is safe to define a "lateral, branch

This it cannot do.' * * * And because we confine our decision to the issue which necessarily arises we do not intimate any opinion upon the question pressed at bar as to whether an order which was solely applicable to purely state business, directing a carrier to deliver property upon a private track beyond the line of the railway company, would be repugnant to the due process clause of the Constitution."

II United States v. Baltimore and Ohio Southwestern Railroad Co., et al., 226 U. S. 14, 57 L. Ed. 104, 33 Sup. Ct. 5. The Baltimore and Ohio Southwestern Railroad and the Norfolk and Western Railway are trunk lines of steam railroads running east and west across the state of Ohio. After almost touching each other at Norwood, a short distance from Cincinnati, these two railroads draw apart, one in a notherly and the other in a southerly direction, but come together again at Hillsboro some fifty-three miles further east. The Cincinnati and Columbus traction line, an interurban electric railway with a state charter runs between Norwood and Hillsboro through the middle of a diamond enclosed by the steam roads. For a number of miles the interurban line is very close and almost parallel to the tracks of one or the other of the steam roads and for a considerable part of the distance the towns on the electric line 
line of railroad" as a railroad by nature tributary to the trunk line and dependent upon it for an outlet to the markets of the country. Subject to the facts of the specific case a feeder might be a lateral branch road of one trunk line at one end and of another trunk line at the other end. And again subject to the peculiar circumstances of each case, a road having a connection with the trunk lines of two roads and enjoying joint routes and through rates with them would not, as a general proposition be considered a lateral, branch line of railroad of still a third road. It was certainly not the intention of Congress to grant carte

are but from five to ten miles from the nearest station on one of the steam roads. The traction company applied to the Interstate Commerce Commission for switch connections with these roads. The question turned upon the point whether the traction line was a "lateral, branch line of railroad," within the terms of the section under discussion. The Supreme Court said, with reference thereto:- "The words 'lateral branch line' do not refer to what the applicant may become or be made by order of the Commission but to what it already is when it applies. The power of the Commission does not extend to ordering a connection wherever it sees fit, but is limited to a certain and somewhat narrow class of lines. The most obvious examples of such lines are those that are dependent upon and incident to the main line-feeders, such as may be built from mines or forests to bring coal, ore or lumber to the main line for shipment. We agree with the Commerce Court that the traction company is not within this class. It is an independent venture, in its general course parallel to, more or less competing with, the steam roads and working on a different plan. Presumably and so far as appears it was built and would have been run without regard to the existence of the steam roads. The cases cited on behalf of the appellants as to the power of railroad companies to construct branch roads under their charter do not apply. There the determination of the company fixes the character of the branch; it builds the branch from the beginning as incident to the purposes of the company. But here, as we have said, this determination of the Commission that the applicants shall be a branch is not enough; the applicant must be a branch before it applies. This is the absolute and reasonable condition. That some shippers would be accommodated by a switch connection is not enough."

In Interstate Commerce Commission v. Delaware, Lackawana and Western Railroad Co., 216 U. S. 531, 54 L. Ed. 605, 30 Sup. Ct. 415, the court said:- "There certainly is force in the contention that the words of the statute mean a railroad naturally tributary to the line of the common carrier ordered to make the connection, and dependent upon it for an outlet to the markets of the country, which, according to the bill, the Rahway road is not. There is force in the argument that a road already having connection with the roads of two carriers subject to the Act and having joint routes and through rates with them cannot be regarded as a 
blanche to every road that might so wish to make a descent upon a trunk line. It was primarily the intention to provide for the needs of shippers seeking an outlet for their goods either by a private road or by the branch of a trunk line.

This section as originally adopted by Congress by the Act of June 29, I906, was declared by the Supreme Court in the case of Interstate Commerce Commission v. Delaware, Lackawanna and Western Railroad (decided March 7, I9ro), to give only to shippers the right to demand switching connections with lateral, branch railroads. ${ }^{112}$ The right belonged exclusively to shippers

lateral, branch line of railroad of another road situated like the appellee. On the other hand, it would be going far to lay down the universal proposition that a feeder might not be a lateral, branch road of one line at one end and of another at the other. We leave this doubtful question on one side because we agree with the circuit judges in the considerations upon which they decided the case. The statute creates a new right not existing outside of it. Wisconsin, Minnesota \& Pacific Railroad Co. v. Jacobson, 179 U. S. $287,296,45$ L. Ed. 1194, 21 Sup. Ct. 124. It is plain from the provisions of the Act, the history of the amendments and justice, that the object was not to give a roving commission to every road that might see fit to make a descent upon a main line, but primarily, at least, to provide for shippers seeking an outlet either by a private road or a branch.." The Rahway road, seeking the connection with the Delaware, Lackawanna and Western, is about ten miles long, having one terminus on the Lehigh Valley railroad and also a terminus on the Central Railroad of New Jersey. One of the branches of the Delaware, Lackawanna and Western road passes through Summit, New Jersey, where the Rahway Valley railroad sought to force it to make a switch connection. The Supreme Court decided the case upon the terms of this section of the Act to Regulate Commerce before it was amended, on the ground that the Act gave this right only on complaint of the shipper and not on the complaint of a branch railroad company.

II2 2 I6 U. S. 53I, 54 L. Ed. 605,30 Sup. Ct. 415. The court here said: - "The remedy given by the section creating the right is given only on complaint by the shipper. We are of opinion that the remedy is exclusive, on familiar principles, and that the general powers given by other sections cannot be taken to authorize a complaint to the Commission by a branch railroad company under section I. If they were applicable to a branch road they would have been equally applicable to shippers, and there was no more reason to mention complaints by shippers than by others. The argument that shippers were mentioned to insure their rights in case of a refusal to connect with a lateral line is excluded by the form of the statute, which obviously is providing the only remedy that Congress has in mind. It may or may not be true that the distinction is not very effective, but it stands in the law and must be accepted as the limit of the Commission's power." 
and could not be invoked by branch roads directly. By the Act of June I8, I9I0, the section was amended so as to permit the owners of such branch roads as well as shippers to make complaint to the Commission in case of the carrier's failure upon written application to make the connection, and it authorizes the Commission to hear, investigate and determine whether the requisite conditions exist and if so to make an order directing the carrier to comply with the provisions of the Act. ${ }^{113}$

II3 The amendment consisted in inserting after the word "shipper," in line I6 of the section the words-"or owner of such lateral, branch line of railroad": and also after the word "shipper" in line 17 of the section the same clause-"or owner of such lateral, branch line of railroad." See United States v. Baltmore and Ohio Southwestern Railroad Co., 226 U. S. 14, 57 L. Ed. I04, 33 Sup. Ct. 5, where the court said:-"That section requires carriers subject to the Act to establish switch connections with such lines on certain conditions; and, as amended, permits owners of such lines as well as shippers to make complaint to the Commission in case ot the carrier's failure upon written application, and authorizes the Commission to hear, investigate and determine whether the conditions exist, and to make an order directing the carrier to comply with the Act." 


\section{SECTION TWO. DISCRIMINATIONS FORBIDDEN.}

SEc. 2. That if any common carrier subject to the provisions of this Act shall, directly or indirectly, by any special rate, rebate, drawback, or other device, charge, demand, collect, or receive from any person or persons a greater or less compensation for any service rendered, or to be rendered, in the transportation of passengers or property, subject to the provisions of this Act, than it charges, demands, Unjust dis- collects, or receives from any other person or percrimination de- sons for doing for him or them a like and contembidden.

poraneous service in the transportation of a like kind of traffic under substantially similar circumstances and conditions, such common carrier shall be deemed guilty of unjust discrimination, which is hereby prohibited and declared to be unlawful.

History of the Section.-The second section has not been amended and stands in exactly the form in which it was incorporated in the Act to regulate commerce as signed February 4 , I887. The section was modelled upon section 90 of the English "Railway Clauses Consolidation Act" of 1845 , known as the "Equality Clause." In the words of the Supreme Court "the principal purpose of the second section is to prevent unjust discrimination between shippers." ${ }_{1}$ It is thus distinguished from

I Texas and Pacific Railway Co. v. Interstate Commerce Commission, (The Import Rate Case), I62 U. S. 197, 40 L. Ed. 940, I6 Sup. Ct. 666. The court here said:- "The principal purpose of the second section is to prevent unjust discrimination between shippers. It implies that, in deciding whether differences in charges, in given cases, were or were not unjust, there must be a consideration of the several questions whether the services rendered were 'like and contemporaneous,' whether the kinds of traffic were 'like,' whether the transportation was effected under 'substantially similar circumstances and conditions.' To answer such questions, in any case coming before the Commission, requires an investigation into the facts; and we think that Congress must have intended that whatever would be regarded by common carriers, apart from the operation of the statute, as matters which warranted differences in charges, ought to be 
the third section which deals with discriminations against and preferences in favor of localities, or with discriminations between kinds of traffic. Under section 2 , in deciding whether differences in charges are or are not unjust consideration must be given to (I) whether the services rendered were "like and contemporaneous," (2) whether the kinds of traffic were "like," and (3) whether the transportation was effected under "substantially similar circumstances and conditions." These questions must be properly considered by the Commission in reaching a conclusion on questions involving the violation of this section of the Act. Certain charges might be unjust to shippers, and other charges might be unjust to the carriers-and the rights and interests of both must be regarded by the Commission.

Before the enactment of the Act to regulate commerce railway traffic in the United States was regulated by the principles of the common law applicable to common carriers which required barely more than that they should carry for all persons who desired to use their services, that they should transport shipments in the order in which the goods were delivered to the carrier, and that the charges for the service should be reasonable. ${ }^{2}$ There was

considered in forming a judgment whether such differences were or were not 'unjust.' Some charges might be unjust to shippers-others might be unjust to the carriers. The rights and interests of both must, under the terms of the Act, be regarded by the Commission."

2. Interstate Commerce Commission v. Baltimore and Ohio Railroad. (The Party Rate Case), I45 U. S. 263, 36 L. Ed. 699, I2 Sup. Ct. 844, where the court said:-"Prior to the enactment of the Act of February 4, I887, to regulate commerce, commonly known as the Interstate Commerce Act, railway traffic in this country was regulated by the principles of the common law applicable to common carriers, which demanded little more than that they should carry for all persons who applied, in the order in which the goods were delivered at the particular station, and that their charges for transportation should be reasonable. It was even doubted whether they were bound to make the same charge to all persons for the same service; though the weight of authority in this country was in favor of an equality of charge to all persons for similar services. In several of the states Acts had been passed with the design of securing the public against unreasonable and unjust discriminations; but the inefficacy of these laws beyond the lines of the state, the impossibility of securing concerted action between the legislatures toward the regulation of traffic between the several states, and the evils which grew up under a policy of unrestricted competition, suggested the necessity of legislation by Congress under its constitutional power to regulate commerce among the several states. These evils ordinarily took the shape of inequality of 
some question whether they were compelled to charge the same amounts to all persons for the same service-although the weight of authority tended to establish the principle of an equality of charge to all persons for similar services.

The purpose of the second section of the Interstate Commerce Act was to insure such equality of charges by the force of statutory enactment. In the words of the Supreme Court, "It was designed to compel every carrier to give equal rights to all shippers over its own road and to forbid it by any device to enforce higher charges against one than another.",

The Elkins Act.-Although section 2 is aimed at the destruction of rebates and unequal charges between different shippers and is considered one of the most important features of the Act to Regulate Commerce, it has been very materially reenforced in the enactment of the so-called Elkins Act of February I9, I903, which sought to eliminate the practice of rebating. Both the Act to regulate commerce and the Elkins Act were designed to kill favoritism. Under section two of the former Act the standard of comparison was the treatment accorded other shippers by which it was necessary to show not merely that the favored shipper paid less than the published rate for

charges made, or of facilities furnished, and were usually dictated by or tolerated for the promotion of the interests of the officers of the corporation or of the corporation itself, or for the benefit of some favored persons at the expense of others, or of some particular locality, or community, or of some local trade or commercial connection, or for the destruction or crippling of some rival or hostile line."

3 Wight v. United States, I67 U. S. 512, 42 L. Ed. 258, 17 Sup. Ct. 822, where the court also said:- "It was the purpose of the section to enforce equality between shippers, and it prohibits any rebate or other device by which two shippers, shipping over the same line, the same distance, under the same circumstances of carriage are compelled to pay different prices therefor."

See also Union Pacific Railway Co. v. Goodridge, I49 U. S. 680, where in discussing a Colorado statute regulating intrastate railroads, the court said:- "This Act was intended to apply to intrastate traffic the same wholesome rules and regulations which Congress two years thereafter applied to commerce between the states, and to cut up by the roots the entire system of rebates and discriminations in favor of particular localities, special enterprises, or favored corporations, and to put all shippers on an absolute equality, saving only a power, not in the railroad company itself, but in the railroad commissioner, to except 'special cases designed to promote the development of the resources of this state,' etc." 
the services rendered, but that other shippers paid a greater rate than that exacted of the favored shipper. But under the Elkins Act the criterion is the published rate and to sustain the charge of violating the Act it is necessary to show only that the favored shipper has paid a lower rate than that filed and published. ${ }^{4}$ For a more extended discussion, see The Elkins Act, post pages 505 et seq.

Through and Local Traffic.-Under section 2 shippers must be treated alike by carriers for the same service that is for transportation under "similar circumstances and conditions." Under section 4 competition may create dissimilar circumstances and conditions between communities. While rates may be thus determined under section 4 for dissimilar circumstances or conditions, section 2 requires that shippers in the same locality must receive the same treatment for the same service. However, through traffic is not of a like kind with local traffic. The service of a railway company in transporting local traffic from one point on its line to another is not identical with the service rendered in transporting through traffic over the same rails. ${ }^{5}$ While the actual mileage is

+ Chicago and Alton Railway Co. v. United States, 156 Fed. 558, affirmed without opinion in 212 U. S. 563,53 L. Ed. 653, 29 Sup. Ct. 689, where it was shown that railroads had repaid to shippers a certain proportion of the carload charges under the pretense of rental of tracks which constituted part of the plant facilities of the shipper. The court said:"This case is ruled in principle, we believe, by the decision in Wight $\mathrm{r}$. United States, 167 U. S. 512, 42 L. Ed. 258, 17 Sup. Ct. 822, that an arrangement whereby a particular shipper was allowed to offset against his freight bills the true value of the use of his teams in hauling the property from the railroad to his warehouse was a discrimination against other shippers of the same class of property in the same city who were compelled to pay the freight in full. It is contended that the citation is inapplicable because the question there was of discrimination and here of rebate. Under the Cullom Act (Act of February 4, I887), the standard of comparison was the treatment of other shippers. It was necessary to prove not only that the favored shipper really paid less than the published rate, but also that other shippers paid the full rate or a greater rate than that of the favored shipper. Under the Elkins Act the standard of comparison is the published rate. It is only necessary to prove that the favored shipper has had his property transported at a lower rate than that published and filed. Both Acts were aimed to kill favoritism, and the favoritism in the Wight case was of the same kind and effect as in this."

5 See Chicago, Milwaukee \& St. Paul Railway Co. v. Tompkins, 176 U. S. 167,44 L. Ed. 417,20 Sup. Ct. 336 , where the court said:- "It is obvious on a little reflection that the cost of moving local freight is greater 
the same for both through and local traffic, the time consumed by the one is greater than that taken by the other. More fuel is consumed in stopping at various local stations, there is the greater wear and tear on the rolling stock in the increased stops and the shifting of cars incidental thereto, and also the wages of employees at the intermediate stations. The mileage cost for the local traffic is greater than for the through traffic and the car-

than that of moving through freight, and equally obvious that it is almost if not quite impossible to determine the difference with mathematical accuracy. Take a single line of 100 miles, with ten stations. One train starts from one terminus with through freight and goes to the other without stop. A second train starts with freight for each intermediate station. The mileage is the same. The amount of freight hauled per mile may be the same, but the time taken by the one is greater than that taken by the other. Additional fuel is consumed at each station where there is a stop. The wear and tear of the locomotive and cars from the increased stops and in shifting cars from main to side tracks is greater; there are the wages of the employees at the intermediate stations, the cost of insurance, and these elements are so varying and uncertain that it would seem quite out of reach to make any accurate comparison of the relative cost. And if this is true when there are two separate trains, it is more so when the same train carries both local and through freight."

In Texas and Pacific Railway Co. v. Interstate Commerce Commission, (The Import Rate Case), i62 U. S. 197, 40 L. Ed. 940, I6 Sup. Ct. 666, the court said:- "Proceeding to the second section, we learn that its terms forbid any common carrier, subject to the provisions of the Act, from charging, demanding, collecting or receiving 'from any person or persons a greater or less compensation for any service rendered or to be rendered, in the transportation of passengers or property, subject to the provisions of the Act, than it charges, demands, collects or receives from any other person or persons for doing for him or them a like and contemporaneous service in the transportation of a like kind of traffic under substantially similar circumstances and conditions,' and declares that disregard of such prohibition shall be deemed 'unjust discrimination,' and unlawful. Here again it is observable that this section contemplates that there shall be a tribunal capable of determining whether, in given cases, the services rendered are 'like and contemporaneous,' whether the respective traffic is of a 'like kind,' and whether the transportation is under 'substantially similar circumstances and conditions.' $* * *$

"The Commission justified its action wholly upon the construction put by it on the Act to Regulate Commerce, as forbidding the Commission to consider the 'circumstances and conditions' attendant upon the foreign traffic as such 'circumstances and conditions' as they are directed in the Act to consider. The Commission thought it was constrained by the Act to regard foreign and domestic traffic as like kinds of traffic under substantially similar circumstances and conditions, and that the action of the 
riers are entitled to charge a larger amount for the local shipments than for the proportionate part of the through traffic. In short, through and local traffic are not of a like kind "under substantially similar circumstances and conditions" within the contemplation of section 2 .

Competition under Section 2.-The phrase "under substantially similar circumstances and conditions" is found also in section 4 where it has been construed in connection with the question of long and short haul rates and where the phrase has been given a much broader and more liberal meaning than under section 2 . Under section 4 competition may constitute a dissimilar circumstance and condition. But under section 2 mere competition between carriers will not legalize a rebate or device by which carriers may charge different rates to different shippers under the same circumstances of carriage. Thus for example, hauling goods on a railroad between two cities and delivering them to the consignee at his warehouse from a switch or siding connection. and hauling other shipments of the same goods for him between the same cities on another road and delivering them to him by trucks from the station of the latter road, there being no siding connection between that road and the warehouse of the consignee, constitutes transportation "under substantially similar circumstances and conditions"; and an allowance or rebate paid the consignee by the latter road to compensate him for trucking shipments to his warehouse constitutes a discrimination against other shippers over the road to whom no such rebate is allowed. ${ }^{6}$

defendant company in procuring through traffic that would, except for the through rates, not reach the port of New Orleans, and in taking its pro rata share of such rates, was an act of 'unjust discrimination,' within the meaning of the Act. In so construing the Act we think the Commission erred.

"The sixth section of the Act of Congress of July I, 1862, relative to the Union Pacific Railroad Company, provided that the government shall at all times have the preference in the use of the railroad 'at fair and reasonable rates of compensation, not to exceed the amount paid by private parties for the same kind of service.' In the case of 'nion Pacific Railway v. United States, I17 U. S. 355, 29 L. Ed. 920, 6 Sup. Ct. 772, it was, in effect held that the service rendered by a railway company in transporting local passengers from one point on its line to another is not identical with the service rendered in transporting through passengers over the same rails."

6 Wight v. United States, 167 U. S. 512, 42 L. Ed. 258, 17 Sup. Ct. 822. A wholesale dealer in beer in Pittsburgh purchased his beer in carload 
Party Rates. - While party rate tickets do not strictly come within the meaning of mileage, excursion or commutation tickets under the exception of section 22, yet that provision being illustrative rather than exclusive the Supreme Court has upheld the legality of party rate tickets-that is tickets sold at less than the established single rate which entitle a certain number of persons

lots from a brewery in Cincinnati. His place of business was on the P., C. and St. L. R. R. track and had a siding connection with that road. The rate from Cincinnati to his warehouse was 15 cents per hundred pounds. The station of the Baltimore \& Ohio Railroad at Pittsburgh was some distance from the warehouse of the shipper and had no siding connection with his warehouse. The rate by that road between the same cities for beer was also 15 cents per hundred pounds in carload lots. The agents of the B. \& O. R. R. made an arrangement with Bruening, the shipper, that if he would ship over that road they would haul his beer free from their station to his warehouse. This being done it was found later that the cost of the hauling by team was three and a half cents per hundred pounds. Bruening then offered to pay the I5 cents per hundred for his shipments between Cincinnati and Pittsburgh and do his own hauling for the cost to the road. This agreement was made and Bruening paid the regular freight rates and each month collected from the road a bill of three and a half cents for hauling. Another shipper, however, receiving shipments of beer from Cincinnati and having a warehouse at Pittsburgh near the B. \& $\mathrm{O}$. but having no siding connection, paid 15 cents per hundred freightage and did his own hauling without any rebate therefor. The court said:-

"Now, it is contended by the defendant that it was necessary for the B. \& O. Company to offer this inducement to $\mathrm{Mr}$. Bruening in order to get his business, and not necessary to make the like offer to Mr. Wolf because he would have to go to the expense of carting by whichever road he transported; that, therefore, the traffic was not under substantially similar circumstances and conditions' within the terms of section 2. We are unable to concur in this view. Whatever the B. \& O. Company might lawfully do to draw business from a competing line, whatever inducements it might offer to the customers of that competing line to induce them to change their carrier, is not a question involved in this case. The wrong prohibited by the section is a discrimination between shippers. It was designed to compel every carrier to give equal rights to all shippers over its own road and to forbid it by any device to enforce higher charges against one than another. Counsel insist that the purpose of the section was not to prohibit a carrier from rendering more service to one shipper than to another for the same charge, but only that for the same service the charge should be equal, and that the effect of this arrangement was simply the rendering to Mr. Bruening of a little greater service for the 15 cents than it did to Mr. Wolf. They say that the section contains no prohibition of extra service or extra privileges to one shipper over that rendered to another. They ask whether if one shipper has a siding con- 
to travel on a single ticket when making the trip together. ${ }^{\top}$ The object of such rates for party tickets is of course to induce more persons to travel and they bear a certain resemblance to wholesale as distinguished from retail rates. The sale of a ticket for a number of passengers at a less rate than for a single passenger does not operate to the prejudice of the single passenger who is

nection with the road of a carrier it cannot run the cars containing such shipper's freight onto that siding and thus to his warehouse at the same rate that it runs cars to its own depot, and there delivers goods to other shippers who are not so fortunate in the matter of sidings. But the service performed in transporting from Cincinnati to the depot at Pittsburgh was precisely alike for each. The one shipper paid is cents a hundred; the other in fact but eleven and one-half cents. It is true he formerly paid 15 cents, but he received a rebate of three and a half cents, and regard must always be had to the substance and not to the form. Indeed, the section itself forbids the carrier 'directly or indirectly by any special rate, rebate, drawback or other device' to charge, demand, collect or receive from any person or persons a greater or less compensation, etc. And section 6 of the Act, as anended in 1889 , throws light upon the intent of the statute, for it requires the common carrier in publishing schedules to 'state separately the terminal charges and any rules or regulations which in any wise change, affect or determine any part or the aggregate of such aforesaid rates and fares and charges.' It was the purpose of the section to enforce equality between shippers, and it prohibits any rebate or other device by which two shippers, shipping over the same line, the same distance, under the same circumstances of carriage are compelled to pay different prices therefor.

"It may be that the phrase "under substantially similar circumstances and conditions,' found in section 4 of the Act, and where the matter of the long and short haul is considered, may have a broader meaning or a wider reach than the same phrase found in section 2. It will be time enough to determine that question when it is presented. For this case it is enough to hold that that phrase, as found in section 2, refers to the matter of carriage, and does not include competition."

7 Interstate Commerce Commission v. Baltimore and Ohio Railroad (The Party Rate Case), I45 U. S. 263, 36 L. Ed. 699, I2 Sup. Ct. 844 . The Court said:- "The principal objects of the Interstate Commerce Act were to secure just and reasonable charges for transportation; to prohibit unjust discriminations in the rendition of like services under similar circumstances and conditions; to prevent undue or unreasonable preferences to persons, corporations or localities; to inhibit greater compensation for a shorter than for a longer distance over the same line; and to abolish combinations for the pooling of freights. It was not designed, however, to prevent competition between different roads, or to interfere with the customary arrangements made by railway companies for reduced fares in consideration of increased mileage, where such reduction did not operate as an unjust discrimination against other persons traveling over the road. 
not injured by the fact that another in a particular instance is able to travel at a less rate than he. To come within the inhibitions of the second section there must exist substantial identity of situation and of service for which differences in charges are made.

However, a different case arises if the traffic is in freight rather

In other words, it was not intended to ignore the principle that one can sell at wholesale cheaper than at retail. It is not all discriminations or preferences that fall within the inhibition of the statute; only such as are unjust or unreasonable. For instance, it would be obviously unjust to charge $A$ a greater sum than $B$ for a single trip from Washington to Pittsburgh; but if $A$ agrees not only to go but to return by the same route, it is no injustice to $B$ to permit him to do so for a reduced fare, since the services are not aiike, nor the circumstances and conditions substantially similar as required by section 2 to make an unjust discrimination. Indeed, the possibility of just discriminations and reasonable preferences is recognized by these sections, in declaring what shall be deemed unjust. We agree, however, with the plaintiff in its contention that a charge may be perfectly reasonable under section $\mathrm{I}$ and yet may create an unjust discrimination or an unreasonable preference under sections 2 and 3 . * * *

"The question involved in this case is, whether the principle above stated as applicable to two individuals applies to the purchase of a single ticket covering the transportation of ten or more persons from one place to another. These are technically known as party-rate tickets, and are issued principally to theatrical and operatic companies for the transportation of their troupes. Such ticket is clearly neither a 'mileage' nor an 'excursion' ticket within the exception of section 22; and upon the testimony in this case it may be doubtful whether it falls within the definition of 'commutation tickets,' as those words are commonly understood among railway officials. The words 'commutation tickets' seem to have no definite meaning. They are defined by Webster as 'a ticket, as for transportation, which is the evidence of a contract for service at a reduced rate.' If this definition be applicable here, then it is clear that it would include a partyrate ticket. In the language of the railway, however, they are principally, if not wholly, used to designate tickets for transportation during a limited time between neighboring towns or cities and suburban towns. The partyrate ticket upon the defendant's road is a single ticket issued to a party of ten or more, at a fixed rate of two cents per mile or a discount of onethird from the regular passenger fare. The reduction is not made by way of a secret rebate or drawback, but the rates are scheduled, posted and open to the public at large.

"But, assuming the weight of evidence in this case to be that the partyrate ticket is not a 'commutation ticket,' as that word was commonly understood at the time of the passage of the Act, but is a distinct class by itself, it does not necessarily follow that such tickets are unlawful. The unlawfulness defined by sections 2 and 3 consists either in an 'unjust discrimination' or an 'undue or unreasonable preference or advantage,' and the object of section 22 was to settle beyond all doubt that the discrimina- 
than in passengers. In the words of the Supreme Court in the Party Rate Case: "If, for example, a railway makes to the public generally a certain rate of freight, and to a particular individual residing in the same town a reduced rate for the same class of goods, this may operate as an undue preference, since it enables the favored party to sell his goods at a lower price than his

tion in favor of certain persons therein named should not be deemed unjust. It does not follow, however, that there may not be other classes of persons in whose favor a discrimination may be made without such discrimination being unjust. In other words, this section is rather illustrative than exclusive. *** It may even admit of serious doubt whether, if the mileage, excursion or commutation tickets had not been mentioned at all in this section, they would have fallen within the prohibition of sections 2 and 3 . In other words, whether the allowance of a reduced rate to persons agreeing to travel one thousand miles, or to go and return by the same road, is a 'like and contemporaneous service under substantially similar conditions and circumstances' as is rendered to a person who travels upon an ordinary single-trip ticket. If it be so, then under state laws forbidding unjust discriminations, every such ticket issued between points within the same state must be illegal. In view of the fact, however, that every railway company issues such tickets; that there is no reported case, state or federal, wherein their illegality has been questioned; that there is no such case in England; and that the practice is universally acquiesced in by the public, it would seem that the issuing of such tickets should not be held an unjust discrimination or an unreasonable preference to the persons traveling upon them.

"But whether these party-rate tickets are commutation tickets proper, as known to railway officials or not, they are obviously within the commuting principle. As stated in the opinion of Judge Sage in the court below:'The difference between commutation and party-rate tickets is, that commutation tickets are issued to induce people to travel more frequently, and party-rate tickets are issued to induce more people to travel. There is, however, no difference in principle between them, the object in both cases being to increase travel without unjust discrimination, and to secure patronage that would not otherwise be secured. * * * In short it was an established principle of the business, that whenever the amount of travel more than made up to the carrier for the reduction of the charge per capita, then such reduction was reasonable and just in the interests both of the carrier and of the public.

"These tickets then being within the commutation principle of allowing reduced rates in consideration of increased mileage, the real question is, whether this operates as an undue or unreasonable preference or advantage to this particular description of traffic, or an unjust discrimination against others. If, for example, a railway makes to the public generally a certain rate of freight, and to a particular individual residing in the same town a reduced rate for the same class of goods, this may operate as an undue preference, since it enables the favored party to sell his goods at a 
competitors, and may even enable him to obtain a complete monopoly of that business. Even if the same reduced rate be allowed to every one doing the same amount of business, such discrimination may, if carried too far, operate unjustly upon the smaller dealers engaged in the same business, and enable the larger ones to drive them out of the market." The analogy between parties and individuals as passengers does not apply to wholesale and retail shipments of freight.

lower price than his competitors, and may even enable him to obtain a complete monopoly of that business. Even if the same reduced rate be allowed to every one doing the same amount of business, such discrimination may, if carried too far, operate unjustly upon the smaller dealers engaged in the same business, and enable the larger ones to drive them out of the market.

"The same result, however, does not follow from the sale of a ticket for a number of passengers at a less rate than for a single passenger; it does not operate to the prejudice of the single passenger, who cannot be said to be injured by the fact that another is able in a particular instance to travel at a less rate than he. If it operates injuriously toward anyone it is the rival road, which has not adopted corresponding rates; but, as before observed, it was not the design of the Act to stifle competition, nor is there any legal injustice in one person procuring a particular service cheaper than another. If it be lawful to issue these tickets, then the Pittsburgh, Chicago \& St. Louis Railway Company has the same right to issue them that the defendant has, and may compete with it for the same traffic; but it is unsound to argue that it is unlawful to issue them because it has not seen fit to do so. Certainly its construction of the law is not binding upon this court. The evidence shows that the amount of business done by means of these party-rate tickets is very large; that theatrical and operatic companies base their calculation of profits to a certain extent upon the reduced rates allowed by railroads; and that the attendance at conventions, political and religious, social and scientific, is, in great measure, determined by the ability of the delegates to go and come at a reduced charge. If these tickets were withdrawn, the defendant road would lose a large amount of travel, and the single-trip passenger would gain absolutely nothing. If a case were presented where a railroad refused an application for a party-rate ticket upon the ground that it was not intended for the use of the general public, but solely for theatrical troupes, there would be much greater reason for holding that the latter were favored with an undue preference or advantage.

"In order to constitute an unjust discrimination under section 2, the carrier must charge or receive directly from one person a greater or less compensation than from another, or must accomplish the same thing indirectly by means of a special rate, rebate or other device; but in either case it must be for a 'like and contemporaneous service in the transportation of a like kind of traffic, under substantially similar circumstances and 
Special Services Entitled to Particular Rates.-There may be a lawful discrimination in rates when special services are rendered to different shippers provided the difference in charges is made in good faith and is measured by the service rendered. For example, a carrier may and should make a special charge for expediting a shipment between two points, beyond the charge made to shippers in general for the regular service. ${ }^{8}$ Such service must, however, be open to all shippers upon the payment of the charge fixed therefor. And there is no discrimination between shippers in violation of section 2 where a different charge is made for the shipment of the same product when made in different kinds of receptacles or packages. Thus where a shipper of oil in barrels is charged for the carriage of such receptacles but no such extra charge is made where the oil is shipped in

conditions.' To bring the present case within the words of this section, we must assume that the transportation of ten persons on a single ticket is substantially identical with the transportation of one, and, in view of the universally accepted fact that a man may buy, contract, or manufacture on a large scale cheaper proportionately than upon a small scale this is impossible.

"In this connection we quote with approval from the opinion of Judge Jackson in the court below:- To come within the inhibition of said sections, the differences must be made under like conditions; that is, there must be contemporaneous service in the transportation of like kinds of traffic under substantially the same circumstances and conditions. In respect to passenger traffic, the positions of the respective persons, or classes, between whom differences in charges are made, must be compared with each other, and there must be found to exist substantial identity of situation and of service, accompanied by irregularity and partiality resulting in undue advantage to one, or undue disadvantage to the other, in order to constitute unjust discrimination." "

8 Chicago and Alton Railroad Co. v. Kirby, 225 U. S. 155, 56 L. Ed. 1033, 32 Sup. Ct. 648, where the shipper contracted for expediting a certain shipment without paying to the carrier any more than the regular rate therefor. The court said:- "The shipper, it is also plain, was contracting for an advantage which was not extended to all others, both in the undertaking to carry so as to give him a particular expedited service, and a remedy for delay not due to negligence. An advantage accorded by special agreement which affects the value of the service to the shipper and its cost to the carrier should be published in the tariffs, and for a breach of such a contract, relief will be denied, because its allowance without such publication is a violation of the Act. It is also illegal because it is an undue advantage in that it is not one open to all others in the same situation." 
tank cars, there is no violation of the second section. ${ }^{9}$ Of course under such circumstances the charges must be reasonable in themselves. And there is no unjust discrimination where a higher charge is made for transporting live stock than for carrying dressed meats and packers' products between the same points. ${ }^{10}$

Rates Based upon Ownership of Goods Transported.While the carrier has the initial authority to fix rates it does not possess the right to discriminate as to those who shall be entitled to enjoy them. Ownership or non-ownership of goods does not constitute a dissimilar circumstance or condition within the meaning of the second section. In the words of the Supreme Court: "The contention that a carrier when goods are tendered to him for transportation can make the mere ownership of the goods the test of the duty to carry or, what is equivalent, may discriminate in fixing the charge for carriage, not upon any difference inhering in the goods or in the cost of the service rendered in transporting them, but upon the mere circumstance that the shipper is or is not the real owner of the goods is so in conflict with the obvious and elementary duty resting upon a carrier, and so destructive of the rights of shippers as to demonstrate the unsoundness of the proposition by its mere statement." 11 Carriers cannot

9 Penn Refining Co. v. Western New York and Pennsylvania Railroad Co., 208 U. S. 208, 52 L. Ed. 456, 28 Sup. Ct. 268.

Io Interstate Commerce Commission v. Chicago Great Western Railway Co., 209 U. S. 108, 52 L. Ed. 705, 28 Sup. Ct. 493, where the court said:- "It is insisted that "the making of the live-stock rate higher than the product rate is violative of the almost universal rule that the rates on raw material shall not be higher than on the manufactured product.' This may be conceded, but that the rule is not universal the proposition itself recognizes, and the findings of the court give satisfactory reasons for the exception here shown. See Findings 2, 3 and 9. The cost of carriage, the risk of injury, the larger amount which the companies are called upon to pay out in damages make sufficient explanation. They do away with the idea that in the relation established between the two kinds of charges any undue or unreasonable preference was intended or secured."

II Interstaie Commerce Commission v. Delaware, Lackawanna and Western Railroad Co., 220 U. S. 235, 55 L. Ed. 448, 31 Sup. Ct. 392. Here the railroad had refused to transport goods in carload lots at carload rates on the ground that the goods did not actually belong to a single shipper but were being shipped by a forwarding agency for the account of others. The court said:- "Before the Act to Regulate Commerce it was usual, first, to give reduced rates to persons who shipped quantities of merchandise; and, second, to charge a proportionately less rate for a carload than was asked for a shipment in less than a carload. After the Act lower 
therefore charge a forwarding agent a higher rate for transporting a carload lot of goods, merely because the title to the goods does not rest in him, than they would charge an individual owning the goods for a like shipment.

rates to wholesale shippers were abandoned, it having been declared that to continue them was contrary to the Act. Providence Coal Case, I I. C. C. Rep. I07. The giving, however, a lesser proportional rate for a carload than for a less than carload continued, the Commission having at an early date announced that such a practice was not prohibited. Thurber v. N. Y. C. \& H. R. R. Co. et al., 3 I. C. C. Rep. 473. Without detailing the theory upon which this conception was based it sufficies broadly to say that it embodied the assumption that a carload was the unit of shipment, and rested upon the difference which existed between the cost of service in the case of a carload shipment by one consignor to one consignee and that occasioned by a shipment in one car of many packages by various consignors to various consignees. Leaving aside possible qualifications arising from exceptional conditions, it is true to say that the Commission, however, recognized that the fixing of a lesser rate for a carload was not imperative, lut was merely optional. Conformably to these administrative conceptions it came universally to pass that wherever a lesser charge for a carload than for a less than a carload shipment was established such charge was only applicable to shipments made at one time by one consignor of merchandise consigned to one consignee at a single destination. While there was this uniformity there was, however, much divergence between carriers as to the character of traffic which was given the benefit of the lesser rate for carload shipments and the circumstances under which, when such rate was established, it would be applied.

"And the benefits of the lesser rate came to be obtained not alone by an owner of all the goods shipped in a carload, but by combinations of owners, by agreements between them concerning particular and isolated shipments, by the organization of associations of shippers having for their object the creating of agencies to receive merchandise belonging to the members of the association and to aggregate and ship them in carload lots in the name of one consignor to a single consignee at one destination by the use of commission houses, storage and other companies, etc. It is also undoubted that in consequence of the facility of shipping at a lesser rate for a carload than for a less than carload shipment there developed a class of persons known as forwarding agents, who embarked in the business of obtaining a carload rate for various owners of merchandise by aggregating their shipments, such agents relying for their compensation upon what they could make from the difference between the carload and less than carload rates.

"The contention that a carrier when goods are tendered to him for transportation can make the mere ownership of the goods the test of the duty to carry, or, what is equivalent, may discriminate in fixing the charge for carriage, not upon any difference inhering in the goods or in the cost of the service rendered in transporting them, but upon the mere circumstance 
Types of Discrimination.-The general purpose of section 2 of the Act was to establish uniform rates and to make any departure therefrom, under whatever guise, illegal. Charges for transportation, whether of passengers or freight, should be paid for in money and in the same amount thereof. And it has been

that the shipper is or is not the real owner of the goods is so in conflict with the obvious and elementary duty resting upon a carrier, and so destructive of the rights of shippers as to demonstrate the unsoundness of the proposition by its mere statement. We say this because it is impossible to conceive of any rational theory by which such a right conld be justified consistently either with the duty of the carrier to transport or of the right of a shipper to demand transportation. This must be, since nothing in the duties of a common carrier by the remotest implication can be held to imply the power to sit in judgment on the title of the prospective shipper who has tendered goods for transportation. In fact, the want of foundation for the assertion of such a power is so obvious that in the argument at bar its existence is not directly contended for as an original proposition, but is deduced by implication from the supposed effect of some of the provisions of the second section of the Act to Regulate Commerce. In substance, the contention is that as the section forbids a carrier from 'charging a greater or less compensation for any service rendered or to be rendered in the transportation of persons or property, * * * than it charges, demands, collects or receives from any other person or persons for doing for him or them a like and contemporaneous service in the transportation of a like kind of traffic under substantially similar circumstances and conditions,' authority is to be implied for basing a charge for transportation upon ownership or nonownership of the goods tendered for carriage, upon the theory that such ownership or nonownership is a dissimilar circumstance and condition within the meaning of the section.

"But this argument, in every conceivable aspect, amounts only to saying that a provision of the statute which was plainly intended to prevent inequality and discrimination has resulted in bringing about such conditions. Moreover, the unsoundness of the contention is demonstrated by authority. It is not open to question that the provisions of section 2 of the Act to Regulate Commerce were substantially taken from section 90 of the English Railway Clauses Consolidation Act of 1845 , known as the Equality Clause. Texas and Pacific Railway v. Interstate Commerce Commission, 162 U. S. I97, 222, 40 L. Ed. 940, I6 Sup. Ct. 666. Certain also is it that at the time of the passage of the Act to Regulate Commerce that clause in the English Act had been construed as only embracing circumstances concerning the carriage of the goods and not the person of the sender, or in other words, that the clause did not allow carriers by railroad to make a difference in rates because of differences in circumstances arising either before the service of the carrier began or after it was terminated. It was therefore settled in England that the clause forbade the charging of a higher rate for the carriage of goods for an intercepting or forwarding 
held illegal and a violation of the Act to regulate commerce to carry passengers on passes even when issued to liquidate a claim against the carrying road for damages received in an accident while traveling on that road. ${ }^{12}$

agent than for others. Great Western R. Co. v. Sutton, I869-L. R. 4 H. L. 226; Evershed v. London \& N. W. Ry. Co., 1878-3 App. Cas. I029, and Denaby Main Colliery Co. v. Manchester, etc., Ry. Co., I885-I I App. Cas. 97. And it may not be doubted that the settled meaning which was affixed to the English Equality Clause at the time of the adoption of the Act to Regulate Commerce applies in construing the second section of that Act, certainly to the extent that its interpretation is involved in the matter before us. Wight v. United States, I67 U. S. 512, 42 L. Ed. 258, I7 Sup. Ct. 822 ; Interstate Commerce Commission v. Alabama Midland Railway Co., I68 U. S. I44, I66, 42 L. Ed. 414, I8 Sup. Ct. 45.

"It is urged that as the wide range of carload rates and the extent of the facility for combining articles for the purpose of obtaining such rates allowed in official classification territory are the result of the voluntary act of the railroads, therefore the power existed in the railroads to restrict and limit the enjoyment of such rate as was done by the assailed rules. In the interest of the public it is urged a limitation should not be now enforced which would compel the carrier to withdraw the facilities which shippers enjoy by the voluntary act of the carriers. But the proposition rests upon the fallacious assumption that because a carrier has the authority to fix rates it has the right to discriminate as to those who shall be entitled to avail of them. Moreover, the contention is not open for review, because the legal question of the right of the carrier to consider ownership under the second section having been disposed of, the finding of the Commission that to permit the enforcement of the rule would give rise to preferences and engender discriminations prohibited by the Act to Regulate Commerce embodies a conclusion of fact beyond our competency to reexamine." See also Great Northern Railway Co. v. O'Connor, 232 U. S. 508, 58 L. Ed. 703, 34 Sup. Ct. 380.

I2 Louisville and Nashville Railroad Co. v. Mottley, 2I9 U. S. 467, 55 L. Ed. 297, 31 Sup. Ct. 265, where the court said:- "The Act of February 4th, I887, Regulating Commerce declared it to be an unjust and unlawful discrimination for any carrier subject to the provisions of that Act, directly or indirectly, by any special rate, rebate, drawback or other device, to charge, demand collect or receive from any person or persons 'a greater or less compensation' for any service rendered or to be rendered in the transportation of passengers or property than was charged, demanded, collected or received from any other person or persons for doing him or them a like and contemperaneous service in the transportation of a like kind of traffic under substantially similar circumstances and conditions. 24 Stat. 379, c. I04, sec. 2. But the Act of June 29th, I906, made a material addition to the words of the Act of 1887 ; for, it expressly prohibited any carrier, unless otherwise provided, to demand, collect or receive 'a greater or less or different compensation' for the transportation 
And similarly furnishing transportation in exchange for advertising is a violation of the provisions of the Act. ${ }^{13}$ And railroads

of persons or property or for any service in connection therewith, than the rates, fares and charges specified in the tariff filed and in effect at the time. We cannot suppose that this change was made without a distinct purpose on the part of Congress. The words 'or different,' looking at the context, cannot be regarded as superfluous or meaningless. * * * In our opinion after the passage of the Commerce Act the railroad company could not lawfully accept from Mottley and wife any compensation 'different' in kind from that mentioned in its published schedule of rates. And it cannot be doubted that the rates or charges specified in such schedule were payable only in money. They could not be paid in any other way, without producing the utmost confusion and defeating the policy established by the Acts Regulating Commerce." And Louisville and Nashville Railroad Co. v. Mottley, 2 I I U. S. I49, 53 L. Ed. I26, 29 Sup. Ct. 42.

In Union Pacific Railway Co. v. Goodridge, I49 U. S. 680, the court said:- "While we do not undertake to say that a railroad company may not justify a fixed rebate in favor of a particular shipper by showing a liquidated indebtedness to such shipper, which the allowance of the rebate was intended to settle, it would practically emasculate the law of its most healthful feature, to permit an unexplained, indefinite, and unadjusted claim for damages arising from a tort, which, though litigated for some time, never seems to have been prosecuted to a final determination in the courts, to be put forward as an excuse for a clear discrimination in rates. * * * To hold a defense thus pleaded to be valid would open the door to the grossest frauds upon the law, and practically enable the railroad company to avail itself of any consideration for a rebate which it considers sufficient, and to agree with the favored customer upon some fabricated claim for damages, which it would be difficult, if not impossible, to disprove. For instance, under the defense made by this company, there is nothing to prevent a customer of the road, who has received a personal injury, from making a claim against the road for any amount he chooses, and in consideration thereof, and of shipping all his goods by that road, receiving a rebate for all goods he may ship over the road for an indefinite time in the future. It is almost needless to say that such a contract could not be supported."

I3 Chicago, Indianapolis and Louisville Railway Co. v. United States, 2 I9 U. S. 486, 55 L. Ed. 305, 3I Sup. Ct. 272, where the court said:-"The acceptance by the railway company of advertising, not of money in payment of the interstate transportation furnished to the publisher of the Munsey magazine, his employees and the immediate members of his and their families, was for the reasons given in the Mottley case, in violation of the Commerce Act. The facts in the present case show how easily, under any other rule, the Act can be evaded and the object of Congress entirely defeated. The legislative department intended that all who obtained transportation on interstate lines should be treated alike in the matter of rates, and that all who availed themselves of the services of the railway company (with certain specified exceptions) should be on a plane 
cannot pay for land purchased by rebating to the grantor a part of the freight rate on interstate shipments over the road built on such right of way, even through the amount of such rebate is less than the value of the land thus acquired. ${ }^{14}$ Likewise a road violates the Act by liquidating a claim for damages by selling coal at a price insufficient to cover the cost of such coal plus the regular rate of transportation to the point designated..$^{15}$ The Act is also violated by a contract by a common carrier to pay a shipper a certain bonus provided the shipper would erect a new packing house in a certain city adjacent to the property of the carrier. operate the plant for a certain number of years and use in its business only stock transported over the lines of such carrier. ${ }^{16}$

of equality. Those ends cannot be met otherwise than by requiring transportation to be paid for in money which has a certain value known to all and not in commodities or services or otherwise than in money."

14 Fourche River Lumber Co. $v$. Bryant Lumber Co., 230 U. S. 316, 57 L. Ed. I498, 33 Sup. Ct. 887, where the court said:- "Carriers, whether saw-mill companies or railroads or both combined, cannot purchase land by rebating to the grantor a part of the freight rate on interstate shipments over the road built on the right of way, even though the amount of such rebate was much less than the value of the land thus acquired. Cf. Louisville \& Nashrille v. Mottley, 219 U. S. 467, 55 L. Ed. 297, 31 Sup. Ct. 265; United States v. Lehigh Railroad, 220 U. S. 257,55 L. Ed. 458 , 3 I Sup. Ct. 387; United States v. Union Stock Yards, 226 U. S. 286, 308, 57 L. Ed. 226. 33 Sup. Ct. 83. The Commerce Act prohibits the payment of rebates, and its command cannot be evaded by calling them differentials or concessions, nor by taking the money from the railroad itself or from a company that is proved to be the same as the railroad."

I5 New York. New Haven and Hartford Railroad Co. v. Interstate Commerce Commission, 200 U. S. 36r, 50 L. Ed. 515, 26 Sup. Ct. 272.

I6 United States v. Union Stock Yards and Transit Co., 226 U. S. 286, 57 L. Ed. 226, 33 Sup. Ct. 83 . Here the stock yard company, declared to be a common carrier, within the terms of the Act to Regulate Commerce, agreed to pay a bonus of $\$ 50,000$ to the packers, provided they would erect their new plant in Chicago adjacent to the stock yard, instead of in Kansas City, as was proposed, and would maintain and operate the plant for fifteen years, and buy and use in their business such live stock only as moves through such stock yard, and pay the regular charges on live stock not so bought, as if the same had moved into the stock yard and had there been purchased. The court said:-"By section 2 of the Act to Regulate Commerce the carrier is guilty of unjust discrimination, which is prohibited and declared to be unlawful, if by any rebate or other device it charges one person less for any service rendered in the transportation of property than it does another for a like service. The Elkins Act makes it an offense for any person or corporation to give or receive any rebate, concession or 
An interstate carrier may not charge a different rate for the transportation of railroad fuel-coal to a given point than for carrying commercial coal to the same point. ${ }^{17}$ However, in the matter of transporting supplies and employees of contractors in

discrimination in respect to the transportation of property in interstate commerce whereby any such property shall be transported at a rate less than that named in the published tariff or whereby any other advantage is given or discrimination is practiced. By the very terms of the contract it is evident that the interest of the Stock Yard Company and also of the Junction Company is in the profit to be made in receiving and delivering, handling and caring for and transporting live stock, shipments of which, to the extent stated, are made in interstate commerce. The contract provides that if the Pfaelzers construct a packing plant adjacent to the stock yards of the Stock Yard Company they shall receive $\$ 50,000$, and it obligates them to maintain and operate the plant for a period of 15 years and buy and use in their slaughtering business such live stock only as moves through such stock yards, and if not so bought to pay the regular charges thereon as if the same had moved into the stock yards and had been there purchased by them. In other words, this plant in effect may pay for the services of the Stock Yard Company, up to the sum of $\$ 50,000$, with the bonus given to the Pfaelzers for the location of their plant in juxtaposition to the stock yards. The only interest which the Stock Yard Company has in Pfaelzer and Sons' interstate business is compensation for its services in handling their freight and its share of the profits realized by the Junction Company in rendering its service. Any other company with which it has made no contract would be compelled to pay the full charge for the services rendered without any rebate or concession. Another company might have a contract for a larger or smaller bonus, and thereby receive different treatment. Certainly as to the company which receives no such bonus there has been an undue advantage given to and an unlawful discrimination practiced in favor of Pfaelzer and Sons. If these companies had filed their tariffs, as we now hold they should have filed them, they would have been subject to the restrictions of the Elkins Act as to departures from published rates-and we must consider the case in that light-and this preferential treatment, as we have said, would have been in violation of that Act. It is the object of the Interstate Commerce Law and the Elkins Act to prevent favoritism by any means or device whatsoever and to prohibit practices which run counter to the purpose of the Act to place all shippers upon equal terms. We think the Commerce Court should have enjoined the carrying out of this contract."

I7 Interstate Commerce Commission v. Baltimore and Ohio Railroad Co., 225 U. S. 326, 56 L. Ed. I 107, 32 Sup. Ct. 742, where the court said:"The railroad company cannot be put out of view as a favored shipper, and we see many differences between such a shipper receiving coal for use in its locomotives and a nation as the destination of goods from other nations for distribution throughout its expense on through rates from points of origin." 
the construction of its own road, or in additions thereto, a railroad does not act as a common carrier and arrangements made in good faith with such contractors for carrying such supplies or employees either free or at reduced rates do not amount to rebates or discriminations in violation of the Act to regulate commerce. $^{18}$

A difference in rates between contract coal and free coal is discriminatory unless properly filed and published. ${ }^{19}$

The bona fidc ownership and operation of tap line railroads as common carriers with equality of treatment for proprietary and non-proprietary traffic is not open to exception. However such tap lines are under the control and supervision of the Interstate

I8 Sante Fe, Prescott and Phœnix Railway Co. v. Grant Brothers, 228 U. S. 177,57 L. Ed. 787,33 Sup. Ct. 474 . The court here said: "It is clear that in dealing with transportation of this character over its own road, in connection with construction or improvement, a railroad company is not acting in the performance of its duty as a common carrier, and the arrangement for free or reduced-rate carriage for the necessary materials and men used in the work, when it is a part of the contract, entered into in good faith and not as a subterfuge, is not obnoxious to the provisions of law prohibiting departures from the published tariffs, for the reason that such an agreement lies outside the policy of these provisions. See Matter of Railroad-Telegraph Contracts, I2 I. C. C. Rep. 10, II."

I9 Pennsylvania Railroad Co. v. International Coal Mining Co., 230 U. S. I84, 57 L. Ed. 1446, 33 Sup. Ct. 893, where the court said:- "For even if a difference in rates could be made between free and contract coal, none was made in the only way in which it could have been lawfully done. The published tariffs made no distinction between contract coal and free coal, but named one rate for all alike. That being true, only that single rate could be charged. When collected, it was unlawful, under any pretense or for any cause, however equitable or liberal, to pay a part back to one shipper or to every shipper. The statute required the carrier to abide absolutely by the tariff. It did not permit the company to decide that it had charged too much and then make a corresponding rebate; nor could it claim that it had charged too little and insist upon a larger sum being paid by the shipper. (24 Stat. 379, Sec. 2; 25 Stat. 855, Sec. 6. Armour Company v. United States, 209 U. S. 56, 83, 52 L. Ed. 68I, 28 Sup. Ct. 428 .) The tariff, so long as it was of force, was, in this respect, to be treated as though it had been a statute, binding as such upon railroad and shipper alike. If, as a fact, the rates were unreasonable the shipper was nevertheless bound to pay and the carrier to retain what had been paid, leaving, however, to the former the right to apply to the Commission for reparation."

See also Mitchell Coal and Coke Co. v. Pennsylvania Railroad Co., 230 U. S. 247,57 L. Ed. 1472, 33 Sup. Ct. 916. 
Commerce Commission by the terms of the Act to regulate commerce and any practices by these lines resulting in rebating or preferences, no matter what their form or in what guise they may appear, are illegal and will be nullified by the Commission. ${ }^{20}$

20 United States $v$. Louisiana and Pacific Railway Co., (The Tap Line Cases), 234 U. S. I, 58 L. Ed. I 185, 34 Sup. Ct. 741. The court here said: - "As we have said, the Commission by its order herein required the trunk lines to re-establish through routes and joint rates as to property to be transported by others than the proprictary owners over the tap lines. This order would of itself create a discrimination against proprietary owncrs, for lumber products are carried from this territory upon blanket rates applicable to all within its limits. It follows that independent owners would get this blanket rate for the entire haul of their products while proprietary owners would pay the same rate plus the cost of getting to the trunk line over the tap line. The Commission, by the effect of its order, recognizes that railroads organized and operated as these tap lines are, if owned by others than those who own the timber and mills, would be entitled to be treated as common carriers and to participate in joint rates with other carricrs. We think the Commission exceeded its authority when it condemned these roads as a mere attempt to evade the law and to secure rebates and preferences for themselves.

"It is doubtless true, as the Conmission amply shows in its full report and supplemental report in these cases, that abuses exist in the conduct and practice of these lines and in their dealings with other carriers which have resulted in unfair advantages to the owners of some tap lines and to discriminations against the owners of others. Because we reach the conclusion that the tap lines involved in these appeals are common carriers, as well of proprietary as nonproprietary traffic, and as such entitled to participate in joint rates with other common carriers that determination falls far short of deciding, indeed does not at all decide, that the division of such joint rates may be made at the will of the carriers involved and without any power of the Commission to control. That body has the authority and it is its duty to reach all unlawful discriminatory practices resulting in favoritism and unfair advantages to particular shippers or carriers. It is not only within its power, but the law makes it the duty of the Commission to make orders which shall nullify such practices resulting in rebating or preferences, whatever form they take and in whatsoever guise they may appear. If the divisions of joint rates are such as to amount to rebates or discriminations in favor of the owners of the tap lines because of their disproportionate amount in view of the service rendered, it is within the province of the Commission to reduce the amount so that a tap line shall receive just compensation only for what it actually does."

United States v. Butler County Railroad, 234 U. S. 29, 58 L. Ed. IIg6, 34 Sup. Ct. $74^{8}$. 
The prohibitions against unjust discrimination include not only inequality of charges and inequality of facilities but also the giving of preferences by means of consent judgments or the waiver of defenses open to the carrier, such as a waiver in a suit of the statutory limitation within which actions must be brought for recoveries from a railroad. ${ }^{21}$

Discriminations created through transit, elevator and similar privileges are discussed under section 3 .

The carrier who has practiced the discrimination or granted the preference is liable therefor, and a connecting carrier will not be liable for such act of the initial carrier merely through its adoption of and participation in a joint through rate which is in itself reasonable. ${ }^{22}$

21 In Phillips Co. v. Grand Trunk Western Ry. Co., decided March 15 , 1915, the court said: "The obligation of the carrier to adhere to the legal rate, to refund only what is permitted by law and to treat all shippers alike would have made it illegal for the carriers, either by silence or by express waiver, to preserve to the Phillips Company a right of action which the statute required should be asserted within a fixed period. To have one period of limitation where the complaint is filed before the Commission and the varying periods of limitation of the different states, where a suit was brought in a court of competent jurisdiction; or to permit a railroad company to plead the statute of limitations as against some and to waive it as against others would be to prefer some and discriminate against others in violation of the terms of the Commerce Act, which forbids all devices by which such results may be accomplished. The prohibitions of the statute against unjust discrimination relate not only to inequality of charges and inequality of facilities, but also to the giving of preferences by means of consent judgments or the waiver of defenses open to the carrier. The Railroad Company, therefore, was bound to claim the benefit of the statute here and could do so here by general demurrer. For when it appeared that the complaint had not been filed within the time required by the statute it was evident, as matter of law, that the plaintiff had no cause of action."

22 Penn Refining Co. v. Western New York and Pennsylvania Railroad Co., 208 U. S. 208, 52 L. Ed. 456, 28 Sup. Ct. 268. 


\section{SECTION 3. FORBIDDING UNDUE OR UNREASON- ABLE PREFERENCE OR ADVANTAGE.}

SEc. 3. That it shall be unlawful for any common carrier subject to the provisions of this Act to

Undue or un- make or give any undue or unreasonable preference reasonable pref erence or ad. or advantage to any particular person, company, den.

firm, corporation, or locality, or any particular description of traffic, in any respect whatsoever, or to subject any particular person, company, firm, corporation, or locality, or any particular description of traffic, to any undue or unreasonable prejudice or disadvantage in any respect whatsoever.

Every common carrier subject to the provisions of this Act shall, according to their respective powFacilities for ers, afford all reasonable, proper, and equal facilities interchange of for the interchange of traffic between their re-
traffic. spective lines, and for the receiving, forwarding, and delivering of passengers and property to and from their several lines and those connecting thereDiscrimination with, and shall not discriminate in their rates and
cetween necting lines for- charges between such connecting lines; but this
bidden. shall not be construed as requiring any such common carrier to give the use of its tracks or terminal facilities to another carrier engaged in like business.

History of this Section.-Section three has not been amended but stands in the form in which it was first enacted in the original Act to regulate conmerce of February 4, I887. The Supreme Court has stated in its earlier decisions that this section of the Act was based upon the second section of the English Act to regulate railways of July 10,1854 , and the eleventh section of the Act amendatory thereof of July $21,1873 .{ }^{1}$ This dis-

I The relation between section 3 of the Act to Regulate Commerce and the English Acts for the same purpose are set forth in detail in Texas and Pacific Railway Company v. Interstate Commerce Commission, $162 \mathrm{U}$. S. 197, 40 L. Ed. 940, 16 Sup. Ct. 666, where several leading English cases are summarized and commented upon. See also Interstate Commerce Commission v. Baltimore and Ohio Railroad Co., I45 U. S. 263, 36 L. Ed. 
tinction, however, is to be noted, that section 3 of the Act regulating commerce provides that no undue or unreasonable preference or advantage shall be given to any particular person, company, firm, corporation, or locality', or any particular description of traffic-the word locality not appearing in the English Act.

Relation of Section 3 to Sections $I$ and 2.-First of all by section 3 only such discriminations and preferences are forbidden as are unjust and unreasonable, it being admitted thereby that some discriminations may be just and some preferences reasonable. ${ }^{2}$ Section 2 prohibits discriminations in rates. Section 3 , however, includes any form of discrimination or advantage whereby any person, firm, locality or description of traffic is subjected "to any undue or unreasonable prejudice or disadvantage in any respect whatsoever." Under section I unreasonable rates are prohibited. The reasonableness or unreasonableness of a rate is naturally a relative question, and the existence of the latter must depend upon the determination of the former. The third section concerns those rates which subject a person, community or class of traffic to any undue or unreasonable prejudice or disadvantage, and which are thus unreasonable. Section 4 , to a certain extent, also treats of the question of reasonable and unreasonable rates-in their relation to long and short hauls. Generally speaking, complaints under section 2 are based upon individual rate discriminations, and under section 3 upon discriminations by the carriers based upon other questions than mere rates,

699, I2 Sup. Ct. 844, and Cincinnati, New Orleans and Texas Pacific Railway Co. v. Interstate Commerce Commission, I62 U. S. I84, 40 L. Ed. 935 , I6 Sup. Ct. 700 .

2 In Cincinnati, New Orleans and Texas Pacific Railway Co. v. Interstate Commerce Commission, I62 U. S. I84, 40 L. Ed. 935, I6 Sup. Ct. 700, the court quoted with approval the following language of Justice Jackson, then circuit judge, in the case of Interstate Commerce Commission $v$. Baltimore and Ohio Railroad Co., 43 Fed. 37, affirmed 145 U. S. 263, 36 L. Ed. 699 , I2 Sup. Ct. 844 :- "Subject to the two leading prohibitions that their charges shall not be unjust or unreasonable, and that they shall not unjustly discriminate, so as to give undue preference or disadvantage to persons or traffic similarly circumstanced, the Act to Regulate Commerce leaves common carriers as they were at the common law, free to make special contracts looking to the increase of their business, to classify their traffic, to adjust and apportion their rates so as to meet the necessities of commerce, and generally to manage their important interests upon the same principles which are regarded as sound, and adopted in other trades and pursuits." 
and involving also preferences to localities and different classes of traffic.

Preferences to Localities.-A primary distinction is to be noted between the provisions of section 3 and those of section 4 in their regulation of rates for different localities. Under section 3 carriers are forbidden to extend any undue or unreasonable preference or advantage to any particular locality, while under section 4 carriers are forbidden to charge a higher rate for a nearer than for a more distant point on the same line except upon the consent of the Interstate Commerce Commission. Competition between different points or localities may constitute a controlling element in rate adjustment, and thus form a natural condition over which the carriers would have no power. The inhibition of the third section is directed to such unjust discriminations and preferences as are within the control of carriers and arise from their voluntary and wrongful action. ${ }^{3}$ Real and sub-

3 East Tennessee, Virginia and Georgia Railway Co. v. Interstate Commerce Commission, 181 U. S. I, 18, 45 L. Ed. 719, 21 Sup. Ct. 516. Here the court said:- "The prohihition of the third section, when that section is considered in its proper relation, is directed against unjust discrimination or undue preference arising from the voluntary and wrongful act of the carriers complained of as having given undue preference, and does not relate to acts the result of conditions wholly beyond the control of such carriers. And special attention was directed to this view in the Behlmer case, in the passage which we have previously excerpted. To otherwise construe the statute would involve a departure from its plain language, and would be to confound cause with effect. For, if the preference occasioned in favor of a particular place by competition there gives rise to the right to charge the lesser rate to that point, it cannot be that the availing of this right is the cause of the preference, and especially is this made clear in the case supposed, since it is manifest that forbidding the carrier to meet the competition would not remove the discrimination.

"The only principle by which it is possible to enforce the whole statute is the construction adopted by the previous opinions of this court; that is, that competition which is real and substantial, and exercises a potential influence on rates to a particular point, brings into play the dissimilarity of circumstance and condition provided by the statute, and justifies the lesser charge to the more distant and competitive point than to the nearer and noncompetitive place, and that this right is not destroyed by the mere fact that incidentally the lesser charge to the competitive point may seemingly give a preference to that point, and the greater rate to the noncompetitive point may apparently engender a discrimination against it. We say seemingly on the one hand and apparently on the other, because in the supposed cases the preference is not 'undue' or the discrimination 'unjust.' This is clearly so, when it is considered that the lesser charge upon which 
stantial competition which exercises a potential influence on rates to a given point, brings into play the dissimilarity of condition contemplated by section 4 and may justify the lesser charge to the more distant and competitive point than to the noncompetitive nearer point. This right, provided under proper conditions by section 4 , is not destroyed by the fact that incidentally the lesser charge to the more distant competitive point may seem to give a preference to that point and the greater charge to the nearer noncompetitive point may apparently work a discrimination against it. In such a case the preference on the one hand is held not to be "undue" and the discrimination on the other hand is declared not to be "unjust." It is to be particularly noted, however, that the competition upon which lower charges to more distant points are based must be real and not simply potential or conjectural or a mere pretence. ${ }^{4}$ Such rates must depend upon the actual existence of competition and not upon the mere possibility of competition arising. Also the competition must be controlling. It must not have been created by the carriers through combination or agreement. In the words of the Supreme Court, "If by agreements or combinations among carriers it were found that at a particular point rates were unduly infuenced by a suppression of competition, that fact would be proper to consider in determining the question of undue discrimination and the reasonableness per se of the rates at such possible competitive points." ${ }^{\prime}$ The competition may relate to the point of shipment as well as to the point of destination and it is not confined to shipments made from the point of origin of the competition, but may be taken advantage of by all carriers shipping to such competitive points. And yet, as set forth in the discussion of section 4, conditions may arise where the carrier cannot avail itself of this competitive condition because of the public interest or because of other provisions of the Act. Such a case arises where the carrier cannot

both the assumption of preference and discrimination is predicated is sanctioned by the statute, which causes the competition to give rise to the right to make such lesser charge."

4 Interstate Commerce Commission v. Chicago Great Western Railway Co., 209 U. S. 108, 52 L. Ed. 705, 28 Sup. Ct. 493, where the court said :- "In fixing their own rates they (carriers) may take into account competition with other carriers, provided only that the competition is genuine and not a pretence."

5 Interstate Commerce Commission v. Louisville and Nashville Railroad Co., 190 U. S. 273, 47 L. Ed. 1047, 23 Sup. Ct. 687. 
meet the competitive rate to a given point without transporting shipments at less than the cost of the service. Engaging in such competitive traffic under these conditions would produce unjust discrimination since it would compel the carriers to charge unreasonable rates to other points to make up the loss of revenues from such traffic. Therefore the rates charged must be at least remunerative. Whether the competition contemplated by section 4 is controlling and creates conditions justifying a lower rate for a longer haul and preventing the inference of an unjust preference or discrimination is not a question of law, but rather one of fact, and under the statute, as now amended, depends upon the decision of the Interstate Commerce Commission. ${ }^{6}$ And whether charges are reasonable or unreasonable, whether discriminations are due or undue, and whether preferences are just or unjust are all questions of fact primarily to be passed upon by the Commission upon proper investigation and consideration.

The Act to regulate commerce was not adopted to reinforce the provisions of the tariff laws, and inland consumers are not to be deprived thereby of the advantages of through rates on import and export shipments. Competition at the seaports is to be considered in determining whether low rates to inland points, made to secure foreign freight traffic, are proper, or whether they constitute an undue and unjust discrimination. And in the consideration of this question due account must be taken of the interest not only of the railroad companies, but also of the shippers and consumers and the communities from which the goods are shipped as well as those to which they are to be delivered. ${ }^{7}$

6 See particularly United States v. Atchison, Topeka and Santa Fe Railway Co., (Inter-Mountain Rate Cases), 234 U. S. 476, 58 L. E.d. I408, 34 Sup. Ct. 986; and also cases cited under section 4 where this question is discussed at length.

7 Texas and Pacific Railway Co. v. Interstate Commerce Commission, (The Import Rate Case), I62 U. S. 197, 40 L. Ed. 940, I6 Sup. Ct. 666. The court here said:- "The third section forbids any undue or unreasonable preference or advantage in favor of any person, company, firm, corporation or locality; and as there is nothing in the Act which defines what shall be held to be due or undue, reasonable or unreasonable, such questions are questions not of law, but of fact. The mere circumstance that there is, in a given case, a preference or an advantage does not of itself show that such preference or advantage is undue or unreasonable within the meaning of the Act. Hence it follows that before the Commission can adjudge a common carrier to have acted unlawfully, it must ascertain the facts; and here again we think it evident that those facts and matters 
Basing Points.-The Supreme Court has held that the basing of rates upon a fixed or competitive point is legal. Thus rates for a section of the country may be determined by fixing a rate to a certain point and for other stations adding to that fixed rate the amount of the local rate or determining it by a percentage process. A low rate may be fixed in a proper case to a more distant competitive point and the rate to a less distant point may be determined by adding to the low competitive rate the local rate from such competitive point to the less distant point from the place of shipment. Such basing points are to a certain extent artificial, and while they are proper subjects of consideration by the Commission in determining the propriety of rates, they are not immutable nor exempt from the regulating power of the Commission which possesses the power to alter or ignore them. ${ }^{8}$

which carriers, apart from any question arising under the statute, would treat as calling, in given cases, for a preference or advantage, are facts and matters which must be considered by the Commission in forming its judgment whether such preference or advantage is undue or unreasonable. When the section says that no locality shall be subjected to any undue or unreasonable prejudice or disadvantage in any respect whatsoever, it does not mean that the Commission is to regard only the welfare of the locality or community where the traffic originates, or where the goods are shipped on the cars. The welfare of the locality to which the goods are sent is also, under the terms and spirit of the Act, to enter into the question.

"Our reading of the Act does not disclose any purpose or intention, on the part of Congress, to thereby reinforce the provisions of the tariff laws. These laws differ wholly in their objects from the law to regulate commerce. Their main purpose is to collect revenues with which to meet the expenditures of the government and those of their provisions whereby Congress seeks to so adjust rates as to protect American manufacturers and producers from competition by foreign low priced labor, operate equally in all parts of the country. The effort of the Commission, by a rigid general order, to deprive the inland consumers of the advantage of through rates, and to thus give an advantage to the traders and manufacturers of the large seaboard cities, seems to create the very mischief which it was one of the objects of the Act to remedy."

8 Interstate Commerce Commission v. Chicago, Rock Island and Pacific Railroad Co., 218 U. S. 88, 54 L. Ed. 946, 30 Sup. Ct. 651. This case involved rates on through shipments from the Atlantic seaboard to various Missouri river cities, the complaint alleging that those portions of the through rates between the Mississippi crossings and the Missouri river cities were excessive. It was alleged that the order of the Commission gave an unreasonable preference to shippers in the seaboard and the Mis- 
In this connection it ought to be said that while the railroad companies may complain of the reduction in rates so far as they affect rival carriers, they will not be permitted to complain of the effect of such rates upon shippers and trade centers on the general theory that the courts will not listen to a party who complains of the grievance of another.

Federal Control of Intrastate Rates.-It must be remembered that the power invested in Congress by the Constitution to regulate commerce among the several states is complete and paramount. The third section of the Act to regulate commerce prohibits any unjust discrimination in rates or any undue preference to one person or locality or class of traffic as against another under substantially the same conditions. Where such discrim-

souri river territory over merchants in the so-called central freight association territory. The court said:-

"Nor did the Commission ignore or underestimate the manner in which the lines of railroads had been extended or the system of rates or ratemaking which had resulted. That is the system of making rates upon certain basing lines or points. Rates 'break' at such points, it was proved as a result of building independent lines westward. In other words, lines of railroads were built to certain cities from the East, seeking such cities, it may be, because of their natural situation and facilities, and other independent lines building westward, each line fixing its own rates or uniting according to circumstances in joint rates. It is the observance of such points that give and maintain, as we understand the contention of the railroads, to certain cities 'the equal opportunity in the distribution of merchandise with the merchants in the East, and with the merchants to the West of said cities, so far as their business is affected by trade rates.' That this was carefully considered is manifest, for the Commission resisted the argument which was made against basing rates on such points, saying :-

" "We are not impressed with the view that the system of making rates on certain basing lines should be abolished. No system of rate making has been suggested as a substitute for it, except one based upon the postage stamp theory, or one based strictly upon mileage. Either of these would create revolution in transportation affairs and chaos in commercial affairs that have been builded upon the system of ratemaking now in effect. It must not, however, be assumed that a basing line for rates may be established and be made an impassable barrier for through rates, or that cities or markets located at or upon such basing line have any inviolable possession of, or hold upon, the right to distribute traffic in or from the territory lying beyond. Development of natural resources, increase in population, growth of manufacturing or producing facilities, and increased traffic on railroads create changed conditions which may warrant changes in rates and in rate adjustments in order to afford just and reasonable opportunity for interchange of traffic between points of production and points of large consumption.' 
inations exist and affect points in different states the power of Congress is supreme and applies whether this discrimination results from purely intrastate rates or from interstate rates. Where the intrastate rates fixed by a state railroad or by a state railroad commission in conjunction with the interstate rates fixed with the approval and consent of the Interstate Commerce Comnission produce preferences or discriminations against points in another state, the power conferred upon the Interstate Commerce Commission under section 3 of the Act is sufficiently broad to embrace the situation, and the limitations of the proviso in section I do not prevent the exercise of such power under section 3 . Whether such intrastate rates actually do give an undue or unreasonable preference or advantage to one locality as against another, or do subject any locality to an improper or unreasonable discrimination is primarily for the investigation and determination of the Interstate Commerce Commission. And the Commission, after proper investigation, has authority to order the discontinuance of such intrastate rates which produce these discriminations and the substitution therefor of other rates not open to this criticism or objection. ${ }^{9}$ The inhibition of section 3 against

"It was the sense of the Commission, however, that such points could not be immovable forever and fixed forever against power of changing, or that through rates based on such points must be exempt from regulation, no matter what their character, or be constituted at the will of the railroad of the sum of local rates or the sum of rates from one basing point to another, however unjust the rates might be.

"That the companies may complain of the reduction made by the Commission so far as it affects their revenues is one thing. To complain of it as it may affect shippers or trade centers is another. We have said several times that we will not listen to a party who complains of a grievance which is not his."

See also Interstate Commerce Commission v. Chicago, Burlington and Quincy Railroad Co., 218 U. S. I13, 54 L. Ed. 1259, 33 Sup. Ct. 827.

9 Houston, East and West Texas Railroad Co. v. United States, 234 U. S. 342, 58 L. Ed. 1341, 34 Sup. Ct. 833. The court in a very complete decision said:-_"This language (of section 3) is certainly sweeping enough to embrace all the discriminations of the sort described which it was within the power of Congress to condemn. There is no exception or qualification with respect to an unreasonable discrimination against interstate traffic produced by the relation of intrastate to interstate rates as maintained by the carrier. It is apparent from the legislative history of the Act that the evil of discrimination was the principle thing aimed at, and there is no basis for the contention that Congress intended to exempt any discriminatory action or practice of interstate carriers affecting interstate 
unjust discrimination and undue preferences thus relates not only to cases arising from the voluntary act of the carrier, but also to cases resulting from such conditions beyond the control of the carrier as orders of state railroad commissions. The Supreme Court in the recently decided Shreveport case laid down this rule in order to protect Louisiana points near the Texas line

commerce which it had authority to reach. The purpose of the measure was thus emphatically stated in the elaborate report of the Senate Committe on Interstate Commerce which accompanied it:- 'The provisions of the bill are based upon the theory that the paramount evil chargeable against the operation of the transportation system of the United States as now conducted is unjust discrimination between persons, places, commodities, or particular descriptions of traffic. The underlying purpose and aim of the measure is the prevention of these discriminations.' * * *

"Congress thus (by the proviso of section I) defined the scope of its regulation and provided that it was not to extend to purely intrastate traffic. It did not undertake to authorize the Commission to prescribe intrastate rates and thus to establish a unified control by the exercise of the rate-making power over both descriptions of traffic. Undoubtedly-in the absence of a finding by the Commission of unjust discrimination-intrastate rates were left to be fixed by the carrier and subject to the authority of the states or of the agencies created by the states. This was the question recently decided by this court in the Minnesota Rate Cases, supra. * * The present question, however, was reserved the court saying (230 U. S. p. 4I9) :- 'It is urged, however, that the words of the proviso' (referring to the proviso above-mentioned) 'are susceptible of a construction which would permit the provisions of section three of the Act, prohibiting carriers from giving an undue or unreasonable preference or advantage to any locality, to apply to unreasonable discriminations between localities in different states, as well when arising from an intrastate rate as compared with an interstate rate as when due to interstate rates exclusively. If it be assumed that the statute should be so construed, and it is not necessary now to decide the point, it would inevitably follow that the controlling principle governing the enforcement of the Act should be applied to such cases as might thereby be brought within its purview; and the question whether the carrier, in such a case, was giving an undue or unreasonable preference or advantage to one locality as against another, or subjecting any locality to an undue or unreasonable prejudice or disadvantage, would be primarily for the investigation and determination of the Interstate Commerce Commission and not for the courts.'

"Here, the Commission expressly found that unjust discrimination existed under substantially similar conditions of transportation and the inquiry is whether the Commission had power to correct it. We are of the opinion that the limitation of the proviso in section one does not apply to a case of this sort. The Commission was dealing with the relation of rates injuriously affecting, through an unreasonable discrimination, traffic that was interstate. The question was thus not simply one of transporta- 
from discriminations arising from the intrastate rates in force in Texas.

State Regulations.-Under the Act to regulate commerce the Commission was not authorized to prescribe intrastate rates.

tion that was 'wholly within one state.' These words of the proviso have appropriate reference to exclusively intrastate traffic, separately considered; to the regulation of domestic commerce, as such. The powers conferred by the Act are not thereby limited where interstate commerce itself is involved. This is plainly the case when the Commission finds that unjust discrimination against interstate trade arises from the relation of intrastate to interstate rates as maintained by a carrier subject to the Act. Such a matter is one with which Congress alone is competent to deal, and in view of the aim of the Act and the comprehensive terms of the provisions against unjust discrimination, there is no ground for holding that the authority of Congress was unexercised and that the subject was thus left without governmental regulation. It is urged that the practical construction of the statute has been the other way. But, in assailing the order, the appellants ask us to override the construction which has been given to the statute by the authority charged with its execution, and it cannot be said that the earlier action of the Commission was of such a controlling character as to preclude it from giving effect to the law. The Commission, having before it a plain case of unreasonable discrimination on the part of interstate carriers against interstate trade, carefully examined the question of its authority and decided that it had the power to make this remedial order. The Commerce Court sustained the authority of the Commission and it is clear that we should not reverse the decree unless the law has been misapplied. This we cannot say; on the contrary, we are convinced that the authority of the Commission was adequate.

"The further objection is made that the prohibition of section three is directed against unjust discrimination or undue preference only when it arises from the voluntary act of the carrier and does not relate to acts which are the result of conditions wholly beyond its control. East Tennessee, etc., Ry. Co. v. Interstate Commerce Commission, I8I U. S. I, I8, 45 L. Ed. 7I9, 21 Sup. Ct. 5I6. The reference is not to any inherent lack of control arising out of traffic conditions, but to the requirements of the local authorities which are assumed to be binding upon the carriers. The contention is thus merely a repetition in another form of the argument that the Commission exceeded its power; for it would not be contended that local rules could nullify the lawful exercise of Federal authority. In the view that the Commission was entitled to make the order, there is no longer compulsion upon the carriers by virtue of any inconsistent local requirement. We are not unmindful of the gravity of the question that is presented when state and federal views conflict. But it was recognized at the beginning that the nation could not prosper if interstate and foreign trade were governed by many masters, and, where the interests of the freedom of interstate commerce are involved, the judgment of Congress and of the agencies it lawfully establishes must control." 
And in the absence of a finding of unjust discrimination by the Commission intrastate rates were left to be fixed by the carrier, subject of course to the authority of the states or the agencies created by the states. The Supreme Court has held that a state may prohibit any unjust discrimination by an intrastate or domestic railroad against any locality upon its lines, and may enpower a state railroad commission to determine whether rates fixed by such roads are discriminatory. ${ }^{10} \mathrm{~A}$ rate which is in it-

Io Portland Railway, Light and Power Co. v. Oregon Railroad Commission, 229 U. S. 397,57 L. Ed. I248, 33 Sup. Ct. 820, where the court said:- "The authority of the states to control by appropriate legislation the rates of fare to be charged by street railway companies and other common carriers wholly within their borders and subject to their laws is unquestionable. In the legitimate exercise of such authority we see no reason why a state may not consistently with due process of law prohibit any unjust discrimination by a domestic railroad company against certain localities upon its lines. If the state may not thus legislate as to its domestic corporations they, by merely arbitrary action, may so exercise their rate fixing power as to build up one community and destroy another, and prevent that equality of treatment which it has been the object of many statutes of this kind, passed under state and federal authority, to secure. The statute does not define unjust discrimination, but leaves it to the Commission, upon hearing, to determine what rates are unjust and discriminatory, and to make orders for other fares, which in its judgment are not open to such objection. The statute expressly provides for a judicial review by the courts of the orders of the Commission to test the lawfulness of the fares fixed and the reasonableness of regulations prescribed by the Commission. We find nothing in the 14 th Amendment which prevents a state from making provision for such relief to communities unjustly discriminated against by companies subject to the laws of the state in which they operate and from which they derive their powers as common carriers and public service corporations.

"Nor do we understand the Supreme Court of Oregon to have construed the statute as permitting no consideration, in determining the question of discrimination, of the circumstances and conditions which may justify differences in rates, other than the number of miles which passengers are carried, as contended by the plaintiff in error. For, upon rehearing, this contention was noticed and the Supreme Court remarked that in the opinion in the case, notwithstanding it was said that the fares were not reasonable when compared with the charges made by other railway companies for similar services, the court had held that the law extended to charges which were 'unreasonable or unjustly discriminatory'; and it was said:-

" "The fact that a rate is per se reasonable does not disprove the charge that it is unlawful, say Messrs. Beale and Wyman in their work on Railroad Regulations, at section 839 . 'If rates are relatively unjust, so that undue preference is afforded to one locality or undue prejudice results to another, the law is violated and its 
self reasonable and lawful may yet be illegal if discriminatory against a shipper or locality. In other words the fact that a rate is per se reasonable does not prevent its being unlawful. The issue turns upon whether the rates are relatively just or unjust in according an undue preference to one locality or inflicting an improper prejudice against another locality.

The purpose of such legislation, state as well as national, is naturally to prohibit an arbitrary exercise of the rate making power of railroads so as to build up one community at the cost of destroying another.

Natural or Artificial Differences Permitting Discriminations.-Where the circumstances and conditions of different shipping points vary there is no unjust preference in allowing certain advantages to shippers or consignees in one town not enjoyed by those of another or neighboring town; as where, for example, a carrier, in meeting competition from another road, furnishes cartage free of charge to the merchants of one town, but does not render any similar service for another town a short distance away on the same line. ${ }^{11}$

Matters of this nature are within the discretion of the Interstate Commerce Commission which may determine whether such service is proper or whether under the peculiar circumstances of the case it constitutes an undue preference or unjust discrimination.

In the words of the Supreme Court the Act to Regulate Commerce "does not attempt to equalize fortune, opportunities or

penalties incurred, although the higher rate is not in itself excessive.' The question presented for consideration is not the reasonableness per se of the charge, but its reasonableness considered in relation to charges made by plaintiff at other localities on its system for like and contemporaneous service; for the statute, as we have construed it. forbids undue preference or discrimination between localities. Circumstances, however, may so explain the difference between rates compared as to deprive the lower rate of any bearing on the higher, but the discrimination, without an excuse recognized by the law, would be in and of itself unjust and unreasonable. Beale and Wyman, section 838.'

To the same effect, Portland Railway, Light and Power Co. v. Oregon Railroad Commission, 229 U. S. 4I4, 57 L. Ed. I259, 33 Sup. Ct. 827.

it Interstate Commerce Commission v. Detroit, Grand Haven and Milwaukee Railway Co., I67 U. S. 633, 42 L. Ed. 310, 17 Sup. Ct. 957. Here in order to meet the competition of another railroad the carrier furnished delivery cartage free to the merchants of one town upon its line but it did not furnish similar service to the merchants of another town on the same line some thirty miles distant. 
abilities."12 And so where, for example, a producer of oil ships in barrels rather than by tank cars, there is no discrimination in charging proper rates for the shipment of oil and including therein a charge for the carriage of the barrels-where such charge was not excessive-and charging for the carriage of the oil only when shipped in tank cars-no extra charge being made for hauling the cars in which the oil is shipped; provided of course those who shipped by barrels made no demand upon the carrier for tank cars. ${ }^{13}$

I2 Interstate Commerce Commission v. Diffenbaugh, 222 U. S. 42,56 L. Ed. 83,32 Sup. Ct. 22.

I3 Penn Refining Co. v. Western New York and Pennsylvania Railroad Co., 208 U. S. 208 , 52 L. Ed. 456, 28 Sup. Ct. 268 . Here the shippers complained that a charge was made for carrying barrels in which the oil was transported but no charge was made for hauling tank cars in which other shippers forwarded their oil, it being claimed that the charge for the barrels resulted in a discrimination against such shippers. The shippers, lowever, had not applied to the railroad for tank cars and moreover their shipments were of such a nature that tank cars could not have been used in handling them. The court said:-

"This limits the case against the defendants upon the finding of the Commission, to that of discrimination, which was decided to exist under the peculiar circumstances of the case by reason of the charge for the barrel in which the oil was contained, while in tank cars the charge was limited to the oil carried. We will therefore inquire what were the peculiar circumstances, as shown by the evidence, which led the Commission to make its order as to discrimination.

They were these:

I. That the railroads owned no tank cars.

2. That they transported oil in tank cars only for those shippers of oil who owned and furnished such cars. That in the case of oil intended for export by such owners it was sent to ports in New York harbor near Perth Amboy; the seaboard, and not Perth Amboy alone, being the place of competition between the plaintiffs and the Standard Oil Trust and others.

3. That the carrier hired tank cars from the shippers of the oil and paid for them a certain sum, measured by the miles run to and from the place of consignment.

4. That the tank cars, thus hired, were used exclusively to carry the oil of the owners of such cars. Other shippers of oil had their oil carried in barrels, in box cars, and a charge was made for the weight of the barrels containing the oil, while the charge for the oil in tank cars was limited to the amount of oil actually carried.

These facts, in the opinion of the Commission, rendered the case an exception to the usual rule as to the right to charge for the weight of a package as well as its contents. In the view of the Commission, although 
A railroad rate fair on its face and reasonable in itself may in fact be both unfair and unreasonable if it operates to give an advantage to one shipper of which another similarly situated can not avail himself. An illustration of this is frequently found in

it admitted that the transportation in tank cars was more profitable to the carrier in yielding a larger revenue above the cost of service than that in barrels, yet the case was not presented 'of two modes of transportation open indiscriminately to shippers in general, the one at a higher rate than the other, and as to which the shipper may take his choice and pay accordingly, but a case where the cheaper rated and, as claimed by the defendants, the better mode of transportation was open practically to only a particular class of shippers.' When, therefore, as was stated 'the carrier accepts tank cars owned by shippers who can afford to build and furnish them, and has none of his own to furnish to other shippers, but can supply only box cars, in which barrels must be used for oil, the carrier is bound to see that he gives no preference in rates to the tank shipper, and that he subjects the barrel shippers to no disadvantage.'

"These facts also appeared before the Circuit Court, and that court left it to the jury to find from them whether there was 'undue discrimination' in favor of the shipper by tank cars and against the shipper by barrels, although the petition made no such allegation, but only alleged that the rates and charges for the service (66 cents per barrel) were excessive, unjust and unreasonable. Discrimination was not alleged between the tank and the barrel car, for what would seem to be the obvious reason that the plaintiffs could make no use of the tank cars, as they had no facilities for unloading them at Perth Amboy and no vessels to export the oil in bulk, and the trade demand there was for oil in barrels. But, although, without such facilities and not being in position, therefore, to use such cars, the plaintiffs nevertheless demanded that no charge for transportation should be made for the barrel package, although the charge made was a reasonable one, unless a charge for the tank packages was made against those who used tank cars for the carriage of their oil to points adjacent to Perth Amboy, and although the transportation by tank cars was more remunerative to the companies than the transportation by barrels. The whole theory of this discrimination rests upon the alleged failure to furnish tank cars to shippers demanding them, while at the same time the defendants leased tank cars from their owners and used them to carry the oil of such owners exclusively, and yet in this case there has been no such failure, because there has been no demand for such cars by the plaintiffs, who, for the reasons stated had no use for them. ***

"It is, therefore, apparent that the failure of plaintiffs to use tank cars during substantially all the period covered by the reparation order was not owing to a refusal or omission of the defendants to supply them on demand, but because they, the plaintiffs, did not demand and could not use them economically for the transportation of oil to Perth Amboy. The opinion of the Commission must be read with reference to this evidence, which, although given on the trial before the court, states the facts exist- 
the payment of elevator charges for services rendered by shippers in the transportation of grain. Such payments should constitute only a reasonable compensation for the services rendered and the instrumentalities furnished by the owners of the property shipped. Contracts by railroads with owners of elevators

ing at Perth Amboy during the time of investigation by the Commission. If it be assumed that it was the duty of the railroads to furnish tank cars to those who demanded them while the railroads continued to hire that kind of car from owners in which to carry their oil, yet the failure to furnish them to a party that did not desire and had not demanded them certainly ought not to render it necessary for the railroads to carry the harrel package free because no charge was made for the tank package. The Commission said it may be conceded that the amount of paying freight was materially greater in tank than in barrel shipments, and that the tank car, after adding the gross weight of the car and oil, pays slightly more to the carrier per ton than the stock car with its full load of oil barrels. Nevertheless it was stated that the facts already adverted to made out a case of unjust discrimination between the tank and barrel shipper, and it was so adjudged in this case where a shipper did not use or demand a tank car.

"We are unable to concur in this view. Because circumstances existed which prevented the economical use of the tank car by plaintiffs (no demand being made for the use of a tank car) is no ground for finding discrimination in the charge for the weight of the barrel package, (such cliarge being in itself not an unreasonable one), while none is made for the tank containing the oil. It might be different if plaintiffs desired tank cars and defendants failed to furnish them on demand. If the carrier must take off such cliarge for the weight of the barrel, although tank cars are not demanded, the result is to make the defendants carry the barrels free from freight charges, even while the shippers were unable to use and did not demand tank cars.

"It is not incumbent, therefore, upon this court to now decide what would be the duty of the carrier as to furnishing tank cars to those who desired and demanded but did not own them, where the railroads accepted tank cars, owned by other shippers of oil, for the purpose of carrying their oil alone, and to different points than Perth Amboy. We are dealing with a case where such question does not arise. There are other reasons in addition to the foregoing why the Lehigh Valley should not be held for any discrimination in this case. That company was but a connecting carrier and took the cars as they were delivered to it by the initial carrier at Buffalo for transportation to Perth Amboy. It was the duty of the connecting carrier to do so, and it was not rendered liable for any alleged wrongful act of the initial carrier merely because of the adoption of a joint through rate from Titusville or Oil City to Perth Amboy, which was in itself reasonable. Nor did the 8 th section of the Commerce Act render it liable for any such alleged wrongful act asserted against the initial carrier." 
for the elevation of their own grain at transshipment points at reasonable rates do not constitute an illegal discrimination or rebate even though such owners at the same time may have also performed services to their own advantage and beyond those for which they are paid by the carriers. However, such payments of allowances must be made in good faith and for the services actually rendered by the shippers, and must not, either directly or indirectly, constitute a discrimination or a rebate. The carriers must treat all shippers alike and must pay the same compensation to all shippers who render the same services. ${ }^{14}$

I4 Interstate Commerce Commission $\therefore$ Diffenbaugh, 222 U. S. 42, 56 L. Ed. 83, 32 Sup. Ct. 22. The court here said: "The ground on which the payment to owners of grain finally was held to be a rebate had been considered from the beginning and, as we have said, had been brought to the mind of Congress. It is that when the owners of the elevators own the grain put into them they have the opportunity to perform other services to the grain in the way of treatment, or cleaning. clipping, and mixing the grain, which although not included under the term elevation or paid for hy the railroad, it is an advantage to them to be able to perform at the same time. This advantage is thought to create an undue preference and unjust discrimination. Of course the opportunities for fraud are adverted to, but the ground of the decision is that even an honest payment of the bare cost of elevating grain in transit gives an undue advantage if the elevator owner also owns the grain. As was pointed out by the court below the final order is confined to grain that has been treated, weighed, inspected, or mixed.

"We agree with the court below that this decision is erroneous in its conception of the grounds on which under the statute an advantage may be pronounced undue, and in its assumption that Congress has left the matter open by merely permissive words. The principle as to advantages is recognized in Penn Refining Co. v. Western New York \& Pennsylvania R. R. Co., 208 U. S. 208, 221, 52 L. Ed. 456, 28 Sup. Ct. 268. The law does not attempt to equalize fortune, opportunities or abilities. On the contrary the Act of Congress in terms contemplates that if the carrier receives services from an owner of property transported, or uses instrumentalities furnished by the latter, he shall pay for them. That is taken for granted in sec. 15; the only restriction being that he shall pay no more than is reasonable, and the only permissive element being that the Commission may determine the maximum in case there is complaint. (or now upon its own motion. Act of June 18, 1910). As the carrier is required to furnish this part of the transportation upon request he could not be required to do it at his own expense, and there is nothing to prevent his hiring the instrumentality instead of owning it. In this case there is no complaint that the rate out of which the allowance is made is unreasonable, and it is admitted that three-quarters of a cent barely would pay the cost of the service rendered without any rea- 
It must be noted that a connecting carrier which merely takes the cars delivered to it by the initial carrier is not rendered liable for a discrimination of the initial carrier merely because of the adoption of a joint through rate which is in itself reasonable. ${ }^{15}$

Discriminations in Wharfage Rights and Facilities.-Railroads may be guilty of unjust and improper discriminations to shippers in the use of wharfage rights and facilities. And the Interstate Commerce Commission has the power to regulate the charges of a terminal company which controls wharves and is a portion of a common carrier under the terms of the Act, so as to prcient undue discriminations and hardship. Thus, for example, it is a violation of section 3 for a carrier to lease to one shipper its wharves and buildings if, by so doing, it relieves the carrier from the payment of wharfage and storage charges beyond the amount of the annual rental, and thereby enables him to acquire a monopoly for the export of certain classes of products when other shippers either can not be or are not offered the same facil-

sonable profit to Peavey \& Co. for the work. See Interstate Commerce Commission v. Stickney, 215 U. S. 98, 54 L. Ed. II2, 30 Sup. Ct. 66."

See also Union Pacific Railway Co. v. Updike Grain Co., 222 U. S. 215, 56 L. Ed. I7I, 32 Sup. Ct. 39, where the court said: "The Union Pacific's desire to have cars promptly unloaded so that they might be returned to its own line may have been the principal motive which induced it to agree to pay elevator charges. But the consideration, moving between the carrier and the elevator, was the service performed by the latter in unloading grain at terminal points. This relieved the carricr of the expense of building similar structures and avoided the delay of having the grain transferred from one car to another by the slow process of shovelling. When the service was rendered, the carrier received value for which it was bound to pay, whether performed by the owner of the grain or some other person hired for the same purpose. *** The carrier cannot pay one shipper for transportation service and enforce an arbitrary rule which deprives another of compensation for similar service. To receive the benefit of such work by one elevator without making compensation therefor would, in effect, be the involuntary payment by such elevator of a rebate to the railroad company, for it would enable the railroad to receive more net freight on its grain than was received from its competitor located on the railroad's tracks. This cannot be directly done, nor indirectly by means of regulation. A rule apparently fair on its face and reasonable in its terms may, in fact, be unfair and unreasonable if it operates so as to give one an advantage of which another similarly situated cannot avail himself."

I5 Penn Refining Co. v. Western New York \& Pennsylvania Railroad Co., 208 U. S. 208, 52 L. Ed. 456, 28 Sup. Ct. 268, supra. 
ities under similar conditions. Manifestly such an arrangement permits the shipper to eliminate certain charges, such as the cost of cartage, and thereby constitutes a direct advantage to him and a handicap to his competitors. ${ }^{16}$ But there is no discrimination where all shippers are given the privilege of using wharves and their incidental facilities upon equal terms with one another.

Rates on Manufactured and Unmanufactured Articles.The transportation of a manufactured article at a rate lower than for similar shipments of raw materials does not constitute an undue discrimination against a manufacturing community provided the rate is in itself reasonable. For example, a higher rate for the transportation of live stock than for shipments of dressed meats and packing products does not constitute an unjust discrimination against a packing house center such as Chicago. Manifestly the transportation of live stock involves certain care and attention, such as feeding and watering stock in transit and liability for injuries, not required for the shipment of dressed meats. ${ }^{17}$

16 Southern Pacific Terminal Co. v. Interstate Commerce Commission, 219 U. S. 498, 55 L. Ed. 310, 3I Sup. Ct. 279. Here the court said: "Two facts are prominent in the case, that the piers of the Terminal Company are facilities of import and export traffic at the port of Galveston and that the arrangement of the Terminal Company with Young has enabled him to largely and rapidly increase his business until his exports of cotton seed products are more than twice those of all other competitiors, that he derives therefrom 30 to 40 cents per ton over the ordinary buying and selling profit, and that some who were his competitors have ceased to export. A direct advantage to Young is manifest. A direct detriment to other exporters is equally manifest. *** An absolute advantage to Young cannot be denied. A facility that has enabled him to acquire practically all the export of cotton seed products must have something in it of advantage which other shippers do not receive, and it would seem to proclaim a power working for his benefit which is not working for others. * * * And the Commission found that as a practical matter other shippers could not be given the same facilities on the same conditions as those granted to him, nor could such facilities be secured on the bay front. It was further found that the Terminal Company had indicated that it is not willing to accord shippers generally such facilities, and that the situation of its docks with respect to space was such that it cannot do so even if it should be willing. It may be contended that the patrons of a railroad are not obliged to seek or compete for extraordinary facilities in its terminals. But, be that as it may, all shippers must be treated alike."

I7 Interstate Commerce Commission v. Chicago Great Western Railway Co., 209 U. S. 108, 52 L. Ed. 705, 28 Sup. Ct. 493, where the court 
Discrimination in Car Service.-No field offers such varied opportunities for discrimination and undue preferences by the railroad companies as that of furnishing cars for the shipment of the products of mines, factories and fields. Under the sweeping provisions of the third section of the Act prohibiting preferences and discriminations, the Interstate Commerce Commission is empowered to so regulate the distribution of railroad cars as to prevent one shipper or locality from being given an advantage over another. This feature of section 3 should be considered in con. nection with that provision of section $\mathrm{I}_{5}$, as amended by the Hepburn Act of 1906, giving to the Interstate Commerce Commission

said: "But the burden of complaint is not that any rates taken by themselves were too high, but that the difference between those on live stock and those on dressed meats and packers' products worked an unjust discrimination. It is insisted that, "the making of the live-stock rate higher than the product rate is violative of the almost universal rule that the rates on raw material shall not be higher than on the manufactured product.' This may be conceded, but that the rule is not universal the proposition itself recognizes, and the findings of the court give satisfactory reasons for the exception here shown. See findings 2,3 , and 9 . The cost of carriage, the risk of injury, the larger amount which the companies are called upon to pay out in damages make sufficient explanation. They do away with the idea that in the relation established between the two kinds of charges any undue or unreasonable preference was intended or secured. *** If the rates complained of have not materially affected any of the markets, prices, or shipments; if they are reasonably fair to Chicago and the shippers; if the shipments of live stock from the West to Chicago are as great in proportion to the bulk of the business as before the present rates were made, and the lower rate given to the packers does not directly influence or injure the shippers of live stock; it is difficult to see what foundation there can be for the claim of an undue and unreasonable preference. It would seem a fair inference from the findings that the real complaint was that the railroad companies did not so fix their rates as to help the Chicago packing industry; that they recognized the fact that along the Missouri river had been put up large packinghouses, and, withous any intent to injure Chicago, had fixed reasonable rates for the carrying of live stock to such packinghouses and also to Chicago; that those packinghouses being nearer to the cattle-fields were able to engage in the packing industry as conveniently and successfully as the packinghouses in Chicago. If we were at liberty to consider the mere question of sentiment, certainly to place packinghouses close to the cattle fields, thus avoiding the necessity of long transportation of the living animals-a transportation which cannot be accomplished without more or less suffering to them-and to induce transportation to those nearer packinghouses would deserve to be commended rather than condemned." 
the power to issue orders and supervise the charges, allowances and regulations of various sorts of common carriers subject to the Act. Thus the Commission may regulate the distribution of coal cars in times of car shortage, and although a carrier may not be at fault in failing to deliver all the cars called for in times of shortage, provided its equipment is sufficient to meet the demand under normal conditions, it will be required to equitably distribute its cars of all classes so that no particular shipper may enjoy an unfair advantage on the one hand, or be subjected to an undue discrimination on the other. ${ }^{18}$ These regulations are within the jur-

I8 Interstate Commerce Commission v. Illinois Central Railroad Co., 215 U. S. 452,54 L. Ed. 280,30 Sup. Ct. 155. Here the court said: "In view of the facts found by the Commission as to preferences and discriminations resulting from the failure to count the company fuel cars in the daily distribution in times of car shortage, and in further view of the far-reaching preferences and discriminations alleged in the answer of the Commission in this case, and which must be taken as true, as the cause was submitted on bill and answer, it is beyond controversy that the subject with which the order dealt was within the sweeping provisions of section 3 of the Act to Regulate Commerce prohibiting preferences and discriminations. But it is contended that although this be the case, as the order of the Commission not only forbade the preferences and discriminations complained of, but also commanded the establishment of a rule, excluding such discriminations for a future definite period of not exceeding two years, the order transcended the authority conferred upon the Commission. This proceeds upon the assumption that section 15 of the Act to Regulate Commerce, as enacted by the Act of June 29, I906, while conferring upon the Commission the authority, upon complaint duly made, to declare a rate or practice affecting rates illegal, and to establish a new and reasonable rule or practice affecting such rates for a term not exceeding two years, has no relation to complaints concerning preferences or discriminations, unless such practices, when complained of, are of a character to affect rates, which it is insisted is not here the case. $* * *$

"We do not stop to critically examine the provision relied upon for the purpose of pointing out, as a matter of grammatical construction, the error of the contention, because we think, when the text of the section is taken into view and all its provisions are given their natural significance it obviously appears that the construction relied upon is without foundation, and that to sustain it would be to frustrate the very purpose which it is clear, when the entire provision is considered, it was designed to accomplish, and thus would be destructive of the plain intent of Congress in enacting the provision. The antecedent construction which the Interstate Commerce Commission Act had necessitated and the remedial character of the amendments adopted in 1906, all serve to establish the want of merit in the contention relied upon. In addition, to adopt it would require us to hold that Congress, in enlarging the power 
isdiction of the Interstate Commerce Commission and being administrative in their nature, they are not subject to judicial supervision until the Commission has been afforded an opportunity to make proper investigation and issue orders based thereon. And such power of review as may be exercised by the courts is limited to the question of whether the Commission has the power to make an order and not the wisdom of the order. This subject is discussed at length under the proper headings of section I $_{5}$.

Railroad Shipments.-While railroads will not be permitted to discriminate in favor of one shipper or locality as against another, neither will they be permitted to discriminate in favor of themselves. They will not be permitted to charge a lower rate on shipments of the same commodities to the same points when made by railroads, than they charge other shippers. A railroad company cannot be placed on the same basis as a locality and thus be entitled to preferential rates in order to meet or accommodate competitive conditions. Thus, for example, it would be an illegal preference and discrimination under section 3 to permit an interstate carrier to charge a different and a lower rate for the transportation of railroad fuel coal between two points than for the

of the Commission over rates, had so drafted the amendment as to cripple and paralyze its power in correcting abuses as to preferences and discriminations which, as this court has hitherto pointed out, it was the great and fundamental purpose of Congress to further."

In Pennsylvania Railroad Co. v. International Coal Mining Co., $230 \mathrm{U}$. S. 184,57 L. Ed. 1446, 33 Sup. Ct. 893, the court said: "Under the statute there are many acts of the carrier which are lawful or unlawful according as they are reasonable or unreasonable, just or unjust. The determination of such issues involves a comparison of rate with service, and calls for an exercise of the discretion of the administrative and rate-regulating body. For the reasonableness of rates, and the permissible discrimination based upon difference in conditions are not matters of law. So far as the determination depends upon facts, no jurisdiction to pass upon the administrative questions involved has been conferred upon the courts. That power has been vested in a single body so as to secure uniformity and to prevent the varying and sometimes conflicting results that would flow from the different views of the same facts that might be taken by different tribunals."

To the same effect see also Baltimore \& Ohio Railroad Co. v. Pitcairn Coal Co., 215 U. S. 48I, 54 L. Ed. 292, 30 Sup. Ct. I64; Robinson v. Baltimore \& Ohio Railroad Co., 222 U. S. 506, 56 L. Ed. 288, 32 Sup. Ct. II4; Morrisdale Coal Co. v. Pennsylvania Railroad Co., 230 U. S. 304, 57 L. Ed. I494, 33 Sup. Ct. 938; Mitchell Coal Co. v. Pennsylvania Railroad Co., 230 U. S. 247,57 L. Ed. I472, 33 Sup. Ct. 916. 
transportation of commercial coal between the same or similar points. ${ }^{19}$

I9 Interstate Commerce Commission v. Baltimore \& Ohio Railroad Co., 225 U. S. 326, 56 L. Ed. I107, 32 Sup. Ct. 742. The court here said: "In its most abstract form the simple statement of the controversy is whether the companies may charge a different rate for the transportation of fuel coal to a given point than for the transportation of commercial coal to the same point. But when we depart from the abstract, complexities appear and attention is carried beyond the consideration of points equally distant, shippers equally circumstanced and traffic affected by similar circumstances and conditions. It is asserted that there are disparities between the traffics and qualifying circumstances which the Commission disregarded and, in error, held that traffic in fuel coal could not be distinguished from the traffic in commercial coal. The Commission insists upon the simplicity of the problem and contends that there is nothing in the conditions of the traffic which dispenses with the clear legal duty of the companies under the Interstate Commerce Act to carry for all shippers alike. * * * The issue of principle between the Commission and the companies is very accurately presented, and we come to consider whether there are differences in the traffic of fuel coal which distinguish it from traffic in commercial coal, and which, as contended by the companies, make the traffic dissimilar in circumstanes and conditions, or whether the opposite is true, as decided by the Commission.

"Tariffs are but forms of words, and certainly the Commission, in the exercise of its powers to administer the Interstate Commerce Act, can look beyond the forms to what caused them and what they are intended to cause and do cause. There are other contentions or rather phases of those that we have considered and which seek to further emphasize the strength of competition as a circumstance or condition differentiating the traffic. For instance, it is urged that the shipment of the fuel coal to a particular railroad 'for the use of that railroad' makes special the traffic. And, further, that 'a railroad is not a person,' but is 'rather in the nature of a geographical division and extends through long distances.' Pushing the argument or illustrations farther, it is urged that a railroad company may be distinguished from the physical thing, the railroad itself, and may be a locality where a commodity is used, like 'a river, a country or a city,' and be entitled to preferential rates to accommodate com. petitive conditions. The Import Rate Case, 162 U. S. 197, is invoked as analagous. We cannot accept the likeness nor the distinctions which are said to establish it. The railroad company cannot be put out of view as a favored shipper, and we see many differences between such a shipper receiving coal for use in its locomotives and a nation as the destination of goods from other nations for distribution throughout its expanse on through rates from points of origin."

See also New York, New Haven and Hartford Railroad Co. v. Interstate Commerce Commission, 200 U. S. 36I, 50 L. Ed. 515, 26 Sup. Ct. 272. 
Demurrage Charges.-The Supreme Court has upheld the exaction of demurrage charges on cars privately owned and leased by the carriers in order to keep such cars in constant use. ${ }^{19 a}$ And such an exaction does not constitute an arbitrary or unjust discrimination.

Transit Charges and Privileges.-While the railroads may extend to shippers the right of milling grain or otherwise performing incidental services affecting shipments in transit, these privileges must be extended to all shippers and localities upon equal terms so as not to confer an undue preference upon some localities, or create any unjust discrimination between individual shippers. This applies also to charges made for the reconsignment of shipments in transit. In this connection the railroads are not limited to charging the actual cost of the privileges extended but they are entitled to make a reasonable profit therefrom. ${ }^{20}$

Preferences in Through Routing.-Prior to the amendments of 1906 and 1910 the Supreme Court held that a regulation of

I9a Proctor and Gamble v. United States, 225 U. S. 282, 56 L. E.d. 109I, 32 Sup. Ct. 76I.

20 Southern Railway Co. v. St. Louis Hay and Grain Co., 214 U. S. 297, 53 L. Ed. 1004, 29 Sup. Ct. 678, where the court said: "It thus appears that the Commission was of the opinion that the shipper could not demand as a matter of right the stopping of the hay for the purposes of treatment or re-consignment unless the same privilege was given to other shippers, and that, in granting this privilege, the railway company could only charge the shipper the actual cost. But this privilege involved to the railway company the cost of hauling to and from the warehouses and the use of the car for some hours, perhaps days. The Commission found that $\$ 2$ or $\$ 2.50$ per car, or approximately one cent per hundred pounds, was the actual cost to the railway company.

"We are unable to concur with the Commission. If the stopping for inspection and reloading is of some benefit to the shipper and involves some service by and expense to the railway company, we do not think that the latter is limited to the actual cost of that privilege. It is justified in receiving some compensation in addition thereto. A carrier may be under no obligations to furnish sleeping or other accommodations to its passengers, but if it does so it is not limited in its charges to the mere cost but may rightfully make a reasonable profit out of that which it does furnish. Especially is this true when, as here, the privilege is in no sense a part of the transportation, but outside thereof. Whether the conclusion of the Commission that the carrier is under no obligations to permit the interruption of the transit is right, and whether it is or is not under such obligation, it is entitled to receive some compensation beyond the mere cost for that which it does." 
carriers reserving the right of determining the routing of shipments beyond their own lines as a condition of making through rates did not constitute a discrimination under the provisions of section 3 and not being violative of any other section of the Act was not illegal or improper. ${ }^{21}$ Of course this rule must be so enforced as not to create any discriminations between shippers.

2 I Southern Pacific Company v. Interstate Commerce Commission, 200 U. S. 536, 50 L. Ed. 585, 26 Sup. Ct. 330. The court here said: "The single question presented is, has the carrier that takes the fruit from the shipper in California the right, under the facts herein, to insist upon the rule permitting such carrier to route the freight at the time it is received from the shipper? The Commission has decided that the carrier has not the right, and that the rule denies to shippers the use of their transportation facilities, which such shippers are entitled to, and that in its application, by the initial carriers to the fruit traffic, the shippers are subjected to undue, unjust and unreasonable prejudice and disadvantage, and the carriers are given an undue and unreasonable preference and advantage. If this be the necessary effect of the rule, it may be assumed to be a violation of section 3 of the Interstate Commerce Act and the Commission, therefore, rightly ordered the carriers to desist from observing it.

"We cannot see that the ruie violates the third section of the Act. All the facts referred to by the Commission are nothing but statements as to how, under such a rule, there might occur a violation of that section, but we find nothing in the facts stated by the Commission, showing that such violation had occurred. In truth, the companies did not always even enforce the rule, still less did they discriminate against shippers or in favor of carriers. On the contrary, the Commission stated that "while the initial carriers do not always route as requested by the shippers, they generally comply with their request.' The mere failure to do so does not, however, prove a violation of the section. The right to route is also complained of because the rule confined it to the fruit business, and therefore it was, as contended, a discrimination against those engaged in it or against the traffic itself. The transportation oi this fruit is a special business, large interests are involved in it, and particular pains are taken to transport it as speedily as possible. With regard to all other freight it has substantially nothing in common. The cases are wholly unlike, and there has been no proof or complaint as to rebates being given in connection with other freight, and the witnesses for the railroad state if there were any evidence or complaint of such rebates, the same rule as to routing would be immediately adopted. As has been said, there is no pretense of discrimination under this rule between the shippers of freight themselves. There seems to be unanimous agreement that all shippers are treated alike and are granted the same privileges, and the routing is generally accorded them. It is the power to route, which rests with the initial carrier, that really takes away the motive for a rebate in the manner indicated, and, therefore, the granting of the request of the 
Lighterage Allowances.-Railroads establishing a free delivery zone, for shipments of freight over their lines, may pay a reasonable compensation to shippers for lightering freight within such zone to the railroad terminals without allowing similar compensation to shippers whose plant is situated beyond the limits of such free zone. This compensation is a proper allowance for instrumentalities furnished and services performed by shippers in aid of transportation by the railroads and does not constitute an allowance for accessorial services which would create an illegal preference or discrimination under section 3 unless accorded to other shippers. ${ }^{22}$

Use of Track and Terminal Facilities.-Under the last clanse of the third section carriers are specifically declared not to be required to give the use of their tracks or terminal facilities to other carriers engaged in like business. Otherwise, any road desiring to enter a large city, by making a physical connection with a road already ruming into such city, could secure the use of the costly terminals of the latter road and require it to do the switching requisite to that end by merely paying for the service of carriage. ${ }^{23}$ Such a requirement would constitute an unlawful taking

shipper as to a particular route may be, and is, generally conceded without danger that the rebate business may be again practiced.

"The important facts that control the situation are that the carrier need not agree to carry beyond its own road, and may agree upon joint through tariff rates or not, as seems best for its own interests. Having these rights of contract the carrier may make such terms as it pleases, at least so long as they are reasonable and do not otherwise violate the law. We think the routing rule is not unreasonable under the facts herein and that it does not violate the third section of the Act. Because opportunities for the violation of the Act may occur, by reason of the rule, is no ground for holding as a matter of law that violations must occur, and that the rule itself is therefore illegal. We are, consequently unable to concur in the view taken by the Commission that the rule violates the third section of the Act."

22 United States v. Baltimore and Ohio Railroad Co., 231 U. S. 274, 58 L. Ed. 218, 34 Sup. Ct. 75.

23 Louisville and Nashville Railroad Co. v. Central Stock Yards Co., 212 U. S. 132, 53 L. Ed. 441, 29 Sup. Ct. 246. A provision of the Constitution of the state of Kentucky required a carrier to deliver its cars to a connecting carrier. The court said: "There remains for consideration only the third division of the judgment, which requires the plaintiff in error to receive at the connecting point, and to switch, transport and deliver all live stock consigned from the Central Stock Yards to any one at the Bourbon Stock Yards. This also is based upon the sections of 
of property within the comprehension of the fifth or fourteenth amendment to the Constitution.

The Supreme Court has held that Congress has not so taken over the whole subject of terminals, switching tracks, sidings, etc., of interstate railways as to invalidate all state regulations governing the interchange of traffic. And a railway company may by state statute be compelled to receive and transport at reasonable rates loaded cars between junction points with other carriers within certain corporate limits and its own team tracks and between such team tracks and industrial sidings on its own line. ${ }^{24}$

Classification of Property.-Under the amendment of June I8, I9Io, to section one of the Act it was made the duty of all common carriers subject to the provisions of the Act to establish, observe and enforce just and reasonable classifications of property for transportation with reference to which rates, tariffs, regulations or practises are or may be made or prescribed, and just and reasonable regulations and practises affecting classifications, etc., and every unjust and unreasonable classification is prohibited and declared unlawful. In 1907, prior to the amendment of 1910 thus outlined, the Supreme Court held that the Interstate Commerce Commission had the power to consider the whole subject and the operation of a new classification in the entire territory for

the Constitution that have been quoted. If the principle is sound every road into Louisville, by making a physical connection with the Louisville and Nashville, can get the use of its costly terminals and make it do the switching necessary to that end, upon simply paying for the service of carriage. The duty of a carrier to accept goods tendered at its station does not extend to the acceptance of cars offered to it at an arbitrary point near its terminus by a competing road, for the purpose of reaching and using its terminal station. To require such an acceptance from a railroad is to take its property in a very effective sense, and cannot be justified, unless the railroad holds that property subject to greater liabilities than those incident to its calling alone." See also Central Stock Yards v. Louisville \& Nashville Railroad, 192 U. S. 568, 48 L. Ed. 565, 24 Sup. Ct. 339. Pennsylvania Co. v. United States, decided February 23, 1915.

24 Grand Trunk Railway Co. v. Michigan Railroad Commission, 23I U. S. 457, 58 L. Ed. 310, 34 Sup. Ct. 152, where the court said: "We will not dwell on the contention of appellants that Congress has taken over the whole subject of terminals, team tracks, switching tracks, sidings, etc. We need make no other comment than that it cannot be asserted as a matter of law that Congress has done so; and where the accommodation between intrastate and interstate traffic shall be made, we are not called upon to say on this record." See also Illinois Central Railroad Co. v. De Fuentes (La. R. R. Com.), 236 U. S. 157. 
which it was framed, and to consider its conformity to the requirements of the Act to regulate commerce, and how far it would be just and reasonable, would create preferences or engender discriminations. ${ }^{25}$

25 Cincinnati, Hamilton and Dayton Railway Co. v. Interstate Commerce Commission, 206 U. S. 142, 5I L. Ed. 995, 27 Sup. Ct. 648. The Commission had here issued an order directing the carrier to cease from further charging the rate for common soap in less than carload lots operating in the official classification territory, increasing the classification from the fourth to the third class which was declared to create discriminations and preferences among manufacturers and shippers of soap as well as between localities in such territory. The court said: "We think the Commission in making an investigation on the complaint filed by the Proctor \& Gamble Company had the power, in the public interest, disembarrassed by any supposed admissions contained in the statement of complaint to consider the whole subject and the operation of the new classification in the entire territory, as also how far its going into effect would be just and reasonable, would create preferences or engender discriminations; in other words, its conformity to the requirements of the act to regulate commerce. * * * The statute gives prima facie effect to the findings of the Commission, and when those findings are concurred in by the Circuit Court, we think they should not be interfered with, unless the record establishes that clear and unmistakeable error las been committed. * * *

"This brings us to the final contention made on behalf of the railway companies, viz., that the order of the Commission was not lawful, because not within the power conferred by the Act of Congress. This is, we think, largely disposed of by what we have previously said as to the nature and scope of the investigation which the Commission was authorized to make and the redress which it was empowered to give irrespective of the particular character of the complaint by which its power may have been previously invoked. Whatever might be the rule by which to determine whether an order of the Commission was too general where the case with which the order dealt involved simply a discrimination as against an individual or a discrimination or preference in favor of or against an individual or a specific commodity or commodities or localities, or as applied to territory subject to different classifications, and we think it is clear that the order made in this case was within the competency of the Commission, in view of the nature and character of the wrong found to have been committed and the redress which that wrong necessitated. Finding, as the Commission did, that the classification by percentage of common soap in less than carload lots operating throughout Official Classification territory, brought about a general disturbance of the relations previously existing in that territory, and created discriminations and preferences among manufacturers and shippers of the commodity and between localities in such territory, we think the Commission was clearly within the authority conferred by the Act to Regulate Commerce in directing the carriers to cease and desist from further enforcing the classification operating such results." 


\section{SECTION 4. THE LONG AND SHORT-HAUL CLAUSE.}

SEc. 4. (As amended June I8, I9IO.) That it shall be unlawful for any common carrier subject to the provisions of this Act to charge or receive any greater compensation in the aggregate for the transportation of passengers, or of like kind of property, for a shorter than for a longer distance over the same line or route in the same direction, vision haul pro. the shorter being included within the longer distance, or to charge any greater compensation as a through route than the aggregate of the intermediate rates subject to the provisions of this Act; but this shall not be construed as authorizing any common carrier within the terms of this Act to charge or receive as great compensation for a shorter as for a longer distance: Provided, how' ever, That upon application to the Interstate Commerce Conmission such common carrier may in special cases, after investigation, be authorized by the Commission to charge less for longer than for shorter distances for the transportation of passengers or property; and the Commission may from time to time prescribe the extent to which such designated common carrier may be relieved from the operation of this section: Provided, further, That no rates or charges lawfully existing at the time of the passage of this amendatory Act shall be required to be changed by reason of the provisions of this section prior to the expiration of six months after the passage of this Act, nor in any case where application shall have been filed before the Commission, in accordance with the provisions of this section, until a determination of such application by the Commission.

History of the Section.-This section of the Act to Regulate Commerce is in many ways the most important in its effect and its historic interest of all the provisions of this legislation. In the 
original Act, as signed February 4, I887, after the word "property" in the sixth line as given above occurred the clause "under substantially similar circumstances and conditions." By the Act of June 18 , I9I0, this clause was stricken out from the section, the second proviso was added and some other slight changes were made in the text and in the first proviso, including particularly the insertion of the clause forbidding carriers "to cliarge any greater compensation as a through route than the aggregate of the intermediate rates subject to the provisions of this Act.'

During the first twenty-three years of the operation of the Act to Regulate Commerce the construction of this section in fact turned upon the meaning of the clause "under substantially similar circumstances and conditions," upon whether competition might determine or create a dissimilarity of conditions thereunder, and whether the carrier might under such conditions make the larger charge for the shorter distance of its own initiative or whether this charge could be made by the carrier only after investigation by and with the permission of the Interstate Commerce Commission.

In construing this section the Interstate Commerce Commission had ruled that actual competition between roads might create dissimilar circumstances and conditions but that the carrier could not determine this condition itself but must apply to the Commission which, after proper investigation and consideration, should determine whether the instance warranted an exception to the regulation that no greater compensation should be received for a shorter than for a longer distance. In 1897 the Supreme Court declared that competition when it affects rates was one of the most obvious and effective circumstances that make conditions, under which a long and short-haul is performed, substantially dissimilar. The court further declared that whether circumstances and conditions are similar or dissimilar under the

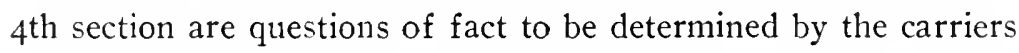
according to the features of each individual case-since from the very nature of the question they are in the first instance better fitted to adjust their rates to suit such circumstances and conditions than courts or commissions-subject of course to review at their peril upon application to the Interstate Commerce Commission and the courts. ${ }^{1}$

I Interstate Commerce Commission v. Alabama and Midland Railway $\mathrm{C}_{0}, 168$ U. S. I44, 42 L. Ed. 4I4, I8 Sup. Ct. 45. This action was based 
The court emphatically declared that the phrase "under substantially similar circumstances and conditions" in the fourth section could not receive the same construction that the same phrase

upon the fact that the Alabama Midland Railway and its connecting lines charged a higher rate for carrying goods to and from Troy, the lesser distance, than for goods carried to and from Montgomery, the longer distance, over the same line. I quote at length from the opinion of the court:

"It is contended, in the briefs filed on behalf of the Interstate Commerce Commission, that the existence of rival lines of transportation and, consequently, of competition for the traffic, are not facts to be considered by the Commission, or by the courts, when determining whether property transported over the same line is carried under 'substantially similar circumstances and conditions,' as that phrase is found in the 4th section of the Act. Such, evidently, was not the construction put upon this provision of the statute by the Commission itself in the present case; for the record discloses that the Commission made some allowance for the alleged dissimilarity of circumstances and conditions, arising out of competition and situation, as affecting transportation to Montgomery and Troy respectively, and that, among the errors assigned, is one complaining that the court erred in not holding that the rates prescribed by Commission in its order made due allowance for such dissimilarity.

"So, too, In Re Louisville and Nashville Railroad, I I. C. C. Rep. 3I, 78, in discussing the long and short haul clause it was said by the Commission, per Judge Cooley, that 'it is impossible to resist the conclusion that in finally rejecting the 'long and short haul clause' of the House Bill, which prescribed an inflexible rule, not to be departed from in any case, and retaining in substance the $4^{\text {th }}$ section as it had passed the Senate, both Houses understood that they were not adopting a measure of strict prohibition in respect to charging more for the shorter than for the longer distance, but that they were instead leaving the door open for exceptions in certain cases, and, among others, in cases where the circumstances and conditions of the traffic were affected by the element of competition, and where exceptions might be a necessity, if the competition was to continue. And water competition was beyond doubt especially in view.'

"It is, no doubt, true that in a later case, Railroad Commission of Georgia v. Clyde Steamship Co., 5 I. C. C. Rep. 326, the Commission somewhat modified their holding in the Louisville and Nashville Railroad Co. case, just cited, by attempting to restrict the competition, that it is allowable to consider, to the cases of competition with water carriers, competition with foreign railroads, competition with railroad lines wholly in a single state; but the principle tlat competition in such cases is to be considered is affirmed.

"That competition is one of the most obvious and effective circumstances that make the conditions under which a long and short haul is performed, substantially dissimilar, and as such must have been in the contemplation of Congress in the passage of the Act to Regulate Com- 
occurring in the second section of the Act to Regulate Commerce must receive. The purposes of the two sections are manifestly different. The phrase "under substantially similar circumstances

merce, has been held by many of the Circuit Courts. It is sufficient to cite a few of the number: Ex parte Koehler, 3I Fed. 315; Missouri Pacific Railway v. Texas and Pacific Railway, 3I Fed. 862; Interstate Commerce Commission v. Atchison, Topeka and Santa Fe R. R., 50 Fed. 295; Interstate Commerce Commission v. New Orleans and Texas Pacific R. R., 56 Fed. 925; Behlmer v. Louisville and Nashville R. R., 7I Fed. 835; Interstate Commerce Commission v. Louisville and Nashville R. R., 73 Fed. 409.

"But the question whether competition as affecting rates is an element for the Commission and the courts to consider in applying the provisions of the Act to Regulate Commerce is not an open question in this court. In Interstate Commerce Commission v. Baltimore and Ohio R. R., I45 U. S. 263,36 L. Ed. 699,12 Sup. Ct. 844 , it was said, approving observations made by Jackson, Circuit Judge, (43 Fed. 37) that the Act to regulate Commerce was "not designed to prevent competition between different roads, or to interfere with the customary arrangements made by railway companies for reduced fares in consideration of increased mileage, where such reduction did not operate as an unjust discrimination against other persons traveling over the road. In other words it was not intended to ignore the principle that one can sell at wholesale cheaper than at retail.'

"In Texas and Pacific Railway v. Interstate Commerce Commission, I62 U. S. 197, 40 L. Ed. 940, I6 Sup. Ct. 666, it was held that 'in passing upon questions arising under the Act, the tribunal appointed to enforce its provisions, whether the Commission or the courts, is empowered to fully consider all the circumstances and conditions that reasonably apply to the situation, and that, in the exercise of its jurisdiction, the tribunal may and should consider the legitimate interests as well of the carrying companies as of the traders and shippers, and in considering whether any particular locality is subjected to an undue preference or disadvantage, the welfare of the communities occupying the localities where the goods are delivered is to be considered as well as that of the communities which are in the locality of the place of shipment; that among the circumstances and conditions to be considered, as well in the case of traffic originating in foreign ports as in the case of traffic originating within the limits of the United States, competition that affects rates should be considered, and in deciding whether rates and charges, made at a low rate to secure foreign freights which would otherwise go by other competitive routes, are or are not undue and unjust, the fair interests of the carrier companies and the welfare of the community which is to receive and consume the commodities are to be considered.'

"To prevent misapprehension, it should be stated that the conclusion to which we are led by these cases, that, in applying the provisions of the $3 \mathrm{~d}$ and 4 th sections of the Act, which make it unlawful for common 
and conditions" in the second section is manifestly restricted to the case of shippers over the same road, thus leaving no room for competition. The purpose of the second section is to en-

carriers to make or give any undue or unreasonable preference or advantage to any particular person or locality, or to charge or receive any greater compensation in the aggregate for the transportation of passengers or of like kind of property, under substantially similar circumstances and conditions, for a shorter than for a longer distance over the same line, in the same direction, competition which affects rates is one of the matters to be considered, is not applicable to the $2 \mathrm{~d}$ section of the Act. As we have shown in the recent case of Wight v. United States, 167 U. S. 512,42 L. Ed. 258 , 17 Sup. Ct. 822, the purpose of the $2 \mathrm{~d}$ section is to enforce equality between shippers over the same line, and to prevent any rebate or other device by which two shippers, shipping over the same line, the same distance, under the same circumstances of carriage, are compelled to pay different prices therefor; and we there held that the phrase 'under substantially similar circumstances and conditions,' as used in the $2 \mathrm{~d}$ section, refers to the matter of carriage, and does not include competition between rival routes.

"This view is not open to the criticism that different meanings are attributed to the same words when found in different sections of the Act; for what we hold is that, as the purposes of the several sections are different, the phrase under consideration must be read, in the second section, as restricted to the case of shippers, over the same road, thus leaving no room for the operation of competition, but that in the other sections, which cover the entire tract of interstate and foreign commerce, a meaning must be given to the phrase wide enough to include all the facts that have a legitimate bearing on the situation-among which we find the fact of competition when it affects rates.

"In order further to guard against any misapprehension of the scope of our decision it may be well to observe that we do not hold that the mere fact of competition, no matter what its character or extent, necessarily relieves the carrier from the restraints of the $3 \mathrm{~d}$ and 4 th sections, but only that these sections are not so stringent and imperative as to exclude in all cases the matter of competition from consideration in determining the questions of 'undue or unreasonable preference or advantage,' or what are 'substantially similar circumstances and conditions.' The competition may in some cases be such as, having due regard to the interests of the public and of the carrier, ought justly to have effect upon the rates, and in such cases there is no absolute rule which prevents the Commission or the courts from taking that matter into consideration.

"It is further contended, on behalf of the appellant, that the courts below erred in holding, in effect, that competition of carrier with carrier, both subject to the Act to Regulate Commerce, will justify a departure from the rule of the $4^{\text {th }}$ section of the act without authority from the Interstate Commerce Commission, under the proviso to that section. In view of the conclusion hereinbefore reached, the proposition comes to 
force equality between shippers over the same line, and to prevent any rebate or other device by which two shippers, shipping over the same line, the same distance, under the same circum-

this, that, when circumstances and conditions are substantially dissimilar, the railway companies can only avail themselves of such a situation by an application to the Commission.

"The claim now made for the Commission is that the only body which has the power to relieve railroad companies from the operation of the long and short haul clause on account of the existence of competition or any other similar element which would make its application unfair is the Commission itself, which is bound to consider the question upon application by the railroad company, but whose decision is discretionary and unreviewable. The first observation that occurs on this proposition is that there appears to be no allegation in the bill or petition raising such an issue. *** Moreover, the view of the scope of the proviso to the 4 th section does not appear to have ever been acted upon or enforced by the Commission. On the contrary, in the Case of In Re Louisville and Nashville R. R. v. Interstate Commerce Commission, I I. C. C. Rep. $3 \mathrm{I}, 57$, the Commission, through Judge Cooley, said, in speaking of the effect of the introduction into the 4th section of the words 'under substantially similar circumstances and conditions,' and of the meaning of the proviso: 'That which the Act does not declare unlawful must remain lawful if it was so before, and that which it fails to forbid, the carrier is left at liberty to do, without permission of any one. *** The charging or receiving the greater compensation for the shorter than for the longer haul is seen to be forbidden only when both are under substantially similar circumstances and conditions; and, therefore, if in any case the carrier, without first obtaining an order of relief, shall depart from the general rule, its doing so will not alone convict it of illegality, since, if the circumstances and conditions of the two hauls are dissimilar, the statute is not violated. ** Beyond question, the carrier must judge for itself what are the 'substantially similar circumstances and conditions' which preclude the special rate, rebate or drawback, which is made unlawful by the second section, since no tribunal is empowered to judge for it until the carrier has acted, and then only for the purpose of determining whether its action constitutes a violation of law. The carrier judges on peril of the consequences; but the special rate, rebate or drawback which it grants is not illegal when it turns out that the circumstances and conditions were not such as to forbid it; and as Congress clearly intended this, it must also, when using the same words in the fourth section, have intended that the carrier, whose privilege was in the same way limited by them, should in the same way act upon its judgment of the limiting circumstances and conditions.'

"The view thus expressed has been adopted in several of the Circuit Courts; Interstate Commerce Commission v. Atchison, Topeka and Santa Fe R. R., 50 Fed. 295, 300; Interstate Commerce Commission v. Cincinnati, New Orleans and Texas Pacific Ry., 56 Fed. 925, 942; Behlmer 
stances of carriage, are compelled to pay different prices therefor. In that section this phrase refers to the matter of carriage and does include competition between rival routes which is the subject comprehended by the fourth section of the Act.

v. Louisville and Nashville R. R., 71 Fed. 835, 839; and we do not think the courts below erred in following it in the present case. We are unable to suppose that Congress intended, by the fourth section and the proviso thereto, to forbid common carriers, in cases where the circumstances and conditions are substantially dissimilar, from making different rates unless the Commission shall authorize them so to do, much less do we think that it was the intention of Congress that the decision of the Commission, if applied to, could not be reviewed by the courts. The provisions of section 16 of the Act, which authorize the court to 'proceed to hear and determine the matter speedily as a court of equity, and without the formal pleadings and proceedings applicable to ordinary suits in equity, but in such manner as to do justice in the premises, and to this end, such court shall have power, if it think fit, to direct and prosecute in such mode and by such persons as it may appoint, all such inquiries as the court may think needful to enable it to form a just judgment in the matter of such petition,' extend as well to an inquiry or proceeding under the fourth section as to those arising under the other sections of the Act.

"Upon these conclusions, that competition between rival routes is one of the matters which may lawfully be considered in making rates, and that substantial dissimilarity of circumstances and conditions may justify common carriers in charging greater compensation for the transportation of like kinds of property for a shorter than for a longer distance over the same line, we are brought to consider whether, upon the evidence in the present case, the courts below erred in dismissing the Interstate Commerce Commission's complaint. As the third section of the Act, which forbids the making or giving any undue or unreasonable preference or advantage to any particular person or locality, does not define what, under that section, shall constitute a preference or advantage to be undue or unreasonable, and as the fourth section, which forbids the charging or receiving greater compensation in the aggregate for the transportation of like kinds of property for a shorter than for a longer distance over the same line, under substantially similar circumstances and conditions does not define or describe in what the similarity or dissimilarity of circumstances and conditions shall consist, it cannot be doubted that whether, in particular circumstances, there has been an undue or unreasonable prejudice or preference, or whether the circumstances and conditions of the carriage have been substantially similar or otherwise, are questions of fact depending on the matters proved in each case. * * * Cincinnati, New Orleans and Texas Pacific Ry. v. Interstate Commerce Commission, 162 U. S. 184, 194, 40 L. Ed. 935, 16 Sup. Ct. 700; Texac and Pacific Ry. v. Interstate Commerce Commission, 162 U. S. 197, 235. 40 L. Ed. 940, 16 Sup. Ct. 666. 
The Supreme Court also held that not merely local relations should be taken into consideration in determining what constituted "substantially similar circumstances and conditions" but that circumstances and conditions which exist beyond the seaboard of the United States could be legitimately regarded for the purpose of justifying a difference in rates between import and domestic traffic and that ocean competition would constitute a

"The Circuit Court of Appeals, in affirming the decree of the Circuit Court, used the following language: " * * The volume of trade to be competed for, the number of carriers actively competing for it, and a constantly open river present to take a large part of it whenever the railroad rates rise up to the mark of profitable water carriage, seem to us, as they did to the Circuit Court, to constitute circumstances and conditions at Montgomery substantially dissimilar from those existing at Troy, and to relieve the carriers from the charges preferred against them by the Board of Trade. * * * The carriers are better qualified to adjust such matters than any court or board of public administration, and, within the limitations suggested, it is safe and wise to leave to their traffic managers the adjusting of dissimilar circumstances and conditions to their business.' 4I U. S. App. 453.

"The last sentence in this extract is objected to by the Commission's counsel, as declaring that the determination of the extent to which discrimination is justified by circumstances and conditions should be left to the carriers. If so read, we should not be ready to adopt or approve such a position. But we understand the statement, read in the connection in which it occurs, to mean only that, when once a substantial dissimilarity of circumstances and conditions has been made to appear, the carriers are, from the nature of the question, better fitted to adjust their rates to suit such dissimilarity of circumstances and conditions than courts or commissions; and when we consider the difficulty, the practical impossibility, of a court or a commission taking into view the various and continually changing facts that bear upon the question, and intelligently regulating rates and charges accordingly, the observation objected to is manifestly just. But it does not mean that the action of the carriers, in fixing and adjusting the rates, in such instances, is not subject to revision by the Commission and the courts, when it is charged that such action has resulted in rates unjust or unreasonable, or in unjust discriminations and preferences."

In Cincinnati, New Orleans and Texas Pacific Railway Co. v. Interstate Commerce Commission, I62 U. S. 184, 40 L. Ed. 935, I6 Sup. Ct. 700 , the court said: "We do not say that, under no circumstances and conditions, would it be unlawful, when engaged in the transportation of foreign freight, for a carrier to charge more for a shorter than a longer distance on its own line, but it is for the tribunal appointed to enforce the provisions of the statute, whether the Commission or the court, to consider whether the existing circumstances and conditions were or were not substantially similar." 
dissimilar condition within the purview of the fourth section." Foreign and domestic traffic are not like kinds of traffic under substantially similar circumstances and conditions, and railroad companies in order to secure such traffic may charge, as their

2 Texas and Pacific Railway Co. r. Interstate Commerce Commission, 162 U. S. 197,40 L. Ed. 940,16 Sup. Ct. 666 . In this case the bill was brought to compel the Texas and Pacific Railway Company to obey an order of the Interstate Commerce Commission to cease from carrying any article imported from any foreign port through a port of entry of the United States upon through bills of lading destined to any place within the United States at any other than upon the inland tariff covering other freight from such port of entry to such place of destination. As against this particular road it was alleged that it carried shipments of freight originating at Liverpool and London on through bills of lading entering the port of New Orleans for lower rates than it charged for carrying to San Francisco freight originating at New Orleans. The carrier insisted that this discrimination was justified because through shipments from a foreign country to the United States interior points differ in circumstances and conditions from shipments originating at the American seaboard for the same interior points and that the railroad company has a legal right to accept for its share of the through rate a lower sum than it receives for domestic shipments to the same destination from the point at which the imported traffic enters this country. The Interstate Commerce Commission after a hearing held that the railroad was not justified in accepting this lower amount on the imported shipments. The railroad insisted that competition of sailing vessels for the entire distance should be considered; also competition by steamships and the Isthmian railroad; and competition by steamships and other railroads in the United States running from New Orleans and other ports of entry to San Francisco.

The court said: "We come now to the main question of the case, and that is whether the Commission erred, when making the order of January 29,1891 , in not taking into consideration the ocean competition as constituting a dissimilar condition, and in holding that no circumstances and conditions which exist beyond the seaboard in the United States could be legitimately regarded by them for the purpose of justifying a difference in rates between import and domestic traffic. $* * *$ These and other uncontroverted facts that appear in this record would seem to constitute 'circumstances and conditions' worthy of consideration, when carriers are charged with being guilty of unjust discrimination or of giving unreasonable and undue preference or advantage to any person or locality. But we understand the view of the Commission to have been that it was not competent for the Commission to consider such facts-that it was shut up by the terms of the Act of Congress to consider only such 'circumstances and conditions' as pertained to the articles of traffic after they had reached and been delivered at a port of the United States or Canada.

"The Commission justified its action wholly upon the construction put 
share of the through rate, a smaller amount for the carriage from the port of entry to the point of destination than for the carriage between the same points of domestic traffic originating at the port of entry. Otherwise the inland consumers would be deprived of

by it on the Act to Regulate Commerce, as forbidding the Commission to consider the circumstances and conditions attendant upon the foreign traffic as such 'circumstances and conditions' as they are directed in the Act to consider. The Commission thought it was constrained by the Act to regard foreign and domestic traffic as like kinds of traffic under substantially similar circumstances and conditions, and that the action of the defendant company in procuring through traffic that would, except for the through rates, not reach the port of New Orleans and in taking its pro rata share of such rates, was an act of 'unjust discrimination,' within the meaning of the Act. In so construing the Act we think the Commission erred. As we have already said it could not be supposed that Congress in regulating commerce, would intend to forbid or destroy an existing branch of commerce, of value to the common carriers and to the consumers within the United States. Clearly, express language must be used in the Act to justify such a supposition. ***

"The only argument, urged in favor of the view of the Commission, that is drawn from the language of the statute, is found in those provisions of the statute that make it obligatory on the common carriers to publish their rates, and to file with the Commission copies of joint tariffs of rates or charges over continuous lines or routes operated by more than one common carrier; and it is said that the place at which it would seem that joint rates should be published for the information of shippers would be at the place of origin of the freight, and that this cannot be done or be compelled to be done, in foreign ports. The force of this contention is not perceived. Room is left for the application of these provisions to traffic originating within the limits of the United States, even if, for any reason, they are not practically applicable to traffic originating elsewhere. Nor does it appear that the Commission may not compel all common carriers within the reach of their jurisdiction to publish such rates, and to furnish the Commission with all statements or reports prescribed by the statute. Nor was there any allegation, evidence or finding, in the present case, that the Texas and Pacific Railroad Company has failed to file with the Commission copies of its joint tariffs, showing the joint rates from English ports to San Francisco, nor that the company has failed to make public such joint rates in such manner as the Commission may have directed.

"Another position taken by the Commission in its report, and defended in the briefs of counsel, is, that it is the duty of the Commission to so construe the Act to Regulate Commerce as to make it practically co-operate with what is assumed to be the policy of the tariff laws. * * * Our reading of the act does not disclose any purpose or intention on the part of Congress to thereby reinforce the provisions of the tariff laws. These laws differ wholly in their objects from the 
the benefits of through rates to the advantage of the traders and manufacturers of the large seaboard cities. The Supreme Court in the Import Rate Case, just cited, expressly disclaimed

law to regulate commerce. Their main purpose is to collect revenues with which to meet the expenditures of the government, and those of their provisions, whereby Congress seeks to so adjust rates as to protect American manufacturers and producers from competition by foreign low-priced labor, operate equally in all parts of the country. The effort of the Commission by a rigid general order, to deprive the inland consumers of the advantage of through rates, and to thus give an advantage to the traders and manufacturers of the large seaboard cities, seems to create the very mischief which it was one of the objects of the Act to remedy.

"Similar legislation by the Parliament of England may render it profitable to examine some of the decisions of the courts of that country construing its provisions. * * * The conclusions that we draw from the history and language of the Act, and from the decisions of our own and the English courts, are mainly these: That the purpose of the Act is to promote and facilitate commerce by the adoption of regulations to make charges for transportation just and reasonable, and to forbid undue and unreasonable preferences or discriminations; That, in passing upon questions arising under the Act, the tribunal appointed to enforce its provisions, whether the commission or the courts, is empowered to fully consider all the circumstances and conditions that reasonably apply to the situation, and that, in the exercise of its jurisdiction the tribunal may and should consider the legitimate interests as well of the carrying companies as of the traders and shippers, and in considering whether any particular locality is subjected to an undue preference or disadvantage the welfare of the communities occupying the localities where the goods are delivered is to be considered as well as that of the communities which are in the locality of the place of shipment; That among the circumstances and conditions to be considered, as well in the case of traffic originating in foreign ports as in the case of traffic originating within the limits of the United States, competition that affects rates should be considered, and in deciding whether rates and charges made at a low rate to secure foreign freights which would otherwise go by other competitive routes are or are not undue and unjust, the fair interests of the carrier companies and the welfare of the community which is to receive and consume the commodities are to be considered; That if the Commission, instead of confining its action to redressing, on complaint made by some particular person, firm, corporation or locality, some specific disregard by common carriers of provisions of the Act, proposes to promulgate general orders which thereby become rules of action to the carrying companies, the spirit and letter of the Act require that such orders should have in view the purpose of promoting and facilitating commerce, and the welfare of all to be affected, as well the carriers as the traders and consumers of the country. *** 
the correctness of the contention of the Interstate Commerce Commission that the Act to Regulate Commerce should be so construed as to make it practically co-operate with the policy of the tariff laws. To adopt such a theory declared the court would be "to create the very mischief which it was one of the objects of the Act to remedy."

In order to permit the larger charge for the shorter haul the dissimilarity in circumstances and conditions must be actual and not potential. They must rest upon the genuine existence of com-

"It is stated in that report that the Illinois Central Railroad Company, one of the respondents, in the proceeding before the Commission, averred in its answer that it was constrained by its obedience to the order of March, I899, to decline to take for shipment any import traffic and, to its great detriment, to refrain from the business, for the reason that to meet the action of the competing lines it would have to make a less rate on the import than on the domestic traffic. Upon this disclosure that their order had resulted in depriving that company of a valuable part of its traffic (to say nothing of its necessary effect in increasing the charges to be finally paid by the consumers), the Commission in its report naively remarks: 'This lets the Illinois Central Railroad Company out.' 4 I. C. C. Rep. 458.

"We also learn from the same source that there was competent evidence adduced before the Commission, on the part of the Pennsylvania Railroad Company, that since that company, in obedience to the order of March, 1899, has charged the full inland rate on the import traffic, the road's business in that particular has considerably fallen off-that the steamship lines have never assented to the road's charging its full inland rates, and have been making demands on the road for a proper division of the through rate-that if it were definitely determined that the road was not at liberty to charge less than the full inland rate, the result would be that it would effectually close every steamship line sailing to and from Baltimore and Philadelphia. The Commission did not find it necessary to consider this evidence because the Pennsylvania Railroad Company was before it in the attitude of having obeyed the order.

"We do not refer to these matters for the purpose of indicating what conclusions ought to have been reached by the Commission or by the courts below in respect to what were proper rates to be charged by the Texas and Pacific Railroad Company. That was a question of fact, and if the inquiry had been conducted on a proper basis we should not have felt inclined to review conclusions so reached. But we mention them to show that there manifestly was error in excluding facts and circumstances that ought to have been considered, and that this error arose out of a misconception of the purpose and meaning of the Act." 
petition as affecting rates and not upon the mere possibility of such competition arising. ${ }^{3}$

This competition was effective to produce the dissimilarity of circumstances and conditions although it in fact arose from

3 Interstate Commerce Commission v. Louisville and Nashville Railroad Company, I90 U. S. 273, 47 L. Ed. 1047, 23 Sup. Ct. 687. This case turned upon the fact that a larger rate was charged for carrying freight from New Orleans to LaGrange than to Atlanta which was the more distant point. Competition prevailing at Atlanta determined the rate to that point. The rate to LaGrange was fixed by adding to the rate from New Orleans to Atlanta the local rate back from Atlanta to LaGrange. Similarly the rate from New Orleans to points between LaGrange and Atlanta was fixed by adding to the rate from New Orleans to Atlanta the locals back from Atlanta to such points with the results that the rates from New Orleans to those points were also lower than the rate from New Orleans to LaGrange. The court said: "When the situation just stated is comprehended it results that the complaint in effect was that a method of rate making had been resorted to which gave to the places referred to a lower rate than they otherwise would have enjoyed. In this situation of affairs, we fail to see how there was any just cause of complaint. Clearly, if, disregarding the competition at Atlanta, the higher rate had been established from New Orleans to the noncompetitive points within the designated radius from Atlanta, the inevitable result would have been to cause the traffic to move from New Orleans to the competitive point (Atlanta), and thence to the places in question thus bringing about the same rates now complained of. It having been established that competition affecting rates existing at a particular point (Atlanta) produced the dissimilarity of circumstances and conditions contemplated by the fourth section of the Act, we think it inevitably followed that the railway companies had a right to take the lower rate prevailing at Atlanta as a basis for the charge made to places in territory contiguous to Atlanta, and to ask in addition to the low competitive rate the local rate from Atlanta to such places provided thereby no increased charges resulted over those which would have been occasioned if the low rate to Atlanta had been left out of view. That is to say, it seems incontrovertible that in making the rate, as the railroads had a right to meet the competition, they were authorized to give the shippers the benefit of it by according to them a lower rate than would otherwise have been afforded. True it is, that by this method a lawer rate from New Orleans than was exacted at LaGrange obtained at the longer distance places lying between LaGrange and Atlanta, but this was only the result of their proximity to the competitive point, and they hence obtained only the advantage resulting from their situation. It could be no legal disadvantage to LaGrange, since if the low competitive rate prevailing at Atlanta had been disregarded, and the rate had been fixed with reference to Montgomery, and the local rate from thence on, the sole result would have been, as we have previously said, 
the action of one or more carriers who were also subject to the law to regulate commerce, and this too without the previous assent of the Interstate Commerce Commission to the rates thereby produced,- the carrier having the right of his own motion to take it into consideration in fixing rates to the competitive point, it being declared that the law and not the discretion of the Commission determined the rights of the parties. And the right to make the lesser charge to the more distant and competitive point than to the nearer and non-competitive point was not destroyed by the mere fact that incidentally the lesser charge to the competitive point might seemingly give a preference to that point, and the greater rate to the noncompetitive point might apparently engender a discrimination against such point. ${ }^{4}$ In this very case the

to cause the traffic to move along the line of least resistance to Atlanta, and thence to the places named, leaving LaGrange in the exact position in which it was placed by the rates now complained of. ***

"In the report of the Commission a suggestion is found that LaGrange should be entitled to the same rate as Atlanta, because if the carriers concerned in this case in connection with other carriers reaching LaGrange chose to do so, they might bring about competition by the way of a line between Macon and LaGrange which would be equivalent to the competitive conditions existing at Atlanta. We are unable, however, to follow the suggestion. To adopt it would amount to this: that the substantial dissimilarity of circumstances and conditions provided by the act to regulate commerce would depend, not as has been repeatedly held, upon a real and substantial competition at a particular point affecting rates, but upon the mere possibility of the arising of such competition. This would destroy the whole effect of the Act and cause every case where competition was involved to depend, not upon the fact of its existence as affecting rates, but upon the possibility of its arising. What the fourth section of the Act to Regulate Commerce has reference to is an actual dissimilarity of circumstances and conditions, not a conjectural one. Of course, if by agreements or combinations among carriers it were found that at a particular point rates were unduly influenced by a suppression of competition, that fact would be proper to consider in determining the question of undue discrimination and the reasonableness per se of the rates at such possible competitive points."

4 East Tennessee, Virginia and Georgia Railway Co. v. Interstate Commerce Commission, 18I U. S. I, 45 L. Ed. 719, 21 Sup. Ct. 516. The complaint here declared that the defendants conveyed freight from the eastern seaboard through and beyond Chattanooga to Nashville for a lesser rate to such long distance points than was cliarged by them for like freight to Chattanooga, the shorter distance. The rate to Nashville was determined by shipments to Cincinnati with the classification and tariff of rates prevailing in the northern or trunk line territory, and 
court took occasion to expressly declare that there might be cases where the carrier could not be allowed to avail itself of the competitive conditions to charge less for a longer than for a shorter haul because of the public interests and the operation of other

the further shipment south of the Ohio river governed by the classification and tariff of rates prevailing in the southern territory. These rates to Nashville had to be met or else traffic to that point abandoned from the eastern seaboard in the southern territory.

The court said: "Taking into view the terms of the order (of the Interstate Commerce Commission) and the reasons given by the Commission for considering only one aspect of the controversy and excluding all others, it is obvious that that body construed the Act to regulate commerce as meaning that, however controlling competition might be on rates to any given place, if it arose from the action of one or more carriers who were subject to the law to regulate commerce, the dissimilarity of circumstances and conditions provided in the fourth section could not be produced by such competition unless the previous assent of the Commission was given to the taking by the carrier of such competition into view in fixing rates to the competitive point. This in effect was to say that the dissimilarity of circumstances and condition prescribed in the law was not the criterion by which to determine the right of a carrier to charge a lesser rate for the longer than for the shorter distance unless the assent of the Commission was asked and given. This in substance but decided that the dissimilarity of circumstances and conditions prescribed in the law was not the rule by which to determine the right of a carrier to charge a lesser rate for the longer than for the shorter distance, but that such right solely sprang from the assent of the Commission. In other words, that the dissimilarity of circumstances and conditions became a factor only in consequence of an act of grace or of a discretion flowing from or exercised by the Commission. This logical result of the construction of the statute adopted by the Commission was well illustrated by the facts found by it and to which the theory announced was in this case applied. Thus, although the Commission found as a fact that the competition at Nashville was of such a preponderating nature that the carrier must either continue to charge a lesser rate for a longer haul to Nashville than was asked for the shorter haul to Chattanooga or to abandon all Nashville traffic, nevertheless they were forbidden to make the lesser charge for the longer haul. In other words, they were ordered to desist from all Nashville traffic unless they applied to the Commission for the privilege of continuing such traffic by obtaining its assent to meet the dominant rate prevailing at Nashville. But since the ruling of the Commission was made in this case, it has been settled by this court that competition which is controlling on traffic and rates produces in and of itself the dissimilarity of circumstance and condition described in the statute, and that where this condition exists a carrier has a right of his own motion to take it into view in fixing rates to the competitive point. That is to say, that the dissimilarity of 
provisions of the Act to Regulate Commerce. It further said that what particular environment might in every case produce such a result could not be indicated in advance, but that an illustration might be found in a case where the carrier could not meet the

circumstance and condition pointed out by the statute which relieves from the long and short haul clause arises from the command of the statute and not from the assent of the Commission; the law, and not the discretion of the Commission, determining the rights of the parties. It follows that the construction affixed by the Commission to the statute upon which its entire action was predicated was wrong. Texas and Pacific Railway Co. v. Interstate Commerce Commission, I62 U. S. I97; Interstate Commerce Commission v. Alabama Midland Railroad Co., I68 U. S. 144 and I64, 42 L. Ed. 4I4, I8 Sup. Ct. 45 ; Louisville and Nashville Railroad Co. v. Behlmer, I75 U. S. 648, 654, 655, 44 L. Ed. 309, 20 Sup. Ct. 209.

"The only principle by which it is possible to enforce the whole statute is the construction adopted by the previous opinions of this court; that is, that competition which is real and substantial, and exercises a potential influence on rates to a particular point, brings into play the dissimilarity of circumstances and condition provided by the statute, and justifies the lesser charge to the more distant and competitive point than to the nearer and noncompetitive place, and that this right is not destroyed by the mere fact that incidentally the lesser charge to the competitive point may seemingly give a preference to that point, and the greater rate to the noncompetitive point may apparently engender a discrimination against it. We say seemingly on the one hand and apparently on the other, because in the supposed cases the preference is not 'undue' or the discrimination 'unjust.' This is clearly so, when it is considered that the lesser charge upon which both the assumption of preference and discrimination is predicated is sanctioned by the statute, which causes the competition to give rise to the right to make such lesser charge. Indeed the findings of fact made by the Commission in this case leave no room for the contention that either undue preference in favor of Nashville or unjust discrimination against Chattanooga arose merely from the act of the carriers in meeting the competition existing at Nashville. The Commission found that if the defendant carriers had not adjusted their rates to meet the competitive condition at Nashville, the only consequence would have been to deflect the traffic at the reduced rates over other lines. From this it follows that, even although the defendant carriers had not taken the dissimilarity of circumstance and condition into view, and had continued their rates to Nashville just as if there had been no dissimilarity of circumstance and condition, the preference of Nashville growing out of the conditions there existing would have remained in force and hence the discrimination which thereby arose against Chattanooga would have likewise continued to exist. In other words, both Nashville and Chattanooga would have been exactly in the same position if the long and short haul clause had not been brought into play. 
competitive rate to a given point without transporting the merchandise at less than the real cost of conveyance and therefore without causing a deficiency which would have to be met by increased charges upon other business-under such circumstances engaging in such competitive traffic would result both in an unjust discrimination and a disregard of the public interest, since a tendency toward unreasonable rates on other business would result from the carriage of traffic at less than the cost of transportation to particular places. In short in order to permit a carrier to take advantage of competition in creating a dissimilar circumstance and condition the carrier must be able to handle the business at a margin of profit over the cost of transportation, and he could not be permitted to conduct it at an actual loss.

In determining the dissimilarity of circumstance and condition the carrier may properly take into consideration all competi-

"That, as indicated in the previous opinions of this court, there may be cases where the carrier cannot be allowed to avail of the competitive conditions because of the public interests and the other provisions of the statute, is of course clear. What particular environment may in every case produce this result cannot be in advance indicated. But the suggestion of an obvious case is not inappropriate. Take a case where the carrier cannot meet the competitive rate to a given point without transporting the merchandise at less than the cost of transportation, and therefore without bringing about a deficiency which would have to be met by increased charges upon other business. Clearly in such a case the engaging in such competitive traffic would both bring about an unjust discrimination and a disregard of the public interest, since a tendency toward unreasonable rates on other business would arise from the carriage of traffic at less than the cost of transportation to particular places.

"Applying the principle to which we have adverted to the condition as above stated, it is apparent that if the carrier was prevented under the circumstances from meeting the competitive rate at Nashville, when it could be done at a margin of profit over the cost of transportation, it would produce the very discrimination which would spring from allowing the carrier to meet a competitive rate where the traffic must be carried at an actual loss. To compel carriers to desist from all Nashville traffic under the circumstances stated would simply result in deflecting the traffic to Nashville to other routes, and thus entail upon the carriers who were inhibited from meeting the competition although they could do so at a margin of profit, the loss which would arise from the disappearance of such business without any wise benefiting the public."

See also Interstate Commerce Commission v. Clyde Steamship Co., 181 U. S. 29, 45 L. Ed. 729, 21 Sup. Ct. 512, to the same effect. 
tion which possesses the attributes of producing a substantial and material effect upon traffic and rate making. And the carrier is not limited to the consideration of competition originating at the initial point of traffic, but it may take into account competition which arises at other places than such initial point. ${ }^{5}$ This is known

5 Louisville and Nashville Railroad Co. v. Behlmer, I75 U. S. 648, 44 L. Ed. 309, 20 Sup. Ct. 209. Here the railroad charged a lesser rate for carrying grain and hay from Memphis to Charleston, South Carolina, than for shipments of the same products from Memphis to Summerville South Carolina, a point on the same line twenty-two miles west of Charleston. The railroad alleged that there was a dissimilarity of circumstance and condition between the two places-first by reason of the competition of eight competing lines of railroad between Memphis and Charleston and second, by the competition originating in Chicago and other points on hay and grain and coming to Charleston by the combinations of lake, canal, ocean and railroad transportation and that this latter traffic was the controlling element in the competition. The court, in passing upon the features of the case, said:

"It is $* * *$ uncontroverted that all the competition relied on by the carriers, to establish that there was a dissimilarity of circumstances and condition, arose solely from two sources; either that originating at Memphis, the initial point of the traffic, from the presence there of carriers who were subject to the provisions of the Commerce Act, or competition based on the fact that Charleston was connected with or accessible to lines of rail and water communication which brought it in relation with many other places and markets other than Memphis, thereby creating competition between Memphis and Charleston, the claim being that Memphis would have been deprived of the benefits of the Charleston traffic, and Charleston would be also cut off from the Memphis supply if the rates from Memphis to Charleston had not been made lower to meet the competition at Charleston.

"The construction of the fourth section of the Act to Regulate Commerce and the question whether competition which materially operated on traffic and rates was a proper subject to be considered by a carrier in charging a greater rate for the shorter than was asked for the longer distance, on account of the dissimilarity of circumstances and condition produced by such competition, has recently, after elaborate argument and great consideration, been passed upon by this court. $* * *$ Texas and Pacific Railway Co. v. Interstate Commerce Commission, I62 U. S. 197, 40 L. Ed. 940, I6 Sup. Ct. 666; and Interstate Commerce Commission v. Alabama Midland Railway Co., i68 U. S. 144, 42 L. Ed. 414, 18 Sup. Ct. 45. *** What was decided in the previous cases was that under the fourth section of the Act substantial competition which materially affected transportation and rates might under the statute be competent to produce dissimilarity of circumstances and condition, to be taken into consideration by the carrier in charging a greater sum for a lesser than for a longer haul. The meaning of the law was not decided to be that one kind of competition 
as "market competition." The statute does not mean that one kind of competition shall be considered and not another kind in determining whether a lesser rate shall be charged for a longer than for a shorter distance.

The Supreme Court has also held that the fourth section of the Act to Regulate Commerce contemplates only the transporta-

could be considered and not another kind, but that all competition, provided it possessed the attributes of producing a substantial and material effect upon traffic and rate making, was proper under the statute to be taken into consideration. Indeed if the distinction contended for were sound it would follow that the greater and more material competition would be without weight in determining whether a dissimilarity of circumstances and conditions existed, whilst the lesser competition would be potential for such purpose. Not only this, but if the distinction be applicable, only that competition which might deflect at the point of origin, the traffic from one carrier to another, would be within the purview of that portion of the fourth section now under consideration, and competition which was so great as to absolutely prevent the movement of the traffic, unless the lesser rate was exacted, would be outside of its operation. This would lead to the construction that the statute, in empowering a carrier, under certain competitive conditions, of his own volition, to exact a lesser rate for the longer haul, contemplated only the interest of some particular carrier and not at all the public interest. Whilst the unsoundness of the proposition is thus shown, from the contradition which inheres in it, the erroneous conception upon which it rests is fully demonstrated in the following excerpt from the opinion in Texas and Pacific Railway Co. v. Interstate Commerce Commission: 'So, too, it could not readily be supposed that Congress intended, when regulating such commerce to interfere with and interrupt, much less destroy, sources of trade and commerce already existing, nor to overlook the property rights of those who had invested money in the railroads of the country, nor to disregard the interests of the consumers, to furnish whom with merchandise is one of the principal objects of all systems of transportation.'

"Indeed, in the cases by which the controversy here before us is controlled, attention was pointedly called to the fact that in considering the power of the carrier, of his own motion, to charge a lesser sum for the longer haul, not only was the interest of the carrier to be taken into account, but also the interest of the public, especially at the place from which the traffic moved and the place to which it was to be delivered. * * * It follows that whilst the carrier may take into consideration the existence of competition as the producing cause of dissimilar circumstances and conditions, his right to do so is governed by the following principles: First, The absolute command of the statute that all rates shall be just and reasonable, and that no undue discrimination be brought about, though, in the nature of things, this latter consideration may in many cases be involved in the determination of whether competition was such as created a substantial dissimilarity of condition. Second. That 
tion of passengers and property by rail and that when the persons or property reached and were discharged from the cars at the carrier's station or warehouse the duties and obligations imposed upon the carrier by the fourth section were fulfilled and satisfied and that there was no violation of the provisions of that section if, the rates being proper to that point, the property or the passengers are carried to their places of business or abode by vehicles furnished by the railroad company without further charge. Specifically this case referred to a situation where the same rate of tariff was charged for the carriage of passengers and freight to two towns, one being some thirty miles further than the other, but in the more distant town, the depot being removed a mile and more from the business center of the town, the railroad furnished its patrons with free carriage in its vehicles to the center of the town, no such arrangement for free local transportation being made in the nearer town. ${ }^{6}$

the competition relied upon be, not artificial or merely conjectural, but material and substantial, thereby operating on the question of traffic and rate making the right in every event to be only enjoyed with a due regard to the interest of the public, after giving full weight to the benefits to be conferred on the place from whence the traffic moved as well as those to be derived by the locality to which it is to be delivered."

6 Interstate Commerce Commission v. Detroit, Grand Haven and Milwaukee Railway Co., 167 U. S. 633, 42 L. Ed. 310, 17 Sup. Ct. 957. Ionia and Grand Rapids are both on the line of the defendant road, the former 124 and the latter 157 miles westerly from Detroit. The charges from eastern points, such as New York and Philadelphia, were the same for Ionia and Grand Rapids though they were on the same line and the shorter was included within the longer distance. The station at Grand Rapids was about a mile and a quarter from the business center of the town and in order to meet the competition of two other roads with stations in the business center of the town, the defendant road at its own expense operated trucks for the free delivery of freight consigned to merchants and others at Grand Rapids but did not do this at Ionia. The Interstate Commerce Commission ordered the road to cease carting free at Grand Rapids unless like service were installed at Ionia and unless the schedules publicly announced the free drayage at Grand Rapids. The Commission conceded that the so-called "group rates" were not a violation of the long and short haul clause and the case turned upon the question of the free cartage at Grand Rapids, a service not gratuitously offered at Ionia. The Supreme Court said:-

"The sole complaint urged is that the railway company carts goods to and from its station or warehouse at Grand Rapids without charging its customers for such service, while its customers at Ionia are left themselves to bring their goods to and take them from the company's ware- 
"Over the Same Line or Route."-Two or more railroad companies which own and operate connecting lines and transport traffic under a through joint tariff or bill of lading with the purpose of making the connecting lines a single road for the purpose

house, and that, in its schedules posted and published at Grand Rapids, there is no notice or statement by the company of the fact that it furnishes such cartage free of charge. These acts are claimed to constitute. violations of sections four and six of the Interstate Commerce Act. * * *

"Under the facts as found and the concessions as made, the Commission's proposition may be thus stated:-There is conventionally no difference, as to distance, between Ionia and Grand Rapids, and the same rates and charges for like kinds of property are properly made in the case of both cities. But as there is an average distance of one and one-fourth of a mile between the station at Grand Rapids and the warehouses and offices of the shippers and consignees, such average distance must be regarded as part of the railway company's line, if the company furnishes transportation for such distance; and if it refrains from making any charge for such transportation facilities, and fails to furnish the same facilities at Ionia, this is equivalent to charging and receiving a greater compensation in the aggregate for the transportation of a like kind of property for a shorter than for a longer distance over the same line in the same direction, the shorter being included within the longer distance.

"The Circuit Court of Appeals was of opinion that this proposition is based on a false assumption, namely, that the distance between the company's station and the warehouses of the shippers and the consignee is part of the company's railway line, or is made such by the act of the company in furnishing vehicles and men to transport the goods to points throughout the city of Grand Rapids. The view of that court was that the railway transportation ends when the goods reach the terminus or station and are there unshipped, and that anything the company does afterwards, in the way of land transportation, is a new and distinct service, not embraced in the contract for railway carriage. The court, in a learned opinion by District Judge Hammond, enforced this view by a reference to numerous English cases which hold that the collecting and delivery of goods is a separate and distinct business from that of railway carriage; that when the railroad companies undertake to do for themselves this separate business, they thereby are subjected to certain statutory regulations and restrictions in respect to such separate business; and that they cannot avoid such restrictions by making a consolidated charge for the railway and cartage service. 43 U. S. App. 308.

"We agree with the Circuit Court of Appeals in thinking that the fourth section of the Interstate Commerce Act has in view only the transportation of passengers and property by rail, and that, when the passengers and property reached and were discharged from the cars at the company's warehouse or station at Grand Rapids, for the same charges as those received for similar services at Ionia, the duties and obligations cast upon the company by the fourth section were fulfilled and satisfied. The sub- 
of such transportation, constitute a single or the same line or route within the meaning of the fourth section of the Act to Regulate Commerce. When goods are shipped under a through bill of lading, or in any other way indicating a common control, management or arrangement, from a point in one state to a point in another state and they are received in transit by an entirely state common carrier, such railroad company thereby subjects its road to an arrangement for a continuous carriage or shipment and thereby becomes amenable to the provisions of the Act to Regulate Commerce. And this is true even where the local road requests the foreign connecting lines not to name or fix any rates for that portion of the transportation which occurs within the state when the goods are shipped to local points on its line, such shipments having been made and accepted upon a through bill of lading with a conventional division of the charges. ${ }^{7}$ Nor is

sequent history of the passengers and property, whether carried to their places of abode and of business by their own vehicles or by those furnished by the railway company, would not concern the Interstate Commerce Commission. It may be that it was open for the Commission to entertain a complaint of the Ionia merchants that such a course of conduct was in conflict with sections two and three of the Act; *** The remaining question is whether, when a railway company furnishes free cartage facilities, even lawfully, that is in circumstances and conditions that would relieve the company from charges of violating sections.two, three and four, the provisions of section six apply."

7 Cincinnati, New Orleans and Texas Pacific Railway Co. v. Interstate Commerce Commission, (The Social Circle Case), I62 U. S. I84, 40 L. Ed. 935, I6 Sup. Ct. 700. On shipments from Cincinnati the same rate was charged to Atlanta, 474 miles distant, and to Augusta, 645 miles distant; 30 cents a hundred pounds more was charged on vehicles shipped to Social Circle, Georgia, than to either Atlanta or Augusta. Social Circle is a local station on the Georgia railroad 52 miles east of Atlanta and IIg miles west of Augusta. Thirty cents a hundred was the local charge by the Georgia railroad on local freight from Atlanta to Social Circle. When goods were shipped from Cincinnati to Social Circle the shippers paid $\$ 1.37$ per hundred pounds which was divided by the three railroads over which the goods passed, the Georgia railroad receiving 30 cents thereof. It was claimed that the 30 cents was the local charge for the purely intrastate haul on the Georgia road and that it was not under a common control or an arrangement for continuous carriage and was not within the provisions of the Act to Regulate Commerce. The Supreme Court said:-

"But when the Georgia Railroad Company enters into the carriage of foreign freight, by agreeing to receive the goods by virtue of foreign through bills of lading, and to participate in through rates and charges, 
the existence of a through shipment or an arrangement for continuous carriage evidenced or determined by the nature of the bill of lading. The Court said: "When we speak of a through bill of lading, we are referring to the usual method in use by connecting companies, and must not be understood to imply that a common control, management or arrangement might not be otherwise manifested."

Briefly to summarize, before the amendment of June 18, I910, the phrase "under substantially similar circumstances and conditions" dominated the long and short-haul clause, and empowered carriers to primarily determine the existence of the required dissimilarity of circumstances and conditions which would justify the larger charge for the shorter than for the longer distance, and competition which materially affected the rate of carriage to a particular point, provided it was real and substantial and not merely conjectural or potential, was a dissimilar circumstance and condition. And moreover while the provisions against preference and discrimination embodied in the second and third sec-

it thereby becomes part of a continuous line, not made by a consolidation with the foreign companies, but made by an arrangement for the continuous carriage or shipment from one state to another, and thus becomes amenable to the Federal Act, in respect to such interstate commerce. We do not perceive that the Georgia Railroad Company escaped from the supervision of the Commission, by requesting the foreign companies not to name or fix any rates for that part of the transportation which took place in the state of Georgia when the goods were shipped to local points on its road. It still left its arrangement to stand with respect to its terminus at Augusta and to other designated points. Having elected to enter into the carriage of interstate freights and thus subjected itself to the control of the Commission, it would not be competent for the company to limit that control, in respect to foreign traffic, to certain points on its road and exclude other points.

"All we wish to be understood to hold is, that when goods shipped under a through bill of lading, from a point in one state to a point in another, are received in transit by a state common carrier, under a conventional division of the charges, such carrier must be deemed to have subjected its road to an arrangement for a continuous carriage or shipment within the meaning of the Act to Regulate Commerce. When we speak of a through bill of lading we are referring to the usual method in use by connecting companies, and must not be understood to imply that a common control, management or arrangement might not be otherwise manifested."

See also Louisville and Nashville Railroad Co. v. Behlmer, I75 U. S. 648, 44 L. Ed. 309, 20 Sup. Ct. 209. 
tions of the Act were operative upon the fourth section yet where a lesser rate was charged for the longer than for the shorter haul because of such dissimilarity of circumstance and condition, such exaction being authorized, it could not constitute either a preference or a discrimination and therefore be illegal. Furthermore it became settled that where competitive conditions authorized carriers to lower their rates to a particular point the right to meet the competition by lowering rates to such point was not confined to shipments made from the point of origin of the competition, but all carriers were empowered to accept shipments to such competitive point at lower than their general tariff rates, in the interest of freedom of commerce and to provide a larger opportunity to shippers-which became known as "market competition" since it served to enlarge markets and develop the freedom of commerce. One injunction remained-this right to meet competition by such lower rates was permitted only when the tariff charges were not so lowered as to be nonremunerative and thereby cast a burden upon other shippers. Above all the carrier was permitted to judge primarily of the competitive conditions and to meet them at its election. However one limitation existed in the right of review of the action of the carrier which was subject to the supervision and control of the Interstate Commerce Commission and the review of the proper courts. Moreover the burden of proving the dissimilar conditions was in reality upon the carrier.

Amendment of June I8, I9I0.-The fundamental change made by the amendment of June 18 , 1910, consisted in the omission of the clause "under similar circumstances and conditions" thereby leaving the long and short-haul clause without qualification except in giving the carrier the right to apply to the Interstate Commerce Commission for authority to charge less for the longer than for the shorter haul and in giving the Commission authority from time to time "to prescribe the extent to which such designated common carrier may be relieved from the operation of this section." The omission of the amendment to either inferentially or specifically exclude the operation of competition as a proper consideration for permitting the carrier to make the larger charge for the shorter haul, under proper circumstances, means that the amendment simply shifts the power conferred by the section as originally enacted. The system of law remains unchanged but a different tribunal, the Interstate Commerce Com- 
mission, is charged with the enforcement of the law. The power to meet competitive conditions by enforcing a greater charge for the shorter than for the longer haul, previously lodged in the carrier is withdrawn and is now reposed in the Commission. And the authority of the Commission to grant upon application this right or permission is made to depend upon the facts established and the judgment of that body in its legal discretion. ${ }^{8}$ The

8 United States v. Atchison, Topeka and Santa Fe Railway Co., (Intermountain Rate Case), 234 U. S. 476, 58 L. Ed. I 408, 34 Sup. Ct. 986. This case was brought to test both the constitutionality and the meaning of the amendment of June 18 , I910. In a lengthy opinion, rendered by the chief justice, the Supreme Court said:

"Before considering the amended text we state briefly some of the more important requirements of the section before amendment and the underlying conceptions of private right, of public duty and policy which it embodied, because to do so will go a long way to remove any doubt as to the amended text and will moreover serve to demonstrate the intent of the legislative mind in enacting the amendment.

"Almost immediately after the adoption of the Act to Regulate Commerce in 1887 the Interstate Commerce Commission in considering the meaning of the law and the scope of the duties imposed on the Commission in enforcing it, reached the conclusion that the words 'under substantially similar circumstances and conditions' of the fourth section dominated the long and short haul clause and empowered carriers to primarily determine the existence of the required dissimilarity of circumstances and conditions and consequently to exact in the event of such difference a lesser charge for the longer than was exacted for the shorter haul and that competition which materially affected the rate of carriage to a particular point was a dissimilar circumstance and condition within the meaning of the Act. We say primarily because of course it was further recognized that the authority existing in carriers to the end just stated was subject to the supervision and control of the Interstate Commerce Commission in the exertion of the powers conferred upon it by the statute and especially in view of the authority stated in the fourth section. In considering the Act comprehensively it was pointed out that the generic provisions against preference and discrimination expressed in the second and third sections of the Act were all-embracing and were therefore operative upon the fourth section as well as upon all other provisions of the Act. But it was pointed out that where within the purview of the fourth section it had lawfully resulted that the lesser rate was charged for a longer than was exacted for a shorter haul such exaction being authorized could not be a preference or discrimination and therefore illegal. In re Louisville and Nashville R. R. Co., I I. C. C. Rep. 3I. These comprehensive views announced at the inception as a matter of administrative construction were subsequently sustained by many decisions of this court. Vide. Interstate Commerce Commission v. Baltimore and Ohio Railroad, I45 U. S. 
amendment takes from the carriers the deposit of power previously lodged in them and vests it in the Commission as a primary instead of a reviewing function. The effect of the amend-

263, 36 L. Ed. 699, 12 Sup. Ct. 844; Cincinnati, New Orleans and Texas Pacific Railway v. Interstate Commerce Commission, I62 U. S. I84, $40 \mathrm{~L}$. Ed. 935, I6 Sup. Ct. 700; Texas and Pacific Railway v. Interstate Commerce Commission, 162 U. S. 197, 40 L. Ed. 940, I6 Sup. Ct. 666; Louisville and Nashville Railway Co. v. Behlmer, I75 U. S. 648, 44 L. Ed. 309, 20 Sup. Ct. 209; Eastern Tennessee, etc., Railway Co. v. Interstate Commerce Commission, I8I U. S. I, 45 L. Ed. 719, 21 Sup. Ct. 516. We observe, moreover, that in addition it came to be settled that where competitive conditions authorized carriers to lower their rates to a particular place the right to meet the competition by lowering rates to such place was not confined to shipments made from the point of origin of the competition, but empowered all carriers in the interest of freedom of commerce and to afford enlarged opportunity to shippers to accept, if they chose to do so, shipments to such competitive points at lower rates than their general tariff rates; a right which came aptly to be described as 'market competition' because the practice served to enlarge markets and develop the freedom of traffic and intercourse. It is to be observed, however, that the right thus conceded was not absolute because its exercise was only permitted provided the rates were not so lowered as to be nonremunerative and thereby cast an unnecessary burden upon other shippers. Eastern Tennessee, etc., Railway Co. v. Interstate Commerce Commission, I8I U. S. I, 45 L. Ed. 719, 21 Sup. Ct. 5 I6. As the statute as thus construed imposed no obligation to carry to the competitive point at a rate which. was less than a reasonable one, it is obvious that the statute regarded the rights of private ownership and sought to impose no duty conflicting therewith. It is also equally clear that in permitting the carrier to judge primarily of the competitive conditions and to meet them at election the statute lodged in the carrier the right to exercise a primary judgment concerning a matter of public concern broader than the mere question of the duty of a carrier to carry for a reasonable rate on the one hand and of the right of the shipper on the other to compel carriage at such rate, since the power of primary judgment which the statute conferred concerned in a broad sense the general public interest with reference to both persons and places, considerations all of which therefore in their ultimate aspects came within the competency of legislative regulation. It was apparent that the power thus conferred was primary, not absolute, since its exertion by the carrier was made by the statute the subject both of administrative control and ultimate judicial review. And the establishment of such control in and of itself serves to make manifest the public nature of the attributes conferred upon the carrier by the original fourth section. Indeed that in so far as the statute empowered the carrier to judge as to the dissimilarity of circumstances and conditions for the purpose of relief from the long and short-haul clause it gave the carrier the power to exert a judgment as to things public was long since pointed out by this court. Texas 
ed fourth section, in short, was not to create new powers theretofore nonexisting, but simply to redistribute the powers already existing and which were then subject to review.

and Pacific Railway v. Interstate Commerce Commission, 162 U. S. 197, 218, 40 L. Ed. 940, 16 Sup. Ct. 666.

"With the light afforded by the statements just made we come to consider the amendment. It is certain that the fundamental change which it makes is the omission of the substantially similar circumstances and conditions clause, thereby leaving the long and short-haul clause in a sense unqualified except in so far as the section gives the right to the carrier to apply to the Commission for authority 'to charge less for longer than for shorter distances for the transportation of persons or property' and gives the Commission authority from time to time 'to prescribe the extent to which such designated common carrier may be relieved from the operation of this section.' From the failure to insert any word in the amendment tending to exclude the operation of competition as adequate under proper circumstances to justify the awarding of relief from the long and short-haul clause and there being nothing which minimizes or changes the application of the preference and discrimination clauses of the second and third sections, it follows that in subtance the amendment intrinsically states no new rule or principle but simply shifts the powers conferred by the section as it originally stood; that is, it takes from the carriers the deposit of public power previously lodged in them and vests it in the Commission as a primary instead of a reviewing function. In other words the elements of judgment or so to speak the system of law by which the judgment is to be controlled remains unchanged but a different tribunal is created for the enforcement of the existing law. This being true, as we think it plainly is, the situation under the amendment is this: Power in the carrier primarily to meet competitive conditions in any point of view by charging a lesser rate for a longer than for a shorter haul has ceased to exist because to do so, in the ab. sence of some authority would not only be inimical to the provision of the fourth section but would be in conflict with the preference and discrimination clauses of the second and third sections. But while the public power, so to speak, previously lodged in the carrier is thus withdrawn and reposed in the Commission the right of carriers to seek and obtain under authorized circumstances the sanction of the Commission to charge a lower rate for a longer than for a shorter haul because of competition or for other adequate reasons is expressly reserved and if not is in any event by necessary implication granted. And as a correlative the authority of the Commission to grant on request the right sought is made by the statute to depend upon the facts established and the judgment of that body in the exercise of a sound legal discretion as to whether the request should be granted compatibly with a due consideration of the private and public interests concerned and in view of the preference and discrimination clauses of the second and third sections.

"The alleged repugnancy of the section as amended to the Constitution. 
The Supreme Court expressly declared the amended fourth section constitutional as a valid delegation of power by Congress to the Interstate Commerce Commission. And it upheld an order of the Interstate Commerce Commission, made after application by the railroads which permitted, in some respects, a charge of a

But if the amendment has this meaning it is insisted that it is repugnant to the Constitution for various reasons which superficially considered seem to be distinct but which really are all so interwoven that we consider and dispose of them as one. The argument is that the statute as correctly construed is but a delegation to the Commission of legislative power which Congress was incompetent to make. But the contention is without merit. Field v. Clark, I43 U. S. 649, 36 L. Ed. 294, I2 Sup. Ct. 495 ; Buttfield v. Stranahan, I92 U. S. 470, 48 L. Ed. 252, 24 Sup. Ct. 349; Union Bridge Co. v. United States, 204 U. S. 364, 5I L. Ed. 523, 27 Sup. Ct. 367 ; United States v. Heinszen, 206 U. S. 370, 5 I L Ed. 1098, 27 Sup. Ct. 742; St. Louis, etc., Railway Co. v. Taylor, 2 Io U. S. 28I, 52 L. Ed. I06I, 28 Sup. Ct. 6I6; Monongahela Bridge Co. v. United States, 216 U. S. I77, 54 L. Ed. 435, 30 Sup. Ct. 356 . We do not stop to review these cases because the mere statement of the contention in the light of its environment suffices to destroy it. How can it otherwise be since the argument as applied to the case before us is this: that the authority in question was validly delegated so long as it was lodged in carriers but ceased to be susceptible of delegation the instant it was taken from the carriers for the purpose of being lodged in a public administrative body? Indeed, when it is considered that in last analysis the argument is advanced to sustain the right of carriers to exert the public power which it is insisted is not susceptible of delegation, it is apparent that the contention is self-contradictory since it reduces itself to an effort to sustain the right to delegate a power by contending that the power is not capable of being delegated. In addition, however, before passing from the proposition we observe that when rightly appreciated the contention but challenges every decided case since the passage of the Act to Regulate Commerce in 1887 involving the rightfulness of the exertion by a carrier of the power to meet competition as a means of being relieved from the long and short-haul clause of the fourth section before its amendment. * * After all has been said the provisions as to undue preference and discrimination, while involving of course a certain latitude of judgment and discretion are no more undefined or uncertain in the section as amended than they have been from the beginning and therefore the argument comes once more to the complaint that because public powers have been transferred from the carriers to the Commission, the wrongs suggested will arise. Accurately testing this final result of the argument it is clear that it exclusively rests upon convictions concerning the impolicy of having taken from carriers, intimately and practically acquainted as they are with the complex factors entering into rate making and moreover impelled to equality of treatment as they must be by the law of self interest operating upon them as a necessary result of the economic forces to which they are subjected, and 
lower rate for the longer haul to the Pacific coast than was asked for intermediate points provided a proportionate relation was maintained between the lower rate for the longer haul to the Pacific coast and the higher rate to the intermediate points, the proportion to be upon the basis of percentages which were fixed. ${ }^{\circ}$

having lodged the power in an official administrative body which in the nature of things must act, however conscientiously, from conceptions based upon a more theoretical and less practical point of view. But this does not involve a grievance based upon the construction of the fourth section as amended but upon the wisdom of the legislative judgment which was brought into play in adopting the amendment, a subject with which we have nothing in the world to do. It is said in the argument on behalf of one of the carriers that as in substance and effect the duty is imposed upon the Commission in a proper case to refuse an application, therefore the law is void because in such a contingency the statute would amount to an imperative enforcement of the long and short-haul clause and would be repugnant to the Constitution. It is conceded in the argument that it has been directly decided by this court that a general enforcement of the long and short-haul clause would not be repugnant to the Constitution (Louisville and Nashville Railway Co. v. Kentucky, 183 U. S. 503) but we are asked to reconsider and overrule the case and thus correct the error which was manifested in deciding it. But we are not in the remotest degree inclined to enter into this inquiry, not only because of the reasons which were stated in the case itself but also because of those already expounded in this opinion and for an additional reason which is that the contention by necessary implication assails the numerous cases which from the enactment of the Act to Regulate Commerce down to the present time have involved the adequacy of the conditions advanced by carriers for justifying their departure from the long and short-haul clause. We say this because the controversies which the many cases referred to considered and decided by a necessary postulate involved an assertion of the validity of the legislative power to apply and enforce the long and short-haul clause. How can it be otherwise since if this were not the case all the issues in the numerous cases would have been merely but moot, affording therefore no basis for judicial action since they would have had back of them no sanction of lawful power whatever."

9 United States v. Atchison, Topeka and Santa Fe Railway Co., 234 U. S. 476,58 L. Ed. 1408, 34 Sup. Ct. 986 . For the purposes of the order in question the Interstate Commerce Commission in substance adopted a division of the entire territory into separate zones which division had been resorted to by the carriers for the purpose of the establishment of the rates in relation to which the petition was filed by the railroads interested. The carriers protested against the validity of this order. As to this feature of the question the court said:-

"The main insistence is that there was no power after recognizing the existence of competition and the right to charge a lesser rate to the competitive point than to intermediate points, to do more than fix a reasonable 
And under the amended form of Section 4, without permission from the Interstate Commerce Commission it is unlawful for railroads to grant reshipping privileges at a designated station on freight originating at certain distant points and to refuse such privileges for freight from nearer points on the lines passing through the same station. ${ }^{10}$ For example, the practice had developed among the roads of charging the local freight rate on hay, grain and grain products, passing through Ohio or Mississippi River crossing points destined for Nashville. This conces-

rate to the intermediate points, that is to say, that under the power transferred to it by the section as amended the Commission was limited to ascertaining the existence of competition and to authorizing the carrier to meet it without any authority to do more than exercise its general powers concerning the reasonableness of rates at all points. But this proposition is directly in conflict with the statute as we have construed it and with the plain purpose and intent manifested by its enactment. To uphold the proposition it would be necessary to say that the powers which were essential to the vivification and beneficial realization of the authority transferred have evaporated in the process of transfer and hence that the power perished as the result of the Act by which it was conferred. As the prime object of the transfer was to vest the Commission within the scope of the discretion imposed and subject in the nature of things to the limitations arising from the character of the duty exacted and flowing from the other provisions of the Act with authority to consider competitive conditions and their relation to persons and places, necessarily there went with the power the right to do that by which alone it could be exerted, and therefore a consideration of the one and the other and the establishment of the basis by percentages was within the power granted. As will be seen by the order and as we have already said for the purpose of the percentages established zones of influence were adopted and the percentages fixed as to such zones varied or fluctuated upon the basis of the influence of the competition in the designated areas."

Io United States v. Louisville and Nashville Railroad Co., 235 U. S. 314, 59 L. Ed. - . The Supreme Court here said:-"We are of opinion that even if the allowance of such rebilling privilege when originally made was authorized by the statute and was therefore not a preference, the right to continue it had been expressly prohibited by statute until on application made to the Commission its consent to that end was given. The express or implied statutory recognition of the authority on the part of carriers to primarily determine for themselves the existence of substantially similar circumstances and conditions as a basis of charging a higher rate for a shorter than for a longer distance within the purview of the fourth section of the Act to Regulate Commerce and the right to make a rate accordingly to continue in force until on complaint it was corrected in the manner pointed out by statute, ceased to exist after the adoption of the amendment to section 4 by the Act of June 18, 1910, chapter 309, 36 Stat. 
sion was originally based upon the water competition between those points. These shipments could then be held at Nashville for not longer than six months during which time they might be rebilled or reshipped to their destination in southern territoryand on such shipments so rebilled the freight charges into and out of Nashville were readjusted so that the total transportation

at L. 547. This results from the fact that by the amendment in question the original power to determine the existence of the conditions justifying the greater charge for a shorter than was exacted for a longer distance, was taken from the carriers and primarily vested in the Interstate Commerce Commission, and for the purpose of making the prohibition efficacious it was enacted that after a time fixed no existing rate of the character provided for should continue in force unless the application to sanction it had been made and granted. Inter Mountain Rate Cases, 234 U. S. $476,5^{8} \mathrm{~L}$. Ed. I 408,34 Sup. Ct. 986 . If then it be that the rebilling privilege which is here in question, disregarding immaterial considerations of form and looking at the substance of things, was when originally established an exertion of the authority conferred or recognized by the fourth section of the Act, as there is no pretense that permission for its continuance had been applied for as required by the amendment and the statutory period for which it could be lawfully continued without such permission had expired, it follows that its continued operation was manifestly unlawful and error was committed in permitting its continuance under the shelter of the injunction awarded by the court below. To determine whether the fourth section is applicable requires a very brief consideration of the uncontroverted situation from which the rebilling privilege arose and upon the existence of which it depended. ***

"It is true that in argument it was said that the question here is whether there was a preference or discrimination under the second and third sections of the Act and not an inquiry under the fourth section and that a distinction between the various sections has been recognized. It has, indeed, been held that the provisions of the second, third and fourth sections of the Act being in pari materia required harmonious construction and therefore they should not be applied so that one section destroyed the others and consequently that a lesser charge for a longer than for a shorter distance permitted by the fourth section could not for such reason be held to be either a preference or discrimination under the second and third sections. Louisville and Nashville R. R. v. Behlmer, I75 U. S. 648, 44 L. Ed. 309, 20 Sup. Ct. 209; East Tennessee, etc., Rwy. Co. v. Interstate Commerce Commission, I8I U. S. I, 45 L. Ed. 719, 21 S. C. 516 . But the rule which requires that a practice which is permitted by one section should not be prohibited upon the theory that it is forbidden by another gives no support to the unwarranted assumption that that may be permitted which is devoid of all sanction and indeed is in direct conflict with all three of the sections, - a result clearly arising in the case before us in consequence of the amendment of section 4. Indeed when the evil which it may be assumed conduced to the adoption of the amendment of the fourth section 
charge on any shipment from any given Ohio or Mississippi River crossing by way of Nashville to any given destination in the designated southern territory was fixed at what it would have been had the shipment been billed and moved from the Ohio or Mississippi River point to its final destination without having been stopped in transit at Nashville. This privilege was not accorded to any shipments from points nearer to Nashville than the Ohio and Mississippi River crossings. Without the prior consent of the Interstate Commerce Commission, the Supreme Court declared, the enforcement of this practice to be a clear breach of the terms of section 4 .

State Legislation on Long and Short-Haul.-The various states may, either by constitutional provision or legislative enactment, forbid intra-state carriers to charge a lesser rate for a longer than for a shorter haul on the same line, provided the traffic in question be between points entirely within the state. ${ }^{11}$

and the remedy which that amendment was intended to make effective are taken into view (see Inter Mountain Rate Cases, supra), it would seem that the case before us cogently demonstrates the applicability of the amendment to the situation. And it needs no argument to demonstrate that the application of the principle of public policy which the statute embodies is to be determined by the substance of things and not by names, for if that were not the case the provisions of the statute would be wholly inefficacious, as names would readily be devised to accomplish such a purpose."

II Louisville and Nashville Railroad Co. v. Kentucky, 183 U. S. 503, 46 L. Ed. 298, 22 Sup. Ct. 95. The state of Kentucky had adopted for intrastate traffic the provisions of the fourth section of the Act to Regulate Commerce. The court said:- "It is plain that the provision in question does not in terms embrace the case of interstate traffic. It is restricted in its regulation to those who own or operate a railroad within the state, and the long and short distances mentioned are evidently distances upon the railroad line within the state. The particular case before us is one involving only the transportation of coal from one point in the state of Kentucky to another by a corporation of that state. It may be that the enforcement of the state regulation forbidding discrimination in rates in the case of articles of a like kind carried for different distances over the same line may somewhat affect commerce generally; but we have frequently held that such a result is too remote and indirect to be regarded as an interference with interstate commerce; that the interference with the commercial power of the general government to be unlawful must be direct, and not the merely incidental effect of enforcing the police powers of a state. Erie Railroad Co. v. Pennsylvania, 158 U. S. 43I, 439, 39 L. Ed. 1043, 15 Sup. Ct. 896; 
But where such legislation interferes with the rates on interstate traffic or compels the interstate carrier to regulate or adjust its interstate rates with some reference to its rates within the state it is to such extent invalid, although its validity will not be questioned where its interference with interstate commerce is remote or merely indirect.

Water Competition.-Whenever a carrier by tition. railroad shall in competition with a water route or routes reduce the rates on the carriage of any species of freight to or from competitive points, it shall not be permitted to increase such rates unless after hearing by the Interstate Commerce Commission it shall be found that such proposed increase rests upon changed conditions other than the elimination of water competition.

No cases have been decided by the Supreme Court involving the construction of this clause of section 4 since its adoption June I8, I910.

Henderson Bridge Co. v. Kentucky, I66 U. S. 150, 4I L. Ed. 953, I7 Sup. Ct. 532."

See also Louisville and Nashville Railroad Co. v. Eubank, I84 U. S. 27, 46 L. Ed. 416, 22 Sup. Ct. 277, where the court said:-"We fully recognize the rule that the effect of a state constitutional provision or of any state legislation upon interstate commerce must be direct and not merely incidental and unimportant; but it seems to us that where the necessary result of enforcing the provision may be to limit or prohibit the transportation of articles from without the state to a point within it, or from a point within to a point without the state, interstate commerce is thereby affected, and may be thereby to a certain extent directly regulated, and in that event the effect of the provision is direct and important and not a mere incident. *** It seems quite clear that any law which in its direct result regulates the interstate transportation of a single individual carrier, or company of carriers, violates the provision in question; that it is no answer to say the commodity can still be transported by another carrier or by water instead of rail, so long as the direct effect of the state legislation is to regulate the transportation of the commodity by a particular means, by rail instead of by water, or by a particular individual or company." 


\section{SECTION 5. POOLING OF FREIGHT AND DIVISION OF EARNINGS.}

SEC 5. That it shall be unlawful for any common carrier subject to the provisions of this Act to enter into any contract, agreement, or combination with Pooling of any other common carrier or carriers for the poolfreights and di- ing of freights of different and competing railroads,
vision of earn. ings forbidden. or to divide between them the aggregate or net proceeds of the earnings of such railroads, or any portion thereof; and in any case of an agreement for the pooling of freights as aforesaid, each day of its continuance shall be deemed a separate offense.

Pooling.-This paragraph was included in the Act to Regulate Commerce of February 4, I887, and has not been amended since that date. Despite the large amount of attention attracted to this clause at the time of the enactment of this statute it has been but seldom before the courts and the Supreme Court has had little occasion to construe its provisions.

This clause was discussed by the Supreme Court in the TransMissouri Freight Association case brought under the provisions of the Sherman Anti-Trust Act of July 2, I890 in connection with the prohibition of all forms of combination, by trusts or otherwise, in restraint of trade. This case grew out of an agreement of a group of western railroads, entering into an association known as the Trans-Missouri Freight Association, for the purpose of dividing the field of business among the different participating roads and determining freight rates to be charged by all of them, and for similar purposes. It was urged that such an agreement by the railroads, as the one under discussion, was authorized by the Commerce Act. The court declared emphatically that the Commerce Act did not authorize an agreement of this nature-that while it did not specifically prohibit such an agreement it did not either directly or by implication confer upon railroads any authority to make such an arrangement. The court said: 'The $5^{\text {th }}$ section prohibits what is termed 'pooling,' but there is no express provision in the Act prohibiting the maintenance of traffic rates among competing roads by making such an 
agreement as this, nor is there any provision which permits it. Prior to the passage of the Act the companies had sometimes endeavored to regulate competition and to maintain rates by pooling arrangements, and in the Act that kind of an arrangement was forbidden. The general nature of a contract like the one before us is not mentioned in or provided for by the act." 1

I United States v. Trans-Missouri Freight Association, I66 U. S. 290, 41 L. Ed. 1007, I7 Sup. Ct. 540. The court, in discussing the subject of the relation of the Act to Regulate Commerce and the Anti-Trust Act, said :-

"The first answer to this argument is that, in our opinion, the Commerce Act does not authorize an agreement of this nature. It may not in terms prohibit, but it is far from conferring either directly or by implication, any authority to make it. If the agreement be legal it does not owe its validity to any provision of the Commerce Act, and if illegal it is not made so by that Act. The fifth section prohibits what is termed 'pooling,' but there is no express provision in the Act prohibiting the maintenance of traffic rates among competing roads by making such an agreement as this, nor is there any provision which permits it. Prior to the passage of the Act the companies had sometimes endeavored to regulate competition and to maintain rates by pooling arrangements, and in the Act that kind of an arrangement was forbidden. After its passage other devices were resorted to for the purpose of curbing competition and maintaining rates. The general nature of a contract like the one before us is not mentioned in or provided for by the Act. The provisions of that Act look to the prevention of discrimination to the furnishing of equal facilities for the interchange of traffic, to the rate of compensation for what is termed the long and the short haul, to the attainment of a continuous passage from the point of shipment to the point of destination, at a known and published schedule, and in the language of counsel for defendants "without reference to the location of those points or the lines over which it is necessary for the traffic to pass,' to procure uniformity of rates charged by each company to its patrons, and to other objects of a similar nature. The Act was not directed to the securing of uniformity of rates to be charged by competing companies, nor was there any provision therein as to a maximum or minimum of rates. Competing and nonconnecting roads are not authorized by this statute to make an agreement like this one.

"As the Commerce Act does not authorize this agreement, argument against a repeal by implication, of the provisions of the Act which it is alleged grant such authority, becomes ineffective. There is no repeal in the case, and both statutes may stand, as neither is inconsistent with the other.

"It is plain, also, that an amendment of the Commerce Act would not be an appropriate method of enacting the legislation contained in the Trust Act, for the reason that the latter Act includes other subjects in addition to the contracts of or combinations among railroads, and is ad- 
Section 5 of the Act to Regulate Commerce does not in any way make it unlawful for an initial carrier to enter into an agreement for joint through rates with any or all of its connecting carriers, though such companies are competitors as between themselves. And there is no violation of this pooling section of the Act by the insertion in the agreement for joint through rates of a provision for routing by the initial carrier."

dressed to the prohibition of other contracts besides those relating to transportation. The omission, therefore, to amend the Commerce Act furnishes no reason for claiming that the later statute does not apply to railroad transportation. Although the commerce statute may be described as a general code for the regulation and government of railroads upon the subjects treated of therein, it cannot be contended that it furnishes a complete and perfect set of rules and regulations which are to govern them in all cases, and that any subsequent Act in relation to them must, when passed, in effect amend or repeal some provision of that statute. The statute does not cover all cases concerning transportation by railroad and all contracts relating thereto. It does not purport to cover such an extensive fiel.d

"The existence of agreements similar to this one may have been known to Congress at the time it passed the Commerce Act, although we are not aware, from the record, that an agreement of this kind had ever been made and publicly known prior to the passage of the Commerce Act. Yet, if it had been known to Congress, its omission to prohibit it at that time, while prohibiting the pooling arrangements, is no reason for assuming that when passing the Trust Act it meant to except all contracts of railroad companies in regard to traffic rates from the operation of such Act. Congress for its own reasons, even if aware of the existence of such agreements, did not see fit when it passed the Commerce Act to prohibit them with regard to railroad companies alone, and the Act was not an appropriate place for general legislation on the subject. And at that time, and for several years thereafter, Congress did not think proper to legislate upon the subject at all. Finally it passed this Trust Act, and in our opinion no obstacle to its application to contracts relating to transportation by railroads is to be found in the fact that the Commerce Act had been passed several years before, in which the entering into such agreements was not in terms prohibited.

"It is also urged that the debates in Congress show beyond a doubt that the Act as passed does not include railroads. * * * If such resort be had, we are still unable to see that the railroads were not intended to be in. cluded in this legislation. *** A reference to this history of the times does not, as we think, furnish us with any strong reason for believing that it was only trusts that were in the minds of the members of Congress, and that railroads and their manner of doing business was wholly excluded therefrom."

2 Southern Pacific Company v. Interstate Commerce Commission, 200 U. S. 536, 50 L. Ed. 585, 26 Sup. Ct. 330. This action had its inception 
The Supreme Court had held that the common carrier need not contract to carry beyond its own line, but may there deliver to the next succeeding carrier and thus end its responsibility, and charge

in an effort to prevent the railroads from enforcing a rule with reference to shipments of citrus fruits from California whereby as a condition to guaranteeing through rates the initial carriers reserved to themselves the right to designate the routes for the transportation of these products from California to the eastern markets. Before the adoption of the rule complained of there had been among the eastern connections of the initial carriers under the joint through rates then existing, the greatest rivalry to obtain the California fruit freight business, and this rivalry led, on the part of the connecting carriers, to a system of rebates from the through tariff rates which was clearly a violation of the Commerce Act and which was demoralizing to the business. These rebates were paid to the shippers or to companies owning fruit or refrigerator cars in consideration of the cars being routed over the line paying the bonus. The abuses became so geat that the initial carriers (the Southern Pacific and the Santa $\mathrm{Fe}$ System, the only ones reaching the section of the country where the orange industry in Southern California exists) determined if possible to crush the practise. Formerly the shippers had been permitted by the initial carriers to control the routing of the freight. A new rule was adopted, in consideration of the through rate for the shipper, reserving to the initial carrier this right to route the traffic, which enabled the initial carriers to secure the discontinuance of the practise of paying rebates. Since the shippers could not control the routing it was obviously useless for the connecting roads to pay the shippers rebates on freight they might receive. The shippers insisted that among other provisions this rule violated section 5, the pooling section, of the Act to Regulate Commerce. The Supreme Court said:-"That court (United States Circuit Court) found that the rule was adopted to uphold their published rates, or in other words to maintain their rates on the joint through tariff. Although, under the previous through rate tariff, these rates had been secretly cut by the eastern connections of the initial carriers, yet when the routing rule was agreed to as part of the through rate tariff these rebates ceased. Hence, as the court said, the purpose of the rule was undoubtedly to maintain the through rate tariff, and that it was effectual. But the court held, as a result, that this routing provision, being part of the through rate tariff, agreed to by the various eastern roads, made a contract among those roads for the pooling of freights on competing railroads within the meaning of section 5 of the Commerce Act. It held that it was not necessary in order to form a pool, in violation of that section, that the contract or agreement should fix the percentages of freight the several railroads were to receive, or that the railroads should know in advance what the percentages should be; that it was sufficient to constitute a pool if the contract or agreement provided for special means or agencies for apportioning freights, which would destroy the rivalry which would otherwise exist between the competing railroads; and an agree18 
its local rate for the transportation. And if it agree to transport beyond its own line, it may do so by such lines as it chooses. Also this right has not been held to depend upon whether the

ment by which the apportionment was left to the will of the initial carrier accomplished that purpose as effectually as though definite percentages were fixed in the contract; that defendant's plan to maintain through rates through the operation of the routing rule necessarily destroyed competition, and the adoption of the routing rule put the shippers in a position where their patronage could not possibly be competed for by the defendant's eastern connections.

"Thus the mere fact that the initial carrier was granted by this through tariff agreement the right to route the freight was held to result in the formation of a pool, in violation of the fifth section of the Act. There was no other agreement proved in the case. It is stated by the Commission that the shipments are forwarded by the initial carrier so as to give certain percentages of the traffic to connecting lines. At the same time the Commission finds that initial carriers generally comply with the requests of the shippers to route the freight as desired. The substance of the report of the Commission is, therefore, that there is a certain percentage of the traffic given the connecting carriers when there is no request for routing given by the shippers. It amounts to the giving of fair treatment to the connecting carriers. It is true the Commission calls this a tonnage pool between the connecting carriers, to which the initial carriers give effect by their routing arrangement, and that its object was not so much to prevent rebates, which was but an incident, as to effect the tonnage division. We are of opinion, however, that the evidence is substantially one way, and that is that the arrangement for routing was to break up rebating, and that it has been accomplished. The evidence before the Circuit Court was to the effect that there was no agreement whatever with the eastern connections that any of them should have any particular proportion of the freight, but the eastern roads entered into the routing agreement because they were satisfied that it would be better than the then present practise of rebating, and they thought that they would get a fair share of the business, or, in other words, would be fairly treated by the initial carriers, who gave them to understand that they would be so treated. The tonnage pool was, as the witnesses said, a myth, and it was testified to that there was not one of the eastern companies that knew what percentage of the whole business that company secured. They simply knew that the through rates were maintained under the operation of the routing agreement and that rebating ceased, and they were satisfied with the manner of their treatment by the initial carrier.

"The Circuit Court, in order to arrive at its result, necessarily treated the connecting carriers as rival and competing transportation lines for this freight, and assumed that between these lines there would exist, but for the routing agreement, a competition for the fruit transportation which could not be extinguished by any agreement as to routing, as a condition for making through tariff rates; that as competition was de- 
original carrier agreed to be liable for the default of the connecting carrier after the goods are delivered to such connecting carrier. Since the initial carrier is not bound to make a through contract, it can do so upon such terms as may be agreed upon,

stroyed by this rule, it was idle to say that such result was not intended by the defendant, and so it was held that the carrying out of the routing agreement violated the Act.

"We think these various roads were really not competing roads within the meaning of the fifth section of the Commerce Act, when the facts are carefully examined. That Act recognizes the right of the carriers to agree upon and provides for the publication of joint through tariff rates between continuous roads, on such terms as the roads may choose to make, provided, of course, the rates are reasonable and no discrimination, or other violation of the Act is practised. The initial carrier did not, on its line, reach the eastern markets, but it reached various connecting railroads which did reach those markets. The initial carrier had the right to enter into an agreement for joint through rates, with all or any one of these connecting companies, though such companies were competing ones among themselves. And the agreements could be made upon such terms as the various companies might think expedient, provided they were not in violation of any other provisions of the Act.

"Prior to the adoption of the routing rule these connecting railroads were already acting under a through rate tariff which continued up to the time when the agreement for the routing was adopted. When so acting it was no longer possible to compete with each other as to rates (and it is upon the rebates as to rates that this whole controversy is founded), provided the companies fulfilled their joint rate tariff agreements. The only way the rate competition could exist under the through rate tariff was by violating the law. This, unfortunately, was habitually done, and during that time the competition consisted in a rivalry between these roads, as to which would be the greatest violator of the law by giving the greatest rebates.

"In truth, the only way in which these connecting lines could legally become competing railroads for this California fruit trade would be in the absence of all joint tariff rate agreements. The moment they made such agreements, and carried them out, rate competition would cease.

"All that would be needed for the total suppression of rate competition among the connecting railroads would be the honest fulfilment of their agreement as to joint through rates. And just here is where they failed and where they violated their agreement and the law by granting rebates, or, in other words, by competing, as to rates, for the freight in violation of the joint rates. In such case we do not see any violation of the pooling section of the Act, by putting in the agreement for joint through rates the provision for routing by the initial carrier. It achieved its purpose and stopped rebating, although it thereby also stopped rate competition which, in the presence of the through rate tariff, was already illegal. The railroads are no longer rate competing roads after the adoption of a 
provided they are reasonable and do not otherwise violate the law. Here the terms consist only of the condition that the initial carrier may control the routing beyond its own line.

The Supreme Court moreover held that connecting roads are no longer rate competing roads after the adoption of a through rate tariff by them. In the absence of a joint through rate from the connecting carrier such connecting roads are competing lines among themselves.

Amendment of August 24, 1912 . by Railroads.-From and after the first day of July, nineteen hundred and fourteen, it shall be unlawful for any railroad company or other common carrier subject to the Act to Regulate Commerce to own, lease, operate, control, or have any interest Railroads not whatsoever (by stock ownership or otherwise, either
own compe-
ing water car. directly, indirectly, through any holding company, or to own competing water car. riers.

\section{Competing Water Carriers not to be Owned} by stockholders or directors in common or in any other manner) in any common carrier by water operated through the Panama Canal or elsewhere with which said railroad or other carrier aforesaid

through rate tariff by them, and they have no right to privately reduce their rates.

"Now, while the most important, if not the only, effect of the routing agreement is to take away this rebating practise, and to hold all parties to that agreement as part of the joint through rate tariff, we think no case is made out of a violation of the pooling provision in the fifth section of the Act, even where the initial carrier promises fair treatment to the connecting roads, and carries out such promises.

"We must remember the general purpose of the Act which is, as has been said, to obtain fair treatment for the public from the roads, and reasonable charges for the transportation of freight and the honest performance of duty, with no improper or unjust preference or discrimination. Under such circumstances, the court ought not to adopt such a strict and unnecessary construction of the Act as thereby to prevent an honest and otherwise perfectly legal attempt to maintain joint through rates, by destroying one of the worst abuses known in the transportation business. The effort to maintain the published through joint tariff rates is entirely commendable.

"We think that the agreement in question, upon its face, does not violate any provision of the Commerce Act, and there is no evidence in the case which shows that in fact there has been any such violation."

See also United States $v$ Pacifi.c and Arctic Railway and Navigation Company, 228 U. S. 87, 57 L. Ed. 742, 33 Sup. Ct. 433. 
does or may compete for traffic or any vessel carrying freight or passengers upon said water route or elsewhere with which said railroad or other carrier aforesaid does or may compete for traffic; and in case of the violation of this provision each day in which such violation continues shall be deemed a separate offense.

Jurisdiction is hereby conferred on the Interstate Commerce Commission to determine questions of fact as to the competition or possibility of to competition. competition, after full hearing, on the application of any railroad company or other carrier. Such application may be filed for the purpose of determining whether any existing service is in violation of this section and pray for an order permitting the continuance of any vessel or vessels already in operation, or for the purpose of asking an order to install new service not in conflict with the provisions of this paragraph. The Commission may on its own motion or the application of any shipper institute proceedings to inquire into the operation of any vessel in use by any railroad or other carrier which has not applied to the Commission and had the question of competition or the possibility of competition determined as herein provided. In all such cases the order of said Commission shall be final.

If the Interstate Commerce Commission shall be of the opinion that any such existing specified service by water other than through the Panama Canal is being operated in the interest of the public and is of advantage to the convenience and commerce of the people, and that such extension will neither exclude, prevent, nor reduce competition on the route by water under consideration, the Interstate Commerce Commission may, by order, extend the time during which such service by water may continue to be operated beyond July first, nineteen hundred and fourteen. In every case of such extension the rates, schedules, and practises of such water carrier shall be filed with the Interstate Commerce

Penalty.

Commis sion

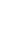


Commission and shall be subject to the Act to Regulate Commerce and all amendments thereto in the same manner and to the same extent as is the railroad or other common carrier controlling such water carrier or interested in any manner in its operation: Provided, Any application for extension under the terms of this provision filed with the Interstate Commerce Commission prior to July first, nineteen hundred and fourteen, but for any reason not heard and disposed of before said date, may be considered and granted thereafter.

Violators of No vessel permitted to engage in the coastwise Sherman
not $t$ canal. mitted to enter or pass through said canal if such ship is owned, chartered, operated, or controlled by any person or company which is doing business in violation of the provisions of the Act of Congress approved July second, eighteen hundred and ninety, entitled "An Act to protect trade and commerce against unlawful restraints and monopolies," or the provisions of sections seventy-three to seventyseven, both inclusive, of an Act approved August twenty-seventh, eighteen hundred and ninety-four, entitled "An Act to reduce taxation, to provide revenue for the Government, and for other purposes," or the provisions of any other Act of Congress amending or supplementing the said Act of July second, eighteen hundred and ninety, commonly known as the Sherman Antitrust Act, and amendments thereto, or said sections of the Act of August twenty-seventh, eighteen hundred and ninety-four. The question of fact may be determined by the judgment of any court of the United States of competent jurisdiction in any cause pending before it to which the owners or operators of such ship are parties. Suit may be brought by any shipper or by the Attorney General of the United States.

This section of the Act to Regulate Commerce was adopted August 24, I912 as a part of the Panama Canal Act and by that Act made an integral part of the Commerce Act. No cases involving any of the provisions thereof have thus far been decided by the Supreme Court. 


\section{SECTION 6. PRINTING, POSTING AND FILING OF RATES AND SCHEDULES.}

SE.c. 6. (Amended March 2, I889. Following section substituted June 29, 1906. Amended June 18, 1910, and August 24, I912.) That every common carrier subject to the provisions of this Act shall file with the Commission created by this Act and print and keep open to public inspection schedules showing all the rates, fares, and charges for transportation between different points on its own route and between points on its own route and points on the route of any other carrier by railroad, by pipe line, or by water when a through route and joint rate have been established. If no joint rate over the through route has been established, the several carriers in such through route shall file, print and keep open to public inspection as aforesaid, the separately established rates, fares and charges applied to the through transportation. The schedules printed as aforesaid by any such common carrier shall plainly state the places between which property and passengers will be carried, and Printing and posting of schedule $\mathrm{s}$ of rates, fares, and charges including rules and regulations affecting the same, cing, storage charges, a $\mathrm{nd}$ freight classifica. shall contain the classification of freight in force, and shall also state separately all terminal charges, storage charges, icing charges, and all other charges which the Commission may require, all privileges or facilities granted or allowed and any rules or regulations which in any wise change, affect, or determine any part or the aggregate of such aforesaid rates, fares, and charges, or the value of the service rendered to the passenger, shipper, or consignee. Such schedules shall be plainly printed in large type, and copies for the use of the public shall be kept posted in two public and conspicuous places in every depot, station, or office of such carrier where passengers or freight, respectively, are received for transportation, in such form that they 
shall be accessible to the public and can be conveniently inspected. The provisions of this section shall apply to all traffic, transportation, and facilities defined in this Act.

Printing and posting schedul e $s$ rates on freigh carried through a foreign coun try. ject to custorns duties in crse of failure to pub. lish throug h raten.

the through rate on which shall not have been made public, as required by this Act, shall, before it is admitted into the United States from said foreign country, be subject to customs duties as if said freight were of foreign production.

Thirty days' No change shall be made in the rates, fares, and public notice of
change in rates charges or joint rates, fares, and charges which must be given. have been filed and published by any common carrier in compliance with the requirements of this section, except after thirty days' notice to the Commission and to the public published as aforesaid, which shall plainly state the changes proposed to be made in the schedule then in force and the time when the changed rates, fares, or charges will go into effect; and the proposed changes shall be shown by printing new schedules, or shall be plainly indicated upon the schedules in force at the time and kept open to public inspection: Provided, That the Commission may, in its discretion and for good cause shown, allow changes upon less than the Commin ion notice herein specified, or modify the requirements may modify re. quirements this section. f of this section in respect to publishing, posting, and filing of tariffs, either in particular instances or by a general order applicable to special or peculiat circumstances or conditions. 
The names of the several carriers which are parties to any joint tariff shall be specified therein, and each of the parties thereto, other than the one filing the same, shall file with the Commission such evidence of concurrence therein or acceptance thereof as may be required or approved by the Commission, and where such evidence of concurrence or acceptance is filed it shall not be necessary for the carriers filing the same to also file copies of the tariffs in which they are named as parties.

Every common carrier subject to this Act shall also file with said Commission copies of all contracts, agreements, or arrangments with other common carriers in relation to any traffic affected by the provisions of this Act to which it may be a party.

The Commission may determine and prescribe $\begin{gathered}\text { Commission } \\ \text { prescribe }\end{gathered}$ the form in which the schedules required by this forms of schedsection to be kept open to public inspection shall be prepared and arranged and may change the form from time to time as shall be found expedient.

No carrier, unless otherwise provided by this Act, shall engage or participate in the transportation of passengers or property, as defined in this Act, unless the rates, fares, and charges upon which the same are transported by said carrier have been filed and published in accordance with the provisions of this Act; nor shall any carrier charge or demand or collect or receive a greater or less or different compensation for such transportation of passengers, or property, or for any service in connection therewith, between the points named in such tariffs than the rates, fares, and charges which are specified in the tariff filed and in effect at the time; nor shall any carrier refund or remit in any manner or by any device any portion of the rates, fares, and charges so specified, nor extend to any shipper or person any privileges or facilities in the transportation of passengers or property, except such as are specified in such tariffs: Provided,

Published rates to be strictly ob. served.
Joint tariffs must $s$ p e cif y names of car. rers participa. ting. Evidence

Copies of con tracts, agree. ments, or arrangements reating to traffic must be filed with Commis. sion.

No carrier shall transporta. tion unless it files and pubfares, and charges there. on. 
"Carrier" That wherever the word "carrier" occurs in this means "com-" Act it shall be held to mean "common carrier."

Preference and expedition of military traf. fic in time of

Penalty for failure to comply with regulation.

Commis ion may reject certain schedules.

That in time of war or threatened war preference and precedence shall, upon the demand of the President of the United States, be given, over all other traffic, to the transportation of troops and material of war, and carriers shall adopt every means within their control to facilitate and expedite the military traffic.

The Commission may reject and refuse to file Amendment of any schedule that is tendered for filing which does June 18 , 1910.

not provide and give lawful notice of its effective date, and any schedule so rejected by the Commission shall be void and its use shall be unlawful.

In case of failure or refusal on the part of any carrier, receiver, or trustee to comply with the terms of any regulation adopted and promulgated or any order made by the Commission under the provisions of this section, such carrier, receiver, or trustee shall be liable to a penalty of five hundred dollars for each such offense, and twenty-five dollars for each and every day of the continuance of such offense, which shall accrue to the United States and may be recovered in a civil action brought by the United States.

Carrier to furnish written statement of rate. Penalty for or in consequence of the misstatement of the rate, misstatement of rate.
If any common carrier subject to the provisions of this Act, after written request made upon the agent of such carrier hereinafter in this section referred to, by any person or company for a written statement of the rate or charge applicable to a described shipment between stated places under the schedules or tariffs to which such carrier is a party, shall refuse or omit to give such written statement within a reasonable time, or shall misstate in writing the applicable rate, and if the person or company making such request suffers damage in consequence of such refusal or omission either through making the shipment over a line or route for which the proper rate is higher than the rate over another available line or route, or through 
entering into any sale or other contract whereunder such person or company obligates himself or itself to make such shipment of freight at his or its cost, then the said carrier shall be liable to a penalty of two hundred and fifty dollars, which shall accrue to the United States and may be recovered in a civil action brought by the United States.

It shall be the duty of every carrier by railroad to keep at all times conspicuously posted in every be posted. station where freight is received for transportation the name of an agent resident in the city, village, or town where such station is located, to whom application may be made for the information by this section required to be furnished on written request; and in case any carrier shall fail at any time to have such name so posted in any station, it shall be sufficient to address such request in substantially the following form: "The Station Agent of the Company at Station," together with the name of the proper post office, inserting the name of the carrier company and of the station in the blanks, and to serve the same by depositing the request so addressed, with postage thereon prepaid, in any post office.

When property may be or is transported from point to point in the United States by rail and water of Amgust 24 , through the Panama Canal or otherwise, the transportation being by a common carrier or carriers, and not entirely within the limits of a single State, the Interstate Commerce Commission shall have Commission jurisdiction of such transportation and of the car- over $\begin{gathered}\text { rai } \\ \text { water trafic in }\end{gathered}$ riers, both by rail and by water, which may or do certain particuengage in the same, in the following particulars, in addition to the jurisdiction given by the Act to Regulate Commerce, as amended June eighteenth, nineteen hundred and ten:

(a) To establish physical connection between the lines of the rail carrier and the dock of the water carrier by directing the rail carrier to make

Physical con. nection between rail lines and dock of water suitable connection between its line and a track or tracks which have been constructed from the dock 
to the limits of its right of way, or by directing either or both the rail and water carrier, individually or in connection with one another, to construct and connect with the lines of the rail carrier a spur track or tracks to the dock. This provision shall only apply where such connection is reasonably practicable, can be made with safety to the public, and where the amount of business to be handled is sufficient to justify the outlay.

Commis $\mathrm{s}$ i o $\mathrm{n}$ may determine terms and con. ditions of construction operation.
$T$ h $r$ o $\mathrm{gh}$ routes and joint rates between rail and water carriers. rates to and from ports.

The Commission shall have full authority to determine the terms and conditions upon which these connecting tracks, when constructed, shall be operated, and it may, either in the construction or the operation of such tracks, determine what sum shall be paid to or by either carrier. The provisions of this paragraph shall extend to cases where the dock is owned by other parties than the carrier involved.

(b) To establish through routes and maximum joint rates between and over such rail and water lines, and to determine all the terms and conditions under which such lines shall be operated in the handling of the traffic embraced.

(c) To establish maximum proportional rates by rail to and from the ports to which the traffic is brought, or from which it is taken by the water carrier, and to determine to what traffic and in connection with what vessels and upon what terms and conditions such rates shall apply. By proportional rates are meant those which differ from the corresponding local rates to and from the port and which apply only to traffic which has been brought to the port or is carried from the port by a common carrier by water.

T h $r$ o $u g h$ routes and joint rates between rail and water carriers from a port in the United States to a foreign country $v$ i a Canal. (d) If any rail carrier subject to the Act to Regulate Commerce enters into arrangements with any water carrier operating from a port in the United States to a foreign country, through the Panama Canal or otherwise, for the handling of through business between interior points of the United States and such foreign country, the Inter- 
state Commerce Commission may require such railway to enter into similar arrangements with any or all other lines of steamships operating from said port to the same foreign country.

The orders of the Interstate Commerce Commission relating to this section shall only be made upon formal complaint or in proceedings instituted amendments.

by the Commission of its own motion and after full hearing. The orders provided for in the two amendments to the Act to Regulate Commerce enacted in this section shall be served in the same manner and enforced by the same penalties and proceedings as are the orders of the Commission made under the provisions of section 15 of the Act to Regulate Commerce, as amended June eighteenth, nineteen hundred and ten, and they may be conditioned for the payment of any sum or the giving of security for the payment of any sum or the discharge of any obligation which may be required by the terms of said order.

History of the Section.-No section of the Act to Regulate Commerce has been more frequently or more substantially amended than this. March 2, I 889, this section was first amended so as to compel the printing of the schedule and its posting in two "public and conspicuous places in every depot, station, or office," to forbid the reduction of any rates without a notice of three days, and so as to specify more definitely the power of the Interstate Commerce Commission to prescribe different schedules, rates, fares and charges. The section was further amended by the Elkins Act of February 19, 1903, in regard to the publication and application of the tariff rates and in making the published rates conclusive against the carrier.

The entire section was substantially rewritten by the Act of June 29, I906 which made many important changes in its provisions. Thereafter the carriers were required to publish joint rates in the same manner as separate rates. Changes in rates, whether joint or separate, were forbidden except upon notice of thirty days-before the amendment three days notice had been required of a decrease and ten days notice had been required of an increase of rates. All terminal charges and other charges for special services as well as privileges or facilities provided 
were required to be separately printed and posted. And the Commission was given authority in its discretion and upon good cause shown to modify the requirements as to publishing, posting and filing of the tariffs.

By the Act of June I8, I9ro the section was still further amended and authority was given the Commission to reject and refuse to file any schedule tendered which failed to give lawful notice of its effective date; penalties were provided for the failure or refusal of any carrier to comply with the terms of any regulation or order made by the Commission under the provisions of this section; the carrier was required, upon written request of any person or company, to furnish a written statement of rates, and was also made liable for damages in consequence of the omission or misstatement of any rate; and the carrier was charged with the duty of keeping posted in the station where freight is received for transportation the name of its agent in such city or town.

By the Act of August 24, I912, very substantial additions were made to the section under discussion in giving to the Interstate Commerce Commission jurisdiction over rail and water traffic in certain particulars; in empowering that body to require physical connection between rail lines and the docks of water carriers and to determine the terms and conditions under which such connections shall be made; in authorizing that body to establish through routes and joint rates between rail and water carriers; also to establish maximum proportional rates by rail to and from the ports where traffic is taken or brought by water carriers; and to require through routes and joint rates between rail and water carriers from a port in the United States to a foreign country, "through the Panama Canal or otherwise" for handling through business between interior points of the United States and such foreign country; finally provision was made for proceedings before the Commission to enforce these amendments, and penalties provided the same as under section $\mathrm{I}_{5}$ of the Act for any failure to comply with such orders and regulations of the Commission.

The dates and the nature of these various changes in the section must be kept in mind when studying the decisions of the courts construing the provisions of the section in the different periods of its transition from its original form as enacted Feb- 
ruary 4,1887 to its present form after the amendments of August 24, I9I2.

Conclusiveness of the Published Rate.-The amount fixed by the published schedule of rates and charges is conclusive as to all interstate shipments and a consignee can receive the goods shipped only upon payment or tender of the amount thus designated. Such rate is absolute and its effect is not modified by the statement of any other rate in the bill of lading. ${ }^{1}$ The ship-

I Gulf, Colorado and Santa Fe Railway Co. v. Hefley, I58 U. S. 98, 39 L. Ed. 910,15 Sup. Ct. 802, decided by the Supreme Court in I895. A Texas statute made it unlawful for a railroad company to charge and col. lect a greater sum for transporting freight than is specified in the bill of lading. A carload of furniture was shipped from St. Louis in Missouri to the plaintiff at Cameron, Texas. The bill of lading named 69 cents per hundred popnds as the rate for this shipment. Upon the arrival of the shipment at Cameron the consignee presented the bill of lading and the a mount of $\$ 82.80$ at the rate of 69 cents per hundred pounds. The agent refused to deliver the goods without the payment of $\$ 100.80$ that being the amount due at the rate of 84 cents per hundred pounds which was the rate named in the printed tariff sheet posted in the railroad office at Cameron. But before the shipment at St. Louis the rate had been reduced to 69 cents but the new tariff sheet had not reached Cameron and the agent there was ignorant of the reduction. The Supreme Court said:- "The question presented by this record is this: Is the statute of Texas imposing a penalty for a failure to deliver goods on tender of the rate named in the bill of lading applicable to interstate shipments, * * Clearly the state and the national Acts relate to the same subject matter and prescribe different rules. By the state Act the bill of lading is made controlling as to the rate collectible, and a failure to comply with that require. ment exposes the delinquent carrier to its penalties, while the national statute ignores the bill of lading and makes the published tariff rate binding, and subjects the offender, both carrier and agent, to severe penalties. The carrier cannot obey one statute without sometimes exposing itselt to the penalties prescribed by the other. Take the case before us: If, in disregard of the joint tariff established by the defendant and the St. Louis and San Francisco Railway Company and filed with the Interstate Commerce Commission, the latter company, as a matter of favoritism, had issued this bill of lading at a rate less than the tariff rate, both the defendant company and its agent would, by delivering the goods upon receipt of only such reduced rate, subject themselves to the penalties of the national law, while, on the other hand, if the tariff rate was insisted upon, then the corporation would become liable for the damages named in the state Act. In case of such a conflict the state law must yield. * * * It is no answer to say that in this case the defendant might have complied with both the state and the national statute; that it was a party to the reduction of the joint rate; that, therefore, the bill of lading was prop- 
per as well as the carrier is bound to take notice of the filed tariff rates, and so long as they remain operative they are conclusive as to the rights of the parties provided there is shown no attempt at rebating or false billing. Otherwise the primary purpose of the Act to Regulate Commerce-to obtain equal treatment of all shippers and the enforcement of one rate from allwould be defeated by a multiplicity of oral agreements for the carriage of goods at rates different from those set forth in the

erly issued at 69 cents per one hundred pounds; that it should have promptly notified its agents at every station of such reduction; that if it had done so the agent at Cameron could have complied with the state as well as the national law, and that its negligence in this respect is sufficient ground for holding it amenable to the state law. The question is not whether, in any particular case, operation may be given to both statutes, but whether their enforcement may expose a party to a conflict of duties. It is enough that the two statutes operating upon the same subject matter prescribe different rules. In such case one must yield, and that one is the state law. It may be conceded that were there no Congressional legislation in respect to the matter, the state Act could be held applicable to interstate shipments as a police regulation."

In Texas Pacific Railway Co. v. Mugg and Dryden, 202 U. S. 242, 50 L. Ed. Iorr, 26 Sup. Ct. 628, to the same point, the court said:-“"This case is within the principle of and is ruled by the decision in Railroad Co. v. Hefley ( 158 U. S. 98, 39 L. Ed. 910, I5 Sup. Ct. 802). Upon the authority of that case the Supreme Court of Alabama denied the liability of a railroad company in a case of similar character to that under review. (Southern Railway Co. v. Harrison, II Ala. 539). The opinion of Chief Justice Brickell, so aptly reviewed and declared the effect of the decision in the Hefley case that we adopt the same in disposing of the present controversy. The Alabama court said:-'The clear effect of the decision (Hefley case) was to declare that one who has obtained from a common carrier transportation of goods from one state to another at a rate, specified in the bill of lading, less than the published schedule rates filed with and approved by the Interstate Commerce Commission, and in force at the time, whether or not he knew that the rate obtained was less than the schedule rate, is not entitled to recover the goods or damages for their detention, upon the tender of payment of the amount of charges named in the bill of lading, or of any sum less than the schedule charges; in other words that, whatever may be the rate agreed upon, the carrier's lien on the goods is, by force of the Act of Congress, for the amount fixed by the published schedule of rates and charges, and this lien can be discharged, and the consignee can become entitled to the goods, only by the payment or tender of payment, of such amount. Such is now the supreme law, and by it this and the courts of all other states are bound, ***" 
published tariffs. ${ }^{2}$ It follows from this that contracts or agreements to pay for advertising or to settle claims by the donation of transportation or by charging less rates than those posted and filed are illegal and violate the provisions of section six. ${ }^{3}$

2 Atchison, Topeka and Sante Fe Railway Co. v. Robinson, 233 U. S. 173, 58 L. Ed. 901, 34 Sup. Ct. 556. Here the court said:-"We regard these cases as settling the proposition that the shipper as well as the carrier is bound to take notice of the filed tariff rates, and that so long as they remain operative they are conclusive as to the rights of the parties, in the absence of facts or circumstances showing an attempt at rebating or false billing. Great Northern Railway Co. v. O'Connor, 232 U. S. 508, $5^{8}$ L. Ed. 703,34 Sup. Ct. 380 . To give to the oral agreement upon which the suit was brought, the prevailing effect allowed in this case by the charge in the trial court, affirmed by the judgment of the Supreme Court of the state, would be to allow a special contract to have binding force and effect though made in violation of the filed schedules which were to be equally observed by the shipper and carrier. If oral agreements of this character can be sustained, then the door is open to all manner of special contracts, departing from the schedules and rates filed with the Commission. Kansas City Southern Railway Co. v. Carl, 227 U. S. 639, 57 L. Ed. 683,33 Sup. Ct. 391. To maintain the supremacy of such oral agreements would defeat the primary purpose of the Interstate Commerce Act, so often affirmed in the decisions of this court which are to require equal treatment of all shippers and the charging of but one rate to all, and that the one filed as required by the Act. The Supreme Court of the state in this case affirmed the instruction of the trial court upon which the case was given to the jury, and held that the oral contract was binding unless it was affirmatively shown that the written agreement, based upon the filed schedules, was brought to the knowledge of the shipper, and its terms assented to by him. This ruling ignored the terms of shipment set forth in the schedules and permitted recovery upon the contract made in violation thereof in a case where there was no proof that there was an attempt to violate the published rates by a fraudulent agreement showing rebating or false billing of the property, and no circumstances which would take the case out of the rulings heretofore made by this court as to the binding effect of such filed schedules and the duty of the shipper to take notice of the terms of such rates, and the obligation to be bound thereby, in the absence of the exceptional circumstances to which we have referred."

See also Atchison, Topeka and Santa Fe Railway Co. v. Moore, 232 U. S. I82, 58 L. Ed. 906, 34 Sup. Ct. 558.

3 Louisville and Nashville Railroad Co. v. Mottley, 2 I9 U. S. 467, 55 L. Ed. 297, 3I Sup. Ct. 265, where free passes for life were to be given to the defendant and his wife in settlement for a claim for injuries by the railroad. The court said:- "In our opinion, after the passage of the Commerce Act the railroad company could not lawfully accept from Mottley and wife any compensation 'different' in kind from that mentioned in its published schedule of rates. And it cannot be doubted that the rates 
The theory of section 6 in its original form was that the shipper could learn the rates in force by a reference to the posted tariff sheets and therefore was estopped from setting up an agreement with the carrier or its agent for another rate than that officially provided. But in practise it was found that the shipper owing to the volume and the intricacy of the tariff sheets, unless he had had special training or experience, was unable of his own initiative to determine the rates applicable to shipments and he therefore was forced to rely upon the information

or charges specified in such schedule were payable only in money. They could not be paid in any other way, without producing the utmost confusion and defeating the policy established by the Acts regulating commerce. The evident purpose of Congres was to establish uniform rates for transportation, to give all the same opportunity to know what the rates were as well as to have the equal benefit of them. To that end the carrier was required to print, post and file its schedules and to keep them open to public inspection. No change could be made in the rates embraced by the schedules except upon notice to the Commission and to the public. But an examination of the schedules would be of no avail and would not ordinarily be of any practical value if the published rates could be disregarded in special or particular cases by the aceptance of property of various kinds, and of such value as the parties immediately concerned chose to put upon it, in place of money for the services performed by the carrier. That money only was receivable for transportation is the basis upon which the Interstate Commerce Commission has proceeded; for, in one of its Conference Rulings (207) issued in 1909, the Commission held that nothing but money could be lawfully received or accepted in payment for transportation, whether of passengers or property, for any service connected therewith, 'it being the opinion of the Commission that the prohibition against the charging or collecting a greater or less or different compensation than the established rates or fares in effect at the time precludes the acceptance of service, property or other payment in lieu of the amount specified in the published schedules.' It is now the established rule that a carrier cannot depart to any extent from its published schedule of rates for interstate transportation on file without incurring the penalties of the statute. Union Pacific Railway Co. v. Goodridge, I49 U. S. 680, 69I, 37 L. Ed. 896, I3 Sup. Ct. 970; Gulf, Colorado, etc., Railway Co. v. Hefley, 158 U. S. 98, 102, 39 L. Ed. 910 , I5 Sup. Ct. 802 ; I. C. C. v. Chesapeake and Ohio Railway Co., 200 U. S. 36I, 39I, 50 L. Ed. 515, 26 Sup. Ct. 272; Texas and Pacific Railway Co. v. Abilene Cotton Oil Co., 204 U. S. 426, 439, 5 I L. Ed. 553, 27 Sup. Ct. 350. That rule was established in execution of a public policy which, it seems, Congress deliberately adopted as applicabie to the interstate transportation of persons or property. The passenger has no right to buy tickets with services, advertising, releases or property, nor can the railroad company buy services, advertising, releases or property with transportation. The 
given to him by local freight agents or other representatives of the carriers without being able to set that up as a defense to any larger charges which might be exacted at the destination of the shipment in accordance with the posted tariff rates. The situation became such that the Interstate Commerce Commission in its annual report for 1908 called attention to the fact and urged the enactment of legislation which would absolve the shipper from the necessity of ascertaining rates at his own peril and would compel the carrier or its agent under proper penalty to furnish a written statement of any charges in response to a request therefor presented in writing. Pursuant thereto Congress adopted the amendment of June 18 , I910 which is now in force and which provides for a penalty of $\$ 250$ to be recovered by the United States in a civil action against the carrier which through its proper agent refuses or omits to give a statement of the proper rate for a described shipment requested in writing, or misstates the rate, as a result of which the shipper suffers a loss. It is to be noticed that the penalty accrues to the United States and not to the shipper for whom no redress is provided.

statute manifestly means that the purchase of a transportation ticket by a passenger and its sale by the company shall be consummated only by the former paying cash and by the latter receiving cash of the amount specified in the published tariffs. In the first of the cases last above cited (the Goodridge Case) the court, referring to the practise of allowing rebates, said: 'So opposed is the policy of the Act to secret rebates of this description that it requires a printed copy of the classification and schedule of rates to be posted conspicuously in each passenger station for the use of the patrons of the road, that every one may be apprised, not only of what the company will exact of him for a particular service, but what it exacts of everyone else for the same service, so that in fixing his own prices he may know precisely with what he has to compete." "

See also Chicago, Indianapolis and Louisville Railway Co. v. United States, 2 I9 U. S. 486, 55 L. Ed. 305, 3I Sup. Ct. 272, which involved the question of the payment by a railroad for advertising by transportation. The court said:- "The legislative department intended that all who obtained transportation on interstate lines should be treated alike in the matter of rates, and that all who availed themselves of the services of the railway company (with certain specified exceptions) should be on a plane of equality. Those ends cannot be met otherwise than by requiring transportation to be paid for in money which has a certain value known to all and not in commodities or services or otherwise than in money."

American Express Company v. United States, 212 U. S. 522, 53 L. Ed. 635, 29 Sup. Ct. 315; Charleston and Western Carolina Railway Co. v. Thompson, 234 U. S. 576, 58 L. Ed. 1476, 34 Sup. Ct. 964. 
However the rates are published and accessible to the shipper and however difficult they may be to understand the shipper is conclusively presumed to know the legal rate. Neither the intentional or accidental misstatement of the applicable published rate will bind either the carrier or the shipper. Nor is the carrier liable to the shipper for damages accruing as the result of a mistake in quoting a rate less than the full published rate.

Posting of Rates in Railroad Stations.-The posting of rates or tariff schedules is not a condition precedent to making them legally operative. The publication and the posting of rates are essentially distinct functions. The former does not include the latter. The publication contemplated by section six consists in promulgating and distributing the tariff in printed form preparatory to putting it into effect. The posting is not a prerequisite to the establishment and enforcement of a tariff of rates but is a continuing act enjoined upon the carrier, during the life and operation of the tariff, in order to provide facilities for the general public to ascertain the rates actually in force. ${ }^{5}$ In the

4 Kansas City Southern Railway Co. v. Carl, 227 U. S. 639, 57 L. Ed. 683, 33 Sup. Ct. 39I. Here the court said:-"It would open a wide door to fraud and destroy the uniform operation of the published tariff rate sheets. When there are two published rates, based upon difference in value, the legal rate automatically attaches itself to the declared or agreed value. Neither the intentional nor accidental misstatement of the applicable published rate will bind the carrier or shipper. The lawful rate is that which the carrier must exact and that which the shipper must pay. The shipper's knowledge of the lawful rate is conclusively presumed, and the carrier may not be required to surrender the goods carried upon the payment of the rate paid, if that was less than the lawful rate, until the full legal rate has been paid. Texas and Pacific Railway v. Mugg, $202 \mathrm{U}$. S. 242,50 L. Ed. I0II, 26 Sup. Ct. 628 . Nor is the carrier liable for damages resulting from a mistake in quoting a rate less than the full published rate. Illinois Central R. R. v. Henderson Elevator Co., 226 U. S. 441, 57 L. Ed. 290, 33 Sup. Ct. 176. Nor can a carrier legally contract with a particular shipper for an unusual service unless he make and publish a rate for such service equally open to all. Chicago and Alton Railroad Co. v. Kirby, 225 U. S. 155, 56 L. Ed. 1033, 32 Sup. Ct. 648."

5 Texas and Pacific Railway Co. v. Cisco Oil Mill, 204 U. S. 449, 5 I L. Ed. 562, 27 Sup. Ct. 358. The case turned upon the question of whether the rates in issue had been posted as required by section 6 of the Act to Regulate Commerce. The court said:- "The filing of the schedule with the Commission and the furnishing by the railroad company of copies to its freight offices incontrovertibly evidenced that the tariff of rates contained in the schedule had been established and put in force as mentioned 
words of the Supreme Court "posting is not a condition to making a tariff legally operative." Nor is it a condition to the continued existence of a tariff once legally established. Otherwise manifestly the accidental or malicious destruction or removal of even one of the posted copies from a depot or freight office would annul or suspend the rates which naturally is not the intention of the Act in view of the provision that rates once lawfully established should not be changed except in the manner prescribed. In short the filing of the schedule with the Interstate Commerce

in the first sentence of the section, and the railroad company could not have been heard to assert to the contrary. The requirement that schedules should be 'posted in two public and conspicuous places in every depot,' etc., was not made a condition precedent to the establishment and putting in force of the tariff of rates, but was a provision based upon the existence of an established rate, and plainly had for its object the affording of special facilities to the public for ascertaining the rates actually in force. To hold that the clause had the far-reaching effect claimed would be to say that it was the intention of Congress that the negligent posting by an employee of but one instead of two copies of the schedule, or the neglect to post either, would operate to cancel the previously established schedule, a conclusion impossible of acceptance. While section 6 forbade an increase or reduction of rates, etc., 'which have been established and published as aforesaid,' otherwise than as provided in the section, we think the publication referred to was that which caused the rates to become operative; and this deduction is fortified by the terms of section to of the Act making it a criminal offense for a common carrier or its agent or a shipper or his employee improperly 'to obtain transportation for property at less than the regular rates then established and in force on the line of transportation of such common carrier.' Whether by the failure to post an established schedule a carrier became subject to penalties provided in the Act to Regulate Commerce, or whether if damage had been occasioned to a shipper by such omission, a right to recover on that ground alone would have obtained, we are not called upon in this case to decide."

Kansas City Southern Railway Co. v. Albers Commission Co., 223 U. S. 573, 56 L. Ed. 556, 32 Sup. Ct. 316. "Although it was shown that the schedules embodying this rate were regularly printed, duly filed with the Interstate Commerce Commission, and kept open to public inspection at the freight offices of the garnishee at Kansas City and other points, it was not shown that copies were posted in public and conspicuous places in those offices as required by section 6 of the Interstate Commerce Act. Posting, however, was not essential to make rates legally operative, and was required only as a means of affording special facilities to the public for ascertaining the rates actually in force."

United States v. Miller, 223 U. S. 599, 56 L. Ed. 568, 32 Sup. Ct. 323. The court here said:- "It is the contention of the defendants that a tariff is not published in the sense in which the Act uses that term unless printed 
Commission and the supplying of copies thereof to the various freight offices by the carriers incontrovertibly evidences the establishment and inauguration of the tariff of rates contained in the schedule and the posting of the two copies in the various stations, although required, is not a condition precedent to the validity of the rates as is the filing with the Commission and the distribution of the copies among the different stations. When the rate is thus filed and distributed by copies it is notice and binding upon both shipper and carrier although not actually posted in the station. Nor is the carrier bound by the action of his agent who either intentionally or inadvertently quotes an

copies are 'kept posted in two public and conspicuous places in every depot,' etc., and it was this contention that prevailed in the Circuit Court. But, in our opinion, it is not sound. Publication and posting in the sense of the Act are essentially distinct. This is the import of the provision that the requirements relating to 'publishing, posting and filing' may be modified by the Commission in special circumstances, for if publishing included posting mention of the latter was unnecessary. And from all the provisions on the subject it is evident that the publication intended consists in promulgating and distributing the tariff in printed form preparatory to putting it into effect, while the posting is a continuing act enjoined upon the carrier, while the tariff remains operative, as a means of affording special facilities to the public for ascertaining the rates in force thereunder. In other words, publication is a step in establishing rates, while posting is a duty arising out of the fact that they have been established. Obviously, therfore, posting is not a condition to making a tariff legally operative. Neither is it a condition to the continued existence of a tariff once legally established. If it were the inadvertent or mischievous destruction or removal of one of the posted copies from a depot would disestablish or suspend the rates, a result which evidently is not intended by the Act, for it provides that rates once lawfully established shall not be changed otherwise than in the mode prescribed. Like views of the posting clause were expressed in Texas and Pacific Railway Co. v. Cisco Oil Mill, 204 U. S. 449, 5I L. Ed. 562, 27 Sup. Ct. 358, and upon further consideration we perceive no reason for departing from them. *** Whether by failure to comply with that clause, a carrier becomes subject to a penalty is apart from the present case and need not now be considered."

In Kansas City Southern Railway Co. v. Carl, 227 U. S. 639, 57 L. Ed. 683, 33 Sup. Ct. 39I, the court said:- "The rate, when made out and filed, is notice, and its effect is not lost, although it is not actually posted in the station." See also Illinois Central Railroad Co. v. Henderson Elevator Co., 226 U. S. 44I, 57 L. Ed. 290, 33 Sup. Ct. 176.

In Berwind-White Coal Mining Co. v. Chicago \& Erie Railroad Co., 235 U. S. 37I, 59 L. Ed. -, complaint was made that demurrage could not 
incorrect rate to a shipper since the filed and published rate is conclusive, although the carrier, as previously stated, is subject to a penalty where the agent in response to a written request misstates a rate to a shipper to the actual damage of the latter.

Absence of Filed and Published Rate.-The Act specifically declares that unless otherwise provided no carrier shall transport passengers or property unless the rates, fares and charges therefor have been filed and published in the manner herein set forth. Thierefore until proper rates have been filed with the Interstate Commerce Commission and published by distribution at the different freight stations it is unlawful for carriers to accept shipments for transportation. ${ }^{6}$ The Commission is vested with the power of determining and prescribing the manner in which the schedules required by the Act are to be kept. If no

be collected because no tariff on the subject was filed or published. The court said:- "The fact is that the railroad had complied with the law as to filing tariff sheets, and had also, long before the time in question, filed a book of rules of the Chicago Car Service Association, of which it was a member, relating to liability for demurrage and a few days after had written the Commission a letter stating that the demurrage charge would be $\$ 1$ per day. The argument is that such documents were not sufficiently formal to comply with the law, and hence afforded no ground for allowing demurrage. But the contention is without merit. The documents were received and placed on file by the Commission without any objection whatever as to their form, and it is certain that, as a matter of fact, they were adequate to give notice. Equally without merit is the in. sistence that there was no proof that the documents were posted for public inspection."

6 Southern Railway Co. v. Reid, 222 U. S. 424, 56 I. Ed. 257, 32 Sup. Ct. I 40, where the court said:- "The Commission is given the power to determine and prescribe the manner in which the schedules required by the Act are to be kept. And it is enacted that, unless otherwise provided, no carrier 'shall engage or participate in the transportation of passengers or property, as defined in this Act, unless the rates, fares and charges upon which the same are transported by said carrier have been filed and published in accordance with the provisions of this Act.' * * * As we have seen, schedules of rates whether the road be single or forms with another a 'through route,' must be established, filed and published, designating the places. They cannot be changed without permission of the Interstate Commerce Commission, and no carrier is permitted to engage or participate in the transportation of passengers or property unless the rates for the same have been so filed and published."

To the same effect Southern Railway Co. v. Reid and Beam, 222 U. S. 444,56 L. Ed. 263, 32 Sup. Ct. I45; Southern Railway Co. v. Burlington Lumber Co., 225 U. S. 99, 56 L. Ed. I00I, 32 Sup. Ct. 657. 
joint through rate has been established the several carriers in the through route are required to file, publish and post the separately established rates applicable to the through transportation. ${ }^{7}$ In

7 Kansas City Southern Railway Co. v. Albers Commission Co., 223 U. S. 573, 56 L. Ed. 556, 32 Sup. Ct. 316 . This case involved a special agreement for transporting grain, no through rate existing. The court said:- "Such being the state of evidence, the necessary conclusion, as matter of law, is that an applicable and lawfully established local rate was in force on each road. And as it was conceded that there was no established joint through rate, it likewise is a necessary conclusion that the shipments, even if moving on through bills of lading, should have taken these local rates, unless the latter were superseded or displaced by the special agreement. *** Section 6 of the Interstate Commerce Act, as it existed at the time, laid upon every carrier subject to the provisions of the Act the duty of filing with the Commission and publishing schedules of the rates to be charged for the transportation of property over its road, provided for changing and superseding such rates by new schedules so filed and published, and make it unlawful for such a carrier to depart from any rate so established and in force at the time. That section also required connecting carriers, agreeing upon joint through rates, to file schedules thereof with the Commission, made similar provision for changing and superseding rates so established, and likewise prohibited any deviation from an established joint rate while remaining in force. *** In every substantial sense local rates and joint through rates were placed on the same level. Both were required to be openly established and uniformly applied. True, the carriers were obliged to establish local rates and were left free to agree upon joint through rates, or not, as they chose; but if they did agree thereon, the rates could become legally operative only by being established as prescribed in the Act. The true effect of the statute in this regard-we speak of the statute as it existed in 1901-is clearly stated in the opinion of the Circuit Court of Appeals for Eighth Circuit, in Chicago, Burlington \& Quincy Railway Co. v. United States, 157 Fed. 830, 833, as follows:-

"If an initial carrier accepts traffic for transportation and issues its bill of lading over a route made up of connecting roads for which no joint through rate has been published and filed with the Commission, the lawful rate to be charged is the sum of the established local rates published and filed by the individual roads; or if, as was the case here, there is a local rate over one road and a joint rate over the others for the remainder of the route, all published and filed with the Commission, the lawful through rate to be charged is the sum of the local and joint rates. By failing to establish or concur in a joint through rate for traffic accepted for interstate transportation, each participating carrier impliedly asserts that the rate which it has duly established, published and filed for its own line shall be a component part of the through rate to be charged. It is competent for carriers, if conditions justify it, to make their proportions of a through rate less than the local charges upon their own lines, but in 
the absence of such filed and published rates shipments cannot be lawfully accepted, and the bad faith of the carrier in insisting upon the lack of a filed and published tariff as a pretext for declining a certain shipment is not open to consideration, since to accept such a shipment under the circumstances would constitute a violation of the provisions of the Act. ${ }^{8}$

A state statute which requires common carriers to receive freight whenever tendered for transportation and forward the same under a penalty of forfeiting a fixed sum for each day of refusal to receive such freight conflicts with the provisions of the Act to Regulate Commerce, as amended by the Hepburn Act, prohibiting the acceptance of freight in the absence of duly filed and published rates and therefore cannot be enforced. ${ }^{3}$ Legisla-

doing so they should observe legal methods, and if no action to that end is taken they in effect adhere to the rates established, published, and filed by them as applying not only to local but to through traffics.'”

8 Texas and Pacific Railway Co. v. American Tie and Timber Co., 234 U. S. 138,58 L. Ed. 1255,34 Sup. Ct. 885 . The railroad in question had filed a tariff fixing joint through lumber rates and under those rates had accepted for transportation an amount of oak cross-ties but then declined to accept further shipments on the ground that it had not filed and published tariff of rates on cross-ties which it claimed were a distinct commodity from lumber. The shippers claimed that the refusal to accept the cross-ties while in name based upon the nonexistence of a filed rate therefor was in fact based upon the desire to force the shipper to sell the crossties to the railroad. The court said:- "There is no room for controversy that the law required a tariff, and therefore if there was no tariff on crossties, the making and filing of such tariff conformably to the statute was essential. * * * Because the railway company did not refuse to transport the ties in good faith and insisted upon the absence of a schedule rate simply as a pretext and device for preventing the shipment of the ties and their delivery in performance of the contract with the Union Pacific Railway, and with the ulterior and wrongful motive of keeping the ties on its line, so as to be able to purchase them itself from the tie company. But without pausing to do more than direct attention to the fact that this proposition is necessarily disposed of by what we have said, that is, by the lawfulness in view of the state of the existing and filed tariff, of the refusal until the Commission had acted, we think all the contentions under this last head are completely answered by the statement that the suit was based upon the unlawfulness of the action of the railway company in refusing to carry the ties in view of the filed tariffs, and therefore the contentions are not open for our consideration."

9 Southern Railway Co. v. Reid, 222 U. S. 424, 56 L. Ed. 257. 32 Sup. Ct. 140. A statute of the state of North Carolina required the agent of a railroad company to receive freight for transportation whenever tendered 
tion by Congress upon this question supersedes state enactments and is paramount.

Charges to be Included in the Filed and Published Schedules.-By the terms of the sixth section the schedules are required to state separately all terminal charges, storage charges, icing charges and all other charges which the Interstate Commerce Commission may designate and all privileges and facilities allowed by the carriers together with the rules or regulations which in any way determine, alter or affect these various rates and charges. In an early case decided in 1897 the Supreme Court declared, upholding the Interstate Commerce Commission, that cartage of goods by the railroad after their arrival at the point of destination was not in general, a terminal expense and was

at a regular station and forward the same by a route selected by the person tendering the same under a penalty of forfeiting $\$ 50$ per day to the aggrieved party for each day of refusal and all damages actually sustained. The carrier refused for six days to receive freight tendered to it by Etta Reid at Charlotte, North Carolina, for transportation to a point in West Virginia. At the time the shipment was tendered there had been established no through or joint rate of freight by the carrier and the connecting carriers over which the shipment would have to pass from the point of initiation to the point of destination. As soon as a joint rate was established the shipment was accepted and a bill of lading issued therefor. The Supreme Court said:- "The question is, Where is the control, in the state or Congress, and has Congress acted? That the control is in Congress we have seen; that it has acted is demonstrated by the provisions of the Interstate Commerce Act to which we have referred. As we have seen, schedules of rates, whether the road be single or forms with another a 'through route,' must be established, filed and published, designating the places. They cannot be changed without permission of the Interstate Commerce Commission, and no carrier is permitted to engage or participate in the transportation of passengers or property unless the rates for the same have been so filed and published. Criminal punishments are imposed for violations of these requirements, and civil redress of injuries received by shippers is given through the Interstate Commerce Commission. * * * The statute of North Carolina conflicts with these requirements. What they forbid the carrier to $\mathrm{dc}$ the statute requires him to do, and punishes disobedience by successive daily penalties. We cannot assume that it was without consideration of its necessity that Congress enacted section 2 of the Hepburn Act. It was no doubt the adaptation of experience to the exigencies of a practical problem, Congress coming to believe that the most effective way to prevent preferences in charges by carriers was to forbid them to 'engage or participate in the transportation of passengers or property' until they had fixed and proclaimed the rate to be charged therefor-a rate that would be not only for one shipper or 
not usually assumed by the carrier. Naturally as between the carrier and the shipper transportation ends when the freight is received at the warehouse at the place of destination and the rate charged is for the service which ends there. At an early date many railroad companies furnished free cartage at some of their stations and the statute at that time contained no requirement that the rate sheets or schedules should contain notice to that effect. The court declared that should the Commission issue an order directing railroad companies to regard cartage, when furnished free, as one of the terminal charges and include it as such in their schedules such an order would be regarded as a reasonable exercise of the powers of that body. ${ }^{10}$ In accordance

shipment, but for all shippers and shipments; not for one time only, but for all times. The power of Congress to so provide cannot be doubted. If the regulation be not exclusive, this situation is presented: If the carrier obey the state law, he incurs the penalties of the Federal law; if he obey the Federal law; he incurs the penalties of the state law. Manifestly one authority must be paramount and when it speaks the other must be silent. We can see no middle ground.

"One other contention remains to be noticed. It is said that there is not presented in the case the dilemma of alternative penalties, for the Hepburn Act, it is pointed out, requires a schedule of rates to be filed only 'when the through route and joint rate have been established,' and that none were established in the case at bar and that, therefore, the railway company was not put to a choice of obligations and subjected to punishment however it might choose. But it is also provided that if no joint rate over the through route has been established, the several carriers in such through route shall file, print, and keep open to public inspection as aforesaid, the separately established rates, fares and charges applied to the through transportation.' There is nothing in the record to show that there were such established separate rates and that separately established rates were published and kept open for inspection. Indeed, the record shows that a through rate had to be fixed by the several carriers in the through route. It was only because of the obligation imposed by the Hepburn Act that the railway company refused to receive the goods tendered to it and the agent of the company informed defendant in error that he was without power to comply with her demand. He promptly acted in the matter when the lines over which the freight had to pass established a joint rate. He then received the goods issued a bill of lading therefor, 'and the shipment went forward to its destination.'" Southern Railway Co. v. Reid and Beam, 222 U. S. 444, 56 L. Ed. 263, 32 Sup. Ct. I45; Southern Railway Co. v. Burlington Lumber Co., 225 U. S. 99, 56 L. Ed. 1001, 32 Sup. Ct. 657 .

Io Interstate Commerce Commission v. Detroit, Grand Haven and Milwaukee Railway Co., I67 U. S. 633, 42 L. Ed. 310, 17 Sup. Ct. 957. In 
with that intimation the Interstate Commerce Commission made a general order February 8, I 898 requiring railroads to state in their schedules all cartage and other terminal services rendered.

Any corporation which comes within the meaning or definition of an interstate common carrier, under the provisions of the Act to

order to meet the competition of a railroad whose station was in the business center of the city the railroad defendant furnished cartage for delivery free of charge to the merchants of the town but did not publish such free cartage in its schedules of rates filed and posted. It was alleged that this constituted discrimination against another town where such cartage was not provided and that it was in violation of the sixth section of the Act as well as the fourth section. The court said:- "It is not claimed that the railway company has not otherwise complied with the provisions of this section, but the complaint is that there was no statement in its schedules, printed and kept open to public inspection at Grand Rapids, of the privilege of free cartage. It is contended for the Commission that this failure to publish the fact of free cartage in the schedule might result in ignorance by some shippers of the existence of such a privilege, and that thus the knowing ones would enjoy an advantage not possessed by others. In view of the finding, that this privilege had been openly and notoriously granted to the shippers and consignees at Grand Rapids for a period of 25 years, it is difficult to suppose that this practise was not well known to all who would have occasion to rely upon it. It should also be noticed that no complaint is made, in the present case, by any resident of Grand Rapids. It may well be doubted whether cartage, when furnished without charge, comes within the meaning of the phrase 'terminal charges' or can be regarded as 'a rule or regulation' which in any wise 'changes, affects or determines' any part or the aggregate of the rates, fares and charges. Judge Cooley in expressing the opinion of the Commission, well said:-

"'It must be conceded, however, that cartage is not in general a terminal expense, and is not in general assumed by the carrier. The transportation as between the carrier and its patrons ends when the freights are received at the warehouse, and the charge made is for a service which ends there.' 3 I. C. C. 613.

"We are informed by an extract from the annual report of the Commission for 1889,3 I. C. C. 309 , that there are many railway companies throughout the country which furnish free cartage at some of their stations, but that in no instance do the rate sheets or schedules contain any statement to that effect. However, in a matter of this kind, much should be left to the judgment of the Commission, and should it direct, by a general order, that railway companies should thereafter regard cartage when furnished free as one of the terminal charges and include it as such in their schedules such an order might be regarded as a reasonable exercise of the Commission's powers. But we are not persuaded, by anything we see in this record, that the defendant company has acted in any intentional disregard of the sixth section." 
Regulate Commerce must file its tariffs with the Commission in accordance with the terms of section 6 ; and this includes a corporation organized for maintaining a stock yard with its usual facilities, which law fully owns and operates a railroad system for the transportation of cars to and from trunk lines in the course of their transportation from beyond the state and to points outside of the state; and it includes proprietors of oil pipe lines. ${ }^{11}$

Naturally the purpose of requiring the different elements of the charges to be filed is to see that all shippers shall have notice thereof, to enable the better detection and prevention of departures from legal rates in violation of the Elkins Act $^{12}$ and to see that the carriers shall receive just compensation only for what they do and the services they render. ${ }^{13}$ In other words, unless an additional service beyond that of transportation is rendered by them an additional charge is not justified. The right exists in the carrier to charge for any terminal service that is accessorial. Thus where a carrier has a line-haul rate which embraces a receiving and delivering service it cannot in conscience make an additional charge for the delivery and receipt of goods on industrial spur tracks within the switching limits of the city when such spur-track service is a substitute for the regular receiving and delivery service included in the line-haul rate. ${ }^{14}$

I I United States v. Union Stock Yard and Transit Co., 226 U. S. 286, 57 L. Ed. 226, 33 Sup. Ct. 83; United States v. Ohio Oil Co., 234 U. S. 548, 58 L. Ed. 1459,34 Sup. Ct. 956.

12 United States v. Union Stock Yard and Transit Co., supra, where the court said:- "If these companies had filed their tariffs as we now hold they should have filed them, they would have been subject to the restrictions of the Elkins Act as to departures from published rates-and we must consider the case in that light-and this preferential treatment, as we have said, would have been in violation of that Act. It is the object of the interstate commerce law and the Elkins Act to prevent favoritism by any means or device whatsoever and to prohibit practises which run counter to the purpose of the Act to place all shippers upon equal terms."

I3 United States v. Louisiana and Pacific Railway Co., (Tap Line Cases), 234 U. S. I, 58 L. Ed. I 185, 34 Sup. Ct. 74 I.

If Interstate Commerce Commission v. Atchison, Topeka and Santa Fe Railway Co., (Los Angeles Switching Case), 234 U. S. 294, 58 L. Ed. I319, 34 Sup. Ct. 8I4. At the city of Los Angeles the railroad delivered freight moving in carloads at team tracks, at freight sheds or at industry spurs. At team tracks and freight sheds no charge was made for the receipt or delivery of freight over the rate named in the tariffs for the haul but an additional charge of $\$ 2.50$ is imposed at industry spurs for every 
But such extra charge may be properly assessed where the carrier performs some actual service or function beyond that of merely transporting shipments to its terminals or equivalent

loaded car moving either in or out. This industry spur service when performed was not in addition to the service at the freight sheds or team tracks but was in lieu therof, it being shown that the trains were divided up at the breaking-up yards at the entrance to the city and the cars separated according to their destination. The Interstate Commerce Commission after inquiry declared that evidently the industry spur service was no more expensive to the carriers than team track delivery for which no extra charge was made. The Commission sustained the propriety of such a charge when the line haul was made by a foreign carrier but ordered its discontinuance where the charge was made in connection with a systemline haul. The court said:-"The Commission conceded the right of the carrier to charge for any terminal service that was accessorial. But it was held that an additional charge was not justified if additional service was not in fact rendered. Nor do we understand that the Commission ruled that the receipt and delivery of goods at plants located upon spurs or sidetracks could not, in any circumstances, be regarded as a distinct service for which separate compensation might be demanded. Cases of an interior movement of plant traffic to and from various parts of the establishment, and of deliveries through a system of interior switching tracks constructed as plant facilities, were expressly distinguished by the Commission ( $18 \mathrm{I}$. C. C. pp. 313,314 ); and it is apparent that the ruling of the Commission would not apply in any case where by reason of the location and extent of the spur tracks and the character of the movement the facts were essentially different from those upon which the decision was based. (Interstate Commerce Commission v. Stickney, 215 U. S. 98 , 105, 54 L. Ed. I12, 30 Sup. Ct. 66.) On the other hand, it cannot be maintained that the delivery and receipt of goods on industrial spur tracks within the switching limits in a city is necessarily an added service for which the carrier is entitled to make, or should make, a charge additional to the line-haul rate to or from that city, when the line-haul rate embraces a receiving and delivering service for which the spur-track service is a substitute. It is said that carriers are bound to carry only to or from their terminal stations. But when industrial spur tracks have been established within the carrier's switching limits, within which also various team tracks are located, these spurs may in fact constitute an essential part of the carrier's terminal system. It was stated by the Commission that carriers throughout the country treat industry spurs of the kind here in question 'as portions of their terminals, making no extra charge for service thereto when the carrier receives the benefit of the line-haul out or in.' It was added that while this general statement covered perhaps ten thousand cities and towns in the United States, the carriers before the Commission could name only three exceptions, to-wit, the cities of Los Angeles, San Francisco and San Diego. But, laying the generalization on one side, it is plain that the question whether or not there is at any point 
points. And such charges must be stated in the tariff sheets. Thus terminal charges for the delivery of live stock to stock yards are proper if reasonable and should be specifically stated in the tariff schedules. ${ }^{15}$ This assumes that the stock yards are

an additional service in connection with industrial spur tracks upon which to base an extra charge, or whether there is merely a substituted service which is substantially a like service to that included in the line-haul rate and not received, is a question of fact to be determined according to the actual conditions of operation. Such a question is manifestly one upon which it is the province of the Commission to pass. We must therefore take the findings of the Commission in the present case as to the character and manner of use of the industrial spurs in Los Angeles-that they constituted part of the carriers terminals and that under the conditions there existing, the receipt and delivery of goods on these spurs was a like service as compared with the receipt and delivery of goods at team tracks and freight sheds-as conclusions of fact. Assuming that they were based upon evidence, they are not open to review."

15 Interstate Commerce Commission v. Stickney, 215 U. S. $98,54 \mathrm{~L}$. Ed. 112, 30 Sup. Ct. 66. Here the court said:-"The sixth section of the Act known as the 'Hepburn Act' requires carriers to file with the Commission and print and keep open to inspection schedules showing, among other things, 'separately all terminal charges $* * *$ and any rules or regulations which in any wise change, affect, or determine any part or the aggregate of such aforesaid rates.' By section 15 the Commission is authorized and required, upon a complaint, to inquire and determine what would be a just and reasonable rate or rates, charge or charges. This, of course, includes all charges, and the carrier is entitled to have a finding that any particular charge is unreasonable and unjust before it is required to change such charge. For services that it may render or procure to be rendered off its own line, or outside the mere matter of transportation over its line, it may charge and receive compensation. Southern Railway Co. v. St. Louis Hay Co., 214 U. S. 297, 53 L. Ed. 1004, 29 Sup. Ct. 678. If the terminal charge be in and of itself just and reasonable it cannot be condemned or the carrier required to change it on the ground that it, taken with prior charges of transportation over the lines of the carrier or of connecting carriers, makes the total charge to the shipper unreasonable. That which must be corrected and condemned is not the just and reasonable terminal charge, but those prior charges which must of themselves be unreasonable in order to make the aggregate of the charges from the point of shipment to that of delivery unreasonable and unjust. In order to avail itself of the benefit of this rule the carrier must separately state its terminal or other special charge complained of, for if many matters are lumped in a single charge it is impossible for either shipper or the Commission to determine how much of the lump charge is for the terminal or special services. The carrier is under no obligations to charge for terminal services. Business interests may justify it in waiving any such 
distinct from the carrier's terminals under the general rule that a carrier may charge and receive compensation for services that it may render or procure to be rendered off its own line or outside the mere matter of transportation over its line. The tariff

charge, and it will be considered to have waived it unless it makes plain to both shipper and Commission that it is insisting upon it."

Interstate Commerce Commission v. Chicago, Burlington and Quincy Railroad Co., I86 U. S. 320, 46 L. Ed. II82, 22 Sup. Ct. 824, where the court said:- "As the right of the defendant carriers to divide their rates and thus to make a distinct charge from the point of shipment to Chicago and a separate terminal charge for delivery to the stock yards, a point beyond the lines of the respective carriers, was conceded by the Commission and was upheld by the Circuit Court of Appeals, no contention on this subject arises. If, despite this concurrence of opinion, controversy was presented on the subject, we see no reason to doubt, under the facts of this case, the correctness of the rule as to the right to divide the rate, admitted by the Commission and announced by the court below. This is especially the case in view of the sixth section of the Act to Regulate Commerce, wherein it is provided that the schedules of rates to be filed by carriers shall 'state separately the terminal charges and any rules or regulations which could in any wise change, affect or determine any part of the aggregate of said aforesaid rates and fares and charges.' Whether the rule which we approve as applied to the facts in this case would be applicable to terminal services by a carrier on his own line which he was obliged to perform as a necessary incident of his contract to carry, and the performance of which was demanded of him by the shipper, is a question which does not rise on this record, and as to which we are, therefore, called upon to express no opinion. *** The purpose of this provision was to compel the schedules to be so drawn as to plainly inform of their import, was to exact that when the rates were changed the change should be so stated as not to mislead and confuse, all of which would be frustrated if the schedules relied upon were given the effect which the defendants now claim for them."

In Mitchell Coal Co. v. Pennsylvania Railroad Co., 230 U. S. 247, 57 L. Ed. 1472, 33 Sup. Ct. 916, the court said:-"Under the Elkins Act of 1903 (U. S. v. Chicago and Alton Ry., I48 Fed. 646; S. C. I56 Fed. 558, affirmed by a divided court, 212 U. S. 563, 53 L. Ed. 653, 29 Sup. Ct. 689), and under the Hepburn Bill of 1906 (Victor Co. v. Atchison Ry., I4 I. C. C. I20) it has been held that the carrier must give notice in the tariff of free cartage, lighterage, ferriage, or any other accessorial service that will be furnished as well as of any allowance that will be made to shippers who furnish transportation facilities or service. But the present case is not to be governed by those statutes, but by the law of force between 1897 and I90I, when the transactions complained of took place. At that time the Commerce Act required the carrier to give notice of every charge it would make against the shipper. But the statute was not construed to compel the railroad to publish what free cartage or accessorial service it would 
sheets should show the extra charge for expediting a shipment. ${ }^{16}$ In order to give a shipper such special service the carrier might and should exact a higher rate but to do so it must make and publish a rate open to all. Likewise different rates for shipments, based upon the difference in valuation of the goods to be carried as declared by the shipper or otherwise revealed, must be

furnish (Detroit v. United States, I67 U. S. 646, 42 L. Ed. 310, 17 Sup. Ct. 957), nor what sums it would pay shippers for transportation service rendered by them to the carrier. Failure to publish these items could, however, easily lead to unjust discrimination, and the court in the case last cited, held that the Commission might, by a general order, require such matters to be published in the rate sheets. We are not cited to any such order for the period now under investigation, and, so far as we can discover, by the general and public custom of all carriers, acquiesced in by the Commission, the tariffs at that time uniformly omitted any statement of allowances that would be paid to the shipper for the use of private cars, or private tracks, or for transportation service in switching, hauling, lightering or other work, included in the rate, but actually performed by the shipper. But although the statute then of force was not construed to require the publication of allowances, their payment was lawful only when supported by a consideration.

I6 Chicago and Alton Railroad Co. v. Kirby, 225 U. S. 155, 56 L. Ed. 1033, 32 Sup. Ct. 648. The shipper wished to ship certain horses to New York for a sale and requested the carrier's agent to forward them rapidly and by a particular train although the shipper was charged no additional rate for such special service nor was any rate published for such service.

The court said:-"But the company, by entering into an agreement for expediting the shipment, came under a liability different and more burdensome than would exist to a shipper who made no such special contract. For such a special service and higher responsibility it might clearly exact a higher rate. But to do so it must make and publish a rate open to all. This was not done. The shipper, it is also plain, was contracting for an advantage which was not extended to all others, both in the undertaking to carry so as to give him a particular expedited service, and a remedy for delay not due to negligence. An advantage accorded by special agreement which affects the value of the service to the shipper and its cost to the carrier should be published in the tariffs, and for a breach of such a contract, relief will be denied, because its allowance without such publication is a violation of the Act. It is also illegal because it is an undue advantage in that it is not one open to all others in the same situation.

That the defendant in error did not see and did not know that the published rates and schedules made no provision for the service he contracted for is no defense. For the purposes of the present question he is presumed to have known. The rates were published and accessible, and, however difficult to understand, he must be taken to have contracted for an advantage not open to others. Railway Co. v. Mugg, 202 U. S. 242, 50 L. Ed. I0II, 26 Sup. Ct. 628." 
filed and published in the manner prescribed. ${ }^{17}$ And the legal rate automatically attaches itself to the declared or agreed value. Neither the intentional nor accidental misstatement of the applicable published rate will bind either the carrier or the shipper. Primarily, of course, the difference in rates based upon the valuation of shipments is measured by the amount of risk assumed in the liability for the loss or injury to the goods carried. For a more extended discussion of this feature see Section 20 and the Carmack amendment thereunder.

A limitation as to the baggage liability of a carrier based upon a rule requiring one to declare its value when more than $\$ 100$, and pay an excess charge, is a regulation determinative of the rate to be charged and affecting the service to be rendered to the passenger which, within the terms of this action, must be filed, published and posted as a part of the carrier's tariff schedules. ${ }^{18}$

I7 Kansas City Southern Railway Co. v. Carl, 227 U. S. 639, 57 L. Ed. 683,33 Sup. Ct. 39I. Here the court said:- "The valuation the shipper declares determines the legal rate where there are two rates based upon valuation. He must take notice of the rate applicable, and actual want of knowledge is no excuse. The rate, when made out and filed, is notice, and its effect is not lost, although it is not actually posted in the station; Texas and Pacific Ry. v. Mugg, 202 U. S. 242, 50 L. Ed. I01 I, 26 Sup. Ct 628 ; C. \& A. Ry. v. Kirby, 225 U. S. 155, 56 L. Ed. I033, 32 Sup. Ct. 648. It would open a wide door to fraud and destroy the uniform operation of the published tariff rate sheets. When there are two published rates, based upon difference in value, the legal rate automatically attaches itself to the declared or agreed value. Neither the intentional nor accidental misstatement of the applicable published rate will bind the carrier or shipper. The lawful rate is that which the carrier must exact and that which the shipper must pay. The shipper's knowledge of the lawful rate is conclusively presumed, and the carrier may not be required to surrender the goods carried upon the payment of the rate paid, if that was less than the lawful rate, until the full legal rate has been paid. Texas and Pacific Ry. v. Mugg, supra. Nor is the carrier liable for damages resulting from a mistake in quoting a rate less than the full published rate. Illinois Central R. R. v. Henderson Elevator Co., 226 U. S. 44I, 57 L. Ed. 290, 33 Sup. Ct. I76. Nor can a carrier legally contract with a particular shipper for an unusual service unless he make and publish a rate for such service equally open to all. Chicago and Alton Ry. v. Kirby, supra."

I8 Boston and Maine Railroad v. Hooker, 233 U. S. 97, 58 L. Ed. 868, 34 Sup. Ct. 526. In this case no declaration was made or excess rate paid for a valuation for a trunk greater than $\$ 100$. Upon the loss of the trunk suit was brought for the real value of the contents claimed to be largely excessive of that amount. The court said:- "Let us now turn to the Interstate Commerce Act and see whether the matter of the limi- 
Similarly tariff sheets must set forth specifically all charges for refrigerating, precooling or preicing shipments of fruits, veg-

tation of baggage liability is covered by that Act. (Here follows a lengthy quotation of the provisions of section six of the Act.) It is to be observed that the schedules are required to state, among other things, in naming certain charges 'all other charges which the Commission may require, all privileges or facilities granted or allowed and any rules or regulations which in any wise change, effect, or determine any part or the aggregate of such aforesaid rates, fares, and charges, or the value of the service rendered to the passenger, shipper, or consignee.' The question then is did the limitation as to liability for baggage based upon the reqirement to declare its value when more than $\$ 100$ was to be recovered come within that provision. It seems to us that the ordinary signification of the terms used in the Act would cover such requirements as are here made for the amount of recovery for baggage lost by the carrier. It is a regulation which fixes and determines the amount to be charged for the carriage in view of the responsibility assumed, and it also affects the value of the service rendered to the passenger. Such requirements are spoken of, in decisions dealing with them, as regulations; as, a common carrier 'may prescribe regulations to protect himself against imposition and fraud, and $f x$ a rate of charges proportionate to the magnitude of the risks he may have to encounter.' York Co. v. Central R. R., 3 Wall. 107, I12, I8 L. Ed. I70.

"Turning to the Act itself we think the conclusion that this limitation is a regulation required to be filed by the Act is strengthened by section 22 which provides: 'But before any common carrier, subject to the provisions of this Act, shall issue any such joint interchangeable mileage tickets with special privileges as aforesaid, it shall file with the Interstate Commerce Commission copies of the joint tariffs of rates. fares, or charges on which such joint interchangeable mileage tickets are to be based, together with specifications of the amount of free baggage permitted to be carried under such tickets, in the same manner as common carriers are required to do with regard to other joint rates by section six of this Act.' This section would indicate that Congress thought that section 6 of the Act had to do with specifications of the amount of baggage which would be carried free and that such regulations should be filed under the requirement of section 6 to which it referred. This conclusion is further strengthened by the action of the Interstate Commerce Commission * * * by its tariff circular No. I5-A, entitled 'Regulations Governing the Construction and Filing of Freight Tariffs and Classification and Passenger Fare Schedules," effective April 15, 1908, and in force at the time of the loss here in question.

"This requirement is a practical interpretation of the law by the administrative body having its enforcement in charge, and is entitled to weight in construing the Act.

"We are therefore of the opinion that the requirement published concerning the amount of the liability of the defendant based upon additional 
etables, etc. ${ }^{19}$ The proper rate for such service, as well as the forms of the schedules and the approval of the tariffs are all rate-making matters which by the Act are committed to the Interstate Commerce Commission and are treated at length under Section 15.

Under section 6, not only must the filed and published rates indicate separately and specifically all charges made to shippers and consignees for services rendered by the carriers but the schedules must also set forth all allowances made to shippers and

payment where baggage was declared to exceed $\$ 100$ in value was determinative of the rate to be charged and did affect the service to be rendered to the passenger, as it fixed the price to be paid for the service rendered in the particular case, and was, therefore, a regulation within the meaning of the statute. By requiring the baggage regulations, including the excess valuation rate, to be filed and become part of the tariff schedules, the rule of the common law that the carrier becomes an insurer of the safety of baggage against accidents not the act of God or the public enemy or the fault of the passenger (the rule established in this country, 3 Hutchinson on Carriers, sec I24I) was not changed. The effect of such filing is to permit the carrier by such regulations to obtain commensurate compensation for the responsibility assumed for the safety of the passenger's baggage, and to require the passenger whose knowledge of the character and value of his baggage is peculiarly his own to declare its value and pay for the excess amount. There is no question of the reasonableness or propriety of making such regulations, which would be binding upon the passenger if brought to his knowledge in such wise as to make an agreement or what is tantamount thereto."

I9 Atchison, Topeka and Santa Fe Railway Co. v. United States, (PreIcing Case), 232 U. S. 199, 58 L. Ed. 568, 34 Sup. Ct. 291. This case dealt with the pre-cooling and pre-icing of shipments of California fruit to the eastern market. The court said:- "What is a proper rate on fruit in precooling shipments, or a fair charge for hauling necessary ice or rendering other transportation services are all rate-making matters committed to the Commission. It may determine what shall be the difference in rate between carload and less than carload lots. It may decide whether the difference in revenue, due to a difference in method of loading, warrants a difference in the rate on carload shipments of the same article. It may prescribe the form in which schedules shall be prepared and arranged (sec. 6) and may approve tariffs stating that the single rate includes both the line haul and accessorial services absorbed in the rate. Conversely, it may prescribe a tariff fixing a through rate which includes not only the haul of the fruit, but the haul of the ice necessary to keep the fruit in condition. All these are matters committed to the decision of the administrative body, which, in each instance, is required to fix reasonable rates and establish reasonable practises. The courts have not been vested with any such power." 
consignees for any services rendered or facilities extended by them in aid of transportation of whatever nature or description they may be. ${ }^{20}$ Such services performed by the shipper or consignee might include, for example, the furnishing of private cars, the use of private tracks, or some element more intimately associated with the physical act of transportation such as switching, hauling, lightering or other work, included in the haul-rate, but actually performed by the shipper.

20 See Chicago and Alton Railway Co. v. United States, 212 U. S. 563, 53 L. Ed. 653. 29 Sup. Ct. 689, where it was contended that an amount paid to the shipper by the carrier was for the use of tracks owned by the shipper but it was contended on the other hand that it was in the nature of a rebate and illegal under the Elkins Act. Without opinion and by a divided court the Supreme Court sustained the opinion of the lower court holding the carrier guilty of the offense charged. In deciding this case the Circuit Court of Appeals (I56 Fed. 558) had said "to secure equality among shippers, the law commands, not only that the rates shall be equal, but that they shall be fixed and certain-subject to no addition or diminution against, or in favor of, anyone-so fixed and certain that any shipper can with his head and pencil figure out from the tariff sheets just what the rate is, both for himself and for his competitors." The District Court ( 148 Fed. 646) had said :- "The word 'rate,' as used in the interstate commerce law, means the net cost to the shipper of the transportation of his property; that is to say, the net amount the carrier receives from the shipper and retains. In determining this net amount in a given case, all money transactions of every kind or character having a bearing on, or relation to, that particular instance of transportation whereby the cost to the shipper is directly or indirectly enhanced or reduced must be taken into consideration. * * The object of the statutes relating to interstate commerce is to secure the transportation of persons and property by common carriers for reasonable compensation. No rate can possibly be reasonable that is higher than anybody else has to pay. Recognizing this obvious truth, the law requires the carrier to adhere to the published rate as an absolute standard of uniformity. The requirement of publication is imposed in order that the man having freight to ship may ascertain by an inspection of the schedules exactly what will be the cost to him of the transportation of his property; and not only so, but the law gives him another and a very valuable right, namely, the right to know, by an inspection of the same schedule, exactly what will be the cost to his competitor of the transportation of his competitor's property."

Mitchell Coal and Coke Co. v. Pennsylvania Railroad Co., 230 U. S. 247, 57 L. Ed. 1472, 33 Sup. Ct. 916, supra; Interstate Commerce Commission v. Diffenbaugh, 222 U. S. 42, 56 L. Ed. 83, 32 Sup. Ct. 22 ; Union Pacific Railroad Co. v. Updike Grain Co., 222 U. S. 2I5, 56 L. Ed. 171, 32 Sup. Ct. 39; United States v. Baltimore and Ohio Railroad Co., 23I U. S. 274, 58 L. Ed. 218, 34 Sup. Ct. 75. 
Thus the primary purpose of the provision requiring the filing, publishing and posting of rates is to secure their uniformity and certainty and to enable shippers to determine by an inspection thereof the cost to themselves and to their competitors for the transportation of their property-in short to establish a published absolute standard of uniformity which shall be adhered to.

Through Rates.-By the amendment of June 29, I906 (the Hepburn Act) the railroads were required to make the same publication, posting and filing of joint as of separate rates. These, of nature, applied to shipments over through routes of connecting carriers as compared with a shipment only over the line of a single carrier. A through route or shipment is most commonly evidenced by a through bill of lading though it is formed by any arrangement, direct or indirect, between carriers with connecting lines. ${ }^{21}$ By an amendment of the same date power was given to the Interstate Commerce Commission in its discretion and for good cause shown to allow changes in tariffs upon less than the thirty days notice specified in the Act and to modify, either in particular instances or by general order the requirements as to the posting and filing of tariffs of rates and charges.

21 Cincinnati, New Orleans and Texas Pacific Railway Co. v. Interstate Commerce Commission, 162 U. S. 184, 40 L. Ed. 935, 16 Sup. Ct. 700. 


\section{SECTION 7. CONTINUOUS CARRIAGE.}

SEC. 7. That it shall be unlawful for any common carrier subject to the provisions of this Act to enter into any combination, contract, or agreement, expressed or implied, to prevent, by change of time schedule, carriage in different cars, or by other means or devices, the carriage of freights from being continuous from the place of shipment to the place of destination; and no break of bulk, stoppage, or interruption made by such common carrier shall prevent the carriage of freights from being and being treated as one continuous carriage from the place of shipment to the place of destination, unless such break, stoppage, or interruption was made in good faith for some necessary purpose, and

Conti nuous carriage of freights from place of shipment to place of destination. without any intent to avoid or unnecessarily interrupt such continuous carriage or to evade any of the provisions of this Act.

This section prohibiting any combination to prevent the continuity of traffic from the place of shipment to the place of destination must be considered in connection with the provision of section 3 governing the interchange of traffic which the courts have declared leaves the carriers free to make their own arrangements for through traffic. The Supreme Court has declared that the provisions of section 7 are aimed solely at the acts of railroad companies which may prevent continuity of transportation for any purpose. It is restrictive of the powers of railroads making it unlawful for such interstate carriers by any means or devices to prevent the carriage of freight from being continuous from the place of shipment to the place of destination. Consequently there could be no violation of this law where a state court might, by proper process under state attachment laws, seize and hold the cars of an interstate carrier, in spite of the possible embarassment to interstate commerce resulting therefrom. ${ }^{1}$

I Davis v. Cleveland, Cincinnati, Chicago and St. Louis Railway Co., 217 U. S. I57, 54 L. Ed. 708, 30 Sup. Ct. 463. This case arose from the 
It seems likely that the purpose of the seventh section was to prohibit railroad companies from interrupting traffic at different state lines and thereby depriving it of its interstate character and

levy in attachment proceedings on freight cars engaged, when attached, in interstate commerce. The railroad company in defense declared that the cars could not be levied upon by reason of the commerce clause of the Constitution and the seventh section of the Act to Regulate Commerce. The court said :-

"In our discussion we may address ourselves to the contention of defendants. They do not contend that the laws of the state have the purpose to interfere with the interstate commerce, or are directly contrary to the Acts of Congress. They do contend, however, that 'to permit the instrumentalities used in the interchange of traffic by railway common carriers to be seized on process from various state courts does directly burden and impede interstate traffic within the inhibition of the Acts of Congress.' In other words, that the Acts of Congress constitute a declaration of exemption of railroad property from attachment, and, of course, from execution as well, by reason of their provisions for continuity of transportation. This can only result if there is incompatibility between the obligations a railroad may have to its creditors and the obligations which it may have to the public, either from the nature of its service or under the Acts of Congress.

"It is very certain that when Congress enacted the Interstate Commerce Law it did not intend to abrogate the attachment laws of the states. It is very certain that there is no conscious purpose in the laws of the states to regulate, directly or indirectly, interstate commerce. We may put out of the case, therefore, as an element an attempt of the state to exercise control over interstate commerce in excess of its power. *** The questions in the case, therefore, depend for their solution upon the interpretation of Federal laws. May the laws of the states for the enforcement of debts, (laws which we need not stop to vindicate as necessary foundations of credit and because they give support to commerce, state and interstate), and the Federal laws which permit or enjoin continuity of transportation, so far incompatible that the provisions of the latter must be construed as displacing the former? We do not think so. Section 5258 of the Revised Statutes is permissive, not imperative. It removed the 'trammels interposed by state enactments or by existing laws of Congress' to the powers of railroad companies to make continuous lines of transportation. Railroad Co. v. Richmond, 19 Wall. 584, 589. The Interstate Commerce Act, however, has a different character. It restricts the powers of the railroads. It regulates interstate railroads, and makes it unlawful for them, by any 'means or devices' to prevent 'the carriage of freight from being continuous from the place of shipment to the place of destination.' (Section 7) The interstate commerce law therefore is directed against the acts of railroad companies which may prevent continuity of transportation. Section 5258 of the Revised Statutes was directed against the trammels of state enactments then existing or which might be at- 
transforming it into groups of mere intrastate traffic beyond the jurisdiction of Congress under the commerce clause and the Interstate Commerce Commission under the Act to Regulate Commerce. Except it be so considered it seems to add little to the provisions and inhibitions of the third section.

tempted. In neither can there be discerned a purpose to relieve the railroads from any obligations to their creditors or take from their creditors any remedial process provided by the laws of the states, and, as we have seen, provided by Federal law as well. *** The interference with interstate commerce by the enforcement of the attachment laws of a state must not be exaggerated. It can only be occasional and temporary. The obligations of a railroad company are tolerably certain, and provisions for them can be easily made. Their sudden assertion can be almost instantly met; at any rate, after short delay and without much, if any, embarassment to the continuity of transportation. However, the pending case does not call for a very comprehensive decision on the subject." 


\section{SECTION 8. LIABILITY OF COMMON CARRIERS FOR DAMAGES.}

SEC. 8. That in case any common carrier subject to the provisions of this Act shall do, cause to be done, or permit to be done any act, matter, or thing in this Act prohibited or declared to be unlawful or shall omit to do any act, matter, or thing in this Act required to be done, such common carrier shall

Liability of common carrier
for damages.

be liable to the person or persons injured thereby for the full amount of damages sustained in consequence of any such violation of the provisions of this Act, together with a reasonable counsel or attorney's fee, to be fixed by the court in every case of recovery, which attorney's fee shall be taxed and collected as part of the costs in the case.

Liability for Damages.-This section has not been amended from its original form in the Act to Regulate Commerce as approved February 4, 1887. The section gives to persons injured by violation of the provisions of the Act the right of action at law for damages and should be considered in connection with section 9 which relates to the same subject. While these sections have not been amended yet their remedial provisions have been quite largely superseded by the amendments of 1906 and I9Io to other sections of the Act.

The Supreme Court in its earliest decision construing this section declared that an action brought thereunder was based entirely on a statute and to enforce what was in its nature a penalty on account of the wrongful conduct of the carrier. A violation of a statute is not to be presumed and the plaintiff is therefore bound by the strict rule of proof. In order to recover he must establish not inferentially but clearly and directly s' ih a violation of the Interstate Commerce Act. "Penalties," declared the court, "are not recoverable on mere possibilities," and thus before a complainant can recover he must establish not merely the wrong of the carrier but he must also show that that wrong has in fact 
operated to his injury. ${ }^{1}$ Thus in this case, it was not sufficient to warrant a recovery for the shipper to show that the carrier had failed to publish its tariff of rates, under the provisions of section

I Parsons v. Chicago and Northwestern Railway Co., I67 U. S. 447, 42 L. Ed. 23I, I7 Sup. Ct. 887. The railroad with its connecting lines had a rate of II cents per hundred pounds on grain shipped from points in Nebraska to Rochelle, Illinois, when destined to eastern points-Rochelle being practically Chicago where the grain was sent for sale and delivery to connecting eastern roads. The plaintiff was charged a rate of $2 \mathbf{I}$ cents per hundred pounds on grain from a station in Iowa, a point on the same line and nearer to Chicago, destined to Chicago. The claimant alleged this to be a discrimination in favor of the Nebraska shippers, the difference in the tariffs of Io cents per hundred pounds being the measure of damages. The court said:- "It is not claimed that the rates charged for shipping corn from points in Iowa to Chicago were not fair and reasonable charges for the services rendered. The burden of the complaint is the partiality and favoritism to places and shippers in Nebraska. The plaintiff is not seeking to recover money which inequitably and without full value given has been taken from him. $\mathrm{He}$ is only seeking to recover money which he alleges is due, not because of any unreasonable charge, but on account of the wrongful conduct of the defendant. Again his cause of action is based entirely on a statute, and to enforce what is in its nature a penalty. * * * So, but for the provisions of the Interstate Commerce Act, the plaintiff could not recover on account of his shipments to Chicago, if only a reasonable rate was charged therefor, no matter though it appeared that through any miconduct of partiality on the part of the railway officials shippers in Nebraska had been given a less rate.

"It was, among other reasons, in order to avoid the public injury which had sprung from such conduct on the part of railway officials that the Interstate Commerce Act was passed, and violations of its provisions were subjected to penalties of one kind or another. But it is a familiar law that one who is seeking to recover a penalty is bound by the rule of strict proof. Before, therefore, the plaintiff can recover of this defendant for alleged violations of the Interstate Commerce Act he must make a case showing not by way of inference but clearly and directly such violation. No violation of statute is to be presumed.

"The allegation is that this joint tariff was not filed with the Commission, and not published at the Iowa stations from which plaintiff made his shipment, and that in consequence thereof he was ignorant of its rates. His argument practically is that if the tariff had been filed with the Commission it might have made an order, either general or special, requiring that it be posted at the Iowa stations; that if it had been so posted he might have examined the rates and might have determined to ship his corn, not to Chicago, but to one of the four eastern points named in such tariff. But these 'might be's' interfere very materially with the line of sequence. He does not show that he had not already contracts with some consignee in Chicago, New Orleans or some place other than the four eastern points 
6 , but he must show that this nonpublication of rates actually injured him directly and not inferentially. In a suit under section 8 the shipper can recover damages only upon proof of what pecuniary loss he has suffered as a result of the discrimination of the carrier or his other violation of the Act to Regulate Commerce. For example if between two shippers of the same product between the same points the railroad grants to one a rebate or unlawful discrimination the measure of damages to the other is the pecuniary loss inflicted upon him as the result of the rebate paid. ${ }^{2}$ The damages might be the same as the

named in the tariff, for shipment to him of all grain at his command. He does not allege that he had or would have made any arrangement with any consignee in any of these points for the receipt and sale of his corn, or even that the extra commissions there would not more than make the difference in rates. In short, he does not allege, either directly or indirectly, that if he had known of these rates he would have shipped his corn, under this tariff, to either of those points, but rests his contention upon the suggestion that the mere difference in the prices would naturally have caused him to ship to one or the other of them, and thus to take advantage of the joint tariff. Every fact which he alleges might be absolutely and fully true, and yet he, with knowledge of the joint tariff, with the privilege of shipping under it, have never offered or sought to forward a single pound of corn to any other place than Chicago. Surely it needs but the statement of this to show that he comes far short of that rule of strict proof which enables one to enforce a penalty for wrong; for if he would not under any circumstances have shipped to New York, was compelled by his contracts or any other consideration to ship to Chicago, he cannot say that he was injured by his ignorance of the rate to New York. The only right of recovery given by the Interstate Commerce Act to the individual is to the "person or person injured thereby for the full amount of damages sustained in consequence of any of the violations of the provisions of this Act.' So, before any party can recover under the Act he must show not merely the wrong of the carrier, but that that wrong has in fact operated to his injury. If he had shipped to New York and been charged local rates he might have recovered any excess thereon over through rates. He did not ship to New York and yet seeks to recover the extra sum he might have been charged if he had shipped. Penalties are not recoverable on mere possibilities."

2 Pennsylvania Railroad Co. v. International Coal Mining Co., $230 \mathrm{U}$. S. 184, 57 L. Ed. I446, 33 Sup. Ct. 893 . The plaintiff coal company sued the defendant carrier for $\$ 37,268$ which was the difference between the rates paid by the plaintiff and lower rates resulting from rebates allowed other coal dealers making like shipments over the same road from the same point to the same destination. The court said:- "Section 2 of the original Senate bill said nothing about damages but in case of rebating gave a shipper a right, in the nature of an action, for a penalty to be meas- 
rebate, or much less than the rebate or many times greater than the amount of the rebate. But unless the damages were specifically proved they could not be recovered by the shipper. A cause

ured by the difference between the lawful and the unlawful rate, whether damage resulted or not. That provision was stricken out and section 8 of the Act, as passed by both Houses of Congress and approved by the President, gave a right of action for damages and attorney's fees to 'the person injured'-and, of course, to the extent of the injury. There were many provisions in the statute for imprisonment and fines. On the civil side the Act provided for compensation-not punishment. Though the Act has been held to be in many respects highly penal, yet there was no fixed measure of damages in favor of the plaintiff. But, as said in Parsons v. Railway, 167 U. S. 447,42 L. Ed. 231 , I7 Sup. Ct. 887 , construing this section (8) 'before any party can recover under the Act he must show not merely the wrong of the carrier, but that that wrong has in fact operated to his injury.' Congress had not then and has not since given any indication of an intent that persons not injured might, nevertheless recover what though called damages would really be a penalty, in addition to the penalty payable to the Government. On the contrary, and in answer to the argument that damages might be a cover for rebates, the Act of June 18, 1910 provided that where a carrier misquotes a rate it should pay a penalty of $\$ 250$, not to the shipper, but to the Government, recoverable by a civil action brought by the United States. 35 Stat. 166. Congressional Record (I9I0), 7569. The danger that payment of damages for violations of the law might be used as a means of paying rebates under the name of damages is also pointed out by the Commission in I2 I. C. C. $418-421$; I4 I. C. C. 82.

"Indeed it is exceedingly doubtful whether there was at common law any right of action for any sort of damages in a case like this, while this statute does give a clear, definite and positive right to recover for unjust discrimination. It thereby either first created the right or removed the doubt as to whether such suit could be brought. The English courts had held that a shipper, who paid a reasonable rate, had no cause of action because the carrier had charged a lower rate to another. *** But the English courts make a clear distinction between overcharge and damages, and the same is true under the Commerce Act. For if the plaintiff here had been required to pay more than the tariff rate it could have covered the excess, not as damages but as overcharge, and while one count of the complaint asserted a claim of this nature, the proof did not justify a verdict thereon, for the plaintiff admitted that it had only paid the lawful rates named in the tariff. Of course, no part of such payment of lawful rates can be treated as an overcharge or as an extortion.

"Having paid only the lawful rate plaintiff was not overcharged, though the favored shipper was illegally undercharged. For that violation of law, the carrier was subject to the payment of a fine to the Government and, in addition, was liable for all damages it thereby occasioned the plaintiff or any other shipper. But under section 8 it was only liable for dam- 
of action does not necessarily arise from those acts or omissions of a common carrier that may subject it to a criminal prosecution by the Government or to corrective or coercive proceedings at

ages. Making an illegal undercharge to one shipper did not license the carrier to make a similar undercharge to other shippers, and if having paid a rebate of 25 cents a ton to one customer, the carrier in order to escape this suit had made a similar undercharge to rebate to the plaintiff, it would have been criminally liable, even though it may have been done in order to equalize the two companies. For, under the statute, it was not liable to the plaintiff for the amount of the rebate paid on the contract coal, but only for the damages such illegal payment caused the plaintiff The measure of damages was the pecuniary loss inflicted on the plaintiff as the result of the rebate paid. Those damages might be the same as the rebate, or less than the rebate or many times greater than the rebate. But unless they were proved they could not be recovered. Whatever they were they could be recovered, because section 8 expressly declares that wherever the carrier did an act prohibited or failed to do any act required, it should be liable to the person injured thereby for the full amount of damages sustained in consequence of such violation, * * * together with reasonable attorney's fees.' In view of this language it becomes necessary to inquire what the evidence shows was the injury inflicted or the damage sustained by the plaintiff in I90I in consequence of paying rebates in Igor on contract coal sold in $1899 . * * *$ There was no proof of injury-no proof of decrease in business, loss of profits, expense incurred or damage of any sort suffered-the plaintiff claiming that, as matter of law the damages should be assessed to it on the basis of giving to it the same rate, on all its tonnage, that had been allowed on any contract coal shipped, on the same dates, whether such tonnage was great or small.

"Considering the multitude of instances in which discrimination has been practised by carriers, in ancient and modern times, it is remarkable how little is to be found in decisions or text books which treat of the elements and measure of damages in such cases. In the absence of any settled rule on the subject, the new question must be determined on general principles. The statute gives a right of action for damages to the injured party, and by the use of these legal terms clearly indicated that the damages recoverable were those known to the law and intended as compensation for the injury sustained. It is elementary that in a suit at law both the fact and the amount of the damage must be proved. And although the plaintiff insists that in all cases like this the fact and amount of the pecuniary loss is matter of law, yet this contention is not sustained by the language of the Act, nor is it well founded in actual experience, as will appear by considering several usual and every-day instances suggested by testimony in this record. For example:-If plaintiff and one of the favored companies had both shipped coal to the same market on the same day, the rebate on contract coal may have given an advantage which may have prevented the plaintiff from selling, may have directly caused it expense, or may have diminished or totally destroyed its profits. The plaintiff, under the pres- 
the instance of the Interstate Commerce Commission, but arises from those acts or omissions which inflict some specific pecuniary injury capable of being established. And these being acts pro-

ent statute in such case being then entitled to recover the full damages sustained:-But the plaintiff may have sold at the usual profit all or a part of its 40,000 tons at the regular market price, the purchaser, on his own acount, paying freight to the point of delivery. In that event not the shipper but the purchaser, who paid the freight, would have been the person injured, if any damage resulted from giving rebates. To say that seller and buyer, shipper and consignee, could both recover would mean that damages had been awarded to two where only one had suffered:-

"Or, to take another example-a favored dealer may have shipped Io,000 tons of coal to the open New York market, receiving thereon a rebate of 35 cents a ton, or $\$ 3,500$. The plaintiff at the same time may have shipped 20,000 tons and sold the same at the regular market price. Under the rule contended for it would then be entitled to 35 cents a ton on 20,000 tons, or $\$ 7,000$ as damages. Such a verdict, instead of compensating it for losses sustained, would have given to the plaintiff a profit on the carrier's crime in paying a rebate of $\$ 3,500$ and would have made it an advantage to it instead of an injury for the carrier to violate the law. In order to avoid this anomalous, yet logical, result it is now suggested, as in the overcharge cases (Denaby v. Manchester Ry., L. R. II App. Cases 97) the plaintiff should only recover a rebate on Io,00o tons, or on the same weight upon which the carrier had allowed a drawback to the competitor. But, while less drastic, this is still an arbitrary measure and ignores the fact that the same anomalous result would follow if there had been, say, ten dealers, each shipping 10,000 tons on the same day. For, each of the ten would have been as much entitled as plaintiff to recover $\$ 3,500$ on their several shipments of 10,000 tons, and the ten verdicts would aggregate $\$ 35,000$, because of the payment of $\$ 3,500$ to the favored shipper.

"It is said, however, that while there may be no presumption that a shipper was injured because the carrier paid a rebate on a single shipment, or on an occasional shipment, yet it could recover if rebates had been so habitually given as to establish a practice of discrimination. Proof that rebates were customarily paid, would come nearer showing that injury was suffered but would still fall short of proving the extent of the damage, and is not the theory on which the plaintiff proceeds. For it argues that whenever it showed that a lower rate had been charged on contract coal sold in 1899 it was entitled to recover the same rate on shipments made by it to the same place on the same day in Ig0I, even though there had been no competition in the two sales and without proof that there had been any fall in market prices, diminution in its profits, decrease in its business, or increase in its expenses. It claimed that it was a mere matter of mathematics and that for every rebate on contract coal, plaintiff was entitled to a like reduction on every ton of its coal without further proof of damage or injury.

"To adopt such a rule and arbitrarily measure damages by rebates would 
hibited by express declaration of law it is not necessary to have any preliminary decision to that effect by the Commission, or any

create a legalized, but endless, chain of departures from the tariff; would extend the effect of the original crime, would destroy the equality and certainty of rates, and, contrary to the statute, would make the carrier liable for damages beyond those inflicted and to persons not injured. The limitation of liability to the persons damaged and to an amount equal to the injury suffered is not out of consideration for the carrier who has violated the statute. On the contrary, the Act imposes heavy penalties, independent of the amount of rebate paid, and as each shipment constitutes a separate offense, the law in its measure of fine and imprisonment is a terror to evil doers. But for the public wrong and for the interference with the equal current of commerce these penalties or fines were made payable to the Government. If by the same act a private injury was inflicted a private right of action was given. But the public wrong did not necessarily cause private damage, and when it did, the pecuniary loss varied with the character of the property, the circumstances of the shipment, and the state of the market, so that instead of giving the shipper the right to recover a penalty fixed in amount or measure, the statute made the guilty carrier liable for the full amount of damages sustained,-whatever they might be and whether greater or less than the rate of rebate paid.

"This conclusion, that the right to recover is limited to the pecuniary loss suffered and proved, is demanded by the language of the statute, the construction put upon it years ago in the Parsons case, and is the view taken in the only other case we find in which this question, under the Act to Regulate Commerce, has been construed. In Knudsen v. Michigan Central R. R., I48 Fed. 968, it was said by the Circuit Court of Appeals for the Eighth Circuit that to 'support a recovery under this section there must be a showing of some specific pecuniary injury. A cause of action does not necessarily arise from those acts or omissions of a common carrier that may subject it to a criminal prosecution by the Government or to corrective or coercive proceedings at the instance of the Commission.' A similar principle was applied in Meeker v. Lehigh Valley R. R., 183 Fed. 548, and in Central Coal Co. v. Hartman, III Fed. 96, where the suit was to recover damages caused by a violation of the Anti-trust Act.

"Another case, on facts quite like those here involved, is that of Hoover v. Pennsylvania R. R., I56 Pa. 220, where the statute, like the Commerce Act, gave the party injured a right of action for damages suffered. In violation of the state law the railroad allowed a manufacturing company a rebate of 20 cents per ton on coal shipped. In a suit for the recovery of damages the trial court charged the jury that the difference between the high and low rate was the measure of recovery. This was reversed, the court saying:-'The amount of injury suffered is the measure of the single damages to be allowed. But it does not at all follow that the amount of injury suffered is the difference in the rates charged. It might be or it might not be, but, in any event, it must be a subject of proof. It does not appear that the plaintiffs sold their coal for any less than the current market price, except when they and the other dealers were engaged 
reparation order, but the courts may, as in any other case, apply the law to the facts proven and award damages to the person

in a war of prices and sold far below cost in a struggle to capture the market.'

"In view of the express provisions of section 8 of the Act to Regulate Commerce, it was error to refuse to charge that to entitle the plaintiff to recover, the jury must be satisfied that it sustained some loss or injury due to the fact that the defendant was carrying at the same time at lower rates coal shipped by other shippers." "

In Meeker v. Lehigh Valley Railroad Company, decided February 23, 1915, the Supreme Court discussed this question of the measure of damages in a suit by a shipper based upon an unreasonable charge by the carrier. The court said:- "But it is said that the reports disclose that the Commission applied an erroneous and inadmissible measure of damages, and therefore that no effect can be given to the award. What the reports really disclose is that the Commission, 'upon consideration of the evidence adduced upon the hearing upon the question of reparation' found (a) that by reason of the unjust discrimination resulting from giving the rebate to the Lehigh Valley Coal Co. Meeker and Co. were 'damaged to the extent of the difference' between what they actually paid from November 1, Ig0o to August I, I90I, and what they would have paid had they been dealt with on the same basis as was the Coal Company, and (b) that by reason of being charged an excessive and unreasonable rate from August I, I90I to July 17, 1907, Meeker and Co. were 'damaged to the extent of the difference' between what they actually paid and what they would have paid had they been given the rate which the Commission found would have been reasonable. In this we perceive nothing pointing to the application of an erroneous or inadmissible measure of damages. The Commission was authorized and required by section 8 of the Act to Regulate Commerce to award 'the full amount of damages sustained,' and that, of course, was to be determined from the evidence. If it showed that the damages corresponded to the rebate in one instance and to the overcharge in the other the claimant was entitled to an award upon that basis. The case of Pennsylvania Railroad v. International Coal Mining Co., 230 U. S. I84, 57 L. Ed. I446, 33 Sup. Ct. 893, is cited as holding otherwise, but it does not do so. There a shipper, without proving that he sustained any damages, sought to recover from a carrier for giving a rebate to another shipper, and this court, referring to section 8 , said (p. 203):-'The measure of damages was the pecuniary loss inflicted on the plaintiff as the result of the rebate paid. Those damages might be the same as the rebate, or less than the rebate, or many times greater than the rebate; but unless they were proved they could not be recovered. Whatever they were they could be recovered.' There is nothing in either report of the Commission which is in conflict with what was said in that case. On the contrary, the plain import of the findings is that the amounts awarded represent the claimant's actual pecuniary loss; and, in view of the recital that the findings were based upon the evidence adduced, it must be presumed, there being no showing to the contrary, that they were justified by it." 
injured and their jurisdiction to that end is not open to question. ${ }^{3}$

It must be borne in mind that section 8 applies to cases where the cause of action is based on an act or omission made unlawful by some provision of the Act. Therefore although the carrier may have sustained a damage, if it was not the consequence of the violation of the Act section 8 has no application. For example damages occasioned by the failure of the carrier to deliver goods is not traceable to a violation of the Act to Regulate Commerce and the shipper or consignee or other injured party cannot recover damages therefor under the provisions of this section."

3 Pennsylvania Railroad Co. v. International Coal Mining Co., $230 \mathrm{U}$. S. 184,57 L. Ed. I446, 33 Sup. Ct. 893. The court here said:-"In view of this imperative obligation to charge, collect and retain the sum named in the tariff, there was no call for the exercise of the rate-regulating discretion of the administrative body to decide whether the carrier could make a difference in rates between free and contract coal. For whether it could do so or not, the refund of any part of the tariff rate collected was unlawful. It could not have been legalized by any proof, nor could the Commission by any order have made it valid. The rebate being unlawful it was a matter where the court, without administrative ruling or reparation order. could apply the fixed law to the established fact that the carrier had charged all shippers the published or tariff rate and refunded a part to a particular class. This departure from the published tariff was forbidden, and section 8 expressly provided that any carrier doing any act prohibited by the statute should be 'liable to the person injured thereby for the full amount of damages sustained in consequence of any such violation, together with reasonable attorney's fees.'"

See also Mitchell Coal and Coke Co. v. Pennsylvania Railroad Co., 230 U. S. 247,57 L. Ed. 1472, 33 Sup. Ct. 916, where the court said:- "The so-called allowance, regardless of the amount, was a mere gift-a rebate, absolutely forbidden by the statute and ipso facto illegal. Being an act prohibited by law, it was not necessary to have any preliminary decision to that effect by the Commission, but the courts could, as in any other case, apply the law to the facts proven and award damages to the person injured. The decision just rendered in International Coal Company v. Pennsylvania Railroad (supra) makes it unnecessary further to discuss this branch of the case. For the court undoubtedly had jurisdiction to proceed with this branch of the case."

And see Morrisdale Coal Co. v. Pennsylvania Railroad Co., 230 U. S. 304, 57 L. Ed. I494, 33 Sup. Ct. 938, where the suit was based on a claim for damages resulting from an alleged improper distribution of coal cars.

4 Galveston, Harrisburg and San Antonio Railroad Co. v. Wallace, 223 U. S. $48 \mathrm{r}, 56$ L. Ed. 516, 32 Sup. Ct. 205. In an action brought for the damages occasioned by the failure to deliver goods shipped to the consignee, the Supreme Court said:- "Damage caused by failure to deliver goods is in no way traceable to a violation of the statute, and is not, there- 
And similarly in an action brought as the result of the loss of the shipper's property which has been entrusted to the carrier, and which was in no way traceable to the violation of any provision of the Act, attorney's fees cannot be taxed as part of the costs under the eighth section. ${ }^{5}$ In this connection the Supreme Court has held that a state statute giving to a shipper bringing suit against a railroad company for recovery based on the loss of goods shipped, or on a claim against a railroad company which is valid and is not settled within thirty days from its presentation, a specified allowance for attorney's fees where the verdict is in his favor, is not in conflict with the Federal Constitution or with the Act to Regulate Commerce and is valid even as to claims based on Interstate Commerce until Congress legislates on the question. ${ }^{8}$

fore, within the provision of sections 8 and 9 of the Act to Regulate Commerce."

5 Atlantic Coast Line Railroad Co. v. Riverside Mills, 219 U. S. I86, 55 L. Ed. I67, 31 Sup. Ct. I64. Here an action was brought against the initial carrier for goods lost while in the care of connecting lines. The court held that such an action is dependent upon the Carmack Amendment of 1906 to section 20; since the cause of action was not traceable to a violation of the provisions of the Act the case did not come within the contemplation of section 8 and therefore attorney's fees could not be taxed as part of the costs. The court said:- "The judgment included an attorney's fee taxed as part of the costs. The authority for this is supposed to be found in the eighth section of the Act to Regulate Commerce of February 4, I887. * * * But that section applies to cases where the cause of action is the doing of something made unlawful by some provision of the Act, or the omission to do something required by the Act, and there is a recovery 'of damages sustained in consequence of any violation of this act,' etc. The cause of action in the present case is not for damages resulting from 'any violation of the provisions of this act.' True, the plaintiff in error attempted by contract to stipulate for a limitation of liability to a loss on its own line, and in this action has defensively denied liability for a loss not occurring on its own line. But the cause of action was the loss of the plaintiff's property which had been entrusted to it as a common carrier, and that loss is in no way traceable to the violation of any provision of the Act to Regulate Commerce. Having sustained no damage which was a consequence of the violation of the Act, the section has no application to this case."

6 Missouri, Kansas and Texas Railway Co. v. Cade, 233 U. S. 642, 58 L. Ed. I135, 34 Sup. Ct. 678; Missouri, Kansas and Texas Railway Co. v. Harris, 234 U. S. 412, 58 L. Ed. 1377, 34 Sup. Ct. 790, where the court said:- "It is true that in Atlantic Coast Line v. Riverside Mills, 2 I9 U. S. 186, 208, 55 L. Ed. 167, 31 Sup. Ct. 164, (a case arising since the Hepburn 
The Supreme Court has specifically held that the attorney's fee for which provision is made in the eighth section can be taxed and collected only for services incident to an action in courts of law for a recovery and not for services rendered before the Interstate Commerce Commission. The Commission is not authorized to allow a fee but merely to determine the amount of the damages and fix a time for payment. If the carrier pays the award within the time specified there is no suit to collect it and no right to an attorney's fee arises. Only when the damages are recovered by suit is the fee allowable under either section 8 or section I6. The manifest purpose is to charge the railroad with the costs and expenses occasioned by its failure to pay without suit, if the claimant finally prevails, and thus to tax as a part of the costs of the suit, where recovery is secured, a reasonable fee for the services of the shipper's attorney in instituting and prosecuting that suit. The natural purpose of the provision is to encourage the payment of orders of this nature without suit. The validity of this provision has been expressly upheld-the statute providing that the fee must be reasonable, that it be fixed by the

Act), it was held that section 8 of the Act of February 4, 1887, does not authorize the allowance of a counsel or attorney's fee in an action for loss of property entrusted to the carrier for purposes of transportation. But that is far from holding that it is not permissible for a state, as a part of its local procedure, to permit the allowance of a reasonable attorney's fee, under proper restrictions. In claims of this character, based upon the ordinary liability of the common carrier, although regulated by the Commerce Act, the state courts have full jurisdiction, and some differences respecting the allowance of costs and the amount of the costs are inevitable, as being peculiar to the forum. And we think that where a state, as in this instance, for reasons of internal policy, in order to offer a reasonable incentive to the prompt settlement of small but well-founded claims, and as a deterrent of groundless defenses, establishes by a general statute otherwise unexceptionable the policy of allowing recovery of a moderate attorney's fee as a part of the costs, in cases where, after specific claim made and a reasonable time given for investigation of it, payment is refused, and the claimant succeeds in establishing by suit his right to the full amount demanded, the application of such statute to actions for goods lost in interstate com. merce is not inconsistent with the provisions of the Commerce Act and its amendments. The local statute, as already pointed out, does not at all affect the ground of recovery, or the measure of recovery; it deals only with a question of costs, respecting which Congress has not spoken. Until Congress does speak, the state may enforce it in such a case as the present." 
court, and that it be not taxed against the carrier until the demand of the plaintiff has been adjudged valid upon full inquiry. ${ }^{?}$

7 Meeker v. Lehigh Valley Railroad Co., decided February 23, 1915. Concerning the provision for attorneys' iees the court here said:- "Section 8 provides that a carrier violating the Act shall be liable to any person injured for the damages he sustains, 'together with a reasonable counsel or attorney's fee, to be fixed by the court in every case of recovery, which attorney's fee shall be taxed and collected as part of the costs in the case.' And section 16, relating to actions to enforce claims for damages after the Commission has acted thereon, provides 'If the petitioner shall finally prevail he shall be allowed a reasonable attorney's fee to be taxed and collected as a part of the costs of the suit.'

"In our opinion the services for which an attorney's fee is to be taxed and collected are those incident to the action in which the recovery is had and not those before the Commission. This is not only implied in the words of the two provisions just quoted but is suggested by the absence of any reference to proceedings anterjor to the action. And that nothing more is intended becomes plain when we consider another provision in section 16 which requires the Commission, upon awarding damages, to make an order directing the carrier to pay the sum awarded 'on or before a day named' and then declares that, if the carrier does not comply with the order 'within the time limit,' the claimant may proceed to collect the damages by suit. The Commission is not to allow a fee, but only to find the amount of the damages and fix a time for payment; and, if the carrier pays the award within the time named, no right to an attorney's fee arises. It is only when the damages are recovered by suit that a fee is to be allowed, and this is as true of the provision in section 8 as of that in section 16. The evident purpose is to charge the carrier with the costs and expenses entailed by a failure to pay without suit-if the claimant finally prevails-and to that end to tax as part of the costs in the suit wherein the recovery is had a reasonable fee for the services of the claimant's attorney. in instituting and prosecuting that suit. It follows that the District Court erred in matter of law in allowing a fee for services before the Commission.

"The contention that the provision for an attorney's fee for services in the suit is invalid as being purely arbitrary and as imposing a penalty for merely failing to pay a debt is without merit. The provision is levelled against common carriers engaged in interstate commerce, a quasi public business, and is confined to cases wherein a recovery is had for damages resulting from the carrier's violation of some duty imposed in the public interest by the Act to Regulate Commerce. Atlantic Coast Line R. R. Co. v. Riverside Mills, 219 U. S. I86, 208, 55 L. Ed. 167, 31 Sup. Ct. 164. One of its purposes is to promote a closer observance by carriers of the duties so imposed; and that there is also a purpose to encourage the payment, without suit, of just demands does not militate against its validity. Missouri, Kansas \& Texas Ry. Co. v. Cade, 233 U. S. 642, 651, 58 L. Ed. II35, 34 Sup. Ct. 678, and cases cited. It requires that the fee be reasonable 
Equity Jurisdiction under the Commerce Act.-The Supreme Court has held that a bill brought in equity to enforce compliance with the Interstate Commerce Act, and to compel railroad companies to comply with the terms of the Act by offering proper and reasonable facilities for interchange of traffic with the plaintiff company, and enjoining them from refusing to receive from the complainant for transportation over their lines any cars which might be tendered them, constitutes a case arising under the constitution and laws of the United States of which the circuit courts have jurisdiction. "A case arises under the constitution and laws of the United States," said the court, "whenever the party plaintiff sets up a right to which he is entitled under such laws, which the parties defendant deny to him, and the correct decision of the case depends upon the construction of such laws." 8 The court also held that prior to the passage of the Elkins Act of February 10, 1903, a United States District Attorney, in pursuance of a request by the Interstate Commerce Commission, was without power to commence a proceeding in equity against a railroad company to restrain it from discriminating in its rates between different localities. The Elkins Act, however, expressly conferred the power of equity jurisdiction, which did not theretofore exist, in cases brought at the instance of the Interstate Commerce Commission though it made no change in the law regarding the remedies available for individuals. ${ }^{\circ}$

and fixed by the court, and does not permit it to be taxed against the carrier until the plaintiff's demand has been adjudged upon full inquiry to be valid. In these circumstances the validity of the provision is not doubtful but certain."

8 In re Lennon, 166 U. S. 548, 4I L. Ed. 11 10, 17 Sup. Ct. 658; Central Stock Yards Co. v. Louisville and Nashville Railway Co., I92 U. S. 568, 48 L. Ed. 565, 24 Sup. Ct. 339, affirming I12 Fed. 823.

9 Missouri Pacific Railway Co. v. United States, I89 U. S. 274, 47 L. Ed. 811, 23 Sup. Ct. 507. 


\section{SECTION 9. CHOICE OF COMPLAINT TO THE COM- MISSION OR SUIT IN UNITED STATES COURT.}

SEC. 9. That any person or persons claiming to be damaged by any common carrier subject to the provisions of this Act may either make complaint to the Commission as hereinafter provided for, or may bring suit in his or their own behalf for the recovery of the damages for which such common carrier may be liable under the provisions of this Act, in any district or circuit court of the United States of competent jurisdiction; but such person or persons shall not have the right to pursue both of said remedies, and must in each case elect which one of the two methods of procedure herein provided for he or they will adopt. In any such action brought for the recovery of damages, the court before which the same shall be pending may compel any director, officer, receiver, trustee, or agent of the corporation or company defendant in such suit to attend, appear, and testify in such case, and $\mathrm{P}$ e $\mathrm{s}$ o $\mathrm{n}$ s claiming to be damaged may elect whether to complain to the Commission or bring suit in a United States court.

Officers of defendant may be compelled to tes. tify. may compel the production of the books and papers of such corporation or company party to any such suit; the claim that any such testimony or evidence may tend to criminate the person giving such evidence shall not excuse such witness from testifying, but such evidence or testimony shall not be used against such person on the trial of any criminal proceeding.

Rights of Private Action before Judicial Tribunals.-Section 9 was a portion of the original Act to Regulate Commerce, approved February 4, I887 and has not been amended since its enactment. Like section 8 it relates to the rights of private individuals to invoke a remedy against common carriers regulated by the Interstate Commerce Act. Moreover like section 8 its influence has been greatly diminished because of the radical changes in the Act by reason of the amendments of 1906 and 1910 and the increased powers of the Interstate Commerce Com- 
mission thereunder. As a result thereof the jurisdiction of the courts to entertain private actions has been considerably changed under the influence of these amendments to the Act.

This section of the Act cannot be construed as an independent piece of legislation but it must be read in connection with the context of the entire Act and it must be construed with a view to its interdependence upon other sections and in harmony with them. The power of the courts to award damages to those claiming to have been injured, within the provisions of the ninth section, contemplates a decree in favor of the individual complainant merely to redress the particular wrong asserted to have been committed and does not include the power to direct the carrier to abstain in the future from similar violations of the Act. It therefore follows from the context of the Act that the independent right of an individual originally to maintain actions to obtain pecuniary redress for violations of the Act, conferred by the ninth section, must be confined to the redress of such wrongs as can, consistently with the context of the Act, be redressed by courts without previous action by the Commission and therefore does not imply the power in a court to primarily hear complaints concerning wrongs springing from the enforcement of a schedule of rates claimed to be excessive, preferential or discriminatory. ${ }^{1}$ As a condition precedent to such an action in

I Texas and Pacific Railway Co. v. Abilene Cotton Oil Co., 204 U. S. 426, 51 L. Ed. 553, 27 Sup. Ct. 350. Here an action was brought in the state courts of Texas to recover from the carrier payments for the carriage of freight alleged to be in excess of a just and reasonable charge. The rate complained of, it is to be noted, was the one fixed in the rate sheets which the railroad company had established, filed, published and posted in accordance with the terms of the Act to Regulate Commerce. The Supreme Court said:- "When the Act to Regulate Commerce was enacted there was contrariety of opinion whether, when a rate charged by a carrier was in and of itself reasonable, the person from whom such a charge was exacted had at common law an action against the carrier because of damage asserted to have been suffered by a discrimination against such person or a preference given by the carrier to another. (Parsons v. Chicago and Northwestern Railway, I67 U. S. 447, 455, 42 L. Ed. 23I, 17 Sup. Ct. 887; Interstate Commerce Commission v. Baltimore and Ohio Railroad, I45 U. S. 263, 275, 36 L. Ed. 699, 12 Sup. Ct. 844). That the Act to Regulate Commerce was intended to afford an effective means for redressing the wrongs resulting from unjust discrimination and undue preference is undoubted. Indeed, is it not open to controversy that to provide for these subjects was among the principal purposes of the Act. 
the courts there must have been some previous ruling of the Interstate Commerce Commission in the premises. Otherwise if the standard of rates fixed in the manner prescribed by the statute

(Interstate Commerce Commission v. Cincinnati, New Orleans and Texas Pacific Railway Co., 167 U. S. 479, 494, 42 L. Ed. 243, 17 Sup. Ct. 896.) And it is apparent that the means by which these great purposes were to be accomplished was the placing upon all carriers the positive duty to establish schedules of reasonable rates which should have a uniform application to all and which should not be departed from so long as the established schedule remained unaltered in the manner provided by law. (Cincinnati, New Orleans and Texas Pacific Railway Co. v. Interstate Commerce Commission, 162 U. S. 184, 40 L. Ed. 935, I6 Sup. Ct. 700; Interstate Commerce Commission v. Cincinnati, New Orleans and Texas Pacific Railway Co., 167 U. S. 479, 42 L. Ed. 243, 17 Sup. Ct. 896.)

"When the general scope of the Act is enlightened by the considerations just stated it becomes manifest that there is not only a relation, but an indissoluble unity between the provision for the establishment and maintenance of rates until corrected in accordance with the statute and the prohibitions against preferences and discrimination. This follows, because unless the requirement of a uniform standard of rates be complied with it would result that violations of the statute as to preferences and discrimination would inevitably follow. This is clearly so, for if it be that the standard of rates fixed in the mode provided by the statute could be treated on the complaint of a shipper by a court and jury as unreasonable, without reference to prior action by the Commission, finding the established rate to be unreasonable and ordering the carrier to desist in the future from violating the Act, it would come to pass that a shipper might obtain relief upon the basis that the established rate was unreasonable, in the opinion of a court and jury, and thus such shipper would receive a preference or discrimination not enjoyed by those against whom the schedule of rates was continued to be enforced. This can only be met by the suggestion that the judgment of a court, when based upon a complaint made by a shipper without previous action by the Commission, would give rise to a change of the schedule rate and thus cause the new rate resulting from the action of the court to be applicable in the future as to all. This suggestion, however, is manifestly without merit, and only serves to illustrate the absolute destruction of the Act and the remedial provisions which it created which would arise from a recognition of the right asserted. For if, without previuus action by the Commission, power might be exerted by courts and juries generally to determine the reasonableness of an established rate, it would follow that unless all courts reached an identical conclusion a uniform standard of rates in the future would be impossible, as the standard would fluctuate and vary, dependent upon the divergent conclusions reached as to reasonableness by the various courts called upon to consider the subject as an original question. Indeed the recognition of such a right is wholly inconsistent with the administrative power conferred upon the Commission and with the duty, which the statute 
could be adjudged unreasonable by a court and jury upon the complaint of a shipper, without reference to a prior decision by the Commission as to its reasonableness, it would necessarily follow

casts upon that body, of seeing to it that the statutory requirement as to uniformity and equality of rates is observed. Equally obvious is it that the existence of such a power in the courts, independent of prior action by the Commission, would lead to favoritism, to the enforcement of one rate in one jurisdiction and a different one in another, would destroy the prohibitions against preferences and discrimination, and afford, moreover, a ready means by which, through collusive proceedings, the wrongs which the statute was intended to remedy could be successfully inflicted. Indeed no reason can be perceived for the enactment of the provision endowing the administrative tribunal, which the Act created, with power, on due proof, not only to award reparation to a particular shipper, but to command the carrier to desist from violation of the Act in the future, thus compelling the alteration of the old or the filing of a new schedule, conformably to the action of the Commission, if the power was left in courts to grant relief on complaint of any shipper, upon the theory that the established rate could be disregarded and be treated as unreasonable, without reference to previous action by the Commission in the premises. This must be, because, if the power existed in both courts and the Commission to originally hear complaints on this subject, there might be a divergence between the action of the Commission and the decision of a court. In other words, the established schedule might be found reasonable by the Commission in the first instance and unreasonable by a court acting originally, and thus a conflict would arise which would render the enforcement of the Act impossible.

"Nor is there merit in the contention that section 9 of the Act compels to the conclusion that it was the purpose of Congress to confer power upon courts primarily to relieve from the duty of enforcing the established rate by finding that the same as to a particular person or corporation was so unreasonable as to justify an award of damages. True it is that the general terms of the section when taken alone might sanction such a conclusion, but when the provision of that section is read in connection with the context of the Act and in the light of the considerations which we have enumerated we think the broad construction contended for is not admissible. And this becomes particularly cogent when it is observed that the power of the courts to award damages to those claiming to have been injured, as provided in the section, contemplates only a decree in favor of the individual complainant, redressing the particular wrong asserted to have been done, and does not embrace the power to direct the carrier to abstain in the future from similar violations of the Act; in other words, to command a correction of the established schedules which power, as we have shown, is conferred by the Act upon the Commission in express terms. In other words, we think that it inevitably follows from the context of the Act that the independent right of an individual originally to maintain actions in courts to obtain pecuniary redress for violations of 
that unless all courts reached an identical conclusion concerning the reasonableness of an established charge a uniform standard of rates for the future would be impossible, and it would not be

the Act conferred by the ninth section must be confined to redress of such wrongs as can, consistently with the context of the Act, be redressed by courts without previous action by the Commission, and, therefore, does not imply the power in a court to primarily hear complaints concerning wrongs of the character of the one here complained of. Although an established schedule of rates may have been altered by a carrier voluntarily or as the result of the enforcement of an order of the Commission to desist from violating the law, rendered in accordance with the provisions of the statute, it may not be doubted that the power of the Commission would nevertheless extend to hearing legal complaints of and awarding reparation to individuals for wrongs unlaw fully suffered from the application of the unreasonable schedule during the period when such schedule was in force.

"And the conclusion to which we are thus constrained by an original consideration of the text of the statute finds direct support, first, in adjudged cases in lower federal courts and in the construction which the Act has apparently received from the beginning in practical execution; and, second, is persuasively supported by decisions of this court, which, whilst not dealing directly with the question here presented, yet necessarily concern the same. *** When it is considered that the Act to Regulate Commerce was enacted in 1887 , and that neither the diligence of counsel nor our own researches have brought into view any case except the one now under consideration, holding that a court could, compatibly with the terms of that Act, grant relief upon the basis that the established rate could be disregarded as unreasonable, it would seem to follow that the terms of the Act had generally been treated in practical execution as incompatible with the existence of such power or right. And this is greatly fortified when it is borne in mind that the reports of the decisions of the Interstate Commerce Commission show that many cases have been passed upon by that body concerning the unreasonableness of a rate fixed in an established schedule, which have resulted in awarding reparation to shippers and to the making of orders directing carriers to desist from future violation of the Act; that is to say, the necessary legal effect correcting established schedules.

"The cases of Cincinnati, New Orleans and Texas Pacific Railway Co. v. Interstate Commerce Commission, I62 U. S. 184, 40 L. Ed. 935, I6 Sup. Ct. 700; Louisville and Nashville Railroad Co. v. Behlmer, I75 U. S. 648, 44 L. Ed. 309, 20 Sup. Ct. 209, and Interstate Commerce Commission v. Louisville and Nashville Railroad Co., I90 U. S. 273, 47 L. Ed. 1047, 23 Sup. 687, involved the enforcement against carriers of orders of the Commission. After deciding that the orders of the Commission were not entitled to be enforced, because of errors of law committed by that body, this court declined to consider the question of the reasonableness per se of the rates as an original question; in other words the correction of the established 
possible to enforce the statutory requirement as to uniformity and equality of rates. The vesting of such a power in the courts, independent of prior action by the Commission, would inevitably promote favoritism, inequality of rates in different jurisdictions, and encourage preferences and discrimination between carriers and shippers. Therefore the shipper seeking reparation predicated upon the unreasonableness of the established rate must, as a basis for a common law recovery of an excessive charge primarily invoke redress through the Commission which alone is vested with power originally to entertain proceedings for

schedule without previous consideration of the subject by the Commission. It was pointed out that by the effect of the Act to Regulate Commerce it was peculiarly within the province of the Commission to primarily consider and pass upon a controversy concerning the unreasonableness per se of the rates fixed in an established schedule. It was, therefore, declared to be the duty of the courts, where the Commission had not considered such a disputed question, to remand the case to the Commission to enable it to perform that duty, a conclusion wholly incompatible with the conception that courts, in independent proceedings, were empowered by the Act to Regulate Commerce, equally with the Commission, primarily to determine the reasonableness of rates in force through an established schedule.

"When the Commission is called upon on the complaint of an individual to consider the reasonableness of an established rate, its power is invoked not merely to authorize a departure from such rate in favor of the complainant alone, but to exert the authority conferred upon it by the Act, if the complaint is found to be just, to compel the establishment of a new schedule of rates applicable to all. And like reasoning would be applicable to the granting of reparation to an individuel after the establishment of a new schedule because of a wrong endured during the period when the unreasonable schedule was enforced by the carrier and before its change and the establishment of a new one. In other words, the difference between the two is that which on the one hand would arise from destroying the uniformity of rates which it was the object of the statute to secure and on the other from enforcing that equality which the statute commands. * * Concluding, as we do, that a shipper seeking reparation predicated upon the unreasonableness of the established rate must, under the Act to Regulate Commerce, primarily invoke redress through the Interstate Commerce Commission, which body alone is vested with power originally to entertain proceedings for the alteration of an established schedule, because the rates fixed therein are unreasonable, it is unnecessary for us to consider whether the court below would have had jurisdiction to afford relief if the right asserted had not been repugnant to the provisions of the Act to Regulate Commerce."

See also Texas and Pacific Railway Co. v. Cisco. Oil Mill, 204 U. S. 449, 5I L. Ed. 562, 27 Sup. Ct. 358. 
the alteration of an established schedule on the ground that the rates fixed therein are unreasonable.

Since the decision in the Abilene Cotton Oil Co. case the Supreme Court has affirmed its ruling in other cases and declared it to be an essential principle that the courts could not primarily interfere with or invade the administrative functions vested in the Commission, and that grievances which were primarily within the administrative competency of the Commission could not be subject to judicial enforcement until that body had been afforded by a complaint made to it the opportunity to exercise its undoubted functions. ${ }^{2}$

2 Baltimore and Ohio Railroad Co. v. United States ex rel. Pitcairn Coal Co., 215 U. S. 481, 54 L. Ed. 292, 30 Sup. Ct. 164. The Pitcairn Coal Co. filed a petition in mandamus to compel the Baltimore and Ohio Railroad Co. to equally distribute its coal cars in times of car shortage, alleging that the plaintiff company was not receiving its proper share. The court said:- "The nature of the controversy and the relief which it requires is such that, even without the assigned error, to which we have referred, the question at the very threshold necessarily arises and commands our attention as to whether there was power in the courts, under the circumstances disclosed by the record, to grant the relief prayed consistently with the provisions of the Act to Regulate Commerce, and to that subject we therefore at once come. To a consideration of this question it is essential to at once summarily and accurately fix the subject matter of the alleged grievances and the precise character of the relief required in order to remedy the evils complained of upon the assumption of their existence. As to the first, it is patent that the grievances involve acts of the Baltimore and Ohio Railroad, regulations adopted by that company and alleged dealings by the other corporations, all of which, it is aserted, concern interstate commerce, and all of which, it is alleged are in direct violation of the duty imposed upon the railroad company by the provisions of the Act to Regulate Commerce. As to the second in view of the nature and character of the acts assailed, of the prayer for relief which we have previously excerpted and of the relief which the court below directed to be awarded, it is equally clear that a prohibition, by way of mandamus, against the Act is sought and an order, by way of mandamus, was inroked, and was allowed which must operate, by judieial decree upon all the numerous parties and various interests as a rule or regulation as to the matters complained of for the conduct of interstate commerce in the future. When the situation is thus defined we see no escape from the conclusion that the grievances complained of were primarily within the administrative competency of the Interstate Commerce Commission and not subject to be judicially enforced, at least until that body, clothed by the statute with authority on the subject, had been afforded by a complaint made to it the opportunity to exert its administrative functions. 
However, the courts could act where under section I6 the Commission had declared the rates unreasonable and the defendants had stipulated in the proceedings that in case the complainants prevailed the court might adjudge the amount of reparation which should be made. ${ }^{3}$

"The controversy is controlled by the considerations which governed the ruling made in Texas and Pacific Railroad Company v. Abilene Cotton Oil Co., 204 U. S. 426, 5 I L. Ed. 553, 27 Sup. Ct. 350. In that case suit was brought in a court of the state of Texas to recover, because of an exaction by a carrier, on an interstate shipment, of an alleged unreasonable rate, although the rate charged was that stated in the schedules duly filed and published in accordance with the Act to Regulate Commerce. After great consideration, it was held that the relief prayed was inconsistent with the Act to Regulate Commerce, since by that Act the rates, as filed, were controlling until they had been declared to be unreasonable by the Interstate Commerce Commission on a complaint made to that body. It was pointed out that any other view would give rise to inextricable confusion, would create unjust preferences and undue discriminations, would frustrate the purposes of the Act, and, in effect, cause the Act to destroy itself. The ruling there made dealt with the provisions of the Act as they existed prior to the amendments adopted in 1906, and when those amendments are considered they render, if possible, more imperative the construction giving to the Act by that ruling, since, by section 15, as enacted by the amendment of June 29, 1906, the Commission is empowered, indeed it is made its duty, in disposing of a complaint, not only to determine the legality of the practice alleged to give rise to an unjust preference or undue discrimination, and to forbid the same, but, moreover, to direct the practise to be followed as to such subject for a future period, not exceeding two years, with power in the Commission, if it finds reason to do so, to suspend, modify, or set aside the same, the order, however, to become operative without judicial action. In considering section 15 in the case of Illinois Central Railroad Co. v. Interstate Commerce Commission, just decided, it was pointed out that the effect of the section was to cause it to come to pass that courts, in determining whether an order of the Commission should be suspended or enjoined, were without power to invade the administrative functions vested in the Commission, and therefore could not set aside an order duly made on a mere exercise of judgment as to its wisdom or expediency. Under these circumstances it is apparent, as we have said, that these amendments add to the cogency of the reasoning which led to the conclusion in the Abilene case, that the primary interference of the courts with the administrative functions of the Commission was wholly incompatible with the Act to Regulate Commerce."

3 Southern Railway Co. v. Tift, 206 U. S. 428, 51 L. Ed. 1124, 27 Sup. Ct. 709, where the court said:- "There is nothing in that case, however, which precludes the parties, after action by the Commission declaring rates unreasonable, from stipulating in the proceedings prosecuted under 
Equity Jurisdiction.-Where the Interstate Commerce Commission, upon application to it, finds that an advance of rates is unreasonable the courts may in a proper procedure enjoin the carriers from enforcing the advance. ${ }^{*}$ By the amendment of I9Io the power of the Interstate Commerce Commission has been greatly enlarged and it now possesses the right to suspend an increase of rates for a stated period for the purpose of investigating their reasonableness and propriety. This amendment therefore gives shippers the right to complain to the Commission and to secure proper relief through that body, and they are no longer dependent upon the courts for that form of relief. Where the case involves the Act to Regulate Commerce and is not one which the law requires to be submitted to the Commission the courts have jurisdiction to entertain it. ${ }^{5}$ For example, where

section 16 that the court adjudge the amount of reparation." See also Macon Grocery Co. v. Atlantic Coast Line Railroad Co., 215 U. S. 501 , 54 L. Ed. 300,30 Sup. Ct. I84, where the case turned upon the question of jurisdiction.

4 Southern Railway Co. v. Tift, 206 U. S. 428, 5 I L. Ed. II24, 27 Sup. Ct. 7og, supra.

5 Louisville and Nashville Railroad Co. v. Cook Brewing Co., 223 U. S. 70,56 L. Ed. 355,32 Sup. Ct. I 89 . A statute of the state of Kentucky made it unlaw ful for carriers to transport liquor into local option or "dry" districts of the state. The railroad company thereupon refused to accept shipments of liquor for points in that state where the local option law was in operation. A petition was filed in equity to compel the railroads to desist from refusing these shipments to such points. The court said:"Valid as the Kentucky legislation undoubtedly was as a regulation in respect to intrastate shipments of such articles, it was most obviously never an effective enactment in so $\mathrm{far}$ as it undertook to regulate interstate shipments to dry points. *** The fact that the circular notice of the company referred to was filed with the Interstate Commerce Commis. sion is incidentally stated in the answer of the company, and this fact is now made the basis for an argument that neither the state court nor the Circuit Court had any jurisdiction, and that an application should have been made to the Interstate Commission Commission for an order requiring the railroad company to desist from refusing to transport such articles in interstate commerce. Why should the brewing company have made complaint to the Commission? What relief could it afford? There was no tariff question. There was no discrimination against shipments tendered by complainant and like shipments tendered by other brewers to the same points. There was no claim that the commodities tendered were inherently dangerous to transport or that the railroad company did not have transportation facilities. Evansville was not discriminated against in favor of like shipments to the same points. To say that there was a discrimi- 
a state statute forbade the shipment of liquor into "dry districts" and railroad companies in accordance therewith declined to receive interstate shipments of that commodity to such points, the courts have jurisdiction to entertain a petition in equity for an order to compel such carriers to accept the proffered shipments from other states since this involves not a question of a rate or tariff or of discrimination, but rather the very validity of the state statute and the Interstate Commerce Commission would have no power to furnish relief in the premises. As a general proposition it may be asserted that an injunction based upon a petition alleging the violation of certain provisions of the Act to Regulate Commerce can relate only to the sections thus violated and the court is not warranted in issuing an injunction of a general character embracing other features not responsive to the complaint. ${ }^{\circ}$

nation between shipments of intoxicants and other commodities does not make a case of discrimination or preference where the denial of such shipments is based, as is the case here, wholly and solely upon an illegal restraint upon that kind of interstate commerce, is to reason in a circle, for the question comes back at last to the validity of the law forbidding such shipments. There was no discrimination if the law was valid, aud the result must turn, not upon any administrative question or questions of fact within the scope of the power of the Commission, but upon the validity of the legislation which controlled the action of the carrier. That is a question of general law for a judicial tribunal, and one not competent for the Commission as a purely administrative body. The decision in the case of Texas and Pacific Railway v. Abilene Cotton Oil Co., 204 U. S. 426, 5I L. Ed. 553, 27 Sup. Ct. 350, is not applicable here. The question there was one of the reasonableness of a rate. Such a question is primarily one of administrative character, and the propriety of a prior resort to the Commission to obtain a ruling upon the question of reasonableness involved the very heart of the whole statute. That there might be uniformity in rate-making necessarily required a resort to that body as a basis for a common law recovery of an excessive charge."

6 New York, New Haven and Hartford Railroad Co. v. Interstate Commerce Commission, 200 U. S. 36I, 50 L. Ed. 515, 26 Sup. Ct. 272, where the court said:- "The contention is that wherever a carrier has been adjudged to have violated the Act to Regulate Commerce in any particular it is the duty of the court, not only to enjoin the carrier from further like violations of the Act but to command it in general terms not to violate the Act in the future in any particular. In other words, the proposition is that by the effect of a judgment against a carrier concerning a specific violation of the Act, the carrier ceases to be under the protection of the law of the land and must thereafter conduct all its business under the jeopardy of punishment for contempt for violating a gen- 
Actions for Damages in Courts of Law.-As stated heretofore on questions involving an administrative function under the Act to Regulate Commerce there must be a decision of the Interstate Commerce Commission as a preliminary to the right to maintain a suit in the courts. A shipper cannot therefore maintain an action without producing an order of the Commission that the rule, regulation or action of the carrier was unreasonable. Under this rule a shipper claiming damages as a result of the failure of a railroad company to properly distribute coal cars in a time of shortage can not maintain an action at law for a recovery until upon investigation after complaint the Commission has determined that the distribution complained of was discriminatory. The complaint of the shipper must be filed with the Commission within two years from the time the cause of action accrues, and the petition for the enforcement of an order for the payment of money must be filed with the court within one year from the date of the order of the Commission. (See section i6.) Filing a petition with a court does not serve to stay the operation of the period of limitation within which the complaint must be filed with the Commission. There is no right of action in court until the decision of the Commission. ${ }^{7}$

eral injunction. To state the proposition is we think, to answer it. *** The requirement of the Act to Regulate Commerce that a court shall enforce an observance of the statute against a carrier who has been adjudged to have violated its provisions in no way gives countenance to the assumption that Congress intended that a court should issue an injunction of such a general character as would be violative of the most elementary principles of justice. *** To accede to the doctrine relied upon would compel us, under the guise of protecting freedom of commerce, to announce a rule which would be destructive of the fundamental liberties of the citizen."

7 Morrisdale Coal Co. v. Pennsylvania Railroad Co. 230 U. S. 304, 57 L. Ed. 1494,33 Sup. Ct. 938 . The plaintiff alleged that the carrier failed to assign to it its fair proportion of the entire number of coal cars of the railroad company as compared with other coal companies and that as a result thereof the plaintiff was obliged to buy coal at times in the outside market in order to fill its contracts to its corresponding damage. The Supreme Court said:- "These rulings as to the validity of a particular practise and the facts that would warrant a departure from a proper rule actually in force are sufficient to show that the question as to the reasonableness of a rule of car distribution is administrative in its character and calls for the exercise of the powers and discretion conferred by Congress upon the Commission. It was distinctly so ruled in the Pitcairn case (215 U. S. 48 I, 54 L. Ed. 292, 30 Sup. Ct. 164) and in I. C. C. v. 
Where the suit is based upon unreasonable charges and unreasonable practises there is no law fixing what is unreasonable and therefore prohibited. And in such a case the whole scope of the

Illinois Central (215 U. S. 452, 54 L. Ed. 28030 Sup. Ct. 155). Those cases involved a consideration of the power of the Commission over the distribution of cars and held that the courts could not by mandamus compel it to make a rule, nor by injunction restrain the enforcement of one it had promulgated. If in those direct proceedings the courts could not pass upon the question of reasonableness of a method of allotting cars, neither can it do so as an incident to an action for damages. In view of the decision in the Abilene, Pitcairn and Robinson cases it is unnecessary again to discuss the statute or do more than say that in this case the plaintiff was not entitled to maintain its action without producing an order of the Commission that the rule adopted by the Pennsylvania railroad was unreasonable. *** It was admitted at the hearing that there had been no discrimination against the plaintiff in the application of the rule, the complaint being that the basis of allotment was unreasonable and that all cars in the district should be distributed according to the capacity of the mine without deducting private cars, foreign fuel cars, or the carrier's own fuel cars. Whether this should be done as a general rule, or under the peculiar conditions prevailing on defendant's road at that time was, as we have seen, an administrative question and to be decided by the Commission as preliminary to the right to maintain this suit. The Circuit Court rightly held that until this was done it had no jurisdiction as a federal court of the cause of action sought to be enforced.

"It is argued in the plaintiff's brief that if this view of the law should be sustained the case should not be dismissed but stayed until the plaintiff could apply to the Commission and obtain a ruling on the question as to whether the method adopted by the Pennsylvania Railroad was not, during the years 1900 to 1906 unjustly discrimatory. Attention is called to Southern Railway v. Tift, 206 U. S. 428, 5I L. Ed. 1124, 27 Sup. Ct. 709, which it is said would support such a provision in the mandate. *** In that case the Statute of Limitations had not run when the bill was filed, when the stay was granted, nor when the application was made to the Commission; while in the present case the plaintiff was barred of the right to apply to the Commission at the date the suit was filed in the United States Circuit Court. The damages which were claimed arose from a failure to deliver cars prior to December 31 , 1905. The suit was brought July I7, 1908, more than two and a half years later and after the passage of the Act of June 29, I906, that 'all complaints for the recovery of damages shall be filed with the Commission within two years from the time the cause of action accrued and not after and a petition for the enforcement of an order shall be filed in the Circuit Court within one year from the date of the order and not afterwards; provided that claims accrued prior to the passage of this Act may be presented within one ycar." "

In Pennsylvania Railroad Co. v. International Coal Mining Co., $230 \mathrm{U}$. 
statute shows that it was intended that the Commission and not the courts should pass upon that administrative question. But where an act is done which is prohibited by statute the injured party may, without previous action by the Commission, maintain a suit for damages against the carrier because the courts can apply the law prohibiting a departure from the tariff to the facts of the case. Where, in the first case such an order is made by the Commission it is as though the law for that particular practise had been determined, and the courts can then apply that order not to one case but to every case, thus giving every shipper equal rights and preserving the desired uniformity of practise sought by the Act. And so the courts have primary jurisdiction of cases brought against a carrier for damages from being charged the full rates under a tariff when the carrier is giving the same service to other shippers at lower rates by the payment of rebates or otherwise. ${ }^{8}$.

S. I84, 57 L. Ed. I446, 33 Sup. Ct. 893 , the court said:-"Under the statute there are many acts of the carrier which are lawful or unlawful according as they are reasonable or unreasonable, just or unjust. The determination of such issues involves a comparison of rate with service, and calls for an exercise of the discretion of the administrative and rate-regulating body. For the reasonableness of rates, and the permissible discrimination based upon difference in conditions are not matters of law. So far as the determination depends upon facts, no jurisdiction to pass upon the administrative questions involved has been conferred upon the courts. That power has been vested in a single body so as to secure uniformity and to prevent the varying and sometimes conflicting results that would flow from the different views of the same facts that might be taken by different tribunals." See also Meeker v. Lehigh Valley Railroad Co., decided February 23,1915 .

8 Mitchell Coal Co. v. Pennsylvania Railroad Co., 230 U. S. 247,57 L. Ed. I472, 33 Sup. Ct. 916. Here suit was brought to recover damages alleged to have been occasioned by the payment of rebates to other shippers under similar conditions. The court said:-"The courts have not been given jurisdiction to fix rates or practises in direct proceedings nor can they do so collaterally during the progress of a law suit when the action is based on the claim that unreasonable allowances have been paid. If the decision of such questions was committed to different courts with different juries the results would not only vary in degree, but might of ten be opposite in character-to the destruction of the uniformity in rate and practise which was the cardinal object of the statute. The necessity under the statutes of having such questions settled by a single tribunal in order to secure singleness of practise and uniformity of rate has been pointed out and settled in the Abilene, Pitcairn and Robinson cases and is referred to here because this record and that in Pennsylvania R. R. v. Inter- 
To recapitulate then, the only case wherein a shipper is permitted to sue originally before the courts is when a carrier has done something contrary to the Act--as for example where it

national Coal Co., just decided, furnish a striking illustration of the results which would follow if the reasonableness of an allowance could be decided by different tribunals. Both cases involve the payment of 18 cents a ton to the Altoona Company during the same period and for identically the same reasons. In both the plaintiff insisted that the payment was a rebate, and the carrier that it was compensation for services rendered. In the International case the judge treated the Altoona allowance as lawful and reasonable. In this case the referee found that it was a rebate, while the trial judge, in passing on exceptions to the report, held that it was a question of fact about which the evidence was conflicting and thereupon approved the referee's report. *** This and like considerations compelled the holding that, as the courts have no primary jurisdiction to fix rates, neither can they do so at the suit of a single plaintiff who claims to have been damaged because an allowance paid its competitors was unreasonable in amount.

"It is argued that this conclusion ignores sections 9 and 22, which give the shipper the option of suing in the courts or applying to the Commission. The same argument was made and answered in the Abilene case by showing that to permit suits based on the charge that a particular practise was unreasonable, without previous action by the Commission, would repeal the many provisions of the statute requiring uniformity and equality. * * Manifestly, different verdicts would occasion inequality between the two shippers and it is equally manifest that if the Commission had made one order of which both could avail themselves, there would have been one finding, of which one, two or a score of shippers could equally avail themselves. The claim that this conclusion nullifies section 9 is concretely answered by the fact that the court has just decided to the contrary in Pennsylvania Railroad v. International Coal Company. There the carrier insisted that a suit for damages, occasioned by rebating, could not be maintained without preliminary action by the Commission. This contention was overruled, and it was held that, for doing an act prohibited by the statute, the injured party might sue the carrier without previous action by the Commission, because the courts could apply the law prohibiting a departure from the tariff to the facts of the case. But where the suit is based upon unreasonable charges or unreasonable practises there is no law fixing what is unreasonable and therefore prohibited. In such cases the whole scope of the statute shows that it was intended that the Commission and not the courts should pass upon that administrative question. When such order is made it is as though the law for that particular practise had been fixed, and the courts could then apply that order, not to one case, but to every case-thereby giving every shipper equal rights and preserving uniformity of practise. Section 9 gives the plaintiff the option of going before the Commission or the courts for damages occasioned by a violation of the statute. But since the Commission is 
has given a rebate, varied from a published rate or made a discrimination forbidden by the Act. The shipper is compelled to resort in the first instance to the Interstate Commerce Commission in all cases except those in which his cause of action does not involve the reasonableness of a rate or practise.

It is again to be borne in mind that damages caused by the failure of the carrier to deliver goods are not traceable to any violation of the statute and do not, therefore, come within the purview of section 9 of the Act to Regulate Commerce. ${ }^{9}$

Furnishing Testimony and Production of Books.-The Supreme Court has in effect declared unconstitutional the provisions of section 9 compelling persons to give testimony and produce books and papers on the ground that the safeguards provided were not sufficient to protect them against the effects of self-incriminatory testimony under the fifth amendment to the Constitution. ${ }^{10}$ The Act of February I I, 1893, related to testimony given before the Commission only as contemplated under section I 2 and did not apply to the ninth section. The Act of February 25, I903, however, did cure this defect.

charged with the duty of determining whether the practise was so unreasonable as to be a violation of the law, the plaintiff must, as a condition to his right to succeed, produce an order from the Commission that the practise or the rate was thus unreasonable and therefore illegal and prohibited." Phillips Co. v. Grand Trunk Western Ry. Co., decided March I5, 1915 .

See also Pennsylvania Railroad Co. v. International Coal Mining Co., 230 U. S. I84, 57 L. Ed. I 446,33 Sup. Ct. 893, where the court said:- "In view of this imperative obligation to charge, collect and retain the sum named in the tariff, there was no call for the exercise of the rate-regulating discretion of the administrative body to decide whether the carrier could make a difference in rates between free and contract coal. For whether it could do so or not, the refund of any part of the tariff rate collected was unlawful. It could not have been legalized by any proof, nor could the Commission by any order have made it valid. The rebate being unlawful it was a matter where the court, without administrative ruling or reparation order, could apply the fixed law to the established fact that the carrier had charged all shippers the published or tariff rate and refunded a part to a particular class. This departure from the published tariff was forbidden."

9 Galveston, Harrisburg and San Antonio Railway Co. v. Wallace, 223 U. S. $4^{81}, 56$ L. Ed. 516, 32 Sup. Ct. 205.

10 Counselman v. Hitchcock, 142 U. S. 547, 35 L. Ed. 1110, 12 Sup. Ct. 195. See also Webster Coal and Coke Co. v. Cassatt, 207 U. S. I8I, 52 L. Ed. 160, 28 Sup. Ct. 108, where it was held, on a writ of error relating to the production of books and papers, that the order was insufficient to support the writ. 


\section{SECTION IO. PENALTIES FOR VIOLATIONS OF THE ACT.}

Penalties for violations of Act by carriers, or when the carrier is a corpo. ration, its offcers, agents, or employees: Fine and ment.
SEC. 1O. (As amended March 2, 1889, and June I8, 1910.) That any common carrier subject to the provisions of this Act, or, whenever such common carrier is a corporation, any director or officer thereof, or any receiver, trustee, lessee, agent, or person acting for or employed by such corporation, who, alone or with any other corporation, company, person, or party, shall willfully do or cause to be done, or shall willingly suffer or permit to be done, any act, matter, or thing in this Act prohibited or declared to be unlawful, or who shall aid or abet therein, or shall willfully omit or fail to do any act, matter, or thing in this Act required to be done, or shall cause or willingly suffer or permit any act, matter, or thing so directed or required by this Act to be done not to be so done, or shall aid or abet any such omission or failure, or shall be guilty of any infraction of this Act for which no penalty is otherwise provided, or, who shall aid or abet therein, shall be deemed guilty of a misdemeanor, and shall, upon conviction thereof in any district court of the United States within the jurisdiction of which such offense was committed, be subject to a fine of not to exceed five thousand dollars for each offense: Provided, That if the offense for which any person shall be convicted as aforesaid shall be an unlawful discrimination in rates, fares, or charges for the transportation of passengers or property, such person shall, in addition to the fine hereinbefore provided for, be liable to imprisonment in the penitentiary for a term of not exceeding two years, or both such fine and imprisonment, in the discretion of the court. 
Any common carrier subject to the provisions of this Act, or, whenever such common carrier is a corporation, any officer or agent thereof, or any person acting for or employed by such corporation, who, by means of false billing, false classification, false weighing, or false report of weight, or by any other device or means, shall knowingly and willfully assist, or shall willingly suffer or permit, any person or persons to obtain transportation for property at less than the regular rates then established and in force on the line of transportation of such common carrier, shall be deemed guilty of a misdemeanor, and shall, upon conviction thereof in any court of the United States of competent jurisdiction within the district in which such offense was committed, be subject to a fine of not exceeding five thousand dollars, or imprisonment in the penitentiary for a term of not exceeding two years, or both, in the discretion of the court, for each offense.

Any person, corporation, or company, or any agent, or officer thereof, who shall deliver property for transportation to any common carrier subject to the provisions of this Act, or for whom, as consignor or consignee, any such carrier shall transport property, who shall knowingly and willfully, directly or indirectly, himself or by employee, agent, officer, or otherwise, by false billing, false classification, false weighing, false representation of the contents of the package or the substance of the property, false report of weight, false statement, or by any other device or means, whether with or without the consent or connivance of the carrier, its agent, or officer, obtain or attempt to obtain transportation for such property at less than the regular rates then established and in force on the line of transportation; or who shall knowingly and willfully, directly or indirectly, himself or by employee, agent, officer, or otherwise, by false statement or representation as to cost, value, nature, or extent of injury, or by the use of any false bill,
Penalties for false billing, etc., by carriers, their officers or agents: Fin e and imprisonment.
Penalties for false billing, etc., by shippers and other per. imprianment. 
bill of lading, receipt, voucher, roll, account, claim, certificate, affidavit, or deposition, knowing the same to be false, fictitious, or fraudulent, or to contain any false, fictitious, or fraudulent statement or entry, obtain or attempt to obtain any allowance, refund, or payment for damage or otherwise in connection with or growing out of the transportation of or agreement to transport such property, whether with or without the consent or connivance of the carrier, whereby the compensation of such carrier for such transportation, either before or after payment, shall in fact be made less than the regular rates then established and in force on the line of transportation, shall be deemed guilty of fraud, which is hereby declared to be a misdemeanor, and shall, upon conviction thereof in any court of the United States of competent jurisdiction within the district in which such offense was wholly or in part committed, be subject for each offense to a fine of not exceeding five thousand dollars or imprisonment in the penitentiary for a term of not exceeding two years, or both, in the discretion of the court; Provided, That the penalty of imprisonment shall not apply to artificial persons.

Penalties for inducing common carriers to justly: F i n e and imprisonment. Joint liability with carrier for damages.
If any such person, or any officer or agent of any such corporation or company, shall, by payment of money or other thing of value, solicitation, or otherwise, induce or attempt to induce any common carrier subject to the provisions of this Act, or any of its officers or agents, to discriminate unjustly in his, its, or their favor as against any ot lier consignor or consignee in the transportation of property, or shall aid or abet any common carrier in any such unjust discrimination, such person or such officer or agent of such corporation or company shall be deemed guilty of a misdemeanor, and shall upon conviction thereof in any court of the United States of competent jurisdiction within the district in which such offense was committed, be subject to a fine of not exceeding five thousand dollars, or imprisonment in the penitentiary for a term of 
not exceeding two years, or both, in the discretion of the court, for each offense; and such person, corporation, or company shall also, together with said common carrier, be liable, jointly or severally, in an action to be brought by any consignor or consignee discriminated against in any court of the United States of competent jurisdiction for all damages caused by or resulting therefrom.

History of the Section.-As originally enacted this section consisted only of the general penalty clause comprising the first paragraph. The amendment of March 2, I889, added the balance of the section including the specific penalties for false billing, classification, weighing, reporting, etc., and the amendment of June 18 , I9Io, specifically included corporations in the section. Until the enactment of the Elkins Law, February 19, 1903, section to contained all the provisions fixing criminal responsibility for violations of the various provisions of the Act to Regulate Commerce. The Act was vitally amended by the Elkins Act which has become of supreme importance in the enforcement of the law in view of the numerous prosecutions for rebating which were comprehended in that legislation. By the Elkins Act, as originally enacted, the penalty of imprisonment was abolished and the penalty fixed by that law was the imposition of fines ranging from one thousand dollars to twenty thousand dollars. The amendment of June 29, 1906 to the Elkins Act restored the penalty of imprisonment. It follows that the provisions of the Elkins law in effect superseded section to in importance and reference is made to the discussion of its provisions, post page 505 , et seq.

Construction of the Section.-By the amendment to section I of June 29, I906 express companies are included in the term "common carrier" and the liability of common carriers under section 1o involves also express companies which may violate the provisions of the Act. ${ }^{1}$

I United States v. Adams Express Co., 229 U. S. 38I, 57 L. Ed. I237, 33 Sup. Ct. 878 , where the express company was indicted for demanding and receiving sums in excess of its schedule rates. The court said:- "By section IO, (amended by Act of June 18, I910), any common carrier subject to the provisions of the Act, wilfully doing this is guilty of a misdemeanor and liable to a fine. *** By section I of the original Act of I887, as amended June 29, I906, 'The term 'common carrier' as used in 
In an action to recover for the loss of a shipment the Supreme Court has held that in case of a misrepresentation of its value by the shipper in order to secure a lower tariff rate, the consequence is not that the shipper shall recover nothing but that he shall recover no more than the value disclosed or alleged to obtain the rate. ${ }^{2}$

this Act shall include express companies and sleeping car companies.' And thus the liability of common carriers created by section Io stands as if it read that express companies violating section 6 should be guilty of a misdemeanor and liable to fine. *** It is true that a doubt was raised by the wording of section Io in the original Act, whether corporations were indictable under it. This doubt was met by the Act of February 19, I903, (the Elkins Act). We do not perceive that any inference can be drawn from this source in favor of a construction of the later amendment other than that that we deem the natural one. The power of Congress hardly is denied. The constitutionality of the statute as against corporations is established, New York Central and Hudson River R. R. Co. v. United States, 2I2 U. S. 48I, 492, 53 L. Ed. 6I3, 29 Sup. Ct. 304, and no reason is suggested why Congress has not equal power to charge the partnership assets with a liability and to personify the company so far as to collect a fine by a proceeding against it by the company name."

2 Wells, Fargo and Co. v. Neiman-Marcus Co., 227 U. S. 469, 57 L. Ed. 600, 33 Sup. Ct. 267, where the court said:- "It is undoubtedly true that the principal defense upon which the defendants seem to have relied in the state court was, that by intentional misrepresentation the plaintiff had obtained a rate based upon a valuation of fifty dollars, and that they had thereby secured transportation of the property for which they sue, at a less rate than that named in the tariffs published and filed by the carrier as required by the Acts of Congress regulating commerce, and thus obtained an illegal advantage and caused an illegal discrimination forbidden by the Acts referred to. But this defense rested upon the misrepresentation as to real value declared only in the carrier's receipt, and, therefore, involved the consequence of the undervaluation by which an unlawful rate had been obtained. The question at last would be shall the shipper or owner recover nothing because of that misrepresentation, or only the valuation declared to obtain the rate upon which the goods were carried? The latter would seem to be the more reasonable and just consequence of the estoppel. The ground upon which the validity of a limitation upon a recovery for loss or damage due to negligence depends is that of estoppel." 


\section{SECTION II. METHOD OF APPOINTMENT AND TERMS OF MEMBERS OF THE INTER- STATE COMMERCE COMMISSION.}

SEC. II. That a Commission is hereby created and established to be known as the Interstate Commerce Commission, which shall be composed of five Commissioners, who shall be appointed by the PresInt erstate Com merce $\mathrm{C}$ o $\mathrm{mm}$ is sion. ers-method of appointment and terms. ident, by and with the advice and consent of the Senate. The Commissioners first appointed under this Act shall continue in office for the term of two, three, four, five, and six years, respectively, from the first day of January, Anno Domini eighteen hundred and eighty-seven, the term of each to be designated by the President; but their successors shall be appointed for terms of six years, except that any person chosen to fill a vacancy shall be appointed only for the unexpired time of the Commissioner whom he shall succeed. Any Commissioner may be removed by the President for inefficiency, neglect of duty, or malfeasance in office. Not more than three of the Commissioners shall be appointed from the same political party. No person in the employ of or holding any official relation to any common carrier subject to the provisions of this Act, or owning stock or bonds thereof, or who is in any manner pecuniarily interested therein, shall enter upon the duties of or hold such office. Said Commissioners shall not engage in any other business, vocation, or employment. No vacancy in the Commission shall impair the right of the remaining Commissioners to exercise all the powers of the Commission.

Section II has been largely altered by the addition to the Act of section 24, approved June 29, 1906, which reads as follows: 
Commission to consist of seven members; terms; salaries.

Qf ualifications ers.

SEC 24. (Added June 29, 1906). That the In. terstate Commerce Commission is hereby enlarged so as to consist of seven members with terms of seven years, and each shall receive ten thousand dollars compensation annually. The qualifications of the Commissioners and the manner of the payment of their salaries shall be as already provided by law. Such enlargement of the Commission shall be accomplished through appointment by the President, by and with the advice and consent of the Senate, of two additional Interstate Commerce Commissioners, one for a term expiring December thirty-first, nineteen hundred and eleven, one for a term expiring December thirty-first, nineteen hundred and twelve. The terms of the present Commissioners, or of any successor appointed to fill a vacancy caused by the death or resignation of any of the present Commissioners, shall expire as heretofore provided by law. Their successors and the successors of the additional Commissioners herein provided for shall be appointed for the full terms of seven years, except that any person appointed to fill a vacancy shall be appointed only for the unexpired term of the Commissioner whom he shall succeed. Not more than four Commissioners shall be appointed from the same political party.

By the Act of June 29, I906, the membership of the Interstate Commerce Commission was increased from five to seven and the salary was increased from seven thousand five hundred dollars (as originally provided under section 18 of the Act) to ten thousand dollars each per year. Under original section I I it was provided that no more than three members should be of the same political party, but with the increase in the size of the Commission four members may be of the same party.

From 1889 to I9Io the Commission elected one of its members as chairman until otherwise ordered which resulted in that member continuing as chairman as long as he served on the Commission. Judge Thomas M. Cooley, of Michigan, was the first chairman of the Commission, serving from the date of the organization of the Commission until his retirement in 1891 . He was succeeded as chairman by Judge William R. Morrison, of Illinois, 
who served in that capacity until December 31, 1897, when he was succeeded by Judge Martin A. Knapp, of New York. Judge Knapp remained chairman until his resignation to become presiding justice of the newly created Commerce Court in December of 19 Io.

With the enormous increase of the functions of the Commission the duties of the chairman have become so onerous that the Commission now elects a new chairman each year, the selection being made from the members of the Commission in rotation in the order of the priority of their appointment. The Commission at present is comprised as follows:

Hon. Charles C. McChord, of Kentucky, Chairman.

Hon. Judson C. Clements, of Georgia.

Hon. Edgar E. Clark, of Iowa.

Hon. James S. Harlan, of Illinois.

Hon. Balthasar H. Meyer, of Wisconsin.

Hon. Henry Clay Hall, of Colorado.

Hon. Winthrop M. Daniels, of New Jersey. 


\section{SECTION I2. POWERS OF INTERSTATE COMMERCE COMMISSION TO CONDUCT INVESTIGATIONS.}

Commis s i o to inquire into business of carriers and keep itself informed in $r e g a r d$ thereto.

Commis $s$ i o $n$ to execute and enforce provisions of this Act.

District attorneys to prosecute under direction of At. torney General.

Commis $\mathrm{s}$ i o $\mathrm{n}$ may require testimony and documentary evidence.

Courts to com pel witnesses to attend and tes tify.
SEc. 12. (As amcnded March 2, 1889, and February $I 0, I 89 I$.) That the Commission hereby created shall have authority to inquire into the management of the business of all common carriers subject to the provisions of this Act, and shall keep itself informed as to the manner and method in which the same is conducted, and shall have the right to obtain from such common carriers full and complete information necessary to enable the Commission to perform the duties and carry out the objects for which it was created; and the Commission is hereby authorized and required to execute and enforce the provisions of this Act; and, upon the request of the Commission, it shall be the duty of any district attorney of the United States to whom the Commission may apply to institute in the proper court and to prosecute under the direction of the Attorney General of the United States all necessary proceedings for the enforcement of the provisions of this Act and for the punishment of all violations thereof, and the costs and expenses of such prosecution shall be paid out of the appropriation for the expenses of the courts of the United States; and for the purposes of this Act the Commission shall have power to require, by subpœna, the attendance and testimony of witnesses and the production of all books, papers, tariffs, contracts, agreements, and documents relating to any matter under investigation.

Such attendance of witnesses, and the production of such documentary evidence, may be required from any place in the United States, at any designated place of hearing. And in case of disobedience to a subpœna the Commission, or any party to a proceeding before the Commission, may invoke the 
aid of any court of the United States in requiring the attendance and testimony of witnesses and the production of books, papers, and documents under the provisions of this section.

And any of the circuit courts of the United States within the jurisdiction of which such inquiry is carried on may, in case of contumacy or refusal to obey a subpœna issued to any common carrier subject to the provisions of this Act, or other person, issue an order requiring such common carrier or other person to appear before said Commission (and produce books and papers if so ordered) and give evidence touching the matter in question; and any failure to obey such order of the court may be punished by such court as a contempt thereof. The claim that any such testimony or evidence may tend to criminate the person giving such evidence shall not excuse such witness from testifying; but such evidence or testimony shall not be used against such person on the trial of any criminal proceeding.

The testimony of any witness may be taken, at the instance of a party, in any proceeding or investigation pending before the Commission, by deposition, at any time after a cause or proceeding is at issue on petition and answer. The Commission may also order testimony to be taken by deposition in any proceeding or investigation pending before it, at any stage of such proceeding or investigation. Such depositions may be taken before any judge of any court of the United States, or any commissioner of a circuit, or any clerk of a district or circuit court, or any chancellor, justice, or judge of a supreme or superior court, mayor or chief magistrate of a city, judge of a county court, or court of common pleas of any of the United States, or any notary public, not being of counsel or attorney to either of the parties, nor interested in the event of the proceeding or investigation. Reasonable notice must first be given in writing by the party or his attorney proposing to take such deposition to the opposite party or his attorney of record, as either may
Cla im that testimony or eri. dence will tend to criminate will not excuse witness.

\section{Depositions.}

Commis io $\mathrm{n}$ may order testi. mony to be taken by deposition. 
be nearest, which notice shall state the name of the witness and the time and place of the taking of his deposition. Any person may be compelled to appear and depose, and to produce documentary evidence, in the same manner as witnesses may be compelled to appear and testify and produce documentary evidence before the Commission as hereinbefore provided.

Every person deposing as herein provided shall be cautioned and sworn (or affirm, if he so request) to testify the whole truth, and shall be carefully examined. His testimony shall be reduced to writing by the magistrate taking the deposition, or under his direction, and shall, after it has been reduced to writing, be subscribed by the deponent.

When witness is in a foreign country.

If a witness whose testimony may be desired to be taken by deposition be in a foreign country, the deposition may be taken before an officer or person designated by the Commission, or agreed upon by the parties by stipulation in writing to be filed with the Commission. All depositions must be promptly filed with the Commission.

Fees of wit. nesses and mag-
istrates.

Witnesses whose depositions are taken pursuant to this Act, and the magistrate or other officer taking the same, shall severally be entitled to the same fees as are paid for like services in the. courts of the United States.

Incriminatory Testimony.-The amendments of section I2 by the Act of March 2, I889, and the Act of February IO, I89I, were trivial in their nature and related merely to the duties of United States district attorneys and to the methods of summoning witnesses to testify in proceedings before the Interstate Commerce Commission. The adjudicated cases which have come before the Supreme Court involving the twelfth section have related to the question of self-incriminating testimony and the rights of witnesses in reference thereto.

Under the third paragraph of this section a witness, accused of having criminally violated the Act to Regulate Commerce by giving rebates, declined to answer certain questions on the plea that his replies might tend to criminate him and show that he had committed an offense within the purview of the Commerce Act 
for which he might be prosecuted. He was adjudged guilty of contempt, fined and committed to custody. In I 892 the Supreme Court, in passing upon the case, declared this paragraph unconstitutional as a violation of the fifth amendment of the Constitution which provides that a person shall not "be compelled in any criminal case to be a witness against himself." 1 The court point-

I Counselman v. Hitchcock, If2 U. S. 547, 35 L. Ed. IIIo, I 2 Sup. Ct. 195. It was claimed that Counselnian by giving certain rebates had criminally violated the Act to Regulate Comnerce. While under investigation before a grand jury he declined to answer certain questions on the ground that his answers might tend to criminate him. The court said:"It is broadly contended on the part of the appellee that a witness is not entitled to plead the privilege of silence, except in a criminal case against himself; but such is not the language of the Constitution. Its provision is that no person shall be compelled in any criminal case to be a witness against himself. This provision must have a broad construction in favor of the right which it was intended to secure. The matter under investigation by the grand jury in this case was a criminal matter, to inquire whether there had been a criminal violation of the Interstate Commerce Act. If Counselman had been guilty of the matters inquired of in the questions which he refused to answer, he himself was liable to criminal prosecution under the Act. The case before the grand jury was, therefore, a criminal case. The reason given by Counselman for his refusal to answer the questions was that his answers might tend to criminate him, and showed that his apprehension was that, if he answered the questions truly and fully (as he was bound to do if he should answer them at all), the answers might show that he had committed a crime against the Interstate Commerce Act, for which he might be prosecuted. His answers therefore, would be testimony against himself, and he would be compelled to give them in a criminal case. It is impossible that the meaning of the constitutional provision can only be that a person shall not be compelled to be a witness against himself in a criminal prosecution against himself. It would doubtless cover such cases; but it is not limited to them. The object was to insure that a person should not be compelled, when acting as a witness in any investigation, to give testimony which might tend to show that he himself had committed a crime. The privilege is limited to criminal matters, but it is as broad as the mischief against which it seeks to guard.

"It is argued for the appellee that the investigation before the grand jury was not a criminal case, but was solely for the purpose of finding out whether a crime had been committed or whether any one should be accused of an offense, there being no accuser and no parties plaintiff or defendant, and that a case could arise only when an indictment should be returned. In support of this view reference is made to Article Six of the amendments to the Constitution of the United States, which provides that in all criminal prosecutions the accused shall enjoy the right to a speedy and public trial by an impartial jury, to be confronted with the witnesses 
ed out that under this section, while the evidence given by the witness could not be used against him, yet that as a result of his evidence other testimony might be uncovered which would per-

against him, to have compulsory process for witnesses, and the assistance of counsel for his defense. But this provision distinctly means a criminal prosecution against a person who is accused and who is to be tried by a petit jury. A criminal prosecution under Article Six of the amendments, is much narrower than a 'criminal case' under Article Five of the amendments. It is entirely consistent with the language of Article Five, that the privilege of not being a witness against himself is to be exercised in a proceeding before a grand jury.

"It remains to consider whether section 860 of the Revised Statutes removes the protection of the constitutional privilege of Counselman. That section must be construed as declaring that no evidence obtained from a witness by means of a judicial proceeding shall be given in evidence or in any manner used against him or his property or estate, in any court of the United States, in any criminal proceeding or for the enforcement of any penalty or forfeiture. It follows, that any evidence which might have been obtained from Counselman by means of his examination before the grand jury could not be given in evidence or used against him or his property in any court of the United States, in any criminal proceeding, or for the enforcement of any penalty or forfeiture. This, of course, protected him against the use of his testimony against him or his property in any prosecution against him or his property, in any criminal proceeding in a court of the United States. But it had only that effect. It could not, and would not, prevent the use of his testimony to search out other testimony to be used in evidence against him or his property, in a criminal proceeding in such court. It could not prevent the obtaining and the use of witnesses and evidence which should be attributable directly to the testimony he might give under compulsion, and on which he might be convicted, when otherwise, and if he had refused to answer, he could not possibly have been convited.

"The constitutional provision distinctly declares that a person shall not 'be compelled in any criminal case to be a witness against himself'; and the protection of section 860 is not coextensive with the constitutional provision. Legislation cannot detract from the privilege afforded by the Constitution. It would be quite another thing if the Constitution had provided that no person shall be compelled in any criminal case to be a witness against himself, unless it should be provided by statute that criminating evidence extracted from a witness against his will should not be used against him. But a mere Act of Congress cannot amend the Constitution, even if it should engraft thereon such a proviso. *** It is quite clear that legislation cannot abridge a constitutional privilege, and that it cannot replace or supply one, at least unless it is so broad as to have the same extent in scope and effect. * * * We are clearly of opinion that no statute which leaves the party or witness subject to prosecution after he answers the criminating question put to him, can have the effect of sup- 
mit his prosecution for the offense concerning which he testified and that this was violative of the safeguards provided by the Fifth Article of the amendments to the Federal Constitution. The court, however, suggested the way by which Congress might obviate this difficulty, and said: "In view of the constitutional provision, a statutory enactment, to be valid, must afford absolute immunity against future prosecution for the offense to which the question relates."

Pursuant to this judicial suggestion Congress passed the Compulsory Testimony Act of February II, I893, which reads as follows :

Be it enacted by the Senate and House of Representatives of the United States of America in Congress assembled, That no person shall be excused from attending and testifying or from producing books, papers, tariffs, contracts, agreements and documents before the Interstate Commerce Commission, or in obedience to the subpœna of the Commission, whether such subpœna be signed or issued by one or more Commissioners, or in any cause or proceeding, criminal or otherwise, based upon or growing out of any alleged violation of the Act of Congress, entitled "An Act to Regulate Commerce," approved February fourth, eighteen hundred and eighty-seven, or of any amendment thereof on the ground or for the reason that the testimony or evidence, documentary or otherwise, required of him, may tend to criminate him or subject him to a Immunity. penalty or forfeiture. But no person shall be prosecuted or subjected to any penalty or forfeiture for or on account of any transaction, matter or thing, concerning which he may testify, or produce evidence, documentary or otherwise, before said Commission, or in obedience to its subpœna, or the sub-

planting the privilege conferred by the Constitution of the United States. Section 860 of the Revised Statutes does not supply a complete protection from all the perils against which the constitutional prohibition was designed to guard, and is not a full substitute for that prohibition. In view of the constitutional provision, a statutory enactment, to be valid, must afford absolute immunity against future prosecution for the offense to which the question relates." 
ceeding: Provided, That no person so testifying pona of either of them, or in any such case or proPerjury may shall be exempt from prosecution and punishment
be punished. for perjury committed in so testifying.

Any person who shall neglect or refuse to attend

Pen a 1 ties: Fine or impris. onment, or both. and testify, or to answer any lawful inquiry, or to produce books, papers, tariffs, contracts, agreements and documents, if in his power to do so, in obedience to the subpœena or law $f u l$ requirement of the Commission shall be guilty of an offense and upon conviction thereof by a court of competent jurisdiction shall be punished by fine not less than one hundred dollars nor more than five thousand dollars, or by imprisonment for not more than one year or by both such fine and imprisonment.

In 1896 the Supreme Court sustained the constitutionality of this Act declaring that it afforded absolute immunity against prosecution, Federal or state, for the offense to which the question relates, and thus deprives a witness of his constitutional right to refuse to answer. ${ }^{2}$

2 Brown v. Walker, 16I U. S. 591, 40 L. Ed. 819, I6 Sup. Ct. 6+4. In this case, Brown, as auditor of a railroad, was subpœnaed before the grand jury to testify concerning certain charges under investigation affecting certain officers and agents of the road concerning the transportation of coal at less than the established rate. He declined to answer on the ground that his replies would tend to accuse and criminate him. The court said: - "The clause of the Constitution in question (Article Five of the amendments) is obviously susceptible of two interpretations. If it be construed literally as authorizing the witness to refuse to disclose any fact which might tend to incriminate, disgrace or expose him to unfavorable comments, then as he must necessarily to a large extent determine upon his own conscience and responsibility whether his answ:er to the proposed question will have that tendency, * * * the practical result would be, that no one could be compelled to testify to a material fact in a criminal case, unless he chose to do so, or unless it was entirely clear that the privilege was not set up in good faith. If, upon the other hand, the object of the provision be to secure the witness against a criminal prosecution, which might be aided directly or indirectly by his disclosure, then, if no such prosecution be possible-in other words, if his testimony operate as a complete pardon for the offense to which it relates-a statute absolutely securing to him such immunity from prosecution would satisfy the demands of the clause in question. * * * It can only be said in general that the clause should be construed, as it was doubtless designed, to effect a practical and beneficent purpose, not necessarily to protect witnesses against every possible detriment which might 
By further legislation approved February 25, 1903 and June 30, 1906, Congress declared, both as to the Act to Regulate Commerce and the Anti-Trust Act, such immunity should extend only

happen to them from their testimony, nor to unduly impede, hinder or obstruct the administration of criminal justice. * * * The danger of extending the principle announced in Counselman $v$. Hitchcock is that the privilege may be put forward for a sentimental reason, or for a purely fanciful protection of the witness against an imaginary danger, and for the real purpose of securing immunity to some third person, who is interested in concealing the facts to which he would testify. * * * It is entirely true that the statute does not purport, nor is it possible for any statute, to shield the witness from the personal disgrace or opprobrium attaching to the exposition of his crime; but, as we have already observed, the authorities are numerous and very nearly uniform to the effect that if the proposed testimony is material to the issue on trial, the fact that the testimony may tend to degrade the witness in public estimation does not exempt him from the duty of disclosure. A person who commits a criminal act is bound to contemplate the consequences of exposure to his good name and reputation, and ought not to call upon the courts to protect that which he has himself esteemed to be of such little value. *** The design of the constitutional privilege is not to aid the witness in vindicating his character but to protect him against being compelled to furnish evidence to convict him of a criminal charge.

"It is argued in this connection that, while the witness is granted immunity from prosecution by the federal government he does not obtain such immunity against prosecution in the state courts. We are unable to appreciate the force of this suggestion. * * * The Act in question contains no suggestion that it is to be applied only to the federal courts. It declares broadly that 'no person shall be excused from attending and testifying * * * before the Interstate Commerce Commission * * * on the ground *** that the testimony *** required of him may tend to criminate him,' etc. 'But no person shall be prosecuted or subjected to any penalty or forfeiture for or on account of any transaction, matter or thing concerning which he may testify,' etc. It is not that he shall not be prosecuted for or on account of any crime concerning which he may testify, which might possibly be urged to apply only to crimes under the federal law and not to crimes, such as the passing of counterfeit money, etc., which are also cognizable under state laws; but the immunity extends to any transaction, matter or thing concerning which he may testify, which clearly indicates that the immunity is intended to be general, and to be applicable whenever and in whatever court such prosecution may be had. But even granting that there was still a bare possibility that by his disclosure he might be subjected to the criminal laws of some other sovereignty, that, as Chief Justice Cockburn said in Queen v. Boyes, I B. \& S. 3II, in reply to the argument that the witness was not protected by his pardon against an impeachment by the House of Commons, is not a real and probable danger with reference to the ordinary 
to a natural person giving testimony under oath in obedience to a subpona, and that no person should be subjected to any penalty or forfeiture because of any transaction or matter concerning which he might testify or produce documentary or other evidence in any suit or proceeding under such Acts, except that he should not be exempt from prosecution for perjury committed in so testifying.

operations of the law in the ordinary courts, but 'a danger of an imaginary and unsubstantial character, having reference to some extraordinary and barely possible contingency, so improbable that no reasonable man would suffer it to influence his conduct.' Such dangers it was never the object of the provision to obviate.

"The same answer may be made to the suggestion that the witness is imperfectly protected by reason of the fact that he may still be prosecuted and put to the annoyance and expense of pleading his immunity by way of confession and avoidance. This is a detriment which the law does not recognize. ***

"As he had no apparent authority to make the forbidden contracts, to receive the money earned upon such contracts, or to allow or pay any rebates, drawbacks or commissions thereon, and was concerned only in auditing acounts, and passing vouchers for money paid by others, it is difficult to see how, under any construction of section to of the Interstate Commerce Act, he could be said to have wilfully done anything, or aided or absetted others in doing anything, or in omitting to do anything in violation of the Act-his duty being merely to see that others had done what they purported to have done, and that the vouchers rendered by them were genuine. But, however this may be, it is entirely clear that he was not the chief or even a substantial offender against the law and that his privilege was claimed for the purpose of shielding the railway or its officers from answering a charge of having violated its provisions. To say that, notwithstanding his immunity from punishment, he would incur personal odium and disgrace from answering these questions, seems too much like an abuse of language to be worthy of serious consideration. But, even if this were true, under the authorities above cited, he would still be compelled to answer, if the facts sought to be elucidated were material to the issue. If, as was justly observed in the opinion of the court below, witnesses standing in Brown's position were at liberty to set up an immunity from testifying, the enforcement of the Interstate Commerce Law or other analagous Acts, wherein it is for the interest of both parties to conceal their misdoings, would become impossible, since it is only from the mouths of those having knowledge of the inhibited contracts that the facts can be ascertained. While the constitutional provision in question is justly regarded as one of the most valuable prerogatives of the citizen, its object is fully accomplished by the statutory immunity and we are, therefore, of opinion that the witness was compellable to answer, and that the judgment of the court below must be affirmed." 
The Elkins Act of February 19, I903, treats this same subject in section 3 in the following language:

And in proceedings under this Act and the Acts to Regulate Commerce the said courts shall have the power to compel the attendance of witnesses, both upon the part of the carrier and the shipper, who shall be required to answer on all subjects relating directly or indirectly to the matter in controversy, and to compel the production of all books and papers, both of the carrier and the shipper, which relate directly or indirectly to such transaction; the claim that such testimony or evidence may tend to criminate the person giving such evidence shall not excuse such person from testifying or such corporaImmunity
testifying
witnesses. tion producing its books and papers, but no person shall be prosecuted or subjected to any penalty or forfeiture for or on account of any transaction, matter, or thing concerning which he may testify or produce evidence, documentary or otherwise, in such proceeding.

Thereby the same immunity is extended to all witnesses, in cases prosecuted either before a commission or a court, who are required to give criminatory testimony. The Elkins Act was of particular importance in this connection in making corporations liable, by section I, to conviction for any act or omission in violation of the Act by any officer acting in its behalf; and in further authorizing compulsory production of its corporate books, papers and records. Although no cases directly pertinent have been decided by the Supreme Court under the Act to Regulate Commerce, that court has decided in cases brought under the Anti-Trust Act that there is no immunity to a corporation from the enforced testimony of its officers, and further that an officer or employee cannot refuse to produce the books of the corporation on the plea that to do so would incriminate the corporation employer. ${ }^{3}$ Herein is found the basis of the Act of June 30 , 1906, declaring that under the several immunity Acts immunity shall extend only to natural persons.

3 Hale v. Henkel, 201 U. S. 43, 50 L. Ed. 652, 26 Sup. Ct. 370; Nelson v. United States, 201 U. S. 92, 50 L. Ed. 673, 26 Sup. Ct. 358; Wilson v. United States, 220 U. S. 614, 55 L. Ed. 610, 31 Sup. Ct. 718. 
Court Process to Aid Inquiries before the Commission.-In I894 the Supreme Court declared constitutional the provision of the twelfth section of the Act authorizing United States Circuit Courts to use their process in aid of inquiries before the Interstate Commerce Commission. It was strongly insisted that this provision was unconstitutional as imposing on judicial tribunals duties which were not judicial in their nature. The court held that a petition filed under this section in the Circuit Court against a witness, duly summoned to testify before the Commission, to compel him to testify or to produce books, documents and papers relating to the matter under investigation before that body, made a case or controversy to which the judicial power of the United States extended; that the inquiry whether a witness before the Commission is bound to answer a question propounded to him, or to produce books, papers, etc., is one that cannot be committed to a subordinate administrative or executive tribunal for final determination, and that under our system of government such a body could not be invested with authority to compel obedience to its orders by a judgment of fine or imprisonment; that with certain enumerated exceptions the power to impose fine or imprisonment in order to compel the performance of a legal duty imposed by the United States can only be exerted by a competent judicial tribunal having jurisdiction in the premises; that a proceeding under the twelfth section of the Act to Regulate Commerce is not merely ancillary and advisory, nor its object merely to obtain an opinion of the Circuit Court that would be without operation upon the rights of the parties. The court further declared that the judgment is none the less one of a judicial tribunal dealing with questions judicial in their nature and presented in the customary forms of judicial proceedings, because its effect may be to aid an administrative or executive body in the performance of duties legally imposed upon it by Congress in accordance with its constitutional power; and that the issue in such a case as this is not one for the determination of a jury, nor could any question of contempt arise until the issue of law in the court is determined adversely to the defendants and they refuse to obey, not the order of the Commission, but the final order of the court."

4 Interstate Commerce Commission v. Brimson, 154 U. S. 447,38 L. Ed. 1047, I4 Sup. Ct. I125. The court said:- "The Constitution expressly confers upon Congress the power to regulate commerce with foreign nations among the several states, and with the Indian tribes, and to make all 
The Supreme Court declared that the powers of the Commission and its functions should not be unduly hampered by narrowing its authority and limiting its field of inquiry under the twelf th

laws necessary and proper for carrying that power into execution.

It is a settled principle of constitutional law that the government which has a right to do an act, and has imposed on it the duty of performing that act, must, according to the dictates of reason, be allowed to select the means. * * * 4 Wheat. 316,409 . The test of the power of Congress is not the judgment of the courts that particular means are not the best that could have been employed to effect the end contemplated by the legislative department. The judiciary can only inquire whether the means devised in the execution of a power granted are forbidden by the Constitution. * * An adjudication that Congress could not establish an administrative body with authority to investigate the subject of interstate commerce and with power to call witnesses before it, and to require the production of books, documents, and papers relating to that subject, would go far towards defeating the object for which the people of the United States placed commerce among the states under national control. * **

"As the Circuit Court is competent under the law by which it was ordained and established to take jurisdiction of the parties and as a case arises under the Constitution or laws of the United States when its decision depends upon either, why is not this proceeding judicial in form and instituted for the determination of distinct issues between the parties, as defined by formal pleadings, a case or controversy for judicial cognizance, within the meaning of the Constitution? It must be so regarded, unless, as is contended, Congress is without power to provide any method for enforcing the statute or compelling obedience to the lawful orders of the Commission, except through criminal prosecutions or by civil actions to recover penalties imposed for noncompliance with such orders. But no limitation of that kind upon the power of Congress to regulate commerce among the states is justified either by the letter or the spirit of the Constitution. Any such rule of constitutional interpretation if applied to all the grants of power made to Congress, would defeat the principal objects for which the Constitution was ordained. As the issues are so presented that the judicial power is capable of acting on them finally as between the parties before the court, we cannot adjudge that the mode prescribed for enforcing the lawful orders of the Interstate Commerce Commission is not calculated to attain the object for which Congress was given power to regulate interstate commerce. *** In accomplishing the objects of a power granted to it, Congress may employ any one or all the modes that are appropriate to the end in view, taking care only that no mode employed is inconsistent with the limitations of the Constitution. We do not overlook these constitutional limitations which, for the protection of personal rights, must necessarily attend all investigations conducted under the authority of Congress.

"The duties assigned to the Circuit Courts of the United States by the twelfth section of the Interstate Commerce Act are judicial in their na- 
section beyond the requirements of the due protection of the rights of citizens as guaranteed to them under the Constitution and that the Commission could require the testimony of wit-

ture. The inquiry whether a witness before the Commission is bound to answer a particular question propounded to him, or to produce books, papers, etc., in his possession, and called for by that body, is one that cannot be committed to a subordinate administrative or executive tribunal for final determination. Such a body could not, under our system of government, and consistently with due process of law, be invested with authority to compel obedience to its orders by a judgment of fine or imprisonment. Except in the particular instances enumerated in the Constitution, and considered in Anderson v. Dunn, 6 Wheat. 204, and in Kilbourn v. Thompson, I03 U. S. I68, I90, 26 L. Ed. 377, of the exercise by either House of Congress of its right to punish disorderly behavior upon the part of its members, and to compel the attendance of witnesses, and the production of papers in election and impeachment cases, and in cases that may involve the existence of those bodies, the power to impose fine or imprisonment in order to compel the performance of a legal duty imposed by the United States, can only be exerted, under the law of the land, by a competent judicial tribunal having jurisdiction in the premises. See Whitcomb's Case, I20 Mass. I 8 and authorities there cited.

"Without the aid of judicial process of some kind, the regulations that Congress may establish in respect to interstate commerce cannot be adequately or efficiently enforced. One mode, as already suggested-the validity of which is not questioned-of compelling a witness to testify before the Interstate Commerce Commission, to answer questions propounded to him relating to the matter under investigation and which the law makes it his duty to answer, and to produce books, papers, etc., is to make his refusal to appear and answer, or to produce the documentary. evidence called for, an offense against the United States punishable by fine or imprisonment. A criminal prosecution of the witness under such a statute, it is conceded, would be a case or controversy within the meaning of the Constitution, of which a court of the United States could take jurisdiction. Another mode would be to proceed by information to recover any penalty imposed by the statute. A proceeding of that character, it is also conceded, would be a case or controversy of which a court of the United States could take cognizance. If, however, Congress, in its wisdom, authorizes the Commission to bring before a court of the United States for determination the issues between it and a witness, that mode of enforcing the Act of Congress, and of compelling the witness to perform his duty, is said not to be judicial, and is beyond the power of Congress to prescribe. We cannot assent to any view of the Constitution that conceded the power of Congress to accomplish a named result, indirectly, by particular forms of judicial procedure, but denies its power to accomplish the same result, directly, and by a different proceeding judicial in form. We could not do so without denying to Congress the broad discretion with which it is invested by the Constitution of employing all or any of the means that are 
nesses or the production of books, papers, documents, etc., which had a legitimate bearing upon the subject matter of the inquiry; and that the relevancy of such testimony or the contents of such books, documents, etc., did not depend upon the conclusiveness

appropriate or plainly adapted to an end which it has unquestioned power to accomplish, namely, the protection of interstate commerce against improper burdens and discriminations. Indeed, of all the modes that could be constitutionally prescribed for the enforcement of the regulations embodied in the Interstate Commerce Act, that provided by the 12th section is the one which, more than any other, will protect the public against the devices of those who, taking advantage of special circumstances, or by means of combinations too powerful to be resisted and overcome by individual effort, would subject commerce among the states to unjust and unreasonable burdens.

"The present proceeding is not merely ancillary and advisory. * * * The proceeding is one for determining rights arising out of specified matters in dispute that concern both the general public and the individual defendants. It is one in which a judgment may be rendered that will be conclusive upon the parties until reversed by this court. And that judgment may be enforced by the process of the Circuit Court. *** The performance of the duty which, according to the contention of the government, rests upon the defendants, cannot be directly enforced except by judicial process. One of the functions of a court is to compel a party to perform a duty which the law requires at his hands. If it be adjudged that the defendants are, in law, obliged to do what they have refused to do, that determination will not be merely ancillary and advisory. * * * It is none the less the judgment of a judicial tribunal dealing with questions judicial in their nature, and presented in the customary forms of judicial proceedings, because its effect may be to aid an administrative or executive body in the performance of duties legally imposed upon it by Congress in execution of a power granted by the Constitution. * * *

"Another suggestion thrown out in argument against the validity of the I2th section of the Interstate Commerce Act, in the particular adverted to, is that the defendants are not accorded a right of trial by jury. If, as we have endeavored to show, this proceeding makes a case or controversy within the judicial power of the United States, the issue whether the defendants, are under a duty to answer the questions propounded to them, and to produce the books, papers, documents, etc., called for, is manifestly not one for the determination of a jury. The issue presented is not one of fact, but of law exclusively. In such a case, the defendant is no more entitled to a jury than is a defendant in a proceeding by mandamus to compel him, as an officer, to perform a ministerial duty. Of course, the question of punishing the defendants for contempt could not arise before the Commission; for, in a judicial sense, there is no such thing as contempt of a subordinate administrative body. No question of contempt could arise until the issue of law, in the Circuit Court, is determined adversely to the defendants and they refuse to obey, not the order of the Commission, 
of their revelations but upon their tendency to prove or disprove the issue raised. The court moreover declared that the fact that such papers might relate to or involve third parties, not parties to the proceedings in question, presented no valid objection to their production and examination and that further such a requirement constituted no violation of the provisions of the fourth amendment to the Constitution relating to the search and seizure of papers. ${ }^{5}$ Under the Act to Regulate Commerce, however, the

but the final order of the court. And, in matters of contempt, a jury is not required by 'due process of law.'

"We are of opinion that a judgment of the Circuit Court of the United States determining the issues presented by the petition of the Interstate Commerce Commission, and by the answers of the appellees, will be a legitimate exertion of judicial authority, in a case or controversy to which, by the Constitution, the judicial power of the United States extends. A final order by that court dismissing the petition of the Commission, or requiring the appellees to answer the questions propounded to them, and to produce the books, papers, etc., called for, will be a determination of questions upon which a court of the United States is capable of acting and which may be enforced by julicial process. If there is any legal reason why appellees should not be required to answer the questions put to them, or to produce the books, papers, etc., demanded of them, their rights can be recognized and enforced by the court below when it enters upon the consideration of the merits of the questions presented by the petition."

5 Interstate Commerce Commission v. Baird, I94 U. S. 25, 48 L. Ed. 860,24 Sup. Ct. 563. This proceeding grew out of an investigation by the Interstate Commerce Commission concerning pooling agreements between certain railroads in the transportation of coal and the charge that unreasonable and unjust rates were demanded which discriminated against certain dealers and consumers. In the course of the hearings certain witnesses refused to produce certain contracts and papers and also to answer questions propounded to them on the ground that the subject matter thereof did not relate to any subject which the Commission had the right to investigate and that the contracts related to the private business of persons not parties to the proceedings before the Commission. The court said:- "Power is conferred upon the Commission under section 12 of the Act (to Regulate Commerce) as amended March 2, 1889, and February I0, I $89 \mathrm{I}$, to inquire into the management of the business of all common carriers subject to the provisions of the Act, and to keep itself informed as to the manner and method in which the same is conducted, with the right to obtain from such common carriers full and complete information neces. sary to enable the Commission to perform the duties and carry out the objects for which it was created. *** It is unnecessary for the present purpose to go into detail as to the provisions of these contracts. In the main they were made with coal companies owned principally by the railroad companies and contain the same general provisions. * * While 
Conmission cannot subject to examination the correspondence received or sent by railroad companies. ${ }^{6}$

By the decision of the Supreme Court in the case of Harriman

the contracts were produced for inspection, the witnesses refused to permit them to be given in evidence. The Circuit Court held them to be irrelevant upon the ground that they related solely to an intrastate transaction - the sale of the coal in Pennsylvania-and had nothing to do with interstate commerce. It appears that the railroad companies proceeded against in the complaint are engaged in carrying coal from the anthracite coal regions to tidewater. * * * The railroads are all engaged in interstate commerce, and into their affairs and methods of doing business the Commission might be, and is, lawfully authorized by the Commerce Act to make investigation.

"In Interstate Commerce Commission v. Cincinnati, New Orleans, etc., Railway Co., I67 U. S. 479. 506. 42 L. Ed. 243, I7 Sup. Ct. 896, this court held that the Commission had no power to fix rates. In the course of the opinion it was said:- It (the Commission) is charged with the general duty of inquiring as to the management of the business of railroad companies, and to keep itself informed as to the manner in which the same is conducted and has the right to compel complete and full information as to the manner in which the same is conducted.' * * * Here is a railroad company engaged at once in the purchase of coal through a company which it practically owns and the transportation of the same coal through different states to the seaboard. Why may not the Interstate Commerce Commission, under the powers conferred, and under this complaint, inquire into the manner in which this business is done? It has the right to know how interstate traffic is conducted, the relations between the carrier and its shippers and the rates charged and collected. We see no reason why contracts of this character, which have direct relation to a large amount of its carrying trade, can be witheld from examination as evidence by the Commission. These contracts were made by the officials of the railroad companies, who were also officials of the coal companies, after protracted conferences. Upon the ground that they pertained to the manner of conducting a material part of the business of these interstate carriers, which was under investigation, we think the Commission had a right to demand their production. And, further, it was claimed that, while these contracts were in form purchases of coal, their real purpose was to fix a rate for transportation to the carriers. who were in fact paid for the only interest they had in the coal-the right to receive pay for its transportation -by the percentage retained from the selling price after deducting charges and expenses in marketing the coal.

"It is to be remembered in this connection that we are not dealing with the ultimate fact of controversy or deciding which of the contending claims will be finally established. This is a question of relevancy of proof before a body not authorized to make a final judgment, but to investigate and make orders which may or may not be finally embodied in judgments or decrees of the court. * * * Relevancy does not depend upon the 
v. Interstate Commerce Commission, in 1908, the power of the Interstate Commerce Commission to compel witnesses to answer questions and to produce books, documents, papers, etc., is limited to complaints of violations of the Act to Regulate Commerce and to investigations by the Commission upon matters that might have been made the subject of complaint, that is to a specific breach of the law." "The power to require testimony is limited," said the

conclusiveness of the testimony offered, but upon its legitimate tendency to establish a controverted fact. *** The inquiry of a board of the character of the Interstate Commerce Commission should not be too narrowly constrained by technical rules as to the admissibility of proof. Its function is largely one of investigation and it should not be hampered in making inquiry pertaining to interstate commerce by those narrow rules which prevail in trials at common law where a strict correspondence is required between allegations and proof.

"As we have seen, the statute protects the witness from such use of the testimony given as will result in his punishment for crime or the forfeiture of his estate. Testimony given under such circumstances presents scarcely a suggestion of an unreasonable search or seizure. Indeed, the parties seem to have made little objection to the inspection of the papers, the contest was over their relevancy as testimony. Nor can we see force in the suggestion that these contracts were made with persons not parties to the proceeding. Undoubtedly the courts should protect nonlitigants from unnecessary exposure of their business affairs and papers. But it certainly can be no valid objection to the admission of testimony, otherwise relevant and competent, that a third person is interested in it. *** It is argued that these contracts, if given in evidence, will tend to show a pooling of freights, in violation of the fifth section of the Commerce Act. While this testimony may not establish such an arrangement as is suggested, it has, in our opinion, a legitimate bearing upon the question. There is a division of freight among several railroads, where, by agreement or otherwise, the companies have a common interest in the source from which it is obtained. Furthermore we think the testimony competent as bearing upon the manner in which transportation rates are fixed, in view of determining the question of reasonableness of rates, into which the Commission has a right to inquire. To unreasonably hamper the Commission by narrowing its field of inquiry beyond the requirements of the due protection of citizens will be to seriously impair its usefulness and prevent a realization of the salutary purposes for which it was established by Congress."

6 United States v. Louisville and Nashville Railroad Co., decided February 23,1915 . See under section 20 where this question is treated at length.

7 2II U. S. 407,53 L. Ed. 253, 29 Sup. Ct. II5. The Interstate Commerce Commission, of its own motion, and not upon any complaint made to it, proceeded to an investigation of certain railroad transactions in which Edward Harriman was concerned. Harriman was questioned with 
court, "as it usually is-to the only cases where the sacrifice of privacy is necessary-those where the investigations concern a specific breach of the law." Only in connection with the dis-

regard to the ownership of certain shares of stock of the Chicago and Alton Railroad and other roads which it was alleged that he and other directors of the Union Pacific and Southern Pacific had bought and deposited with certain bankers. The Supreme Court said:-"Many broad questions were discussed in the argument before us, but we shall confine ourselves to comparatively narrow ground. The contention of the Commission is that it may make any investigation that it deems proper, not merely to discover any facts tending to defeat the purposes of the Act of February 4, I887, but to aid it in recommending any additional legislation relating to the regulation of commerce that it may conceive to be within the power of Congress to enact; and that in such an investigation it has power, with the aid of the courts, to require any witness to answer any question that may have a bearing upon any part of what it has in mind. The contention necessarily takes this extreme form, because this was a general inquiry started by the Commission of its own motion, not an investigation upon complaint, or of some specific matter that might be made the object of a complaint. To answer this claim it will be sufficient to construe the Act creating the Commission, upon which its powers depend. Before taking up the words of the statute the enormous scope of the power asserted for the Commission should be emphasized and dwelt upon. The legislation that the Commission may recommend embraces, according to the arguments before us, anything and everything that may be conceived to be within the power of Congress to regulate, if it relates to commerce with foreign nations or among the several states. And the result of the arguments is that whatever might influence the mind of the Commission in its recommendations is a subject upon which it may summon witnesses before it and require them to disclose any facts, no matter how private, no matter what their tendency to disgrace the person whose attendance has been compelled. If we qualify the statement and say only, legitimately influence the mind of the Commission in the opinion of the court called in aid, still it will be seen that the power, if it exists, is unparalleled in its vague extent. Its territorial sweep also should be noticed. By section 12 of the Act of 1887 , the Commission has authority to require the attendance of witnesses 'from any place in the United States, at any designated place of hearing.' No such unlimited command over the liberty of all citizens ever was given, so far as we know, in constitutional times, to any Commission or court.

"How far Congress could legislate on the subject matter of the questions put to the witnesses as was one of the subjects of discussion, but we pass it by. Whether Congress itself has the unlimited power claimed by the Commission, we also leave on one side. It was intimated that there was a limit in Interstate Commerce Commission v. Brimson, 154 U. S. 447, 478, 479, $38 \mathrm{~L}$. Ed. 1047, I4 Sup. Ct. I 125 . Whether it could delogate the power if it possesses it, we also leave untouched, beyond remarking that so unquali- 
charge of the quasi-judicial functions of the Commission therefore did that body have the power to compel the attendance of witnesses, the production of books, documents, etc., and the sub-

fied a delegation would present the constitutional difficulty in most acute form. It is enough for us to say that we find no attempt to make such a delegation anywhere in the Act. Whatever may be the power of Congress, it did not attempt, in the Act of February 4, 1887, to do more than to regulate the interstate business of common carriers, and the primary purpose for which the Commission was established was to enforce the regulations which Congress had imposed. The earlier sections of the statute require that charges shall be reasonable, prohibit discrimination and pooling of freights, require the publication of rates, and so forth, in well-known provisions. Then, by section II, the Interstate Commerce Commission is created, and by section 12, as amended by later Acts, the Commission has 'authority to inquire into the management of the business of all common carriers subject to the provisions of this Act, and shall keep itself informed as to the manner and method in which the same is conducted, and shall have the right to obtain from such common carriers full and complete information necessary to enable the Commission to perform the duties and carry out the objects for which it was created; and the Commission is hereby authorized and required to execute and enforce the provisions of this Act.' District attorneys to whom the Commission may apply are to institute and prosecute all necessary proceedings for the enforcement of the Act and for the punishment of violations of it; and 'for the purposes of this Act the Commission shall have power to require, by subpœna, the attendance and testimony of witnesses and the production of all books, papers, tariffs, contracts, agreements, and documents relating to any matter under investigation.' Then comes the provision to which we already have called attention, by which a witness could be summoned from Maine to Texas, and then follow clauses for enforcing obedience to the subpœna by an order of court and for taking depositions, which do not need statement.

"The Commission it will be seen is given power to require the testimony of witnesses 'for the purposes of this Act.' The argument for the Commission is that the purposes of the Act embrace all the duties that the Act imposes and the powers that it gives the Commission; that one of the purposes is that the Commission shall keep itself informed as to the manner and method in which the business of the carriers in conducted, as required by section 12 ; that another is that it shall recommend additional legislation under section 2I, to which we shali refer again, and that for either of these general objects it may call on the courts to require any one whom it may point out to attend and testify if he would avoid the penalties for contempt. We are of opinion on the contrary that the purposes of the Act for which the Commission may exact evidence embrace only complaints for violation of the Act, and investigations by the Commission upon matters that might have been made the object of complaint. As we already have implied the main purpose of the Act was to regulate 
mission to personal examination. These were the limits within which the Commission possessed these powers under section 12 of the Act. The power under this section, given for specific pur-

the interstate business of carriers, and the secondary purpose, that for which the Commission was established, was to enforce the regulations enacted. These in our opinion are the purposes referred to; in other words the power to require testimony is limited, as it usually is in Englishspeaking countries at least, to the only cases where the sacrifice of privacy is necessary-those where the investigations concern a specific breach of the law.

"That this is the true view appears, we think, sufficiently from the original form of section 14. That section made it the duty of the Commission, 'whenever an investigation shall be made' to make a report in writing, which was to 'include the findings of fact upon which the conclusions of the Commission are based, together with its recommendation as to what reparation, if any, should be made by the common carrier to any party or parties who may be found to have been injured; and the findings so made shall thereafter, in all judicial proceedings, be deemed prima facie evidence as to each and every fact found.' As this applied, in terms, to all investigations, it is plain that at that time there was no thought of allowing witnesses to be summoned except in connection with a complaint for contraventions of the Act, such as the Commission was directed to 'investigate' by section I3, or in connection with an inquiry instituted by the Commission, authorized by the same section, 'in the same manner and to the same effect as though complaint had been made.' Obviously such an inquiry is limited to matters that might have been the object of a complaint.

"The plain limit to the authority to institute an inquiry given by section I3, and the duty to make a report with findings of facts. etc., in the section next following, with hardly a word between, hang together, and show the purposes for which it was intended that witnesses should be summoned. They quite exclude the inference of broader power from the general words in section I2, as to inquiring into the management of the business of common carriers, subject to the provisions of the Act, the Commission keeping itself informed, etc. They equally exclude such an inference from section 2I, the other section on which most reliance is placed. That, as it now stands, requires an annual report, containing 'such information and data collected by the Commission as may be considered of value in the determination of questions connected with the regulation of Commerce, together with such recommendations as to additional legislation relating thereto as the Commission may deem necessary.' Act of March 2, I889.

"It is true that in the latest amendment of section I4, findings of fact are required only in case damages are awarded. Act of June 29, I906, c. 3591, section 3. But there is no change sufficient to affect the meaning of the words in section 12 , as already fixed. By virtue of section 21 the power exists to summon witnesses for the purpose of recommending legislation, we hardly see why, under the same section, it should not extend to 
poses, the court declared could not be exercised by the Commission in connection with its duties of investigation, consideration and report under other sections of the Act to Regulate Commerce.

summoning them for the still vaguer reason that their testimony might furnish data considered by the Commission of value in the determination of questions connected with the regulation of commerce. If we did not think, as we do, that the Act clearly showed that the power to compel the attendance of witnesses was to be exercised only in connection with the quasi judicial duties of the Commission, we still should be unable to suppose that such an unprecedented grant was to be drawn from the counsels of perfection that have been quoted from sections I2 and 2I. We could not believe on the strength of other than explicit and unmistakable words that such autocratic power was given for any less specific object of inquiry than a breach of existing law, in which, and in which alone, as we have said, there is any need that personal matters should be revealed.

"In sections 15 and $\mathrm{I} 6$ are further provisions for the enforcement of the Act, not otherwise material than as showing the main purpose that Congress had in mind. The only other section that is thought to sustain the argument for the Commission is section 20, amended by Act of June 29, 1906, c. 359I, section 7. This authorizes the Commission to require annual reports from all the carriers concerned, with details of what is to be shown, to which the Commission may add in certain particulars, and further 'to require from such carriers specific answers to all questions upon which the Commission nay need information.' The Commission may require certain other reports, and is to have accesss to all accounts, records and memoranda. The section now deals at length with this matter and how accounts shall be kept and the like. It seems to us plain that it is directed solcly to accounts and returns, and is imposing a duty on the common carrier only from whom the returns come.

"All that we are considering is the power under the Act to Regulate Commerce and its amendments to extort evidence from a witness by compulsion. What reports or investigations the Commission may make without that aid but with the help of such returns or special reports as it may require from the carrier, we need not decide. Upon the point before us we should infer from the later action of Congress with regard to its resolution of March 7, 1906, 34 Stat. 823, directing the Commission to investigate and report as to railroad discrimination and monopolies in coal and oil, that it took the same view that we do. For it thought it advisable to amend that resolution on March 2I by adding a section giving the Commission the same power it then had to compel the attendance of witnesses in the investigation ordered. 34 Stat. 824. The mention of the power then possessed obviously is intended simply to define the nature and extent of the power by reference to section 12 of the original Act. The passage of the amendment indicates that without it the power would be wanting. The case is not affected by the provision of section 9 of the Act of June 29, 1906, c. 3591, section 9, 34 Stat. 595, extending the former Acts relating to the attendance of witnesses and the compelling of testi- 
For example, the Commission could not compel the attendance of witnesses, their cross-examination and the production and submission of documents, books, papers, etc., by them for the purpose of keeping itself advised as to the manner and method in which common carriers conduct their business under the i2th section, nor under section 20 whereby common carriers are required to make certain reports and returns to the Commission of their annual business, accounts, etc., nor under section $2 \mathrm{I}$ whereby the obligation is imposed upon the Commission to make an annual report to Congress containing information and data gathered by that body which may be considered of value in determining questions connected with the regulation of commerce, and containing also recommendations as to additional legislation which might be desired.

"We could not believe," said the court, "on the strength of other than explicit and unmistakable words that such autocratic power was given for any less specific object of inquiry than a breach of existing law."

It is to be noted that this decision was rendered subsequent to the amendment of 1906, but prior to the amendment of I9IO. The powers and functions of the Interstate Commerce Commission have been so enlarged by subsequent amendments that the provisions of section 12 have been in effect superseded by the powers conferred by sections 15,16 and 20 , as amended to date.

mony to 'all proceedings and hearings under this Act.' If we felt more hesitation than we do, we still should feel bound to construe the statute not merely so as to sustain its constitutionality but so as to avoid a succession of constitutional doubts, so far as candor permits." 


\section{SECTION I3. COMPLAINTS TO THE COMMISSION.}

Complaints to C o m $\mathrm{mis}$ sion. llow and by w h o $\mathrm{m}$ made. How served.

Commis sion to have discretion as to manner of investigation.

Commis sion may issue or ders in investi. gations begun on its own motion.
Skc. I3. (As amended June I8, I9IO.) That any person, firm, corporation, company, or association, or any mercantile, agricultural, or manufacturing society or other organization, or any body politic or municipal organization, or any common carrier, complaining of anything done or omitted to be done by any common carrier subject to the provisions of this Act, in contravention of the provisions thereof, may apply to said Commission by petition, which shall briefly state the facts; whereupon a statement of the complaint thus made shall be forwarded by the Commission to such common carrier, who shall be called upon to satisfy the complaint, or to answer the same in writing, within a reasonable time, to be specified by the Commission. If such common carrier within the time specified shall make reparation for the injury alleged to have been done, the common carrier shall be relieved of liability to the complainant only for the particular violation of law thus complained of. If such carrier or carriers shall not satisfy the complaint within the time specified, or there shall appear to be any reasonable ground for investigating said complaint, it shall be the duty of the Commission to investigate the matters complained of in such manner and by such means as it shall deem proper.

Said Commission shall, in like manner and with the same authority and powers, investigate any complaint forwarded by the railroad commissioner or railroad commission of any state or territory at the request of such commissioner or commission, and the Interstate Commerce Commission shall have full authority and power at any time to institute an inquiry, on its own motion, in any case and as to any matter or thing concerning which a complaint is authorized to be made, to or before said Commis- 
sion by any provision of this Act, or concerning which any question may arise under any of the provisions of this Act, or relating to the enforcement of any of the provisions of this Act. And the said Commission shall have the same powers and authority to proceed with any inquiry instituted on its own motion as though it had been appealed to by complaint or petition under any of the provisions of this Act, including the power to make and enforce any order or orders in the case, or relating to the matter or thing concerning which the inquiry is had excepting orders for the payment of money. No complaint shall at any time be dismissed because of the absence of direct damage to the complainant.

Complainant's interest imma. terial.

History of the Section.-Section 13 has been amended only by the Act of June 18, 1910. As originally passed and as it remained until that date this section provided for complaints only by shippers or their agents or representatives, but did not pro. vide for complaints by railroads. And further while the Interstate Commerce Commission had been authorized to make inquiries upon its own motion or initiative, not until this amendment was there any specific declaration of the powers which the Commission might exercise in investigations thus inaugurated. This was provided by that portion of the amendment of June 18 , I9I0, which reads: "And the said Commission shall have the same powers and authority to proceed with any inquiry instituted on its own motion as though it had been appealed to by complaint or petition under any of the provisions of this Act, including the power to make and enforce any order or orders in the case, or relating to the matter or thing concerning which the inquiry is had, excepting orders for the payment of money." For example, prior to this amendment it had been held by the Supreme Court that in an investigation undertaken by the Commission upon its own initiative it had no power to compel witnesses to give testimony. ${ }^{1}$ Section 9 of the Act should be considered in connection with the provisions of section 13 .

I Harriman v. Interstate Commerce Commission, 2 I I U. S. 407, 53 L. Ed. 253, 29 Sup. Ct. II5, where the Commission sought to compel a witness to testify in an investigation being conducted for the purpose of recommending certain legislation by Congress. The court said:- "We are of opinion * * * that the purposes of the Act for which the Commission 
Procedure.-In line with its general policy all sections of the Act regarding procedure before the Interstate Commission have been liberally construed by that body. This applies particularly to parties complainant, but also to parties defendant so as to bring in all parties interested in a case or complaint as to rates or practices. ${ }^{2}$ Generally speaking the burden of proof is upon the parties making the complaint or presenting the allegation.

It will be seen that parties may complain of existing rates and be entitled to an award by the Commission fixing a new rate under the proper section, but not to an award of reparation since such parties are not shippers and therefore not entitled to an award of pecuniary damages. This section declares that complaints may be made by mercantile, agricultural or manufacturing societies or bodies politic or municipal organizations, and while they may secure a rate order they would not be entitled to a reparation order. ${ }^{3}$ Moreover there are manifestly cases in

may exact evidence embrace only complaints for violation of the Act, and investigations by the Commission upon matters that might have been made the object of complaint. As we have already implied the main purpose of the Act was to regulate the interstate business of carriers, and the secondary purpose, that for which the Commission was established, was to enforce the rgeulations enacted. These in our opinion are the purposes referred to; in other words, the power to require testimony is limited, as it usually is in English-speaking countries at least, to the only cases where the sacrifice of privacy is necessary-those where the investigations concern a specific breach of the law. *** It is plain that at that time (when the original law was passed) there was no thought of allowing witnesses to be summoned except in connection with a complaint for contraventions of the Act, such as the Commission was directed to 'investigate' by section 13, or in connection with an inquiry instituted by the Commission, authorized by the same section, in the same manner and to the same effect as though complaint had been made.' Obviously such an inquiry is limited to matters that might have been the object of a complaint."

2 Texas and Pacific Railway Co. v. Interstate Commerce Commission, I62 U. S. 197, 40 L. Ed. 940, 16 Sup. Ct. 666.

3 Baer Brothers Merchantile Co. v. Denver and Rio Grande Railroad Co., 233 U. S. 479, 58 L. Ed. 1055, 34 Sup. Ct. 641. Here the court said: - "Section 4 (of the Hepburn Act) conferred the power of making rates. Section 5 (same Act) gave the Commission power to make reparation orders. Not only were the two functions separately treated, but an analysis of the Act shows that there is no such necessary connection between them as to make the quasi-judicial order for reparation depend for its validity upon being joined with a quasi-legislative order fixing rates. Persons entitled to one may have no interest in the other. Persons interested in both may be entitled to reparation and not to a new rate; or to a 
which a rate, reasonable, when made, becomes unreasonable as the result of a gradual change in conditions, so that no reparation is ordered though for the future a new rate may be established. And conversely a rate, unreasonable in the past, may be found reasonable for the same reasons at the time of the hearing so that an order of reparation would issue though no new rate would be established for the future. As to this see sections $I_{5}$ and 16 of the Act.

The Interstate Commerce Commission is an administrative body and even where it acts in a quasi-judicial capacity is not limited by the strict rules, as to the admissibility of evidence, which prevail in suits between private parties. ${ }^{4}$

new rate and not to reparation. For example,-section 13 permits 'any mercantile, agricultural or manufacturing society or any body politic or municipal organization to make complaints against the carrier.' On the application of such bodies, old rates might be declared unjust and new rates established, but, of course, no reparation would be given, for the reason that such complainants were not shippers and, therefore, not entitled to an award of pecuniary damages."

See also Smyth v. Ames (Nebraska Rate Case) I69 U. S. 466, 42 L. Ed. 8 I9, 18 Sup. Ct. 418. Interstate Commerce Commission v. Louisville and Nashville Railroad Co., 227 U. S. 88, 57 L. Ed. 431, 33 Sup. Ct. 185. Meeker v. Lehigh Valley Railroad Co., decided February 23, 1915.

4 Interstate Commerce Commission v. Baird, IM U. S. 25, 48 L. Ed. 860,24 Sup. Ct. 563; Interstate Commerce Commission v. Louisville and Nashville Railroad Co., 227 U. S. 88, 57 L. Ed. 431, 33 Sup. Ct. 185. 


\section{SECTION 14. ANNUAL REPORTS OF THE COMMIS- SION.}

Commis s ion must $r$ eport stating its con clusions and order.

Reparation.

Reports must be entered of record. Serv.
ice of copies on partles.

Reports and decisions to be published, and be competent as evidence.
SEc. 14. (Amended March 2, 1889, and June 29, 1906.) That whenever an investigation shall be made by said Commission, it shall be its duty to make a report in writing in respect thereto, which shall state the conclusions of the Commission, together with its decision, order, or requirement in the premises; and in case damages are awarded such report shall include the findings of fact on which the award is made.

All reports of investigations made by the Commission shall be entered of record, and a copy thereof shall be furnished to the party who may have complained, and to any common carrier that may have been complained of.

The Commission may provide for the publication of its reports and decisions in such form and manner as may be best adapted for public information and use, and such authorized publications shall be competent evidence of the reports and decisions of the Commission therein contained in all courts of the United States and of the several states without any further proof or authentication thereof. The Commission may also cause to be printed for early distribution its annual reports.
Annual
ports of mission.

History of the Section.-Prior to the amendment of June 29, 1906, the Commission was required to report its findings of fact upon which the conclusions reached were based and these findings were made prima facie evidence in all judicial proceedings of later date as to all of the facts found by that body. As amended in 1906 , this section requires the findings of fact to be reported only where there has been an award of money damages and in these cases only are the findings made prima facie proof in judicial proceedings. ${ }^{1}$ In cases other than these the reports of the Commission need only state its conclusions together with the

1 Harriman v. Interstate Commerce Commission, 211 U. S. 407, 53 L. Ed. 253, 29 Sup. Ct. II5. 
order which it has entered. In this connection see also the provisions of section 16 .

The Commission and the Courts.-Section 16 attributes prima facie effect to the findings of fact made by the Commission which from the nature of its organization, its duties and its powers is essentially competent to pass upon questions of fact. ${ }^{2}$ The St1-

2 Louisville and Nashville Railroad Co. v. Behlmer, 175 U. S. 648, 44 L. Ed. 309, 20 Sup. Ct. 209, where the court said:- "If, then, we were to undertake the duty of weighing the evidence, in this record, we would be called upon, as a matter of original action, to investigate all these serious considerations which were shut out from view by the Commission and were not weighed by the Circuit Court of Appeals, because both the Commission and the court erroneously construed the statute. But the law attributes prima facie effect to the findings of fact made by the Commission, and that body, from the nature of its organization and the duties imposed upon it by the statute, is peculiarly competent to pass upon questions of fact of the character here arising."

Texas and Pacific Railway Co. v. Interstate Commerce Commission, I62 U. S. 197, 40 L. Ed. 940, I6 Sup. Ct. 666 . Here the court, to the same effect, said:-"We have therefore to deal only with a question of law, and that is, what is the true construction, in respect to the matters involved in the present controversy, of the Act to Regulate Commerce? If the construction put upon the Act by the Commission was right, then the order was lawful; otherwise it was not. *** We do not refer to these matters for the purpose of indicating what conclusions ought to have been reached by the Commission or by the courts below in respect to what were proper rates to be charged by the Texas and Pacific Railroad Company. That was a question of fact, and if the inquiry had been conducted on a proper basis we should not have felt inclined to review conclusions so reached. But we mention them to show that there manifestly was error in excluding facts and circumstances that ought to have been considered, and that this error arose out of a misconception of the purpose and mean. ing of the Act.

"If the Circuit Court of Appeals was of opinion that the Commission in making its order had misconceived the extent of its powers, and if the Circuit Court had erred in affirming the validity of an order made under such misconception, the duty of the Circuit court of Appeals was to reverse the decree, set aside the order, and remand the cause to the Commission, in order that it might, if it saw fit, proceed therein according to law. The defendant was entitled to have its defense considered, in the first instance at least, by the Commission upon a full consideration of all the circumstances and conditions upon which a legitimate order could be founded. The question whether certain charges were reasonable or otherwise, whether certain discriminations were due or undue, were questions of fact, to be passed upon by the Commission in the light of all the facts duly alleged and supported by competent evidence, and it did not comport with the true scheme of the statute that the Circuit Court of Appeals 
preme Court will not review the decisions of the Commission as to facts unless the Commission has incorrectly applied principles of law to the situation or has acted upon a misapprehension of the law and its powers. In other words while the court has at times been constrained to correct erroneous constructions which have been placed upon the statute by the Commission-because the law imposes upon the Commission the duty of considering evidence-it has refused to exercise its original judgment on the facts where under the statute it was entitled, before approaching the facts, to the aid of the previous judgment of the Commission. But the courts may review the conclusions reached by the Commission where that body, for example, erred in excluding facts and circumstances that ought to have been considered as a result of some misconception of the purpose and meaning of the Act. The Supreme Court has stated it succinctly in the following words: "The statute gives prima facie effect to the findings of the Commission, and when those findings are concurred in by the Circuit Court, we think they should not be interfered with, unless the record establishes that clear and unmistakable error has been committed."3

should undertake, of its own motion, to find and pass upon such questions of fact, in a case in the position in which the present one was. We do not, of course, mean to imply that the Commission may not directly institute proceedings in a Circuit Court of the United States charging a common carrier with disregard of provisions of the Act, and that thus it may become the duty of the court to try the case in the first instance. Nor can it be denied that, even when a petition is filed by the Commission for the purpose of enforcing an order of its own, the court is authorized to 'hear and determine the matter as a court of equity,' which necessarily implies that the court is not concluded by the findings or conclusions of the Commission; yet as the Act provides that, on such hearing, the findings of fact in the report of said Commission shall be prima facie evidence of the matters therein stated, we think it plain that if, in such a case the Commission has failed in its proceedings to give notice to the alleged offender, or has unduly restricted its inquiries upon a mistaken view of the law, the court ought not to accept the findings of the Commission as a legal basis for its own action, but should either inquire into the facts on its own account or send the case back to the Commission to be law fully proceeded in."

See East Tennessee, Virginia and Georgia Railway Co. v. Interstate Commerce Commission, 18I U. S. I, 45 L. Ed. 719, 21 Sup. Ct. 516, also to the same effect; and Interstate Commerce Commission v. Chicago, Burlington and Quincy Railroad Co., 186 U. S. 320, 46 L. Ed. I182, 22 Sup. Ct. 824 .

3 Cincinnati, Hamilton and Dayton Railway Co. v. Interstate Com- 
Under the amended statute, it is to be remembered, that only in cases of an award of money damages are the findings of the Commission made prima facie evidence in judicial proceedings and those are the only cases which require a proceeding in court.

For example, the question of the reasonableness of a rate is a question of fact and subject to review only where the Commission has erroneously applied the law or has excluded facts and circumstances which ought to have been considered by that body.

Under the construction of the Act by the Supreme Court all the testimony in the case should be offered before the Commission for its decision and determination of the questions of fact and it is improper for parties to withhold a portion of their evidence to submit it de novo in the courts in proceedings instituted by the Commission to secure the enforcement of its orders."

The provision of this section which makes the decisions of the Commission, as published, admissible in evidence without other proof of their genuineness, does not require that they be judicially noticed or relieve litigants from offering them in evidence in the same manner as other evidence presented in judicial actions. ${ }^{s}$

merce Commission, 206 U. S. I42, 5I L. Ed. 995, 27 Sup. Ct. 648. Illinois Central Railroad Co. v. Interstate Commerce Commission, 206 U. S. 44I, where the court said:- "The findings of the Commission are made by law prima facie true. This court has ascribed to them the strength due to the judgments of a tribunal appointed by law and informed by experience. Louisville and Nashville Railroad Co. v. Behlmer, 175 U. S. 648; East Tenn., etc., Railroad Co. v. Interstate Commerce Commission, I8I U. S. I, 27. And in any special case of conflicting evidence a probative force must be attributed to the findings of the Commission, which, in addition to 'knowledge of conditions, of environment and of transportation relations,' has had witnesses before it and has been able to judge of them and their manner of testifying. In the case at bar these considerations are reinforced by a concurrent judgment of the Circuit Court. The question is one of the reasonableness of a rate, and such a question was said to be one of fact in Texas and Pacific Ry. v. Interstate Commerce Commission, 162 U. S. 197, 40 L. Ed. 940, I6 Sup. Ct. 666; C., N. O. \& T. P. Ry. v. Interstate Commerce Commission, I62 U. S. I84, 40 L. Ed. 935, I6 Sup. Ct. 700 . In these cases, however, it was declared that the conclusions of the Commission are subject to review if it excluded 'facts and circumstances that ought to have been considered.'"

4 Texas and Pacific Railway Co. v. Interstate Commerce Commission, I62 U. S. 197, 40 L. Ed. 940, I6 Sup. Ct. 666.

5 Robinson v. Baltimore and Ohio Railroad Co., 222 U. S. 506, 56 L. Ed. 288, 32 Sup. Ct. II4. Here the court said:- "The next question to be considered is whether judicial notice should have been taken of the deci- 
The purpose of this provision is to relieve litigants of the inconvenience and expense of securing certified copies of the decisions but it does not otherwise change the rules of evidence.

The statute does not require the Interstate Commerce Commission in its reports or in its orders to state evidential facts through which its conclusions have been reached. The law requires only a finding of the ultimate facts. ${ }^{6}$

sion of the Commission in Clade Coal Co. v. Baltimore and Ohio Railroad Co., wherein, as it is said, the rate here in question was found to be unjustly discriminatory and the railroad company was directed to desist from its enforcement. The decision was rendered April 28, 1904, and authoritatively published in $10 \mathrm{I}$. C. C. 226 , but was not mentioned in the pleadings or in the agreed statement of facts. In the Supreme Court of Appeals of the state it was contended that the decision should have been judicially noticed by the trial court, but the contention was rejected and that ruling is now challenged as contravening the provision in section I4 of the Act, which reads:-'The Commission may provide for the publication of its reports and decisions in such form and manner as may be best adapted for public information and use, and such authorized publications shall be competent evidence of the reports and decisions of the Commission contained therein, in all courts of the United States and of the several states, without any further proof or authentication thereof.' Undoubtedly this provision makes the decisions of the Commission, as so published, admissible in evidence without other proof of their genuineness but it does not require that they be judicially noticed or relieve litigants from offering them in evidence as they would any other competent evidence intended to be relied upon. Its purpose is to relieve litigants from the inconvenience and expense of obtaining certified copies of the decisions by authorizing the use of the published copies, but it does not othewise change the rules of evidence. The ruling, therefore, was not in contravention of the statute."

6 Meeker v. Lehigh Valley Railroad Co., decided February 23, I915. The Court here said:- "Another objection which was directed against the orders as well as the reports is that they contain no findings of fact or at least not enough to sustain an award of damages. The arguments advanced to sustain this objection proceed upon the theory that the statute requires that the reports, if not the orders, shall state the evidential rather than the ultimate facts, that is to say, the primary facts from which through a process of reasoning and inference the ultimate facts may be determined. We think this is not the right view of the statute and that what it requires is a finding of the ultimate facts-a finding which, as applied to the present case, would disclose (1) the relation of the parties as shipper and carrier in interstate commerce; (2) the character and amount of the traffic out of which the claims arose; (3) the rates paid by the shipper for the service rendered and whether they were according to the established tariff; (4) whether and in what way unjust discrimination was practiced against the shipper from November I, 1900, to August 
Published Reports of Decisions.-The amendment of March 2,1889 , provided for the publication of the decisions of the Commission. The volumes are variously cited as "Int. Com. Rep.," "I. C. C. R." and as "I. C. C." The volumes to and including volume thirteen have been published by a law publishing house. From Volume XIV to date-approximately thirty volumes have thus far been published-they have been printed by the Government Printing Office, where they can be purchased either by the volume or in advance sheets at the cost of printing, which is nominal. The reports contain not merely the decisions or written opinions of the Commission, but also a list of cases considered and disposed of without printed report thereon. The Commission, in addition to its formal rulings or opinions, also issues at frequent intervals "conference rulings" on informal questions submitted to it; tariff circulars embracing regulations as to the filing and construction of freight tariffs, express company tariffs and passenger rates; also quarterly statements of railroad accidents are issued by the Commission.

I, IgOI; (5) whether, if there was unjust discrimination, the shipper was injured thereby, and, if so, the amount of his damages; (6) whether the rate collected from the shipper from August I, Ig0 I, to July I7, 1907, was excessive and unreasonable and, if so, what would have been a reasonable rate for the service; and (7) whether, if the rate was excessive and unreasonable, the shipper was injured thereby, and, if so, the amount of his damages. Upon examining the reports as set forth in the record, we think they contain findings of fact which meet the requirements of the statute and that the facts stated in the findings, if taken as prima facic true, sustain the award of the Commission. True, the findings in the original report are interwoven with other matter and are not expressed in the terms which courts generally employ in special findings of fact, but there is no difficulty in separating the findings from the other matter or in fully understanding them, and particularly is this true when the two reports are read together, as they should be." 


\section{SECTION I5. CONTROL OF RATES BY THE COM- MISSION.}

SEC. 15. (As amended June 29, 1906, and June

Commis $\mathrm{s}$ i o $\mathrm{n}$ may determine and prescribe just and rea. sonable rates and classifica. tions to be ob. served as maxi. mum charges.

Commis $\mathrm{s}$ i o $\mathrm{n}$ may determine and prescribe just and rea. sonable regula. tions or prac. tises. Commission may order carricrs to cease and desist from $\mathrm{v}$ i o l a tions found. Orders of the Commis. sion effective as prescribed, but in not less than thirty days. I8, I9IO.) That whenever, after full hearing upon a complaint made as provided in section 13 of this Act, or after full hearing under an order for investigation and hearing made by the Commission on its own initiative (either in extension of any pending complaint or without any complaint whatever), the Commission shall be of opinion that any individual or joint rates or charges whatsoever demanded, charged, or collected by any common carrier or carriers subject to the provisions of this Act for the transportation of persons or property or for the transmission of messages by telegraph or telephone as defined in the first section of this Act, or that any individual or joint classifications, regulations, or practises whatsoever of such carrier or carriers subject to the provisions of this Act are unjust or unreasonable or unjustly discriminatory, or unduly preferential or prejudicial or otherwise in violation of any of the provisions of this Act, the Commission is hereby authorized and empowered to determine and prescribe what will be the just and reasonable individual or joint rate or rates, charge or charges, to be thereafter observed in such case as the maximum to be charged, and what individual or joint classification, regulation, or practise is just, fair, and reasonable, to be thereafter followed, and to make an order that the carrier or carriers shall cease and desist from such violation to the extent to which the Commission finds the same to exist, and shall not thereafter publish, demand, or collect any rate or charge for such transportation or transmission in excess of the maximum rate or charge so prescribed, and shall adopt the classification and shall conform to and observe the regula- 
tion or practise so prescribed. All orders of the Commission, except orders for the payment of money, shall take effect within such reasonable time, not less than thirty days, and shall continue in force for such period of time, not exceeding two years, as shall be prescribed in the order of the Commission, unless the same shall be suspended or modified or set aside by the Commission, or be suspended or set aside by a court of competent jurisdiction. Whenever the carrier or carriers, in obedience to such order of the Commission or otherwise, in respect to joint rates, fares, or charges, shall fail to agree among themselves upon the apportionment or division thereof the Commission may, after hearing, make a supplemental order prescribing the just and reasonable proportion of such joint rate to be received by each carrier party thereto, which order shall take offect as a part of the original order.

Whenever there shall be filed with the Commission any schedule stating a new individual or joint rate, fare, or charge, or any new individual or joint classification, or any new individual or joint regulation or practise affecting any rate, fare, or charge, the Commission shall have, and it is hereby given, authority, either upon complaint or upon its own initiative without complaint, at once, and if it so orders, without answer or other formal pleading by the interested carrier or carriers, but upon reasonable notice, to enter upon a hearing concerning the propriety of such rate, fare, charge, classification, regulation, or practise; and pending such hearing and the decision thereon the Commission upon filing with such schedule and delivering to the carrier or may su spend new schedules. carriers affected thereby a statement in writing of its reasons for such suspension may suspend the operation of such schedule and defer the use of such rate, fare, charge, classification, regulation, or practise, but not for a longer period than one hundred and twenty days beyond the time when such rate, fare, charge, classification, regulation, or practise would otherwise go into effect; and after full

Orders in force not ex. ceeding two years, unles. suspended or set aside by Com. mission or court.

When car. riers fail to agree on divisions of joint rate, Commission may pre. scribe proporrate to be re. ceived by each carrier.

Investigati on of new sched ules.

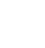

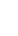


Commis $s$ io $n$ may extend suspension.

Burden of proof on car. rier as to rea. sonableness of increased rates.

Commis $s$ i o $n$ may establish through noutes and joint rates a n d classifica. tions. hearing, whether completed before or after the rate, fare, charge, classification, regulation, or practise goes into effect, the Commission may make such order in reference to such rate, fare, charge, classification, regulation, or practise as would be proper in a proceeding initiated after the rate, fare, charge, classification, regulation, or practise had become effective: Provided, That if any such hearing can not be concluded within the period of suspension, as above stated, the Interstate Commerce Commission may, in its discretion, extend the time of suspension for a further period not exceeding six months. At any hearing involving a rate increased after January first, nineteen hundred and ten, or of a rate sought to be increased after the passage of this Act, the burden of proof to show that the increased rate or proposed increased rate is just and reasonable shall be upon the common carrier, and the Commission shall give to the hearing and decision of such questions preference over all other questions pending before it and decide the same as speedily as possible.

The Commission may also, after hearing, on a complaint or upon its own initiative without complaint, establish through routes and joint classifications, and may establish joint rates as the maximum to be charged and may prescribe the division of such rates as hereinbefore provided and the terms and conditions under which such through routes shall be operated, whenever the carriers themselves shall have refused or neglected to establish voluntarily such through routes or joint classifications or joint rates; and this provision shall apply when one of the connecting carriers is a water line. The Commission shall not, however, establish any through route, classification, or rate between street electric passenger railways not engaged in the general business of transporting freight in addition to their passenger and express business and railroads of a different character, nor shall the Commission have the right to establish any route, classification, 
rate, fare, or charge when the transportation is wholly by water, and any transportation by water affected by this Act shall be subject to the laws and regulations applicable to transportation by water.

And in establishing such through route, the Commission shall not require any company, without its consent, to embrace in such route substantially less than the entire length of its railroad and of any intermediate railroad operated in conjunction and under a common management or control therewith which lies between the termini of such proposed through route, unless to do so would make such through route unreasonably long as compared with another practicable through route which could otherwise be established.

In all cases where at the time of delivery of property to any railroad corporation being a common carrier, for transportation subject to the provisions of this Act to any point of destination, between which and the point of such delivery for shipment two or more through routes and through rates shall have been established as in this Act provided to which through routes and through rates such carrier is a party, the person, firm, or corporation making such shipment, subject to such reasonable exceptions and regulations as the Interstate Commerce Commission shall from time to time prescribe, shall have the right to designate in writing by which of such through routes such property shall be transported to destination, and it shall thereupon be the duty of the initial carrier to route said property and issue a through bill of lading therefor as so directed, and to transport said property over its own line or lines and deliver the same to a connecting line or lines according to such through route, and it shall be the duty of each of said connecting carriers to receive said property and transport it over the said line or lines and deliver the same to the next succeeding carrier or consignee according to the routing instructions in said bill of lading: Provided, however, That the shipper shall in all 
Unlawful to give or receive information relative to shipments.

Exceptions. instances have the right to determine, where competing lines of railroad constitute portions of a through line or route, over which of said competing lines so constituting a portion of said through line or route his freight shall be transported.

It shall be unlawful for any common carrier subject to the provisions of this Act, or any officer, agent, or employee of such common carrier, or for any other person or corporation lawfully authorized by such common carrier to receive information therefrom, knowingly to disclose to or permit to be acquired by any person or corporation other than the shipper or consignee, without the consent of such shipper or consignee, any information concerning the nature, kind, quantity, destination, consignee, or routing of any property tendered or delivered to such common carrier for interstate transportation, which information may be used to the detriment or prejudice of such shipper or consignee, or which may improperly disclose his business transactions to a competitor; and it shall also be unlawful for any person or corporation to solicit or knowingly receive any such information which may be so used: Provided, That nothing in this Act shall be construed to prevent the giving of such information in response to any legal process issued under the authority of any state or federal court, or to any officer or agent of the government of the United States, or of any state or territory, in the exercise of his powers, or to any officer or other duly authorized person seeking such information for the prosecution of persons charged with or suspected of crime; or information given by a common carrier to another carrier or its duly authorized agent, for the purpose of adjusting mutual traffic accounts in the ordinary course of business of such carriers.

Penalty. Any person, corporation, or association violating any of the provisions of the next preceding paragraph of this section shall be deemed guilty of a misdemeanor, and for each offense, on conviction, shall pay to the United States a penalty of not more than one thousand dollars. 
If the owner of property transported under this Act directly or indirectly renders any service connected with such transportation, or furnishes any instrumentality used therein, the charge and allowance therefor shall be no more than is just and reasonable, and the Commission may, after hearing on a complaint or on its own initiative, determine what is a reasonable charge as the maximum to be paid by the carrier or carriers for the services so rendered or for the use of the instrumentality so furnished, and fix the same by appropriate order, which order shall have the same force and effect and be enforced in like manner as the orders above provided for under this section.

The foregoing enumeration of powers shall not exclude any power which the Commission would otherwise have in the making of an order under the Enumeratio $n$ of powers in this section not exclusive. provisions of this Act.

History of the Section.-No other section of the Act to Regulate Commerce has been more radically amended than this one. As originally enacted it merely provided that after the Interstate Commerce Commission had found that there had been some violation of the Act it should serve notice upon the carrier to desist from the practise in question. This notice was a condition precedent to the subsequent proceeding in court against the offending carrier to enforce the order or decree of the Commission. In its original form the Commission did not possess the power to prescribe either directly or indirectly maximum, minimum or absolute rates, although it could forbid the further enforcement of a rate which was unreasonable, unjust or discriminatory under the various sections of the Act.

By the Hepburn Act of June 29, 1906, section 15 was substantially rewritten and re-enacted. The powers of the Commission were greatly enlarged and that body was clothed with the most far reaching jurisdiction. It was given power to declare unjust or unreasonable or prejudicial any charge, regulation, or practise of carriers subject to the Act. It was authorized to establish through routes when no reasonable or satisfactory through routes exist, as well as joint rates and classifications. Most important of all the Commission was vested with the power of fix- 
ing maximum rates or charges to be collected by carriers for a period not exceeding two years.

By the Act of June I8, I9I0, the powers of the Commission were still further enlarged. It was given the power, either upon complaint or upon its own initiative without complaint, upon reasonable notice to investigate any new rates, fares or charges, etc., filed with it, and pending such investigation to suspend such schedules for a period not exceeding 120 days beyond the time when such schedules would otherwise go into effect; but if such hearing and investigation cannot be completed within that time the Commission may further extend the suspension for a period not exceeding six months. Moreover the burden of proof is upon the carrier to show the reasonableness of such increased rates. The Commission may also establish through routes and joint rates and classifications. The shipper may select his own through route where there are two or more through routes. The Commission is also empowered by the amendments of I9ro to determine what shall be just and reasonable charges or allowances for services rendered by the shipper or for any instrumentality furnished by such shipper and used in connection with such transportation. These amendments also make it unlawful for any common carrier subject to the Act, or any officer or agent of such carrier, to either give or receive information relative to the shipments of others.

Inasmuch as under other sections of the Act the orders of the Commission, other than for the payment of money as reparation, are now directly enforceable under penalties levied on the carrier by the order of the Commission, and court procedure for their enforcement is not required, the provision originally incorporated in this section requiring a formal notice of the orders of the Commission to the carriers is omitted.

Regulation of Rates.-Prior to the enactment of the Hepburn law of June 29, 1906, the Interstate Commerce Commission, as already suggested, did not possess the power of prescribing rates. Subject to the provisions of the Act to Regulate Commerce that their charges should not be unjust or unreasonable, and that they should not be unjustly discriminatory so as to either give an undue preference or impose a disadvantage on persons or shipments similarly situated, railroads under the Act prior to the Hepburn amendments were free to determine their rates in accordance with their own desires or what they, considered the necessities of 
commerce. ${ }^{1}$ While the Commission did possess the power to pass upon and determine the reasonableness of a rate at that time existing, it was not clothed with the legislative power of prescribing rates, either maximum, minimum or absolute. ${ }^{2}$ And since

I Cincinnati, New Orleans and Texas Pacific Railway Co. v. Interstate Commerce Commission, I62 U. S. I84, 40 L. Ed. 935, I6 Sup. Ct. 700, where the court said:- "Whether Congress intended to confer upon the Interstate Commerce Commission the power to itself fix rates, was mooted in the courts below, and is discussed in the briefs of the counsel. We do not find any provision of the Act that expressly, or by necessary implication, confers such a power. It is argued on behalf of the Commission that the power to pass upon the reasonableness of existing rates implies a right to prescribe rates. This is not necessarily so. The reasonableness of the rate, in a given case, depends on the facts, and the function of the Commission is to consider these facts and give them their proper weight. If the Commission, instead of withholding judgment in such a matter until an issue shall be made and the facts found, itself fixes a rate, that rate is prejudged by the Commission to be reasonable. We prefer to adopt the view expressed by the late Justice Jackson, when circuit judge, in the case of Interstate Commerce Commission v. Baltimore and Ohio Railroad Co., 43 Fed. 37 , and whose judgment was affirmed by this court, I45 U. S. 263 : - Subject to the two leading prohibitions that their charges shall not be unjust or unreasonable, and that they shall not unjustly discriminate, so as to give undue preference or disadvantage to persons or traffic similarly circumstanced, the Act to Regulate Commerce leaves common carriers as they were at the common law, free to make special contracts looking to the increase of their business, to classify their traffic, to adjust and apportion their rates so as to meet the necessities of commerce, and generally to manage their important interests upon the same principles which are regarded as sound, and adopted in other trades and pursuits" "

See also Interstate Commerce Commission v. Baltimore and Ohio Railroad Co., I45 U. S. 263,36 L. Ed. 699, 12 Sup. Ct. 844 , to the same effect.

2 Interstate Commerce Commission v. Cincinnati, New Orleans and Texas Pacific Railway Co., 167 U. S. 479, 42 L. Ed. 243, 17 Sup. Ct. 896. After investigation the Commission found certain rates charged by the carrier to be unreasonable and unjust. Thereupon the Conmission set forth a table of rates and issued an order requiring the roads to abstain from charging higher rates in the future than those set forth in this table. The railroads did not comply with this order and the Commission instituted suit for a mandamus to compel their obedience. In an exhaustive discussion of the power of the Commission in the matter of rates, the court said:- "There is nothing in the Act fixing rates. Congress did not attempt to exercise that power, and if we examine the legislative and public history of the day it is apparent that there was no serious thought of doing so. The question debated is whether it vested in the Commission the power and the duty to fix rates; and the fact that this is a debatable question, and has been most strenuously and earnestly debated, is very persuasive that it did 
that power was not directly bestowed upon the Commission it was impossible to suppose that it was intended to indirectly grant it by empowering the Commission to determine what in respect to

not. The grant of such a power is never to be implied. The power itself is so vast and comprehensive, so largely affecting the rights of carrier and shipper, as well as indirectly all commercial transactions, the language by which the power is given had been so often used and was so familiar to the legislative mind and is capable of such definite and exact statement, that no just rule of construction would tolerate a grant of such power by mere implication. $* * *$ It is one thing to inquire whether the rates which have been charged and collected are reasonable-that is a judicial act; but an entirely different thing to prescribe rates which shall be charged in the future-that is a legislative act. *** It will be perceived that in this case the Interstate Commerce Commission assumed the right to prescribe rates which should control in the future, and their application to the court was for a mandamus to compel the companies to comply with their decision; that is, to abide by their legislative determination as to the maximum rates to be observed in the future. Now nowhere in the Interstate Commerce Act do we find words similar to those in the statutes referred to, giving to the Commission power to "increase or reduce any of the rates'; 'to establish rates of charges;' 'to make and fix reasonable and just rates of freight and passenger tariffs;' 'to make a schedule of reasonable maximum rates of charges;' 'to fix tables of maximum charges;' to compel the carrier 'to adopt such rates, charge or classification as said commissioners shall declare to be equitable and reasonable.' The power, therefore, is not expressly given. Whence then is it deduced? In the first section it is provided that 'all charges *** shall be reasonable and just; and every unjust and unreasonable charge for such service is prohibited and declared to be unlawful.' Then follows sections prohibiting discrimination, undue preferences, higher charges for a short than for a long haul, and pooling, and also making provision for the preparation by the companies of schedules of rates, and requiring their publication. *** But the power of fixing rates under the Interstate Commerce Act is not to be determined by any mere considerations of omission or implication.

"We have, therefore, these considerations presented:-First. The power to prescribe a tariff of rates for carriage by a common carrier is a legislative and not an administrative or judicial function, and, having respect to the large amount of property invested in railroads, the various companies engaged therin, the thousands of miles of road, and the millions of tons of freight carried, the varying and diverse conditions attaching to such carriage, is a power of supreme delicacy and importance. Second. That Congress has transferred such a power to any administrative body is not to be presumed or implied from any doubtful and uncertain language. The words and phrases efficacious to make such a delegation of power are well understood and have been frequently used, and if Congress had intended to grant such a power to the Interstate Commerce Commission it 
the past was a just and reasonable rate, whether maximum, minimum or absolute, and then enable it to secure from the courts a peremptory order that in the future the railroads must adhere to the rates thus determined to have been reasonable and just in the

cannot be doubted that it would have used language open to no misconstruction, but clear and direct. Third. Incorporating into a statute the common law obligation resting upon the carrier to make all its charges reasonable and just, and directing the Commission to execute and enforce the provisions of the Act, does not by implication carry to the Commission or invest it with the power to exercise the legislative function of prescribing rates which shall control in the future. Fourth. Beyond the inference which irresistibly follows from the omission to grant in express terms to the Commission this power of fixing rates, is the clear language of section 6 , recognizing the right of the carrier to establish rates, to increase or reduce them, and prescribing the conditions upon which such increase or reduction may be made, and requiring, as the only conditions of its action, first, publication and, second, the filing of the tariff with the Commission. The grant to the Commission of the power to prescribe the form of the schedules, and to direct the place and manner of publication of joint rates, thus specifying the scope and limit of its functions in this respect, strengthens the conclusion that the power to prescribe rates or fix any tariff for the future is not among the powers granted to the Commission. These considerations convince us that under the Interstate Commerce Act the Commission has no power to prescribe the tariff of rates which shall control in the future, and, therefore, cannot invoke a judgment in mandamus from the courts to enforce any such tariff by it prescribed.

"But has the Commission no functions to perform in respect to the matter of rates; no power to make any inquiry in respect thereto? Unquestionably it has, and most important duties in respect to this matter. It is charged with the general duties of inquiring as to the management of the business of railroad companies, and to keep itself informed as to the manner in which the same is conducted, and has the right to compel complete and full information as to the manner in which such carriers are transacting their business. And with this knowledge it is charged with the duty of seeing that there is no violation of the long and short-haul clause; that there is no discrimination between individual shippers, and that nothing is done by rebate or any other device to give preference to one as against another; that no undue preferences are given to one place or places or individual or class of individuals, but that in all things that equality of right, which is the great purpose of the Interstate Commerce Act, shall be secured to all shippers. It must also see that that publicity which is required by section 6 is observed by the railroad companies.

See also Cincinnati, New Orleans and Texas Pacific Railway Co. v. Interstate Commerce Commission, I62 U. S. 184, 40 L. Ed. 935, I6 Sup. Ct. 700, to the same effect. 
past. While the Commission could not either directly or indirectly prescribe a rate, maximum, minimum or absolute, it could prohibit the enforcement of charges that were unreasonable or unjust, discriminatory or preferential or that resulted in a higher rate for a short than for a long haul.

3 Interstate Commerce Commission v. Cincinnati, New Orleans and Texas Pacific Railway Co., I67 U. S. 479, 42 L. Ed. 243, I7 Sup. Ct. 896, supra, where as to this the court said:- "The argument is now made, and made with force, that while the Commission may not have the legislative power of establishing rates, it has the judicial power of determining that a rate already established is unreasonable, and with it the power of determining what should be a reasonable rate, and of enforcing its judgment in this respect by proceedings in mandamus. The vice of this argument is that it is building up indirectly and by implication a power which is not in terms granted. It is not to be supposed that Congress would ever authorize an administrative body to establish rates without inquiry and examination; to evolve, as it were, out of its own consciousness, the satisfactory solution of the difficult problem of just and reasonable rates for all the various roads in the country. And if it had been intended to grant the power to establish rates, it would have said so in unmistakable terms. * * Still again it is urged that the Commission has decided that it possesses this power and has acted upon such decision, and appeal is made to the rule of contemporaneous construction. But it would be strange if an administrative body could by any mere process of construction create for itself a power which Congress has not given to it. And, indeed, an examination of the decisions of the Commission discloses this curious fact. In the early case of Thatcher $v$. Delaware and Hudson Canal Co., I I. C. C. Rep. 152, I56, a case heard and decided in July of the year in which the Commission was created, the Commission declined, for lack of evidence, to fix certain rates, saying:-'It is therefore impossible to fix them in this case, even if the Commission had power to make rates generally, which it has not. Its power in respect to rates is to determine whether those which the roads impose are for any reason in conflict with the statute.'

"Again it will be perceived that nowhere in the Act is there any suggestion of a maximum or minimum rate. The first section declares that the rates shall be reasonable and just, and prohibits every unreasonable and unjust charge. Now the rate may be unreasonable because it is too low as well as because it is too high. In the former case it is unreasonable and unjust to the stockholder, and in the latter to the shipper. It was declared by this court in Covington \& Lexington Turnpike Road Co. v. Sanford, I64 U. S. 578, 597, 4I L. Ed. 560, I7 Sup. Ct. I98, that in determining the question of reasonableness 'its duty is to take into consideration the interests both of the public and of the owner of the property'; but in the matter of the Chicago, St. Paul and Kansas City Ry., 2 I. C. C. Rep. 23I, the Commission held that it had no power to order rates to be increased upon the ground that they were so low that persistence in them 
With the Act of June 29, 1906, Congress invested the Interstate Commerce Commission with the legislative function of prescribing rates to be thereafter observed by carriers subject to the Act. Under the statute, however, the carrier still retains the primary right to make rates, but if, after a hearing, they are shown to be unreasonable, the Commission may set them aside

would be ruinous. The opinion in that case, prepared by Commissioner Cooley, and with his usual ability, while seeking to prove that under the provisions of the statute the Commission has no power to prescribe a minimum or to establish an absolute rate but only to fix a maximum rate, goes on further to show how the operation of other provisions of the Act tend to secure just and reasonable rates. Were it not for its length, we should be glad to quote all that he says on the subject. We think that nearly all of the argument which he makes to show that the Commission has no power to fix a minimum or establish an absolute rate, goes also to show that it has no power to prescribe any tariff, or fix any rate to control in the future.

"Our conclusion then is that Congress has not conferred upon the Com. mission the legislative power of prescribing rates either maximum or minimum or absolute. As it did not give the express power to the Commission it did not intend to secure the same result indirectly by empowering that tribunal to determine what in reference to the past was reasonable and just, whether as maximum, minimum or absolute, and then enable it to obtain from the courts a peremptory order that in the future the railroad companies should follow the rates thus determined to have been in the past reasonable and just."

In Interstate Commerce Commission v. Alabama Midland Railway Co., 168 U. S. 144, 42 L. Ed. 4I4, 18 Sup. Ct. 45, the court said:-"Several of the assignments of error complain of the action of the Circuit Court of Appeals in not rendering a decree for the enforcement of those portions of the order of the Interstate Commerce Commission which prescribed rates to be thereafter charged by the defendant companies, for services performed in the transportation of goods. Discussion of these assignments is rendered unnecessary by recent decisions of this court, wherein it has been held, after elaborate argument, that Congress has not conferred upon the Interstate Commerce Commission the legislative power of prescribing rates, either maximum or minimum, or absolute; and that, as it did not give the express power to the Commission, it did not intend to secure the same result indirectly by empowering that tribunal, after having determined what, in reference to the past, were reasonable and just rates to obtain from the courts a peremptory order that in the future the railroad companies should follow the rates thus determined to have been in the past reasonable and just. Cincinnati, New Orleans and Texas Pacific Railway Co. v. Interstate Commerce Commission, I62 U. S. 184, 40 L. Ed. 935, 16 Sup. Ct. 700. Interstate Commerce Commission v. Cincinnati, New Orleans and Texas Pacific Railway Co., I67 U. S. 479, 42 L. Ed. 243, I7 Sup. Ct. 8g6." 
and compel the substitution of proper charges. The Supreme Court has held that this delegation of power, legislative as well as administrative in its nature, is not violative of the Constitution. Because of the multitude of details and the variable conditions affecting rate determination the subject is not susceptible of direct legislative control by Congress. With such limitations as Congress may impose the Commission may exercise this legislative function as fully and as freely as Congress might directly exercise it if it so chose. Before an order can be legal under the statute the carrier is entitled to a hearing-whether the investigation is based upon a complaint or is undertaken upon the initiative of the Commission itself. A finding by the Commission without evidence is capricious and baseless and therefore unconstitutional as an arbitrary exercise of power. The right of the Commission to act depends under the Act upon the unreasonableness of the existing or proposed rate, and if there is no evidence to indicate that the rates are unreasonable the Commission has no jurisdiction to make the order. ${ }^{4}$ The Commission cannot arbi-

4 Interstate Commerce Commission v. Louisville and Nashville Railroad Co., 227 U. S. 88, 57 L. Ed. 431, 33 Sup. Ct. I85. This suit was based on a bill filed by a carrier seeking to enjoin the enforcement of an order of the Interstate Commerce Commission directing the discontinuance of certain rates and the substitution of other rates. The court in part said:"But the statute gave the right to a full hearing, and that conferred the privilege of introducing testimony and at the same time imposed the duty of deciding in accordance with the facts proved. A finding without evidence is arbitrary and baseless. And if the government's contention is correct it wotld mean that the Commission had a power possessed by no other officer, administrative body, or tribunal under our government. It would mean that where rights depended upon facts, the Commission could disregard all rules of evidence and capriciously make findings by administrative fiat. Such authority, however beneficently exercised in one case, could be injuriously exerted in another; is inconsistent with rational justice, and comes under the Constitution's condemnation of all arbitrary exercise of power.

"Under the statute the carrier retains the primary right to make rates, but if, after hearing, they are shown to be unreasonable, the Commission may set them aside and require the substitution of just for unjust charges. The Commission's right to act depends upon the existence of this fact, and if there was no evidence to show that the rates were unreasonable, there was no jurisdiction to make the order. Interstate Commerce Commission v. Northern Pacific Railway, 216 U. S. 538, 54 L. Ed. 608, 30 Sup. Ct. 4I7. In a case like the present the courts will not review the Commission's conclusions of fact (Interstate Commerce Commission v. Delaware, etc., Ry., 220 U. S. 235, 55 L. Ed. 448, 31 Sup. Ct. 392), by passing 
trarily make findings by administrative fiat. The Commission cannot act upon its own information or conduct an ex parte investigation. All parties must be fully informed of the evidence submitted or to be considered, and they must be given an opportunity to cross-examine witnesses, to inspect documents and to offer evidence in explanation or rebuttal. In that manner alone can a defense be made and the actual situation understood. On the other hand the Commission is above all an administrative body and even when acting in a quasi-judicial capacity it is not limited by the strict rules as to the admissibility

upon the credibility of witnesses, or conflicts in the testimony. But the legal effect of evidence is a question of law. A finding without evidence is beyond the power of the Commission. An order based thereon is contrary to law and must, in the language of the statute, "be set aside by a court of competent jurisdiction.' 36 Stat. 551 .

"The government further insists that the Commerce Act requires the Commission to obtain information necessary to enable it to perform the duties and carry out the objects for which it was created, and having been given legislative power to make rates it can act, as could Congress, on such information, and therefore its findings must be presumed to have been supported by such information, even though not formally proved at the hearing. But such a construction would nullify the right to a hearing - for manifestly there is no hearing when the party does not know what evidence is offered or considered and is not given an opportunity to test, explain, or refute. The information gathered under the provisions of section 12 may be used as basis for instituting prosecutions for violations of the law, and for many other purposes, but is not available, as such, in cases where the party is entitled to a hearing. The Commission is an administrative body and, even where it acts in a quasi-judicial capacity, is not limited by the strict rules, as to the admissibility of evidence, which prevail in suits between private parties. Interstate Commerce Commission v. Baird, I94 U. S. 48 L. Ed. 860, 24 Sup. Ct. 563. But the more liberal the practise in admitting testimony, the more imperative the obligation to preserve the essential rules of evidence by which rights are asserted or defended. In such cases the Commissioners cannot act upon their own information as could jurors in primitive days. All parties must be fully apprised of the evidence submitted or to be considered, and must be given opportunity to cross-examine witnesses, to inspect documents and to offer evidence in explanation or rebuttal. In no other way can a party maintain its rights or make its defense. In no other way can it test the sufficiency of the facts to support the finding; for otherwise, even though it appeared that the order was without evidence, the manifest deficiency could always be explained on the theory that the Commission had before it extraneous, unknown but presumptively sufficient information to support the finding. Interstate Commerce Commission v. Baltimore, etc., R. R., 226 U. S. I4, 57 L. Ed. 104, 33 Sup. Ct. 5." 
of evidence which prevail in suits between individuals in courts of law and equity.

Regulation of Car Distribution.-Not only are carriers engaged in interstate commerce subject to the control of the Interstate Commerce Commission as to their interstate business, but the instrumentalities employed for the purpose of such commerce are also subject to control. And by the provisions of section I 5 the Commission has been vested with control of "any regulation or practises whatsoever" affecting rates or violative of any of the provisions of the Act. We have seen that under section 3 the Commission might so control the question of car distribution as to prevent undue preferences or advantages to any particular shippers or locality. And so where the Commission finds that a system of car distribution employed by interstate railroads serves to unduly favor or unfairly prejudice any shipper or community it may not only issue an order suspending the enforcement of such a system but it may also exercise its undoubted legislative and administrative function by substituting therefor a proper system of regulation which shall control the question for the future. And subject to the right of review by competent courts it may enforce such orders and regulations by the imposition of penalties. $^{5}$ Emphasis must be given to the fact that questions as to the

5 See Interstate Commerce Commission v. Illinois Central Railroad Co., 215 U. S. 452,54 L. Ed. 280, 30 Sup. Ct. 155, decided subsequent to the amendments of June 29, I906, but before the amendments to section 15 of the Act of June 18, 1910. It was here claimed that the method of distribution of coal cars to the mines during periods of car shortage operated to create preferences and engender discriminations. The Commission issued an order commanding the railroad company to desist from enforcing the regulations which it had found preferential and to deliver cars to mines along its line in conformity with the rule promulgated by the Commission. A suit was then brought to enjoin the enforcement of this order. The court said:- "It may not be doubted that the equipment of a railroad company engaged in interstate commerce, included in which are its coal cars, are instruments of such commerce. From this it necessarily follows that such cars are embraced within the governmental power of regulations which extends, in time of car shortage, to compelling a just and equal distribution and the prevention of an unjust and discriminatory one. The corporation as a carrier engaged in interstate commerce being then, as to its interstate commerce business, subject to the control exerted by the Act to Regulate Commerce, and the instrumentalities employed for the purpose of such commerce, being likewise so subject to control, we are brought to consider the remaining proposition, which is, That even if power has been delegated to the Commission by the Act to Regulate Commerce, the order 
reasonableness of a rule or system of car distribution are administrative in their character and call for the exercise of the powers and discretion conferred by Congress upon the Interstate Com-

whose continued enforcement was enjoined by the court below was be. yond the authority delegated by the statute. In view of the facts found by the Commission as to preferences and discriminations resulting from the failure to count the company fuel cars in the daily distribution in times of car shortage, and in further view of the far-reaching preferences and discriminations alleged in the answer of the Commission in this case, and which must be taken as true, as the cause was submitted on bill and answer, it is beyond controversy that the subject with which the order dealt was within the sweeping provisions of section 3 of the Act to Regulate Commerce prohibiting preferences and discriminations. But it is contended that although this be the case, as the order of the Commission not only forbade the preferences and discriminations complained of, but also commanded the establishment of a rule, excluding such discriminations for a future definite period of not exceeding two years, the order transcended the authority conferred upon the Commission. This proceeds upon the assumption that section I5 of the Act to Regulate Commerce, as enacted by the Act of June 29, 1906, while conferring upon the Commission the authority, upon complaint duly made, to declare a rate or practise affecting rates illegal, and to establish a new and reasonable rule or practise affecting such rates for a term not exceeding two years, has no relation to complaints concerning preferences or discriminations, unless such practises, when complained of, are of a character to affect rates, which it is insisted is not here the case. $* * *$ The contention gives to the words found in the earlier part of the section (15), 'any regulation or practise whatsoever of such carrier or carriers affecting such rates,' a dominant and controlling power so as to cause them to limit every provision in the section, however general in its language. We do not stop to critically examine the provision relied upon for the purpose of pointing out, as a matter of grammatical construction, the error of the contention, because we think, when the text of the section is taken into view and all its provisions are given their natural significance, it obviously appears that the construction relied upon is without foundation, and that to sustain it would be to frustrate the very purpose which it is clear, when the entire provision is considered, it was designed to accomplish, and thus would be destructive of the plain intent of Congress in enacting the provision. The antecedent construction which the Interstate Commerce Act had necessitated, and the remedial character of the amendments adopted in 1906, all serve to establish the want of merit in the contention relied upon. In addition, to adopt it would require us to hold that Congress, in enlarging the power of the Commission over rates, had so drafted the amendment as to cripple and paralyze its power in correcting abuses as to preferences and discriminations which, as this court has hitherto pointed out, it was the great and fundamental purpose of Congress to further.

"Conceding, for the sake of the argument, the existence of the prefer- 
merce Commission. Operative effect is given to the orders of the Commission without the sanction of previous judicial authority and to enforce these provisions penalties and forfeitures are provided in this section. Indeed the courts in determining whether an order of the Commission should be suspended or enjoined are without power to invade the administrative functions vested in that body, and therefore can not set aside an order duly made on their judgment as to its wisdom or expediency, but are confined to the consideration of its legality. ${ }^{6}$

ences and discriminations charged, it is insisted, when the findings made by the Commission are taken into view and the pleadings as an entirety are considered, it results that the discriminations and preferences arose from the fact that the railroad company chose to purchase its coal for its fuel supply from a particular mine or mines, and that, as it had a right to do so, it is impossible, without destroying freedom of contract, to predicate illegal preferences or wrongful discriminations from the fact of purchase. But the proposition overlooks the fact that the regulation addresses itself, not to the right to purchase, but to the duty to make equal distribution of cars. The right to buy is one thing and the power to use the equipment of the road for the purpose of moving the articles purchased in such a way as to discriminate or give preference are wholly distinct and different things. The insistence that the necessary effect of an order, compelling the counting of company fuel cars in fixing, in case of shortage, the share of cars a mine from which coal has been purchased will be entitled to, will be to bring about a discrimination against the mine from which the company buys its coal and a preference in favor of other mines, but inveighs against the expedience of the order. And this is true also of a statement in another form of the same proposition, that is, that if, when coal is bought from a mine by a railroad the road is compelled to count the cars in which the coal is moved in case of car shortage, a preference will result in favor of the mine selling coal and making delivery thereof at the tipple of the mine to a person who is able to consume it without the necessity of transporting it by rail. At best, these arguments but suggest the complexity of the subject, and the difficulty involved in making any order which may not be amenable to the criticism that it leads to or may beget some inequality. Indeed, the arguments just stated, and others of a like character which we do not deem it essential to specially refer to, but assail the wisdom of Congress in conferring upon the Commission the power which has been lodged in that body to consider complaints as to violations of the statute and to correct them if found to exist, or attack as crude or inexpedient the action of the Commission in performance of the administrative functions vested in it, and upon such assumption invoke the exercise of unwarranted judicial power to correct the assumed evils."

6 Baltimore and Ohio Railroad Co. v. Pitcairn Coal Co., 215 U. S. 48I, 54 L. Ed. 292, 30 Sup. Ct. I64. The court here said:-“By section 15, as 
Control of Through Routes.-In the spring of 1906 , prirr to the amendments of June 29, 1906, the Supreme Court he'd that a carrier guaranteeing a through route might legally reserve the

enacted by the amendment of June 29, I906, the Commission is empowered, indeed it is made its duty, in disposing of a complaint, not only to determine the legality of the practise alleged to give rise to an unjust preference or undue discrimination, and to forbid the same, but, moreover, to direct the practise to be followed as to such subject for a future period, not exceeding two years, with power in the Commission, if it finds reason to do so, to suspend, modify, or set aside the same, the order, however, to become operative without judicial action. In considering section 15 in the case of Interstate Commerce Commission v. Illinois Central Railroad Co., just decided, it was pointed out that the effect of the section was to cause it to come to pass that courts, in determining whether an order of the Commission should be suspended or enjoined, were without power to invade the administrative functions vested in the Commission, and therefore could not set aside an order duly made on a mere exercise of judgment as to its wisdom or expediency. Under these circumstances it is apparent, as we have said, that these amendments add to the cogency of the reasoning which led to the conclusion in the Abilene case, that the primary interference of the courts with the administrative functions of the Commission was wholly incompatible with the Act to Regulate Commerce.

"Now it cannot in reason be questioned that among the purposes contemplated by the amendments adopted in Igo6 was the curing of the presumed remedial inefficiency of the Act by supplying efficient means for giving effiect to the orders of the Commission, made in the exertion of the authority conferred upon that body. To that end one of the amendments, section 15, gives operative effect to the orders of the Commission without the sanction of previous judicial authority, and endows that body with the power, not only as to unreasonable rates, but as to practises found upon complaint to be unduly prejudicial and unjustly discriminatory, to correct the same by its order, which order should have effect within the period fixed in the statute, and, to enforce these provisions, penalties and forfeitures are provided."

In Morrisdale Coal Co. v. Pennsylvania Railroad Co., 230 U. S. 304, 57 L. Ed. I494, 33 Sup. Ct. 938, the court said:-"These rulings as to the validity of a particular practise and the facts that would warrant a departure from a proper rule actually in force are sufficient to show that the question as to the reasonableness of a rule of car distribution is administrative in its character and calls for the exercise of the powers and discretion conferred by Congress upon the Commission. It was distinctly so ruled in the Pitcairn Case (215 U. S. 48I, 54 L. Ed. 292, 30 Sup. Ct. I64), and in I. C. C. v. Illinois Central (215 U. S. 452, 54 L. Ed. 280, 30 Sup. Ct. 155). Those cases involve a consideration of the power of the Commission over the distribution of cars and held that the courts could not by mandamus compel it to make a rule, nor by injunction restrain the enforcement of one it had promulgated. If in those direct proceedings the courts 
right to route shipments beyond its own terminal, provided its terms were reasonable and did not otherwise violate the law. ${ }^{6 a}$ By the amendments of June 29, I906, under the $15^{\text {th }}$ section the Commission was empowered to establish an additional through route where no satisfactory or reasonable through route existed. In March, I9Io, the Supreme Court held that the question of whether a "reasonable or satisfactory through route exists" was jurisdictional and that the existence of such a route might be inquired into by the courts. ${ }^{7}$ The court held that while the prefer-

could not pass upon the question of reasonableness of a method of allotting cars, neither could it do so as an incident to an action for damages." See also Interstate Commerce Commission v. Chicago and Alton Ry. Co., 215 U. S. 479, 54 L. Ed. 29I, 30 Sup. Ct. I63.

6a Southern Pacific Railway Co. v. Interstate Commerce Commission, 200 U. S. 536, 50 L. Ed. 585, 26 Sup. Ct. 330, where in order to break up the practise of rebating to shippers by the connecting roads this road reserved, as a condition of guaranteeing a through rate, the right to route goods beyond its own terminal. The court said:- "The important facts that control the situation are that the carrier need not agree to carry beyond its own road, and may agree upon joint through tariff rates or not, as seems best for its own interests. Having these rights of contract the carrier may make such terms as it pleases, at least so long as they are reasonable and do not otherwise violate the law. We think the routing rule is not unreasonable under the facts herein and that it does not violate the third section of the Act. Because opportunities for the violation of the Act may occur, by reason of the rule, is no ground for holding as a matter of law that violations must occur, and that the rule itself is therefore illegal. We are, consequently, unable to concur in the view taken by the Commission that the rule violates the third section of the Act."

7 Interstate Commerce Commission v. Northern Pacific Railway Co., 216 U. S. 538, 54 L. Ed. 608, 30 Sup. Ct. 417. The court here said:- "The authority of the Commission to establish through rates and joint rates is conditioned by the proviso that 'no reasonable or satisfactory through route exists.' Act of June 29, I906, c. 359I, sec. 4. 34 Stat. 584, 589. It is urged that this condition is addressed only to the opinion of the Commission and cannot be re-examined by the courts as a jurisdictional fact. The difficulty of distinguishing between a rule of law for the guidance of a court and a limit set to its power is sometimes considerable. Words that might seem to concern jurisdiction may be read as simply imposing a rule of decision, and often will be read in that way when dealing with a court of general powers. Fauntleroy v. Lum, 210 U. S. 230, 235, 52 L. Ed. I039, 28 Sup. Ct. 64r. But even in such a case there may be a difference of opinion, ibid 245 , and when we are dealing with an administrative order that seriously affects property rights, and does so by way rather of fiat than of adjudication, there seems to be no reason for not taking the proviso of the statute in its natural sense. See Interstate Commerce Com- 
ences of travelers for a second through route might make such a route desirable they could not warrant the declaration that no reasonable or satisfactory through route existed. And the Commission could make no such order if a reasonable and satisfactory through route already existed, and that question might be examined by the courts.

By the amendments of June I8, I9IO, Congress dropped from the Act the provision as to the reasonableness of an existing route and the Commission was endowed with the power, either upon its own initiative or upon complaint, to establish through routes and joint classifications and maximum joint rates to be charged, whenever the carriers themselves have refused or neglected to establish voluntarily such through routes, or joint classi-

mission v. Illinois Central Railroad Co., 215 U. S. 452, 470, 54 L. Ed. 280, 30 Sup. Ct. 155.

"We are of opinion then that the Commission had no power to make the order if a reasonable and satisfactory through route already existed, and that the existence of such a route may be inquired into by the courts. How far the courts should go in that inquiry we need not now decide. No doubt in complex and delicate cases great weight at least would be attached to the judgment of the Commission. But in the present instance there is no room for difference as to the facts, and the majority of the Commission plainly could not and would not have made the declaration in their order that there was no such through route, but for a view of the law upon which this court must pass. It is admitted that the Northern Pacific route is shorter than that of the Union Pacific by way of Portland and the running time somewhat less, and it is added by the majority that the 'passenger goes in as good a car and is provided with as good a berth and as good a meal.'

"There is some suggestion that at times the northern route may not be as good as the southern, although at other times it may be better, but the ground of the order avowedly was that the personal perferences of many travelers is to go by the southern way. If they do, it is said, they can select from a great variety of routes as far as Ogden, Utah, they can visit cities not reached by the northern lines, they can search over a wide area for homesteads, they can behold the natural beauties that may be rivalled but not repeated on the other roads. It appears to us that these grounds do not justify the order. The most that can be said by them is that they are reasons for desiring a second through route, but they are not reasons warranting the declaration that 'no reasonable or satisfactory through route exists.' Obviously that is not true, except by an artificial use of words. It cannot be said that there is no such route, because the public would prefer two. The condition in the statute is not to be trifled away. Except in case of a need such as the statute implies, the injustice pointed out by the chairman in his dissent is not permitted by the law." 
fications or joint routes, both as to connecting railroad lines and where one of the connecting lines is a carrier by water. ${ }^{8}$

Regulation of Allowances to Shippers.-As already suggested under section 3 , allowances by carriers to shippers for services rendered by them in the line of transportation have constituted one of the most fruitful sources of preferences and discriminations, and such agreements will be carefully scrutinized by the Commission to see that such allowances are not made the cover for irregularities and that the same allowances are made to all shippers under the same conditions, and for the same services. As for example, payments to shippers for the elevation of grain at transshipment points at reasonable rates do not constitute a discrimination or a rebate provided such allowances are made to all carriers performing the same services under similar conditions. ${ }^{9}$ And in case of complaint as to the rates or upon its own

8 United States v. Pacific and Arctic Railway and Navigation Co., 228 U. S. 87,57 L. Ed. 742, 33 Sup. Ct. 433, is of interest in this connection. It was here held in substance that while under the Act to Regulate Commerce a carrier may select its through route connections, agreements for such connections may constitute violations of the Sherman Anti-Trust Act.

9 Interstate Commerce Commission v. Diffenbaugh, 222 U. S. 42, 56 L. Ed. 83,32 Sup. Ct. 22. The court here said:- "The law does not attempt to equalize fortune, opportunities or abilities. On the contrary the Act of Congress in terms contemplates that if the carrier receives services from an owner of poperty transported, or uses instrumentalities furnished by the latter he shall pay for them. That is taken for granted in section I5; the only restriction being that he shall pay no more than is reasonable, and the only permissive element being that the Commission may determine the maximum in case there is complaint, (or now, upon its own motion, Act of June 18, 1910, c. 309 , sec. 12, 36 Stat. 539, 553). As the carrier is required to furnish this part of the transportation upon request he could not be required to do it at his own expense, and there is nothing to prevent his hiring the instrumentality instead of owning it."

In Union Pacific Railroad Co. v. Updike Grain Co., 222 U. S. 215, 56 L. Ed. I7I, 32 Sup. Ct. 39, on this same question the court said:- "The Union Pacific's desire to have cars promptly unloaded so that they might be returned to its own line may have been the principal motive which induced it to agree to pay elevator charges. But the consideration, moving between the carrier and the elevator, was the service performed by the latter in unloading grain at terminal points. This relieved the carrier of the expense of building similar structures and avoided the delay of having the grain transferred from one car to another by the slow process of shovelling. When the service was rendered, the carrier received value for which it was bound to pay, whether performed by the owner of the grain or some other person hired for the same purpose." 
motion the Commission may determine what shall be the maximum rate. And in determining what shall constitute reasonable rates the real consideration is the service rendered by the shipper. In this connection it must be borne in mind that allowances are not to be paid for services which the carriers were under no obligation to perform but only for services which the carrier can be compelled to perform but for which it prefers to pay the shipper.

Where the railroads establish a free delivery zone about their terminals and pay shippers in that zone a lighterage allowance for lightering their shipments, as of sugar, to such railroad terminals, this does not constitute a discrimination against a sugar refinery situated some ten miles outside of the free lighterage zone and which therefore does not come within the terms of such allowances. ${ }^{10}$ And so reasonable lateral allowances are law-

Io United States v. Baltimore and Ohio Railroad Company, 231 U. S. 274, 58 L. Ed. 218, 34 Sup. Ct. 75. The railroads entering New York or Jersey City and neighboring points established a zone covering the greater part of the commercial and manufacturing river front of New York within which as a part of transportation they performed lighterage service without additional charge to and from any public or private dock. They also agreed to pay a reasonable amount based upon tonnage to the owners of a water front within the zone, who were operating a sugar refinery nearby, for the maintenance by them of a public freight terminal station there, and for lightering all freight between such freight station and the rail terminals. The court held that this did not constitute a discrimination against sugar refiners with a plant some ten miles beyond the limits of this zone who were not allowed a compensation for lightering their sugar from their refinery to such terminals, though touching on the way at a pier within the free lighterage district, but not notifying the railway companies, or making any tender to them at the pier. No question was raised as to the reasonableness of the allowance per se but only that it created a discrimination. The court said:-

"But the carriers have not established any public station at pier 24 and the Federal Company did not notify them, nor make any tender to them at that pier of their sugar for transportation. If such sugar had been tendered to them there and they had refused to receive it and lighter it at their own cost across the river, a very different question would have arisen. * * That certain advantages enured to the Arbuckle Brothers from the fact that their refinery was so near this public station that their product might be trucked or carted to the station at slight cost, is obvious. That this was a consideration which operated as an inducement to make these contracts, may be true. But this mere advantage of nearness was one which they shared in common with every other shipper who chanced to be near a shipping station. That they were large shippers was also 
ful when paid by trunk line carriers to tap lines for services connected with transportation rendered by them off of the main trunk lines. And the fact that such tap lines are owned by the shippers does not of itself affect the legality of such allowances, provided they are reasonable and are not made the cover for the payment of rebates or are not otherwise discriminatory. ${ }^{11}$

more or less an inducement to the railroads to place their depot in a locality which would tend to secure their shipments as against rival carriers, may also be conceded. But these were business considerations which are far from showing any purpose to give them any illegal preference or to discriminate against other shippers. That the station constituted a great public utility by which the shipping public was served is too plain for argument.

"To say that the 'allowance' made to Arbuckle Brothers is an allowance for lightering their own sugar across the river is to only half state the case. This so-called allowance is not only for such lighterage service, but is also compensation for the use of all of the terminal properties, docks, warehouses, tracks, steam lighters, car floats and every instrumentality used under the contract. It includes the services and responsibility of Arbuckle Brothers as agents for the several lessees using the station, and their staff of employees engaged in receiving, delivering, loading and unloading freights thus received, both incoming and outgoing. As the measure of compensation is the tonnage in and out of the station and as this compensation is paid by the several railroads maintaining the station in proportion to the tonnage which they severally handle, there is a sense in which it is in part an allowance to Arbuckle Brothers upon their own shipments. But they receive the same compensation upon the tonnage of every other shipper through that station, and it is the aggregate of the compensation which must determine the reasonableness of the allowance when we come to deal with it as an allowance to them for services or instrumentalities furnished, under the 15 th section of the Act to Regulate Commerce."

For other features of the same case, see United States v. Baltimore and Ohio Railroad Co., 225 U. S. 306, 56 L. Ed. I I00, 32 Sup. Ct. 817.

I I United States v. Louisiana and Pacific Railway Co., (Tap Line Cases), 234 U. S. I, 58 L. Ed. I 85,34 Sup. Ct. 74I. The court here said: - "Because we reach the conclusion that the tap lines involved in these appeals are common carriers, as well of proprietary as nonproprietary traffic, and as such entitled to participate in joint rates with other common carriers that determination falls far short of deciding, indeed does not at all decide, that the division of such joint rates may be made at the will of the carriers involved and without any power of the Commission to control. That body has the authority and it is its duty to reach all un. lawful discriminatory practises resulting in favoritism and unfair advantages to particular shippers or carriers. It is not only within its power, but the law makes it the duty of the Commission to make orders which shall nullify such practises resulting in rebating or preferences, whatever 
Conversely railroads may charge shippers for services rendered off their own lines and outside of the mere field of transportation. ${ }^{12}$ Such charges will not be permitted except for some distinct service outside of the contract of shipment for which separate compensation might be demanded. For example, the switching of cars to side tracks involving no greater haul than to the public terminal, may not be made the basis of an extra charge beyond that for the line transportation, but the switching of such cars into and about a plant clearly constitute services not accessorial to transportation in their character and should therefore be made the subject of reasonable charges by the carriers. ${ }^{19}$ And

form they take and in whatsoever guise they may appear. If the divisions of joint rates are such as to amount to rebates or discriminations in favor of the owners of the tap lines because of their disproportionate amount in view of the service rendered, it is within the province of the Commission to reduce the amount so that a tap line shall receive just compensation only for what it actually does."

See also United States v. Butler County Railroad, 234 U. S. 29, 58 L. Ed. I 196, 34 Sup. Ct. 748; Mitchell Coal Co. v. Pennsylvania Railroad Co., 230 U. S. 247,57 L. Ed. I 472,33 Sup. Ct. 916.

I2 Interstate Commerce Commission v. Stickney, 215 U. S. 98, 54 L. Ed. I12, 30 Sup. Ct. 66, where the court said:-"For services that it may render or procure to be rendered off its own line, or outside the mere matter of transportation over its line, it may charge and receive compensation."

I3 Interstate Commerce Commission v. Atchison, Topeka and Santa Fe Railway Co., (Los Angeles Switching Case), 234 U. S. 294, 58 L. Ed. I3I9, 34 Sup. Ct. 8I4, involving the question of additional charges made by the railroads for a switching service in lieu of the delivery of the cars in question at the public terminals. The court said:- "The Commission conceded the right of the carrier to charge for any terminal service that was accessorial. But it was held that an additional charge was not justified if additional service was not in fact rendered. Nor do we understand that the Commission ruled that the receipt and delivery of goods at plants located upon spurs or side-tracks could not, in any circumstances, be regarded as a distinct service for which separate compensation might be demanded. Cases of an interior movement of plant traffic to and from various parts of the establishment, and of deliveries through a system of interior switching tracks constructed as plant facilities, were expressly distinguished by the Commission ( 18 I. C. C. pp. 313,314 ); and it is apparent that the ruling of the Commission would not apply in any case where by reason of the location and extent of the spur tracks and the character of the movement the facts were essentially different from those upon which the decision was based. (Interstate Commerce Commission v. Stickney, 215 U. S. 98, 105, 54 L. Ed. 112, 30 Sup. Ct. 66.) On the other hand, it cannot be maintained that the delivery and receipt of goods on industrial 
so the carrier is entitled to compensation where shipments are stopped in transit for inspection and reloading for the benefit of the shipper. ${ }^{14}$

While under proper conditions a carrier might lease the tracks of a shipper yet if these tracks constitute but a part of the plant facilities and are not instrumentalities necessary for the discharge of the public function of transportation any payments for the use of the tracks are unlawful and constitute a rebate. ${ }^{15}$

And where the carrier renders some such extraneous service to the shipper it is not limited to charging the actual cost thereof but it is justified in receiving some compensation in addition thereto. ${ }^{10}$ This is especially true when the privilege in question is in no sense a part of the transportation, but is outside thereof.

Control Exercised by Commission under Section 15.-Many examples might be cited from the decisions of the Supreme Court to illustrate the powers granted by this section to the Commission and their exercise by that body in the matter of railroad rates and regulations. For instance, in enforcing an equitable distribution of coal cars in times of shortage to which extended

spur tracks within the switching limits in a city is necessarily an added service for which the carrier is entitled to make, or should make, a charge additional to the line-haul rate to or from that city, when the line-haul rate embraces a receiving and delivering service for which the spur track service is a substitute."

14 Southern Railway Co. v. St. Louis Hay and Grain Co., 214 U. S. 297, 53 L. Ed. 1004, 29 Sup. Ct. 678.

I5 Chicago and Alton Railway Co. v. United States, 212 U. S. 563, 53 L. Ed. 653, 29 Sup. Ct. 689, affirming I56 Fed. 559, affirming I48 Fed. 646. See also the discussion of this case under the treatment of the Elkins Act.

I6 Southern Railway Co. v. St. Louis Hay and Grain Co., 2I4 U. S. 297, 53 L. Ed. I004, 29 Sup. Ct. 678, supra, where the court said:- "If the stopping for inspection and reloading is of some benefit to the shipper and involves some service by and expense to the railway company, we do not think that the latter is limited to the actual cost of that privilege. It is justified in receiving some compensation in addition thereto. A carrier may be under no obligations to furnish sleeping or other accommodations to its pasengers, but if it does so it is not limited in its charges to the mere cost, but may rightfully make a reasonable profit out of that which it does furnish. Especially is this true when, as here, the privilege is in no sense a part of the transportation, but outside thereof. Whether the conclusion of the Commission that the carrier is under no obligations to permit the interruption of the transit is right, and whether it is or is not under such obligation, it is entitled to receive some compensation beyond the mere cost for that which it does." 
reference has already been made. ${ }^{17}$ In ordering the discontinuance of certain discriminations involved in leasing wharfage rights and facilities to a single shipper. ${ }^{18}$ In instructions to railroads regarding cartage charges and their inclusion in terminal charges under certain conditions. ${ }^{19}$ In investigating rates and pronouncing them unreasonable and prescribing other rates, even where compliance with such order involves a change in basing points formerly fixed by the carriers for determining charges and rates. ${ }^{20}$ In the discontinuance of switching charges where such service really constitutes a portion of the line haul. ${ }^{21}$ In the control of lighterage allowances, ${ }^{22}$ and elevator allowances for grain in transit. ${ }^{23}$ In the regulation of charges or allowances connected with the pre-cooling and pre-icing of perishable goods. ${ }^{24}$ In preventing a railroad from discriminating against another road by refusing to accept its cars or grant switching facilities to its cars within the switching limits of a town on their lines, although it performs such services for other roads for a proper charge. ${ }^{24 a}$

Powers of Commission in Regulation of Rates, etc.-First of all, the power of the Interstate Commerce Commission to alter or to make rates depends upon whether those in existence are reasonable. And if there is no evidence to show that the rates in force are unreasonable, or otherwise violative of the Act to Reg-

17 Interstate Commerce Commission v. Illinois Central R. R. Co., 215 U. S. 452, 54 L. Ed. 280, 30 Sup. Ct. I55; Baltimore and Ohio Railroad Co. v. Pitcairn Coal Co., 215 U. S. 48I, 54 L. Ed. 292, 30 Sup. Ct. I64; Morrisdale Coal Co. v. Pennsylvania Railroad Co., 230 U. S. 304, 57 L. Ed. 1494, 33 Sup. Ct. 938.

18 Southern Pacific Terminal Co. v. Interstate Commerce Commission, 219 U. S. 498, 55 L. Ed. 310, 3I Sup. Ct. 279.

19 Interstate Commerce Commission v. Detroit, Grand Haven and Milwaukee Railway Co., 167 U. S. 633, 42 L. Ed. 310, 17 Sup. Ct. 957.

20 Interstate Commerce Commission v. Chicago, Rock Island and $\mathrm{Pa}$ cific Railway Co., 218 U. S. 88, 54 L. Ed. 946, 30 Sup. Ct. 65I.

2 I Interstate Commerce Commission $\mathrm{v}$ Atchison, Topeka and Santa Fe Railway Co., (Los Angeles Switching Case), 234 U. S. 294, 58 L. Ed. I3I9, 34 Sup. Ct. 814.

22 United States v. Baltimore and Ohio Railroad Co., 23I U. S. 274, 58 L. Ed. 218, 34 Sup. Ct. 75.

23 Interstate Commerce Commission v. Diffenbaugh, 222 U. S. 42, 56 L. Ed. 83, 32 Sup. Ct. 22 ; Union Pacific Railroad Co. v. Updike Grain Co., 222 U. S. 215, 56 L. Ed. 17 I, 32 Sup. Ct. 39.

24 Atchison, Topeka and Santa Fe Railway Co. v. United States, 232 U. S. 199, 58 L. Ed. 568, 34 Sup. Ct. 291.

24a Pennsylvania Company v. United States, decided February 23, I9I5. 
ulate Commerce, the Commission lacks jurisdiction to make the order enforcing new rates. ${ }^{25}$ And where a new and advanced rate is reasonable the railroads cannot be estopped from enforcing it merely because a lower rate has been maintained for a considerable time. ${ }^{26}$ The ordinary presumption of right and

25 Interstate Commerce Commission v. Louisville and Nashville Rail. road Co., 227 U. S. 88, 57 L. Ed. 431, 33 Sup. Ct. I85, where the court said:- "Under the statute the carrier retains the primary right to make rates, but if, after hearing, they are shown to be unreasonable, the Commission may set them aside and require the substitution of just for unjust charges. The Commission's right to act depends upon the existence of this fact, and if there was no evidence to show that the rates were unreasonable, there was no jurisdiction to make the order. Interstate Commerce Commission v. Northern Pacific Ry., 216 U. S. 538, 544, 54 L. Ed. 608 , 30 Sup. Ct. 417."

26 Southern Pacific Company v. Interstate Commerce Commission, 219 U. S. 433,55 L. Ed. 283,3 I Sup. Ct. 288 . Here it was admitted that the new rates were reasonable but it was claimed that because they were higher than the old rates which had been in force for a considerable time they would militate against certain industries and cities which had been founded and which had developed under the old rates. The court said:"Coming to the consideration of that subject, we are of opinion that the court below erred in not restraining the enforcement of the order complained of, because we see no escape from the conclusion that the order was void because it was made in consequence of the assumption by the Commission that it possessed the extreme powers which the railroad companies insist the order plainly manifests. We proceed very briefly to state the reasons which compel us to this conclusion. In the first place, when the complaint which was made to the Commission and the answer of the railroad companies to that complaint are considered they give rise to the inference that in substance the subject complained of was not the intrinsic unreasonableness of the new rate which the railroad companies substituted for the former rate, but the injury it was thought would be suffered from not continuing the old rate in force, an injury arising from circumstances extrinsic to the new rate; that is, a loss which would be suffered by substituting the higher rate, even if that rate was in and of itself reasonable and just. That such was the view entertained by the complainants when the hearing began before the Commission is too clear to require anything but statement.

"While it is true that the opinion of the Commission may contain some sentences which, when segregated from their context, may give some support to the contention that the order was based upon a consideration merely of the intrinsic unreasonableness of the rate which was condemned, we think when the opinion is considered as a whole in the light of the condition of the record to which we have referred it clearly results that it was based upon the belief by the Commission that it had the right under the law to protect the lumber interests of the Willamette Valley from the 
good faith attends the action of carriers, and there is no presumption of wrong arising from a change made in rates or charges by a carrier. ${ }^{27}$ The Commission has the power to consider the whole subject of rates and the operation of a new classification in the entire territory, where such a classification has been made by the railroads, and also how far its effect would tend to create preferences or engender discriminations, or whether such rates and classification would be just and reasonable. ${ }^{28}$ And the Commission may fix and determine rates by zones. ${ }^{2 \theta}$ The carrier is

consequences which it was deemed would arise from a change of the rate, even if that change was from an unreasonably low rate which had prevailed for some time to a just and reasonable charge for the service rendered for the future. Manifestly, this was deemed by the Commission to be the power which was being exerted, since Mr. Commissioner Harlan, joined by the chairman of the Commission, dissented on the ground that the order was an exertion of a power not possessed to give effect to a supposed equitable estoppel, and no language was inserted in the opinion to indicate to the contrary."

27 Interstate Commerce Commission v. Chicago Great Western Railway Co., 209 U. S. 108, 52 L. Ed. 705, 28 Sup. Ct. 493, where the court said:- "It must also be remembered that there is no presumption of wrong arising from a change of rate by a carrier. The presumption of honest intent and right conduct attends the action of carriers as well as it does the action of other corporations or individuals in their transactions in life. Undoubtedly when rates are changed the carrier making the change must, when properly called upon, be able to give a good reason therefor, but the mere fact that a rate has been raised carries with it no presumption that it was not rightfully done. Those presumptions of good faith and integrity which have been recognized for ages as attending human actions have not been overthrown by any legislation in respect to common carriers."

28 Cincinnati, Hamilton and Dayton Railway Co. v. Interstate Commerce Commission, 206 U. S. 142, 5I L. Ed. 995, 27 Sup. Ct. 648. Here the court said:- "We think the Commission in making an investigation on the complaint filed by the Proctor \& Gamble Company had the power, in the public interest, disembarassed by any supposed admissions contained in the statement of complaint to consider the whole subject and the operation of the new classification in the entire territory, as also how far its going into effect would be just and reasonable, would create preferences or engender discriminations; in other words, its conformity to the requirements of the Act to Regulate Commerce.

29 United States v. Atchison, Topeka and Santa Fe Railway Co.. (Intermountain Rate Case), 234 U. S. 476, 58 L. Ed. 1408, 34 Sup. Ct. 986. The court as to this power, said:- "As will be seen by the order and as we have already said for the purpose of the percentages established zones of infuence were adopted and the percentages fixed as to such zones varied or fluctuated upon the basis of the influence of the competition in the 
entitled to have a finding by the Commission that any particular charge is unreasonable and unjust before it is required to change such rate or charge. ${ }^{30}$

While an order of reparation under section 16 and an order for a new and different rate under section 15 are frequently included in the same ruling of the Commission this is not necessarily so and these questions, though growing out of the same case, may be the subject of distinct rulings. ${ }^{31}$

Two Year Limitation Upon Orders of the Commission.Section 15 provides that all orders of the Interstate Commerce Commission, except for the payment of money, shall take effect within such reasonable time, not less than thirty days, and shall continue in force for such period of time, not exceeding two years, as shall be prescribed in the order of the Commission unless the same be suspended, modified or set aside by a competent court. An appeal on a suit involving an order of the Commission will not be dismissed merely because the two year period

designated areas. As we have pointed out though somewhat modified the zones as thus selected by the Commission were in substance the same as those previously fixed by the carriers as the basis of the rate making, which was included in the tariffs which were under investigation and therefore we may put that subject out of view. Indeed, except as to questions of power there is no contention in the argument as to the inequality of the zones or percentages or as to any undue preference or discrimination resulting from the action taken. But be this as it may, in view of the findings of the Commission as to the system of rates prevailing in the tariffs which were before it, of the inequalities and burdens engendered by such system, of the possible aggrandizement unnaturally beyond the limits produced by competition in favor of the competitive points and against other points by the tariff in question, facts which we accept and which indeed are unchallenged, we see no ground for saying that the order was not sustained by the facts upon which it was based or that it exceeded the powers which the statute conferred or transcended the limits of the sound legal discretion which it lodged in the Commission when acting upon the subject before it."

30 Interstate Commerce Commission v. Stickney, 215 U. S. 98, 54 L. Ed. II2, 30 Sup. Ct. 66, where the court said:-"By section 15 the Commission is authorized and required upon a complaint to inquire and determine what would be a just and reasonable rate or rates, charge or charges. This, of course, includes all charges, and the carrier is entitled to have a finding that any particular charge is unreasonable and unjust before it is required to change such charge."

31 See Baer Brothers Mercantile Co. v. Denver \& Rio Grande Railroad Co., 233 U. S. 479, 58 L. Ed. 1055, 34 Sup. Ct. 64I. 
nominated in the statute has expired, since despite this limitation the orders of the Commission are in a measure continuing and may be the basis for later reparation proceedings. Otherwise the parties thereto might have their rights determined by the Commission without an opportunity for redress through the courts. $^{32}$ Furthermore the existence of the rate fixed for two years would have an effect upon the exercise by the railroads of their authority to fix just and reasonable rates in the future. ${ }^{39}$

32 Southern Pacific Terminal Co. v. Interstate Commerce Commission, 219 U. S. 498,55 L. Ed. 3I0, 3I Sup. Ct. 279, where it was maintained that the appeal should be dismissed since with the expiration of the statutory two years the question had become moot. The court said:- "It will be observed that the order of the Commission required appellants to cease and desist from granting Young the alleged undue preference for a period of not less than two years from September I, 1908, (subsequently extended to November I5). It is hence contended that the order of the Commission has expired and that the case having thereby become moot the appeal should be dismissed. This court has said a number of times that it will only decide actual controversies, and if, pending an appeal, something occurs without any fault of the defendant which renders it impossible, if our decision be in favor of the plaintiff, to grant him effectual relief, the appeal will be dismissed. Jones v. Montague, 194 U. S. 147, 48 L. Ed. 913 , 24 Sup. Ct. 6II, and Richardson v. McChesney, 218 U. S. 487, 54 L. Ed. II2I, 3I Sup. Ct. 43. But in those cases the Acts sought to be enjoined had been completely executed, and there was nothing that the judgment of the court, if the suits had been entertained, could have affected. The case at bar comes within the rule announced in United States v. Freight Assn., I66 U. S. 290, 308, 4 I L. Ed. 1007, 17 Sup. Ct. 540, and Boise City Irr. \& Land Co. v. Clark, I3I Fed. 4I5.

"In the case at bar the order of the Commission may to some extent (the exact extent it is unnecessary to define) be the basis of further proceedings. But there is a broader consideration. The questions involved in the orders of the Interstate Commerce Commission are usually continuing (as are manifestly those in the case at bar) and these considerations ought not to be, as they might be, defeated, by short term orders, capable of repetition, yet evading review, and at one time the Government and at another time the carriers have their rights determined by the Com. mission without a chance of redress.

33 Southern Pacific Co. v. Interstate Commerce Commission, 219 U. S. 433, 55 L. Ed. 283,3 I Sup. Ct. 288, where the court said:- "It is claimed at bar that the questions arising for decision are moot, since in consequence of the lapse of more than two years since the order of the Commission became effective, by operation of law the order of the Commission has spent its force, and therefore the question for decision is moot. The contention is disposed of by Southern Pacific Terminal Co. et al. v. Interstate Commerce Commission et $\mathrm{al}$; this day decided. In addition to the con- 


\section{Court Review of Orders of The Interstate Commerce Com-} mission.- The powers enjoyed by the Interstate Commerce Commission are conferred by statute and its findings of fact made within the scope of its administrative functions are not susceptible of judicial review. However, the courts do have the power to pass upon the orders of the Commission, in actions brought for the purpose of enforcing them or restraining their enforcement, but in so doing the courts are confined to determining whether such orders are violative of the Constitution, whether the statutory powers conferred upon the Commission have been transcended, or whether they have been exercised in such an arbitrary manner as to virtually transcend the authority conferred although they may not technically appear to do so. ${ }^{34}$ The court

siderations expressed in that case it is to be observed that clearly the suggestion is without merit, in view of the possible liability for reparation to which the railroads might be subjected if the legality of the order were not determined and the influence and effect which the existence of the rate fixed for two years, if it were legal, would have upon the exercise by the railroads of their authority to fix just and reasonable rates in the future, clearly causes the case to involve not merely a moot controversy."

34 United States v. Atchison, Topeka and Santa Fe Railway Co., (Inter-Mountain Rate Case), 234 U. S. 476, 58 L. Ed. I408, 34 Sup. Ct. 986, where the court said:- "It is of course true as pointed out in Interstate Commerce Commission v. Illinois Central Railroad, 215 U. S. 452, 470,54 L. Ed. 280, 30 Sup. Ct. 155, and since repeatedly applied that findings of fact made by the Commission within the scope of its administrative duties must be accepted in case of judicial review, but that doctrine as was also pointed out, does not relieve the courts in a proper case from determining whether the Constitution has been violated or whether statutory powers conferred have been transcended or have been exercised in such an arbitrary way as to amount to the exertion of authority not given, doctrines which but express the elementary principle that an investiture of a public body with discretion does not imply the right to abuse but on the contrary carries with it as a necessary incident the command that the limits of a sound discretion be not transcended which by necessary implication carries with it the existence of judicial power to correct wrongs done by such excess."

In Interstate Commerce Commission v. Illinois Central Railroad Commission, 215 U. S. 452,54 L. Ed. 280, 30 Sup. Ct. 155, the court said:-"The statute endowing the Commission with large administrative functions, and generally giving effect to its orders concerning complaints before it without exacting that they be previously submitted to judicial authority for sanction, it becomes necessary to determine the extent of the powers which courts may exert on the subject. Beyond controversy, in determining whether an order of the Commission shall be suspended or set aside, we 
confines itself to the ultimate question of whether the Commission has acted within its power. The court will not consider the wisdom or the expediency of the order or even whether on the same testimony it would have reached the same conclusion and

must consider; a, all relevant questions of constitutional power or right; $b$, all pertinent questions as to whether the administrative order is within the scope of the delegated authority under which it purports to have been made; and, c, a proposition which we state independently, although in its essence it may be contained in the previous one, viz., whether, even although the order be in form within the delegated power, nevertheless it must be treated as not embraced therein, because the exertion of authority which is questioned has been manifested in such an unreasonable manner as to cause it, in truth, to be within the elementary rule that the substance, and not the shadow, determines the validity of the exercise of the power. Postal Telegraph Co. v. Adams, 155 U. S. 688, 698, 39 L. Ed. 3II, I5 Sup. Ct. 360 . Plain as it is that the powers just stated are of the essence of judicial authority, and which, therefore may not be curtailed, and whose discharge may not be by us in a proper case avoided, it is equally plain that such perennial powers lend no support whatever to the proposition that we may, under the guise of exerting judicial power, usurp merely administrative functions by setting aside a lawful administrative order upon our conception as to whether the administrative power has been wisely exercised. Power to make the order and not the mere expediency or wisdom of having made it, is the question."

In Proctor and Gamble Co. v. United States, 225 U. S. 282, 56 L. Ed. 1091, 32 Sup. Ct. 761, the Supreme Court said:- "Originally the duty of the courts to determine whether an order of the Commission should or should not be enforced carried with it the obligation to consider both the facts and the law. But it had come to pass prior to the passage of the Act creating the Comnerce Court that in considering the subject of orders of the Commission, for the purpose of enforcing or restraining their enforcement, the courts were confined by statutory operation to determining whether there had been violations of the Constitution, a want of conformity to statutory authority, or of ascertaining whether power had been so arbitrarily exercised as virtually to transcend the authority conferred although it may be not technically doing so."

In Interstate Commerce Commission v. Union Pacific Railroad Co., 222 U. S. 54I, 56 L. Ed. 308, 32 Sup. Ct. I08, the court discussed thoroughly the question of judicial review of the orders of the Commission saying:"There has been no attempt to make an exhaustive statement of the principle involved, but in cases thus far decided, it has been settled that the orders of the Commission are final unless (I) beyond the power which it could constitutionally exercise; or (2) beyond its statutory power; or (3) based upon a mistake of law. But questions of fact may be involved in the determination of questions of law, so that an order, regular on its face, may be set aside if it appears that (4) the rate is so low as to be confiscatory and in violation of the constitutional prohibition against taking prop- 
made a similar ruling. ${ }^{35}$ The courts will examine the facts only so far as to determine whether there was substantial evidence to sustain the order. The court will not review the Commission's

erty without due process of law; or (5) if the Commission acted so arbitrarily and unjustly as to fix rates contrary to evidence, or without evidence to support it; or (6) if the authority therein involved has been exercised in such an unreasonable manner as to cause it to be within the elementary rule that the substance, and not the shadow, determines the validity of the exercise of the power. Interstate Commerce Commission v. Illinois Central, 215 U. S. 452, 470, 54 L. Ed. 280, 30 Sup. Ct. I55; Southern Pacific v. Interstate Commerce Commission, 219 U. S. 433, 55 L. Ed. 283, 31 Sup. Ct. 288; Interstate Commerce Commission v. Northern Pacific, 216 U. S. 538, 544, 54 L. Ed. 608, 30 Sup. Ct. 417 ; Interstate Commerce Commission v. Alabama Midland, 168 U. S. 144, 174, 42 L. Ed. 414, 18 Sup. Ct. 45.

"In determining these mixed questions of law and fact, the court confines itself to the ultimate question as to whether the Commission acted within its power. It will not consider the expediency or wisdom of the order, or whether on like testimony, it would have made a similar ruling. 'The findings of the Commission are made by law prima facie true, and this court has ascribed to them the strength due to the judgments of a tribunal appointed by law and informed by experience.' Illinois Central v. I. C. C., 206 U. S. 44I, 5I L. Ed. 1 1 28, 27 Sup. Ct. 700 . Its conclusion, of course, is subject to review, but when supported by evidence is accepted as final; not that its decision, involving as it does so many and such vast public interests, can be supported by a mere scintilla of proof-but the courts will not examine the facts further than to determine whether there as substantial evidence to sustain the order." Pennsylvania Company v. United States, decided February 23, 1915, where the court said:- "If the order made by the Commission does not contravene any constitutional limitation and is within the constitutional and statutory authority of that body, and not unsupported by testimony, it cannot be set aside by the courts, as it is only the exercise of an authority which the law vests in the Commission. Interstate Commerce Commission v. Delaware, Lackawana and Western R. R. Co., 220 U. S. 235, 25I, 55 L. Ed. 448, 31 Sup. Ct. 392; Los Angeles Switching Case, 234 U. S. 294, 31 I, 58 L. Ed. 1319, 34 Sup. Ct. 814; Houston and Texas Railway v. United States, 234 U. S. 342, 359, 58 L. Ed. 1341, 34 Sup. Ct. 833."

35 Baltimore and Ohio Railroad v. Pitcairn Coal Co., 215 U. S. 481, 54 L. Ed. 292, 30 Sup. Ct. 164, where the court said:-"In considering section 15 in the case of Illinois Central Railroad Co. v. Interstate Commerce Commission, just decided, it was pointed out that the effect of the section was to cause it to come to pass that courts, in determining whether an order of the Commission should be suspended or enjoined, were without power to invade the administrative functions vested in the Commission, and therefore could not set aside an order duly made on a mere exercise of judgment as to its wisdom or expediency." 
findings of fact by passing upon the credibility of witnesses or conflicts in the testimony. But the legal effect of evidence is a question of law and a finding without evidence transcends the power of the Commission and therefore, being contrary to law, may be set aside by the proper court. ${ }^{38}$ The court will not enter upon a new and independent investigation of facts-since that is a matter within the province of the Commission-even to sustain the orders of that body. ${ }^{37}$ However, the fact that there is

See also Interstate Commerce Commission v. Union Pacific Railway Co., 222 U. S. 54I, 56 L. Ed. 308, 32 Sup. Ct. I08, supra, and other cases just cited.

36 Interstate Commerce Commission v. Louisville and Nashville Railroad Co., 227 U. S. 88, 57 L. Ed. 43I, 33 Sup. Ct. I85, where the court said:- "Under the statute the carrier retains the primary right to make rates, but if, after hearing, they are shown to be unreasonable, the Commission may set them aside and require the substitution of just for unjust charges. The Commission's right to act depends upon the existence of this fact, and if there was no evidence to show that the rates were unreasonable, there was no jurisdiction to make the order. Interstate Commerce Commission v. Northern Pacific Railway, 216 U. S. 538, 544, 54 L. Ed. 608 , 30 Sup. Ct. 417 . In a case like the present the court will not review the Commission's conclusions of fact (Interstate Commerce Commission v. Delaware, Lackawana and Western R. R. Co., 220 U. S. 235, 55 L. Ed. 448, 3I Sup. Ct. 392), by passing upon the credibility of witnesses, or conflicts in the testimony. But the legal effect of evidence is a question of law. A finding without evidence is beyond the power of the Commission. An order based thereon is contrary to law and must, in the language of the statute, "be set aside by a court of competent jurisdiction.'"

In Florida East Coast Railway Co. v. United States, 234 U. S. 167, 58 L. Ed. 1267, 34 Sup. Ct. 867, the court said:-"While a finding of fact made by the Commission concerning a matter within the scope of the authority delegated to it is binding and may not be re-examined in the courts, it is undoubted that where it is contended that an order whose enforcement is resisted was rendered without any evidence whatever to support it, the consideration of such a question involves not an issue of fact, but one of law which it is the duty of the courts to examine and decide. (I. C. C. v. Louis. and Nash. R. R. 227 U. S. 88, 91, 92, 57 L. Ed. 431, 33 Sup. Ct. 185, and cases cited.) *** But coming to make a review of the testimony before the Commission on the issue raised by the second supplemental petition, we fail to find the slightest proof tending to sustain the reduction in rates as to the East Coast line, which was made."

See also Interstate Commerce Commission v. Delaware, Lackawanna and Western Railroad Co., 220 U. S. 235, 55 L. Ed. 448, 31 Sup. Ct. 392.

37 Interstate Commerce Commission v. Chicago, Burlington and Quincy Railroad, 186 U. S. 320,46 L. Ed. 1182, 22 Sup. Ct. 824, where the court said:- "Being then constrained to the conclusion that the order of the 
no conflicting or disputed evidence before the Commission does not make of it a question of law upon which it is the province of the courts to reach an independent conclusion. ${ }^{38}$ The court may

Commission was not sustained by the facts upon which it was predicated, we cannot enter into an independent investigation of the facts, even if it be conceded the record is in a condition to enable us to do so, in order that new and substantive findings of fact may be evolved, upon which the order of the Commission may be sustained. (Louisville, etc., R. R. Co. v. Behlmer, I75 U. S. 648, 675, 44 L. Ed. 309, 20 Sup. Ct. 209.)"

38 United States v. Louisville and Nashville R. R. Co., 235 U. S. 3I4, 59 L. Ed. - where the Suprem Court said-"The Commerce Court, finding that there was no conflicting or disputed evidence concerning the origin and character of the reshipping privilege, concluded that whether such privilege was an undue preference was not a matter of fact but a question of law upon which it was its duty to reach an independent conclusion.

"In view of the doctrine announced in Interstate Commerce Commission v. Illinois Cent. R. R., 2I5 U. S. 452, 54 L. Ed. 280, 30 Sup. Ct. I55; Interstate Commerce Commission v. Delaware, L. \& W. R. Co., 220 U. S. 235, 55 L. Ed, 448, 3I Sup. Ct. 392 ; Interstate Commerce Commission v. Louisville and Nashville R. R., 227 U. S. 88, 57 L. Ed. 43I, 33 Sup. Ct. 185, it plainly results that the court below in substituting its judgment as to the existence of preference for that of the Commission on the ground that where there was no dispute as to the facts it had a right to do so, obviously exerted an authority not conferred upon it by the statute. It is not disputable that from the beginning the very purpose for which the Commission was created was to bring into existence a body which from its peculiar character would be most fitted to primarily decide whether from facts, disputed or undisputed, in a given case preference or discrimination existed. East Tennessee, etc., Ry. Co. v. Interstate Commerce Commission, I8I U. S. I, 23-29, 45 L. Ed. 7I9, 2I Sup. Ct. 5I6. And the amendments by which it came to pass that the findings of the Commission were made not merely prima facie but conclusively correct in case of judicial review, except to the extent pointed out in the Illinois Central and other cases, supra, show the progressive evolution of the legislative purpose and the inevitable conflict which exists between giving that purpose effect and unholding the view of the statute taken by the court below. It cannot be otherwise since if the view of the statute upheld below be sustained, the Commission would become but a mere instrument for the purpose of taking testimony to be submitted to the courts for their ultimate action.

"While these conclusions demonstrate the error in the action of the court below, that result does not authorize us to reverse and give effect to the order of the Commission without going further, since it must be determined whether the action of the Commission was repugnant to the Constitution, in excess of the powers which that body possessed, or, what is equivalent thereto, was wholly unsustained by proof,-questions which the 
not substitute its judgment for that of the Commission on the ground that there is no dispute as to the facts involved-since no such authority is conferred by the statute. Otherwise, in the words of the Supreme Court, "the Commission would become but a mere instrument for the purpose of taking testimony to be submitted to the courts for their ultimate action."

It is thus beyond the power of the Interstate Commerce Commission to regulate the policy of carriers in fixing rates and to compel them to substitute a lower rate for one that is just and reasonable, and an order to that effect will be set aside by the proper courts. ${ }^{39}$ And, before the amendment of I9Io, it was held that the public preference for another route no shorter and no better than one existing was not sufficient to give the Commission power under the Act to fix a through route where no reasonable or satisfactory route existed. ${ }^{40}$

In the matter of orders based on administrative functions of the Commission, such for instance as orders regulating the dis-

court below failed to pass upon because of the erroneous conception in which it indulged concerning its own powers."

39 Southern Pacific Company v. Interstate Commerce Commission, 219 U. S. 433, 55 L. Ed. 283, 3 I Sup. Ct. 288, supra, where the court said:"In the argument at bar the railroad companies do not question that if a complaint is made to the Interstate Commerce Commission concerning the unreasonableness of a rate that body has the authority to examine the subject, and if it finds the rate complained of is in and of itself unreasonable, having regard to the service rendered, to order the desisting from charging such rate, and to fix in a new and reasonable rate, to be operative for a period of two years. The companies further do not deny that where the Commission exercises such authority, its finding is not subject to be reviewed by the court. (Interstate Commerce Commission v. Illinois Central Railroad Co., 215 U. S. 452, 54 L. Ed. 280, 30 Sup. Ct. 155. In other words, the argument on behalf of the railroads fully concedes that an order of the Commission is not open to attack in the courts so long as that body has kept within the powers conferred by the statute. * * * The insistence is that both in form and in substance the order of the Commission is roid, because it manifests that that body did not merely exert the power conferred by law to correct an unjust and unreasonable rate, but that it made the order which is complained of upon the theory that the power was possessed to set aside a just and reasonable rate lawfully fixed by a railroad whenever the Commission deemed that it would be equitable to shippers in a particular district to put in force a reduced rate." The order of the Commission was set aside.

40 Interstate Commerce Commission v. Northern Pacific Railway Co., 216 U. S. 538,54 L. Ed. 608 , 30 Sup. Ct. 417, supra. 
tribution of coal and fuel cars, the courts cannot interfere until after the Commission has acted and then merely to determine not their wisdom or expediency but only their legality within the limitations already set forth. ${ }^{41}$ And an action for reparation for wrongful charges requires as a precedent condition an investigation and order by the Commission, although as pointed out under section 16 , the order permitting reparation and the order fixing new and proper rates for the future may or may not be a part of the same ruling. ${ }^{42}$

$4 \mathrm{I}$ Baltimore and Ohio Railroad Co. v. Pitcairn Coal Co., 215 U. S. 48I, 54 L. Ed. 292, 30 Sup. Ct. 164. The court here said:-"When the situation is thus defined we see no escape from the conclusion that the grievances complained of were primarily within the administrative competency of the Interstate Commerce Commission and not subject to be judicially enforced, at least until that body, clothed by the statute with authority on the subject, had been afforded by a complaint made to it the opportunity to exert its administrative functions."

Morrisdale Coal Co. v. Pennsylvania Railroad Co., 230 U. S. 304, 57 L. Ed. 1494, 33 Sup. Ct. 938, where the court said:- "These rulings as to the validity of a particular practise and the facts that would warrant a departure from a proper rule actually in force, are sufficient to show that the question as to the reasonableness of a rule of car distribution is administrative in its character and calls for the exercise of the powers and discretion conferred by Congress upon the Commission. It was distinctly so ruled in the Pitcairn case (215 U. S. 481, 54 L. Ed. 292, 30 Sup. Ct. 164), and in I. C. C. v. Illinois Central, (2I5 U. S. 452, 54 L. Ed. 280, 30 Sup. Ct. 155). Those cases involved a consideration of the power of the Commission over the distribution of cars and held that the courts could not by mandamus compel it to make a rule, nor by injunction restrain the enforcement of one it had promulgated. If in those direct proceedings the courts could not pass upon the question of reasonablencss of a method of allotting cars, neither can it do so as an incident to an action for damages."

See also United States v. Pacific and Arctic Railway and Navigation Co., 228 U. S. 87, 57 L. Ed. 742, 33 Sup. Ct. 433.

42 Robinson v. Baltimore and Ohio Railroad Co., 222 U. S. 506. The court, as to this, said:- "When the purpose of the Act and the means selected for the accomplishment of that purpose are understood, it is altogether plain that the Act contemplated that such an investigation and order by the designated tribunal, the Interstate Commerce Commission, should be a prerequisite to the right to seek reparation in the courts because of exactions under an established scliedule alleged to be violative of the prescribed standards. And this is so, because the existence and exercise of a right to maintain an action of that character, in the absence of such an investigation and order, would be repugnant to the declared rule that a rate established in the mode prescribed should be deemed the legal rate and obligatory alike upon carrier and shipper until changed in the 
When a carrier has been adjudged guilty of having violated certain provisions of the Act to Regulate Commerce the injunction issued by the court can relate only to the sections actually violated and should not command the carrier in general terms not to violate the Act in the future in any particular whatsoever. ${ }^{43}$

manner provided, would be in derogation of the power expressly delegated to the Commission, and would be destructive of the uniformity and equality which the Act was designed to secure."

See also Bear Brothers Mercantile Co. v. Denver and Rio Grande Railroad Co., 233 U. S. 479, 58 L. Ed. 1055, 34 Sup. Ct. 641.

43 New York, New Haven and Hartford Railroad Co. v. Interstate Commerce Commission, 200 U. S. 36I, 50 L. Ed. 515, 26 Sup. Ct. 272, where the court said:- "The contention therefore is that whenever a carrier has been adjudged to have violated the Act to Regulate Commerce in any particular it is the duty of the court, not only to enjoin the carrier from further like violations of the Act, but to command it in general terms not to violate the Act in the future in any particular. In other words, the proposition is that by the effect of a judgment against a carrier concerning a specific violation of the Act, the carrier ceases to be under the protection of the law of the land and must thereafter conduct all its business under the jeopardy of punishment for contempt for violating a general injunction. To state the proposition is, we think, to answer it. (Swift and Company v. United States, I96 U. S. 375, 49 L. Ed. 518, 25 Sup. Ct. 276.) The contention that the cited case is inapposite because it did not concern the Act to Regulate Commerce, but involved a violation of the Anti-Trust Act, we think is also answered by the mere statement of the proposition. The requirement of the Act to Regulate Commerce that a court shall enforce an observance of the statute against a carrier who has been adjudged to have violated its provisions, in no way gives countenance to the assumption that Congress intended that a court should issue an injunction of such a general character as would be violative of the most elementary principles of justice." 


\section{SECTION I6. ORDERS OF THE COMMISSION.}

SEC. I6. (Amended March 2, 1889, June 29,

A ward of damages by Commission.

To be en forced by courts.

Findings of fact of Commis evidence in rep. aration cases.

Petitioner's at. torney's fees.
1906, and June I8, 1910.) That if, after hearing on a complaint made as provided in section 13 of this Act, the Commission shall determine that any party complainant is entitled to an award of damages under the provisions of this Act, for a vioiation thereof, the Commission shall make an order directing the carrier to pay to the complainant the sum to which he is entitled on or before a day named.

If a carrier does not comply with an order for the payment of money within the time limit in such order, the complainant, or any person for whose benefit such order was made, may file in the Circuit Court of the United States for the district in which he resides or in which is located the principal operating office of the carrier, or through which the road of the carrier runs, or in any state court of general jurisdiction having jurisdiction of the parties, a petition setting forth briefly the causes for which he claims damages, and the order of the Commission in the premises. Such suit in the Circuit Court of the United States shall proceed in all respects like other civil suits for damages, except that on the trial of such suit the findings and order of the Commission shall be prima facie evidence of the facts therein stated, and except that the petitioner shall not be liable for costs in the Circuit Court nor for costs at any subsequent stage of the proceedings unless they accrue upon his appeal. If the petitioner shall finally prevail he shall be allowed a reasonable attorney's fee, to be taxed and collected as a part of the costs of the suit. All complaints for the recovery of damages shall be filed with the Commission within two years from the time the cause 
of action accrues, and not after, and a petition for the enforcement of an order for the payment of money shall be filed in the Circuit Court or state court within one year from the date of the order, and not after.

In such suits all parties in whose favor the Commission may have made an award for damages by a single order may be joined as plaintiffs, and all of the carriers parties to such order awarding such damages may be joined as defendants, and such suit may be maintained by such joint plaintiffs and against such joint defendants in any district where any one of such joint plaintiffs could maintain such suit against any one of such joint defendants; and service of process against any one of such defendants as may not be found in the district where the suit is brought may be made in any district where such defendant carrier has its principal operating office. In case of such joint suit the recovery, if any, may be by judgment in favor of any one of such plaintiffs, against the defendant found to be liable to such plaintiff.

Every order of the Commission shall be forthwith served upon the designated agent of the carrier in the city of Washington or in such other manner as may be provided by law.

The Commission shall be authorized to suspend or modify its orders upon such notice and in such manner as it shall deem proper.

It shall be the duty of every common carrier, its agents and employees, to observe and comply with such orders so long as the same shall remain in effect.

Any carrier, any officer, representative, or agent of a carrier, or any receiver, trustee, lessee, or agent of either of them, who knowingly fails or neglects to obey any order made under the provisions of sec-

Commis s ion may suspend or modify order.

Cartiers, their agents and employees, must comply with such orders.

Punishment by forfeiture for refusal to obey order of Com. mission under section 15 . tion 15 of this Act shall forfeit to the United States the sum of five thousand dollars for each offense. Every distinct violation shall be a separate offense, and in case of a continuing violation each day shall be deemed a separate offense. 
Forfei ture pa y a ble into treasury and recoverable in civil suit.

Duty of district attorneys to prosecute.

Costs and expenses to be paid out of ap. propriation for court expenses.

Commis $\mathrm{s}$ i o $\mathrm{n}$ may employ at. torneys.

Commerce Court to enforce orders other than for pay. ment of money.
The forfeiture provided for in this Act shall be payable into the treasury of the United States, and shall be recoverable in a civil suit in the name of the United States, brought in the district where the carrier has its principal operating office, or in any district through which the road of the carrier runs.

It shall be the duty of the various district attorneys, under the direction of the Attorney General of the United States, to prosecute for the recovery of forfeitures. The costs and expenses of such prosecution shall be paid out of the appropriation for the expenses of the courts of the United States.

The Commission may employ such attorneys as it finds necessary for proper legal aid and service of the Commission or its members in the conduct of their work or for proper representation of the public interests in investigations made by it or cases or proceedings pending before it, whether at the Commission's own instance or upon complaint, or to appear for and represent the Commission in any case pending in the Commerce Court; and the expenses of such employment shall be paid out of the appropriation for the Commission.

If any carrier fails or neglects to obey any order of the Commission other than for the payment of money, while the same is in effect, the Interstate Commerce Commission or any party injured thereby, or the United States, by its Attorney General, may apply to the Commerce Court for the enforcement of such order. If, after hearing, that court determines that the order was regularly made and duly served, and that the carrier is in disobedience of the same, the court shall enforce obedience to such order by a writ of injunction or other proper process, mandatory or otherwise, to restrain such carrier, its officers, agents, or representatives, from further disobedience of such order, or to enjoin upon it or them obedience to the same. 
The copies of schedules and classifications and tariffs of rates, fares, and charges, and of all contracts, agreements, and arrangements between common carriers filed with the Commission as herein provided, and the statistics, tables, and figures contained in the annual or other reports of carriers made to the Commission as required under the proSched u les, contracts, and annual reports filed with Com$\mathrm{mis}$ sion are public records receivable as prima facie evidence. Certified copies or extracts therefrom also prima facie evidence. visions of this Act shall be preserved as public records in the custody of the secretary of the Commission, and shall be received as prima facie evidence of what they purport to be for the purpose of investigations by the Commission and in all judicial proceedings; and copies of and extracts from any of said schedules, classifications, tariffs, contracts, agreements, arrangements, or reports, made public records as aforesaid, certified by the secretary, under the Commission's seal, shall be received in evidence with like effect as the originals.

History of the Section.- Somewhat amended in 1889 , the sixteenth section was substantially rewritten by the Act of June 29, 1906, to accord with the revolutionary changes made in the power and jurisdiction conferred upon the Interstate Commerce Commission in the fifteenth section by that Act. Under the section as originally enacted the orders of the Commission were enforced by the courts upon the petition of that body, the findings of fact rendered by the Commission being prima facie evidence of the matters considered. By the amendment of March 2, I889, the right of trial by jury was saved in line with the seventh amendment to the Constitution.

The principal changes made in the section by the Act of June 29, 1906, were-the provision for limiting the time within which actions might be brought; for service of the orders of the Commission by registered mail; penalties assessed upon carriers for neglect or failure to observe such orders; the enforcement of reparation orders; schedules, contracts, tariffs, agreements and reports filed with the Commission and certified copies to be prima facie evidence; a provision for the venue of suits brought against the Commission and the application of the provisions of the Expediting Act thereto, and the proper regulation of procedure in such cases and for appeals to the Supreme Court only from either final or interlocutory orders in such suits. 
By the amendments of Section 16 under the Act of June 18 , I9IO, provision was made for the institution of suits in courts of the states, for service upon a designated agent of the carrier in Washington instead of by registered mail and for the employment of necessary attorneys by the Commission-and without the necessity of securing the consent of the Attorney General as provided in the Act of June 29, 1906.

Future Rate Need not be Determined by Commission before Order of Reparation.- The two subjects of reparation and rates may be dealt with in one order but awarding reparation for the past and fixing rates for the future involve the determination of essentially different matters. The former involves the quasi-judicial capacity of the Commission in measuring past injuries received by an individual; the latter the quasi-legislative capacity of that body in preventing future injury to the public. As suggested, the one is of a private and the other of a public nature. The unreasonableness of a past rate and the determination of the future rate can be, and they often are, disposed of by the Commission by the same order. But this is not necessarily so. Under the original form of the Act to Regulate Commerce, the two questions could not be combined in a single order for the reason that at that time while the Interstate Commerce Commission could require the carrier to desist from unreasonable practises and award damages, it could not fix rates. The result of this situation was most anomalous. For after a shipper had obtained an order of reparation because of an unreasonable rate which the railroad was ordered to discontinue, a slightly different, but none the less unreasonable, rate might be charged by the carrier for the future, which the shipper was forced to pay and again institute proceedings for reparation. The Hepburn Act relieved this situation by conferring upon the Interstate Commerce Commission the new power to determine rates for the future in addition to its already existing power to make reparation. However, the two matters are dealt with in separate sections of the Act and treated as different subjects. Thus, section 4 of the Hepburn Act (section 15 of the amended Act to Regulate Commerce) conferred upon the Commission power to make rates, while section 5 of that Act (section 16 of the Act to Regulate Commerce) gave the Commission power to make reparation orders. Not merely were the two subjects separately treated in the legislation, but there is no such necessary connection between 
them, or interrelation, as to make the quasi-judicial order for reparation depend for its validity upon being joined with a quasilegislative order fixing rates for the future. Persons entitled to the one may have no interest in the other. Those interested in both might be entitled to reparation and not to a new rate; or vica versa, they might be entitled to a new rate and not to reparation. For instance, under section 13 of the Act any mercantile or agricultural society, or municipal organization may make complaints to the Commission against a carrier. Upon the application of such bodies, the old rates might be declared unjust and new rates established. But, manifestly, no reparation would be ordered for the reason that such complainants were not shippers and thus not entitled to an award of pecuniary damages. ${ }^{1}$ Fur-

I Baer Brothers Mercantile Co. v. Denver and Rio Cirande Railroad Co., 233 U. S. 479,58 L. Ed. 1055, 34 Sup. Ct. 64I. The plaintiff brought proceedings before the Interstate Commerce Commission to have the rate between St. Louis and Leadville, Colorado, declared unreasonable and unjust, to have a new and just rate established and to require the railroads to make a certain payment as reparation for excess rates paid on shipments already made between those points. The Commission ordered the payment of a certain amount by way of reparation for unreasonable charges and left for future decision the fixing of a new and just rate. When the case reached the Circuit Court of Appeals that court reversed the judgment of the lower court in the suit based on the order of the Commission, declaring that the order was void on its face and could not be the basis of recovery for the reason that, while reparation had been awarded on the ground that the old rate was unreasonable, the Commission had not fixed a new and just rate for the future.

The Supreme Court said:- "That the two subjects of reparation and rates may be dealt with in one order is undoubtedly true. Abilene $v$. Texas and Pacific Ry., 204 U. S. 426, 446, 5 I L. Ed. 553, 27 Sup. Ct. 350; Robinson v. Baltimore and Ohio Railroad, 222 U. S. 506, 56 L. Ed. 288, 32 Sup. Ct. II 4. But awarding reparation for the past and fixing rates for the future involve the determination of matters essentially different. One is in its nature private and the other public. One is made by the Commission in its quasi-judicial capacity to measure past injuries sustained by a private shipper; the other, in its quasi-legislative capacity, to prevent future injury to the public. But testimony showing the unreasonableness of a past rate may also furnish information on which to fix a reasonable future rate and both subjects can be, and often are, disposed of by the same order. This, however, is not necessarily so. Indeed, under the original Commerce Act, the two matters could not possibly be combined in a single order for the reason that, while at that time the Commission could order the carrier to desist from unreasonable practises and award damages, it could not fix rates. This brought about an anomalous state of 
ther a rate, reasonable when made, might become unreasonable as the result of a change in conditions, so that no reparation would be ordered even though a new rate were established for the fu-

affairs. For if the shipper obtained his order of reparation because of unreasonable charges which the railroad company was ordered to discontinue, a slightly different, but still unreasonable, rate might be put in for the future, which the shipper had to pay and again institute proceedings for reparation. 24 Stat. 384 , sec. 15 .

"This situation was dealt with by the Hepburn Act, which, in addition to the existing power to make reparation, conferred upon the Commission the new power to make rates for the future. But the two matters were treated as different subjects and were dealt with in separate sections. Section 4 conferred the power of making rates. Section 5 gave the Commission power to make reparation orders. 34 Stat. 589, Sec. 4; 590, Sec. 5. Not only were the two functions separately treated, but an analysis of the Act shows that there is no such necessary connection between them as to make the quasi-judicial order for reparation depend for its validity upon being joined with a quasi-legislative order fixing rates. Persons entitled to one may have no interest in the other. Persons interested in both may be entitled to reparation and not to a new rate; or to a new rate and not to reparation. For example,-section 13 permits 'any mercantile, agricultural or manufacturing society or any body politic or municipal organization to make complaints against the carrier.' On the application of such bodies, old rates might be declared unjust and new rates established, but, of course, no reparation would be given, for the reason that such complainants were not shippers and, therefore, not entitled to an award of pecuniary damages. cf. Louisville, etc., R. R. v. I. C. C., 227 U. S. 88,57 L. Ed. 43I, 33 Sup. Ct. 185 . The1, too, there are cases in which a rate, reasonable when made, becomes unreasonable as the result of a gradual change in conditions so that no reparation is ordered even though a new rate be established for the future. Anadarko Cotton Oil Co. v. Atchison, etc., Rwy., 20 I. C. C. 43. Conversely, there may be cases where what was an unreasonable rate in the past is found to be reasonable at the date of the hearing. In such a case reparation would be awarded for past unreasonable charges collected but no new rate would be established for the future.

"It may, however, be said that even in such a case, the order while con. demning the rate for the past, should contain a provision validating it for the future. But while this consideration might show that it was erroneous not to name the new rate, it would not follow that the order awarding reparation was void. The Hepburn Act treats the two subjects as related, but independent. The grounds of complaint may be joint or separate, and the very fact that they may sometimes be separate shows that the presence of both is not jurisdictional, and that the absence of a provision for one need not operate to invalidate an order as to the other. This conclusion is strengthened by considering the hardships that would result from nullifying a reparation order for error in omitting a provision 
ture. On the other hand, a rate unreasonable in the past may be found reasonable at the date of the hearing. Of course in such a case reparation would be awarded for past unreasonable

for the future rate. It would punish the shipper for the failure of the Commission. It would deprive him of his award of damages for his private injury, because of the Commission's omission to make a rate for the benefit of the public. The shipper might or might not intend to remain in business. He might or might not be interested in future rates. He might have been able to prove unreasonableness as to the past without being able to furnish evidence as to what would be reasonable for the future. Or, the Commission might be in position to say with certainty that the rates had been unreasonable and award reparation accordingly, but it might require a protracted and lengthy hearing to establish what would be just for the future. To make the shipper wait on such a finding and deprive him of his present right to reparation, until the determination of an independent question, would work a hardship not contemplated by the Act and not required by any of its provisions.

"The present case illustrates some of these features. The plaintiff's petition asks for reparation and that the Commission would establish just rates. On the hearing it appeared that there was no through route or joint rate and that the established local charge of one of the carriers was just while that of the other had not been established or included in a filed tariff and was also unjust. The evidence was sufficient to sustain a finding of damages against such carrier, but it did not show how the through rate should be divided between the two companies, one of which hauled 923 miles and the other 160 miles. The carriers did not ask for an extension of the time within which the reparation should be paid. The fact that they were given an opportunity to agree on a through rate and how it should be divided, ought not to deprive plaintiff of its rights to damages for the past, under a reparation order which could not, by any possibility be changed by any subsequent finding as to rates for the future, The report and order gave the plaintiff no preference over other shippers,

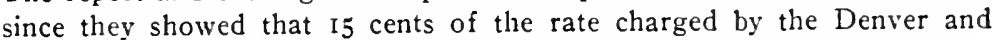
Rio Grande was unreasonable. If such a finding of unreasonableness was not sufficiently general to inure to the benefit of all other shippers, they could, on application, have secured such a modification as to enable them to maintain a suit for the recovery of damages for unjust charges and collections in the past. So far as the future operation of the order was concerned, all shippers were left in the same position, where, from the necessity of the case, the old rate had to be paid until the time had elapsed within which a new and just through rate could be put into effect. But however desirable it may have been to deal with the entire matter at one time, the joinder of the two subjects was not jurisdictional. There was no such necessary connection between the two as to make the order of reparation void because of the absence of a concurrent provision establishing a rate for the future." 
charges collected by the carrier but no new rate would be established for the future.

While an order for reparation is usually accompanied by the promulgation of a new rate the fact remains that the two subjects are in reality independent though related. But the presence of both is not jurisdictional and the absence of a provision for one need not operate to invalidate an order as to the other. Otherwise the nullification of a reparation order because of an omission to provide for the future rate would punish the shipper for the failure of the Commission-would deprive him of his award of damages for his private injury owing to the omission of the Commission to make a rate for the benefit of the general public in which the shipper, for a variety of reasons, might not be interested. Again the shipper might be able to prove unreasonableness as to the past without being able to furnish evidence as to what would be in fact a reasonable rate for the future. Or, again the Commission might be able to say with assurance that the rates had been unreasonable and so award reparation accordingly but it might be necessary to hold a protracted hearing to determine what rate would be just for the future. To compel the shipper to await the result of such hearing and deprive him of his right of reparation until the settlement of this independent question would constitute a hardship not contemplated by the Act. In the words of the Supreme Court-"There was no such necessary connection between the two as to make the order of reparation void because of the absence of a concurrent provision establishing a rate for the future."

Even where an established rate has been altered voluntarily by a carrier, or as the result of an order of the Commission, nevertheless the Commission may hear complaints and award reparation for overcharges resulting from the application of the unreasonable schedule during the period such schedule was in force. $^{2}$

2 Texas and Pacific Railway Co. v. Abilene Cotton Oil Co., 204 U. S. 426, 5I L. Ed. 553, 27 Sup. Ct. 350, where the court said:-"Although an established schedule of rates may have been altered by a carrier voluntarily or as the result of the enforcement of an order of the Commission to desist from violating the law, rendered in accordance with the provisions of the statute, it may not be doubted that the power of the Commission would nevertheless extend to hearing legal complaints of and awarding reparation to individuals for wrongs unlawfully suffered from 
Jurisdiction in Reparation Actions.-The jurisdiction of the Interstate Commerce Commission in awarding reparation under this section extends to all cases where parties are injured or prejudiced by any rate or regulation of the carrier which the Commission declares unreasonable or prejudicial. It is to be noted, however, that the award of the Commission is as it were preliminary and subject to enforcement by the courts. Under the amendment of June I8, I910, the beneficiary of a reparation order may bring suit for the damages declared in the Circuit Court of the United States for the district in which he resides or in which is located the principal operating office of the carrier, or through which the road of the carrier runs, or in any state court of general jurisdiction having jurisdiction of the parties. First of all it is to be noted, that without preliminary action by the Interstate Commerce Commission the courts have no jurisdiction of a suit by a shipper or other party for damages for discrimination by which he has been prejudiced. As a preliminary to the maintenance of such action the plaintiff must produce an order of the Commission that the rate upon which the suit was based was unreasonable. ${ }^{3}$

the application of the unreasonable schedule during the period when such schedule was in force." See also Robinson $v$. Baltimore and Ohio Railroad Co., 222 U. S. 506, 56 L. Ed. 288, 32 Sup. Ct. 114.

3 Texas and Pacific Railway v. Abilene Cotton Oil Co., 204 U. S. 426. 5I L. Ed. 553, 27 Sup. Ct. 350, where a suit was brought for excessive and unreasonable freight rates on interstate shipments where the rates had not been found unreasonable by the Interstate Commerce Commission. The court said:- "The proposition that if the statute be construed as depriving courts generally, at the instance of shippers, of the power to grant redress upon the basis that an established rate was unreasonable without previous action by the Commission great harm will result, is only an argument of inconvenience which assails the wisdom of the legislation or its efficiency and affords no justification for so interpreting the statute as to destroy it. * * * Concluding, as we do, that a shipper seeking reparation predicated upon the unreasonableness of the established rate must, under the Act to Regulate Commerce, primarily invoke redress through the Interstate Commerce Commission, which body alone is vested with power originally to entertain proceedings for the alteration of an established schedule, because the rates fixed therein are unreasonable, it is unnecessary for us to consider whether the court below would have had jurisdiction to afford relief if the right asserted had not been repugnant to the provisions of the Act to Regulate Commerce."

See also Mitchell Coal Co. v. Pennsylvania Railroad, 230 U. S. 247,57 L. Ed. I472, 33 Sup. Ct. 916, where the court said:-"It is urged that a 
But where action is brought by a shipper for damages based on a rebate paid to a competing shipper there is a distinct and specific violation of the Act and the court may entertain the suit

claim based upon the unreasonableness of past rates and discontinued practises raises a judicial question, of which the courts and not the Commission have jurisdiction. There are several answers to this proposition. In the first place, the plaintiff cannot claim under the Act and against it. To say the least, it is extremely doubtful whether, at common law, one shipper had a cause of action because the carrier paid another shipper more than the market value of transportation services rendered to the carrier. I. C. C. v. B. \& O. R. R., I45 U. S. 263, 275, 36 L. Ed. 699, 12 Sup. Ct. 844. But if any such right existed it was abrogated or forbidden by the Commerce Act, and one was given which, as a condition of the right to recover, required a finding by the Commission that the allowance was unreasonable and operated as an unjust discrimination or as an undue preference. Texas, etc., Ry. v. Cisco, 204 U. S. 449. 5I L. Ed. 562, 27 Sup. Ct. 358; Texas, etc., Ry. v. Abilene, 204 U. S. 426, 444, 51 L. Ed. 553, 27 Sup. Ct. 350; Southern Ry. v. Tift, 206 U. S. 428, 5I L. Ed. II24, 27 Sup. Ct. 709 ; U. S. v. Pacific and Arctic R. R., 228 U. S. 87, 57 L. Ed. 742, 33 Sup. Ct. 433. Such orders, so far as they are administrative are conclusive, whether they relate to past or present rates, and can be given general and uniform operation, since all shippers, who have been or may be affected by the rate, can take advantage of the ruling and avail themselves of the reparation order. They are quasi-judicial and only prima facie correct in so far as they determine the fact and amount of damage-as to which, since it involves the payment of money and taking of property, the carrier is by section 16 of the Act given its day in court and the right to a judicial hearing.

"In considering the administrative questions as to reasonableness, the elements of the problem are the same, whether they involve the validity of obsolete allowances discarded tariffs, or current rates and practises. In both classes of cases there is a call for the exercise of the rate-regulating discretion and the same necessity for having the matter settled by a single tribunal. For if at the suit of one shipper, a court could hold a past rate or allowance to have been unreasonable and award damages accordingly, it is manifest that such shipper would secure a belated but undue preference over others who had not sued and could not avail themselves of the verdict. But more than this-to permit separate suits and separate findings would not only destroy the equality which the statute intended should be permanent, even after the rates had been changed, but it would bring about direct conflict in the administration of the law. Under the statute the carrier has the primary right to fix rates, and so long as they are acquiesced in by the Commission the carrier and shippers are alike bound to treat them as lawful. After the rate had been abandoned the carrier is still obliged to treat it as having been lawful, and cannot refund what had been collected under it until the Commission determines that what was apparently reasonable had in fact been unreasonable. But 
without a preliminary order of the Commission since this is not an administrative or rate-regulating question or function."

Where suit is brought, either in state or federal courts, to secure a judgment based on a finding of the Commission the declaration must allege that the plaintiff had made application for reparation to the Interstate Commerce Commission and that this right to reparation had been sustained by the Commission. ${ }^{5}$

such a determination cannot be made by the courts, for they would not only have first to exercise an administrative function and make a rate by which to measure the reasonableness of the charge collected, but they would have to go further and treat as unreasonable a rate, past or present, which the statute had declared should be deemed lawful until it had been held to be otherwise by the Commission. As to past and present practises or allowances, the Commission has the same power and there is the same necessity to take preliminary action."

See also Morrisdale Coal Co. v. Pennsylvania Railroad, 230 U. S. 304. 57 L. Ed. I494, 33 Sup. Ct. 938.

4 Pennsylvania Railroad Co. v. International Coal Mining Co., 230 U. S. 184, 57 L. Ed. 1446, 33 Sup. Ct. 893, where suit was brought for damages against a carrier because of rebates paid to a competing shipper. In the words of the court:- "The rebate being unlawful it was a matter where the court, without administrative ruling or reparation order, could apply the fixed law to the established fact that the carrier had charged all shippers the published or tariff rate and refunded a part to a particular class."

5 Darnell v. Illinois Central Railroad Co., 225 U. S. 243,56 L. Ed. 1072, 32 Sup. Ct. 760, where the court said:- "It is plain, from the record, that this was but the equivalent of saying that the declaration did not state a cause of action because of the failure to allege the existence of a supposed condition precedent to recovery in a court of law, viz: a finding by the Interstate Commerce Commission that a right to reparation was possessed by the plaintiff. But the right to take cognizance of a claim based upon an award of reparation made by the Commission is not confined solely to an appropriate Circuit Court of the United States, but is equally possessed by state courts having general jurisdiction. See amendment to section 16 of the Act to Regulate Commerce resulting from the Act of June 18, 1910, chap. 309, 36 Stat. 554. Under these circumstances it is clear that the question of whether the plaintiff was entitled to the relief prayed in the absence of an averment of previous action by the Interstate Commerce Commission involved, merely the determination of whether there was a cause of action stated, and hence that under these circumstances this issue did not call in question the jurisdiction of the court below, as a federal court, becomes equally clear when it is considered that exactly the same question concerning the sufficiency of the averments to justify affording relief would have arisen for decision bad the suit been pending in a state court of general authority having jurisdiction over the person." 
However, after action by the Commission declaring rates unreasonable the parties may stipulate in the proceedings prosecuted under section 16 that the court shall adjudge the amount of reparation. The foundation is thus established by the Commission for the reparation, as provided in the Act, and the inquiry submitted to the court relates only to the amount thereof. ${ }^{6}$

It is to be noted in connection with these orders of the Commission for reparation that a finding without evidence is beyond the power of that body. An order made without a hearing is contrary to law and will be set aside by a proper court. Similarly if the hearing granted was inadequate or manifestly unfair; or if the finding was contrary to the undoubted character of the evidence. While the courts will not review the Commission's conclusions of fact by passing upon the credibility of witnesses or conflicts in the testimony, the legal effect of evidence is a question of law."

6 Southern Railway Co. v. Tift, 206 U. S. 428, 5I L. Ed. II24, 27 Sup. Ct. 709. Here the court said:- "There is nothing in that case (Texas and Pacific Railway v. Abilene Cotton Oil Co., 204 U. S. 426, 5 I L. Ed. 553, 27 Sup. Ct. 350), however, which precludes the parties after action by the Cominission declaring rates unreasonable, from stipulating in the proceedings prosecuted under section 16 that the court adjudge the amount of reparation. By the action of the Commission the foundation for reparation, as provided in the Interstate Commerce Act, was established, and the inquiry submitted to the court was but of its amount, and had the natural and justifiable inducement to end all the controversies between the parties without carrying part of them to another tribunal."

7 Interstate Commerce Commission v. Louisville and Nashville Railroad Co., 227 U. S. 88, 57 L. Ed. 431, 33 Sup. Ct. I85. The court here said :- "In the comparatively few cases in which such questions have arisen it has been distinctly recognized that administrative orders, quasi-judicial in character, are void if a hearing was denied; if that granted was inadequate or manifestly unfair; if the finding was contrary to the 'indisputable character of the evidence,' * * * or if the facts found do not, as a matter of law, support the order made. * * * Interstate Commerce Commission v. B. \& O. S. W. R. R., 226 U. S. I4. 57 I. Ed. 104, 33 Sup. Ct. 5 ; Atlantic Coast Line v. North Carolina Corp. Com., 206 U. S. I, 20 , 51 L. Ed. 933,27 Sup. Ct. 585 ; Interstate Commerce Commission v. Illinois Central, 215 U. S. 452, 470, 54 L. Ed. 280, 30 Sup. Ct. I55; Southern Pacific v. Interstate Commerce Commission, 219 U. S. 433, 55 L. Ed. 283 , 3 I Sup. Ct. 288 . * * * The statute, instead of making its orders conclusive against a direct attack, expressly declares that 'they may be suspended or set aside by a court of competent jurisdiction.' 36 Stat. $35 \mathrm{I}$ (15). Of course, that can only be done in cases presenting a justiciable question. But whether the order deprives the carrier of a constitutional 
By this section all complaints for the recovery of damages must be filed with the Commission within two years from the time the cause of action accrues and a petition for the enforcement of an order must be filed in the circuit court within one year from the date of the order. ${ }^{8}$

Attorney's Fee.-Section I6 specifically provides for taxing and collecting a reasonable attorney's fee in favor of the petitioner if he is succeeful in a suit to recover on an award of the Commission. The services for which an attorney's fee is to be taxed and collected are those rendered in the actual suit in court and not those before the Commission. The Commission is not authorized to fix a fee but only to determine the amount of the damages and fix a time for payment. If the carrier liquidates the award within the nominated time there is no right in the peti-

or statutory right; whether the hearing was adequate and fair, or whether, for any reason, the order is contrary to law-are all matters within the scope of judicial power.

"Under the statute the carrier retains the primary right to make rates, but if, after hearing, they are shown to be unreasonable, the Commission may set them aside and require the substitution of just for unjust charges. The Commission's right to act depends upon the existence of this fact, and if there was no evidence to show that the rates were unreasonable, there was no jurisdiction to make the order. Interstate Commerce Commission v. Northern Pacific Ry., 216 U. S. 538, 54t, 54 L. Ed. 608, 30 Sup. Ct. 4I7. In a case like the present the courts will not review the Commission's conclusions of fact (Interstate Com. Comm. v. Delaware, \&c.. Ry., 220 U. S. 235, 25I, 55 L. Ed. 448, 31 Sup. Ct. 392), by passing upon the credibility of witnesses, or conflicts in the testimony. But the legal effect of evidence is a question of law. A finding without evidence is beyond the power of the Commission. An order based thereon is contrary to law and must in the language of the statute, "be set aside by a court of competent jurisdiction. 36 Stat. 55I."

For a more extended discussion of this question, see section 15, supra.

8 Morrisdale Coal Co. v. Pennsylvania Railroad Co., 230 U. S. 304, 57 L. Ed. 1494, 33 Sup. Ct. 938, where a suit was dimissed when brought more than two and a half years after it was claimed that the damages had accrued.

In Meeker v. Lehigh Valley Railroad Co., decided February 23, 1915, the Supreme Court declared that the provision of the Hepburn Act providing that "claims accrued before this Act becomes effective may be presented within one year thereafter" meant that they need not be presented within one year from the date of the approval of the Act by the President but they might be presented within one year from the end of sixty days after such approval at which time by joint resolution of Congress it was declared the Act should become operative. 
tioner to an attorney's fee. Only when the claimant is forced to bring suit for a recovery is the fee allowed. The apparent purpose of the provision is to charge against the carrier the expenses resulting from his failure to settle the award of the Commission without suit-to tax as part of the costs therein a reasonable fee for the services of the petitioner's attorney in prosecuting the suit. It is designed to encourage the payment of just damages without the expensive necessity of suit and the provision is clearly valid. ${ }^{9}$

9 Meeker v. Lehigh Valley Railroad Co., decided February 23, I915. The Supreme Court said:- "In our opinion the services for which an attorney's fee is to be taxed and collected are those incident to the action in which the recovery is had and not those before the Commission. This is not only implied in the words of the two provisions just quoted but is suggested by the absence of any reference to proceedings anterior to the action. And that nothing more is intended becomes plain when we consider another provision in section 16 which requires the Commission, upon awarding damages, to make an order directing the carricr to pay the sum awarded 'on or before a day named' and then declares, that if the carrier does not comply with the order "within the time limit," the claimant may proceed to collect the damages by suit. The commission is not to allow a fee, but only to find the amount of the damages and fix a time for payment; and, if the carrier pays the award within the time named, no right to an attorney's fee arises. It is only when the damages are recovered by suit that a fee is to be allowed, and this is as true of the provision in section 8 as of that in section 16 . The evident purpose is to charge the carrier with the costs and expenses entailed by a failure to pay without suit-if the claimant finally prevails-and to that end to tax as part of the costs in the suit wherein the recovery is had a reasonable fee for the services of the claimant's attorney in instituting and prosecuting that suit. It follows that the District Court erred in matter of law in allowing a fee for services before the Commission.

"The contention that the provision for an attorney's fee for services in the suit is invalid as being purely arbitrary and as imposing a penalty for merely failing to pay a debt is without merit. The provision is leveled against common carriers engaged in interstate commerce, a quasi public business, and is confined to cases wherein a recovery is had for damages resulting from the carrier's violation of some duty imposed in the public interest of the Act to Regulate Commerce. Atlantic Coast Line Railroad Co. v. Riverside Mills, 219 U. S. 186, 208, 55 L. Ed. I67, 31 Sup. Ct. 164. One of its purposes is to promote a closer observance by carriers of the duties so imposed; and that there is also a purpose to encourage the payment, without suit, of just demands does not militate against its validity. Missouri, Kansas \& Texas Railway Co. v. Cade, 233 U. S. 642, 65I, 58 L. Ed. II35, 34 Sup. Ct. 678, and cases cited. It requires that the fee be reasonable and fixed by the court, and does not permit it to be taxed 
Procedure.-The Interstate Commerce Commission is a body corporate with legal capacity to be a party plaintiff or defendant in the federal courts and proceedings to enforce its orders may be brought by any interested person or by the Commission as a party plaintiff. ${ }^{10}$ The Supreme Court has declared that while neither party to a proceeding in the courts is to be restricted to the evidence that was before the Commission, the purposes of the Act call for a full inquiry by the Commission into all the circumstances and conditions pertinent to the questions involved. And in this connection the court expressed its disapproval of a method of procedure by which one of the parties to such an action withheld the larger part of its evidence from the Commission, and first adduced it before the Circuit Court. ${ }^{11}$

In view of the fact that the Commerce Court has been abolished no discussion will be given of its jurisdiction or procedure since that could be of no more than historical interest at this time. ${ }^{12}$

against the carrier until the plaintiff's demand has been adjudged upon full inquiry to be valid. In these circumstances the validity of the provision is not doubtful but certain."

Io Texas and Pacific Railway Co. v. Interstate Commerce Commission, I62 U. S. 197, 40 L. Ed. 940, I6 Sup. Ct. 666, where the court said:-"We think the language of the statute, in creating the Commission, and in providing that it shall be lawful for the Commission to apply by petition to the Circuit Court sitting in equity, sufficiently implies the intention of Congress to create a body corporate with legal capacity to be a party plaintiff or defendant in the Federal Courts."

II Cincinnati, New Orleans and Texas Pacific Railway Co. v. Interstate Commerce Commission, I62 U. S. 184,40 L. Ed. 935, 16 Sup. Ct. 700. The court said :- "We think this a proper occasion to express disapproval of such a method of procedure on the part of the railroad companies as should lead them to withhold the larger part of their evidence from the Commission, and first adduce it in the Circuit Court. The Commission is an administrative board, and the courts are only to be resorted to when the Commission prefers to enforce the provisions of the statute by a direct proceeding in the court, or when the orders of the Commission have been disregarded. The theory of the Act evidently is, as shown by the provision that the findings of the Commission shall be regarded as prima facie evidence, that the facts are to be disclosed before the Commission. We do not mean, of course, that either party, in a trial in the court, is to be restricted to the evidence that was before the Commission, but that the purposes of the Act call for a full inquiry by the Commission into all the circumstances and conditions pertinent to the questions involved."

I2 See, however, Proctor and Gamble v. United States, 225 U. S. 282, 56 L. Ed. I09I, 32 Sup. Ct. 76I, where the jurisdiction of the Commerce 
Orders of the Commission and Their Finality.-In determining the reasonableness of a rate or regulation fixed by carriers the orders of the Interstate Commerce Commission which are administrative in their nature are final. In the words of the Supreme Court: "Power to make the order and not the mere expediency or wisdom of having made it, is the question." 13 The courts are without power to invade the administrative functions vested in the Commission and therefore they can not set aside an order duly made on a mere exercise of judgment as to its wisdom or expediency. As already suggested the orders of the Commission are final unless they transcend the statutory power conferred upon that body or are based upon a mistake of law. ${ }^{14}$ For example it is beyond the power of the Commission to make an order which is not based upon real evidence or proper proof and such an order may be set aside by the courts. ${ }^{15}$ This question is

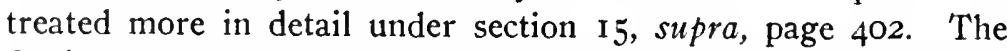
findings of the Commission are made by law prima facie true, and while its conclusions are subject to review, if within the constitutional power of that body and supported by evidence they are accepted as final. ${ }^{16}$ This provision does not infringe upon the right of trial by jury or operate as a denial of due process of law. It merely establishes a rebuttable presumption. In the words of the Supreme Court- "It cuts off no defense, interposes no obstacle to a full contestation of all the issues, and takes no question of fact from either court or jury. At most therefore it is merely a rule of evidence. It does not abridge the right of trial by jury

Court is discussed at length, and United States v. Baltimore and Ohio Railroad Co., 225 U. S. 306, 56 L. Ed. 1100,32 Sup. Ct. 817.

I3 Interstate Commerce Commission v. Illinois Central Railroad Co., 215 U. S. 452, 54 L. Ed. 280, 30 Sup. Ct. 155. See also Baltimore and Ohio Railroad Co. v. Pitcairn Coal Co., 215 U. S. 48I, 54 L. Ed. 292, 30 Sup. Ct. 164; United States v. Pacific and Arctic Railway and Navigation Co., 228 U. S. 87,57 L. Ed. 742,33 Sup. Ct. 433 .

14 Interstate Commerce Commission v. Chicago, Rock Island and $\mathrm{Pa}$ cific Ry. Co., 218 U. S. 88, 54 L. Ed. 946, 30 Sup. Ct. 65I; Southern Pacific Co. v. Interstate Commerce Commission, 219 U. S. 433, 55 L. Ed. 283, 3r Sup. Ct. 288.

15 Florida East Coast Railway Co. v. United States, 234 U. S. 167, 58 I. Ed. 1267, 34 Sup. Ct. 867.

I6 Cincinnati, Hamilton and Dayton Railway Co. v. Interstate Commerce Commission, 206 U. S. I42, 5I L. Ed. 995, 27 Sup. Ct. 648; Interstate Commerce Commission v. Union Pacific Railroad Co., 222 U. S. 54I, 56 L. Ed. 308, 32 Sup. Ct. 108. 
or take away any of its incidents. a denial of due process of law." 17

Nor does it in any wise work

Limitation of Court Actions. - Where a shipper has not filed a complaint for unreasonable charges with the Interstate Commerce Commission or intervened in such a complaint, but has a claim for excessive charges growing out of shipments at rates on which the Commission has ruled, he must bring his action for damages in the courts within two years of the date on which the cause of action arose or be debarred. ${ }^{18}$

17 In Meeker v. Lehigh Valley Railroad Co., decided February 23, 1915, the Supreme Court said:- "It is also urged *** that the provision in section 16 that in actions like this, 'the findings and order of the Commission shall be prima facie evidence of the facts therein stated,' is repugnant to the Constitution in that it infringes upon the right of trial by jury and operates as a denial of due process of law. This provision only established a rebuttal presumption. It cuts off no defense, interposes no obstacle to a full contestation of all the issues, and takes no question of fact from either court or jury. At most therefore it is merely a rule of evidence. It does not abridge the right of trial by jury or take away any of its incidents. Nor does it in any wise work a denial of due process of law. In principle it is not unlike the statutes in many of the states whereby tax deeds are made prima facie evidence of the regularity of all the proceedings upon which their validity depends. Such statutes have been generally sustained."

18 Phillips Co. v. Grand Trunk Western Ry. Co., decided March 15, 1915. The Supreme Court said: "The inquiry as to the reasonableness of the advance was general in its nature. The finding thereon was general in its operation and inured to the benefit of every person that had been obliged to pay the unjust rate...... The plaintiff and every other shipper similarly situated was entitled by appropriate proceedings before the Commission or the courts to obtain the benefit of that general finding and order...... But while every person who had paid the rate could take advantage of the finding that the advance was unreasonable, he was obliged to assert his claim within the time fixed by law. When the overcharge was collected a cause of action at once arose and the shipper at once had the right to file a complaint or to intervene in proceedings instituted by others. If he failed to take either of those steps and there was a finding of unreasonableness in the proceedings begun by others, he could, if in time, present his claim, and await the result of the litigation over the validity of any order made at the instance of those parties. If it was ultimately sustained by the court as valid he would then be in position to obtain reparation from the Commission-or a judgment from a court of competent jurisdiction, on a claim that had been seasonably presented. But neither proceedings begun by other shippers, nor findings of unreasonableness and orders issued thereon by the Commission, would save the rights of those who disregarded the requirements of the Hepburn amendment." 


\section{SECTION 16a. REHEARINGS BY THE COMMISSION.}

Commis s i o $\mathrm{n}$ may grant rehearings.

Applic a tion for rehearing shall not operate as a stay of proceedings, unless so ordered by Commission.

Commis $\mathrm{s}$ i o $\mathrm{n}$ inay, on rehear. ing, $r$ e verse, change, or mod. ify order.

This section was incorporated in the Act to Regulate Commerce on June 29, 1906, and although adopted on the recommendation of the Commission it seems superfluous in view of the very extensive powers granted by other sections of the Act. No cases involving the construction of this section have been adjudicated by the Supreme Court. 


\section{SECTION 17. PRACTISE AND PROCEDURE.}

SEc. 17. (As amended March 2, I889.) That the Commission may conduct its proceedings in such manner as will best conduce to the proper dispatch of business and to the ends of justice. A majority of the Commission shall constitute a quorum for the transaction of business, but no commissioner shall participate in any hearing or proceeding in which he has any pecuniary interest. Said Commission may, from time to time, make or amend such general rules or orders as may be requisite for the order and regulation of proceedings before it, including forms of notices and the service thereof, which shall conform, as nearly as may be, to those in use in the courts of the United States. Any party may appear before said Commission and be heard, in person or by attorney. Every vote and official act of the Commission shall be entered of Parties may
appear in per. appear in per.
son or by at.

torney. record, and its proceedings shall be public upon the request of either party interested. Said Commission shall have an official seal, which shall be juCommission
may determine
its own procedure. dicially noticed. Either of the members of the Commission may administer oaths and affirmations and sign subpœnas.

The rules of practise and forms of procedure are simple and have been liberally construed by the Commission. For the rules of practise adopted by the Commission, see Appendix, page 533 . For forms of procedure, see Appendix, page 543. They have not been the subject of litigation before the Supreme Court. 


\section{SECTION 18. SALARIES OF COMMISSIONERS AND EXPENSES OF COMMISSION.}

S a 1 a $r$ ies of Commissionerg.

Secret a r $\mathbf{y}-$
w appointed; salary. fees.

Wit nesses'

Eimployees.

Offices and supplies.

Expenses of the Commis. sion - how paid.

SEC. I8. (As amended March 2, I889.) [See section 24, increasing salaries of commissioners.] That each commissioner shall receive an annual salary of seven thousand five hundred dollars, payable in the same manner as the judges of the courts of the United States. The Commission shall appoint a secretary, who shall receive an annual salary of three thousand five hundred dollars, payable in like manner. The Commission shall have authority to employ and fix the compensation of such other employees as it may find necessary to the proper performance of its duties. Until otherwise provided by law, the Commission may hire suitable offices for its use, and shall have authority to procure all necessary office supplies. Witnesses summoned before the Commission shall be paid the same fees and mileage that are paid witnesses in the courts of the United States.

All of the expenses of the Commission, including all necessary expenses for transportation incurred by the commissioners, or by their employees under their orders, in making any investigation, or upon official business in any other places than in the city of Washington, shall be allowed and paid on the presentation of itemized vouchers therefor approved by the chairman of the Commission.

By section 24, added June 29, 1906, the salaries of the members of the Commission were increased to ten thousand dollars and by the sundry civil Act of March 4, 1907, the salary of the secretary of the Commission was increased to five thousand dollars.

The Act to Regulate Commerce, amended as indicated above, provides that "all of the expenses of the Commission * * * shall be allowed and paid on the presentation of itemized vouchers therefor approved by the chairman of the Commission"; and 
the appropriation Act of the same date provides "that hereafter expenses of the Interstate Commerce Commission shall be audited by the proper accounting officers of the treasury." The Supreme Court has held that it is not necessary to submit to the comptroller of the treasury actual copies of telegrams relating to the business of the Commission accompanying vouchers therefor if in the opinion of the Commission such messages are so far confidential that the requirement for their production is unreasonable and against public interest. ${ }^{2}$

I United States v. Moseley, 187 U. S. 322, 47 L. Ed. 198, 23 Sup. Ct. 90. The accounts for money expended by the secretary of the Commission for telegrams sent pursuant to the directions of the Commission were disallowed by the auditor of the treasury because the secretary had not complied with the requirement of the comptroller to furnish the original telegrams or, if confidential, in lieu thereof a certificate to that effect signed by the chairman of the Commission. The secretary, however offered to submit the books of the Commission to the comptroller and auditors of the treasury. The court said:- "It is to be remembered that the petitioner is but the secretary of the Commission. He does not direct its functions, its expenditures, or control its records. He could only submit the requirement of the comptroller to the Commission and its response to the comptroller. Its response was 'that so much of the comptroller's communication as required copies of telegrams relating to the business of the Commission to accompany telegraph vouchers for which credit is asked be disregarded by the secretary and disbursing agent, the Commission holding that such messages are so far confidential as to justify refusal to disclose their contents, and that the requirement for their production is unreasonable and against public interest.' This was a substantial compliance with the requirement of the comptroller." 


\section{SECTION I9. PRINCIPAL OFFICE OF THE INTER- STATE COMMERCE COMMISSION AND PLACE OF HOLDING HEARINGS.}

Principal of-
. mission.

Sessions of the Commission.

Commis $\mathrm{s}$ ion may prosecute inquiries by one or more of its members in any part of the
SEC. 19. That the principal office of the Commission shall be in the city of Washington, where its general sessions shall be held; but whenever the convenience of the public or the parties may be promoted, or delay or expense prevented thereby, the Commission may hold special sessions in any part of the United States. It may, by one or more of the commissioners, prosecute any inquiry necessary to its duties, in any part of the United States, into any matter or question of fact pertaining to the business of any common carrier subject to the provisions of this Act.

No cases have been decided by the Supreme Court involving section 19. From its inception the Interstate Commerce Commission has followed the practise of hearing cases involving local rates and complaints through one or more of its members sitting at a point in the territory involved in the inquiry. 


\section{SECTION Iga. PHYSICAL VALUATION OF THE PROPERTY OF COMMON CARRIERS.}

SEC. I9a. That the Commission shall, as hereinafter provided, investigate, ascertain, and report Amendment of March I, 1913. the value of all the property owned or used by every common carrier subject to the provisions of this Act. To enable the Commission to make such investigation and report, it is authorized to employ such experts and other assistants as may be necessary. The Commission may appoint examiners who shall have power to administer oaths, examine witnesses, and take testimony. The Commission shall make an inventory which shall list the property of every common carrier subject to the provisions of this Act in detail, and show the value thereof as hereinafter provided, and shall classify the physical property, as nearly as practicable, in conformity with the classification of expenditures for road and equipment, as prescribed by the Interstate Commerce Commission.

First. In such investigation said Commission shall ascertain and report in detail as to each piece of property owned or used by said common carrier for its purposes as a common carrier, the original cost to date, the cost of reproduction new, the cost of reproduction less depreciation, and an analysis of the methods by which these several costs are obtained, and the reason for their differences, if any. The Commission shall in like manner ascertain and report separately other values, and elements of value, if any, of the property of such common carrier, and an analysis of the methods of valuation employed, and of the reasons for any differences between any such value, and each of the foregoing cost values.

Second. Such investigation and report shall state in detail and separately from improvements

Investigation by Commission.

Experts.

Classificati on and inventory.

Cost of prop. erty used for common-cartier purposes.

Other prop. erty.

Value of real property. 
Property held for other than common-carrie purposes.

Corporate organization.

the original cost of all lands, rights of way, and terminals owned or used for the purposes of a common carrier, and ascertained as of the time of dedication to public use, and the present value of the same, and separately the original and present cost of condemnation and damages or of purchase in excess of such original cost or present value.

Third. Such investigation and report shall show separately the property held for purposes other than those of a common carrier, and the original cost and present value of the same, together with an analysis of the methods of valuation employed.

Fourth. In ascertaining the original cost to date of the property of such common carrier the Commission, in addition to such other elements as it may deem necessary, shall investigate and report upon the history and organization of the present Stocks and and of any previous corporation operating such
bonds. property; upon any increases or decreases of stocks, bonds, or other securities, in any reorganization; upon moneys received by any such corporation by reason of any issues of stocks, bonds, or other securities; upon the syndicating, banking, and other financial arrangements under which such issues were made and the expense thereof; and

Earnings and upon the net and gross earnings of such corpora-
expenditures. tions; and shall also ascertain and report in such detail as may be determined by the Commission upon the expenditure of all moneys and the purposes for which the same were expended.

Grants from Fifth. The Commission shall ascertain and report the amount and value of any aid, gift, grant of right of way, or donation, made to any such common carrier, or to any previous corporation operating such property, by the government of the United States or by any state, county, or municipal government, or by individuals, associations, or corporations; and it shall also ascertain and report

Value of land grants. the grants of land to any such common carrier, or any previous corporation operating such property, by the government of the United States, or by any 
state, county, or municipal government, and the amount of money derived from the sale of any portion of such grants and the value of the unsold portion thereof at the time acquired and at the present time, also, the amount and value of any concession and allowance made by such common carrier to the

Concess ion s made by carrier. government of the United States, or to any state, county, or municipal government in consideration of such aid, gift, grant, or donation.

Except as herein otherwise provided, the Commission shall have power to prescribe the method of procedure to be followed in the conduct of the investigation, the form in which the results of the valuation shall be submitted, and the classification of the elements that constitute the ascertained value, and such investigation shall show the value of the property of every common carrier as a whole and separately the value of its property in each of the several states and territories and the District of Columbia, classified and in detail as herein required.

Such investigation shall be commenced within sixty days after the approval of this Act and shall be prosecuted with diligence and thoroughness, and the result thereof reported to Congress at the beginning of each regular session thereafter until completed.

Every common carrier subject to the provisions of this Act shall furnish to the Commission or its agents from time to time and as the Commission may require maps, profiles, contracts, reports of engineers, and any other documents, records, and papers, or copies of any or all of the same, in aid of such investigation and determination of the value of the property of said common carrier, and shall grant to all agents of the Commission free access to its right of way, its property, and its accounts, Access of agents to prop. records, and memoranda whenever and wherever requested by any such duly authorized agent, and every common carrier is hereby directed and required to cooperate with and aid the Commission in the work of the valuation of its property in such

Method of procedure.

Prosecut io $n$ and report of investigation.

Documents to aid investiga. tion. erty. 
further particulars and to such extent as the Commission may require and direct, and all rules and regulations made by the Commission for the purpose of administering the provisions of this section and section 20 of this Act shall have the full force and effect of law. Unless otherwise ordered by the Commission, with the reasons therefor, the records and data of the Commission shall be open to the inspection and examination of the public.

Upon the completion of the valuation herein pro-

Valuation of extensions and improvements.

Reports to Congress.

Informat $\mathrm{i}$ o $\mathrm{n}$ required of car. riers.

Notice of tentative valu. ation.

Finality if 110 protest filed. vided for the Commission shall thereafter in like manner keep itself informed of all extensions and improvements or other changes in the condition and value of the property of all common carriers, and shall ascertain the value thereof, and shall from time to time, revise and correct its valuations, showing such revision and correction classified and as a whole and separately in each of the several states and territories and the District of Columbia, which valuations, both original and corrected, shall be tentative valuations and shall be reported to Congress at the beginning of each regular session.

To enable the Commission to make such changes and corrections in its valuations of each class of property, every common carrier subject to the provisions of this Act shall make such reports and furnish such information as the Commission may require.

Whenever the Commission shall have completed the tentative valuation of the property of any common carrier, as herein directed, and before such valuation shall become final, the Commission shall give notice by registered letter to the said carrier, the attorney general of the United States, the governor of any state in which the property so valued is located, and to such additional parties as the Commission may prescribe, stating the valuation placed upon the several classes of property of said carrier, and shall allow thirty days in which to file a protest of the same with the Commission. If no protest is filed within thirty days, said valuation shall become final as of the date thereof. 
If notice of protest is filed the Commission shall fix a time for hearing the same, and shall proceed as promptly as may be to hear and consider any matter relative and material thereto which may be presented in support of any such protest so filed as aforesaid. If after hearing any protest of such tentative valuation under the provisions of this Act the Commission shall be of the opinion that its valuation should not become final, it shall make such changes as may be necessary, and shall issue an order making such corrected tentative valuation final as of the date thereof. All final valuations by the Commission and the classification thereof shall be published and shall be prima facie evidence of the value of the property in all proceedings under the Act to Regulate Commerce as of the date of the fixing thereof, and in all judicial proceedings for the enforcement of the Act approved February fourth, eighteen hundred and eighty-seven, commonly known as "the Act to Regulate Commerce," and the various Acts amendatory thereof, and in all judicial proceedings brought to enjoin, set aside, annul, or suspend, in whole or in part, any order of the Interstate Commerce Commission.

If upon the trial of any action involving a final value fixed by the Commission, evidence shall be introduced regarding such value which is found by the court to be different from that offered upon the hearing before the Commission, or additional thereto and substantially affecting said value, the court, before proceeding to render judgment shall transmit a copy of such evidence to the Commission, and shall stay further proceedings in said action for such time as the court shall determine from the date of such transmission. Upon the receipt of such evidence the Commission shall consider the same and may fix a final value different from the one fixed in the first instance, and may alter, modify, amend or rescind any order which it has made involving said final value, and shall report its action thereon to said court within the time fixed by
Hearings of protests.

Changes.

Effect of final valuation and classification.
Effect of evidence.

Transmissi o $\mathrm{n}$ to Conmission.

Action of Commission. 
Modificat io $n$ of order.

Judgment on original order.

Applicable to receivers.

Penalty.

Jurisdiction of district courts to compel compliance.

Supplement a 1 Act of August I. 1924 . the court. If the Commission shall alter, modify, or amend its order, such altered, modified, or amended order shall take the place of the original order complained of and judgment shall be rendered thereon as though made by the Commission in the first instance. If the original order shall not be rescinded or changed by the Commission, judgment shall be rendered upon such original order.

The provisions of this section shall apply to receivers of carriers and operating trustees. In case of failure or refusal on the part of any carrier, receiver, or trustee to comply with all the requirements of this section and in the manner prescribed by the Commission such carrier, receiver, or trustee shall forfeit to the United States the sum of five hundred dollars for each such offense and for each and every day of the continuance of such offense, such forfeitures to be recoverable in the same manner as other forfeitures provided for in section 16 of the Act to Regulate Commerce.

That the district courts of the United States shall have jurisdiction, upon the application of the attorney general of the United States at the request of the Commission, alleging a failure to comply with or a violation of any of the provisions of this section by any common carrier, to issue a writ or writs of mandamus commanding such common carrier to comply with the provisions of this section.

It shall be the duty of every common carrier by railroad whose property is being valued under the Act of March first, nineteen hundred and thirteen, to transport the engineers, field parties, and other employees of the United States who are actually engaged in making surveys and other examination of the physical property of said carrier necessary to execute said Act from point to point on said railroad as may be reasonably required by them in the actual discharge of their duties; and, also, to move from point to point and store at such points as may be reasonably required the cars of the United States which are being used to house and maintain 
said employees; and, also, to carry the supplies necessary to maintain said employees and the other property of the United States actually used on said railroad in said work of valuation. The service above required shall be regarded as a special service and shall be rendered under such forms and regulations and for such reasonable compensation as may be prescribed by the Interstate Commerce Commission and as will insure an accurate record and account of the service rendered by the railroad, and such evidence of transportation, bills of lading, and so forth, shall be furnished to the Commission as may from time to time be required by the Commission.

Section I9a was added to the Act to Regulate Commerce by the Act approved March I, I9I3. The section was amended by the supplemental Act of August I, I9I4, to provide for transportation by the railroads of employees of the government engaged in the work of physical valuation, their supplies, etc. As yet no cases involving the construction of any of the provisions of this section have been adjudicated by the Supreme Court. 


\section{SECTION 20. REPORTS AND LIABILITIES OF CAR- RIERS.}

Commis $\mathrm{s}$ io $\mathrm{n}$ may require an. nual reports and prescribe method of making same.

What reports of carriers shall contain.

Commis s i o may prescribe uniform system of accounts.

Sec. 20. (As amended June 29, I906, February 25, I909, and June I8, 1910.) That the Commission is hereby authorized to require annual reports from all common carriers subject to the provisions of this Act, and from the owners of all railroads engaged in interstate commerce as defined in this Act, to prescribe the manner in which such reports shall be made, and to require from such carriers specific answers to all questions upon which the Commission may need information. Such annual reports shall show in detail the amount of capital stock issued, the amounts paid therefor, and the manner of payment for the same; the dividends paid, the surplus fund, if any, and the number of stockholders; the funded and floating debts and the interest paid thereon; the cost and value of the carrier's property, franchises, and equipments; the number of employees and the salaries paid each class; the accidents to passengers, employees, and other persons, and the causes thereof; the amounts expended for improvements each year, how expended, and the character of such improvements; the earnings and receipts from each branch of business and from all sources; the operating and other expenses; the balances of profit and loss; and a complete exhibit of the financial operations of the carrier each year, including an annual balance sheet. Such reports shall also contain such information in relation to rates or regulations concerning fares or freights, or agreements, arrangements, or contracts affecting the same as the Commission may require; and the Commission may, in its discretion, for the purpose of enabling it the better to carry out the purposes of this Act, prescribe a period of time within which all common 
carriers subject to the provisions of this Act shall have, as near as may be, a uniform system of accounts, and the manner in which such accounts shall be kept.

Said detailed reports shall contain all the required statistics for the period of twelve months ending on the thirtieth day of June in each year, or on the thirty-first day of December in each year if the Commission by order substitute that period for the year ending June thirtieth, and shall be made out under oath and filed with the Commission at its office in Washington within three months after the close of the year for which the report is made, unless additional time be granted in any case by the Commission; and if any carrier, person, or corporation subject to the provisions of this Act shall fail to make and file said annual reports within the time above specified, or within the time extended by the Commission, for making and filing the same, or shall fail to make specific answer to any question authorized by the provisions of this section within thirty days from the time it is lawfully required so to do, such party shall forfeit to the United States the sum of one hundred dollars for each and every day it shall continue to be in default with respect thereto. The Commission shall also have authority by general or special orders to require said carriers, or any of them, to file monthly reports of earnings and expenses, and to file periodical or special, or both periodical and special, reports concerning any matters about which the Commission is authorized or required by this or any other law to inquire or to keep itself informed or which it is required to enforce; and such periodical or special reports shall be under oath whenever the Commission so requires; and if any such carrier shall fail to make and file any such periodical or special report within the time fixed by the Commission, it shall be subject to the forfeitures last above provided.

Said forfeitures shall be recovered in the man-

Commis 8 i on may grant addi. tional time.

Penalty.

Monthly or periodical reports.

Annual re.
ports to be filed with Commis sion by Septem. year. 
Recovery of ner provided for the recovery of forfeitures under forfeitures. the provisions of this Act.

The oath required by this section may be taken Oath to an- before any person authorized to administer an oath nual $r$ e ports, how taken.

Commis s ion may prescribe for $\mathrm{ms}$ of accounts, records, and $m e m o$. randa, and have access thereto.

Carrier to keen no other accounts than those pre. scribed by Com. mission.

Commis s io $\mathrm{n}$ may e m p loy special examin. ers to inspect accounts a n d records.

Punish me n t of carrier by forfeiture for failure to keep a c counts or records as prescribed by Commission or to allow inspection thereof.

Punish $m$ e $n t$ person for false entry in accounts or rec. ords, or muti. lation of accounts
ords,

The Commission may, in its discretion, prescribe the forms of any and all accounts, records, and memoranda to be kept by carriers subject to the provisions of this Act, including the accounts, records, and memoranda of the movement of traffic as well as the receipts and expenditures of moneys. The Commission shall at all times have access to all accounts, records, and memoranda kept by carriers subject to this Act, and it shall be unlawful for such carriers to keep any other accounts, records, or memoranda than those prescribed or approved by the Commission, and it may employ special agents or examiners, who shall have authority under the order of the Commission to inspect and examine any and all accounts, records, and memoranda kept by such carriers. This provision shall apply to receivers of carriers and operating trustees.

In case of failure or refusal on the part of any such carrier, receiver, or trustee to keep such accounts, records, and memoranda on the books and in the manner prescribed by the Commission, or to submit such accounts, records, and memoranda as are kept to the inspection of the Commission or any of its authorized agents or examiners, such carrier, receiver, or trustee shall forfeit to the United States the sum of five hundred dollars for each such offense and for each and every day of the continuance of such offense, such forfeitures to be recoverable in the same manner as other forfeitures provided for in this Act.

Any person who shall willfully make any false entry in the accounts of any book of accounts or in any record or memoranda kept by a carrier, or who shall willfully destroy, mutilate, alter, or by any 
account, record, or memoranda, or who shall willfully neglect or fail to make full, true, and correct entries in such accounts, records, or memoranda of all facts and transactions appertaining to the carrier's business, or shall keep any other accounts, records, or memoranda than those prescribed or approved by the Commission, shall be deemed guilty of a misdemeanor, and shall be subject, upon conviction in any court of the United States of competent jurisdiction, to a fine of not less than one thousand dollars nor more than five thousand dollars or imprisonment for a term not less than one year nor more than three years, or both such fine and imprisonment: Provided, That the Commission may in its discretion issue orders specifying such operating, accounting, or financial papers, records, books, blanks, tickets, stubs, or documents of carriers which may, after a reasonable time, be destroyed, and prescribing the length of time such books, papers, or documents shall be preserved.

Any examiner who divulges any fact or information which may come to his knowledge during the course of such examination, except in so far as he may be directed by the Commission or by a court or judge thereof, shall be subject, upon conviction in any court of the United States of competent jurisdiction, to a fine of not more than five thousand dollars or imprisonment for a term not exceeding two years, or both.

That the Circuit and District Courts of the United States shall have jurisdiction, upon the application of the attorney general of the United States at the request of the Commission, alleging a failure to comply with or a violation of any of the provisions of said Act to Regulate Commerce or of any Act supplementary thereto or amendatory thereof by any common carrier, to issue a writ or writs of mandamus commanding such common carrier to comply with the provisions of said Acts, or any of them.

And to carry out and give effect to the provisions

United States courts may issue mandamus to compel compliance with pro. visions of Act.
Amend m e $n t$ 1909.

Commis $\mathrm{s} i$ on may permit de. struction of records.

Punish m e $\mathrm{t}$ of special examiner who divulges information without authority. Fine or imprisonment or both. 
Commis sion m a y e m ploy special examin. ers to receive evidence.

Initial carrier liable for loss or damage on through shipments.

Remedieg un der existing law not barred.

Initial carrier may have recourse upon car. rier responsible for loss or dam. age.

Amend $m$ e $n t$ of January 20 , 1914. of said Acts, or any of them, the Commission is hereby authorized to employ special agents or examiners who shall have power to administer oaths, examine witnesses, and receive evidence.

That any common carrier, railroad, or transportation company receiving property for transportation from a point in one state to a point in another state shall issue a receipt or bill of lading therefor and shall be liable to the lawful holder thereof for any loss, damage, or injury to such property caused by it or by any common carrier, railroad, or transportation company to which such property may be delivered or over whose line or lines such property may pass, and no contract, receipt, rule, or regulation shall exempt such common carrier, railroad, or transportation company from the liability hereby imposed: Provided, That nothing in this section shall deprive any holder of such receipt or bill of lading of any remedy or right of action which he has under existing law.

That the common carrier, railroad, or transportation company issuing such receipt or bill of lading shall be entitled to recover from the common carrier, railroad, or transportation company on whose line the loss, damage, or injury shall have been sustained the amount of such loss, damage, or injury as it may be required to pay to the owners of such property, as may be evidenced by any receipt, judgment, or transcript thereof.

No suit brought in any state court of competent jurisdiction against a railroad company, or other corporation, or person, engaged in and carrying on the business of a common carrier, to recover damages for delay, loss of, or injury to property received for transportation by such common carrier under section twenty of the Act to Regulate Commerce, approved February fourth, eighteen hundred and eighty-seven, as amended June twenty-ninth, nineteen hundred and six, April thirteenth, nineteen hundred and eight, February twenty-fifth, nineteen hundred and nine, and June eighteenth, nineteen 
hundred and ten, shall be removed to any court of the United States where the matter in controversy does not exceed, exclusive of interest and costs, the sum or value of $\$ 3,000$.

History of the Section and Amendments.-Few sections of the Act have been more extensively amended than this. By the Hepburn Act of June 29, I906, mere specific provision was made for the annual reports required from railroad companies subject to the Act; reports of accidents were required, the Commission was authorized to prescribe the forms of accounts, records and memoranda to be kept by the carriers and the carriers were forbidden to keep any other accounts, records, or memoranda than those prescribed or approved by the Commission. That body was given the power of inspection of such accounts by special agents, penalties were provided for the failure to keep such accounts or permit their inspection or for making false entries, and the proper courts were given jurisdiction to issue writs of mandamus to insure compliance with these provisions. And by the Carmack amendment of the Hepburn Act the initial or receiving carrier was made liable for loss or damage on through shipments carried by it or by any connection, regardless of any contract to the contrary. By the amendment of January 20, I9I4, suits brought in proper state courts to recover damages for delay, loss of, or damage to property received for transportation under this section can not be removed to any federal court unless the matter in controversy exceeds, exclusive of interest and costs, the sum or value of $\$ 3, \infty 00$.

By the amendment of February 25, I909, the Commission was given the power of prescribing the length of time for which all papers, books, documents, etc., should be preserved and of specifying what papers, accounts, documents, etc., might be destroyed.

By the Act of June I8, I9Io, more specific provision was made for the filing of the annual as well as the monthly or special reports by carriers subject to the Act.

Reports of Carriers and Systems of Accounting.-The power conferred in section 20 extends to all common carriers subject to the provisions of the Act as outlined in section I. This also applies to the power of the Commission to require uniform systems of accounting, and to prohibit other methods of accounting than those which that body may prescribe. These features of the section have been unsuccessfully attacked as an unlawful delegation 
of legislative power. The Supreme Court declared that while Congress may not delegate its purely legislative power to a commission, it may itself, as here, lay down the general rules of action under which a commission shall proceed, and require of that commission the application of such rules to particular situations and the investigation of facts, with a view to making orders in a particular matter within the rules laid down by Congress. Section 20 prescribes in detail what the reports of the carriers shall contain and permits the Commission, in its discretion, to require a uniform system of accounting and prohibit other systems than those prescribed-in other words Congress has laid down general rules for the guidance of the Commission leaving to it merely the matter of carrying out the details in the exercise of the power with which it is clothed.

The Commission may compel all carriers subject to the provisions of the Act to report on all matters concerning their business and operations. This relates not merely to that portion of their business which is interstate but includes as well their purely intrastate business. And this applies as well to the control of the system of accounting. The Commission may compel them to keep their accounts according to the uniform system when they relate to purely local business not crossing state lines. Under the intricate and complex transportation system railroads engaged in both interstate and intrastate transportation could not maintain separate systems of accounting so completely is the local business involved with the through business. For example, traffic of all kinds is conducted upon the same train or the same boat and in the same haul or passage. It would be impracticable or impossible to separate the items of expense entailed in the carriage of shipments of the different classes. The same cars, the same roadbed, the same crew are involved in both operations. There is the same depreciation of rolling stock and roadbed and the same cost of upkeep for lines, terminals, stations, etc. The Act of Congress has, naturally, been given a practical construction and one that will enable the Commission to perform its statutory duties. While the Commission may not be given the power to regulate strictly intrastate business it is still essential that, to enable that body to perform its duties even with regard to joint and interstate rates and to make the required reports to Congress relative to the business of railroads and carriers subject to the terms of the Act, it should be advised as to the features of all 
classes of business conducted by such carriers. The Supreme Court has stated that if the Commission is to properly and successfully perform its duties with reference to reasonable rates, undue discriminations and favoritism, is must be informed as to the business of the carriers by a system of accounting which will not permit the possible concealment of forbidden practises in accounts which it is not permitted to see and concerning which it can require no information. Requiring information concerning the business methods of such carriers as shown in their accounts, does not constitute a regulation of business not within the jurisdiction of the Commission. Securing information is not synonymous with regulation. The manifest object of requiring such accounts to be kept in a uniform manner and to be open to the inspection of the Commission is not to enable it to regulate the affairs of the corporation not within its jurisdiction, but to be informed regarding the business methods of the corporations subject to the Act in order that it may properly regulate such matters as are really within its jurisdiction.

Thus a carrier engaged in commerce of such a nature as to bring it within the purview of the Act to Regulate Commerce may be required to include in its reports statements concerning amusement parks which it owns and operates in connection therewith. ${ }^{1}$ The Interstate Commerce Commission was upheld in its

I Interstate Commerce Commission v. Goodrich Transit Co., 224 U. S. 194, 56 L. Ed. 729, 32 Sup. Ct. 436. The Goodrich Transit Company was engaged in the carriage of passengers and freight by water upon the Great Lakes. An order of the Interstate Commerce Commission prescribed the method of accounts and bookkeeping as to the operating expenses of the carriers and a similar order as to the operating revenues; and an order requiring a report of the carriers respecting their corporate organization, financial condition, etc. The carriers did both a port-to-port interstate and a port-to-port intrastate business. One of the carriers involved operated two amusement parks both in Michigan and in connection therewith operated lunch stands, merry-go-rounds, bowling alleys, bath houses, etc. The complaint was made that these orders involved purely intrastate operations of the carriers and amounted to an illegal regulation of intrastate business.

The court said:- "The terms of the Act of Congress, as amended June 29. 1906, and in force at the time when these orders were made, are plain and simple, and, we think not difficult to comprehend. *** The first section makes the Act apply alike to common carriers engaged in the transportation of passengers or property wholly by railroad or partly by railroad and partly by water under an arrangement for a contiuous carriage or shipment. It is conceded that the carriers filing the bills in these cases 
demand for a report requiring a general description of such outside operations and also a statement of the income and the expenses connected therewith. In the language of the Supreme

were common carriers engaged in the transportation of passengers and property partly by railroad and partly by water under a joint arrangement for a continuous carriage or shipment. Such common carriers are declared to be subject to the provisions of the Act in precisely the same terms as those which comprehend the other companies named in the Act. Carriers partly by railroad and partly by water under a common arrangement for a continuous carriage or shipment are as specifically within the terms of the Act as any other carrier named therein. * * *

"As to annual reports the power conferred in section 20 of the Act, extends to all common carriers subject to the provisions of the Act. The Commission is vested with authority to prescribe the manner in which such reports shall be made and to require specific answers to all questions as to which the Commission may need information. The report required in these cases was declared to be needed to enable the Commission to procure full information of the scope and character of the business of carriers by water within the jurisdiction of the Commission and of the extent of their operations, such as would enable the Commission to determine the form for annual report which would best give the information required by the Commission, and at the same time conform as nearly as may be to the accounting systems of carriers by water. The form of report adopted by the Commission requires a showing as to the corporate organization of each carrier by water subject to the Act, the companies owned by it and the parties or companies controlling it; as to the financial condition of the carrier, the cost of its real property and equipment, its capital stock and other stock and securities owned by it, together with all special funds and current assets and liabilities, as well as its funded indebtedness, with collateral security covering same; and as to finances with respect to the operations of the carrier for the current year, giving the revenue of the company and its source, whether from transportation, and what kind, or from outside operations, and all expenses, detailed, with a statement as to the net income or deficit from the various sources, and the report contains a profit and loss account and a general balance sheet. The report further requires certain statistical information, as follows:-The routes of the carrier and their mileage; a general description of the equipment owned, leased or chartered by the carrier; the amouni of traffic, both passenger and freight, and mileage and revenue statistics, together with a separation of freight into the quantity of the various products transported, showing also whether originating on the carrier's line or received from a connecting line; and a general description of any separate business carried on by the carrier. But such report is no broader than the annual report of such carriers as prescribed by the Act, for section 20 provides that:-

" "Such annual reports shall show in detail the amount of capital stock issued, the amounts paid therefor, and the manner of payment for the same; the dividends paid, the surplus fund, if any, and the number of stockholders; the funded and floating debts and the in- 
Court, if the Commission is to be informed of the business of the corporation, at least as far as its bookkeeping and reports will permit, "it must have full knowledge and full disclosures thereof,

terest paid thereon, the cost and value of the carriers property, franchises, and equipments; the number of employees and the salaries paid each class; the accidents to passengers, employees, and other persons and the causes thereof; the amounts expended for improvements each year, how expended, and the character of such improvements; the earnings and receipts from each branch of business and from all sources; the operating and other expenses; the balances of profit and loss; and a complete exhibit of the financial operations of the carrier each year, including an annual balance sheet. Such reports shall also contain such information in relation to rates or regulations concerning fares or freights, or agreements, arrangements, or contracts affecting the same as the Commission may require.' * * *

"We think this section contains ample authority for the Commission to require a system of accounting as provided in its orders and a report in the form shown to have been required by the order of the Commission. It is true that the accounts required to be kept are general in their nature and embrace business other than such as is necessary to the discharge of the duties required in carrying passengers and freight in interstate commerce by joint arrangement between the railroad and the water carrier, but the Commission is charged under the law with the supervision of such rates as to their reasonableness and with the general duty of making reports to Congress which might require a knowledge of the business of the carrier beyond that which is strictly of the character mentioned. If the Commission is to successfully perform its duties in respect to reasonable rates, undue discriminations and favoritism, it must be informed as to the business of the carriers by a system of accounting which will not permit the possible concealment of forbidden practises in accounts which it is not permitted to see and concerning which it can require no information. It is a mistake to suppose that the requiring of information concerning the business methods of such corporations, as shown in its accounts, is a regulation of business not within the jurisdiction of the Commission, as seems to be argued for the complainants. The object of requiring such accounts to be kept in a uniform way and to be open to the inspection of the Commission is not to enable it to regulate the affairs of the corporations not within its jurisdiction, but to be informed concerning the business methods of the corporations subject to the Act that it may properly regulate such matters as are really within its jurisdiction. Further, the requiring of information concerning a business is not regulation of that business. The necessity of keeping such accounts has been developed in the reports of the Commission and has been the subject of great consideration. It caused the employment of those skilled in such matters, and has resulted in the adoption of a general form of accounting which will enable the Commission to examine into the affairs of the corporations, with a view to discharging its duties of regulation concerning them.

The learned Commerce Court was of the opinion that the Commission might require accounts and reports, so far as the business of the water 
in order that it may ascertain whether forbidden practises and discriminations are concealed, even unintentionally, in certain accounts and whether charges of expense are made against one part of a business which ought to be made against another."

carriers with reference to joint rates by rail and water under a common arrangement was concerned and remanded the cases to the Commission for revision of their orders upon that basis. But it is argued for the Commission, and it seems to us with great force, that it would be impracticable to make such separation in any system of accounting. It is a matter of general knowledge, of which we may take judicial notice, that traffic of all kinds is conducted upon the same ship and passage. A boat may leave a lake port carrying passengers and freight destined for ports within the state and for ports beyond the state, and as a part of the freight for carriage embrace some carried under the terms of joint arrangements made with connecting railroad carriers. How would it be practicable to separate the items of expense entailed in the carriage of these various classes? It is done upon one boat, with one set of officers and crew and must in the nature of things be under one general bill of expense-at least it would seem impracticable to separate it into its items so as to show the expense of that which it is contended is alone within the terms of the Act, as construed by the carriers.

"We think the Act should be given a practical construction, and one which enable the Commission to perform the duties required of it by Congress, and, conceding for this purpose that the regulating power of the Commission is limited so far as rates are concerned to joint rates of the character named in section $I$, it is still essential that to enable the Commission to perform its required duties, even with respect to such rates, and to make reports to Congress of the business of carriers subject to the terms of the Act, it should be informed as to matters contained in the report. Congress, in section 20 , has authorized the Commission to inquire as to the business which the carrier does and to require the keeping of uniform accounts, in order that the Commission may know just how the business is carried on, with a view to regulating that which is confessedly within its power. *** Furthermore, it is said that such construction of section 20 makes it an unlawful delegation of legislative power to the Commission. We cannot agree to this contention. The Congress may not delegate its purely legislative power to a Commission, but having laid down the general rules of action under which a Commission shall proceed, it may require of that Commission the application of such rules to particular situations and the investigation of facts, with a view to making orders in a particular matter within the rules laid down by the Congress. This rule has been frequently stated and illustrated in recent cases in this court, and needs no amplification here. Buttfield v. Stranahan, I92 U. S. 470, 48 L. Ed. 252, 24 Sup. Ct. 349; Union Bridge Co. v. United States, 204 U. S. 364, 5 I L. Ed. 523, 27 Sup. Ct. 367; United States v. Grimaud, 220 U. S. 506, 55 L. Ed. 563, 3I Sup. Ct. 480 . In section 20 Congress has authorized the Commission to require annual reports. The Act itself prescribes in 
In order that accounts may be standardized, which is one of the essential purposes of this section, it is necessary that the transactions of the various carriers subject to the Act to Regulate Commerce shall be arranged under like headings or titlescharges and credits being allocated under the proper headings the same with one carrier as with another. In short they must be uniform. To the execution of the supervisory and regulatory powers conferred by Congress upon the Interstate Commerce Commission it is essential that a proper distinction be maintained between property accounts and operating accounts. And the Commission under this section may enforce such a system of accounts and bookkeeping." As, for example, where in order to

detail what those reports shall contain. The Commission is permitted. in its discretion, to require a uniform system of accounting, and to prohibit other methods of accounting than those which the Commission may prescribe. In other words, Congress has laid down general rules for the guidance of the Commission, leaving to it merely the carrying out of details in the exercise of the power so conferred. This, we think, is not a delegation of legislative authority.

"As to one of the corporations it is said that its business includes not only the carriage of passengers and freight, but that it owns and operates in connection therewith certain amusement parks. The report in controversy, as to business other than commerce, requires a general description of such outside operations, and also a statement of the income from and the expenses of the same. As we have said, if the Commission is to be informed of the business of the corporation, so far as its bookkeeping and reports are concerned, it must have full knowledge and full disclosures thereof, in order that it may ascertain whether forbidden practises and discriminations are concealed, even unintentionally, in certain accounts and whether charges of expense are made against one part of a business which ought to be made against another. Bookkeeping, it is said, is not interstate commerce. True, it is not. But bookkeeping may and ought to show how a business which, in part at least, is interstate commerce, is carried on, in order that the Commission, charged with the duty of making rea. sonable rates and prohibiting unfair and unreasonable ones, may know the nature and extent of the business of the corporation, the cost of its interstate transactions and otherwise to inform itself so as to enable it to properly regulate the matters which are within its authority. We think the uniform system of accounting prescribed and the report called for are such as it is within the power of the Commission to require under section 20 of the Act. Nor do the requirements exceed the constitutional authority of Congress to pass such a law."

2 Kansas City Southern Railway Co. v. United States, 23I U. S. 423, 58 L. Ed. 296, 34 Sup. Ct. I25. The road issued bonds for the purpose of reducing grades by relocating tracks and to erect a new and enlarged shop and terminal plant at Shreveport. Under the order of the Interstate Com- 
eliminate grades the tracks are relocated and bonds are issued therefor, the Commission may compel the carrier to enter a portion of the amount under the heading "Additions and Better-

merce Commission the road was required to carry part of the expenditure under the heading of "Operating Expenses" apportioned for several years and the balance under "Additions and Betterments" since this improvement was not essentially an addition but a substitution. The road complained of this order on various grounds, among others because it was an illegal invasion of the rights of preferred stockholders since it would diminish the amount available for the payment of interest on such stock. The court, in an exhaustive opinion, said:- "The contention of appellant in the Commerce Court and in this court is, that the regulations of the Interstate Commerce Commission relative to the method of keeping the accounts of common carriers, so far as they are here questioned, are unreasonable, beyond the power or authority of either Congress or the Commission, and violative of the Fifth Article of Amendments to the Constitution of the United States, as being a deprivation of property without due process of law. It is claimed that the effect of enforcing the regulations under the circumstances of the case is to reduce the amount of net earnings applicable to dividends, and thereby cause an irreparable loss to the preferred stockholders, whose dividends are noncumulative and payable only out of the income of the current year.

"The authority of the Commission rests upon sec. 20 of the 'Act to Regulate Commerce,' as amended by the Hepburn Act of June 29, 1906. The constitutional validity of this legislation was sustained in Interstate Commerce Commission v. Goodrich Transit Co., 224 U. S. 194, 21 I, 2I4, 56 L. Ed. 729, 32 Sup. Ct. 436. * * * The very object of a system of accounts is to display the pertinent financial operations of the company, and throw light upon its present condition. If they are to truly do this, the form must correspond with the substance. In order that accounts may be standardized, it is necessary that the accounts of the several carriers shall be arranged under like headings or titles; and it is obviously essential that charges and credits shall be allocated under the proper headings-the same with one carrier as with another. Unless 'Additions and Betterments,' on the one hand, and 'Operating Expenses,' on the other, are to indicate the same class of entries upon the books of one carrier that they indicate upon the books of other carriers, there is no possibility of standardization. So far as such uniformity requirements control or tend to control the conduct of the carrier in its capacity as a public servant en. gaged in interstate commerce, they are within the authority constitutionally conferred by Congress upon the Commission. There is no direct interference with the internal affairs of the corporation; and if any such interference indirectly results, it is only such as is incidental to the lawful control of the carrier by the Federal authority and to this the rights of stockholders and bondholders alike are necessarily subject.

"Congress in authorizing the Commission to prescribe a uniform system of accounts, recognized that accounting systems were not then uniform; 
ments" and a portion-the cost of property abandoned as an incident to permanent improvement-under the heading of "Operating Expenses." The authority for the first time conferred

and in reiterating this authorization in 1906 , and adding a probibition against the keeping of other accounts than those prescribed, manifested a purpose to standardize and render uniform the accounts of the different carriers with respect to matters that entered into property and the improvements thereof, on the one hand, and the current operations of the company, on the other. By the very terms of section 20, Congress at least outlined the classification of the carriers' accounts, for it required the annual reports to show 'the amount of capital stock issued, the amounts paid therefor, and the manner of payment for the same * * * the surplus fund, if any, *** the funded and floating debts *** the cost and value of the carrier's property, franchises and equipments; $*^{*} *$ the amounts expended for improvements each year, how expended, and the character of such improvements; the earnings and receipts from each branch of business and from all sources; the operating and other expenses; the balances of profit and loss; and a complete exhibit of the financial operations of the carrier each year, including an annual balance sheet.' By the same section the Commission was authorized to require these annual reports from all carriers subject to the Act, and to prescribe the manner in which the reports should be made, and for this and other purposes to require carriers to have 'as near as may be, a uniform system of accounts, and (to prescribe) the manner in which such accounts shall be kept.'

"Plainly the law-making body recognized the essential distinctions between property accounts and operating accounts, between capital and earnings; it recognized that the practise of different carriers varied in respect to these matters; and that no system of supervision and regulation would be complete without requiring the accounts of all the carriers to speak a common language. There is here no unconstitutional delegation of legislative powers. The reasoning adopted in Interstate Commerce Commission v. Goodrich Transit Co., 224 U. S. 194, 210, etc., 56 L. Ed. 729, 32 Sup. Ct. 436 is controlling. And since, as just shown, uniformity in accounting is dependent upon the adoption and enforcement of precise classification, the authority to define the terms of the classification necessarily follows. It amounts, after all, to no more than laying down the general rules of action under which the Commission shall proceed, and leaving it to the Commission to apply those rules to particular situations and circumstances by the establishment and enforcement of administrative regulations. It is contended that the regulations of the Commission, in respect to the matters now under consideration, are so unreasonable and arbitrary as to constitute an abuse rather than an exercise of the powers conferred by section 20 , and consequently that they ought to be set aside by judicial action. This is not on the ground that the Commission did not proceed with due deliberation and after proper inquiry.

"Since the regulation of the railroad carrier by the public authority, and 
upon the Commission by the Hepburn Act in 1906 to determine and prescribe the maximum rates to be charged by carriers for services to be performed by them furnished a new and more

especially the fixing of the rates to be charged, depend primarily upon two fundamental considerations, (a) the value of the property that is employed in the public service, and (b) the current cost of carrying on that service, it is clear that the maintenance of a proper line of distinction between property accounts and operating accounts is essential to the execution by the Interstate Commerce Commission of the supervisory and regulatory powers conferred upon it by Congress. Appellant contends, inter alia, that since the original locations were necessary in the development of its railroad line and were abandoned only as an incident to the improvement and development of the property, the cost thereof, being as it is termed a part of the 'cost of progress,' should remain in the property account, as representing a part of the stockholder's present investment.

And since one of the manifest objects of Congress in authorizing the supervision and standardization of carriers' accounts as is done in section 20 of the Interstate Commerce Act, was to enable the commissioners to intelligently perform their duties respecting the regulation of carriers' rates for the services performed, and since it is settled that the property investment which is to be taken into consideration as one of the elements in fixing such rates is the property then in use (Smyth v. Ames, I69 U. S. 466, 546, 42 L. Ed. 819, I8 Sup. Ct. 418; San Diego Land and Town Co. v. National City, 174 U. S. 739, 757, 43 L. Ed. I154, I9 Sup. Ct. 804; San Diego Land and Town Co. v. Jasper, I89 U. S. 439, 442, 47 L. Ed. 892, 23 Sup. Ct. 57I; Wilcox v. Consolidated Gas Co., 212 U. S. 19, 4I, 53 L. Ed. 382, 29 Sup. Ct. 192; Minnesota Rate Cases, 230 U. S. 352, 434, 458, 57 L. Ed. I5I I, 33 Sup. Ct. 729), it is obvious that so far as the regulations of the Commission now under consideration discard the 'cost of progress' theory they need no further vindication.

"The accounting regulations do not seek to control railroad companies in the exercise of their discretion respecting what shall be done and how it shall be done but only to systematize their accounts with respect to whatever is done. It is to be presumed that boards of directors will select that method of accomplishing a needed grade revision that shall be preferable from the engineering standpoint and suited to the financial condition and prospects of the company; not that they will adopt an inferior or more costly method of improvement because of the accounting requirements. * * * It is said that the effect of the regulations, if complied with, is to deprive the preferred stockholders of a considerable part of the noncumulative dividends from the net earnings of the company, to which they would otherwise be entitled. The preferred stockholders, as such, are not before the court, and this is not a proper occasion for determining their rights. Supposing, however, that the enforcement of the accounting system does require them to forego their current dividends, we do not concede that this amounts to an unlawful taking of their property. Assuming (as of course we must) that the management of the company has acted 
pressing reason for establishing a uniform system of accounts, in order to enable the Commission to intelligently perform its rate fixing duties by a proper knowledge of property investment as an element in their determination. Nor in such case as that suggested is it any defense that the system of accounting prescribed by the Commission compels the carrier to devote to certain purposes funds which would otherwise be set aside in order to pay dividends, and that as a result thereof the owners of noncumulative preferred stock are for a period deprived of interest or dividends upon their investment. This does not amount to an unlawful taking of property in violation of the Constitution.

Right to Examine Papers of Railroad Companies.-Under section 20 the Interstate Commerce Commission has the right through its proper agents to inspect and examine any and all accounts, records and memoranda kept by railroads. This does not however include the power to examine the correspondence of a railroad. The primary object of the section was to establish a uniform system of accounting and bookkeeping and to have an inspection thereof. But the examiners of the Commission do not from this grant have the authority to seize and examine the correspondence, either confidential or otherwise, received or sent by railroad companies subject to the Act to Regulate Commerce.

prudently in making these extensive improvements within a short time, instead of distributing them throughout a series of years, and without providing in advance any fund applicable to them, still it must be presumed that the improvements are necessary to the general welfare of the company, and will result in its increased prosperity, and therefore make better the assurance of dividends for the preferred stockholders in the future. But, aside from that, the Interstate Commerce Act deals with the carrier in its capacity as a servant of the public, and as a distinct entity, amenable to the legitimate regulation of Congress and the Commission. If in this aspect the carrier is not unwarrantably injured or deprived of its property by the exercise of the regulatory powers, the operation of such regulations cannot be restrained on the ground of agreements made by the stockholders amongst themselves for apportioning profits to one or the other class of stockholders. To admit this might materially hamper the Federal control over interstate carriers and evidently would tend to render impracticable the standardization of methods of accounting. *** But did we agree with appellant that the abandonments ought to be charged to surplus or to profit and loss, rather than to operating expenses, we still should not deem this a sufficient ground to declare that the Commission had abused its power. So long as it acts fairly and reasonably within the grant of power constitutionally conferred by Congress, its orders are not open to judicial review." 
While it is true that correspondence may contain a record, and the only record, of certain business transactions that fact does not suggest the right of the Commission to an inspection of the letters of a railroad. The right of inspection and examination given by this section is not limited to such accounts, records and memoranda merely as have been made since the date when the Hepburn Act became effective (August 29, 1906), but extends as well to preexisting accounts, records and memoranda. ${ }^{2 a}$

2a United States v. Louisville and Nashrille Railroad Company, decided February 23, I915. In compliance with a resolution of the Senate, the Interstate Commerce Commission undertook an investigation of the Louisville and Nashville Railroad to determine whether it had been guilty of certain practices. The officials of the road declined to permit the examiners access to the letter files of the carrier and the Commission sought to obtain a mandamus to force the officials to submit their correspondence for examination. The Supreme Court said:- "To authorize the Government to demand the writ of mandamus in this case two sections of the Interstate Commerce Act are invoked-Twelve and Twenty. It is enough to say of section 12 that the record discloses that the proceedings and the demands for inspection in this case were not conducted under its authority. See Harriman v. Interstate Commerce Commission, 2 I I U. S. 407, 53 L. Ed. 253, 29 Sup. Ct. II5. Section I2 deals with the production of evidence in certain cases; it does not make provision for inspection by examiners duly authorized by the Commission. That feature of the law was added by the amendment to section 20, of June 29, 1906. The substantial question in the case is:-Was the right of inspection of the accounts, records and memoranda of the defendant in the manner attempted by the agents who represented the Commission in this respect, authorized by section 20 of the Act, as the same is amended by the Hepburn Act of June, 1906?

"This section, it will be observed, gives authority to the Commission to employ special agents or examiners, who shall have authority under the order of the Commission to inspect and examine any and all accounts, records and memoranda kept by such carriers. The copy of the authority issued by the Commission to the special agent or examiner who made the demand for inspection in this case shows that he was clothed with authority to examine any and all 'accounts, records and memoranda' kept by carriers subject to the Act to Regulate Commerce. The language here used, taken from section 20, shows that the Commission acted under authority of that section, and the examiner was thereby authorized to make the demand the refusal to comply with which was the basis for the petition for the writ of mandamus in this case. This part of the amended section, as the report of the Interstate Commerce Commission, I905, page II shows, was framed by the Commission and became a part of the law upon its recommendation. The appendix to the report (page 182) shows the amendment in the form in which it became a law. *** 
Writs of Mandamus for the Enforcement of Reports.-In I905 the Supreme Court held that under the Act to Regulate Commerce as it then existed, the Circuit Courts of the United

"Of course this Act, like other Acts, may be read in the light of the purpose it was intended to subserve and the history of its origin. We find then that in this section Congress has authorized the Commission to prescribe the forms of accounts, records, and memoranda, which shall include accounts, records and memoranda of the movements of traffic, as well as the receipts and expenditures of money, to which accounts, records and memoranda the Commission is given access at all times. The railroads are not allowed to keep any other than those prescribed by the Commis. sion. The Commission is empowered to appoint agents or examiners with authority to inspect and examine such accounts, records and memoranda, and provision is made penalizing the failure to comply with the orders of the Commission concerning such accounts, records and memoranda, or the falsification thereof, or the willful destruction or mutilation thereof, or the failure to make full, true and correct entries in such accounts, records and memoranda of all facts and transactions pertaining to the carrier's business, or keeping any other accounts, records and memoranda.

"Reading these provisions of the Act, there is nothing to suggest that they were intended to include correspondence relative to the railroad's business. In recommending the passage of the Act, the Commission did not suggest that it was essential to its purpose to have an inspection of the correspondence of the railroad. And, with its expert consideration of the questions involved and having clearly in mind the authority it was intended to secure, it can scarcely be supposed that the Commission would have confined its proposed amendment to the carefully chosen words 'accounts, records or memoranda,' and would have omitted the word 'correspondence,' if it had intended to include the latter. If we apply the rule of construction-noscitur a sociis-we find that all the provisions of the Act as to the inspection of accounts have relation to such as are kept in the system of bookkeeping to be prescribed by the Commission. It would be a great stretch of the meaning of the term as here used, to make 'memoranda' include correspondence. The 'records' of a corporation import the transcript of its charter and by-laws, the minutes of its meetings -the books containing the accounts of its official doings and the written evidence its contracts and business transactions. Certainly it was not intended that the Commission should prescribe the forms of correspondence, although it was given the power to prescribe the forms of all accounts, records and memoranda subject to the provisions of the Act.

"It is urged that the amendment to section 20 of February 25, 1909, adding a proviso to paragraph 7 , shows the intention of Congress to provide for accounts, records and memoranda, including more than those as to which the form may be prescribed by the Commission, in the word 'document' making this section broad enough to include correspondence. * * * It may be that the section is broad enough, particularly when read in the light of this proviso, to authorize an inspection of accounts, 
States had no original jurisdiction to issue a writ of mandamus at the instance of the Interstate Commerce Commission against a railroad company to compel it to make a report of the matters

records and memoranda for which no form has been prescribed by the Commission, but we do not find in this proviso anything to indicate that Congress in the original Act or the amendment intended to provide for the compulsory inspection of correspondence.

"There is nothing from the beginning to the end of the section to indicate that Congress had in mind that it was making any provisions concerning the correspondence received or sent by the railroad companies. The primary object to be accomplished was to establish a uniform system of accounting and bookkeeping and to have an inspection thereof. If it intended to permit the Commission to authorize examiners to seize and examine all correspondence of every nature, Congress would have used language adequate to that purpose. A sweeping provision of that nature attended with such consequences, would not be likely to have been enacted without probable exceptions as to some lines of correspondence required to be kept open and subject to inspection upon demand of the agents of the Government. In the brief filed on behalf of the United States, it is frankly admitted that there is much force in the objection that Congress did not intend in this grant of authority to include the confidential correspondence of the railroad companies between itself and its counsel, and it is admitted that in this respect the demand of the agent of the Commission may be too broad. The desirability of protecting confidential communications between attorney and client as a matter of public policy is too well known and has been too often recognized by text-books and courts to need extended comment now. If such communications were required to be made the subject of examination and publication, such enactment would be a practical prohibition upon professional advice and assistance.

"How far such a demand as embodied in this petition can be permitted within the constitutional rights set up by the defendant, we do not need to consider, as we do not think that the section of the Act of Congress under which the demand was made authorizes the compulsory submission of the correspondence of the company to inspection. It is true that correspondence may contain a record, and it may be the only record of business transactions, but that fact does not authorize a judicial interpretation of this statute which shall include a right to inspection which Congress did not intend to authorize.

"The court below held that the right to demand inspection of documents before August 29, I906, the date when the Hepburn Act went into effect, was of such a doubtful character that the writ ought not to issuc. We think the right of inspection and examination given by the Interstate Commerce Act by the amendment to section 20, was not intended to be limited to such accounts, records, and memoranda only as were made after the passage of the Act, but is intended to permit an examination of all such accounts, records, and memoranda, for the purpose of carrying out the 
specified in section $20 .^{3}$ The court declared that power to issue writs of mandamus could not be inferred and that such power existed in the Circuit Courts only when specifically conferred by

provisions of the Act. It is not contended that Congress might not do this within its constitutional authority, and the argument is that it had no such right in contemplation and did not intend to authorize it; but we think it is clear from the terms of the Act, read in the light of its purpose, that Congress did not intend to draw the line of inspection at pre-existing accounts, records and memoranda."

3 Knapp v. Lake Shore and Michigan Southern Railway Co., 197 U. S. 536, 49 L. Ed. 870, 25 Sup. Ct. 538. The railroad defendant failed to make out and return the report called for by the Commission under section 20 and the Commission filed a petition for mandamus which was dismissed by the Circuit Court. The Supreme Court said:- "Congress has undoubtedly power to authorize a Circuit Court to issue a mandamus in an original proceeding. Kendall v. United States, I2 Pet. 524, 9 L. Ed. II8I ; United States v. Schurz, I02 U. S. 378, 26 L. Ed. 167. But has Congress done so, as contended by sections 12 and 20 of the Interstate Commerce Act as amended? Under section 12 the Commission is given the authority to inquire into the management of the business of common carriers subject to the Act, and have the right to obtain from the carriers full and complete information to enable it to perform its duties. It is also authorized to enforce the provisions of the Act. By section 20 the Commission may require annual reports and fix the time and prescribe the manner in whicl such reports shall be made. And it is made the duty of any district attorney of the United States, to whom the Commission may apply, to institute in the proper court and to prosecute under the direction of the attorney general all necessary proceedings for the enforcement of the provisions of this Act. It is hence contended that the power of the Commission to require the report stated in the petition is undoubted and having power to order the report to be made the Commission has the power to enforce obedience to the order. But in what way? Manifestly only in such way as the courts have jurisdiction to give. All powers are given in view of that jurisdiction, and the amendments of the Interstate Commerce Act are so framed. Jurisdiction to issue mandamus is conferred by section 6 , to enforce the filing or publishing by a common carrier of its schedules or tariffs of rates, fares and charges. And such jurisdiction is also given to the circuit courts and district courts upon the relation of any person or persons, firm or corporation, alleging a violation of any of the provisions of the Act which prevents the relator from having interstate traffic moved on terms as favorable as any other shipper. The remedy is expressly made cumulative of the other remedies provided by the Act. It is clear, therefore, when Congress intended to give the power to issue mandamus, it expressed that intention explicitly. Such power cannot be inferred from the grant of authority to the Commission to enforce the Act or from the direction to district attorneys or the attorney general to institute 'all necessary proceedings for the enforcement of the provisions' 
statute. By the amendments to this section of June 29, I906, this situation was remedied and the right to issue original writs of mandamus to compel compliance with any of the provisions of the Act, or Acts supplementary thereto, was conferred upon the Circuit and District Courts of the United States upon the application of the attorney general at the request of the Commission.

The Carmack Amendment, Liability of the Primary Carrier. $^{3 a}$ - By the Carmack amendment to the Hepburn Act of June

of the Act (section 12). The proceedings meant are, as we have said, those within the jurisdiction of the court. And special remedies are given. For instance, by section 16 a summary proceeding in equity is authorized, and the form of the ultimate order of the court may be that of a 'writ of injunction or other proper process, mandatory or otherwise.' Without attempting now to define the extent of that section, we may say, it seems adequate to enable the Commission to enforce any order it is authorized to make."

3a By an Act approved Marcl 4, I9I5 this feature of section 20 was vitally amended. For that paragraph of the section set forth above reading:- "That any common carrier, railroad, or transportation company receiving property for transportation from a point in one state, etc. *** Provided, That nothing in this section shall deprive any holder of such receipt or bill of lading of any remedy or right of action which he has under existing law," the Act of March 4, I9I5 substitutes the following:

"That any common carrier, railroad, or transportation company subject to the provisions of this act, receiving property for transportation from a point in one State or Territory or the District of Columbia to a point in another State, Territory, or District of Columbia, or from any point in the United States to a point in an adjacent foreign country shall issue a receipt or bill of lading therefor, and shall be liable to the lawful holder thereof for any loss, damage, or injury to such property caused by it or by any common carrier, railroad, or transportation company to which such property may be delivered or over whose line or lines such property may pass, within the United States or within an adjacent foreign country when transported on a through bill of lading, and no contract, receipt, rule, regulation, or other limitation of any character whatsoever, shall exempt such common carrier, railroad, or transportation company from the liability hereby imposed; and any such common carrier, railroad, or transportation company so receiving property for transportation from a point in one State, Territory, or the District of Columbia to a point in another State or Territory, or from a point in a State or Territory to a point in the District of Columbia, or from any point in the United States to a point in an adjacent foreign country, or for transportation wholly within a Territory shall be liable to the lawful holder of said receipt or bill of lading or to any party entitled to recover thereon, whether such receipt or bill of lading has been issued or not, for the full actual loss, damage, or injury to any such property caused by it or by any common carrier, railroad, or transportation company to which such property may be delivered or over whose line or lines such property may pass within the United States or within an adjacent 
29, 1906, Congress stipulated that a receiving carrier, in spite of any stipulation to the contrary, shall be deemed, when it receives property in one state to be transported to a point in another state involving the use of a connecting carrier for some part of the

foreign country when transported on a through bill of lading, notwithstanding any limitation of liability or limitation of the amount of recovery or representation or agreement as to value in any such receipt or bill of lading, or in any contract, rule, regulation, or in any tariff filed with the Interstate Commerce Commission; and any such limitation, without respect to the manner or form in which it is sought to be made, is hereby declared to be unlawful and void: Provided, however, That if the goods are hidden from view by wrapping, boxing, or other means, and the carrier is not notified as to the character of the goods, the carrier may require the shipper to specifically state in writing the value of the goods, and the carrier shall not be liable beyond the amount so specifically stated, in which case the Interstate Commerce Commission may establish and maintain rates for transportation, dependent upon the value of the property shipped as specifically stated in writing by the shipper. Such rates shall be published as are other rate schedules: Provided further. That nothing in this section shall deprive any holder of such receipt or bill of lading of any remedy or right of action which he has under the existing law: Prozided further. That it shall be unlawful for any such common carrier to provide by rule, contract, regulation, or otherwise a shorter period for giving notice of claims than 90 days, and for the filing of claims for a shorter period than four months, and for the institution of suits than two years: Procided, howeier. That if the loss, damage, or injury complained of was due to delay or damage while being loaded or unloaded, or damaged in transit by carelessness or negligence, then no notice of claim nor filing of claim shall be required as a condition precedent to recovery.

"SEC. 2. That this act shall take effect and be in force from 90 days after its passage."

Manifestly the object of this amendment to the Act to Regulate Commerce is to make carriers engaged in interstate commerce liable for the actual loss, damage, or injury to such property caused by them and their connecting lines, notwithstanding any limitation of liability or of the amount of recovery in any receipt, or contract, or bill of lading or in any tariff filed with the Interstate Commerce Commission, except in one case: Where the property received for transportation is hidden from view by wrapping or boxing and the carrier is not notified of the character of the goods, when the carriers may require the shipper to state the value in writing. The carrier then shall not be liable beyond the amount so specifically stated and in that case the Interstate Conımerce Commission may establish rates for transportation dependent upon the valuation thus declared. The Carmack amendment in general terms prohibited common carriers from exempting themselves from liability for goods carried by them and their connecting lines. This amendment goes further and seeks to prevent carriers from limiting their liability to an amount less than the actual value of the goods carried, except when the goods are hidden from view, and in that case the shipper is estopped from recovering an amount larger than that declared by him. It is to be especially no- 
way, to have adopted such other carrier as its agent, and to incur liability throughout the entire route, with the right to reimbursement for a loss not due to its own negligence." Independently of

ticed that this amendment does not prevent common carriers from limiting by contract their liability in the case of shipments to foreign countries not contiguous to the United States.

The amendment also forbids the carrier to fix an unreasonable time limit for the presentation of notices and claims and for bringing suits for losses or damages incurred in these shipments.

4 Atlantic Coast Line v. Riverside Mills, 219 U. S. I86, 55 L. Ed. 167, 3 I Sup. Ct. I64. Suit was brought against an initial carrier for the loss of goods delivered to it for shipment to a point in another state over it and connecting carriers. The bill of lading issued by the initial carrier contained among others the stipulation that "No carrier shall be liable for loss or damage not occurring on its portion of the route." The goods were lost by a connecting carrier to whom they had been safely delivered. The court said :

"Though received for a point beyond its own line and for a point on the line of a succeeding carrier, there was no agreement for their safe carriage beyond the line of the plaintiff in error, but, upon the contrary, an express agreement that the initial carrier should not be liable for 'a loss or damage not occurring on its own portion of the route.' Such a provision is not a contract for exemption from a carrier's liability as such, but a provision making plain that it did not assume the obligation of a carrier beyond its own line, and that each succeeding carrier in the route was but the agent of the shipper for a continuance of the transportation. It is therefore obvious that at the common law an initial carrier under such a state of facts would not be liable for a loss through the fault of a connecting carrier to whom it had, in due course, safely delivered the goods for further transportation. Railroad v. Pratt, 22 Wall. 123, 22 L. Ed. 827; Myrick v. Railroad, 107 U. S. 102, 27 L. Ed. 325, I Sup. Ct. 425 ; Southern Pacific Ry. v. Interstate Commerce Commission, 200 U. S. 536, 554, 50 L. Ed. 585, 26 Sup. Ct. 330 . Liability is confessedly dependent upon the provision of the Act of Congress regulating commerce between the states known as the Carmack Amendment of January 29, 1906. *** The power of Congress to enact this legislation has been denied, first, because it is said to deprive the carrier and the shipper of their common law power to make a just and reasonable contract in respect to goods to be carried to points beyond the line of the interstate carrier; and, second, that in casting liability upon the initial carrier for loss or damage upon the line of a connecting carrier the former is deprived of its property without due process of law. The indisputable effect of the Carmack amendment is to hold the initial carrier engaged in interstate commerce and 'receiving property for transportation from a point in one state to a point in another state' as having contracted for through carriage to the point of destination, using the lines of connecting carriers as its agents.

"Independently of the Carmack amendment the carrier, when tendered 
the Carmack amendment the carrier when tendered property for such transportation, might contract to carry it to its destination, in which case it necessarily agreed to do so through the agency

property for such transportation, might elect to contract to carry to destination, in which case it necessarily agreed to do so through the agency of other and independent carriers in the line; or, it might elect to carry safely over its own lines only and then deliver to the next carrier, who would then become the agent of the shipper. In the first case the receiving carrier's liability, as carrier, extends over the whole route, for, on obvious grounds, the principal is liable for the acts of its agent. In the other case its carrier liability ends at its own terminal, and its further liability is merely that of a forwarder. Having this power to make the one or the other contract, the only question which has occasioned a conflict in the decided cases was whether it, in the particular case, made the one or the other. The general doctrine accepted by this court, in the absence of legislation, is, that a carrier, unless there be a special contract, is only bound to carry over its own line, and then deliver to a connecting carrier. That such an initial carrier might contract to carry over the whole route was never doubted. It is equally indisputable that if it does so contract, its common law carrier liability will extend over the entire route. Railway v. McCarthy, 96 U. S. 258, 266, 24 L. Ed. 693; Railroad v. Pratt, 22 Wall. 123, 22 L. Ed. 827; Railroad v. American Trading Co., 195 U. S. 439, 49 L. Ed. 260, 25 Sup. Ct. 84; Muschamp v. Lancaster Railway Co., 8 M. \& W. $42 \mathrm{I}$.

"In this conflicting condition of the decisions as to the circumstances from which an agreement for through transportation of property designated to a point beyond the receiving carrier's line might be inferred, Congress by the Act here involved has declared, in substance, that the act of receiving property for transportation to a point in another state and beyond the line of the receiving carrier shall impose on such receiving carrier the obligation of through transportation with carrier liability throughout. But this uncertainty of the nature and extent of the liability of a carrier receiving goods destined to a point beyond its own line was not all which might well induce the interposition of the regulating power of Congress. Nothing has perhaps contributed more to the wealth and prosperity of the country than the almost universal practise of transportation companies to cooperate in making through routes and joint rates. Through this method a situation has been brought about by which, though independently managed, connecting carriers became in effect one system. This practise has its origin in the mutual interests of such companies and in the necessities of an expanding commerce. * * * Along with this singleness of rate and continuity of carriage there grew up the practise by receiving carriers, illustrated in this case, of refusing to make a specific agreement to transport to points beyond its own line, whereby the connecting carrier for the purpose of carriage would become the agent of the primary carrier. The common form of receipt, as the court may judicially know, is one by which the shipper is compelled to make with each 
of other and independent lines. And in that case the initial carrier's liability would extend over the whole route since the principal is liable for the acts of its agents. Or the carrier might

carrier in the route over which his package must go a separate agreement limiting the carrier liability of each separate company to its own part of the through route. As a result the shipper could look only to the initial carrier for recompense for loss, damage or delay occurring on its part of the route. If such primary carrier was able to show a delivery to the rails of the next succeeding carrier, although the packages might and usually did continue the journey in the same car in which they had been originally loaded, the shipper must fail in his suit. He might, it is true, then bring his action against the carrier so shown to have next received the shipment. But here, in turn he might be met by proof of safe delivery to a third separate carrier. In short, as the shipper was not himself in possession of the information as to when and where his property had been lost or damaged and had no access to the records of the connecting carriers who in turn had participated in some part of the transportation, he was compelled in many instances to make such settlement as should be proposed. This burdensome situation of the shipping public in reference to interstate shipments over routes including separate lines of carriers was the matter which Congress undertook to regulate.

"It must be conceded that the effect of the Act in respect of carriers receiving packages in one state for a point in another and beyond its own lines, is to deny such an initial carrier the former right to make a contract limiting liability to its own line. This it is said is a denial of the liberty of contract secured by the Fifth Amendment of the Constitution. * * * Having the express power to make rules for the conduct of commerce among the states, the range of congressional discretion as to the regulation best adapted to remedy a practise found inefficient or hurtful, is a wide one. If the regulating Act be one directly applicable to such commerce, not obnoxious to any other provision of the Constitution, and reasonably adapted to the purpose by reason of legitimate relation between such commerce and the rule provided, the question of power is foreclosed. 'The test of power,' said Mr. Justice White, speaking for the court in the Employer's Liability Cases, 207 U. S. 463, 52 L. Ed. 297, 28 Sup. Ct. I4I, 'is not merely the matter regulated, but whether the regulation is directly one of interstate commerce, or is embraced within the grant conferred on Congress to use all lawful means necessary and appropriate to the execution of the power to regulate commerce.'

"That a situation had come about which demanded regulation in the public interest was the judgment of Congress. The requirement that carriers who undertook to engage in interstate transportation, and as a part of that business held themselves out as receiving packages destined to places beyond their own terminal, should be required as a condition of continuing in that traffic to obligate themseives to carry to the point of destination, using the lines of connecting carriers as their own agencies, was not beyond the scope of the power of regulation. The rule is adapted to 
prefer to carry shipments safely over its own lines only and then deliver them to the next carrier who would thus become the agent not of the carrier but rather of the shipper. In this case

secure the rights of the shippers by securing unity of transportation with unity of responsibility. The regulation is one which also facilitates the remedy of one who sustains a loss, by localizing the responsible carrier. Neither does the regulation impose an unreasonable burden upon the receiving carrier. The methods in vogue, as the court may judicially know, embrace not only the voluntary arrangement of through routes and rates, but the collection of the single charge made by the carrier at one or the other end of the route. This involves frequent and prompt settlement of traffic balances. The routing in a measure depends upon the certainty and promptness of such traffic balance settlements, and such balances have been regarded as debts of a preferred character when there is a receivership. Again, the business association of such carriers affords to each facilities for locating primary responsibility as between themselves which the shipper cannot have. These well-known conditions afford a reasonable security to the receiving carrier for a reimbursement of a carrier liability which should fall upon one of the connecting carriers as between themselves.

"But, it is said, that any security resulting from a voluntary agreement constituting a through route and rate is destroyed if the receiving carrier is not at liberty to select his own agencies for a continuance of the transportation beyond his own line. This is an objection which has no application to the present case. This action was for loss and damage arising from several distinct shipments to different places beyond the line of the plaintiff in error who was the initial or receiving carrier. The presumption from the absence of anything to the contrary in the record is that the routing was over connecting lines with whom the plaintiff in error had theretofore made its own arrangements and rate. This record presents no question as to the right of the initial carrier to refuse a shipment designated for a point beyond its own line, nor its right to refuse to make a through route or joint ratc when such route and rate would involve the continuance of a transportation over independant lines. We, therefore, refrain from any consideration of the large question thus suggested. The shipments involved in the present case were voluntarily received by an initial carrier who undertook to escape carrier's liability beyond its own line by a provision limiting liability to loss upon its own line. This was forbidden by the Carmack amendment and any stipulation and condition in the special receipt which contravenes the rule in question is invalid.

"Reduced to the final results, the Congress has said that a receiving carrier, in spite of any stipulation to the contrary, shall be deemed, when it receives property in one state to be transported to a point in another involving the use of a connecting carrier for some part of the way, to have adopted such other carrier as its agent, and to incur liability throughout the entire route, with the right to reimbursement for a loss not due to his own negligence. The conditions which justified this extension of carrier 
the liability of the primary carrier ends at its own terminus, and its further liability is solely that of a forwarder. In the absence of legislation otherwise, the courts have accepted the doctrine that, unless there exists a special contract, a carrier is bound to carry only over its own line and then deliver to a connecting carrier. But such a carrier might contract to carry over the whole route under which condition its common law carrier liability will extend over the entire route.

With this singleness of rate and continuity of carriage railroads developed the practise of refusing to make a specific agreement to transport to points beyond their own lines thus declining to make the connecting carriers their agents. A form of receipt or bill of lading was adopted by which the shipper was compelled

liability we have already adverted to. The rule of the common law which treated a common carrier as an insurer grew out of a situation which required that kind of security for the protection of the public. *** If it is to be assumed that the ultimate power exerted by Congress is that of compelling co-operation by connecting lines of independent carriers for purposes of interstate transportation, the power is still not beyond the regulating power of Congress, since without merging identity of separate lines or operation it stops with the requirement of oneness of charge, continuity of transportation and primary liability of the receiving carrier to the shipper, with the right of reimbursement from the guilty agency in the route. That there is some chance that this right of recoupment may not be always effective may be conceded without invalidating the regulation. If the power existed and the regulation is adapted to the purpose in view, the public advantage justifies the discretion exercised and upholds the legislation as within the limit of the grant conferred upon Congress. $* * *$

"But it is said that the Act violates the fifth amendment by taking the property of the initial carrier to pay the debt of an independent connecting carrier whose negligence may have been the sole cause of the loss. But this contention results from a surface reading of the Act and misses the true basis upon which it rests. The liability of the receiving carrier which results in such a case is that of a principal for the negligence of his own agents. In substance Congress has said to such carriers, 'If you receive articles for transportation from a point in one state to a place in another, beyond your own terminal you must do so under a contract to transport to the place designated. If you are obliged to use the services of independent carriers in the continuance of the transit, you must use them as your own agents and not as agents of the shipper.' It is, therefore, not the case of making one pay the debt of another. The receiving carrier is, as principal, liable not only for its own negligence, but for that of any agency it nay use, although, as between themselves, the company actually causing the loss may be pimarily liable." 
to make with each carrier in the route traversed by his goods a separate agreement limiting the carrier liability of each separate company to its own part of the through route. Under such an arrangement the shipper could look to the initial carrier only for reimbursement for loss or damage occurring on its part of the route. If the primary carrier could show delivery to the next succeeding carrier the shipper would fail in his suit. He could then sue the succeeding carriers with a possible repetition of the same defense by them. The records of the carriers would naturally show just where the loss or damage occurred to the shipment but the shipper would not have access to such records, would be forced to bring suits, as it were, in the dark and would be subjected to the expense of a multitude of actions, or else accept a settlement dictated by the carriers. On the other hand, the railroads through their records are able to definitely fix the responsibility for loss or damage to shipments and through their traffic balances are able to settle such claims between themselves promptly and equitably. The Carmack amendment was adopted to secure unity of responsibility with unity of transportation,in detail by requiring oneness of charge, continuity of transportation and primary liability of the receiving carrier to the shipper, with the right of reimbursement from the guilty agency in the route.

The Supreme Court denied that the amendment in question was violative of the fifth amendment to the Constitution either in denying the liberty of contract or by taking the property of the initial carrier to pay the debt of an independent carrier. The liability of the receiving carrier, it declared, was merely that of a principal for the negligence of his own agents, and was not, therefore, a case of compelling one to pay the debt of another. There remained the right of the primary carrier to recoup from the connecting carrier which served as its agent.

Wherever the carrier voluntarily accepts goods for shipment to a point on another line in another state it is conclusively treated as having made a through contract, and the situation must be treated as though the point of destination was on its own line and is to be governed by the same rules of pleading, practise and presumption as if the shipment had been between stations in different states, but both on the initial carrier's railroad. And thus when the holders of the bills of lading proved the goods have not been delivered to the consignee the presumption arises that 
they have been lost through the negligence of the carrier or its agents. The burden of proof that the loss resulted from some cause for which the initial carrier was not responsible in law or by contract, as by the act of God, is then cast upon the carrier. ${ }^{5}$

5 Galveston, Harrisburg and San Antonio Railway Co. v. Wallace, 223 U. S. 481, 56 L. Ed. 516, 32 Sup. Ct. 205. Liability for failure to deliver a shipment of goods was denied by the initial carrier on the ground that under the contract expressed in the bills of lading its obligation and liability ceased when it safely delivered the goods to the next carrier. The court said:- "The question as to the constitutionality of the Carmack amendment, though ably and elaborately argued, is out of the case, having been decided adversely to the contention of the plaintiff in Atlantic Coast Line R. R. v. Riverside Mills, 219 U. S. 186, 55 L. Ed. 167, 31 Sup. Ct. 164, after the present suit was instituted. The company, however, seeks to distinguish this from that on the ground that in the Riverside case it was admitted that the damage to the freight was caused by the negligence of the connecting carrier. And, as the statute applies to cases where the damage is caused by the initial or connecting carrier, and as the cause of the loss of the goods does not appear here, it is argued that liability is to be governed by the contract, which provides that the initial carrier should not be responsible beyond its own line. Plaintiff in error insists that the Carmack Amendment did not make it an insurer. Under the construction given that statute in Matter of Released Rates, I3 I. C. C. Rep. 550; Patterson v. Adams Express Co., 205 Mass. 254; Travis v. Wells-Fargo Express Co., 74 Atl. Rep. 444, it claims that the initial carrier is not deprived of its right to contract with the shipper against liability for damages not caused by either carrier's negligence. But the failure to plead and to prove the cause of the nondelivery of the goods at destination precludes any determination of such questions.

"Under the Carmack Amendment, as already construed in the Riverside Mills Case, wherever the carrier voluntarily accepts goods for shipment to a point on another line in another state, it is conclusively treated as having made a through contract. It thereby elected to treat the connecting carriers as its agents, for all purposes of transportation and delivery. The case, then must be treated as though the point of destination was on its own line, and is to be governed by the same rules of pleading, practise and presumption as would have applied if the shipment had been between stations in different states, but both on the company's railroad. Thus considered, when the holders of the bills of lading proved the goods had not been delivered to the consignee, the presumption arose that they had been lost by reason of the negligence of the carrier or its agents. The burden of proof that the loss resulted from some cause for which the initial carrier was not responsible in law or by contract was then cast upon the carrier. The plaintiffs were not obliged both to prove their case and to disprove the existence of a defense. The carrier and its agents, having received possession of the goods, were charged with the duty of delivering them or explaining why that had not been done. This must be so, because 
And the action of the carrier is voluntary where it accepts an interstate shipment to be transported over a route selected by the shipper though it was a different one from that which the carrier otherwise would have chosen and was one over which the carrier had no established through route or rate. ${ }^{6}$

State Legislation and Regulation Superseded.-Prior to the Carmack amendment the rule of carrier's liability for an interstate shipment, as enforced both by federal and state courts, was either that of the common law as declared by the Supreme Court and enforced in the federal courts of the country, or that determined by the public policy of a particular state, or that prescribed by statute law of an individual state. The result was that there was neither uniformity of obligation nor liability. The silence of Congress on the question permitted the exercise of the police

carriers not only have better means, but often the only means, of making such proof. If the failure to deliver was due to the act of God, the public enemy or some cause against which it might lawfully contract, it was for the carrier to bring itself within such exception. In the absence of such proof, the plaintiffs were entitled to recover."

6 Norfolk and Western Railway Co. v. Dixie Tobacco Co., 228 U. S. 593, 57 L. Ed. 980, 33 Sup. Ct. 609. The tobacco shipment was sent partly by railroad and partly by sea and there was evidence that the shipper chose the route for the tobacco and a different one from that which the railroad would have adopted which would have been all rail. The railroad had no through route or rate established with the line of steamers by which the tobacco went. The court said:- "The Supreme Court of Appeals (Virginia) followed the ruling in Atlantic Coast Line R. Co. v. Riverside Mills, 219 U. S. I86, 55 L. Ed. I67, 31 Sup. Ct. I64, (to which may be added Galveston, H. \& S. A. R. Co. v. Wallace, 223 U. S. 48 I, 56 L. Ed. 516, 32 Sup. Ct. 205), as conclusive. The plaintiff in error contends that these cases may be distinguished on the ground that in both of them it was to be presumed that the carrier was a voluntary party to a through route and rate, whereas here the stipulation against liability beyond its line, and the fact that it had no through route with the steamship company, exclude that presumption. It argues that as it was bound to accept goods destined beyond its line for delivery to the next carrier, and was required by the statute to give a through bill of lading, if, on such compulsory acceptance, it is made answerable for damages done by others, its property is taken without due process of law. But in the former case there was the same stipulation in the bill of lading, and the supposed through routes were only presumed. In the second case the carrier is spoken of as voluntarily accepting goods for a point beyond its line; but there, too, there was the same attempt to limit liability, and in the present case the acceptance was voluntary in the same degree as in that. There is no substantial distinction between the earlier decisions and this." 
power of the states concerning such contract of interstate shipment. The Carmack amendment was so broad in its scope and so thorough in its provisions that as an exercise by Congress of its conceded authority it superseded the regulations and policies of the states whose power over the question ceased to exist. Congress thereby adopted a uniform rule with the purpose of relieving such contracts of shipment from the varied and diverse regulation to which they had previously been subject." Congress

7 Adams Express Co. v. Croninger, 226 U. S. 49I, 57 L. Ed. 3I4, 33 Sup. Ct. 148. Under the Kentucky statutes a contract limiting the shipper's recovery to the agreed or declared value was declared invalid and the shipper was entitled to recover the actual value of the shipment lost or destroyed. The Supreme Court said:- "The question upon which the case must turn is, whether the operation and effect of the contract for an interstate shipment, as shown by the receipt or bill of lading, is governed by the local law of the state, or by the Acts of Congress regulating interstate commerce. That the constitutional power of Congress to regulate commerce among the states and with foreign nations comprehends power to regulate contracts between the shipper and carrier of an interstate shipment by defining the liability of the carrier for loss, delay, injury or damage to such property, needs neither argument nor citation of authority. But it is equally well settled that until Congress has legislated upon the subject, the liability of such carrier, exercising its calling within a particular state, although engaged in the business of interstate commerce, for loss or damage to such property, may be regulated by the law of the state. Such regulations would fall within that large class of regulations which it is competent for a state to make in the absence of legislation by Congress, growing out of the territorial jurisdiction of the state over such carriers and its duty and power to safeguard the general public against acts of misfeasance and nonfeasance committed within its limits, although interstate commerce may be indirectly affected. Smith v. Alabama, I24 U. S. 465, 3I L. Ed. 508, 8 Sup. Ct. 564; New York, etc., Railroad v. New York, I65 U. S. 628, 4I L. Ed. 853, I7 Sup. Ct. 418; Chicago and Milwaukee Ry. v. Solan, I69 U. S. 133, I37, 42 L. Ed. 688, I8 Sup. Ct. 289; Richmond, etc., Ry. v. Patterson Co., I69 U. S. 31 I, 42 L. Ed. 759, I8 Sup. Ct. 335; Cleveland, etc., Ry. v. Illinois, 177 U. S. 514, 44 L. Ed. 868, 20 Sup. Ct. 722 ; Pennsylvania Railroad v. Hughes, I91 U. S. 477, 48 L. Ed. 268, 24 Sup. Ct. I32. In the Solan case, cited above, it was said of such state legislation:-

"'They are not, in themselves, regulations of interstate commerce, although they control, in some degree, the conduct and the liability of those engaged in such commerce. So long as Congress has not legislated upon the particular subject, they are rather to be regarded as legislation in aid of such commerce, and as a rightful exercise of the police power of the state to regulate the relative rights and duties of all persons and corporations within its limits.'

"* * * The original Interstate Commerce Act of February 4, 1887, was extensively amended by the Act of June 29, 1906, 34 Statutes at Large 584. We may pass by many of the changes and amendments made by the 
has imposed upon the initial carrier a liability to any holder of the bill of lading which the primary carrier is required to issue, "for any loss, damage or injury to such property caused by it," or by any one of the connecting carriers to whom the goods are delivered in transit.

latter Act as not decisive and come at once to the far more inportant amendment made in the 2oth section, an amendment bearing directly upon the carrier's liability or obligation under interstate contracts of shipment, and generally referred to as the Carmack amendment. This amendment came under consideration in Atlantic Coast Line $v$. Riverside Mills, 2 I9 U. S. 186,55 L. Ed. 167,31 Sup. Ct. I64. but the opinion and judgment was confined to that provision of the Act which made the initial carrier liable for a loss upon the line of a connecting carrier, the property having been received under a bill of lading which confined the liability of the initial carrier to loss occurring upon its own line.

"Prior to that amendment the rule of carriers liability, for an interstate shipment of property, as enforced in both Federal and state courts, was either that of the general common law as declared by this court and enforced in the Federal courts throughout the United States. Hart v. Pa. Railroad, II2 U. S. 33I, 28 L. Ed. 717, 5 Sup. Ct. 151; or that determined by the supposed policy of a particular state, Pennsylvania R. R. $\checkmark$. Hughes. 19I U. S. 477,48 L. Ed. 268,24 Sup. Ct. 132; or that prescribed by statute law of a particular state, Chicago, etc., Railroad v. Solan, I69 U. S. 133, 42 L. Ed. 688, I8 Sup. Ct. 289. Neither uniformity of obligation nor of liability was possible until Congress should deal with the subject.

"That the legislation supersedes ali the regulations and policies of a particular state upon the same subject results from its general character. It embraces the subject of the liability of the carrier under a bill of lading which he must issue and limits his power to exempt himself by rule, regulation or contract. Almost every detail of the subject is covered so completely that there can be no rational doubt but that Congress intended to take possession of the subject and supersede all state regulation with reference to it. Only the silence of Congress authorized the exercise of the police power of the state upon the subject of such contracts. But when Congress acted in such a way as to manifest a purpose to exercise its conceded authority, the regulating power of the state ceased to exist. Northern Pacific Ry. v. State of Washington, 222 C. S. 370.56 L. Ed. 237, 32 Sup. Ct. I60; Southern Railway v. Reid, 222 U. S. 424. 56 L. Ed. 257, 32 Sup. Ct. I40; Mondou $v$ Railroad. 223 L. S. I, 56 L. Ed. 327, 32 Sup. Ct. I69; Michigan Central Railroad v. Vreeland, 227 U. S. 59. To hold that the liability therein declared may be increased or diminished by local regulation or local views of public policy will either make the provision less than supreme or indicate that Congress has not shown a purpose to take possession of the subject. The first would be unthinkable and the latter would be to revert to the uncertainties and diversities of rulings which led to the amendment. The duty to issue a bill of lading and the liability 
But the Supreme Court has held that where a state, for reasons of internal policy, in order to offer an incentive to the prompt settlement of small but just claims, and as a deterrent of groundless defenses, established by a general statute otherwise unexceptionable the policy of allowing recovery of a moderate attorney's fee as a part of the costs, in cases where, after specific claim made and a reasonable time given for investigation thereof, payment is refused, and the claimant succeeds in establishing by suit his right to the full amount demanded, the application of such statute to actions for goods lost or damaged in interstate commerce is not inconsistent with the provisions of the Act to Regulate Commerce and its amendments. Such a statute does not affect the ground of recovery or the measure of recovery but

thereby assumed are covered in full, and though there is no reference to the effect upon state regulation, it is evident that Congress intended to adopt a uniform rule and relieve such contracts from the diverse regulation to which they had been therefore subject."

In Boston and Maine Railroad Co. v. Hooker, 233 U. S. 97,58 L. Ed. $868,3+$ Sup. Ct. 526, the court said:- "Since the decision in the Hughes case (191 U. S. 477,48 L. Ed. 268,24 Sup. Ct. 132) the Hepburn Act of June 29, 1906, has been passed, and this court has held that by virtue of that Act (particularly section 20, the Carmack amendment) the subject of interstate transportation of property has been regulated by Federal law to the exclusion of the power of the states to control in such respect by their own policy or legislation."

In Atchison, Topeka and Santa Fe Railway Co. r. Robinson, 233 U. S. 173, 58 L. Ed. 901,34 Sup. Ct. 556, the court said:- "That the effect of the Carmack amendment to the Hepburn Act was to give to the Federal jurisdiction control over interstate commerce, and to make supreme the Federal legislation regulating liability for property transported by common carriers in interstate commerce, has been so recently and repeatedly decided in this court as to require now little more than a reference to some of the cases."

To the same effect, see also Wells Fargo Co. v. Neiman-Marcus Co., 227 U. S. 469, 57 L. Ed. 600, 33 Sup. Ct. 267; Chicago, Burlington and Quincy Ry. Co. v. Miller, 226 U. S. 513,57 L. Ed. 323, 33 Sup. Ct. 155; Chicago, St. Paul, Minneapolis and Omaha Ry. Co. v. Latta, 226 U. S. $519,57 \mathrm{~L}$. Ed. 328 , 33 Sup. Ct. 155; Missouri, Kansas and Texas Ry. Co. v. Harriman Bros.. 227 U. S. 657, 57 L. Ed. 690, 33 Sup. Ct. 397 ; Great Northern Ry. Co. v. O'Connor, 232 U. S. 508, 58 L. Ed. 703, 34 Sup. Ct. 380 ; Chicago, Rock Island and Pacific Ry. Co. v. Cramer, 232 U. S. 490, 58 L. Ed. 697 , 34 Sup. Ct. 383; Atchison, Topeka and Santa Fe Ry. Co. v. Moore, 233 U. S. 182, 58 L. Ed. 906,34 Sup. Ct. 558. 
deals only with the question of costs concerning which Congress has not legislated. ${ }^{8}$

\section{Limitation of Time for Bringing Action.-Under the Car-}

8 Missouri, Kansas and Texas Ry. Co. v. Harris, 234 U. S. 412, 58 L. Ed. 1377,34 Sup. Ct. 790. A statute of the state of Texas allows an attorney's fee of $\$ 10$ as part of the costs to be recovered by a shipper when he succeeds in a suit against a carrier for loss or damage to a shipment when payment has been denied within a specified time by the carrier. The court said :- "The 'Act to Regulate Commerce' (Act of February 4, 1887,) is now invoked, together with its amendments, and especially that part of the Hepburn Act of June 29, 1906, known as the Carmack amendment; and it remains to be considered whether the Texas statute, as applied to claims for loss or damage to interstate freight while in the possession of the carrier in the state of Texas, is repugnant to this Federal legislation. It is of course settled that when Congress has exerted its paramount legislative authority over a particular subject of interstate commerce. state laws upon the same subject are superseded. Northern Pacific Ry. v. Washington, 222 U. S. 370, 378. 56 L. Ed. 237, 32 Sup. Ct. I60; Erie Railroad Co. $v$. New York, 233 U. S. 67I. But it is equally well settled that the mere creation of the Interstate Conmerce Commission, and the grant to it of a measure of control over interstate commerce, does not of itself, and in the absence of specific action by the Commission or by Congress itself. interfere with the authority of the states to establish regulations conducive to the welfare and convenience of their citizens, even though interstate commerce be thereby incidentally affected, so long as it be not directly burdened or interfered with. Missouri Pacific Ry. v. Larabee Mills, 211 U. S. 612, 623, 53 L. Ed. 352, 29 Sup. Ct. 214; Southern Ry. Co. v. Reid, 222 U. S. 424, 437, 56 L. Ed. 257,32 Sup. Ct. 140.

"With respect to the specific effect of the Carmack amendment. it has been held, in a series of recent cases *** that the special regulations and policies of particular states upon the subject of the carrier's liability for loss or damage to interstate shipments and the contracts of carriers with respect thereto, have been superseded. But the Texas statute now under consideration does not in anywise either enlarge or limit the responsibility of the carrier for the loss of property entrusted to it in transportation, and only incidentally affects the remedy for enforcing that responsibility. As pointed out in the Cade case, supra, it imposes not a penalty, but a compensatory allowance for the expense of employing an attorney. applicable in cases where the carrier unreasonably delays payment of a just demand and thereby renders a suit necessary. In fact and effect, it merely authorizes a moderate increment of the recoverable costs of suit in the large class of cases that are within its sweep, among which are incidentally included claims for freight lost or damaged in interstate commerce.

"It is true that in Atlantic Coast Line v. Riverside Mills, 219 U. S. 186, 208, 55 L. Ed. I67, 31 Sup. Ct. I64, (a case arising since the Hepburn Act), it was held that section 8 of the Act of February 4.1887 . does not author- 
mack amendment carriers by contract could require actions to be brought within a reasonable stated time. ${ }^{\theta}$ But the Act of March 4 , 1915 , forbids carriers to compel notice of claims in less than 90 days, their filing in less than four months, or the institution of suits within two years.

ize the allowance of a counsel or attorney's fee in an action for loss of property entrusted to the carrier for purposes of transportation. But that is far from holding that it is not permissible for a state, as a part of its local procedure, to permit the allowance of a reasonable attorney's fee, under proper restrictions. In claims of this claracier, based upon the ordinary liability of the common carrier, although regulated by the Commerce Act, the state courts have full jurisdiction, and some differences respecting the allowance of costs and the amount of the costs are inevitable, as being peculiar to the forum. And we think that where a state, for reasons of internal policy, in order to offer a reasonable incentive to the prompt settlement of small but well-founded claims, and as a deterrent of groundless defenses, establishes by a general statute otherwise unexceptionable the policy of allowing recovery of a moderate attorney's fee as a part of the costs, in cases, where, after specific claim made and a reasonable time given for investigation of it, payment is refused, and the claimant succeeds in establishing by suit his right to the full amount demanded, the application of such statute to actions for goods lost in interstate commerce is not inconsistent with the provisions of the Commerce Act and its amendments. The local statute, as already pointed out, does not at all effect the ground of recovery, or the measure of recovery; it deals only with a question of costs, respecting which Congress has not spoken. Until Congress does speak, the state may enforce it in such a case as the present."

9 Missouri, Kansas and Texas Ry. Co. v. Harriman Bros., 227 U. S. 657,57 L. Ed. 690,33 Sup. Ct. 397. In a bill of lading involving the shipment of cattle which were killed in transit there was a provision that action must be brought, if at all, within ninety days. In defense to the action it was claimed that action had not been brought until after the expiration of ninety days after the damage sustained. The court said:- "The policy of statutes of limitation is to encourage promptness in the bringing of actions, that the parties shall not suffer by loss of evidence from death or disappearance of witnesses, destruction of documents or failure of memory. But there is nothing in the policy or object of such statutes which forbids the parties to an agreement to provide a shorter period, provided the time is not unreasonably short. That is a question of law for the determination of the court. Such stipulations have been sustained in insurance policies. Riddlesbarger v. Hartford Ins. Co., 7 Wall. 386, I9 L. Ed. 257. A stipulation that an express company should not be held liable unless claim was made within ninety days ofter a loss was held good in Express Co. v. Caldwell, 21 Wall. 264, 22 L. Ed. 556. Such limitations in bills of lading are very customary and have been upheld in a multitude of cases. We cite a few: Central Vermont R. R. v. Soper, 59 Fed. 879, 8 C. C. A. 341 ; Ginn v. Ogdensburg, 85 Fed. 985,29 C. C. A. 521 ; Cox v. Central Railroad of Vermont, 9 App. Div. N. Y. 4, affd. I58 N. Y. 726. 
Liability of Carrier Measured by Rate Charged for Shipment. - Among its other provisions, the Carmack amendment affirmatively declared that "no contract, receipt, rule or regulation shall exempt such common carrier, railroad, or transportation company from the liability hereby imposed." Under the common law rule a common carrier, as already suggested was liable for any loss or damage which resulted from human agency or any cause not the act of God or the public enemy. But the rigor of this liability could be modified by any reasonable and proper agreement with the shipper which did not include exemption against the negligence of the carrier or his servants. The Supreme Court has declared in many cases that it has become an established rule of the common law that such a carrier might by a fair, open, just and reasonable agreement limit the amount recoverable by a shipper in case of loss or damage to an agreed value made for the purpose of obtaining the lower of two or more rates of charges proportioned to the amount of the risk. This is based on the theory that the charge should bear some reasonable relation to the responsibility assumed which is determined by the character of the shipment. Carriers have thus fixed their rates of charges upon the basis primarily of the weight of the shipment, the distance to be hauled and the value of the article as declared by the shipper. Upon the question of value declared depends partly the rate to be charged, a certain rate for a minimum of value and higher rates for similar shipments of greater value. The minimum rate represents the charge for carriage simply and the higher rate represents as well the cost of the insurance risk assumed by the carrier against loss or damage to the shipment by it or its agents. The Supreme Court has declared valid contracts in bills of lading limiting the liability of the shipper for loss or damage to shipments to fixed amounts declared in the valuation named by the shipper on which the rate for carriage was based. ${ }^{10}$ The validity

Before the Texas and Missouri statutes forbidding such special contracts, short limitations in bills of lading were held to be valid and enforceable. McCarty v. Gulf, etc., Ry., 79 Texas 33, 15 S. W. 164; Thompson v. Chicago, etc., Ry., 22 Mo. App. 32I. See cases to same effect cited in 6 Cyc. p. 508. The provision requiring suit to be brought within ninety days is not unreasonable." See Act of March 4, 1915, footnote, page 460.

to The leading case is that of Adams Express Co. v. Croninger, $226 \mathrm{U}$. S. 491, 57 L. Ed. 314, 33 Sup. Ct. 148, decided in 1913. Here the court said:- "We come now to the question of the validity of the provision in 
of the limitation upon a recovery for loss or damage due to negligence is based upon the doctrine of estoppel which prohibits a shipper from assigning to a shipment, when action is brought to recover for its loss or damage, a different and a higher value than

the receipt or bill of lading limiting liability to the agreed value of fifty dollars, as shown therein. * * * That no inquiry was made as to the actual value is not vital to the fairness of the agreement in this case. The receipt which was accepted showed that the charge was based upon a valuation of fifty dollars unless a greater value should be stated therein. The knowledge of the shipper that the rate was based upon the value is to be presumed from the terms of the bill of lading and of the published schedules filed with the Commission. That presumption is strengthened by the fact that across the top of this bill of lading there was this statement in bold type, 'This Company's charge is based upon the value of the property, which must be declared by the shipper.' That a common carrier cannot exempt himself from liability for his own negligence or that of his servants is elementary. * * * The rule of the common law did not limit his liability to loss and damage due to his own negligence, or that of his servants. That rule went beyond this and he was liable for any loss or damage which resulted from human agency, or any cause not the act of God or the public enemy. But the rigor of this liability might be modified through any fair, reasonable and just agreement with the shipper which did not include exemption against the negligence of the carrier or his servants. The inherent right to receive a compensation commensurate with the risk involved the right to protect himself from fraud and imposition by reasonable rules and regulations, and the right to agree upon a rate proportionate to the value of the property transported.

"It has therefore become an established rule of the common law as declared by this court in many cases that such a carrier may by a fair, open, just and reasonable agreement limit the amount recoverable by a shipper in case of loss or damage to an agreed value made for the purpose of obtaining the lower of two or more rates of charges proportioned to the amount of the risk. York Co. v. Railroad, 3 Wallace 107, 18 L. Ed. 170; Railroad v. Lockwood, I7 Wallace 357, 21 L. Ed. 627; Hart v. Pennsylvania Railroad, r12 U. S. 33I, 28 L. Ed. 7I7, 5 Sup. Ct. I5I; Phœnix Ins. Co. v. Erie Trans. Co., II7 U. S. 312, 322, 29 L. Ed. 873, 6 Sup. Ct. 750, I I76; Steam Co. v. Phœnix Ins. Co., I 29 U. S. 397, 442, 32 L. Ed. 788, 9 Sup. Ct. 469; New York, etc., Ry. v. Estill, 147 U. S. 59I, 619, 37 L. Ed. 292, 13 Sup. Ct. 444; Primrose v. W. U. Tel. Co., I54 U. S. I, 15, 38 L. Ed. 883, I4 Sup. Ct. 1098; Chicago, etc., Ry. v. Solan, I69 U. S. 133, I35, 42 L. Ed. 688, I8 Sup. Ct. 289; Calderon v. Steamship Co., 170 U. S. 272, 278, 42 L. Ed. 1033, I8 Sup. Ct. 588; Pennsylvania R. R. v. Hughes, I9I U. S. $477,485,48$ L. Ed. 268,24 Sup. Ct. I32. That such a carrier might fix his charges somewhat in proportion to the value of the property is quite as reasonable and just as a rate measured by the character of the shipment. The principle is that the charge should bear some reasonable relation to the responsibility, and that the care to be exercised shall be in some 
that which he declared when seeking a rate for its transportation. In this respect there is no provision in the Carmack amendment contrary to the doctrine of the common law as construed by the

degree measured by the bulk, weight, character and value of the property carried.

"Neither is it conformable to plain principles of justice that a shipper may understate the value of his property for the purpose of reducing the rate, and then recover a large value in case of loss. Nor does a limitation based upon an agreed value for the purpose of adjusting the rate conflict with any sound principle of public policy. The reason for the legality of such agreements is well stated in Hart v. Pennsylvania Railroad, cited above, where it is said :-

"'The limitation as to value has no tendency to exempt from liability for negligence. It does not induce want of care. It exacts from the carrier the measure of care due to the value agreed on. The carrier is bound to respond in that value for negligence. The compensation for carriage is based on that value. The shipper is estopped from saying that the value is greater. The articles have no greater value, for the purposes of the contract of transportation, between the parties to that contract. The carrier must respond for negligence up to that value. It is just and reasonable that such a contract, fairly entered into, and where there is no deceit practised on the shipper, should be upheld. There is no violation of public policy. On the contrary, it would be unjust and unreasonable, and would be repugnant to the soundest principles of fair dealing and of the freedom of contracting, and thus in conflict with public policy, if a shipper should be allowed to reap the benefit of the contract if there is no loss, and to repudiate it in case of loss.'

"The statutory liability, aside from responsibility for the default of a connecting carrier in the route, is not beyond the liability imposed by the common law as that body of law applicable to carriers has been interpreted by this court as well as many courts of the states. Greenwald v. Barrett, 199 N. Y. 170, 92 N. E. 218, 35 L. R. A. (N. S.) 97I ; Bernard v. Adams Express Co., 205 Mass. 254, 259, 9I N. E. 325, I8 An. Cas. 35I, 28 L. R. A. (N. S.) 293. The exemption forbidden is, as stated in the case last cited, 'a statutory declaration that a contract of exemption from liability for negligence is against public policy and void.' This is no more than this court, as well as other courts administering the same general common law, have many times declared. In the same case, just such a stipulation as that here involved was upheld, the court saying:-

" 'But such a contract as we are considering in this case is not an exemption from liability for negligence in the management of property within the meaning of the statute. It is a contract as to what the property is, in reference to its value. The purpose of it is not to change the nature of the undertaking of the common carrier, or limit his obligation in the care and management of that which is entrusted to him. It is to describe and define the subject matter of the contract, so far as the parties care to define it, for the purpose of showing of what value that is which comes into the carrier's possession, and for which he must account in the performance of his duty as a carrier. It is not in any proper sense a contract exempting 
Supreme Court and other courts of the land. As the Supreme Court has said "The statutory liability," imposed by the Carmack amendment, "aside from responsibility for the default of a connecting carrier in the route, is not beyond the liability imposed by the common law as that body of law applicable to carriers has been interpreted by this court as well as many courts of the states." Such an agreement basing the rate upon the valuation of the shipment-fixing at once thereby the rate and the amount of the liability of the carrier in case of loss or damage-is not in any proper sense a contract exempting the carrier from liability for the loss, damage or injury to the property, but is rather an agreement as to the price which the shipper shall pay for the service to be rendered and for the risk of loss which the carrier assumes in his undertaking.

As we have seen, tariffs of rates which have been duly filed, published and posted are legally binding and conclusive both as to the carrier and the shipper. Therefore when the carrier has filed rate-sheets which show different rates based upon the valuation of

him from liability for the loss, damage or injury to the property, as the shipper describes it in stating its value for the purpose of determining for what the carrier shall be accountable upon his undertaking, and what price the shipper shall pay for the service and for the risk of loss which the carrier assumes.'

"In Greenwald v. Barrett, cited above, the same conclusion was reached as to the nature of the liability imposed and the purport of the exemption forbidden, the court, among other things, saying :-

" "The language of the enactment does not disclose any intent to abrogate the right of common carriers to regulate their charges for carriage by the value of the goods or to agree with the shipper upon a valuation of the property carried. It has been the uniform practise of transportation companies in this country to make their charges dependent upon the value of the property carried and the propriety of this practise and the legality of contracts signed by the shipper agreeing upon a valuation of the property were distinctly upheld by the Supreme Court of the United States in Hart v. Pennsylvania R. R. Co., II2 U. S. 33I, 34I, 28 L. Ed. 7I7, 5 Sup. Ct. I5I.'

"That a carrier rate may be graduated by value and that a stipulation limiting recovery to an agreed value made to adjust the rate is recognized by the Interstate Commerce Commission, see I3 I. C. C. Rep. 550. We therefore reach the conclusion that the provision of the Act forbidding exemptions from liability imposed by the Act is not violated by the contract here in question."

See also Louisville and Nashville Railroad Co. v. Woodford, 234 U. S. 46, 58 L. Ed. 1202, 34 Sup. Ct. 739; New Orleans and Northeastern Railroad Co. v. National Rice Milling Co., 234 U. S. 80,58 L. Ed. I223, 34 Sup Ct. 726. 
a particular kind or class of traffic it is legally bound to apply the rate to the shipment that corresponds to the valuation alleged. The shipper is charged with notice of the rates published for the valuation automatically determines which of the rates is the lawful rate. Where there are several rates based upon differences in value of the shipment, the legal rate automatically attaches itself to the declared or, in some cases, agreed value. The lawful rate is that which the carrier must charge and it is that which the shipper must pay. Neither the intentional nor accidental misstatement of the applicable published rate will bind the carrier or shipper. And it follows that the valuation declared or agreed upon, as witnessed by the contract of shipment or bill of lading, upon which the published tariff rate is applied, is conclusive in an action brought to recover for loss or damage in a greater sum. ${ }^{11}$ Actual want of knowledge of the applicable rate on the part of the

I I Kansas City Southern Ry. v. Carl, 227 U. S. 639, 57 L. Ed. 683, 33 Sup. Ct. 39r. This case involved a suit on a shipment of household goods of which one box of the value of $\$ 75$ was lost. There were two rates in effect on the line of the initial carrier which accepted the shipment-one based upon a released valuation of five dollars per hundredweight and a higher rate upon such articles not so released. The goods were shipped at the lower rate, the shipper claiming that he was not aware of the two rates and that if he had had knowledge of them he would have shipped at the higher rate. The court said:- "A declared value by the shipper for the purpose of determining the applicable rate, when the rates are based upon valuation, is not an exemption from any part of its statutory or common law liability. The right of the carrier to base rates upon value has been always regarded as just and reasonable. The principle that compensation should bear a reasonable relation to the risk and responsibility assumed is the settled rule of the common law. * * * It follows therefore, that when the carrier has filed rate-sheets which show two rates based upon valuation upon a particular class of traffic, that it is legally bound to apply that rate which corresponds to the valuation. If the shipper desires the lower rate, he should disclose the valuation, for in the absence of knowledge the carrier has a right to assume that the higher of the rates based upon value applies. In no other way can it protect itself in its right to be compensated in proportion to its insurance risk. But when a shipper delivers a package for shipment and declares a value. either upon request or voluntarily, and the carrier makes a rate accordingly, the shipper is estopped upon plain principles of justice from recovering, in case of loss or damage, any greater amount. The same principle applies if the value be declared in the form of a contract. If such a valuation be made in good faith for the purpose of obtaining the lower rate applicable to a shipment of the declared value, there is no exemption from carrier liability due to negligence forbidden by the statute when the shipper is 
shipper is no excuse, in view of the conclusive presumption of knowledge. This is true even where the rate is not actually posted in the station.

limited to a recovery of the value so declared. The ground upon which such a declared or agreed value is upheld is that of estoppel. ****

"The valuation declared or agreed upon as evidenced by the contract of shipment upon which the published tariff rate is applied, must be conclusive in an action to recover for loss or damage a greater sum. In saying this we lay one side, as not here involved, every question which might arise when it is shown that the carrier intentionally connived with the shipper to give him an illegal rate, thereby causing a discrimination or preference forbidden by the positive terms of the Act of Congress and made punishable as a crime. To permit such a declared valuation to be overthrown by evidence aliunde the contract, for the purpose of enabling the shipper to obtain a recovery in a suit for loss or damage in excess of the maximum valuation thus fixed, would both encourage and reward undervaluations and bring about preferences and discriminations forbidden by the law. Such a result would neither be just nor conducive to sound morals or wise policies. The valuation the shipper declares determines the legal rate where there are two rates based upon valuation. He must take notice of the rate applicable, and actual want of knowledge is no excuse. The rate, when made out and filed, is notice, and its effect is not lost, although it is not actually posted in the station. Texas and Pacific Railway v. Mugg, 202 U. S. 242, 50 L. Ed. I0I I, 26 Sup. Ct. 628; Chicago and Alton Railway v. Kirby, 225 U. S. 155, 56 L. Ed I033, 32 Sup. Ct. $6+8$.

"It would open a wide door to fraud and destroy the uniform operation of the published tariff rate sheets. When there are two published rates, based upon difference in value, the legal rate automatically attaches itself to the declared or agreed value. Neither the intentional nor accidental misstatement of the applicable published rate will bind the carrier or shipper. The lawful rate is that which the carrier must exact and that which the shipper must pay. The shipper's knowledge of the lawful rate is conclusively presumed, and the carrier may not be required to surrender the goods carried upon the payment of the rate paid, if that was less than the lawful rate, until the full legal rate has been paid. Texas \& Pacific Railway v. Mugg, supra. Nor is the carrier liable for damages resulting from a mistake in quoting a rate less than the full published rate. Illinois Central Railroad v. Henderson Elevator Co., 226 U. S. 44I, 57 L. Ed. 290, 33 Sup. Ct. 176. Nor can a carrier legally contract with a particular shipper for an usual service unless he make and publish a rate for such service open to all. Chicago and Alton Railway v. Kirby, supra. That the valuation and the rate are dependent each upon the other is an administrative rule applied in reparation proceedings by the Interstate Commerce Commission. Southern Oil Co. v. Southern Railway Co., 19 I. C. C. 79; Miller \& Lux v. Southern Pacific Railway Co., 20 I. C. C. I29. In Hart v. Pennsylvania Railroad, supra, parole evidence that the horses shipped were of a far greater value than the valuation agreed upon was rejected as incompe- 
Nor can evidence aliunde the contract overthrow the declared valuation in order to enable the shipper to recover in a suit for loss or damage greater than the maximum valuation thus fixed. To permit such evidence would put a premium on undervaluations

tent. 'The presumption is conclusive,' said the court, 'that if the liability had been assumed on a valuation as great as that now alleged, a higher rate of freight would have been charged. The rate of freight is indissolubly bound up with the valuation.'

"The difference between two rates upon the same commodity based upon valuation is presumably no more than sufficient to protect the carrier against the greater amount of risk he assumes by reason of the difference in value. When the higher rate is no more than to reasonably insure the carrier against the larger responsibility a real choice of rate is offered and the shipper has no reasonable excuse for undervaluation. If the margin between the rates is unreasonably beyond protection against the larger risk the shipper may be induced to misrepresent the value to escape the unreasonably high rate upon the real value. This would result in permitting the shipper to obtain a rate to which he is not entitled, and in the carrier escaping from a portion of its statutory liability. Both the adjustment of rates upon the class of articles based upon difference in valuation, as well as the acceptance of stipulations in the carrier's bill of lading which affect the liability declared by the Carmack amendment, are administrative duties of the Commission. To the extent that such limitations of liability are not forbidden by law, they become, when filed, a part of the rate.

"In the instant case, we must assume that the difference between the rates upon household goods of less value than five dollars per hundredweight and the rate upon the same class of goods of a higher value has been fixed upon this principle. We must for the purpose of this case accept the high and low rate as reasonable. If the present rates upon such goods, as shown in the tariffs filed, are inadequate to protect the shipper, a remedy can be had by an order of the Interstate Commerce Commission readjusting the rates to meet the requirements of justice alike to shipper and carrier.

"It has been suggested that a rate of five dollars per hundred pounds upon household goods indiscriminately is arbitrary, and has no reasonable relation to the actual value. This objection goes to the classification made in the filed tariff sheets. They place two rates upon household goods valued over and under five dollars per hundred pounds. This basis has not been regarded by the Commission as either arbitrary or unreasonable. In the opinion styled 'In the matter of Released Rates,' 13 I. C. C. 550, the Commission, among other things, said:-

" "The practise of basing rates upon the condition that the carrier shall not be responsible for losses due to causes beyond its control has received legal sanction. Similarly we find no impropriety in a graduation of rates in accordance with the actual values of specific commodities. Household goods, for example, differ widely in value. and it is fair to all that the man who ships goods of low value should receive the benefit of a lower rate than the man who ships 
and produce preferences and discriminations which are forbidden by the law, as well as destroy the uniform operation of the published tariff rate sheets. Thus limitations of liability consistent with the law become, when duly filed and published, a part of the rate. And similarly a special contract for an interstate railway shipment without limitation of liability, made between the shipper and the agent of the carrier, can have no binding force where the carrier's published and filed tariffs graduate the rates according to declared value and limit the carrier's liability accordingly,-the properly filed rates being conclusive as to the rights of the parties, in the absence of facts or circumstances showing an attempt at rebating or false billing, and not to be varied by verbal agreements. ${ }^{12}$

more expensive goods. Rate-making upon this principle is in every respect legitimate.'

"Our conclusion is that the shipping contract does not upon its face offend against the statute."

I2 Atchison, Topeka and Santa Fe Railway Co. v. Robinson, 233 U. S. 173, 58 L. Ed. 9or, 34 Sup. Ct. 556. Here the owner of a race horse called the agent of the carrier by telephone and arranged for the carriage by immediate train service of a race horse without any agreement as to what valuation should be given the shipment. On a suit to recover for damages to the horse the shipper endeavored to secure a judgment for the full value thereof. The court said:- "That the effect of the Carmack amendment to the Hepburn Act (sec. 20. Act of June 29, 1906.) was to give to the Federal jurisdiction control over interstate commerce and to make supreme the Federal legislation regulating liability for property transported by common carriers in interstate commerce, has been so recently and repeatedly decided in this court as to require now little more than a reference to some of the cases. Kansas City Southern R. Co. v. Carl, 227 U. S. 639, 57 L. Ed. 683, 33 Sup. Ct. 391 ; Missouri, K. \& T. R. Co. v. Harriman, 227 U. S. 657,57 L. Ed. 690, 33 Sup. Ct. 397 ; Chicago, R. I. \& P. R. R. Co. v. Cramer, 232 U. S. 490, 58 L. Ed. 697, 34 Sup. Ct. 383; Great Northern R. Co. v. O'Connor, 232 U. S. 508, 58 L. Ed. 703, 34 Sup. Ct. 380 . We regard these cases as settling the proposition that the shipper as well as the carrier is bound to take notice of the filed tariff rates, and that so long as they remain operative they are conclusive as to the rights of the parties, in the absence of facts or circumstances showing an attempt at rebating or false billing. Great Northern R. Co. v. O'Connor, supra. To give to the oral agreement upon which the suit was brought, the prevailing effect allowed in this case by the charge in the trial court, affirmed by the judgment of the Supreme Court of the state, would be to allow a special contract to have binding force and effect though made in violation of the filed schedules which were to be equally observed by the shipper and carrier. If oral agreements of this character can be sustained, then the door is open to all 
Rate sheets frequently provide for a choice between two rates, one with and one without a declared valuation. In the latter case the carrier is liable for whatever loss or damage the shipper sustains, and in the former its liability is limited to the valuation upon which the rate was based for the shipment. ${ }^{13}$ Where there

manner of special contracts, departing from the schedules and rates filed with the Commission. Kansas City Southern R. Co. v. Carl, 227 U. S. $639,652,57$ L. Ed. 683,33 Sup. Ct. 391. To maintain the supremacy of such oral agreements would defeat the primary purposes of the Interstate Commerce Act, so often affirmed in the decisions of this court, which are to require equal treatment of all shippers and the charging of but one rate to all, and that the one filed as required by the Act. The Supreme Court of this state in this case affirmed the instruction of the trial court upon which the case was given to the jury, and held that the oral contract was binding unless it was affirmatively shown that the written agreement, based upon the filed schedules, was brought to the knowledge of the shipper, and its terms assented to by him. This ruling ignored the terms of shipment set forth in the schedules and permitted recovery upon the contract made in violation thereof in a case where there was no proof that there was an attempt to violate the published rates by a fraudulent agreement showing rebating or false billing of the property, and no circumstances which would take the case out of the rulings heretofore made by this court as to the binding effect of such filed schedules and the duty of the shipper to take notice of the terms of such rates, and the obligation to be bound thereby, in the absence of the exceptional circumstances to which we have referred."

To the same effect see Atchison, Topeka and Santa Fe Railway Co. v. Moore, 233 U. S. I82, 58 L. Ed. 906, 34 Sup. Ct. 558.

I3 Missouri, Kansas and Texas Railway Co. v. Harriman, 227 U. S. 657. 57 L. Ed. 690, 33 Sup. Ct. 397. In a suit for damages to a shipment of show cattle it was shown that by the contract the shipment was made at a rate fixing a stated liability of a nominal amount for each of the cattle. The court said:- "In any event the rate sheets do provide for a choice between two rates, one with and one without a declared valuation. In one case the carrier is liable for whatever loss or damage the shipper sustains and in the other its liability is limited to the valuation upon which the rate was based. The ground upon which the shipper is limited to the valuation declared is that of estoppel, and presupposes the valuation to be one made for the purpose of applying the lower of two rates based upon the value of the cattle. This whole matter has been so fully considered in Adams Express Co. v. Croninger, 226 U. S. 49I, 57 L. Ed. 3I4, 33 Sup. Ct. I48, and Kansas City Southern Railway v. Carl, just decided, that we only need to refer to the opinions in those cases without further elaboration. That the trial court and the Court of Civil Appeals erred in holding this stipulation null and void because forbidden by either the law of the state of Texas, or by the 2oth section of the Act of June 29. I906, is no longer an open question since the decisions of this court in the cases just referred 
has been a misrepresentation of value by the shipper for the purpose of securing a lower rate the consequence is not that he is prohibited from recovering for a loss, but that he can recover no

to. Nor is there anything upon the face of this contract, when read in connection with the rate sheets referred to therein, (of which the defendants in error were compelled to take notice not only because referred to in the contract signed by them, but hecause they had been lawfully filed and published) which offends against the provisions of the 20 th section of the Act of Junc 29, 1906.

"In the case at bar it has been said that the shipper was not asked to state the value, but only signed the contract handed to him and made no declaration. But the same point was made in the Hart case, when the court said :-

" A distinction is sought to be drawn between a case where a shipper, on requirement, states the value of the property, and a rate of freight is fixed accordingly, and the present case. It is said, that, while in the former case the shipper may be confined to the value he so fixed, in the event of a loss by negligence, the same rule does not apply to a case where the valuation inserted in the contract is not a valuation previously named by the shipper. But we see no sound reason for this distinction. The valuation named was the agreed valuation,' the one on which the minds of the parties met, however it came to be fixed, and the rate of freight was based on that valuation, and was fixed on condition that such was the valuation, and that the liability should go to that extent and no further.'

"It is not unreasonable for the purpose of graduating freight according to value to divide the particular subject of transportation into two classes, those above and those below a fixed minimum amount. No other method is practicable, and this is a method administratively approved by the Commerce Commission. That the value of the cattle shipped under this valuation did greatly exceed the valuation therein represented, may be true. It only serves to show that the shipper obtained a lower rate than he was lawfully entitled to have by a misrepresentation. It is neither just nor equitable that he shall benefit by the lower rate, and then recover for a value which he said did not exist, in order to obtain that rate. Having obtained a rate based upon the declared value, he is concluded, and there is no room for parol evidence to show otherwise. Hart v. Pennsylvania Railroad and Kansas City, etc., Railroad v. Carl, supra. When the carrier graduates its rates by value and has filed its tariffs showing two rates applicable to a particular commodity or class of articles, based upon a difference in valuation, the shipper must take notice, for the valuation automatically determines which of the rates is the lawful one. If he knowingly declares an undervaluation for the purpose of obtaining the lower of two published rates, he thereby obtains an advantage and causes a discrimination forbidden and made unlawful by the first section of the Elkins Act of February 19. 1903. T. \& P. Railway v. Mugg, 202 U. S. 242, 50 L. Ed. I0I I, 26 Sup. Ct. 628; C. \& A. Railway v. Kirby, 225 U. S. 155, 56 L. Ed. 1033, 32 Sup. Ct. 648. The particular cattle were loaded by the shipper and were never seen by the company's agent. Neither was it claimed that 
more than the value which he has declared. There is no substantial distinction between a value stated upon inquiry and one agreed upon or declared voluntarily. ${ }^{14}$ Nor is the situation changed because of the use of printed forms. It remains none the less the valuation on which the minds of the parties to the contract met however it came to be fixed..$^{15}$

And so where the duly filed and published rates of the carrier

he was informed of the value or quality of the cattle to be shipped. We see no ground upon which this contract can be held upon its face to have offended against the statute."

I4 Wells Fargo and Co. v. Neiman-Marcus Co., 227 U. S. 469, 57 L. Ed. 600,33 Sup. Ct. 267. Here an action was brought by a shipper to recover for the loss of a package of furs. The receipts thercfor issued by the express company provided that it should not be liable beyond the sum of $\$ 50$ unless a different value was declared. No different value was in fact declared. The court said, as to the defense of undervaluation :- "The question at last would be shall the shipper or owner recover nothing because of that misrepresentation, or only the valuation declared to obtain the rate upon which the goods were carried? The latter would seem to be the more reasonable and just consequence of the estoppel. The ground upon which the validity of a limitation upon a recovery for loss or damage due to negligence depends is that of estoppel. *** There is no substantial distinction between a value stated upon inquiry and one agreed upon or declared voluntarily. The rate of freight was based upon the valuation thus fixed, and the liability should not cxceed the amount so made the rate basis. Hart $v$. Pennsylvania Railroad, Ir U. S. 33I, 338, 28 L. Ed. 717, 5 Sup. Ct. 151."

15 Great Northern Railway Co. v. O'Connor, 232 U. S. 508, 58 L. Ed. 703, 34 Sup. Ct. 380 . The court here said:- "The tariffs are filed with the Commission and are open to inspection at every station. In view of the multitude of transactions, it is not necessary that there shall be an inquiry as to each article. or a distinct agreement as to the value of each shipment. If no value is stated, the tariff rate applicable to such a state of facts applies. * * * Nor was the result changed because of the use of printed forms. This appears from the ruling in Hart v. Pennsylvania R. Co., I1 2 U. S. 33I, 28 L. Ed. 7I7, 5 Sup. Ct. 151, where it was claimed that the shipper had not been asked to state the value, but had merely signed a printed contract naming a value. The court said:-'The valuation named was the 'agreed valuation,' the one on which the minds of the parties met, however it came to be fixed, and the rate of freight was based on that valuation, and was fixed on condition that such was the raluation, and that the liability should go to that extent and no further.' The rule of the Hart, Carl and Harriman cases was not applied in the court below and the judgment must be reversed."

To the same effect see Chicago, Rock Island and Pacific Railway Co. v. Cramer, 232 U. S. 490, 58 L. Ed. 697, 34 Sup. Ct. 383. 
provide for a limitation of $\$ 100$ in the amount of liability for personal baggage which it assumes upon a ticket of transportation for an individual traveler, with an added tariff rate for a value in excess of that amount, the shipper is bound by that limitation and can collect on a suit for loss or damage thereto only the amount of $\$$ I oo unless a higher valuation is declared and the proper rate paid therefor by the traveler. ${ }^{16}$ Upon the valuation assumed or declared the rate and also the liability therefor automatically attach.

16 Boston and Maine Railroad v. Hooker, 233 U. S. 97, 58 L. Ed. 868 , 34 Sup. Ct. 526. By the schedules of the carrier the free transportation of baggage on a traveler's ticket was limited to the value of \$IOo. A rate was lawfully filed and published for baggage carried in excess of that valuation. This suit was brought for the loss of haggage, of a value not declared at the time of shipment, but now maintained to be several times the amount of the limitation named. No valuation had been declared or special rate paid by the traveler. The court said:- "It follows therefore, from the previous decisions in this court, that if it be found that the linitation of liability for baggage is required to be filed in the carrier's tariffs, the plaintiff was bound by such limitation. Having the notice which follows from the filed and published regulations, as required by the statute and the order of the Interstate Conmerce Commission, she might have declared the valuc of her luggage, paid the excess tariff rate and thus secured the liability of the carrier to the full amount of the value of her baggage, or she might. for the purpose of transportation, have valued it at $\$ 100$ and received free transportation and liability to that extent only, or, as she did, she might have made no valuation of her baggage, in which event the rate and the corresponding liability would have automatically attached. As to the finding that the plaintiff's baggage was apparently worth more than $\$ 100$, as above set forth, it appears that the contents of the two trunks and suit case were not disclosed or known to the carrier, and the finding in this respect, necessarily based on the appearance of the baggage, cannot be said to show a procurement of transportation in viola tion of the requirements of the filed schedules at a rate disproportionate to its known value.

"It seems to us that the ordinary signification of the terms used in the Act would cover such requirements as are here made for the amount of recovery for baggage lost by the carrier. It is a regulation which fixes and determines the amount to be charged for the carriage in view of the responsibility assumed, and it also affects the value of the service rendered to the passenger. Such requirements are spoken of, in decisions dealing with them, as regulations; as, a common carrier 'may prescribe regulations to protect himself against imposition and fraud, and fix a rate of charges proportionate to the magnitude of the risks he may have to encounter.' York Co. v. Central R. R., 3 Wall. 107, 112, 18 L. Ed. I7o. 'It is undoubtedly competent for carriers of passengers, by specific regulations, distinctly brought to the knowledge of the passenger, which are reasonable 
The requirement of the Carmack amendment that a carrier receiving property for transportation in interstate commerce shall issue a receipt or bill of lading therefor does not require other receipts for baggage than baggage checks. ${ }^{17}$ Such checks are in

in their character and not inconsistent with any statute or their duties to the public, to protect themselves against liability, as insurers, for baggage exceeding a fixed amount in value, except upon additional compensation, proportioned to the risk. And in order that such regulations may be practically effective and the carrier advised of the full extent of its responsibility, and, consequently. of the degree of precaution necessary upon its part, it may rightfully require, as a condition precedent to any contract for the transportation of baggage, information from the passenger as to its value; and if the value thus disclosed exceeds that which the passenger may reasonably demand to be transported as baggage without extra compensation the carrier, at its option, can make such additional charge as the risk fairly justifies.' Railroad Co. v. Fraloff, 100 U. S. 24, 27, 25 L. Ed. $53 \mathrm{I}$.

"We are therefore of the opinion that the requirement published concerning the amount of the liability of the defendant based upon additional payment where baggage was declared to exceed $\$ 100$ in value was determinative of the rate to be charged and did affect the service to be rendered to the passenger, as it fixed the price to be paid for the service rendered in the particular case, and was, therefore, a regulation within the meaning of the statute. *** But the effect of the regulations, filed as required, giving notice of rates based upon value when the baggage to be transported was of a higher value than $\$ 100$, and the delivery and acceptance of the baggage without declaration of value or notice to the carrier of such higher value. charges the carrier with liability to the cxtent of \$Ioo only."

I7 In Boston and Maine Railroad v. Hooker, 233 U. S. 97, 58 L. Ed. 868, 34 Sup. Ct. 526, supra, as to this, the court said:- "We do not think the requirement of the Carmack amendment, that a railway company receiving property for transportation in interstate commerce shall issue a receipt or bill of lading therefor, required other receipts than baggage checks, which it is shown were issued when the baggage was received in this case. When the amendment was passed Congress well knew that baggage was not carried upon bills of lading, and that carriers had been accustomed to issue checks upon receipt of baggage. We do not think it was intended to require a departure from this practise when the matter was placed under regulation by schedules filed and subject to change for unreasonableness upon application to the Commission. Such checks are receipts, and there is no special requirement in the statute as to their form. It is doutless in the power of the Interstate Commerce Commission to make requirements as to the checks or receipts to be given for baggage if that subject needs regulation. Act of June I8, I9Io, secs. I and I5 (36 Stat. 539)." 
fact receipts and the statute contains no special requirement as to the form of such receipts as it nominates.

Liability of Carrier to Suit in Foreign District.-The provisions of the Carmack amendment, while intended to facilitate the remedy of the shipper by making the initial carrier responsible for the entire carriage, were not intended to make foreign corporations through connecting carriers liable to suit in a district where they were not carrying on business in the sense which the courts have held necessary to confer jurisdiction. The business necessary to give a court jurisdiction must be such in character and extent as to warrant the inference that the corporation has subjected itself to the jurisdiction and laws of the district in which it is served and in which it is bound to appear when a proper agent has been served with process. Each case is subject to the facts therein within the comprehension of this rule. And a carrier corporation which establishes an office in a foreign district and maintains agents there who attend to claims presented against the road for settlement is carrying on business within the meaning of the rule and is amenable to process and suit in that district. ${ }^{18}$

I8 St. Louis Southwestern Railway Co. $v$. Alexander, 227 U. S. 218,57 L. Ed. 486,33 Sup. Ct. 245 . The defendant in crror filed suit against the railroad in New York County to recover damages for loss sustained by him arising from the alleged negligence of the carrier in failing to propcrly ice and re-ice poultry shipped from Waco, Texas, to New York City. Upon the door of an office in New York City appeared the name of the railroad corporation together with the names of certain officials and their resignation. Claims were presented to these officials at this office by correspondence and replies thereto were received showing that attention was heing paid to the claims. The railroad denied jurisdiction of the New York court in the case. The Supreme Court said:- "In this class of cases where it is undertaken to hold a corporation personally liable in a foreign jurisdiction, two questions ordinarily arise: the first, Was the corporation within the jurisdiction in which it is sued? the second, Was process duly served upon an authorized agent of the corporation? As to the latter question there is littie difficulty in this case. The cause of action having accrued in New York by the failure to keep the contract for the safe delivery of the goods there, the service could be properly made under the New York statute, in the absence of other designated officials, upon the resident director. Pennsylvania Lumbermen's Mutual Fire Insurance Company v. Meyer, 197 U. S. 407, 49 L. Ed. 810, 25 Sup. Ct. 483. The other question as to the presence of the corporation within the jurisdiction of the court in which it was sued raises more difficulty. A long line of decisions in this court has established that in order to render a corporation amenable to service of process in a foreign jurisdiction it must 
appear that the corporation is transacting business in that district to such an extent as to subject it to the jurisdiction and laws thereof. The Lafayette Ins. Co. v. French, 18 How. 404. 15 L. Ed. 45I ; St. Clair v. Cox, 106 U. S. 350, 27 L. Ed. 222. I Sup. Ct. 354; Goldey v. Morning News, 156 U. S. 518, 39 L. Ed. 517, I5 Sup. Ct. 559; Conley v. Mathieson Alkali Works, 190 U. S. 406, 47 L. Ed. III3, 23 Sup. Ct. 728; Geer v. Mathieson Alkali Works, I90 U. S. 428, 47 L. Ed. I122, 23 Sup. Ct. 754; Peterson v. Chicago. Rock Island and Pac. Ry. Co., 205 U. S. 364, 5I L. Ed. 84I, 27 Sup. Ct. 5I3; Green v. Chicago, Burlington \& Quincy Ry. Co., 205 U. S. 530, 5I L. Ed. 916, 27 Sup. Ct. 594; Mechanical Appliance Co. v. Castleman, 2 I 5 U. S. 437, 54 L. Ed. 272, 30 Sup. Ct. 125; Harndon-Carter Co. v. Norris, Son \& Co., 224 U. S. 496, 56 L. Ed. 857, 32 Sup. Ct. 550.

"In the court below it was adjudged that the so-called Carmack amendment, under the circumstances here detailed, had had the effect of making the corporation liable to suit in New York and, because of the agency within New York of the connecting carrier, effected by that statute, must be held to be there present and subject to service of process. In view of the recent consideration of the Carmack amendment in this court it is unneccssary to now enter upon any extended discussion of it. The object of the statute was to require the initial carrier receiving freight for transportation in interstate commerce to obligate itself to carry to the point of destination, using the lines of connecting carriers as its agencies, thus sccuring for the benefit of the shipper unity of transportation and responsibility. Atlantic Coast Line R. R. Co. $v$. Riverside Mills, 2 I9 U. S. I86, 203, 55 L. Ed. I67, 3I Sup. Ct. I64. The provisions of the amendment had the effect of facilitating the remedy of the shipper by making the initial carrier responsible for the entire carriage, but the amendment was not intended, as we view it. to make foreign corporations through connecting carriers liable to suit in a district where they were not carrying on business in the sense which has heretofore been held necessary to confer jurisdiction.

"We reach the conclusion that this case is to be decided upon the principles which have heretofore prevailed in determining whether a foreign corporation is doing business within the district in such sense as to subject it to suit therein. This court has decided each case of this character upon the facts brought before it and has laid down no all-embracing rule by which it may be determined what constitutes the doing of business by a foreign corporation in such manner as to subject it to a given jurisdiction. In a general way it may be said that the business must be such in charactcr and extent as to warrant the inference that the corporation has subjected itself to the jurisdiction and laws of the district in which it is served and in which it is bound to appear when a proper agent has been served with process. Lafayette Ins. Co. v. French, supra, 407; Green v. Chicago, Burlington \& Quincy Ry. Co., supra, 532. Applying the general principles which we regard as settled by this court, Was this company doing business in the state of New York in that sense?

"The testimony discloses that the two roads together constitute a continuous line from St. Louis, through the states of Illinois, Missouri, Tenessee. Arkansas and Louisiana into Texas, and are together known as the 
'Cotton Belt Route.' This combination has an office in the city of New York, upon the door of which, as upon the stationery and literature of the companies, the symbol, 'Cotton Belt Route,' is found in use. Underneath appears the general description, 'St. Louis Southwestern Lines,' and there is also named a general eastern freight agent and traveling freight agent of the lines. With this joint freight agent at the office in New York the matter of the plaintiff's claim was taken up and considered, and correspondence concerning it was had through his office, and a settlement of the claim attempted. It was only after such negotiations for a settlement had failed that this action was brought. Here, then was an authorized agent attending to this and presumably other matters of a kindred character. undertaking to act for and represent the company, negotiating for it and in its behalf declining to adjust the claim made against it. In this situation we think this was the transaction of business in belialf of the company by its authorized agent in such manner as to bring it within the district of New York, in which it was sued, and to make it subject to the service of process there. See in this connection, Pennsylvania Lumbermen's Mutual Fire Insurance Company v. Meyer, supra. 415; Commercial Mutual Accident Co. v. Davis, 2 I3 U. S. 245, 255, 53 L. Ed. 782, 29 Sup. Ct. 45. In our opinion the court did not err in holding the corporation subject to process and duly served in this case." 


\section{SECTION 2I. ANNUAL REPORTS OF THE INTER- STATE COMMERCE COMMISSION.}

SFc. 21. (As amended March 2, 1889.) That the Commission shall, on or before the first day of December in each year, make a report, which shall Annual re. Commission to Congress. be transmitted to Congress, and copies of which shall be distributed as are the other reports transmitted to Congress. This report shall contain such information and data collected by the Commission as may be considered of value in the determination of questions connected with the regulation of commerce, together with such recommendations as to additional legislation relating thereto as the Commission may deem necessary; and the names and compensation of the persons employed by said Commission.

No cases involving the construction of this section have been decided by the Supreme Court. Annual reports have been submitted to Congress, twenty-eight in number, including that for the year I9I4, since the creation of the Commission. These reports contain a statement of the work of the Commission during the preceding year; a summary of the various hearings and decisions of the Commission; a statement and digest of the decisions of the various courts in cases involving the construction of the Act to Regulate Commerce as amended; a statement of appropriations and expenditures and of persons employed by the Commission; together with recommendations for further legislation to increase the efficacy of the Act. 


\section{SECTION 22. PERSONS AND PROPERTY CARRIED FREE OR AT REDUCED RATES.}

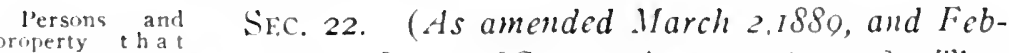
may be carriel ruary 8, 1895.) [See section I, 5th par.] That duced rates. nothing in this Act shall prevent the carriage, storage, or handling of property free or at reduced rates for the United States, state, or municipal governments, or for charitable purposes, or to or from fairs and expositions for exhibition thereat, or the free carriage of destitute and homeless persons transported by charitable societies, and the necessary agents employed in such transportation, or the is-

Mileage, ex. cursion, or com. mutation pas senger tickets.

Pas es and free transportation to officers and employees of railroad com. panies.

Provisions of Act are in addi. tion to remedies existing at com. mon law. Pend. ing litigation not affected by Act.

Joint inter changeable five$t h$ o u s a n dmile tickets. Amount of free haggage. suance of mileage, excursion, or commutation passenger tickets; nothing in this Act shall be construed to prohibit any common carrier from giving reduced rates to ministers of religion, or to municipal governments for the transportation of indigent persons, or to inmates of the National Homes or State Homes for Disabled Volunteer Soldiers, and of Soldiers' and Sailors' Orphan Homes, including those about to enter and those returning home after discharge, under arrangements with the boards of managers of said homes; nothing in this Act shall be construed to prevent railroads from giving free carriage to their own officers and employees, or to prevent the principal officers of any railroad company or companies from exchanging passes or tickets with other railroad companies for their officers and employees; and nothing in this Act contained shall in any way abridge or alter the remedies now existing at common law or by statute, but the provisions of this Act are in addition to such remedies: Prozided, That no pending litigation shall in any way be affected by this Act: Provided further, That nothing in this Act shall prevent the issuance of joint interchangeable five-thousand-mile tickets, with special privileges as to the amount of free bag- 
gage that may be carried under mileage tickets of one thousand or more miles. But before any common carrier, subject to the provisions of this Act, shall issue any such joint interchangeable mileage tickets with special privileges, as aforesaid, it shall file with the Interstate Commerce Commission copies of the joint tariffs of rates, fares, or charges on which such joint interchangeable mileage tickets are to be based, together with specifications of the amount of free baggage permitted to be carried under such tickets, in the same manner as common carriers are required to do with regard to other joint rates by section 6 of this Act; and all the provisions of said section 6 relating to joint rates, fares, and charges shall be observed by said common carrates.

Publication of riers and enforced by the Interstate Commerce Commission as fully with regard to such joint interchangeable mileage tickets as with regard to other joint rates, fares, and charges referred to in said section 6 . It shall be unlawful for any common carrier lint has issued or authorized to be issued any such joint interchangeable mileage tickets to demand, collect. or receive from any person or perSale of tick-
ets. sons a greater or less compensation for transportation of persons or baggage under such joint interchangeable mileage tickets than that required by the rate, fare, or charge specified in the copies of the joint tariff of rates, fares, or charges filed with the Commis ion in force at the time. The provisions of section Io of this Act shall apply to any violation of the requirements of this proviso.

History of the Section.-Section 22, as originally phrased in the Act of February 4. I887, was amended March 2, I889, to include the following provision:- "Nothing in this Act contained shall in any way abridge or alter the remedies now existing at common law, or by statute, but the provisions of this Act are in adddition to such remedies." The amendment of February 8, I 895 , related to the issuance of joint interchangeable mileage tickets. It is to be borne in mind that so much of this section as relates to the issuance of free passes and free transportation must 
be considered in connection with the regulation of this subject to be found in section I of the Act.

Scope and Purposes of the Section.-In the words of the Supreme Court, "this section is rather illustrative than exclusive." Its purpose was to declare and determine that the discrimination in favor of certain persons therein designated should not be deemed unjust. But it does not follow that there may not be other classes of persons in whose favor a discrimination may be made without such discrimination being unjust. Lnder this section carriers are permitted to issue mileage, commutation and excursion tickets and also party-rate tickets, by which people travelling in groups of ten or other designated numbers shall be sold transportation at a smaller sum than is charged to individuals travelling alone when carried between the same points. ${ }^{1}$

I Interstate Commerce Commission $\checkmark$ Baltimore and Ohio Railroad Co., 145 U. S. 263, 36 L. Ed. Gog, I2 Sup. Ct. 84t, known as the Party Rate Case. The carrier in question issued a "party rate ticket" for the transportation of ten or more persons from a point in one state to a point in another state at a rate less than that charged to a single individual for a like transportation on the same trip. Upon a hearing the Interstate Commerce Commission declared that this practise amounted to discrimination and ordered the railroad to cease the practise. The railroad declined and the Commission filed a petition for an injunction to restrain the road from continuing the practise. The court said:- "These are technically known as party-rate tickets, and are issued principally to theatrical and opreatic companies for the transportation of their troupes. Such ticket is clearly neither a 'mileage' nor an 'excursion' ticket within the exception of section 22; and upon the testimony in this case it may be doubtful whether it falls within the definition of 'commutation tickets,' as those words are commonly understood among railway officials. The words 'commutation ticket' seem to have no definite meaning. They are defined by Webster as 'a ticket, as for transportation, which is the evidence of a contract for service at a reduced rate.' If this definition be applicable here, then it is clear that it would include a party-rate ticket. In the language of the railway, however, they are principally, if not wholly, used to designate tickets for transportation during a limited time between neighboring towns or cities and suburban towns. The party-rate ticket upon the defendant's road is a single ticket issued to a party of ten or more, at a fixed rate of two cents per mile, or a discount of one-third from the regular passenger rate. The reduction is not made by way of a secret rebate or drawback, but the rates are scheduled, posted and open to the public at large. But, assuming the weight of evidence in this case to be that the party-rate ticket is not a 'commutation ticket,' as that word was commonly understood at the time of the passage of the Act, but is a distinct class by itself, it does not necessarily follow that such tickets are unlawful. The unlaw- 
While this section permits the issuance and sale of these special forms of tickets, including nontransferable round trip tickets, yet in view of the restrictions embodied in the Act concerning equality

fulness defined by sections 2 and 3 consist either in an 'unjust discrimination' or an 'undue or unreasonable preference or advantage,' and the object of section 22 was to settle beyond all doubt that the discrimination in favor of certain persons therein named should not be deemed unjust. It does not follow, however, that there may not be other classes of persons in whose favor a discrimination may be made without such discrimination being unjust. In other words, this section is rather illustrative than exclusive. Indeed, many, if not all, the excepted classes named in section 22 are those which, in the absence of this section, would not necessarily be held the subjects of an unjust discrimination, if more favorable terms were extended to them than to ordinary passengers. Such, for instance, are property of the United States. state or municipal governments; destitute and homeless persons transported free of charge by charitable societies; indigent persons transported at the expense of municipal governments; inmates of soldiers' homes, etc., and ministers of religion, in favor of whom a reduction of rates had been made for many years before the passage of of the Act. It may even admit of serious doubt whether, if the mileage, excursion or commutation tickets had not been mentioned at all in this section, they would have fallen within the prohibition of sections 2 and 3 . In other words, whether the allowance of a reduced rate to persons agreeing to travel 1,000 miles, or to go and return by the same road, is a like and contemporaneous service under substantially similar conditions and circumstances,' as is rendered to a person who travels upon an ordinary single-trip ticket. * * But whether these party-rate tickets are commutation tickets proper, as known to railway officials or not, they are obviously within the commuting principle. As stated in the opinion of Judge Sage in the court below:- The difference between commutation and party-rate tickets is, that commutation tickets are issued to induce people to travel more frequently, and party-rate tickets are issued to induce more people to travel. There is, however, no difference in principle between them, the object in both cases being to increase travel without discrimination, and to secure patronage that would not otherwise be secured.

"The testimony in the case indicates that for many years before the passage of the Act it was customary for railroads to issue tickets at reduced rates to passengers making frequent trips, trips for long distances and trips in parties of ten or more, lower than the regular single fare charged between the same points; and such lower rates were universally made at the date of the passage of the Act. As stated in the answer, to meet the needs of the commercial traveler the thousand mile ticket was issued; and to meet the needs of the suburban resident or frequent traveler several forms of tickets were issued. For example, monthly or quarterly tickets, good for any number of trips within the specified time; and ten, twenty-five or fifty trip tickets, good for a specified number of trips by one person, or for one trip by a specified number of persons; to accommodate parties of ten or 
of rates and the prohibitions against preferences, the right to issue these forms of ticket carries with it the duty of exercising due diligence to prevent their use by others than the original purchasers on whose account they have been issued. For example, in the case of a nontransferable round trip ticket, its use by a third party would be violative of the very fundamental principles both of the ticket contract and the Act to Regulate Commerce by permitting the person travelling upon it to enjoy a preference over a similar oneway travellers who have been charged and who have paid their full fare. The railroads issuing such tickets are therefore charged with the use of diligence to enforce the provision forfeiting them when found in the hands of those other than the

more a single ticket, one way or round trip, for the whole party, was made up by the agent on a skeleton form furnished for that purpose; to accommodate excursionists traveling in parties too large to use a single ticket, special individual tickets were issued to each person. Tickets good for a specified number of trips were also issued between cities where travel was frequent. In short it was an established principle of business, that whenever the amount of travel more than made up to the carrier for the reduction of the charge per capita, then such reduction was reasonable and just in the interests botll of the carrier and of the public. Although the fact that railroads had long been in the habit of issuing these tickets would be by no means conclusive evidence that they were legal, since the main purpose of the Act was to put an end to certain abuses which had crept into the management of railroads, yet Congress may be presumed to have had those practices in view, and not to have designed to interfere with them, except so far as they were unreasonable in themselves or unjust to others. These tickets then being within the commutation principle of allowing reduced rates in consideration of increased mileage, the real question is, whether this operates as an undue or unreasonable preference or advantage to this particular description of traffic, or an unjust discrimination against others.

"The evidence shows that the amount of business done by means of these party-rate tickets is very large; that theatrical and operatic companies base their calculation of profits to a certain extent upon the reduced rates allowed by railroads; and that the attendance at conventions, political and religious, social and scientific, is, in great measure, determined by the ability of the delegates to go and come at a reduced charge. If these tickets were withdrawn, the defendant road would lose a large amount of travel, and the single-trip passenger would gain absolutely nothing. If a case were presented where a railroad refused an application for a partyrate ticket upon the ground that it was not intended for the use of the general public, but solely for theatrical troupes, there would be much greater reason for holding that the latter were favored with an undue preference or advantage." 
parties to whom they have been issued. And an injunction may be granted to restrain their sale by ticket scalpers and others seeking to traffic in them. ${ }^{2}$

2 Bitterman v. Louisville and Nashville Railroad Co., 207 U. S. 205, 52 L. Ed. 17I, 28 Sup. Ct. 91. Here a bill was filed to enjoin ticket brokers from dealing in nontransferable round trip tickets issued at reduced rates on account of the Mardi Gras celebration held at New Orleans. The court said:- "The power of carriers engaged in interstate commerce to issue nontransferable reduced rate excursion tickets was expressly recognized by that Act (Act to Regulate Commerce), and the operation and binding effect of the nontransferable clause in such tickets upon all third persons acquiring the same and attempting to use them, and the duty of the carrier in such case to use due diligence to enforce a forfeiture results from the context of the Act. Thus by section 22 it was provided that nothing in this Act shall prevent *** the issuance of mileage, excursion, or commutation tickets.' And it is to be observed that despite the frequent changes in the Act including the comprehensive amendments emtodied in the Act of June 29. 1906, the provision in question remains in force, although the Interstate Commerce Commission, charged with the administrative enforcement of the $\mathrm{Act}$, has directed the attention of Congress to the importance of defining the scope of such tickets in view of the abuses which might arise from the exercise of the right to issue them. ( 2 Int. Com. Comsn. Rep. 529. 539.) And when the restrictions embodied in the Act concerning equality of rates and the prohibitions against preferences are borne in mind the conclusion cannot be escaped that the right to issue tickets of the class referred to carried with it the duty on the carrier of exercising due diligence to prevent the use of such tickets by other than the original purchasers, and therefore caused the nontransferable clause to be operative and effective against any one who wrongfully might attempt to use such tickets. Any other view would cause the Act to destroy itself, since it would necessarily imply that the recognition of the power to issue reduced rate excursion tickets conveyed with it the right to disregard the prohibitions against preferences which it was one of the great purposes of the Act to render efficacious. This must follow, since, if the return portion of the round-trip ticket be used by one not entitled to the ticket, and who otherwise would have had to pay the full one way fare, the person so successfully traveling on the ticket would not only defraud the carrier but effectually enjoy a preference over similar one way travelers who had paid their full fare and who were unwilling to be participants in a fraud upon the railroad company.

"Nor is there merit in the contention that the decision in New Haven Railroad v. Interstate Commerce Commission, (200 U. S. 36r, 404, 50 L. Ed. 515, 26 Sup. Ct. 272) supports the view here relied upon as to the limited authority of a court of equity to enjoin the continued commission of the same character of acts as those adjudged to be wrongful. On the contrary, the ruling in that case directly refutes the claim based on it. There certain acts of the carrier were held to have violated the Act to 
Free Passes and Franks.- The right to issue and exchange passes and free transportation is not limited to the carriers subject to the Act to Regulate Commerce but extends to carriers not so subject. And so railroads subject to the Act may grant passes to the officers and employees of ocean steamship lines and also the railroads of foreign countries. ${ }^{3}$ The provision of section

Regulate Commerce. The contention of the government was that because wrongful acts of a particular character had been committed, therefore an injunction should be awarded against any and all violations in the future of the Act to Regulate Commerce. Whilst this broad request was denied, it was carefully pointed out that the power existed to enjoin the future commission of like acts to those found to be illegal, and the injunction was so awarded. The whole argument here made results from a failure to distinguish between an injunction generally restraining the commission of illegal acts in the future and one which simply restrains for the future the commission of acts identical in character with those which have been the subject of controversy and which have been adjudged to be illegal."

3 United States $:$ Erie Railroad Co., decided February 23, 1915. The Erie railroad had given passes to certain officers, agents and employees of various trans-Atlantic steamship lines and of the Cireat Eastern Railway of England. This was defended by the railroal under the proviso of section I and also under section 22, and was based upon considerations of business policy. The Supreme Court affirmed the dismissal by the lower court of bills filed by the Lnited States to enjoin the railroad company from issuing passes to employecs of common carriers not subject to the Act to Regulate Commerce. The court said:- "The Act was passed to regulate the conduct and affairs of the carriers of the country and necessarily they are brought under its provisions and subject to them. It controls their relations, but the carriers subject to the Act may have relations with other carriers, and special provisions would naturally be made to govern that relation. And certainly the reasoning is not impressive which justifies an interchange of passes between carriers subject to the Act and denies it to those not so subject, the same business reasons existing in both cases.

"Counsel for the United States sounds an alarm at such extension and lets imagination loose in portrayal of its consequences and sees included tap lines and other industrial railroads, street car lines, local traction companies, omnibus transfer companies and herdic lines, hackmen, boatmen, ferrymen, truckmen, lumber flumes, bucket lines for ore, parcel deliveries, district messenger services, carriers of all descriptions, both in this country and abroad'-a formidable enumeration, it must be admitted And there must be included, too, all their officers, all their employees and their families. There is, however, an opposing picture. It is conceded that carriers subject to the Act may interchange passes, the officers and employees of each carrier receiving free transportation, and giving it to every other carrier subject to the Act. making an army of the privileged with the same discrimination and the same burden on the passenger 
22 does not authorize express companies to issue franks to the officers and members of their families of their own and other companies for the free carriage of packages although passes may be interchanged among the officers of railroad companies." The

service of the railroads as in the illustration of the Government. There is no argument, therefore, in a comparison of the possibilities under one construction rather than the other. At best it is but a comparison of the excesses which may be but are not likely to be practiced. Counsel seem to think that the railroads have an eager desire to distribute passes and burden their transportation service with a crowd of free passengers. Congress certainly had no such view and gave power to exchange passes, considering that the best safeguard against its abuse was the interest of the carriers. The cases at bar are a typical instance of its exercise. It has its justification in a strictly business policy, and instead of being a burden upon the resources of the companies it is an aid to them. With these examples before us, and in view of the other reasons which we have adduced, we see no reason to disregard the literal terms of the statute. And this view is strengthened. not weakened by the proviso inserted on June $18 \mathrm{th}, \mathrm{I} 9 \mathrm{I}$ (in section I of the Act to Regulate Commerce).

In such case the statute makes a special limitation, as will be observed; in other words, restricts the privilege of exchanging telegraph and telephone franks for employees. etc. of such lines and of other common carriers subject to the Act-that is, there are words of explicit limitation."

4 American Express Company: $\because$. Lited States, 212 U. S. 522, 53 L. Ed. 635,29 Sup. Ct. 315 . Here the court said:- "While it is true the language here used (section I) has reference to common carriers and by the terms of the Hepburn Act express companies are within that description, yet the proviso is as clearly limited to the carriage of passengers and the interchange of passes for officers, agents and employees of common carriers and their families, as is the body of the section itself. It is contended that this section if limited to the carriage of passengers was unnecessary in view of the concluding part of section 22 of the Act of February 4. $188 ;$, as amended by the Acts of March 2, 1889 , and February 8, 1905. which provides: "Nothing in this Act shall be construed to prevent railroads from giving free carriage to their own officers and employees, or to prevent the principal officers of any railroad company or companies from exchanging passes or tickets with other railroad companies for their officers and employces;' etc. But we are to consider the language which Congress has used in passing a given law, and when the language is plain and explicit our only province is to give effect to the Act as plainly expressed in its terms. We are clearly of the opinion that, without doing violence to the language used in section I-including the proviso-its terms cannot be held to include the transportation of goods. It is likely that there is no substantial reason why Congress should not extend to express companies, their officers, agents and employees, corresponding privileges for free carriage of goods with those which are given to the officers, agents and employees of railroad companies in respect 
question of free transportation and the interchange and use of passes is treated at length under the proper paragraphs of section I of the Act.

\section{Cumulative Remedies and Common Law Rights.-This} clause of section 22 does not continue in shippers common law rights whose existence is contrary to or inconsistent with the provisions of the Act, otherwise the Act would be self-destructive. The purpose of this provision is to declare specifically that any special remedy given by the Act shall be regarded as cumulative when other appropriate common law or statutory remedies existed for the redress of the particular grievance or wrong dealt with in the Act. The clause is conccrned only with rights recognized in or duties imposed by the Act itself. For example a shipper cannot maintain an action in a state court for excessive or unreasonable freight rates on interstate shipments where the rates charged are those fixed by the carrier according to the terms of the Act and which had not been found unreasonable by the Interstate Commerce Commission. ${ }^{3}$

to transportation of persons, but-if the law is defective in this respectthe remedy must be applied by Congress and not by the courts."

5 Texas and Pacific Railway Co. v. Abilene Cotton Oil Co., 204 U. S. 426, 5 I L. Ed. 553, 27 Sup. Ct. 350, where the Supreme Court said in reference to section 22 :- "This clause. however, cannot in reason be construed as continuing in shippers a common law right, the continued existence of which would be absolutely inconsistent with the provisions of the Act. In other words, the Act can not be held to destroy itself. The clause is concerned alone with rights recognized in or duties imposed by the Act, and the manifest purpose of the provision in question was to make plain the intention that any specific remedy given by the Act should be regarded as cumulative, when other appropriate common law or statutory remedies existed for the redress of the particular grievance or wrong dealt with in the Act."

See also Mitchell Coal Co. v. Pennsylvania Railroad Co., 230 U. S. 247 , 57 L. Ed. 1472, 33 Sup. Ct. 916. 


\section{SECTION 23. JURISDICTION OF FEDERAL COURTS TO ISSUE WRITS OF MANDAMUS.}

Sec. 23. (Added March 2, 1889.) That the Circuit and District Courts of the United States shall have jurisdiction upon the relation of any person or persons, firm, or corporation, alleging such riolation by a common carrier, of any of the provisions of the Act to which this is a supplement and all Acts amendatory thereof, as prevents the relator from having interstate traffic moved by said common carrier at the same rates as are charged, or upon terms or conditions as farorable as those given by said common carrier for like traffic under similar conditions to any other shipper, to issue a writ or writs of mandamus against said common carrier. commanding such common carrier to move and transport the traffic, or to furnish cars or other facilities for transportation for the party applying for the writ: Prozided, That if any question of fact as to the proper compensation to the common carrier for the service to be enforced by the writ is raised by the pleadings, the writ of peremptory mandamus may issue, notwithstanding such question of fact is undetermined, upon such terms as to security, payment of money into the court. or otherwise, as the court may think proper, pending the determination of the question of fact: Provided, That the remedy hereby given by writ of mandamus shall be cumulative, and shall not be held to exclude or interfere with other remedies provided by this Act or the Act to which it is a supplement.

Jurisdic tion
Un it ed States courts to issue writs of peremptory man: damus command. ing the move. ment of interstate trafic or the furnishing of cars or other transportation facilities.

Peremptory mandamus nay issue notwithstanding proper compensation of carrier may be undetermined.

Mandamus.-This section was incorporated in the Act to Regulate Commerce March 2, I889, and has not been amended. This section was added for the purpose of making the remedial processes of the Act more speedy and efficacious. But it must be construed in connection with the amendments adopted in 1906 to section 15 and section 16 , giving operative effect to the orders of the Com- 
mission without the sanction of previous judicial authority, and endowing that body with the power, not only as to unreasonable rates, but as to practises found upon complaint to be unduly prejudicial and unjustly discriminatory, to correct them by its order, which order shall be effective within the fixed statutory period, and to enforce those provisions, penalties and forfeitures are provided. Therefore to give a broad construction to the provisions of section 23 would either destroy or render inefficacious the purposes of the amendments of 1906-since the narrow remedial processes of section 23 would destroy the wider and more far-reaching remedies created at the later date. 'Then harmonizing the provisions of these various sections, the Supreme Court has held that the remedy afforded by section 23 , in the cases which it embraces, must be limited either to the performance of duties which are so plain and so independent of previous administrative action of the Commission as not to require a prerequisite exertion of power by that body, or to compelling the performance of duties which plainly arise from the obligatory force which the statute attaches to orders of the Commission rendered within the lawful scope of its authority, until such orders are set aside by the Commission or enjoined by the courts. ${ }^{1}$ 'To give to the courts

I Baltimore and Ohio Railroad v. United States ex rel. Pitcairn Coal Co., 215 U. S. 48 I, 54 L. Ed. 292, 30 Sup. Ct. 164. Here a petition was filed to secure a writ of peremptory mandamus to compel a certain distribution of coal cars. The court said:- "The court below deemed that it was its duty to award to the coal company the relief by mandamus which was prayed, upon the theory that section 23 of the Act to Regulate Commerce rendered it imperative to do so, this conclusion being specially based upon the provision of that section authorizing the remedy of mandamus to compel carriers 'to furnish cars or other facilities for transportation for the party applying for the writ.' *** That it is not necessary to point out that there is ample scope for giving effect to and applying the remedy embraced in section 23, if that section be construed in harmony with the Act of which it forms a part, and not as destructive of one of the main purposes of the Act, we think, is obvious. It is to be observed that the section, besides empowering the use of the writ of mandamus to compel the furnishing of cars and other facilities for transportation, also authorizes the use of that writ for the purpose of compelling the movement of traffic 'at the same rates as are charged, or upon terms or conditions as favorable as those given by said common carrier for like traffic under similar conditions to any other shipper.' As it was settled in the Abilene case that the right to question in the courts the rates established in accordance with the Act to Regulate Commerce without previous resort, by complaint, to the Commission, in order to determine their unreasonableness, would be 
authority to consider and pass upon the administrative questions which the statute has primarily confided to the Commission, without the preliminary action of that body, would be entirely de-

destructive of the Act, and therefore was not permissible, that ruling is equally applicable to the provision as to furnishing cars contained in section 23, which is here relied upon. But as we are required for the determination of the case now before us, to consider the scope of the Act to Regulate Commerce as now existing, as a result of the amendments of 1906 , we shall not rest our conclusion alone upon the persuasive force of the reasoning which constrained to the conclusion announced in the Abilene case. Speaking generally, it is true to say that, prior to 1889 , although the prohibitions of the Act to Regulate Commerce as to preferences and discriminations were far reaching, the mechanism provided by the statute for the enforcement of orders of the Commission on the subject, as well as those concerning a finding as to unreasonable rates, were deemed to be in many respects ineffective, or at least tardy in operation or unsatisfactory in prompt remedial results, and this because immediate effect was not given to the orders of the Commission, but the aid of judicial authority was required as a prerequisite for such result. Section 23, here relied upon, was not part of the original Act, but, as we have said, was added thereto on March 2, 1889, for the obvious purpose of making the remedial processes of the Act more speedy and efficacious. Now, it cannot in reason be questioned that among the purposes contemplated by the amendments adopted in 1906 was the curing of the presumed remedial inefficiency of the Act by supplying efficient means for giving effect to the orders of the Commission, made in the exertion of the authority conferred upon that body. To that end one of the amendments, section 15 , gives operative effect to the orders of the Commission without the sanction of previous judicial authority, and endows that body with the power, not only as to unreasonable rates, but as to practises found upon complaint to be unduly prejudicial and unjustly discriminatory, to correct the same by its order, which order should have effect within the period fixed in the statute, and, to enforce these provisions, penalties and forfeitures are provided. Section I6. It being demonstrable, as we have seen, that to give to section 23 the broad meaning which the court below affixed to it would be to destroy or render inefficacious the remedial purposes of the amendments enacted in 1306, it must follow that such construction cannot be adopted, since to do so would compel us to hold that the wide and far-reaching remedies created by the amendments of 1906 were, in effect, destroyed by the narrower remedial processes which had been previously enacted in 1889 . This conclusion being in reason impossible, it must follow that, construing the provisions of section 23 in the light of and in harmony with the amendments adopted in Ig06, the remedy afforded by that section, in the cases which it embraces, must be limited either to the performance of duties which are so plain and so independent of previous administrative action of the Commission as not to require a prerequisite exertion of power by that body, or to compelling the performance of duties which plainly arise from the obligatory force which 
structive of the entire system of regulation devised by the Act to Regulate Commerce. To give such power to the courts would compel the Commission either to abdicate its administrative duties or violate the decrees of the courts. And the test to be applied here, as in other cases, by the courts is the power of the Commission to make the order in question and not its wisdom. In this connection and in considering the provisions of section 23 special attention is called to the features of sections 15 and 16 as amended.

the statute attaches to orders of the Commission, rendered within the lawful scope of its authority, until such orders are set aside by the Commission or enjoined by the courts."

See also Interstate Commerce Commission v. Illinois Central Railroad Co., 2 I5 U. S. 452, 54 L. Ed. 280, 30 Sup. Ct. 155; Interstate Commerce Commission v. Chicago and Alton Railroad Co., 215 U. S. 479, 54 L. Ed. 29I, 30 Sup. Ct. I63. 


\section{THE ELKINS ACT, APPROVED FEBRUARY 19, 1903.}

Be it enacted by the Senate and House of Representatives of the United States of America in Congress assembled, Sic. I. (As amended June 29, 1906.) That any thing done or omitted to be done by a corporation common carrier, subject to the Act to Regulate Commerce and the Acts amendatory thereof, which, if done or omitted to be done by any director or officer thereof, or any receiver, trustee, lessee, agent, or person acting for or employed by such corporation, would constitute a misdemeanor under said Acts or under this Act, shall also be held to be a misdemeanor committed by such corporation, and upon conviction thereof it shall be subject to like penalties as are prescribed in said Acts or by this Act with reference to such persons, except as such penalties are herein changed. The willful failure upon the part of any carrier subject to said Acts to file and publish the tariffs or rates and charges as required by said Acts, or strictly to observe such tariffs until changed according to law, shall be a misdemeanor, and upon conviction thereof the corporation offending shall be subject to a fine of not less than one thousand dollars nor more than twenty thousand dollars for each offense; and it shall be unlawful for any person, persons, or corporation to offer, grant, or give, or to solicit, accept, or receive any rebate, concession, or discrimination in respect to the transportation of any property in interstate or foreign commerce by any common carrier subject to said Act to Regulate Commerce and the Acts amendatory thereof whereby any such property shall by any device whatever be transported at a less rate than that named in the tariffs published and filed by such carrier, as is required by said Act to Regulate Commerce and the Acts amendatory thereof, or whereby any other ad-
Corporat i o as well as offi. cer or agent liable.

Penalty.

Failure of car. rier to publish rates or observe tariffs a misde. meanor.

Penalty, fine.

Misdemean or to offer, grant, give, solicit, accept, or receive any rebate, concession or discrimination. 
Penalty, fine or imprisonment, or both.

Prosecutions may be in any $\mathrm{d}$ i s t $r$ i c t through which transporta $\mathrm{t}$ i o $\mathrm{n}$ passes.

Principals are liable for acts of agents.

Rates filed or participated in by carrier shall, as against such c a r rier, be deemed Jegal. rantage is given or discrimination is practised. Every person or corporation, whether carrier or shipper, who shall, knowingly, offer, grant, or give, or solicit, accept, or receive any such rebates, concession, or discrimination shall be deemed guilty of a misdemeanor, and on conviction thereof shall be punished by a fine of not less than one thousand dollars nor more than twenty thousand dollars: Provided, That any person, or any officer or director of any corporation subject to the provisions of this Act, or the Act to Regulate Commerce and the Acts amendatory thereof, or any receiver, trustee, lessee, agent, or person acting for or employed by any such corporation, who shall be convicted as aforesaid, shall, in addition to the fine herein provided for, be liable to imprisonment in the penitentiary for a term of not exceeding two years, or both such fine and imprisonment, in the discretion of the court. Every violation of this section shall be prosecuted in any court of the United States having jurisdiction of crimes within the district in which such violation was committed, or through which the transportation may have been conducted; and whenever the offense is begun in one furisdiction and completed in another it may be dealt with, inquired of, tried, determined, and punished in either jurisdiction in the same manner as if the offense had been actually and wholly committed therein.

In construing and enforcing the provisions of this section, the act, omission, or failure of any officer, agent, or other person acting for or employed by any common carrier, or shipper, acting within the scope of his employment, shall in every case be also deemed to be the act, omission, or failure of such carrier or shipper as well as that of the person. Whenever any carrier files with the Interstate Commerce Commission or publishes a particular rate under the provisions of the Act to Regulate Commerce or Acts amendatory thereof, or participates in any rates so filed or published, that rate as against such carrier, its officers or agents, in any prosecution 
begun under this Act shall be conclusively deemed to be the legal rate, and any departure from such rate, or any offer to depart therefrom, shall be deemed to be an offense under this section of this Act.

Any person, corporation, or company who shall deliver property for interstate transportation to any common carrier, subject to the provisions of this Act, or for whom as consignor or consignee, any such carrier shall transport property from one state, territory, or the District of Columbia, to any other state, territory, or the District of Columbia, or foreign country, who shall knowingly by employee, agent, officer, or otherwise, directly or indirectly, by or through any means or device whatsoever, receive or accept from such common carrier any sum of money or any other valuable consideration as a rebate or off set against the regular charges for transportation of such property, as fixed by the schedules of rates provided for in this Act, shall in addition to any penalty provided by this Act forfeit to the United States a sum of money three times the amount of money so received or accepted and three times the value of any other consideration so received or accepted, to be ascertained by the trial court; and the attorney general of the United States is authorized and directed, whenever he has reasonable grounds to believe that any such person, corporation, or company has knowingly received or accepted from any such common carrier any sum of money or other valuable consideration as a rebate or offset as aforesaid, to institute in any court of the United States of competent jurisdiction a civil action to collect the said sum or sums so forfeited as aforesaid; and in the trial of said action all such rebates or other considerations so received or accepted for a period of six years prior to the commencement of the action, may be included therein, and the amount recovered shall be three times the total amount of money, or three times the total
Forfeit ure may be en. receivers of re. bates. 
Persons inter. ested in matters involved in cases before Interstate Com. merce Commission or Circuit Court may be mad e parties subject to orders or decrees.

Court may re strain departures from published rates or any discriminat ion prohibited law. value of such consideration, so received or accepted, or both, as the case may be.

SEC. 2. That in any proceeding for the enforcement of the provisions of the statutes relating to interstate commerce, whether such proceedings be instituted before the Interstate Commerce Commission or be begun originally in any Circuit Court of the United States, it shall be lawful to include as parties, in addition to the carrier, all persons interested in or affected by the rate, regulation, or practise under consideration, and inquiries, investigations, orders, and decrees may be made with reference to and against such additional parties in the same manner, to the same extent, and subject to the same provisions as are or shall be authorized by law with respect to carriers.

SEC. 3. That whenever the Interstate Commerce Commission shall have reasonable ground for belief that any common carrier is engaged in the carriage of passengers or freight traffic between given points at less than the published rates on file, or is committing any discriminations forbidden by law, a petition may be presented alleging such facts to the Circuit Court of the United States sitting in equity having jurisdiction; and when the act complained of is alleged to have been committed or as being committed in part in more than one judicial district or state, it may be dealt with, inquired of, tried, and determined in either such judicial district or state, whereupon it shall be the duty of the court summarily to inquire into the circumstances, upon such notice and in such manner as the court shall direct and without the formal pleadings and proceedings applicable to ordinary suits in equity, and to make such other persons or corporations parties thereto as the court may deem necessary, and upon being satisfied of the truth of the allegations of said petition said court shall enforce an observance of the published tariffs or direct and require a discontinuance of such discrimination by proper orders, writs, and process, which said orders, writs and 
process may be enforceable as well against the parties interested in the traffic as against the carrier, subject to the right of appeal as now provided by law. It shall be the duty of the several district attorneys of the United States, whenever the Attorney General shall direct, either of his own motion or upon the request of the Interstate Commerce Commission, to institute and prosecute such proceedings, and the proceedings provided for by this Act shall not preclude the bringing of suit for the recovery of damages by any party injured, or any other action provided by said Act approved February fourth, eighteen hundred and eightyseven, entitled "An Act to Regulate Commerce," and the Acts amendatory therof. And in proceedings under this Act and the Acts to Regulate Commerce the said courts shall have the power to compel the attendance of witnesses, both upon the part of the carrier and the shipper, who shall be required to answer on all subjects relating directly or indirectly to the matter in controversy, and to compel the production of all books and papers, both of the carrier and the shipper, which relate directly or indirectly to such transaction; the claim that such testimony or evidence may tend to criminate the person giving such evidence shall not excuse such person from testifying or such corporation producing its books and papers, but no person shall be prosecuted or subjected to any penalty or forfeiture for or on account of any transaction, matter, or thing concerning which he may testify or produce evidence documentary or otherwise in such proceeding: Provided, That the provisions of an Act entitled "An Act to expedite the hearing and determination of suits in equity pending or hereafter brought under the Act of July second, eighteen hundred and ninety, entitled 'An Act to protect trade and commerce against unlawful restraints and monopolies,' 'An Act to Regulate Commerce,' approved February fourth, eighteen hundred and eighty-seven, or any other Acts having a like pur-

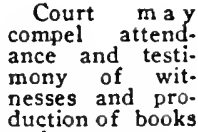
and papers.

Immunity.

Exped it in $g$ Act of Feb. II, 1903, to apply in cases prosecuted under di. rection of attorney general in name of In. terstate Com. merce Commis. sion. 
pose that may be hereafter enacted, approved February eleventh, nineteen hundred and three," shall apply to any case prosecuted under the direction of the attorney general in the name of the Interstate Commerce Commission.

Conflict in $\mathrm{g}$ laws repealed.

SF.C. 4. That all Acts and parts of Acts in conflict with the provisions of this Act are hereby repealed, but such repeal shall not affect causes now pending nor rights which have already accrued, but such causes shall be prosecuted to a conclusion and such rights enforced in a manner heretofore provided by law and as modified by the provisions of this Act.

SEC. 5. That this Act shall take effect from its passage.

History of the Act.-The Elkins Act was aimed at the abolition of all forms of rebates and rebating. It also amended vitally the penal provisions of section 10 and in effect changed sections 2 and 6 of the Act to Regulate Commerce. It abolished the penalty of imprisonment, though this penalty was restored by an amendment of the Hepburn Act of June 29, I906. It also made railroad corporations liable to prosecution in all cases where their officers and agents were liable under the original Act-the officers and agents continuing to be liable as theretofore. The Elkins Act further made the published tariff rates the standard of lawfulness of rates, and declared any departure therefrom a misdemeanor. It made every violation of the Act subject to the jurisdiction of any court of the United States having jurisdiction of crimes within the district in which such violation was committed, or through which the transportation may have been conducted. Further it provided that in construing and enforcing the provisions of the Act, the act, omission or failure of any officer or agent of any carrier or shipper, acting within the scope of his employment, should be deemed to be the act, omission or failure of such carrier or shipper as well as of that person.

By the Hepburn Act of June 29, 1906, the penalty of imprisonment was restored-so that in its present form the penalty of both fine and imprisonment may be inflicted on both the carrier and the shipper, and also in addition the shipper shall forfeit to the United States a sum of money three times that accepted or received as a rebate from any carrier. 
Constitutionality of the Act.-The Supreme Court has frequenty declared the Elkins Act constitutional although its legality has been attacked upon several grounds. For example, it was insisted that the Sixth Amendment to the Constitution was violated by the provision of the Act whereby any violation of the inhibition against transporting freight at less than the published rates could be prosecuted in any court of the United States in the district in which such violation was committed, or through which the transportation may have been conducted. The court declared that the constitutional amendment in question does not require the prosecution of the defendant in the district wherein he may reside at the time of the commission of the offense, or where he may be at that time, provided he is prosecuted where the offense is committed. Transportation was declared to be an essential element of the offense charged and transportation equally takes place over any and all of the travelled route and during transportation the crime is being constantly committed. ${ }^{1}$ Therefore prosecution is not

I Armour Packing Company v. United States, 209 U. S. 56, 52 L. Ed. 68I, 28 Sup. Ct. 428. Shippers were convicted in the District Court of western Missouri for violation of the Elkins Act in obtaining from a raitroad company an unlawful concession on packing house products from the lawful rates published as in force between Kansas City, Kansas, and New York, the goods being for export. The court said:-

"It is next contended that there is no jurisdiction to prosecute the offense named, because the allegad offense, if any, was not committed in the western district of Missouri, where the prosecution was had, but the same was complete in Kansas City in the state of Kansas; and it is contended in this connection that if the Act can be construed to include prosecutions in other districts it is unconstitutional within the provisions of the sixth amendment of the Constitution of the United States, which provides that the accused shall have the right to be tried by an impartial jury of the state and district wherein the crime shall have been committed. ***

"In this case the indictment charges the actual transportation of the property from Kansas City, Kansas, to New York City, the course of transportation being through the western district of Missouri, in which the prosecution was had. We are not now concerned with the construction of the Act in making provision for punishing the carrier or shipper for offering, granting or giving, or soliciting, accepting or receiving, rebates, concessions, or discriminations, irrespective of actual transportation, for it is specifically made an offense to receive any rebate or concession whereby any such property is by any device whatever transported at a less rate than that named, published and filed by the carrier; and jurisdiction is given to prosecute in any criminal court of the United States in the district through which the transportation may have been conducted. Having 
limited to the district in which the contract complained of was made and the goods on which the concession was secured actually shipped. The constitutional requirement is as to the locality of

in view the offense charged in this case, we think it is clearly within the terms of the Act making it penal to procure the actual transportation, by any of the means denounced in the Act, of goods at a less rate than that named in the tariffs. It is the purpose of the Act to punish those who give or receive transportation, in the sense of actual carriage at a concession from the published rates. Wherever such transportation is received, there the offense is to be deemed to have been committed. Why may this not be so? In this feature of the statute, the transportation being of the essence of the offense, when it takes place, whether in one district or another, whether at the beginning, at the end, or in the middle of the journey, it is equally and at all times committed. Congress also embraced in section I of the Elkins Act offenses not depending upon actual transportation through districts; and as to the trial of such, it also made provisions in the venue section.

"For the penal section is not only aimed at offenses whereby property is transported in interstate commerce at less than published rates, but in terms covers the offering, granting, giving, soliciting, accepting or receiving of rebates, concessions or discriminations, 'whereby any other advantage is given or discrimination is practised' in respect of interstate transportation. Congress doubtless had in mind that some of these offenses might be complete in a single district; some might be begun in one and completed in another; and those wherein transportation-actual carriage -was made an essential element might continue through several districts, and hence undertook to provide places for trial of any offense which might be committed against the provisions of the Act. It is at least certain that these sections, construed together, make an offense of obtaining transportation at a concession from the published rate, which shall be triable in any district through which it is had. That is the offense of which the accused is charged in this case, and such is the district in which it was tried. * * Under the amended Act, transportation, with a rebate, or at a concession from the established rates, is made an offense as to the shipper as well as the carrier, thereby differentiating the Elkins Act from section Io of the Act of 1889 .

"But it is said this construction of the Act is in violation of the sixth amendment of the Constitution of the United States, which requires crimes to be prosecuted and punished in the state or district where the same are committed, and that as the transportation was had, at least, in part in Kansas, the offense was there completed and could not be prosecuted elsewhere. But the constitutional provision does not require the prosecution of the defendant in the district wherein he may reside at the time of the commission of the offense, or where he may happen to be at that time, provided he is prosecuted where the offense is committed. The constitutional requirement is as to the locality of the offense and not the personal presence of the offender. *** We think the doctrine for stronger 
the offense and not the personal presence of the offender. This does not mean, however, that a single transportation of goods can be made the basis or cause for a number of separate criminal

reason applies in the present case, for transportation is an essential element of the offense, and, as we have said, transportation equally takes place over any and all of the traveled route, and during transportation the crime is being constantly committed. It does not follow from this view of the character of the offense that a single transportation of goods can be made the basis of repeated separate criminal charges in each of the districts through which the transportation at an illegal rate is had. Take the present case. The charge is of a single, continuous carriage from Kansas City to New York at a concession from the legal rate for the part of the carriage between the Mississippi River and New York of 12 cents for each 100 pounds so transported. This is a single, continuing offense, not a series of offenses, although it is continuously committed in each district through which the transportation is received at the prohibited rate. * * We think there was jurisdiction to prosecute for the offense charged within the western district of Missouri.

"It is further contended by petitioners that the statutes have no application to a shipment on a through bill of lading from an interior point in the United States to a foreign port. It is alleged that the Elkins law refers to the original Interstate Commerce Act, and that its terms do not include such shipments. Analyzing the first section of the Act, it is said that it applies to the following kinds of commerce: (a) interstate commerce; (b) commerce between the United States and an adjacent foreign country; (c) commerce between places in the United States passing through a foreign country; (d) commerce from the United States to a foreign country only while being transported to a point of transshipment; (e) commerce from a foreign country to points in the United States, but only while being carried from port of entry either in the United States or an adjacent foreign country. And, it is contended, that section 6 , as amended, does not require the filing of through export tariffs. The purpose of Congress to embrace the whole field of interstate commerce is made apparent by the exclusion only of wholly domestic commerce in the last clause of section I of the original Act of 1887 , and in the declaration of the scope and purpose of the Act declared in its title. Texas and $\mathrm{Pa}$ cific Railway Co. v. Interstate Commerce Commission, I62 U. S. I97, 211 , 40 L. Ed. 940, I6 Sup. Ct. 666 . There is no attempt in the language of the Act to exempt such foreign commerce as is carried on a through bill of lading; on the contrary, the Act in terms applies to the transportation of property shipped from any place in the United States to a foreign country and carried from such place to a port of transshipment.

"What reasonable ground is there for supposing that Congress intended to exercise no control over such commerce if it happens to be billed through to the foreign port? Such construction would place such important commerce shipped in the United States to a port for transshipment abroad wholly outside the restrictions of the law, and enable shippers to 
charges in each of the districts through which the goods may be transported at an illegal rate.

Nor is a prosecution under the Elkins Act based on a shipment under a through bill of lading from a point within the United States to a foreign port in violation of the provision of the Constitution forbidding the levying of export taxes, nor does it run counter to that provision of the Constitution forbidding the giving of a preference to the ports of one state over those of another state. $^{2}$ The injunction of compliance with the established rate on

withdraw such commerce from the regulations enforced against other interstate commerce by the expedient of a through bill of lading. Take the present case. The through rate is obtained by adding the acean rate to the inland rate. There is no contractual relation between the railroad carrier and the ocean carrier. The ocean rate is uncertain and variable, depending upon time of sailing and available space. The accomodation for ocean shipment was obtained by the shipper and by it made known to the inland carrier. We think the language of the statute, read in the light of the manifest purpose of its passage, shows the intent of Congress to bring interstate commerce within the control of the provisions of the law up to the time of ocean shipment. This construction is reinforced by the broad provisions of section 6 of the Act as to publishing schedules, showing rates, fares and charges, and filing the same with the Interstate Commerce Commission. That such rates, notwithstanding through bills of lading. were subject to the provisions of the Act, was held, upon full consideration, and rightfully, as we think, by the Interstate Commerce Commission. Re Tariffs v. Export and Import Traffic, Io I. C. C. Rep. 55."

2 Armour Packing Company v. United States, 209 U. S. 56, 52 L. Ed. 68I, 28 Sup. Ct. 428, supra. As to these features of the case the court said:-

"It is contended that the Act, as construed by the Circuit Court of Appeals, makes it conflict with art. I, section 9, par. 5, of the Constitution, which provides: 'No tax or duty shall be laid on articles exported from any state. No preference shall be given by any regulation of commerce or revenue to the ports of one state over those of another; nor shall vessels bound to or from one state be obliged to enter, clear or pay duties in another.' The petitioner contends that to permit a statute to have such application to articles intended for foreign export is to place a burden on the exercise of this right, because before the shipper can lawfully send his goods abroad and before the carrier can lawfully accept them there must be a compliance with the established rate on file with the Interstate Commerce Commission. This rate is subject only to be changed as provided by law; and this can be done without notice to the exporter and regardless of his power to comply with the legal rate and meet the competition at the seaport and the conditions of foreign markets. These things, it is said, place a distinct burden upon export trade, and therefore come within the constitutional prohibition. But it is to be observed that the Constitution 
file with the Interstate Commerce Commission docs not bring the case within the terms of the constitutional inhibition against a burden by way of taxation or duty levied on goods for export, the courts having held that it is only interference of that nature that comes within the constitutional prohibition. The merely incidental effect of the legal regulation of interstate commerce upon exportation does not come within the scope of this constitutional limitation.

Again the Elkins Act is not unconstitutional on the charge that it deprives one of the due process of law by attributing the acts of the agents to the common carriers and making the carriers responsible for the acts of their agents. ${ }^{3}$ The Act is therefore valid in

provides for a burden only by the way of taxation or duty, and unless the alleged interference amounts to such taxation or duty it does not come within the constitutional prohibition. Cornell $r$. Coyne, I92 L. S. 418.

"The regulations of interstate commerce provided by the statute now under consideration are within the acknowledged power of Congress under the interstate commerce clause of the Constitution. There is no attempt to levy duties on goods to be exported, and the mere incidental effect in the legal regulation of interstate commerce upon such exportations does not come within this constitutional prohibition. Nor do we think there is any more force in the contention that this legislation amounts to a preference of ports of one state over those of another within the meaning of the constitutional provision under consideration. This provision was intended to prevent legislation intended to give and having the effect of giving preference to the ports of one state over those of another state. It may be true that the regulation of interstate commerce by rail has the effect to give an advantage to commerce wholly by water and to ports which can be reached by means of inland navigation, but these are natural advantages and are not created by statutory law. The fact that regulation, within the acknowledged power of Congress to enact, may affect the ports of one state more than those of another cannot be construed as a violation of this constitutional provision. South Carolina v. Georgia, 93 U. S. 4 , 13, 23 L. Ed. 782; Pennsylvania v. Wheeling and Belmont Bridge Co., I8 How. 421, 433, I5 L. Ed. 435."

3 New York Central and Hudson River Railroad v. United States, 212 U. S. 481, 53 L. Ed. 613, 29 Sup. Ct. 304. The railroad company herein was convicted of the payment of rebates under the Elkins Act. The assistant traffic manager was also convicted. The court said:- "It is contended that these provisions of the law are unconstitutional because Congress has no authority to impute to a corporation the commission of criminal offenses, or to subject a corporation to a criminal prosecution by reason of the things charged. The argument is that to thus punish the corporation is in reality to punish the innocent stockholders, and to deprive them of their property without opportunity to be heard. consequently 
imputing to the employing corporation the acts of its agents and imposing penalties upon the corporation for violations of the law committed by such agents acting within the scope of their employ-

without due process of law. And it is further contended that these provisions of the statute deprive the corporation of the presumption of innocence, a presumption which is part of due process in criminal prosecutions. It is urged that as there is no authority shown by the board of directors or the stockholders for the criminal acts of the agents of the company, in contracting for and giving rebates, they could not be lawfully charged against the corporation. As no action of the board of directors could legally authorize a crime, and as indeed the stockholders could not do so, the arguments come to this: that owing to the nature and character of its organization and the extent of its power and authority, a corporation cannot commit a crime of the nature charged in this case.

"In this case we are to consider the criminal responsibility of a corporation for an act done while an authorized agent of the company is exercising the authority conferred upon him. It was admitted by the defendant at the trial that at the time mentioned in the indictment the general freight traffic manager and the assistant freight traffic manager were authorized to establish rates at which freight should be carried over the line of the New York Central and Hudson River Company, and were authorized to unite with other companies in the establishing, filing and publishing of through rates, including the through rate or rates between New York and Detroit referred to in the indictment. Thus the subject matter of making and fixing rates was within the scope of the authority and employment of the agents of the company, whose acts in this connection are sought to be charged upon the company. Thus clothed with authority, the agents were bound to respect the regulation of interstate commerce enacted by Congress, requiring the filing and publication of rates and punishing departures therefrom. Applying the principle governing civil liability, we go only a step farther in holding that the act of the agent, while exercising the authority delegated to him to make rates for transportation, may be controlled in the interest of public policy by imputing his act to his employer and imposing penalties upon the corporation for which he is acting in the premises.

"It is true that there are some crimes, which in their nature cannot be committed by corporations. But there is a large class of offenses, of which rebating under the federal statutes is one, wherein the crime consists in purposely doing the things prohibited by statute. In that class of crimes we see no good reason why corporations may not be held responsible for and charged with the knowledge and purposes of their agents, acting within the authority conferred upon them. 2 Morawetz on Corporations, sec. 733; Green's Brice on Ultra Vires, 366. If it were not so, many offenses might go unpunished and acts be committed in violation of law, where, as in the present case, the statute requires all persons, corporate or private, to refrain from certain practises forbidden in the interest of public policy. It is a part of the public history of the times that statutes 
ment. Without saying that the constitutional prohibition invalidated such a provision as to individual carriers, if there were any such, the court declared that it did not invalidate these provisions

against rebates could not be effectually enforced so long as individuals only were subject to punishment for violation of the law, when the giving of rebates or concessions inured to the benefit of the corporations of which the individuals were but the instruments. This situation, developed in more than one report of the Interstate Commerce Commission, was no doubt influential in bringing about the enactment of the Elkins law, making corporations criminally liable. This statute does not embrace things impossible to be done by a corporation; its objects are to prevent favoritism, and to secure equal rights to all in interstate transportation, and one legal rate, to be published and posted and accessible to all alike. New Haven Railroad Co. v. Interstate Commerce Commission, 200 U. S. 36r, 399, 50 L. Ed. 515, 26 Sup. Ct. 272; Armour Packing Co. v. United States, 209 U. S. 56, 52 L. Ed. 68I, 28 Sup. Ct. 428.

"We see no valid objection in law, and every reason in public policy, why the corporation which profits by the transaction, and can only act through its agents and officers, shall be held punishable by fine because of the knowledge and intent of its agents to whom it has intrusted authority to act in the subject matter of making and fixing rates of transportation, and whose knowledge and purposes may well be attributed to the corporation for which the agents act. While the law should have regard to the rights of all, and to those of corporations no less than to those of individuals, it cannot shut its eyes to the fact that the great majority of business transactions in modern times are conducted through these bodies, and particularly that interstate commerce is almost entirely in their hands, and to give them immunity from all punishment because of the old and exploded doctrine that a corporation cannot commit a crime would virtually take away the only means of effectually controlling the subject matter and correcting the abuses aimed at. There can be no question of the power of Congress to regulate interstate commerce, to prevent favoritism and to secure equal rights to all engaged in interstate trade. It would be a distinct step backward to hold that Congress cannot control those who are conducting this interstate commerce by holding them responsible for the intent and purposes of the agents to whom they have delegated the power to act in the premises.

"It is contended that the Elkins law is unconstitutional, in that it applies to individual carriers as well as those of a corporate character, and attributes the act of the agent to all common carriers, thereby making the crime of one person that of another thus depriving the latter of due process of law and of the presumption of innocence which the law raises in his favor. *** We think the answer to this proposition is obvious; the plaintiff in error is a corporation, and the provision as to its responsibility for acts of its agents is specifically stated in the first paragraph of the section. There is no individual in this case complaining of the unconstitutionality of the act, if objectionable on that ground, and the 
as to corporation carriers. The court declared that while, by their nature, some crimes could not be committed by corporations it is an exploded doctrine that a corporation cannot commit a crime, and that it was but a step beyond the principle governing civil liability to hold that the act of the agent, while exercising the authority delegated to him, may be controlled by imputing his act to his employer and imposing penalties upon the corporation for which he is acting. Otherwise it would be impossible to enforce statutes against offenses, the commission of which inured to the benefit and profit of corporations of which the individuals were only the instruments. To render a statute effective its penalties must reach those who would profit by its violation.

Participants in Joint Rates.-Although as a matter of practise joint tariffs are filed by the initial carrier, all carriers are bound by the published and filed rate in which they participate as much as if the tariff had been actually published and filed by each participating carrier." One portion of the first section of the Elkins

case does not come within that class of cases in which unconstitutional provisions are so interblended with valid ones that the whole Act must fall, notwithstanding its constitutionality is challenged by one who might be legally brought within its provisions. Employers Liability Cases, 207 U. S. 463. It may be doubted whether there are any individual carriers engaged in interstate commerce, and every act is to be construed so as to maintain its constitutionality if possible. There can be no question that Congress would have applied these provisions to corporation carriers, whether individuals were included or not. In this view the Act is valid as to corporations. Berea College v. Kentucky, 2 II U. S. 45, 53 L. Ed. 81, 29 Sup. Ct. 33."

4 United States v. New York Central and Hudson River Railroad Co., 212 U. S. 509, 53 L. Ed. 629, 29 Sup. Ct. 313. It was argued that inasmuch as the tariff was filed and published by the initial carrier and not by the defendant railroad it could not be prosecuted for the offense charged in the indictment. The court said:- "It is said to have been the practise that such joint tariffs should be filed by the initial carrier. In any event, it was contended and was held by the Circuit Court that inasmuch as the Elkins Act referred only to the tariffs 'published and filed by such carrier,' and the rebates in this case had been given by a carrier who did not publish and file the rate, the latter company did not come within the terms of the Act. We find, however, that section I of the Elkins Act, in which the language quoted is used, also contains the following language:

"'Whenever any carrier files with the Interstate Commerce Commission or publishes a particular rate under the provisions of the Act to Regulate Commerce or Acts amendatory thereto, or participates in any rates so filed or published, that rate as against such carrier, its officers or agents, in any prosecution begun under this Act 
Act, declared the Supreme Court, was evidently enacted with a view to including cases wherein a joint rate has been established binding upon all who are parties thereto and has been filed by one only of the participating carriers. Therefore, offenses under the Act can be prosecuted not only as against the carrier actually filing and publishing the joint rate but against all carriers participating therein.

Lack of Intent to Rebate not a Defense.-The original Act to Regulate Commerce as amended prior to the enactment of the Elkins law prohibited, or provided penalties for, various false and fraudulent acts, such as false billing, false weighing, false report of weight and declared such an offender guilty of fraud. Before the Elkins Act only fraudulent conduct in obtaining transportation at a less rate than other shippers was denounced and the imposition aimed at was principally such as might be practised by the ship-

shall be conclusively deemed to be the legal rate, and any departure from such rate, or any offer to depart therefrom, shall be deemed to be an offense under this section of this act.'

"The learned judge of the Circuit Court treated this provision as one relating to evidence, and as not as establishing a substantive offense. But we think this is giving too narrow a construction to the terms of the statute and fails to give effect to the language used. We recognize the rule which is laid down in the cases citcd by counsel for the defendant in error, that criminal statutes are not to be enlarged by construction, and that a crime must be clearly defined in the terms of the Act before it can be held to be embraced within its provisions. But while this is true, criminal statutes, like other acts of legislation, are to receive a reasonable construction, with a view to effecting the purpose of their enactment, and we think it entirely clear that the concluding part of section I of the Elkins Act which we have above quoted brings all of the carriers who have participated in any rate filed or published within the terms of the Act, as much so as if the tariff had been actually published and filed by such participating carrier. For the statute specifically provides that the published rate shall be conclusively deemed in any prosecution under the Act to be the legal rate as against the carrier who files the same, or 'participates in any rates so filed and published'; and the section further provides than any departure from such rate, which would include rates either published or participated in, shall be deemed to be an offense under the Act. This part of the first section of the Elkins Act was evidently enacted with a view to meeting the very situation developed in this case, wherein a joint rate has been established binding upon all who are parties thereto, and has been filed by one of the participating carriers. We think the learned judge was in error in holding that offenses of the character charged in this indictment could be prosecuted only as against the carrier actually filing and publishing the joint rate." 
pers upon the carriers in order to procure the preference. In the Elkins Act it is made unlawful for any person or corporation to offer, grant, solicit, give, or to accept or receive any rebate, concession or discrimination in respect to transportation whereby such property shall, by any device whatever, be transported for a less rate than that published and filed by the carriers. No mention is made in the Act of false declarations, fraudulent conduct or other actions synonymous therewith. The Act seeks to reach all means and methods by which rebates, concessions or discriminations are offered, granted, given or received. Therefore intent does not become an element of the offense and a lack of criminal intent does not become a defense for a violation of the provisions of the law. In the words of the court, "Had it been the intention of Congress to limit the obtaining of such preferences to fraudulent schemes or devices, or to those operating only by dishonest, underhanded methods, it would have been easy to have so provided in words that would be unmistakable in their meaning." The fact and not the form or the motive is the question at issue.

5 Armour Packing Co. v. United States, 209 U. S. 56, 52 L. Ed. 68I, 28 Sup. Ct. 428. It was the contention of the shippers that in order to admit of conviction it must be shown that they were guilty of some bad faith or fraudulent conduct in the use of the device or that they obtained the rebate by some intentionally dishonest or underhanded method, concession or discrimination denounced in the Act. The court said:-“"The history of the Act in this feature may be of service in interpreting the meaning of Congress. The Act of February 4, 1887 , made no provision for criminal offenses against the shippers, but it was provided (section 2) that if the common carrier should directly or indirectly, by any special rate, rebate, or other device, demand, collect, or receive, through any person or persons, a greater or less compensation for any service rendered or to be rendered in the transportation of property subject to the provisions of the Act, than it charges, demands, collects or receives, etc., from any other person or persons for doing for him or them a like service in the transportation of a like kind of traffic under substantially the same circumstances, such common carrier shall be deemed guilty of unjust discrimination, which by the Act was prohibited and made unlawful. And it was made unlawful for a common carrier to deviate from the published schedule of rates, fares and charges.

"By the Act of March 2, 1889, the shipper was brought within certain criminal provisions of the law and one who should knowingly and willfully, by false billing, false classifying, false weighing, false representation of the contents of the package, or false report of weight, or by any other device or means, with or without the consent or connivance of the carrier, obtain or dispose of property at less than the regular rate 
Unit of Offense and When Offense Complete.-The Elkins Act prohibits the acceptance of a rebate by the shipper as well as its payment by the carrier. We have seen that the transportation of goods at less than the published rate is a single continuing offense and not a series of separate offenses in each district through

established and in force, should be deemed guilty of fraud. It will be noticed that in these statutes the term device is associated with other words indicative of its meaning and in the Act of March 2, 1889, the shipper, for falsely acting as to weighing, billing, classifying or obtaining the transportation of property at less than the regular weight, or by any other device, was deemed guilty of fraud. In this Act the term device, as one of the means of consummating a fraud, shows the sense in which the term is used by Congress. It was only fraudulent conduct in obtaining transportation at less rates than others, which was denounced by the Act, and the imposition aimed at was principally such as might be practised by the shippers upon the carriers in order to procure the preference.

"In this Act (Elkins law) we find punishment by imprisonment abolished, and the shipper and carricr are placed upon the like footing, and it is made unlawful for any person or corporation to offer, grant, solicit, give, or to accept or receive, any rebate, concession or discrimination in respect to transportation of property in interstate or foreign commerce, whereby any such property shall, by any device whatever, be transported for a less rate than that published and filed by such carriers, or whereby any other advantage is given or discrimination practised. And we find the word device disassociated from any such words as fraudulent conduct, scheme or contrivance, but the Act seeks to reach all means and methods by which the unlawful preference of rebate, concession or discrimination is offered, granted, given or received. Had it been the intention of Congress to limit the obtaining of such preferences to fraudulent schemes or devices, or to those operating only by dishonest, underhanded methods, it would have been easy to have so provided in words that would be unmistakable in their meaning. A device need not be necessarily fraudulent; the term includes anything which is a plan or contrivance. Webster defines it to be 'that which is devised or formed by design; a contrivance; an invention; a project,' etc. This Act is not only to be read in the light of the previous legislation, but the purpose which Congress evidently had in mind in the passage of the law is also to be considered.

"The Elkins Act proceeded upon broad lines and was evidently intended to effectuate the purpose of Congress to require that all shippers should be treated alike, and that the only rate charged to any shipper for the same service under the same conditions should be the one established, published and posted as required by law. It is not so much the particular form by which or the motive for which this purpose was accomplished, but the intention was to prohibit any and all means that might be resorted to to obtain or receive concessions and rebates from the fixed rates, duly posted and published." 
which the shipment passes. ${ }^{6}$ But where upon each of numerous shipments the full, legal, published rate was paid by the shipper and at intervals rebates thereon were received by him from the carrier each payment constitutes a separate and complete offense. The fact that the various payments were made under a single agreement does not make of them a single continuous offense.

What May Constitute Rebates.-A rebate, generally speaking, consists of any device whereby any property is transported in interstate or foreign commerce at a lesser rate than that lawfully filed and published. The original Act to Regulate Commerce as approved February 4, I887, expressly forbid discriminations and under that Act the standard of comparison was the treatment accorded other shippers. To successfully prosecute a violation of that provision it was necessary to show not only that the favored shipper really paid less than the published rate, but also that other shippers paid the full rate or a greater rate than that of the favored shipper. But under the Elkins Act the standard of comparison was made the published rate. Thereunder it is only necessary to prove that the favored shipper had paid a less rate for the transportation of his property than that filed and pub-

6 Armour Packing Co. v. United States, 209 U. S. 56, 52 L. Ed. 68I, 28 Sup. Ct. 428, supra.

7 New York Central and Hudson River Railroad v. United States, 212 U. S. 481, 53 I. Ed. 613, 29 Sup. Ct. 304. In this case several payments of rebates were made by the railroad to the shipper in accordance with an agreement to that effect. It was insisted that inasmuch as they all came under and were a part of a single agreement, they constituted but a single offense. The government contended that each payment constituted a separate offense under the law. The court said:- "It is insisted that if any criminal offense was committed at all it was a single and continuing one against the railroad company because of the agreement evidenced by the letters which preceded the transportation, and under the terms of which the shipnents were made. We cannot agree to this contention. The statute makes it an offense to give or receive a rebate whereby goods are transported in interstate commerce at less than the published rate; in the present case the jury found the railroad company guilty of rebating as charged. We are not dealing with a case where there was an agreement to carry the goods in the first place at a concession from the established rate, and wherein the railroad company never received the full legal rate. In this case, upon each of the numerous shipments, the full legal rate was paid, and upon claims being presented at short intervals the amount of the stipulated rebate was remitted by check to the shipper. We think the offense was complete when the railroad company thus paid the stipulated rebate to the shipper." 
lished. The vital question under the Elkins Act thus is not what another shipper paid for the same service, but whether the published and filed rate was actually paid for the shipment at issue. Naturally rebates may take varied forms depending in number upon the range of human ingenuity and indifference to law. For example a payment by a carrier to the shipper for the use of his railroad tracks no reference to such allowance being made in the published rate violates section $\mathrm{I}$ of the Elkins Act. ${ }^{8}$ Similarly an

8 Chicago and Alton Railway Co. v. United States, 2 I2 U. S. 563, 53 L. Ed. 653. 29 Sup. Ct. 689. wherein the Supreme Court by a divided court and without opinion affirmed the judgment of the lower court as reported in 156 Fed. 559, affirming the District Court in 148 Fed. 646. The carrier paid back to the shipper the sum of $\$$ I on each carload of product shipped from his packing house under the name of a rental for the use of the tracks, which were declared to constitute plant facilities, no reference to such an allowance being made in the published and filed rates. The District Court said:- "The real question here is simply this:-'Has the payment back to the shipper of \$I per car out of the money paid by the shipper to the railway company in the first instance resulted in the shipper getting its property transported at a less cost to it than that specified in the published schedules?' It would seem that to state this question is to answer it. The word 'rate' as used in the interstate commerce law, means the net cost to the shipper of the transportation of his property; that is to say, the net amount the carrier receives from the shipper and retains. In determining this net amount in a given case, all money transactions of every kind or character having a bearing on or relation to, that particular instance of transportation whereby the cost to the shipper is directly enhanced or reduced must be taken into consideration. $* * *$ With equal propriety (its schedules being silent on the subject) a carrier might, for the purpose of inducing the routing of traffic via its line, pay the consignors and consignees bills for the cartage of property between their warehouses and the railway depots. The object of the statutes relating to interstate commerce is to secure the transportation of persons and property by common carriers for reasonable compensation. No rate can possibly be reasonable that is higher than anybody else has to pay. Recognizing this obvious truth, the law requires the carrier to adhere to the published rate as an absolute standard of uniformity."

The following is from the opinion of the Circuit Court of Appeals:"This case is ruled in principle, we believe, by the decision in Wight $v$. United States, 167 U. S. 512, 42 L. Ed. 258, 17 Sup. Ct. 822, that an arrangement whereby a particular shipper was allowed to offset against his freight bills the true value of the use of his teams in hauling the property from the railroad to his warehouse was a discrimination against other shippers of the same class of property in the same city who were compelled to pay the freight in full. It is contended that the citation is inapplicable because the question there was of discrimination and here of re- 
agreement with the shipper to expedite a shipment at the regularly posted rates and to forward the shipment by a particular train where no rate has been published for such expedited and special service. The implied agreement is to carry safely and deliver at destination within a reasonable time. But by entering into an agreement for expediting the shipment, or to make a particular connection or to carry by a particular train, the company was making a more burdensome contract than that for which the rate publisherl and filed called and for such contract the company might exact a higher rate after first filing, publishing and posting it ; and on the other hand the shipper was contracting for a special advantage not extended to the general public, both as to the expedited service and the remedy for delay therein. ${ }^{9}$

bate. Under the Cullom Act (Act of Feb. 4, 1887, ) the standard of comparison was the treatment of other shippers. It was necessary to prove not only that the favored shipper really paid less than the published rate, but also that other shippers paid the full rate or a greater rate than that of the favored shipper. Under the Elkins Act the standard of comparison is the published rate. It is only necessary to prove that the favored shipper has had his property transported at a less rate than that published and filed. Both Acts were aimed to kill favoritism, and the favoritism in the Wight case was of the same kind and effect as this. * * * We exclude from the case, as not being within the issues, any question of the right of a railroad to render greater service or to furnish more facilities for one shipper than another for the same published charge. The issue here is the right to furnish the same or more at a less price."

9 Chicago and Alton Railroad Company v. Kirby, 225 U. S. 155, 56 L. Ed. 1033, 32 Sup. Ct. 648. The shipper having some horses for exhibition and sale at a fair arranged with the carrier for their transportation by an expedited service with special train connections, no rate being published and filed for such service. The court said :-"The implied agreement of a common carrier is to carry safely and deliver at destination within a reasonable time. It is otherwise when the action is for a breach of a contract to carry within a particular time, or to make a particular connection, or to carry by a particular train. The railroad company by its contract, became liable for the consequence of a failure to transport according to its terms. Evidence of diligence would not excuse. If the action had been for the common law carrier liability evidence that there had been no unreasonable delay would be an answer. But the company, by entering into an agreement for expediting the shipment, came under a liability different and more burdensome than would exist to a shipper who made no such special contract.

"For such a special service and higher responsibility it might clearly exact a higher rate. But to do so it must make and publish a rate open to all. This was not done. The shipper, it is also plain, was contracting for 
So also it is manifestly a violation of the Act for the carrier to pay back and for the shipper to receive back a portion of the amount paid under the published and filed rate for the shipment of goods as a result of which the shipper received the service at less than that demanded of other shippers as evidenced by the lawful rates. ${ }^{10}$ Or where in the first place the shipper pays and the carrier accepts less than the rate duly published and filed for such shipments. ${ }^{11}$ The following are examples of rebates or discrimination which have been declared illegal under the provisions of the Act to Regulate Commerce as construed by the Supreme Court. For more detailed reference thereto consult the discussion of sections 2 and 3 of that Act. A contract for annual passes for life in settlement of a claim for personal injuries resulting from a railroad collision $;^{12}$ the delivery of transportation in payment of advertising matter in magazines and newspapers for the

an advantage which was not extended to all others, both in the undertaking to carry so as to give him a particular expedited service, and a remedy for delay not due to negligence. An advantage accorded by special agreement which affects the value of the service to the shipper and its cost to the carrier should be published in the tariffs, and for a breach of such a contract, relief will be denied, because its allowance without such publication is a violation of the Act. It is also illegal because it is an undue advantage in that it is not one open to all others in the same situation.

"The broad purpose of the Commerce Act was to compel the establishment of reasonable rates and their uniform application. That purpose would be defeated if sanction be given to a special contract by which any such advantage is given to a particular shipper as that contracted for by the defendant in error. To guarantee a particular connection and transportation by a particular train was to give an advantage or preference not open to all and not provided for in the published tariffs. * * That the defendant in error did not see and did not know that the published rates and schedules made no provision for the service he contracted for, is no defense. For the purposes of the present question he is presumed to have known. The rates were published and accessible, and, however difficult to understand, he must be taken to have contracted for an advantage not open to others. Railway Co. v. Mugg, 202 U. S. 242, 50 L. Ed. 1011 , 26 Sup. Ct. 628." See M., K. \& T. Ry. v. Harriman, 227 U. S. 657, 57 L. Ed. 690, 33 Sup. Ct. 397.

10 New York Central Railroad Co. v. United States, 212 U. S. 48I, 53 L. Ed. 613, 29 Sup. Ct. 304, supra.

II Armour Packing Co. v. United States, 209 U. S. 56, 52 L. Ed. 681, 28 Sup. Ct. 428 , supra.

12 Louisville and Nashville Railroad Co. v. Mottley, 219 U. S. 467, 55 L. Ed. 297, 31 Sup. Ct. 265. 
carrier $;^{13}$ the payment for land purchased by the carrier by rebating to the owner a portion of the freight rate for interstate shipments over the road built on such land $;^{14}$ carriage of goods for less than the cost thereof in settlement of a claim for damages against the carrier $;^{15}$ payments to shippers owning tap lines in the nature of concessions or rebates under the cover of participation in joint rates $;^{16}$ agreement to build a plant for a shipper in return for the routing of his shipments over the line of the carrier thus contracting. ${ }^{17}$

Sufficiency of the Indictment.-Under the Elkins Act an indictment is sufficient and free from objection if it states the offense alleged with sufficient particularity to enable the defendant to make his defense, by advising him of the nature and cause of the accusation against him, and to avail himself of the record of conviction or acquittal for his protection against further prosecutions for the same transgressions, and to inform the court of the facts charged. It is not sufficient to charge the offense in generic terms but it must state the particulars. Each and every element of the offense as to time, place and circumstances, must be set forth and the defendant must be distinctly advised of the issues to be met at the trial. Under this statute it is not necessary to allege intent since that is not an element of the offense thereunder. ${ }^{18}$ In the words of the Supreme Court, "There is a class

13 Chicago, Indianapolis \& Louisville Railway Co. v. United States, 219 U. S. 486, 55 L. Ed. 305, 31 Sup. Ct. 272.

I4 Fourche River Co. v. Bryant Lumber Co., 230 U. S. 316, 57 L. Ed. I 498, 33 Sup. Ct. 887.

15 New York, New Haven \& Hartford Railroad Co. v. Interstate Commerce Commission, 200 U. S. 36r, 50 L. Ed. 515, 26 Sup. Ct. 272.

16 United States v. Louisiana and Pacific Railway Co., (Tap Line Cases), 234 U. S. I. 58 L. Ed. 1185,34 Sup. Ct. 741 ; United States v. Butler County Railroad Co., (Tap Line Cases), 234 U. S. 29, 58 L. Ed. I 196, 34 Sup. Ct. 748.

I7 United States v. Union Stock Yards and Transit Co. of Chicago, 226 U. S. 286,57 L. Ed. 226, 33 Sup. Ct. 83.

18 Armour Packing Co. v. United States, 209 U. S. 56. 52 L. Ed. 681, 28 Sup. Ct. 428 , supra. Here the court said:- "It is alleged that the indictment is insufficient, in that it fails to set out the kind of device by which traffic was obtained, and of what the concession consisted, and how it was granted. Authorities are cited to the proposition that in statutory offenses every element must be distinctly charged and alleged. This court has frequently had occasion to hold that the accused is entitled to know the nature and cause of the accusation against him, and that a charge must 
of cases, within which we think the one under consideration falls, where purposely doing a thing prohibited by statute may amount to an offense although the act does not involve turpitude or moral

be sufficiently definite to enable him to make his defense and avail himself of the record of conviction or acquittal for his protection against further prosecutions and to inform the court of the facts charged, so that it may decide as to their sufficiency in law to support a conviction, if one be had, and the elements of the offense must be set forth in the indictment with reasonable particularity of time, place and circumstances. And it is true it is not always sufficient to charge statutory offenses in the language of the statutes, and where the offense includes generic terms it is not sufficient that the indictment charges the offense in the same generic terms, but it must state the particulars. United States v. Hess, I24 U. S. 483 , 3I L. Ed. 516,8 Sup. Ct. 571 ; Evans v. United States, I53 U. S. 584,38 L. Ed. 830 , I4 Sup. Ct. 934, 939. But an indictment which distinctly and clearly charges each and every element of the offense intended to be charged, and distinctly advises the defendant of what he is to meet at the trial, is sufficient.

"As we interpret this law, it is intended, among other things, to prohibit and punish the receiving of a concession for the transportation of goods from the duly filed and published rate. Each and all of the elements of the offense, with allegations of time, place, kind of goods and name of carrier, are distinctly charged in the indictment, and include the fixing of the published rate at 23 cents per 100 pounds; the changing of the rate and the new publication at 35 cents per 100 pounds; the knowledge of this change on the part of the shipper, and the carriage of the goods over a described route at a concession of the difference between the published and the contract rate-all these facts being stated, the indictment is clearly sufficient. Whether it was necessary to charge actual knowledge of the change of rate on the shipper's part is a question not involved in this case, as the indictment charges such knowledge, and the facts stipulated show that the shipper knew of the establishing of the new rate when the goods described in the indictment were shipped.

"It is again contended that the submission in the trial court of the question of whether there was a device to avoid the operation of the act and to obtain the transportation at the less rate, was prejudicial to the petitioners, as such issue was not within the agreed facts upon which the case was tried. It is true, as we have held in another part of this opinion, that no device or contrivance, secret or fraudulent in its nature, is requisite to the commission of the offense outlined in the statute, and that any means by which transportation by a concession from the established rate was had is sufficient to work a conviction. Hence this charge was not prejudicial to the petitioner.

"It is contended by the petitioner, that there is nothing in the facts found in this case to show any intentional violation of the law; that on the contrary the petitioner believed itself to be within its legal rights in insisting upon the performance of its contract, and maintained in good 
wrong." Prosecutions under the Elkins Act are governed by section 1045 of the Revised Statutes, as amended in 1876 , limiting prosecutions to three years in the case of misdemeanors.

Effect of Hepburn Act on Prosecutions under Elkins Law.The provision of section 10 of the Hepburn law repealing all laws and parts of laws in conflict with the provisions of that Act, with the provision that the amendments therein provided should not affect causes then pending in the courts of the United States but that such cases should be prosecuted to a conclusion in the manner theretofore provided by law, did not deprive the government of the right to prosecute for violations of the Elkins law committed prior to the enactment of the Hepburn Act. ${ }^{10}$ Under this

faith that the Interstate Commerce Act did not and could not interfere with it and that the statute had no application to a shipment of goods for exportation in the manner shown in this case. While intent is in a certain sense essential to the commission of a crime, and in some classes of cases it is necessary to show moral turpitude in order to make out a crime there is a class of cases within which we think the one under consideration falls, where purposely doing a thing prohibited by statute may amount to an offense although the act does not involve turpitude or moral wrong. In this case the statutes provide that it shall be penal to receive transportation of goods at less than the published rate. Whether shippers who pay a rate under the honest belief that it is the lawfully established rate, when in fact it is not, are liable under the statute because of a duty resting on them to inform themselves as to the existence of the elements essential to establish a rate as required by law, is a question not decided because not arising on this record. The stipulated facts show that the shippers had knowledge of the rates published and shipped the goods under a contention of their legal right so to do. This was all the knowledge or guilty intent that the act required. I Bish. Cr. Law, 5th ed., sec. 343. A mistake of law as to the right to ship under the contract after the change of rate is unavailing upon well-settled principles. Reynolds v. United States, 98 U. S. 145,25 L. Ed. 244."

See also New York Central and Hudson River Railroad Co. v. United States, 212 U. S. 48 I, 53 L. Ed. 613, 29 Sup. Ct. 304.

19 Great Northern Railway Co. v. United States, 208 U. S. 452, 52 L. Ed. 567,28 Sup. Ct. 3 I3. The court here construed the provision in question in the Hepburn law as follows:- "The provision commanding that the new remedies should not be applicable to causes then pending in the courts of the United States gives significance to the whole clause and serves to make clear the fact that the legislative mind was concerned with the confusion and uncertainty which might be begotten from applying the new remedies to causes then pending in the courts, and demonstrates therefore that this subject, and this subject alone, was the matter with which the provision in question was intended to deal. In other words, when the ob- 
section cases then pending in the courts should be prosecuted under the prior remedies, with the new remedies to be applied to other prosecutions. This provision was solely addressed to the remedies to be applied in the future conduct of the cases then pending in the courts. Nor did the Hepburn law exclude the right of the government to prosecute for past offenses not then pending because pending cases were enumerated in and saved by section Io of that law.

The payment of a rebate after the enactment of the Elkins law, though in pursuance of an agreement made prior thereto and though growing out of a shipment also made prior thereto is covered by the Act and may be prosecuted thereunder. ${ }^{20}$

ject contemplated by the provision is accurately fixed the subject is freed from difficulty, and not only the letter but the spirit of the provision becomes clear; that is to say, it but manifests the purpose of Congress to leave cases pending in the courts to be prosecuted under the prior remedies, thus causing the new remedies created to be applicable to all controversies not at the time of the passage of the Act pending in the courts. And all the arguments relied upon to sustain the theory that the power to prosecute for past offenses not then pending in the courts was abrogated by the Hepburn law rest in substance upon the disregard of the true significance of the provision of section 10. Thus the argument that by the application of the elementary rule by which the inclusion of one must be considered as the exclusion of the other, it follows that the power to further prosecute all but cases then pending in the courts was destroyed by the Hepburn law; because pending causes are enumerated in section 10, and are hence not saved by R. S., sec. 13, simply assumes that the provision of section Io was intended to save the right to further prosecute the cases then pending in the courts, and disregards the fact that the provision as to pending causes was solely addressed to the remedies to be applied in the future carrying on of such cases. Again, the contention that unless the provision as to pending causes in section to be construed as relating to the further right to prosecute such cases it becomes meaningless, but overlooks the fact that the purpose of the provision was, by express enactment, to prevent the application of the new remedies to the causes then pending in the courts of the United States, a result which would not necessarily have followed without the direction in question."

20 New York Central and Hudson River Railroad Co. v. United States, 212 U. S. 500, 53 L. Ed. 624, 29 Sup. Ct. 309. In this case the agreement in question was made July 24,1902 , and the goods were actually transported before the Elkins Act went into effect. The payment of the rebate was made on April 2, 1903, after the Act went into effect. The court said:- "Before considering the terms of the Elkins Act it is to be noted that the arrangement for the rebate was an illegal act, for which the agents of the carrier might have been criminally punished in accordance 
with the terms of the Interstate Commerce Act then in force. Sections 6 and 10, 25 Stat. 855 . The Elkins Act amended the former law by providing punishment in criminal proceedings against the corporation as well as its agents for the offense of making illegal rebates from the published tariff rates. There was then no vested right in the shipper or the carrier to have the illegal agreement consumated by the payment of the rebate arranged for. In this attitude and with the purpose of making the law more effectual it was amended by the Elkins Act so as to bring corporations within the provisions of the law and to make offenses under it punishable by criminal proceedings against corporations.

"Manifestly the Act does not refer alone to the transportation of the property although that is an essential element of the offense, but the thing aimed at is the giving or receiving of a rebate whereby the property shall be transported at less than the rates named in the published tariffs. It is the transaction of giving or receiving the rebate, etc., with the effect that the goods of the shipper thus preferred shall be transported at a reduction from the published rates which is penalized. As we have had occasion to say in No. 57, ante, the giving of the rebate is complete and the offense committed when a part of the legal rate already paid has been refunded. The word shall refers to the happening of the event-the giving of the illegal rebate-and was not introduced into the statute for the purpose of making future transportation illegal. No new legislation was required to make transportation under such an agreement illegal. The object of the statute was to punish rebates given or received after the passage of the Act in respect of property, the subject of interstate transportation, and to make the carrier corporation criminally liable therefor." 


\section{APPENDIX.}

Rules of Practise Before the Commission.

Forms. 



\title{
RULES OF PRACTISE
}

BEFORE THE

\author{
COMMISSION \\ IN CASES AND PROCEEDINGS \\ UNDER THE ACT TO REGULATE \\ COMNERCE
}

I.

Public Sessions.

Sessions of the Commission for hearing contested cases, including oral arguments, will be held as ordered by the Commission.

The office of the Conmission at Washington, D. C., is open each business day from 9 a. m. to $4: 30$ p. m.

II.

\section{Parties to Cases.}

Any person, firm, company corporation, or association, mercantile, agricultural, or manufacturing society, body politic or municipal organization, or any common carrier, or the railroad commissioner or commission of any State or Territory, may complain to the Commission of anything done, or omitted to be done, in violation of the provisions of the Act to Regulate Commerce by any common carrier subject to the provisions of said Act. If a complaint relates to matters in which two or more carriers, engaged in transportation by continuous carriage or shipment, are interested, the several carriers participating in such carriage or shipment are necessary parties defendant.

If a complaint relates to rates, regulations, or practises of car- 
riers operating different lines, and the object of the proceeding is to sccure correction of such rates, regulations, or practises on each of said lines, all the carriers operating such lines should be made defendants.

If a complaint relates to provisions of a classification it will ordinarily be sufficient to name as defendants the principal carriers named as parties to the classification.

If the line of a carrier is operated by a receiver or trustee, both the carrier and its receiver or trustee must be made defendants in cases involving transportation over such line.

Any person may petition in any proceeding for leave to intervene prior to or at the time of the hearing and not after. Such petition shall set forth the petitioner's interest in the proceedings, but intervention will not be permitted, except upon allegations that are reasonably pertinent to the issues of the original complaint. Leave granted on such petition will entitle such interveners to have notice of hearings, to produce and cross-examine witnesses, and to be heard in person or by counsel upon brief and at the oral argument.

III.

\section{Complaints.}

Complaints nust be in typewriting on one side of the paper only, on paper not more than $8 \mathrm{r} / 2$ inches wide and not more than 12 inches long, and weighing not less than 6 pounds to the ream, folio base, I 7 by 22 inches, with left hand margin not less than I $1 / 2$ inches wide, setting forth briefly the facts claimed to constitute a violation of the law. Complaints may also be printed in the size designated in Rule XIV regarding briefs. The corporate name of the carrier or carriers complained against must be stated in full without abbreviations, and the address of the complainant, with the name and address of his attorney or counsel, if any, must appear upon each copy of the complaint. The complaint need not be verified, but must be signed in ink by the complainant or his duly authorized attorney. The complainant must furnish as many complete copies of the complaint as there may be parties complained against to be served, including receiver or receivers, and three additional copies for the use of the Commission.

The Commission will serve the complaint upon each defendant by leaving a copy with its agent in the District of Columbia, or, 
if no such agent has been designated, by posting a copy in the office of the secretary of the Commission.

Two or more complaints involving the same principle, subject, or state of facts may be included in one complaint. The several rates, regulations, discriminations, and shipments involved should be separately set out. One or more persons may join in one complaint against one or more carriers if the subject matter of the complaint involves substantially the same principle, subject, or state of facts.

Except under unusual circumstances and for good cause shown, reparation will not be awarded unless specifically prayed for in the complaint or in an amendment thereto filed before the submission of the case.

After a final order has been entered upon a complaint in which reparation is not sought or, if prayed, has been denied, the Commission will not ordinarily award reparation upon a complaint subsequently filed and based upon any finding upon the first complaint.

Where reparation is demanded under a general rate adjustment challenged in the complaint, or upon many shipments under a particular rate, or where many points of origin or destination are involved, it is the practise of the Commission first to determine and make a formal announcement respecting the reasonableness of the rate or rates in issue, and whether the facts justify an award of reparation, giving to the parties thereafter an opportunity to make proof respecting the shipments upon which reparation is claimed. Fireight bills and other exhibits must therefore be reserved until such further hearing and must not be filed with the complaint. In such cases the complaint, without unnecessary details, should disclose in general terms the basis and extent of the damages demanded in such manner as reasonably to advise the defendants thereof.

When a claim for reparation has been before the Commission informally and the parties have been notified by the Commission that the claim is of such a nature that it can not be determined informally, formal complaint must be filed within six months after such notification, or the parties will be deemed to have abandoned their claim: Prozided, however, That this rule does not apply to formal complaints for reparation filed within two years from the date of the delivery of the shipments. 
IV.

\section{Answers.}

One copy of each answer must, unless the Commission orders otherwise, be filed with the secretary of the Commission at his office in Washington, D. C., within 30 days after the day of service of the complaint by defendants whose general offices are at or west of El Paso, Tex., Salt Lake City, Ltah, or Spokane, IVash., and within 20 days by all other defendants, and a copy of each such answer must be at the same time served personally or by mail upon the complainant or his attorney. The Commission will, when advisable, shorten or extend the time for answer. If a defendant satisfies a complaint before answering, a written acknowledgment thereof, showing the character and extent of the satisfaction given, must be filed by the complainant. In such case a statement of the fact and manner of satisfaction without other matter may be filed as answer. If the complaint is satisfied after the filing and service of answer, a written acknowledgment thereof must be filed by the complainant and a supplemental answer setting forth the fact and manner of satisfaction must be filed by the defendant. Answers in typewriting must be on one side of the paper only, on paper not more than $81 / 2$ inches wide and not more than 2 inches long and weighing not less than 16 pounds to the rean, folio base, 17 by 22 inches, with left-hand margin not less than $I / 2$ inches wide, or may be printed in the size designated in Rule XIV regarding briefs.

\section{V.}

\section{Motion to Dismiss.}

A defendant who deems the complaint insufficient to show a breach of legal duty may, instead of answering or formally demurring, serve on the complainant notice of hearing on the complaint; and in such case the facts stated in the complaint will be deemed admitted. A copy of the notice must at the same time be filed with the secretary of the Commission. The filing of an answer, however, will not be deemed an admission of the sufficiency of the complaint, but a motion to dismiss for insufficiency may be made at the hearing. 
VI.

\section{Service of Papers.}

Copies of notices or papers, other than complaints, presented by a party must be served upon the adverse party or parties personally or by mail. When any party has appeared by attorney, service upon such attorney will be deemed proper service upon the party.

\section{VII.}

\section{Amendments.}

Amendments to any complaint or answer in any proceeding or investigation will be allowed by the Commission at its discretion.

VIII.

\section{Continuances and Extensions of Time.}

Continuances and extensions of time will be granted at the discretion of the Commission.

\section{IX.}

\section{Stipulations.}

Parties to any proceeding may, by stipulation in writing filed with the secretary, agree upon the facts, or any portion thereof, involved therein. It is desired that the facts be thus agreed upon whenever practicable.

$\mathrm{X}$.

\section{Hearings.}

Upon issue being joined by service of answer or by notice of hearing on the complaint, or by failure of defendant to answer, the Commission will assign a time and place for hearing. Witnesses will be examined orally before the Commission or one of its examiners, unless their testimony be taken by deposition or the facts be agreed upon as provided for in these rules.

XI.

\section{Depositions.}

The deposition of a witness for use in a case pending before the Commission may, after such case is at issue, be taken upon compliance with the following rules of procedure, which are pre- 
scribed by the Commission under authority conferred upon it by section 17 of the Act, but not otherwise.

Such depositions may be taken before a special agent or examiner of the Conmission, or any judge or commissioner of any court of the L'nited States, or any clerk of a District Court, or any chancellor, justice, or judge of a Supreme or Superior Court. mayor or chief magistrate of a city, judge of a county court or Court of Common Pleas of any of the United States, or any notary public, not being of counsel or attorney to either of the parties, nor interested in the event of the proceeding or investigation, according to such designation as the Commission may make in any order made by it in the premises. except that where such deposition is taken in a foreign country it may be taken before an officer or person designated by the Commission or agreed upon by the parties by stipulation in writing to be filed with the Commission.

Any party desiring to take the deposition of a witness in such a case shall notify the Commission to that effect, and in such notice shall state the time when, the place where, and the name and postoffice address of the party before whom it is desired the deposition be taken, the name and post-office address of the witness, and the subject matter or matters concerning which the witness is expected to testify, whereupon the Commission will make and serve upon the parties or their attorneys an order wherein the Commission shall name the witness whose deposition is to be taken and specify the time when, the place where, and the party before whom the witness is to testify, but such time and place, and the party before whom the deposition is to be taken. so specified in the Commission's order, may or may not be the same as those named in said notice to the Commission.

Every person whose deposition is so taken shall be cautioned and take oath (or affirm) to testify the whole truth and nothing but the truth concerning the matter about which he shall testify. and shall be carefully examined. His testimony shall be reduced to typewriting by the officer before whom the deposition is taken, or under his direction, after which the deposition shall be subscribed by the witness and certified in usual form by the officer. After the deposition has been so subscribed and certified it shall, together with two copies thereof made by such officer or under his direction, be forwarded by such officer under seal in an envelope addressed to the Commission at its office in Washington, D. C. Upon receipt of the deposition and copies the Commission will 
file in the record in said case such deposition and forward one copy to the complainant or his attorney, and the other copy to the defendant or its attorney, except that where there is more than one complainant or defendant the copies will be forwarded by the Commission to the parties designated by such complainants or de. fendants as the case may be.

Such depositions shall be typewritten on one side only of the paper, which shall be not more than $81 / 2$ inches wide and not more than 2 inches long and weighing not less than 16 pounds to the ream, folio base $I 7$ by 22 inches, with left-hand margin not less than $I \frac{1}{2}$ inches wide.

No deposition shall be taken except after 6 days' notice to the parties, and where the deposition is taken in a foreign country such notice shall be at least I $_{5}$ days.

No such deposition shall be taken either before the case is at issue or, unless under special circumstance and for good cause shown, within Io days prior to the date of the hearing thereof assigned by the Commission, and where the deposition is taken in a foreign country it shall not be taken after 30 days prior to such date of hearing.

Witnesses whose depositions are taken pursuant to these rules and the magistrate or the officer taking the same, unless he be an examiner of the Commission, shall severally be entitled to the same fees as are paid for like service in the courts of the United States, which fees shall be paid by the party or parties at whose instance the depositions are taken.

\section{XII.}

\section{Witnesses and Subpœnas.}

Subpœnas requiring the attendance of witnesses from any place in the United States to any designated place of hearing may be issued by any member of the Commission.

Subpœenas for the production of books, papers, or documents (unless directed to issue by the Commission upon its own motion) will issue only upon application in writing. Applications to compel witnesses not parties to the proceeding to produce documentary evidence must be verified and must specify, as near as may be, the books, papers, or documents desired and the facts to be proven by them. Applications to compel a party to the proceeding to produce books, papers, or documents need only set forth in a general way the books, papers, or documents sought, with a 
statement that the applicant believes they will be of service in the determination of the case.

Witnesses whose testimony is taken orally are severally entitled to the same fees as are paid for like services in the courts of the United States, such fees to be paid by the party at whose instance the testimony is taken.

\section{XIII. \\ Documentary Evidence.}

Where relevant and material matter offered in evidence is embraced in a document containing other matter not material or relevant and not intended to be put in evidence, such document will not be filed, but the party offering the same shall also present to opposing counsel and to the Commission in proper form for filing copies of such material and relevant matter, and that only shall be filed.

In case any portion of a tariff, report, circular, or other document on file with the Commission is offered in evidence, the party offering the same must give specific reference to the items or pages and lines thereof to be considered. In case any testimony in other proceedings than the one on hearing is introduced in evidence, a copy of such testimony must be presented as an exhibit. When exhibits of a documentary character are offered in evidence, two copies should be furnished at the hearing for the use of the Commission and a copy for each of the principal parties represented.

\section{XIV.}

\section{Briefs.}

Unless otherwise specifically ordered, briefs may be filed upon application made at hearings or upon order of the Commission. Briefs shall be printed and contain an abstract of the evidence relied upon by the parties filing the same; and in such abstract reference shall be made to the pages of the record wherein the evidence appears. The abstract of evidence should follow the statement of the case and precede the argument. Every brief of more than Io pages shall contain on its front fly leaves a subject index with page references, the subject index to be supplemented by a list of all cases referred to alphabetically arranged, together with references to pages where the cases are cited. Briefs must be printed in Io or I 2 point type, on good unglazed paper, $5 \% 8$ inches 
wide by 9 inches long, with inside margins not less than I inch wide, and with double-leaded text and single-leaded citations.

At the close of the testimony in each case the presiding commissioner or examiner will fix the time for filing and service of the respective briefs, as follows, unless good cause for variation therefrom is shown: To the complainant, 30 days from date of conclusion of the testimony; to the defendants and interveners, I5 days after the date fixed for the complainant; and to complainant for reply brief, io days after the date fixed for defendants or interveners. Briefs not filed and served on or before the dates fixed therefor will not be received unless a special order therefor is made by the Commission. All briefs must be filed with the secretary and be accompanied by notice, showing service upon the adverse parties, and 15 copies of each brief shall be furnished for the use of the Commission, unless otherwise ordered. Applications for extension of time in which to file briefs shall be by petition, in writing, stating the facts on which the application rests, which must be filed with the Commission at least five days before the time for filing such brief.

Oral argument will be had only as ordered by the Commission. Applications therefor must be made at the hearing or in writing within ro davs after the completion of proof.

XV.

\section{Rehearings.}

Applications for reopening a case after final submission, or for rehearing after decision, must be by petition stating specifically the grounds relied upon; such petition must be served by the party filing same upon the opposing counsel who appeared at the hearing or on brief.

If such application be to reopen the case for further evidence, the nature and purpose of such evidence must be briefly stated, and the same must not be merely cumulative. If the application be for a rehearing, the petition must specify the matters claimed to be erroneously decided, with a brief statement of the alleged errors. If any order of the Commission is sought to be reversed, changed, or modified on account of facts and circumstances arising subsequent to the hearing, or of consequences resulting from compliance therewith, the matters relied upon by the applicant must be fully set forth. At least ro copies of all such applications must be filed. 
XVI.

\section{Transcripts of Testimony.}

One copy of the testimony will be furnished by the Commission for the use of the complainant and one copy for the use of the defendant, without charge. If two or more complainants or defendants have appeared at the hearing, such complainants or defendants must designate to whom the copy for their use shall be delivered.

In proceedings instituted by the Commission on its own motion, including proceedings involving the suspension of tariffs, no free copies of testimony will be furnished.

\section{XVII}

\section{Compliance With Orders.}

An order having been issued, the defendant or defendants named therein must promptly notify the secretary of the Commission on or before the date upon which such order becomes effective, whether or not compliance has been made therewith. If a change in rates is required, the notification to the secretary must be given in addition to the filing of proper tariffs.

\section{XVIII.}

\section{Applications Under Fourth Section.}

Any common carrier may apply to the Commission, under the proviso clause of the fourth section, for authority to charge for the transportation of like kind of property less for a longer than for a shorter distance over the same line, in the same direction, the shorter being included within the longer distance, or for authority to charge more as a through rate than the aggregate of the intermediate rates subject to the Act. Such application shall be by petition, which shall specify the places and traffic involved, the rates charged on such traffic for the shorter and longer distances, the carriers other than the petitioner which may be interested in the traffic, the character of the hardship claimed to exist, and the extent of the relief sought by the petitioner. Upon the filing of such a petition, the Commission will take such action as the circumstances of the case require. 
XIX.

\section{Suspensions.}

Suspensions of rates under section $5_{5}$ of the Act to Regulate Commerce will not ordinarily be made unless request in writing therefore is made at least Io days before the time fixed in the tariff for such rates to take effect. Requests for suspension must indicate the schedule affected by its I. C. C. number and give specific reference to the parts thereof complained against, together with a statement of the grounds thereof.

XX.

\section{Information to Parties.}

The secretary of the Commission will, upon request, advise any party as to the form of complaint, answer, or other paper necessary to be filed in the case.

XXI.

Address of the Commission.

All communications to the Commission must be addressed to Washington, D. C., unless otherwise specifically directed.

\section{FORMS.}

These forms may be used in cases to which they are applicable, with such alterations as the circunstances may render necessary.

No. I.

\section{Complaint.}

BEFORE, THF, INTERSTATE, COMMERCE, COMMISSION.

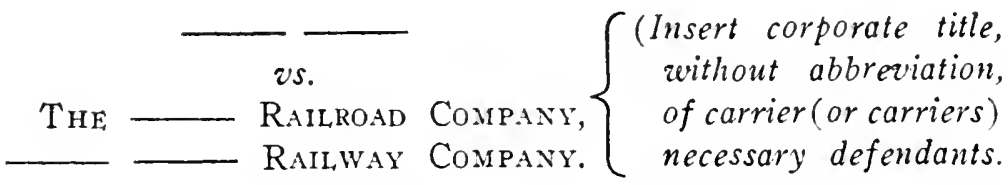

The complaint of the above-named complainant respectfully shows:

I. That (complainant should here state occupation and place of business, also whether it is a corporation, firm, or partnership, and 
if a firm or partnership, the indicidual name's of the purties composing the same should be yizen.)

II. That the defendant (defendants) above named is a common carrier (are common carriers) engaged in the transportation of passengers and property, wholly ly railroad (partly by railroad and partly by water), between points in the State of - and points in the State of - and as such common carrier (carriers) is (are) subject to the provisions of the Act to Regulate Commerce approved February 4, 1887, and Acts amendatory thereof or supplementary thereto.

III. That (state in this and subsequent paragraphs, to be numbered numerically, the matter or matters intended to be complained of, naming ea'ery rate, rule, regulation, or practise whose laa'fulness is challenged. and also each point of origin and point of destination betrieen which the rates complained of are applied.)

(Following this a paragraph or paragraphs should be inserted alleging that by reason of the facts stated in the foregoing paragraphs complainant (complainants) has (har'e) been subjected to the payment of rates of transportation ahich aiere ahen exacted, and still are, unjust and unreasonable in itolation of section I of the Act to Regulate Commerce, or unduly discriminatory in arolation of sections 2, 3, or thereof.)

Wherefore complainant prays that defendants may be severally required to answer the charges herein; that after due hearing and investigation an order be made commanding said defendants and each of them to cease and desist from the aforesaid violation of said Act to Regulate Commerce, and establish and put in force and apply as marima in future to the transportation of between the shipping and destination points named in paragraph - hereof, in lieu of the rates named in said paragraph, such other rates as the Commission may deem reasonable and just (and also pay to complainants by way of reparation for the unlawful charges hereinbefore described the sum of - - , or such other sum as, in view of the evidence to be adduced herein, the Commission may consider complainant entitled to), and that such other and further order or orders be made as the Commission may consider proper in the premises and complainant's cause may appear to require.

Date at $\longrightarrow$, $19-$ 
No. 2.

\section{Answer.}

BEFORE TIIE INTERSTATE COMMERCE COMMISSION.

THE US.

The above-named defendant, for answer to the complaint in this proceeding, respectfully states:

I. (Here follow the usual admissions, denials, and averments, answering the complaint paragraph by paragraph.)

Wherefore the defendant prays that the complaint in this proceeding be dismissed.

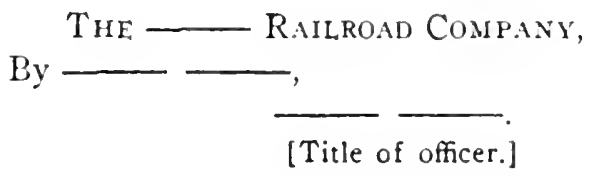

No. 3 .

Notice by Carrier Under Rule V.

INTERSTATE, COMMERCE COM MISSION.

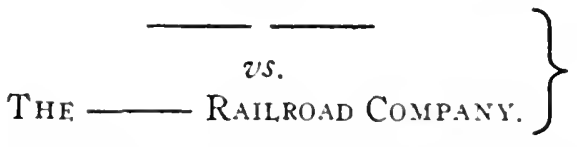

Notice is hereby given under Rule $V$ of the Rules of Practise in proceedings before the Commission that a hearing is desired in this proceeding upon the facts as stated in the complaint.

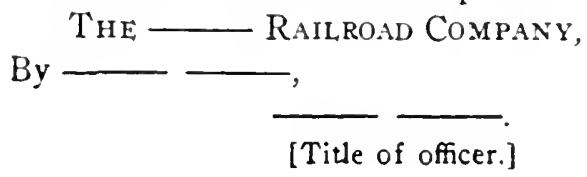





\section{TABLE OF CASES CITED}

(The figures refer to pages.)

A.

Abilene Cotton Oil Co. v. Texas \& Pacific Ry. Co. (204 U. S. 426, 5 I L. Ed. 553, 27 Sup. Ct. 350), 415.

Adams Express Co. v. Croninger (226 U. S. 491, 57 L. Ed. 314, 33 Sup. Ct. I48), 95, 470, 475, 483.

Adams Express Co. v. United States (212 U. S. 522, 53 L. Ed. 635, 29 Sup. Ct. 315), 153.

Allen v. St. Louis, Iron Mountain \& Southern Ry. Co. (230 U. S. 553, 57 L. Ed. I625. 33 Sup. Ct. 1030), I37.

American Express Co. $v$. United States (212 U. S. 522, 53 L. Ed. 635, 29 Sup. Ct. 315), 95, I54, 281, 499.

American Steel \& Wire Co. v. Speed (r92 U. S. 500, 48 L. Ed. 538, 24 Sup. Ct. 365), 87 .

Anadarko Cotton Oil Co. v. Atchison, Topeka \& Santa Fe Ry. (20 I. C. C. 43), 416 .

Anderson v. Dunn (6 Wheat. 204, 5 L. Ed. 242), 352.

Armour Packing Co. v. United States (209 U. S. 56, 52 L. Ed. 68r, 28 Sup. Ct. 428), 60. I53, 197, 5II, 5I4. 5I7, 520, 522, 525, 526.

Asbell v. Kansas (209 U. S. 251, 52 L. Ed. 778, 28 Sup. Ct. 485), 25.

Atchison, Topeka \& Santa Fe Ry. Co. v. Moore (232 U. S. 182, 58 L. Ed. 906, 34 Sup. Ct. 558), 279, 472, 483.

Atchison, Topeka \& Santa Fe Ry. Co. v. Robinson (233 U. S. 173, 58 L. Ed. 901, 34 Sup. Ct. 556), 279, 472, 482.

Atchison, Topeka \& Santa Fe Ry. Co. v. United States (The Pre-Icing Case, (232 U. S. I99. 58 L. Ed. 568, 34 Sup. Ct. 29r), 124, 298, 397.

Athanasaw $r$. United States (227 U. S. 326, 57 L. Ed. 528, 33 Sup. Ct. 285). 56.

Atlantic \& Pacific Telegraph Co. v. Philadelphia (I90 U. S. I60, 47 L. Ed. 995, 23 Sup. Ct. 817), 31.

Atlantic Coast Line R. R. Co. $r$. North Carolina Commission (206 U. S. I. 5I L. Ed. 933, 27 Sup. Ct. 585), 23. I36, I72, 422.

Atlantic Coast Line R. R. Co. v. Riverside Mills (219 U. S. 186, 55 L. Ed. 167, 3I Sup. Ct. I64), 92, 3I3, 315, 424, 462, 468, 469, 47 I, 473, 489.

Atlantic Coast Line v. Wharton (207 U. S. 328, 52 L. Ed. 230, 28 Sup. Ct. I 2 I), 23.

Attorney General v. Great Northern Ry. Co. (29 Law Journal [N. S. Eq.] 794). I6I.

Austin v. Tennessee (I79 U. S. 343, 45 L. Ed. 225, 21 Sup. Ct. 132), 25. 
(The figures refer to pages.)

B.

Bacon v. Illinois (227 U. S. 504, 57 L. Ed. 615, 33 Sup. Ct. 299), 87.

Baer Bros. Mercantile Co. v. Denver \& Rio Grande R. R. Co. (233 U. S.

479, 58 L. Ed. 1055, 34 Sup. Ct. 641), 79, 364, 400, 409, 415.

The Daniel Ball (10 Wall. 557, i9 L. Ed. 999), 68.

Baltimore \& Ohio R. R. Co. v. Interstate Commerce Commission (22I

U. S. 612, 55 L. E.d. 878, 31 Sup. Ct. 621), I4, 55, 69.

Baltimore \& Ohio R. R. Co. v. Pitcairn Coal Co. (The Pitcairn Coal Case)

(215 U. S. 481,54 L. Ed. 292, 30 Sup. Ct. 164), 220, 323, 327, 388, 397, 404, $408,426,502$.

Baltimore \& Ohio Southwestern R. R. Co. v. United States (220 U. S. 94. 55 I. Ed. 384, 3I Sup. Ct. 368), 55.

Barrett v. New York City (232 U. S. I4, 58 L. Ed. 483, 34 Sup. Ct. 203), 94. Behlmer v. Louisville \& Nashville R. R. Co. (7 I Fed. 835), 230, 233.

Bennett v. United States (227 U. S. 333, 57 L. Ed. 531, 33 Sup. Ct. 288), 56. Berea College v. Kentucky (2II U. S. 45. 53 L. Ed. 81, 29 Sup. Ct. 33), 5 I8. Bernard $v$. Adams Express Co. (205 Mass. 254. 91 N. E. 325, 18 Ann. Cas.

351, 28 L. R. A. [N. S.] 293), 477.

Berwind-White Coal Mining Co.v. Chicago \& Eric R. R. Co. (235 U. S. 371,59 L. Ed. - ), 284.

Bitterman v. Louisville \& Nashville R. R. Co. (207 U. S. 205, 52 L. Ed. I 7 I, 28 Sup. Ct. 91), 497.

Boering v. Chesapeake Beach Ry. Co. (193 U. S. 442, 48 L. Ed. 742, 24 Sup. Ct. 515), 158.

Boise City Irrigation \& Land Co. v. Clark (131 Fed. 415), 401.

Boston \& Maine R. R. Co. v. Hooker (233 U. S. 97, 58 L. Ed. 868, 34 Sup.

Ct. 526), 296, 472, 486, 487 .

Bowman v. Chicago \& Northwestern Ry. Co. (I25 U. S. 465, 3I L. Ed. 700, 8 Sup. Ct. 689), 16, 30.

Brinkmeier v. Missouri Pacific Ry. Co. (224 U. S. 268, 56 L. Ed. 758, 32 Sup. Ct. 412), 55 .

Brown v. Houston (II4 U. S. 622, 29 L. Ed. 257, 5 Sup. Ct. 109I), 16, 86. Brown v. Maryland (12 Wheat. 419, 6 L. Ed. 678), 30, 51.

Brown v. Walker (16I U. S. 59I, 40 L. Ed. 819, I6 Sup. Ct. 644), 346. Budd v. New York (143 U. S. 517, 36 L. Ed. 247, 12 Sup. Ct. 468), 38. Buttifeld v. Stranahan ( 192 U. S. 470, 48 L. Ed. 252, 24 Sup. Ct. 349), 254 , 450.

C.

Calderon v. Steamship Co. (170 U. S. 272, 42 L. Ed. 1033, 18 Sup. Ct. $588), 476$.

Cardwell v. Bridge Co. (II3 U. S. 205, 28 L. Ed. 959, 5 Sup. Ct. 423), 24. Central Coal Co. v. Hartman (i I Fed. 96), 310.

Central Stock Yards Co. v. Louisville \& Nashville R. R. Co. (I92 U. S. 568, 48 L. Ed. 565, 24 Sup. Ct. 339), 173, 225, 316.

Central Vermont R. R. Co. v. Soper (59 Fed. 879,8 C. C. A. 341 ), 474.

Charleston \& Western Carolina Ry. Co. v. Thompson (234 U. S. 576, 58 L. Ed. 1476, 34 Sup. Ct. 964), 158, $28 \mathrm{r}$. 
(The figures refer to pages.)

Chesapeake \& Ohio Ry. Co. v. Conley (230 U. S. 513, 57 L. Ed. 1597, 33 Sup. Ct. 985), 134 .

Chicago \& Alton R. R. Co. v. Kirby (225 U. S. 155, 56 L. Ed. 1033, 32 Sup. Ct. 648), 189, 282, 295, 296, 480, 484, 524.

Chicago \& Alton Ry. Co. v. United States (212 U. S. 563, 53 L. Ed. 653, 29 Sup. Ct. 689, affg. 148 Fed. 646 and 156 Fed. 558), 181, 294, 299, 396, 523.

Chicago, Burlington \& Quincy Ry. Co. v. Iowa (94 U. S. 155, 24 L. Ed. 94), 33, 34 .

Chicago, Burlington \& Quincy Ry. Co. v. Miller (226 U. S. 513, 57 L. Ed. 323, 33 Sup. Ct. 155 ), 472.

Chicago, Burlington \& Quincy Ry. Co. v. United States (220 U. S. 559, 55 L. Ed. 582, 31 Sup. Ct. 612), 55.

Chicago, Burlington \& Quincy Ry. Co. v. United States (157 Fed. 830), 286.

Chicago \& Grand Trunk Ry. Co. v. Wellman (143 U. S. 339), 30 L. Ed. 176, 12 Sup. Ct. 400), 38.

Chicago, Indianapolis \& Louisville Ry. Co. v. United States (219 U. S. 486, 55 L.. Ed. 305. 31 Sup. Ct. 272), 156, 194, 281, 526.

Chicago, Milwaukee \& St. Paul R. R. Co. v. Ackley (94 U. S. 179, 24 L. Ed. 99), 35.

Chicago, Milwaukee \& St. Paul Ry. Co. v. Iowa (233 U. S. 334, 58 L. Ed. 988,34 Sup. Ct. 592 ), 82.

Chicago, Milwaukee \& St. Paul Ry. Co. v. Minnesota (134 U. S. 418, 33 L. Ed. 970, 10 Sup. Ct. 462), 37, 49.

Chicago, Milwaukee \& St. Paul Ry. Co. v. Solan (169 U. S. 133, 42 L. Ed. 688, I8 Sup. Ct. 289), 20, 74, 470, 471, 476.

Chicago, Milwaukce \& St. Paul Ry. Co. v. Tompkins (The South Dakota Rate Case) (176 U. S. 167, 44 L. Ed. 417, 20 Sup. Ct. 336), 144, 148, I49, I72, I8I.

Chicago, Rock Island \& Pacific Ry. Co. ․ Brown (229 U. S. 317), 57 L. Ed. 204, 33 Sup. Ct. 840), 55.

Chicago, Rock Island \& Pacific Ry. Co. v. Cramer (232 U. S. 490,58 L. Ed. 697, 34 Sup. Ct. 383), 472, 482, 485.

Chicago, Rock Island \& Pacific Ry. Co. v. Hardwick Farmers' Elevator Co. (226 U. S. 426, 57 L. Ed. 284. 33 Sup. Ct. 174), 106, 107.

In re Chicago. St. Paul \& Kansas City Ry. Co. (2 I. C. C. Rep. 23I), 382. Chicago, St. Paul, Minneapolis \& Omaha Ry. Co. v. Latta (226 U. S. 519. 57 L. Ed. 328, 33 Sup. Ct. 155), 472.

Chiles $r$. Chesapeake \& Ohio Ry. Co. (218 U. S. 71, 54 L. Ed. 936, 30 Sup. Ct. 667), 28.

Cincinnati, Hamilton \& Dayton Ry. Co. v. Interstate Commerce Commission (206 U. S. 142, 51 L. Ed. 995, 27 Sup. Ct. 648), 226, 368, 369, 399, 426.

Cincinnati, New Orleans \& Texas Pacific R. R. Co. v. Interstate Commerce Commission (The Social Circle Case) (162 U. S. 184, 40 L. Ed. 935. 16 Sup. Ct. 700), 80, 84, 90, 127, 201, 233, 234, 248, 252, 300, 319, 321, $369,379,381,383,425$. 
(The figures refer to pages.)

Cleveland, Cincinnati, Chicago \& St. Louis Ry. Co. v. Backus ( 154 U 439, 38 L. Ed. 104I, 14 Sup. Ct. 1122), 3 I.

Cleveland, Cincinnati, Chicago \& St. Louis Ry. Co. v. Illinois (177 U 51 4, 44 L. Ed. 868, 20 Sup. Ct. 722), 19, 23. 24. 73, 470.

Coe v. Errol (116 U. S. 517, 29 L. Ed. 715, 6 Sup. Ct. 475), 74. 77. 78, 86.

Commercial Mutual Accident Co. v. Davis (213 U. S. 245, 53 I. Ed. 29 Sup. Ct. 445), 490.

Conley v. Mathicson Alkali Wrorks (190 U. S. 406, 47 L. Ed. III3, Sup. Ct. 728), I65, 489 .

Cook v. Pennsylvania (97 U. S. 566, 24 I. Lid. Ior5), 26, 5 I.

Cooley v. Port Wardens (12 How. 299, 13 I.. Ed. 996), II.

Cornell v. Coyne (192 U. S. 4I8, 48 L. E.d. 504. 24 Sup. Ct. 38,3), 515.

Cotting v. Godard (The Kansas City Stock Yords Case) (I83 U. S. 46 L. Ed. 92, 22 Sup. Ct. 30), 45, 49, I42.

Covington \& Cincinnati Bridge Co. v. Kentucky (I54 U. S. 204. 38 I. 962, 14 Sup. Ct. 1087), II, 29, 72.

Covington \& I.exington Turnpike Road Co. v. Sanford ( 164 U. S. 578 L. Ed. 560, 17 Sup. Ct. 198), 4I, 49, 14I. 382.

Covington Stock Yards Co. v. Kcith (139 U. S. 128, 35 I. Ed. 73, II S Ct. 416), 86, I04, III, II3, II $8,123$.

Counselman v. Hitcheock (142 U. S. 547, 35 I. Ed. 1110,12 Sup. Ct. Is $331,343,347$.

Cox v. Central Railroad of Vermont (9 App. Div. N. Y. 4, affd. I58 N 726), 474 .

Crandall v. Nevada (6 Wall. 35, I 8 L. Ed. 745), I7.

Crossman v. Lurman (192 U. S. 189, 48 L. Ed. 401, 24 Sup. Ct. 234), 25

D.

Darnell v. Illinois Central R. R. Co. (225 U. S. 243, 56 I. E.d. 1072, 32 S Ct. 760$), 421$.

Davis v. Cleveland, Cincinnati. Chicago \& St. Louis Ry. Co. (217 U. 157, 54 L. Ed. 708, 30 Sup. Ct. 463), 301.

Delaware. Lackawanna \& Western R. R. Co. v. United States (23I U. 363, 58 L. Ed. 269, 34 Sup. Ct. 65), I68.

Delk v. St. Louis \& San Francisco R. R. Co. (220 U. S. 580, 55 L. Ed. 3I Sup. Ct. 6r7), 55.

Denaby Main Colliery Co. v. Manchester Ry. Co. ( 1885 , il App. Cas. 9 193. 309 .

Detroit v. United States (167 U. S. 646, 42 L. Ed. 310, 17 Sup. Ct. 95 295.

Dow v. Beidelman (125 U. S. 680, 3I I. Ed. 84 I, 8 Sup. Ct. I028), 36.

E.

East Tennessee, Virginia \& Georgia Ry. Co. v. Interstate Commerce Co mission (I8I U. S. I, 45 L. Ed. 719, 2I Sup. Ct. 516), 202, 209, 2 252, 257, 368, 369, 406 .

Employers' Liability Cases (207 U. S. 463, 52 L. Ed. 297, 28 Sup. Ct. I4 464,518 . 
(The figures refer to pages.)

Erb v. Morasch ( 1.7 U. S. 584, 44 L. Ed. 897, 20 Sup. Ct. 819), 24.

Erie R. R. Co. v. New York (233 U. S. $671,5^{8}$ L. Ed. I149. 34 Sup. Ct. 756), 473.

Erie R. R. Co. v. Pennsylvania (158 U. S. 431, 39 L. Ed. 1043, I5 Sup. Ct. $896), 258$.

Erie R. R. Co. v. Williams (233 U. S. 685,58 L. Ed. 1155, 34 Sup. Ct. $761), 55$.

Evans v. United States (153 U. S. 584, 38 L. Ed. 830, 14 Sup. Ct. 934), 527. Evershed v. London \& Northwestern Ry. Co. (1878, 3 App. Cas. 1029), 193. Express Co. v. Caldwell (21 Wall. 264, 22 L. Ed. 556), 474.

F.

Fairbank v. United States (181 U. S. 283, 45 L. Ed. 862, 2 I Sup. Ct. 648), 65.

Fargo v. Hart (193 U. S. 490, 48 L. Ed. 76I, 24 Sup. Ct. 498). 3 I.

Fargo v. Michigan (121 U. S. 230, 30 L. Ed. 888, 7 Sup. Ct. 857), 30.

Fauntleroy v. Lum (210 U. S. 230, 52 L. E.d. 1039, 28 Sup. Ct. 64I), 390.

Field v. Barber Asphalt Co. (194 U. S. 618, 48 L. Ed. 1142, 24 Sup. Ct. $784), 49$.

Field v. Clark ( 143 U. S. 649. 36 L. F.d. 294. I2 Sup. Ct. 495), 254.

Florida East Coast Ry. Co. v. United States (234 U. S. 167. 58 L. Ed. 1 267,34 Sup. Ct. 867), 405, 426.

Fourche River Lumber Co. v. Bryant Lumber Co. (230 U. S. 316,57 L. Ed. 1498, 33 Sup. Ct. 887), 195, 526.

G.

Galveston, Harrisburg \& San Antonio R. R. Co. v. Texas (210 U. S. 217. 52 L. Ed. 1031, 28 Sup. Ct. 638), 30.

Galveston. Harrisburg \& San Antonio R. R. Co. v. Wallace (223 U. S. 481, 56 L. Ed. 516, 32 Sup. Ct. 205), 312, 331, 468, 469.

Geer v. Mathieson Alkali Works (190 U. S. 428, 47 L. Ed. 1122, 23 Sup. Ct. 754), 489.

General Oil Co. v. Crain (209 U. S. 211,52 L. Ed. 754, 28 Sup. Ct. 475), $86,87$.

Georgia Railroad Commission v. Clyde Steamship Co. (5 I. C. C. Rep. 326), 229.

Gibbons v. Ogden (9 Wheat. 1, 6 L. Ed. 23), 8, 12, 28.

Ginn v. Ogdensburg ( 85 Fed. 985,29 C. C. A. 521 ), 474.

Glade Coal Co. v. Baltimore \& Ohio R. R. Co. (ro I. C. C. Rep. 226), 370. Gladson v. Minnesota (I66 U. S. 427, 41 L. Ed. 1064, 17 Sup. Ct. 627), 21. Gloucester Ferry Co. v. Pennsylvania (114 U. S. 196, 29 L. Ed. 158, 5 Sup. Ct. 826), 20.

Goldey v. Morning News (156 U. S. 518, 39 L. Ed. 517, 15 Sup. Ct. 559), 489.

Grand Haven Cartage Case (Interstate Commerce Commission v. Detroit, Grand Haven \& Milwaukee Ry. Co.) (167 U. S. 633, 42 L. Ed. 310, 17 Sup. Ct. 957), 110, 246, 289. 397.

Grand Trunk Ry. Co. v. Michigan Railroad Commission (23I U. S. 457, 58 L. Ed. 310, 34 Sup. Ct. 152), I01, 225. 
(The figures refer to pages.)

Grand Trumk Western Ry. Co. v. Lindsay (233 U. S. 42, 58 L. Ed. 838, 34 Sip. Ct. 58I ), 56.

Great Northern Railway Co. v. O'Connor (232 U. S. 508, 58 L. E.d. 703, 34 Sup. Ct. 380), 193, 279, 472, 482, 485 .

Great Northern Railway Co. v. United States ( 208 U. S. 452, 52 L. Ed. 567, 28 Sup. Ct. 313), 528.

Great Western Railway Co. v. Sutton (I869, L. R. 4 H. L. 226), 193.

Green v. Chicago, Burlington \& Quincy Railway Co. (205 U. S. 530, 5 I L. Ed. 916,27 Sup. Ct. 594), 489 .

Greenwald v. Barrett (199 N. Y. 170, 92 N. E. 218, 35 L. R. A. [N. S.] $971), 477$.

Gulf, Colorado \& Santa Fe Ry. Co. v. Hefley (158 U. S. 98,39 L. Ed. 910, 15 Sup. Ct. 802), 19, 277, 278, 280.

Gulf, Colorado \& Santa Fe Ry. Co. v. McGinnis (228 U. S. 173, 57 L. E.d. 785, 33 Sup. Ct. 426), 56.

Gulf, Colorado \& Santa Fe Ry. Co. v. Texas (204 U. S. 403, 5I L. Ed. 540,27 Sup. Ct. 360), 78, 80.

Hale v. Henkel (201 U. S. 43, 50 L. Ed. 652, 26 Sup. Ct. 370), 349.

Hall v. De Cuir ( 95 U. S. 485,24 L. E.d. 547 ), 23, 26, 72.

Hampton v. St. I.ouis. Iron Mountain \& Southern Ry. Co. (227 U. S. 456, 57 L. Ed. 596, 33 Sup. Ct. 263), I го.

Hanley v. Kansas City Southern Ry. Co. (187 U. S. 6r7, 47 L. Ed. 333, 23 Sup. Ct. 214), 72.

Harndon-Carter Co. Norris Son \& Co. (224 U. S. 496, 56 L. Ed. 857, 32 Sup. Ct. 550), 489 .

Harriman v. Interstate Commerce Commission (2II U. S. 407, 53 L. Ed. 253,29 Sup. Ct. I15), 356, 363, 366, 456.

Harriman, et al., v. Northern Securities Co. (197 U. S. 244. 49 L. Ed. 739, 25 Sup. Ct. 493), 57.

Harris v. United States (227 U. S. 340,57 L. Ed. 534,33 Sup. Ct. 289), 56. Hart v. Pennsylvania Railroad Co. (II2 U. S. 33I, 28 L. Ed. 717, 5 Sup.

Ct. I5I ), 47I, $476,478,485$.

Henderson v. Mayor of New York (92 U. S. 259, 23 L. Ed. 543), 18, $25,29$. Henderson Bridge Co. v. Kentucky (166 U. S. 150, 4I L. Ed. 953, 17 Sup. Ct. 532), 259 .

Hemington v. Georgia (i 63 U. S. 299, 4 I L. Ed. 166, i6 Sup. Ct. 1086), 20,74 .

Herndon v. Chicago, Rock Island \& Pacific Ry. Co. (218 U. S. 135, 54 L. Ed. 970, 30 Sup. Ct. 633), 23.

Hoke v. United States (227 U. S. 308, 57 L. Ed. 523, 33 Sup. Ct. 28I), 56,94 .

Hooper v. California (155 U. S. 648, 39 L. Ed. 297, I5 Sup. Ct. 207), 29.

Hoover v. Pennsylvania Railroad Co. (I56 Pa. 220), 310.

Houston, East \& West Texas Ry. Co. v. United States (The Shreveport Case) (234 U. S. 342, 58 L. Ed. I341, 34 Sup. Ct. 833), 67, 138, 207.

Houston \& Texas Central R. R. v. Mayes (20I U. S. 321, 50 L. Ed. 772, 26 Sup. Ct. 491), 74, 108, 109.

Houston \& West Texas Ry. Co. v. United States (234 U. S. 342, 58 L.

Ed. I34I, 34 Sup. Ct. 833), 404. 
(The figures refer to pages.)

Howard v. Illinois Central R. R. Co. (207 U. S. 463, 52 L. Ed. 297, 28 Sup. Ct. I4I), 56 .

I.

Illinois Central R. R. v. Behrens (233 U. S. 473, 58 L. Ed. 105I, 34 Sup. Ct. 646), 56, 69, I02.

Illinois Central R. R. Co. v. De Fuentes (Louisiana R. R. Commission) (236 U. S. 157), 75, I0I, 225.

Illinois Central R. R. v. Henderson Elevator Co. (226 U. S. 44I, 57 L. Ed. 290, 33 Sup. Ct. 176), 282, 284, 296, 480 .

Illinois Central R. R. v. Illinois (163 U. S. I42, 4 I L. Ed. 107, I6 Sup. Ct. 1096), 22.

Illinois Central R. R. v. Interstate Commerce Commission (206 U. S. 44I, 5I L. Ed. I 28,27 Sup. Ct. 700), 145. 147, 324, 369, 404.

Import Rate Case (Texas \& Pacific Ry. Co. v. Interstate Commerce Commission) (162 U. S. 197, 40 L. Ed. 940, 16 Sup. Ct. 666), 61, 88, 178, $182,192,200,204,221,230,233,235,242,244,245,252,253,364,367$, 369425,5 I 3 .

Inter Mountain Rate Case (United States v. Atchison, Topeka \& Santa Fe Ry. Co.) (234 U. S. 476,58 L. Ed. I408, 34 Sup. Ct. 986), 204, 25I, 255 , 257, 399, 402 .

Interstate Commerce Commission v. Alabama Midland Ry. Co. ( 68 U. S. I44, 42 I. Ed. 414 , I8 Sup. Ct. 45), 53, I30, 193, 228, 242, 244. 383, 404. Interstate Commerce Commission v. Atchison, Topeka \& Santa Fe Ry. Co. (The Los Angeles Switching Case) (234 U. S. 294, 58 L. Ed. I319, 34 Sup. Ct. 814), 104, 291, 395, 397, 404.

Interstate Commerce Commission v. Atchison, Topeka \& Santa Fe R. R. Co. (50 Fed. 295), 230, 232.

Interstate Commerce Commission v. Baird (194 U. S. 25, 48 L. Ed. 860, 24 Sup. Ct. 563), 354, 365, 385.

Interstate Commerce Commission $v$. Baltimore \& Ohio R. R. Co. (The Party Rate Case) (I45 U. S. 263, 36 L. Ed. 699, I2 Sup. Ct. 844), 60, I28, 179, 185, 187, 200, 201, 230, 25I, 318, 379, 420, 494.

Interstate Commerce Commission v. Baltimore \& Ohio R. R. Co. (225 U. S. 326, 56 L. Ed. I 107, 32 Sup. Ct. 742), 196, 221.

Interstate Commerce Commission v. Baltimore \& Ohio Southwestern R. R. Co. (226 U. S. 14, 57 L. Ed. I04, 33 Sup. Ct. 5), 385, 422.

Interstate Commerce Commissoin v. Brimson (154 U. S. 447, 38 L. Ed. I047, I4 Sup. Ct. II25), 350, 357.

Interstate Commerce Commission v. Chesapeake \& Ohio Ry. Co. (200 U. S. 361, 50 L. Ed. 515, 26 Sup. Ct. 272), 280.

Interstate Commerce Commission v. Chicago \& Alton Ry. Co. (215 U. S. 479, 54 L. Ed. 291, 30 Sup. Ct. 163), 390.

Interstate Commerce Commission v. Chicago, Burlington \& Quincy R. R. Co. (I 86 U. S. 320, 46 L. Ed. I 182, 22 Sup. Ct. 824), I 18, 294, 368, 405.

Interstate Commerce Commission v. Chicago, Burlington \& Quincy R. R. Co. (218 U. S. I13, 54 L. Ed. I259, 33 Sup. Ct. 827), 207.

Interstate Commerce Commission v. Chicago, Great Western Ry. Co. (209 U. S. 108, 52 L. Ed. 705, 28 Sup. Ct. 493), 190, 203, 217, 399. 
(The figures refer to pages.)

Interstate Commerce Commission $\vee$. Chicago, Rock Jsland \& Pacific R. R. Co. (218 U.S. 88, 54 L. V.1. 946, 30 Sup. Ct. 651), 205. 397. 426.

Interstate Commerce Commission $\checkmark$. Cincinnati, New Orleans \& Texas Pacific Ry. Co. (The Maximum Rate Case) (167 U. S. 479. 42 L. Ed. 243,17 Sup. Ct. 896), 12, 14, 60, 129, 141, 319, 355, 379, 382, 383.

Interstate Commerce Commission $\vee$. Cincinnati, New Orleans \& Texas Pacific Ry. Co. (56 Fed. 925 ), 230, 232.

Interstate Commerce Commission $\therefore$ Clyde Steamship Co. (18I U. S. 29, 45 L. LAd. 729, 21 Sup. Ct. 512 ), 145, 243.

Interstate Commerce Commission $v$. Delaware, Lackawanna \& Western R. R. Co. (216 U. S. 531, 54 L. Ed. 605. 30 Sup. Ct. 415), 175, 176.

Interstate Commerce Commission $\vee$ Delaware, Lackawanna \& Western R. R. Co. (220 U. S. 235, 55 L. Ed. 448, 31 Sup. Ct. 392), I90, 384. 404. $405,406,423$.

Interstate Commerce Commission $v$. Detroit, Grand Haven \& Milwankee Ry. Co. ('The Grand Hlaven Cartage Case) (167 U. S. 633, 42 L. Ed. 310, 17 Sup. (t. 957), 110, 246, 289, 397.

Interstate Commerce Commission v. Diffenbaugh (222 U. S. 42, 56 L. Ed. 83, 32 Sup. Ct. 22), 122, $212,215,290,392,397$.

Interstate Commerce Commission $\because$ Goodrich Transit Co. (224 U. S. 194, 56 1. Ed. 729. 32 Sup. Ct. 436), 69, 89, 147, 447, 452, 453.

Interstate Commerce Commission $\because$. Humboldt Steamship Co. (224 U. S. 474. 56 L. Ed. 729, 32 Sup. Ct. 436), 83.

Interstate Commerce Commission $\therefore$ Louisville \& Nashville R. R. Co. (73 Fed. 409), 230.

Interstate Commerce Commission $\vee$ Louisville \& Nashville R. R. Co. (190 U. S. 273, 47 L. Ed. 1047, 23 Sup. Ct. 687), 203, 239, 321.

Interstate Commerce Commission $\checkmark$. Illinois Central R. R. Co. (215 U. S. 452, 54 L. Ed. 280, 30 Sup. (t. 155), $219,327,328,386,389,390,391$, $397,402,404,406,407,408,422,426,504$.

Interstate Commerce Commission $r$ L Louisville \& Nashville R. R. Co. (227 U. S. 88, 57 L. Ed. 43 I, 33 Sup. Ct. 185), 145, 365, 384, 398, 405, $406,422$.

Interstate Commerce Commission v. Northern Pacific Ry. Co. (216 U. S. 538, 54 L. Ed. 608, 30 Sup. Ct. 417), 384, 390, 398, 404, 407, 423.

Interstate Commerce Commission $v$. Stickney (215 U. S. 98, 54 L. Ed. 112, 30 Sup. Ct. 66), 114, 119, 216, 292, 293, 395, 400.

Interstate Commerce Commission v. Union Pacific R. R. Co. (222 U. S. 541, 56 L. Ed. 308, 32 Sup. Ct. 108), 1 49, 403. 405, 426.

$\mathrm{J}$.

Johnson v. Southern Pacific Co. (196 U. S. I, 49 L. Ed. 872, 25 Sup. Ct. 158), 55, 101, 102, 103.

Jones v. Montague (194 U. S. 147, 48 L. Ed. 913, 24 Sup. Ct. 6II), 401. $\mathrm{K}$.

Kansas City Southern Ry. Co. v. Albers Commission Co. (223 U. S. 573, 56 L. Ed. 556, 32 Sup. Ct. 316), 283, 286.

Kansas City Southern Ry. Co. v. Carl (227 U. S. 639, 57 L. Ed. 683, 33 Sup. Ct. 39I ), 279, 282, 284, 296, 479, 482, 483, 484. 
(The figures refer to pages.)

Kansas City Southern Ry. Co. v. United States (23I U. S. 423, 58 L. Ed. 206, 34 Sup. Ct. 125), 147, 45 I.

Kansas City Stock Yards Case (Cotting v. Godard) (183 U. S. 79,46 L. Ed. 92, 22 Sup. Ct. 30), 45. 49. I42.

Kendall v. United States (12 Pet. 524, 9 L. Ed. 1181 ), 459.

Kidd v. Pearson (128 U. S. I. 32 L. Ed. 346, 9 Sup. Ct. 6), 14.

Kilbourne v. Thompson (103 U. S. I68, 26 L. Ed. 377), 352.

Knapp v. Lake Shore \& Michigan Southern Ry. Co. (197 U. S. 536, 49 L. Ed. 870, 25 Sup. Ct. 538), 459.

Knott v. Chicago, Burlington \& Quincy R. R. Co. (Missouri Rate Cases) ( 230 U. S. 474, 57 L. Ed. 1571, 33 Sup. Ct. 975), 140.

Knoxville v. Knoxville Water Co. (212 U. S. 1, 53 L. Ed. 371,29 Sup. Ct. $148), 143,146$.

Knudsen v. Michigan Central R. R. Co. (148 Fed. 968), 310.

Ex parte Koehler (3I Fed. 315), 230.

L.

Lafayette Insurance Co. v. French (18 How. 404, I5 L. Ed. 45I), 489.

Lake Shore \& Michigan Southern Ry. Co. v. Ohio (173 U. S. 285, 43 I.

Ed. 702, 19 Sup. Ct. 465), 2 I.

Leisy v. Hardy (135 U. S. I00, 34 L. Ed. I28, Io Sup. Ct. 68I ), 30.

I.eloup v. Port of Mobile (127 U. S. 640, 32 L. Ed. 3I I, 8 Sup. Ct. I380), 31.

In re Lennon ( 166 U. S. 548, 41 I. Fd. III0, I7 Sup. Ct. 658), 3 I6.

Lord v. Steamship Co. (102 U. S. 541, 26 I.. Fd. 224), 72.

I.os Angeles Switching Case (Interstate Commerce Commission v. Atchison, Topeka \& Santa Fe Ry. Co.) (234 U. S. 294. 58 I. Ed. 1319. 34 Sup. Ct. 814), 104, 291, 395. 397, 404.

Lottery Cases (Champion v. Ames) (I88 U. S. 32 I, 47 I. Ed. 492, 23 Sup. Ct. 32I ), 29, 94.

Louisiana Railroad Commission v. Texas \& Pacific Ry. Co. (229 U. S. 336, 57 L. Ed. I215, 33 Sup. Ct. 837), 75, 82, 86.

In re Louisville \& Nashville R. R. Co. (1 I. C. C. Rep. 31), 229, 232, 25 I.

Louisville \& Nashville R. R. Co. v. Behlmer (175 U. S. 648, 44 L. Ed. 309, 20 Sup. Ct. 209), 91, 145, 146, 242, 244, 249, 252, 257, 32 I, 367, 369, 406.

Louisville \& Nashville R. R. Co. v. Central Stock Yards (212 U. S. I32, 53 L. Ed. 44I, 29 Sup. Ct. 246), 105. I08, 224.

Louisville \& Nashville R. R. Co. v. Cook Brewing Co. (223 U. S. 70, 56 L. Ed. 355, 32 Sup. Ct. 189), 325.

Louisville \& Nashville R. R. Co. v. Eubank (184 U. S. 27,46 L. Ed. 4I6, 22 Sup. Ct. 277), 259.

Louisville \& Nashville R. R. Co. v. Garritt (231 U. S. 298, 58 L. Ed. 229, 34 Sup. Ct. 48), I37.

Louisville \& Nashville R. R. Co. v. Interstate Commerce Commission (227 U. S. 88, 57 L. Ed. 431, 33 Sup. Ct. 185), 416.

Louisville \& Nashville R. R. Co. v. Kentucky (I6I U. S. 677, 40 L. Ed. 849, 16 Sup. Ct. 714), 20, 74.

Louisville \& Nashville R. R. Co. v. Kentucky (183 U. S. 503, 46 L. Ed. 298, 22 Sup. Ct. 95), 255, 258. 
(The figures refer to pages.)

Louisville \& Nashville R. R. Co. v. Mottley (2I U. S. I49), 53 I.. E.d. 126, 29 Sup. Ct. 42), $154,194$.

Louisville \& Nashville R. R. Co. v. Mottley (219 U. S. 467,55 L. E.d. 297 , 31 Sup. Ct. 265), 152, 156, 193, 195, 279, 525.

Louisville \& Nashville R. R. Co. v. Woodford (23.4 U. S. 46, 58, I. Ed. 1202, 34 Sup. Ct. 739), 478.

l.udwig v. Western Union Telegraph Co. (2I6 U. S. 146,54 L. Ed. 423 . 30 Sup. Ct. 280), 30.

Lyng v. Michigan ( 35 U. S. 16r, 34 L. Ed. 130, 10 Sup. Ct. 725), 30.

M.

McCarty v. Gulf, etc., Ry. Co. (79 Texas 33, 15 S. W. 164), 475.

MeNeill v. Southern Ry. Co. (202 U. S. 543, 50 L. Ed. 1142, 26 Sup. Ct. $722), 102,108,173$.

Macon Grocery Co. v. Atlantic Coast I.ine R. R. Co. (215 U. S. 50 r, 54 L. Fid. 300,30 Sup. Ct. 184), 325.

Maximum Rate Case (Interstate Commerce Commission v. Cincinnati, New Orleans \& Texas Pacific Ry. Co.) (167 U. S. 479. 42 I. E.d. 243, 17 Sup. Ct. 896), 12, 14, 60, 129, I41, 319, 355, 379, 382, 383 .

Mechanical Appliance Co. v. Castleman (215 U. S. 437, 54 L. E.d. 272, 30 Sup. Ct. 125), 48 9.

Meeker v. Lehigh Valley R. R. Co. (183 Fed. 548), 310.

Meeker v. Lehigh Valley R. R. Co. (decided Feb. 23, 1915), 3II, 315, 329, $365,370,423,424,427$.

Michigan Central R. R. Co. v. Vreeland (227 U. S. 59, 57 L. Ed. 417, 33 Sup. Ct. 192), 56, 47 I.

Miller \& Lux v. Southern Pacific Ry. Co. (20 I. C. C. 129), 480.

Minneapolis \& St. Louis Ry. Co. v. Minnesota (186 U. S. 257, 46 L. Ed. I151, 22 Sup. Ct. 900), 141, 148, 149.

Minneapolis Eastern Ry. Co. v. Minnesota (134 U. S. 467, 33 L. Ed. 985, Io Sup. Ct. 473), 37.

Minnesota Rate Cases (Simpson v. Shepard) (230 U. S. 352, 57 I. Ed. I51 I, 33 Sup. Ct. 729), I1, 48, 61, 66, 69, 71, 73, 134, 139, 208, 454.

Minnesota v. Northern Securities Co. ( 194 U. S. 48,48 L. Ed. 870, 24 Sup. Ct. 598), 57.

Missouri, Kansas \& Texas Ry. Co. v. Cade (233 U. S. 642, 58 L. Ed. I135, 34 Sup. Ct. 678), 313, 316, 424.

Missouri, Kansas \& Texas Ry. Co. v. Harriman Bros. (227 U. S. 657, 57 L. Ed. 690, 33 Sup. Ct. 397), 472, 474, 482, 483, 525.

Missouri, Kansas \& Texas Ry. Co. v. Harris (234 U. S. 412, 58 L. Ed. 1 377, 34 Sup. Ct. 790), 313, 473.

Missouri, Kansas \& Texas Ry. Co. v. United States (23I U. S. 112, 58 L. Ed. I44, 34 Sup. Cr. 26), 55.

Missouri Pacific Ry. Co. v. Castle (224 U. S. 541, 56 L. Ed. 875, 32 Sup. Ct. 60I ), 56.

Missouri Pacific Ry. Co. v. Kansas (216 U. S. 262, 54 L. Ed. 472, 30 Sup. Ct. 330), 23, 172 .

Missouri Pacific Ry. Co. v. Larabee Mills (2I I U. S. 612, 53 L. Ed. 352, 29 Sup. Ct. 214), 16, 63. 65, 74, 135, 473. 
(The figures refer to pages.)

Missouri Pacific Ry. Co. v. Texas \& Pacific Ry. (3I Fed. 862), 230.

Missouri Pacific Ry. Co. v. Tucker (230 U. S. 340, 57 L. Ed. 1507, 33 Sup. Ct. 961$), 136$.

Missouri Pacific Ry. Co. v. United States (189 U. S. 274, 47 L. Ed. 8I I, 23 Sup. Ct. 507), 316.

Missouri Railroad Commission v. Illinois Central Railroad Co. (203 U. S. 335, 51 L. Ed. 209, 27 Sup. Ct. 90 ), $23,74$.

Missouri Rate Case (Knott v. Chicago, Burlington \& Quincy R. R. Co.) (230 U. S. 474,57 L. Ed. 1571, 33 Sup. Ct. 975), 140.

Mitchell Coal \& Coke Co. v. Pennsylvania R. R. Co. (230 U. S. 247, 57

L. Ed. 1472, 33 Sup. Ct. 916), 197, 220, 294, 299, 312, 329, 395, 419, 500.

County of Mobile v. Kimball (102 U. S. 691, 26 L. Ed. 238), 68.

Mondou v. New York, New Haven \& Hartford R. R. Co. (Second Employers' Liability Case) (223 U. S. I, 56 L. Ed. 327, 32 Sup. Ct. 169), $56,68,69,471$.

Monongahela Bridge Co. v. United States (216 U. S. 177, 54 L. Ed. 435, 30 Sup. Ct. 356), 254.

Montello (11 Wall. 411,20 L. Ed. 19I; s. c. 20 Wall. 430, 22 L. Ed. 191), I4.

Morgan v. Louisiana (I18 U. S. 455. 30 L.. Ed. 237, 6 Sup. Ct. III4), I9.

Morrisdale Coal Co. v. Pennsylvania Railroad Co. (230 U. S. 304, 57 L.

Ed. 1494, 33 Sup. Ct. 938), 220, 312, 327, 389, 397, 408, 421, 423.

Munn v. Illinois (94 U. S. 113, 24 L. Ed. 77), 32, 33, 34.

Muschamy v. Lancaster Ry. Co. (8 M. \& W. 421 ), 463.

Muskogee National Tel. Co. v. Hall (118 Fed. 382), 29.

N.

Nashville, Chattanooga \& St. Louis Ry. Co. v. Alabama (128 U. S. 96,32 I. Ed. 352, 9 Sup. Ct. 28), 19. 74.

Nebraska Rate Case (Smyth v. Ames) (I69 U. S. 466, 42 L. Ed. 819, I8 Sup. Ct. 418), 43, 44, 47, 49, 134, 142, 365, 454.

Nelson v. United States (201 U. S. 92, 50 I. Ed. 673, 26 Sup. Ct. 358), 349.

New Orleans Gas Co. v. Louisiana Light Co. (115 U. S. 650, 29 L. Ed. $516), 18$.

New Orleans \& Northeastern R. R. Co. v. National Rice Milling Co. (234

U. S. 80,58 L. Ed. 1223, 34 Sup. Ct. 726), 478.

New York v. Miln (11 Peters 102, 9 L. Ed. 648), io.

New York Central \& Hudson River R. R. v. Hudson County (227 U. S. 248, 57 L. Ed. 499, 33 Sup. Ct. 269), 98.

New York Central \& Hudson River R. R. Co. v. United States (212 U. S. 481,53 L. Ed. 613, 29 Sup. Ct. 304), 336, 515, 522, 525, 528.

New York Central \& Hudson River R. R. Co. v. United States (212 U. S. 500, 53 L. Ed. 624, 29 Sup. Ct. 309), 529.

New York, Lake Erie \& Western R. R. Co. v. Estill (147 U. S. 591, 37 L. Ed. 292, 13 Sup. Ct. 444), 476.

New York, New Haven \& Hartford R. R. Co. v. Interstate Commerce Commission (200 U. S. 361, 50 L. Ed. 515, 26 Sup. Ct. 272), 60, 61, 160, 195, 221, 326, 409, 497, 517, 526. 
New York, New Haven \& Hartford R. R. Co. V. New York (165 U. S. 628,41 L. Eid. 853, 17 Sup. Ct. 418), 20, 74, 470.

Norfolk \& Western Ry. Co. $\therefore$. Dixie Tobacco Co. (228 U. S. 593, 57 L. Ed. $980,33$ Sup. Ct. $6(x)), 4(09$.

Norfolk \& Western Ry. Co. v. Earnest (229 U. S. 114, 57 L. Ed. 1096, 33 Sup. Ct. 654), 56 .

Norfolk \& Western Ry. Co. V. West Virginia (West Virginia Rate Case) (decided March 8, 1915), 140, 142.

North Caroline R. R. v. Zachary (232 U. S. 248,58 1. Ed. 591,34 Sup. Ct. 305), 56, 101.

Northern Pacific Ry. Co. v. Adams (192 U. S. 440, 48 L. E.d. 513, 24 Sup. Ct. 408 ), I 58.

Northern Pacific Ry. Co. v. North Dakota (216 U. S. 579, 54 L. Ed. 624, 30 Sup. Ct. 423), 137.

Northern Pacific Ry. Co. v. North Dakota (decided March 8, 1915), I40, $142,146$.

Northern Pacific Ry. Co.v. Mashington (222 U. S. 370,56 L. Ed. 237, 32 Sup. Ct. 160), 471, 473.

North Pennsylvania R. R. Co. v. Commercial Bank of Chicago (123 U. S. 727, 31 L. Ed. 287,8 Sup. Ct. 266), 104.111. 112, I18.

O.

Ohio Railroad Commission v. Worthington (225 U. S. 101, 56 L. Ed. 1087, 32 Sup. Ct. 653), 76, 78, 79, 82.

Oklahoma v. Atchison, Topeka \& Santa Fe Ry. Co. (220 U. S. 277,55 L. Ed. 465. 31 Sup. Ct. 434), 84 .

Oklahoma v. Chicago, Rock Island \& Pacific Ry. Co. (220 U. S. 302, 55 L. Ed. 474. 31 Sup. Ct. 442), 84.

Oklahoma v. Wells Fargo \& Co. (223 U. S. 298, 56 L. Ed. 445, 32 Sup. Ct. 218), 30 .

Omaha Street Railway Co. v. Interstate Commerce Commission (230 U. S. 324. 57 L. Ed. I501, 33 Sup. Ct. 890), 96.

Oregon Railroad \& Navigation Co. v. Campbell (230 U. S. 525. 57 L. Ed. I604, 33 Sup. Ct. I026), I35.

Ouachita Packet Co. v. Aiken (121 U. S. 444, 30 L. Ed. 976, 7 Sup. Ct. $907), 20$.

\section{P.}

Pacific Coast Steamship Co. v. Railroad Commissioners (9 Sawyer 253), 72.

Parsons v. Chicago \& Northwestern Ry. Co. (167 U. S. 447, 42 L. Ed. 23I, 17 Sup. Ct. 887), 305, 307, 318.

Party Rate Case (Interstate Commerce Commission v. Baltimore \& Ohio R. R. Co.) (145 U. S. 263, 36 L. Ed. 699, i2 Sup. Ct. 844), 60, 128, 179, I 85, I $87,200,201,230,251,318,379,420,494$.

Passenger Cases (7 Howard 283, 12 L. Ed. 702), 10.

Patterson v. Adams Express Co. (205 Mass. 254), 468.

Paul v. Virginia (8 Wall. I68, I9 L. Ed. 357), 29. 
(The figures refer to pages.)

Pederson v. Delaware, Lackawanna \& Western R. R. Co. (229 U. S. 146, 57 L. Ed. I125, 33 Sup. Ct. 648), 56, I00.

Peik v. Chicago \& Northwestern Ry. Co. (94 U. S. 164, 24 L. Ed. 97), 34, 35.

Penn Refining Co. v. Western New York \& Pennsylvania R. R. Co. (208 U. S. 208, 52 L. Ed. 456, 28 Sup. Ct. 268), 190, 199, 212, 215, 216.

Pennsylvania v. Wheeling \& Belmont Bridge Co. (18 How. 421, 15 L. Ed. 435), 515 .

Pennsylvania Co. v. United States (decided Feb. 23, 1915), 225, 397, 404. Pennsylvania Lumberman's Mutual Fire Insurance Co. v. Meyer (197 U. S. 407, 49 L. Ed. 810, 25 Sup. Ct. 483), 488, 490.

Pennsylvania Railroad Co. v. Hughes (I9I U. S. 477,48 L. Ed. 268,24 Sup. Ct. 132), $470,471,472,476$.

Pennsylvania Railroad Co. v. International Coal Mining Co. (230 U. S. 184, 57 L. Ed. 1446, 33 Sup. Ct. 893), 197, 220, 306, 312, 328, 329, 330, 331,421 .

Pensacola Tel. Co. v. Western Union (96 U. S. I, 24 L. Ed. 708), 29.

Peterson v. Chicago, Rock Island \& Pacific Ry. Co. (205 U. S. 364), 5I L. Ed. 841,27 Sup. Ct. 513 ), 489.

Philadelphia, Baltimore \& Washington R. R. Co. v. Schubert (224 U. S. $603,56$ L. Ed. 911,32 Sup. Ct. 589$), 56$.

Phillips Co. v. Grand Trunk Western Ry. Co. (decided March 15, 1915), I99, 33I, 427.

Phoenix Insurance Co. v. Erie Transportation Co. (117 U. S. 312, 29 L. Ed. 873,5 Sup. Ct. 151), 476.

Pierce v. New Hampshire (5 How. 504, 12 L. Ed. 256), I8.

Pitcairn Coal Case (Baltimore \& Ohio R. R. Co. v. United States, ex rel. Pitcairn Coal Co.) (215 U. S. 481, 54 L. Ed. 392, 30 Sup. Ct. 164), 220, $323,327,388,397,404,408,426,502$.

Pittsburgh, Cincinnati, Chicago \& St. Louis Ry. Co. v. Backus (I54 U. S. 42I, 38 L. Ed. I031, I4 Sup. Ct. I114), 3 I.

Plumley v. Massachusetts (155 U. S. 46I, 39 L. Ed. 223, I5 Sup. Ct. 154), 25.

Portland Railway, Light \& Power Co. v. Oregon Railroad Commission (229 U. S. 397, 57 L. Ed. 1248, 33 Sup. Ct. 820), 135, 210.

Portland Railway, Light \& Power Co. v. Oregon Railroad Commission (229 U. S. 414, 57 L. Ed. 1259), 33 Sup. Ct. 827), 136, 211.

Postal Telegraph Co. v. Adams (155 U. S. 688, 39 L. Ed. 31 II, I5 Sup. Ct. $360), 30,403$.

Pre-Icing Case (Atchison, Topeka \& Santa Fe Ry. Co. v. United States) (232 U. S. 199, 58 L. Ed. 568, 34 Sup. Ct. 291), 124, 298, 397.

Prentis v. Atlantic Coast Line R. R. Co. (Virginia Rate Case) (2I I U. S. 210, 53 L. Ed. 150, 29 Sup. Ct. 67), 140.

Primrose v. Western Union Telegraph Co. (154 U. S. I, 38 L. Ed. 883, 14 Sup. Ct. 1098$), 476$.

Proctor \& Gamble v. United States (225 U. S. 282, 56 L. Ed. 1091, 32 Sup. Ct. 761), 222, 403, 425.

Providence Coal Case (I I. C. C. Rep. 107), 19r. 
Pullinan Palace Car Co. v. Missouri Pacific R. R. Co. (115 U. S. 587, 29 L. Ed. 499, 6 Sup. Ct. 194), I64.

Q.

Queen v. Boyes (I B. \& S. 3I I), 347.

R.

In re Rahrer (140 U. S. 545, 35 L. Ed. 572, in Sup. Ct. 865), 30.

Railroad v. American Trading Co. (195 U. S. 439, 49 L. Ed. 260, 25 Sup. Ct. 84), 463 .

Railroad Commission Cases (116 U. S. 307, 29 L. Ed. 636, 6 Sup. Ct. 334), 24.

Railroad Co. v. Fraloff (100 U. S. 24, 25 L. Ed. 53I), 487.

Railroad Co. v. Husen (95 U. S. 465,24 L. Ed. 527 ), 26.

Railroad v. Lockwood (17 Wall. 357, 21 L. Ed. 627), 476.

Railroad Co. v. Maryland (2I Wall. 456, 22 L. Ed. 678), I3, 15.

Railroad Co. v. Pratt (22 Wall. 123, 22 L. Ed. 827), 462, 463.

Railroad Co. v. Richmond (19 Wall. 584, 22 L. Ed. 173), 302.

Railroad Co. v. Riclimond ( 96 U. S. 52I, 24 L. Ed. 734), 24.

Matter of Railroad Telegraph Contracts (12 I. C. C. Rep. 10), 159, 197.

Railway Co. v. Fuller (17 Wall. 560, 21 L. Ed. 710), $19,74$.

Railway Co. v. McCarthy (96 U. S. 258, 24 L. Ed. 693), 463.

Reagan v. Farmers' Loan \& Trust Co. (I54 U. S. 362, 38 L. Ed. 1014, 14 Sup. Ct. 1047), 38, 4 I.

Reagan v. Mercantile Trust Co. (I54 U. S. 413, 38 I. Ed. 1028, 14 Sup. Ct. 1060), 4 I.

Rearick v. Pennsylvania (203 U. S. 507, 51 L. Ed. 295, 27 Sup. Ct. 159), 92. Natter of Released Rates (I3 I. C. C. Rep. 550), 468.

Reynolds v. United States (98 U. S. 145, 25 L. Ed. 244), 528.

Rhodes v. Iowa (170 U. S. 412 , 42 L. Ed. 1088, I8 Sup. Ct. 664), 30.

Richardson v. McChesney (218 U. S. 487,54 L. Ed. II2I, 3 I Sup. Ct. 43), 401.

Richmond \& Allegheny R. R. Co. v. Patterson Tobacco Co. (I69 U. S. 3II, 42 L. Ed. 759, 18 Sup. Ct. 335), 20, 74, 470.

Riddlesbarger v. Hartford Insurance Co. (7 Wall. 386, 19 L. Ed. 257), 474. Robbins v. Shelby Taxing District (120 U. S. 489, 30 L. Ed. 694, 7 Sup. Ct. 592), 26, 30 .

Robinson v. Baltimore \& Ohio R. R. Co. (222 U. S. 506, 56 L. Ed. 288, 32 Sup. Ct. I14), 220, 369, 408, 4I5, 419.

Ruggles v. Illinois (108 U. S. 526, 27 L. Ed. 812, 2 Sup. Ct. 832), 35.

$\mathrm{S}$.

St. Clair v. Cox (106 U. S. 350, 27 L. Ed. 222, I Sup. Ct. 354), 489.

St. Louis, Iron Mountain \& Southern Ry. Co. v. Edwards (227 U. S. 265 , 57 L. Ed. 506, 33 Sup. Ct. 262), I07.

St. Louis, Iron Mountain \& Southern Ry. Co. v. Hesterly (228 U. S. 702, 57 L. Ed. 1031, 33 Sup. Ct. 703), 56.

St. Louis, Iron Mountain \& Southern Ry. Co. v. Taylor (210 U. S. 28I, 52 L. Fd. 1061, 28 Sup. Ct. 616), 55, 254. 
(The figures refer to pages.)

St. Louis, Iron Mountain \& Southern Ry. Co. v. McWhirter (229 U. S. 265, 57 L. Ed. I179, 33 Sup. Ct. 858), 55.

St. Louis \& San Francisco Ry. Co. v. Gill (156 U. S. 649, 39 L. Ed. 567, I5 Sup. Ct. 484), 4 I.

St. Louis, San Francisco \& Texas Ry. Co. v. Seale (229 U. S. 156, 57 L. Ed. II 29, 33 Sup. Ct. 65I), 102.

St. Louis Southwestern Ry. Co. v. Alexander (227 U. S. 218, 57 L. Ed. 486, 33 Sup. Ct. 245), 488.

St. Louis Southwestern Ry. Co. v. Arkansas (217 U. S. 136, 54 L. Ed. 698, 30 Sup. Ct. 476), 110.

San Diego Land \& Town Co. v. Jasper (I89 U. S. 439, 47 L. Ed. 892, 23 Sup. Ct. 571 ) 454.

San Diego Land Co. v. National City (174 U. S. 739, 43 L. Ed. I154, 19 Sup. Ct. 804), 44, I41, 454.

Sands v. Manistee River Improvement Co. (I23 U. S. 288, 3I L. Ed. I49, 8 Sup. Ct. II3), 20.

Santa Fe, Prescott \& Phønix Ry. Co. v. Grant Bros. Construction Co. (228 U. S. 177, 57 L. Ed. 787, 33 Sup. Ct. 474), 159, 197.

Schlemmer v. Buffalo, Rochester \& Pittsburgh Ry. Co. (205 U. S. 1, 5 I L. Ed. 681, 27 Sup. Ct. 407), 55, 103.

Schlemmer v. Buffalo, Rochester \& Pittsburgh Ry. Co. (220 U. S. 590, 55 L. Ed. 596, 31 Sup. Ct. 56I), 55.

Seaboard Air Line R. R. Co. v. Horton (233 U. S. 492, 58 L. Ed. 1062, 34 Sup. Ct. 635), 56 .

Seaboard Air Line Ry. v. Moore (228 U. S. 433, 57 L. Ed. 907, 33 Sup. Ct. 580 ), 101 .

Second Employers' Liability Case (Mondou v. New York, New Haven \& Hartford R. R. Co.) (223 U. S. I, 56 L. Ed. 327,32 Sup. Ct. I69), 56, $68,69,47 \mathrm{I}$.

Sherlock v. Alling (93 U. S. 103, 23 L. Ed. 819), 28.

Shreveport Case (Houston, East \& West Texas Ry. Co. v. United States) (234 U. S. 342, 58 L. Ed. 1341, 34 Sup. Ct. 833), 67, 138, 207.

Simpson v. Shepard (Minnesota Rate Cases) (230 U. S. 352, 57 L. Ed. I5II, 33 Sup. Ct. 729), II, 48, 6I, 66, 7I, 73, 134, 139, 208, 454.

Smith v. Alabama (124 U. S. 465, 3 I L. Ed. 508, 8 Sup. Ct. 564), I9, 74, 470.

Smyth v. Ames (Nebraska Rate Case) (I69 U. S. 466, 42 L. Ed. 819, 18 Sup. Ct. 4I8), 43, 44, 47, 49, I34, I 42, 365, 454.

Smyth v. Ames (171 U. S. 361, 43 L. Ed. I97, I8 Sup. Ct. 888), 44.

Social Circle Case (Cincinnati, New Orleans \& Texas Pacific Ry. Co. v. Interstate Commerce Commission) (162 U. S. 184, 40 L. Ed. 935, 16 Sup. Ct. 700), 80, 84, 90, 127, 201, 233, 234, 248, 252, 300, 319, 321, 369, $379,381,383,425$.

South Carolina v. Georgia (93 U. S. 4, 23 L. Ed. 782), 5 I5.

South Dakota Rate Case (Chicago, Milwaukee \& St. Paul Ry. Co. v. Tompkins) (176 U. S. 167,44 L. Ed. 417,20 Sup. Ct. 336), 144, 148, I49, $172,18 \mathrm{I}$.

Southern Oil Co. v. Southern Ry. Co. (19 I. C. C. 79 ), 480. 
Southern Pacific Co. v. Campbell (230 U. S. 537, 57 1. Ed. 1610, 33 Sup.

Ct. 1027 ), 134.

Southern Pacific Co. v. Interstate Commerce Commission (200 U. S. 536, 5o L. Ed. 585, 26 Sup. Ct. 330), 223, 262, 390, 462.

Southern Pacific Co. v. Interstate Commerce Commission (219 U. S. 433. 55 L. Fid. 283, 31 Sup. Ct. 288), 1 46, 1 49, 398, 401, 404, 407, 422, 426.

Southern Pacific Terminal Co. v. Interstate Commerce Commission \& Young (219 U. S. 498, 55 L. E.d. 310. 3I Sup. Ct. 279), 77. 78, 86, 115. $217,397,401$.

Southern Pacific Co. v. Schuyler (227 U. S. 601, 57 L. Ed. 662, 33 Sup. Ct. 277), 157.

Southern Railway Co. v. Burlington Lumber Co. (225 U. S. 99, 56 L. Ed. 1001, 32 Sup. Ct. 657), 285, 289.

Southern Railway Co. v. Gadd (233 U. S. 572, 58 L. Ed. I099. 34 Sup. Ct. $696), 56$.

Southern Railway Co. v. Harrison (I19 Alabama 539), 278.

Southern Railway Co. v. Indiana Railroad Commissison (decided Feb. 23, 1915), 55.

Southern Railway Co. v. King (217 U. S. 524. 54 L. Ed. 868, 30 Sup. Ct. $594), 24$.

Southern Railway Co. v. Reid (222 U. S. 424, 56 L. Ed. 257, 32 Sup. Ct. I 40), 61, 107, 285, 287, 471, 473.

Southern Railway Co. v. Reid \& Beam (222 U. S. 444, 56 L. Ed. 263, 32 Sup. Ct. I 45), 285, 289.

Southern Railway Co. v. St. Louis, Hay \& Grain Co. (214 U. S. 297, 53 L. Ed. 1004, 29 Sup. Ct. 678), I17, I I9, 123, 222, 293, 396.

Southern Railway Co. v. Tift (206 U. S. 428, 5 I L. Ed. I124, 27 Sup. Ct. $709), 324,325,328,420,422$.

Southern Railway Co. v. United States (222 U. S. 20, 56 I. Ed. 72, 32 Sup. Ct. 2), I4, 55, 66, 69, 103 .

The Southwark (19I U. S. I, 48 L. Ed. 65, 24 Sup. Ct. I), 123.

Standard Oil Co. v. United States (22I U. S. I, 55 L. Ed. 6I9, 3 I Sup. Ct. 502), 57 .

State v. Engle, Receiver (5 Vroom [N. J.] 435), 86.

Case of State Freight Tax (I5 Wall. 232, 21 L. Ed. 146), 25.

State Tax on Railway Gross Receipts (I5 Wall. 284, 21 L. Ed. I64), 30, 33.

Steam Co. v. Phœnix Insurance Co. (129 U. S. 397, 32 L. Ed. 788, 9 Sup.

Ct. 469$), 476$.

Steamer Coquitlam v. United States ( 163 U. S. 346, 41 L. Ed. 184, I6 Sup. Ct. I I I 7), 83 .

Stone, et al., v. Farmers' Loan \& Trust Co. (116 U. S. 307, 29 L. Ed. 636, 6 Sup. Ct. 334), 35, 36.

Stone v. Wisconsin (94 U. S. 18I, 24 L. Ed. 102), 35.

Susqueiranna Coal Co. v. South Amboy (228 U. S. 665, 57 L. Ed. I015, 33 Sup. Ct. 712), 87.

Swift \& Co. v. United States (196 U. S. 375, 49 L. Ed. 518, 25 Sup. Ct. 276), 28, 79, 409 . 


\section{TABLE OF CASES CITED.}

(The figures refer to pages.)

$T$.

Tap Line Cases (U. S. v. Louisiana \& Pacific Ry. Co.) (234 U. S. I, 58 L. Ed. I185, 34 Sup. Ct. 741), I66, I69, I98, 394, 526.

In re Tariffs v. Export \& Import Traffic (10 I. C. C. Rep. 55), 514.

Telegraph Co. v. Texas ( 105 U. S. 460, 26 L. Ed. I067), 30.

Texas \& New Orleans R. R. Co. v. Sabine Tram Co. (227 U. S. III, 57

L. Ed. 442, 33 Sup. Ct. 229), 75, 78, 82, 86, 92.

Texas \& Pacific Ry. Co. v. Abilene Cotton Oil Co. (204 U. S. 426, 51 L.

Ed. 553, 27 Sup. Ct. 350), I31, 280, 318, 324, 326, 418, 419, 420, 422, 500.

Texas \& Pacific Ry. Co. v. American Tie \& Lumber Co. (234 U. S. 138 ,

58 L. Ed. 1255, 34 Sup. Ct. 885), 287.

Texas \& Pacific Ry. Co. v. Cisco Oil Mill (204 U. S. 449, 51 L. Ed. 562, 27 Sup. Ct. 358), 282, 284, 322, 420.

Texas \& Pacific Ry. Co. v. Interstate Commerce Commission (The Import

Rate Case) (162 U. S. 197. 40 L. Ed. 940, 16 Sup. Ct. 666), 61, 88, 178, I $82,192,200,204,22$ I, 230, 233, 235, 242, 244, 245, 252,253,364, 367, 369 $425,513$.

Texas \& Pacific Ry. Co. v. Mugg ( 202 U. S. 242, 50 L. Ed. 1011, 26 Sup. Ct. 628), 278, 282, 295, 296, 480, 484, 525 .

Thatcher v. Delaware \& Hudson Canal Co. (1 I. C. C. Rep. 152), 382.

Thompson v. Chicago, etc., Ry. Co. (22 Mo. App. 321), 475.

Thurber v. New York Central \& Hudson River R. R. Co. (3 I. C. C. Rep. 473). 191

Toledo, St. Louis \& Western R. R. Co. v. Slavin (decided Feb. 23, 1915), 56.

Travis v. Wells-Fargo Express Co. (74 Atl. Rep. 444), 468.

U.

Union Bridge Co. v. United States (204 U. S. 364, 51 L. Ed. 523, 27 Sup. Ct. 367$), 254,450$.

Union Pacific Railway Co. v. Goodridge ( 149 U. S. 680, 37 L. Ed. 896, 13 Sup. Ct. 970), 180, 194, 280.

Union Pacific Railway Co. v. United States (117 U. S. 355, 29 L. Ed. 920, 6 Sup. Ct. 772), 183

Union Pacific R. R. Co. v. Updike Grain Co. (222 U. S. 215, 56 L. Ed. I7I, 32 Sup. Ct. 39), 121, 122, 216, 299, 392, 397.

United States v. Adams Express Co. (229 U. S. 381, 57 L. Ed. 1237, 33 Sup. Ct. 878), 95, 335.

United States v. Atchison, Topeka \& Santa Fe Ry. Co. (220 U. S. 37, 55 L. Ed. 361, 31 Sup. Ct. 362), 55.

United States v. Atchison, Topeka \& Santa Fe Ry. Co. (The Inter Mountain Rate Case) (234 U. S. 476, 58 L. Ed. 1408, 34 Sup. Ct. 986), 204, $25 \mathrm{I}, 255,257,399,402$.

United States v. Baltimore \& Ohio R. R. Co. (225 U. S. 306, 56 L. Ed. I 100,32 Sup. Ct. 817), 394, 426.

United States v. Baltimore \& Ohio R. R. Co. (23I U. S. 274, 58 L. Ed. 218), 34 Sup. Ct. 75), 224, 299, 393, 397.

United States v. Baltimore \& Ohio Southwestern R. R. Co. (226 U. S. I4, 57 L. Ed. 104, 33 Sup. Ct. 5), 174, 177. 
(The figures refer to pages.)

United States x. Butler County R. R. Co. (234 U. S. 29, 58 L. Ed. I I96, 34 Sup. Ct. 748), I70, 198, 395, 526.

United States v. Delaware \& Hudson Co. (213 U. S. 366, 53 L. Ed. 836, 29 Sup. Ct. 527), 163, 168, I70.

United States v. Dewitt (9 Wall. 4I, 19 L. Ed. 593), 15.

United States v. Erie R. R. Co. (decided Feb. 23, 1915), 154, 498.

United States v. Grimaud (220 U. S. 506, 55 L. Ed. 563, 3 I Sup. Ct. 480), 450.

United States v. Hess (124 U. S. 483, 31 L. Ed. 516, 8 Sup. Ct. 571 ), 527.

United States v. Heinszen (206 U. S. 370, 5I L. Ed. 1098, 27 Sup. Ct. 742), 254.

United States v. Holte (236 U. S. I40), 56.

United States v. Lehigh Valley R. R. Co. (220 U. S. 257, 55 L. Ed. 458, 31 Sup. Ct. 387), 167, 195.

United States v. Louisiana \& Pacific Ry. Co. (The Tap Line Cases) (234 U. S. I, 58 L. Ed. 1185,34 Sup. Ct. 741 ), 166, 169, 198, 394, 526.

United States v. Louisville \& Nashville R. R. Co. (235 U. S. 3I4, 59 L. Ed. $\longrightarrow), 256,406$.

United States v. Louisville \& Nashville R. R. Co. (decided Feb. 23, 1915), 356,456 .

United States v. Miller (223 U. S. 599, 56 L. Ed. 568, 32 Sup. Ct. 323), 283. United States v. Moseley (187 U. S. 322, 47 L. Ed. 198, 23 Sup. Ct. 90), 43 I. United States v. New York Central \& Hudson River R. R. Co. (2I2 U. S. 509, 53 L. Ed. 629, 29 Sup. Ct. 313), 518.

United States v. Ohio Oil Co. (234 U. S. 548, 58 L. Ed. 1459, 34 Sup. Ct. 956), 92, 29I.

United States v. Pacific \& Arctic Ry. \& Navigation Co. (228 U. S. 87, 57 L. Ed. 742, 33 Sup. Ct. 433), 266, 392, 408, 420, 426.

United States v. Reading Co. (226 U. S. 324, 57 L. Ed. 243, 33 Sup. Ct. $90), 57$.

United States v. Trans-Missouri Freight Assn. (166 U. S. 290, 4I L. Ed. I007, 17 Sup. Ct. 540), 261, 401.

United States v. Union Stock Yards Co. (226 U. S. 286, 57 L. Ed. 226, 33 Sup. Ct. 83), 79, 85, 100, 119, 120, 195, 291, 526.

United States Express Co. v. Minnesota (223 U. S. 335, 56 L. Ed. 459, 32 Sup. Ct. 21 I), 30.

$\mathrm{V}$.

Vance v. Vandercook (170 U. S. 438, 42 L. Ed. I 10o, 18 Sup. Ct. 674), 30. Veazie v. Moor ( 14 How. 568, 14 L. Ed. 545), I3.

Victor Co. v. Atchison, Topeka \& Santa Fe Ry. Co. (I4 I. C. C. Rep. 120), 294.

Virginia Rate Case (Prentis v. Atlantic Coast Line R. R. Co.) (21I U.S. 210,53 L. Ed. 150, 29 Sup. Ct. 67), 140.

W.

Wabash, St. Louis \& Pacific Ry. Co. v. Illinois (I18 U. S. 557, 30 L. Ed. 244, 7 Sup. Ct. 4), 14, 26, 50, 72.

Washington ex rel. Oregon Railroad \& Navigation Co. v. Fairchild (224 U. S. 510,56 L. Ed. 863, 32 Sup. Ct. 535), 171 . 
(The figures refer to pages.)

Webster Coal \& Coke Co. v. Cassatt (207 U. S. 181, 52 L. Ed. 160, 28 Sup. Ct. I08), 331 .

Wells-Fargo Co. v. Neiman-Marcus Co. (227 U. S. 469, 57 L. Ed. 600, 33 Sup. Ct. 267), 95, 336, 472, 485.

Welton v. Missouri (91 U. S. 282, 23 L. Ed. 349), 28.

Western Union Telegraph Co. v. Commercial Mrilling Co. (218 U. S. 406, 54 L. Ed. 1088, 31 Sup. Ct. 59), 88.

Western Union Telegraph Co. v. Crovo (220 U. S. 364, 55 L. Ed. 498, 3I Sup. Ct. 399), 88.

Western Union Telegraph Co. v. James (I62 U. S. 650, 40 L. Ed. I105, 16 Sup. Ct. 934), I9, 74.

Western Union Telegraph Co. v. Kansas (216 U. S. I, 54 L. Ed. 355, 30 Sup. Ct. 190), 30.

West Virginia Rate Case (Norfolk \& Western Ry. Co. v. West Virginia) (decided March 8, 1915), I40, I42.

Whitcomb's Case (I 20 Mass. I 8 ), 352.

Wight $v$. United States (167 U. S. 5 12, 42 L. Ed. 258, 17 Sup. Ct. 822), I80, I8I, 183, 193, 231, 523 .

Wilcox v. Consolidated Gas Co. (212 U. S. 19, 53 L. Ed. 382, 29 Sup. Ct. I92), I37. I44. 454.

Willson r. Rock Creck R. R. Co. (7 I. C. C. Rep. 83), 96.

Wilmington Transportation Co. $v$. California Railroad Commission (236 U. S. I51), 89 .

Wilson v. United States (220 U. S. 614. 55 L. Ed. 6I0, 3I Sup. Ct. 718), 349.

Wilson v. United States (232 U. S. 563, 58 L. Ed. 728,34 Sup. Ct. 347 ), 56. Winona \& St. Peter R. R. Co. v. Blake (94 U. S. I89, 24 L. Ed. 995), 35. Wisconsin, Minnesota \& Pacific R. R. Co. v. Jacobson (179 U. S. 287, 45 L. Ed. 1194, 21 Sup. Ct. 124), 171, I72. 176.

Wood v. Vandalia R. R. Co. (23I U. S. I, 58 L. Ed. 97,34 Sup. Ct. 7 ), I37. Y.

Yazoo \& Mississippi Valley R. R. Co. v. Greenwood Grocery Co. (227 U.

S. I, 57 L. Ed. 389, 33 Sup. Ct. 213), 108.

Yturbide v. United States (22 How. 290, 16 L. Ed. 342), 152.

York Co. v. Central R. R. Co. (3 Wall. 107, 18 L. Ed. 170), 297, 476, 486, 


\section{INDEX}

(The figures refer to pages.)

A.

Accidents, reports of, to Interstate Commerce Commission, 55.

Accounting, control of system of, by Interstate Commerce Commission, 445 et seq.

Act of March 4, 1915, relating to liability of carriers for shipments lost or damaged, 460 , footnote $3 a$.

Act to Regulate Commerce, aimed to prevent discrimination and secure equality between shippers, 59, 60, 6r .

amendments to, summarized, 53, 54 .

conditions inducing enactment of, 52,53 .

foreign commerce, when included by, $88,89$.

governing provision and delivery of cars, ro6 et seq.

intended to reach ficld not covered by state statutes, 61 .

penalties for violations of, 332 et seq.

purposes of, I3I.

summary of, 53,54 .

Actions for damages, limitation of, 327.

Administrative functions of Commission, may not be invaded by the courts, $388,407,408$.

orders final unless beyond power of that body, 426 .

Advantage to one shipper not enjoyed by another is unfair and unreasonable, 213, 214 .

Advertising, exchange of transportation for, illegal, 194.

Alaska, within terms of the Act to Regulate Commerce, 83.

Allowances to shippers, control of by Commission, 392 et seq.

measure of. 393 .

stated in schedules, 298, 299.

Animals, feeding, watering and resting of, in transit, 55 .

Annual Reports of the Interstate Commerce Commission. 366 to 371, 491 .

Appendix, 53I et seq.

Attachment laws of states affecting cars of interstate carriers, 30r.

Attorney's fees, right to tax as costs, 313 et seq.

under Section 16, 423, 424 .

B.

Baggage, liability of carrier for, 296.

limitation of liability to $\$ 100$ for loss of personal, $485-86$.

checks for, as form of receipt or bill of lading, 487-88.

Basing points for determining rates subject to control of Commission, 205-06. 


\section{(The figures refer to pages.)}

Bill of lading, determining single route under Section 4, 247-48.

evidence of common control, management, etc., of shipment, 90,91 . indicating character of shipments, 74, 75, 82, 300 .

rate named in, does not supersede published rate, 277.

Boilers, inspection of, 55 .

Bridges, between states, a highway of commerce, 29. used by railroads engaged in interstate commerce, 99, 100 .

Burden of proof, in attacks on rates on complainants, 364 . on carrier to show reasonableness of advance in rates, 148-49. on shipper to show existing rates excessive, 148 .

C.

Capitalization of railroad as an element in determining reasonableness of rates, 134.143.

Car distribution, discrimination in, 218-20, 386 et seq.

Carmack Amendment, liability of carriers for loss under, 460 et seq. superseded by Act of March 4, I9I5, 460, footnote 3a.

supplanted state legislation affecting carriers' liability for loss or injury to shipments, 469 et seq.

Carrier, burden of proof rests on, to show reasonableness of advance in rates, I49, 150.

liable for acts of agents under Elkins Act, 5 ro.

liability of, for shipments under Carmack Amendment to Section 20, 460 et seq.

liability of, measured by rate charged for shipment, $475 \mathrm{et}$ seq.

liability of, to suit in foreign district, 488 .

may charge for services rendered beyond transportation, 29I et seq. need not contract to carry beyond own line, 263 to 266 .

not liable to shipper for quoting less than full rate, 282.

not permitted to discriminate in favor of self or other carriers, 220, 221.

not required to give use of tracks and terminal facilities to other carriers, $224,225$.

obligation to accept shipments tendered, I05, 106.

obligations under common law, 127.

power to determine dissimilarity of conditions under Section 4, 228 et seq.

reports and liabilities of-Section 20,440 to 490 .

required to equitably distribute cars, $218,219$.

required to state rates in reply to written request, $280-82$.

right of, to bring suit before judicial tribunals, 317 et seq.

right of, to demand switch connections, 177.

right of, to secure reasonable rates for services, I40, I4I.

Cars, all classes of, included under Act to Regulate Commerce, 103. furnishing and delivery of, governed by Act to Regulate Commerce, 106-10.

Cartage charges, control of, 397.

filed under Section 6, 289-90. 
(The figures refer to pages.)

Charges, by railroads for services, measure of, 396.

carriers may make extra charges for services rendered beyond mere

transportation, I04 et seq., 110, 29 I et seq.

equality of, purpose of Section 2, 180.

for extra services rendered by carriers may include profit, II 7 .

for services rendered in furnishing stock yard facilities, 118-20.

for terminal services, II4-15.

just alike to carriers and shippers, I79.

must be just, and reasonable, I26 et seq.

must be paid in money, 193, 194.

of carrier for services rendered beyond transportation, 104, 291 ct seq.

of railroads under common law, 59.

separately published, 123.

to be included in filed and published schedules, 288 to 30

Circumstances and conditions, dissimilarity of, must be actual and not potential under Section 4, 238, 239, 249.

traffic under substantially similar, 228 ct seq.

Classification of property, 225, 226.

must be just and reasonable, 126.

Clayton Anti-Trust Act, 57.

Commerce, between states not subject to control of states, 16, 17.

character of, determined when shipment is started in course of trans-

portation, 74 et seq.

defined, $9,10,28$.

development of, since Constitutional Convention, 7,8 .

lottery tickets subjects of, 29.

included under Act to Regulate Commerce, 84 to 88 .

insurance policies not subjects of, 29.

taxation of articles of, by states, 30, 3 I.

Commerce Clause, early construction of, in Gibbons v. Ogden, 8.

legislation passed by Congress under authority of, 57 .

powers of states and national government under, I et seq.

powers under, distinguished from police powers of states, 25, 26.

reasons for adoption of, 5 et seq.

views of framers of Constitution on, 7 .

Commerce Court, abolished by Act of October 22, I9I3, 55 .

created by Mann Act of June 18, 1910, 54.

Commissioners, appointment of Interstate Commerce, 337 to 339.

Common control, management, etc., of shipment, how evidenced, 90-91.

Commodities Clause, I6o et seq.

constitutionality of, 163-65.

feature of Hepburn Act of June 29, Ig06, I60.

interest of carrier in commodity transported, $163,166$.

purposes of, $160-63$.

relation of tap lines to, 169 .

stock ownership by railroad in mining or producing company, 166 .

Common carriers, express companies and sleeping car companies included as, $93-95$.

liability of, for damages, 304 et seq. 
(The figures refer to pages.)

Common law, obligations of common carriers under, 59, 127.

principles of, applicable to common carriers, 179, 180.

rule of, governing liability of common carrier, 475 .

suit under, to recover overcharge, I30, I3I.

Compensation, carriers must pay same, to all shippers for same services, 215 .

shippers entitled to, for lightering freight, 224.

Competing water carriers, not to be owned by railroads, 266-68.

Competition at point of shipment and at point of destination, 203.

at seaports, 204 .

determining dissimilarity of conditions under Section 4, 228 et seq.

may constitute dissimilar circumstance and condition, 183.

real and substantial and not potential under Section 4, 203, 238, 239,

249.

right of public to benefit from, $4 \mathrm{I}$.

under Section 2, 183.

Complaints, investigation by the Interstate Commerce Commission, $362-65$.

to Commission or suit in United States Court, 317 et seq.

under Sections 2 and 3, 201.

Compulsory Testimony Act of February II, I893, 345 et seq.

Conclusiveness of published rate, 277 et seq.

Confederation of the states, lack of power over commerce, 5 et seq.

Confiscation of property through unreasonable rates, 35 tt seq.

Congress, legislation of, supersedes state enactments regarding provision and delivery of cars, 106-10.

when non-action by, leaves commerce free and untrammelled, 16, 17.

without power to regulate purely intrastate traffic, 6i et seq.

Connecting carrier not liable for discrimination of primary carrier, 199, 216.

Constitutionality of the Elkins Act, 511 et seq.

Continuous carriage, 301-03.

Corporations, indictable under the Elkins Act, 54, 510.

liable for acts of agents under Elkins Act, 517,518 .

not immune from prosecution because of testimony of officials, 349 .

Correspondence of railroads not subject to examination by the Interstate

Commerce Commission, $354,355,455,456$.

Cost, railroads not limited to, for services rendered, 222.

Courts, function of, to review and not establish rates, 39.

logic of, in construing constitutional provisions, 8.

may issue decrees to redress particular wrongs only, 318.

may not primarily invade administrative functions of Commission,

323 et seq., 327 to 331 .

power of, to award damages, I3I, I32.

process of, to aid inquiries before the Commission, 350 et seq.

review of orders of the Commission, 402 et seq.

review of rate regulation by, 35 et seq.

when they will review decisions of the Commission, 368 .

will not consider wisdom of orders of the Commission, 403 et seq.

will not enter upon new investigation of facts, 405 . 
D.

Damages, claim for, cannot be liquidated by issuance of passes, 192, 193.

by carrier under Section 8 to be strictly proven, 304 et seq.

liability of common carrier for, 304 et seq.

measure of, under Section 8, 305.

to shipper resulting from improper rates, 3 I 8 et seq.

Decisions of Interstate Commerce Commission not judicially noticed, 369 .

370.

Delivery of freight, carriers must furnish adequate facilities for, tro et seq.

included under the term transportation, I03 et seq.

Demurrage charges, 222.

Depositions of witnesses, 341 .

Depreciation as a factor in determining reasonableness of rates, 146, 147 .

Discrimination, bona fide exaction of demurrage charges is not, 222.

by preferences in through routing, 222, 223 .

by tap lines, 197,198 .

in furnishing cars, $106-10,218-20$.

in interstate rates produced by intrastate rates, 138, 206-09.

in intrastate rates subject to state control, 210,211 .

in transit charges and privileges, 222.

in wharfage rights and facilities, $216,217$.

lighterage allowances do not constitute, 224.

not permitted in favor of railroads, 220, $22 \mathrm{I}$.

not warranted by competition, 183 .

of primary carrier, connecting carrier not liable for, 199.

permitted by certain natural or artificial differences, $2 \mathbf{1}, \mathbf{2} \mathbf{2}$.

produced by intrastate rates in connection with interstate rates, 67 ct seq.

produced through classification of property, 225, 226.

produced under Section 4 by lesser charge to more distant point, 240

to 243 .

purpose of Act to Regulate Commerce to destroy, 53.

resulting from issuance of passes, I5I, I53.

states may prohibit, in intrastate commerce, 135, 136.

unjust, forbidden, i 78 et seq.

what may constitute, 192 to 199.

when not unjust, 203.

within control of carriers, 202.

Dissimilarity of circumstances and conditions under Section 4 must be actual and not potential, 238, 239, 249.

Distribution of cars, control of, by Interstate Commerce Commission, 327.

Dividends, rights of stockholders to, I4I.

Division of earnings forbidden, 260 et seq.

Due process of law, railroads may not be deprived of property without, 47 . what constitutes, 36 et seq.

E.

Earnings, division of, forbidden, 260 et seq. 
(The figures refer to pages.)

Eighteenth section-Salaries of Commissioners and expenses of commission, 430, 431 .

Eighth section-Liability of common carriers for damages, 304 to 316.

Elevation of grain, allowances for, 121-23, 392.

discriminations in, 214, 215.

Elevator allowances, control of, 397.

Eleventh section-Method of appointment and terms of members of the Interstate Commerce Commission, 337 to 339.

Elkins Act, 53, 54, 180, 505 to 530 .

amendatory of Section 6 of Act to Regulate Commerce, 275.

constitutionality of, 5 II et seq.

corporations liable for acts of agents under, 510.

effect of Hepburn Act on prosecutions under, 528, 529.

imprisonment under, 510 .

lack of intent to rebate not a defense, 519,520 .

offense of rebating, when complete and of what it consists, 521 et seq.

penalty of imprisonment under, 335 .

provisions of, regarding immunity to witnesses, 349 .

rebates, what may constitute, 522 et seq.

standard of comparison under, 180 , 181 .

sufficiency of indictment for violation of, 526 to 528 .

Employees of railroads, defined, 150 .

may be granted passes, I49, 150.

Employers' Liability Act, 56.

English Act to Regulate Railways, basis of Act to Regulate Commerce, 60.

Section 3 of Act to Regulate Commerce based on, 200, 201.

English Railway Clauses Consolidation Act, 178.

Equal treatment of shippers, purpose of Act to Regulate Commerce, 59 to $6 \mathrm{I}$.

Equity jurisdiction over rates, 325, 326.

under Act to Regulate Commerce, 316.

Estoppel, governing recovery for loss of shipments, 476 .

Expediting shipments, charges for, 294, 295.

Expenses of Interstate Commerce Commission, 43r.

Expenses of railroads, an element in determining reasonableness of rates,

144.

Express companies, as common carriers under Act to Regulate Commerce, 335.

included under Act to Regulate Commerce, 93 to 95.

unlawful for, to issue franks, 154 .

F.

Facilities for receiving and discharging property, carriers must furnish, without extra charges, 104 et seq.

False billing, penalties for, 333 .

False weighing, penalties for, 333 .

Families of railroad employees, defined, 150, 151 .

may be given passes, 150.

Favoritism, destruction of, aim of Act to Regulate Commerce, 59-6r. 
Federal control of intrastate rates, 138, 206 to 209.

Federal Trade Commission Act, 57.

Fees of witnesses and magistrates, 342.

Ferries under Act to Regulate Commerce, 98.

Fifteenth section-Control of rates by the Commission, 372 to 409.

Fifth section-Pooling of freight and division of earnings, forbidden, 260 to 269 .

Filing, printing and posting of rates, 269 to 300 .

Findings of Commission, when prima facie evidence, 366 et seq.

First section, 58 to 177 .

Foreign and domestic commerce, determining similar circumstances and conditions, under Section 4, 234 to 238 .

Foreign commerce, efforts to regulate under confederation, 6.

shipped on local bills of lading, 74, 75 .

Foreign countries, commerce shipped to and from, $88,89$.

Foreign district, liability of carrier to suit in, 488 .

Forms of pleadings before Interstate Commerce Commission, 543 to 545 .

Forwarding agents, rates to, 190, I9I.

Fourteenth section-Annual reports of Interstate Commerce Commission, 366 to $37 \mathrm{r}$.

Fourth section-The Long and Short Haul Clause, 227 to 259.

amendment of June $18,1910,250$ ct seq.

distinguished from other sections, 201, 202.

distinguished from Section 2, 229 to $233,249,250$.

limited to transportation enly, $245,246$.

re-shipping privileges under, 256 to 258 .

water competition clause of, 259.

Franchise values as element in determining rates, 46.

Franks for free carriage of packages by express companies, 498-99.

Free delivery zones, 393 .

Free transportation prohibited, 149 et seq.

Freight, receipt and delivery of, included in transportation, 103 et seq.

Freight, pooling of, forbidden, 260 et seq.

G.

Gas, pipe lines for carrying, not within terms of Act to Regulate Commerce, 91,92 .

Gibbons v. Ogden, earliest construction of Commerce Clause in, 8.

Grain, elevation of, allowances for, 121 to 123 .

discriminations in, 214,215 .

Granger Cases, 32 et seq.

Granger Movement, 31 et seq., 50, 128.

Greater charge for shorter than for longer haul, 228 et seq.

Gross receipts of roads, a factor in determining reasonableness of rates, I44, 145 .

H.

Hamilton, Alexander, views of, concerning Commerce Clause, 7.

Hay, reconsignment of, I22, 123. 
(The figures refer to pages.)

Health laws, legal as exercise of police power, ro.

Hearings of Interstate Commerce Commission, where held, 432.

Hepburn Act of June 29, 1906, 130.

amending Section $15,377,378$.

Commodity Clause a feature of, 160.

effest of, on prosecutions under Elkins Act, 528, 529.

forbidding giving passes, I5I.

places express companies and sleeping car companies under provisions

of Act to Regulate Commerce, 94, 95.

prohibits acceptance of freight in absence of filed rates therefor, 287 , 288.

provisions of, 54 .

provision and delivery of cars under, I06 to I 10.

reparation orders under, $4 \mathrm{I} 4$.

Hours of Service Act, 55 .

I.

Icing of shipments, facilities for, 123 to 126.

Import Rate Case, 237-38.

Improvements, necessity for, a factor in determining reasonableness of rates, 146,147 .

Increased rates, burden on carrier to show reasonableness of, 378 .

Incriminating testimony, 342 et seq.

constitutional provision regarding, refers only to natural person, 347 , 348 .

Indictment, sufficiency of, for violation of Elkins Act, 526-28.

Initial carrier, agreement for routing by, 262-64.

Injunction based on violations of Act to Regulate Commerce, 409.

Inspection laws as an exercise of police power of states, $r o$.

Insurance policies not articles of commerce, 29.

Interest on investment, right of railroads to earn, 4I, 42.

Interstate Commerce, bridge across river between states a highway of, 29 .

bridges used by railroads engaged in, $99,100$.

defined, 28,85 to 87 .

development of, 57 .

distinguished from intrastate commerce, $5 \mathrm{I}, 65,66,76$ et seq., 85 to 88 .

evidenced by bills of lading, 90,91 .

extent and limitations of, 9, I0.

ferries as instruments of, 98 .

goods shipped between points within a state destined to a foreign country, 74,75 .

importance of, 57 .

indirectly affected by police regulations, 20, 2 r.

must not be interfered with by intrastate regulations, 49 to $52,134,135$.

objects of, not liable to exercise of police powers, 25, 26.

segregation of races by state legislation, 26 .

state can not tax, but may tax instruments of, 17 .

street railways as instruments of, 95, 96 .

switches, tracks and terminals used in, I00, 101 . 
taxation of articles of, by states illegal, 30, 31 .

telegraph messages as, 88.

Interstate Commerce Commission, a body corporate and may sue and be sued, 425.

annual reports of, 366 to 371,491 .

anomalous functions of, 56 .

cannot arbitrarily change rates without evidence of their unreasonableness, 384,385 .

cannot subject correspondence of railroads to examination, 354, 355. charged with determining competitive conditions under Section 4 by

Amendment of June 18, 1910, 250 et seq.

complaints to, 362 to 365 .

control of allowances and charges to shippers, 392 to 397 .

control of rates by, 372 et seq.

control of system of accounting of carriers, 445 et seg.

control of through routes, 389,407 .

courts may not primarily invade administrative functions of, 323,327

to 331 .

decision by, as preliminary to suit for damages based on violation of law, 308 et seg.

decisions of, must be offered in evidence, 369,370 .

decisions of, when reviewed by courts, 368 .

duty of, in determining reasonableness of rates, I45, 146.

finality of orders of, 426,427 .

findings of, when prima facie evidence, 366 et seg.

forms of pleadings before, 543 to 545 .

jurisdiction of, in reparation actions, 419 et seq.

jurisdiction over rail and water traffic, 273.

jurisdiction over stock yards, 120 .

jurisdiction over terminal facilities, I14, II5.

may designate regulations a ecting rates and charges, 288 et seq.

may order switch connections, I70 et seq.

necessity for preliminary ruling on rates as a condition to suit for

damages, 318 et seq.

orders of-Section 16,410 to 427 .

power of, in regulation of rates, 397 et seq.

power of review under Section 4, 228, 250.

power over wharves owned by common carrier, $216,217$.

power to compel witnesses to answer questions and produce books

limited to complaints of violations of the Act, 356 et seq.

power to conduct investigations, 340 to $36 \mathrm{I}$.

power to determine competition between railroads and water carriers, $267,268$.

power to consider classification of property, $225,226$.

power to determine existence of dissimilarity of conditions under Sec-

tion 4,228 et seg.

power to determine reasonableness of rates, I30, I31.

power to examine papers of railroad companies, 455,456 . 
(The figures refer to pages.)

power to fix rates, 127 et seq.

power to modify regulations of Section 6,300 .

power to permit railroads to charge larger rate for shorter haul under

Section 4, 250 et seq.

power to prescribe rates before Hepburn Act, 378 et seq.

power to prescribe rates under Hepburn Act, 383 et seq.

power to regulate distribution of cars, 218 to 220.

power to reject any schedules which do not give lawful notice of ef-

fective date, 276 .

procedure in presentation of case before, 425 .

reparation orders made by, 414 et seq.

reports of, how published, 37I.

review of orders of, by courts, 402 et seq.

right to secure writs of mandamus to compel reports of carriers

under Section 20, 457 et seq.

rules of practise before, 533 et seq.

two year limitation upon orders of, 400,401 .

vested with power to prescribe manner in which schedules are to be kept, 285 to 287 .

Interstate Commerce Commissioners, appointment of, 337 to 339 .

Interstate rates, difficulty of determining reasonableness of, 139 et seq.

railroads cannot be forced to make up losses from intrastate rates

through high charges in, 44 .

Interurban street railway traffic, 95,96 .

Intrastate commerce, Congress without power to regulate, 6I et seq.

control of by Commerce Act expressly excluded by proviso of Section

I, 6I et seq., 84,85 .

controlled by the states, 49 to 51 , 6I to 72 .

evidenced by bills of lading, 90,91 .

goods shipped within a state but intended for foreign country do not

constitute, 74, 75 .

not within terms of Act to Regulate Commerce, 84, 85 .

power of states over, exclusive, 12 et seq.

reasonableness of rates for, 133 et seq.

Intrastate discriminations subject to state regulation, 210, 2II.

Intrastate portion of interstate traffic, states may not control, 50 to 52.

Intrastate rates, federal control of, I38, 206 to 209.

must be reasonable without regard to returns from interstate traffic,

44.

when subject to control of Interstate Commerce Commission, 67 to 71 .

Intrastate traffic, as portion of interstate traffic under Act to Regulate

Commerce, 248, 249.

Interstate Commerce Commission may regulate accounts of carriers

regarding, 447 et seq.

must be within single trip throughout entire trip, 7I, 72.

smaller charge for longer haul in, 258, 259.

Investigations, discretion of Commission in manner of conducting, 362 .

power of Commission to conduct, 340 to $36 \mathrm{I}$.

of rates by Interstate Commerce Commission, 378 . 
$\mathrm{J}$.

Joint tariff, determining single route under Section 4, 247, 248.

Joint through rates, action for rebating against carriers participating in, $518,519$.

with competing connecting carriers, 262.

Judicial functions of Interstate Commerce Commission, I29.

Judicial review, or orders of the Interstate Commerce Commission, 422.

of orders of Interstate Commerce Commission regulating distribution of cars, $219,220$.

of rates, $145,146$.

of rate regulation, evolution of position of Supreme Court on, 37 to 39. 49 .

Jurisdiction, in reparation actions, 419 ct seq.

of federal courts to issue writs of mandamus, 50 I to 504.

L.

Lateral allowances, 393, 394.

Lateral branch line, defined, 174,175 .

Legality of orders of the Interstate Commerce Commission determined by the courts, 402 et seq.

Legislative function of Commission in determining rates, 46, 47, 129, I 40 .

Legislative power to fix rates subject to judicial review, 37 to 39 .

Legislature, action of, at first considered due process of law, 33 .

Liability of common carrier, for damages, $304 \mathrm{ct}$ seq.

for injury on pass accepted as a gratuity, I 58 .

for loss under Carmack Amendment to Section 20, 460 et seq.

for shipments, state regulation superseded by Carmack Amendment, 469 et seq.

to shipper exists only for some specific pecuniary injury, 308, 309 .

Lighterage allowances, 224, 393, 397.

Like and contemporaneous services, 179.

Limitation of time for bringing action for loss or damage to shipments, 473,474 .

Liquors, interstate transportation of, 30 .

Live stock and dressed meats, different rates for transportation of, 2 I 7 .

Local and through traffic, I8I to I83.

Local rates compared with through rates, $147,148$.

L.ocalitics, preferences to, 202 to 204.

Long and short haul clause, 227 to 259.

Long and short haul, rates, 183 .

state legislation on, $258,259$.

Lottery tickets, subject of commerce, 29.

M.

Mandamus, jurisdiction of federal courts to issue writs of, 501 to 504 . writs of, for enforcement of reports by railroads under Section 20,

457 ct seq.

Mann Act of June I8, I910, provisions of, 54,55 . 
(The figures refer to pages.)

Manufactured and unmanufactured articles, rates on, 217.

Market competition under Section 4, 243 to 245, 250.

Minnesota rate cases, 45 to 49,73 .

Misrepresentation of value of shipment affecting recovery for loss, 336, 484.

Misstatement of rates by carrier, penalty for, 28I, 282.

Money, charges must be paid in, 193, 194.

N.

Natural or artificial differences permitting discriminations, $21 \mathrm{I}, 212$.

Nineteenth section-Principal office of Interstate Commerce Commission and place of holding hearings, 432.

Nineteen a section-Physical valuation of property of common carriers, 433 to 439 .

Ninth section-Choice of complaint to Commission or suit in United States Court, 317 to 33 I.

O.

Office of the Interstate Commerce Commission, 432.

Oil pipe lines, proprietors of, required to file tariffs of changes, $29 \mathrm{I}$. under Act to Regulate Commerce, 9I to 93 .

Orders of the Interstate Commerce Commission-Section 16, 4 to to 427. courts will not consider wisdom of, 403 et seq.

finality of , 426,427 .

two year limitation upon, $400,401$.

when subject to court review, 422 .

Overcharge, suit to recover, under common law, I30, I3I.

Ownership of goods, not a basis for rate discrimination, 190, I9I.

\section{P.}

Panama Canal, rail carriers having arrangements with water carriers through, 274 to 276 .

violators of Sherman Act not permitted to utilize, 268.

Papers of railroads, production of, under Section 9, 33I.

right of Interstate Commerce Commission to examine, 455,456 .

Party rates, 184 to 188.

Penalties for misstatement of rates by carrier, 28I, 282.

for violations of Act to Regulate Commerce, 332 to 336 .

Persons and property, when carried free or at reduced rates-Section 22, 492 et seq.

Physical connection between rail lines and docks of water carriers under Act to Regulate Commeree, 273, 274.

Physical valuation of property of common carriers-Section 19a, 433 to 439.

Pipe lines under Act to Regulate Commerce, 9I to 93.

Pleadings before Interstate Commerce Commission, forms of, 543 to 545 .

Passes, acceptance of, does not deprive passenger of right to care and protection, 157 .

contract for, as a rebate, $\mathbf{5 2 5}$.

illegal, even when issued in liquidation of damages, 152, 192, 193. 
(The figures refer to pages.)

interchange of, when authorized, 150, 492 et seq.

issuance of, made unlawful by Hepburn Act, 15I.

issued as gratuity may exempt railroad from liability for injury, 158. legal only for classes enumerated in Act to Regulate Commerce, 153. 155.

may be issued by railroads to own employees or employees of contractors engaged in building extensions, I58, I59.

prohibited except to certain classes, I49 et seq.

when allowed, 492 et seq.

unlaw ful though issued to liquidate claims, 152, 192, 193.

unlawful when issued in payment for advertising or other services, I $55,156$.

Police power, Congress does not have power to interfere with, when relating to intrastate traffic, 14 and 15 .

defined, iz et seq.

distinguished from control over interstate commerce, to et seq., 73.

distinguished from power under Commerce Clause, 25, 26.

governing stops of railroad trains, 21 to 23.

illustrations of state legislation under, 19 et seq.

indirectly affecting interstate commerce, $2 \mathbf{1}$.

state legislation valid under, when only indirectly affecting interstate commerce, 73 .

subordinate to action of Congress only when directly interfering with interstate commerce, 17 et seq.

what are not proper subjects of regulation under, 25, 26.

Pooling of freights forbidden, 260 ct seq.

Port warden's case, decision in, Io, II.

Posting, printing and filing of rates, 269 to 300 .

Posting of rates, in railroad stations, 282 to 285 .

not a condition precedent to making them legally operative, 282 to 284 .

Practise and procedure-Section 17, 429.

Practise before Interstate Commerce Commission, Rules of, 533 et seq.

Preferences, produced under Section 4 by lesser charge to more distant point, $240,241$.

to localities, 202 to 204 .

when not undue, 203

Pre-icing charges, control of, 397.

Presumption of reasonableness of rates, I48, 149.

Primary carrier, liable for loss or injury to shipments by connecting carriers, 460 et seq.

Printing, posting and filing of rates, 269 to 300 .

Procedure of Commission, 364, 365, 425.

Property, classification of, 225, 226.

value of, as basis for determining rates, I4I, 142 .

Proviso of Section 1, amended June 18, 1910, 64, 65.

relation to federal control of intrastate rates, 207 .

Publication of rates, attributes of, 282.

Published rate, conclusiveness of, 277 et seq.

shipper and carrier both bound to take notice of, 278, 279.

Purposes of Act to Regulate Commerce, 59 to 61 . 
INDEX.

(The figures refer to pages.)

$Q$.

Quarantine laws of states legal as exercise of police power, Io.

R.

Races, segregation of, by state legislation in interstate commerce illegal, 26.

Railroads, carriers may not discriminate in favor of their shipments, 220, 221.

defined by Act to Regulate Commerce, 93, 97, 98 .

early efforts to regulate, 3 I et seq.

elements in determining reasonableness of rates of, 46 to 48 .

entitled to fair return from intrastate business without regard to interstate business, 44 .

forbidden to own competing water carriers, 266 to 268.

may charge for extra services rendered outside of mere transportatiun, Iro et seq., $395 \mathrm{et}$ seq.

measure of charges for extra services, 396 .

not to be deprived of property without due process of law, 47 .

physical valuation of, under Act of March 1, I913, 55.

right of, to earn interest on investment, $4 I, 42$.

valuation of property in determining reasonableness of rates, 46,47 .

what constitutes value of, in determining reasonableness of rates, $42,43$.

Randolph, Edmund, views of, concerning Commerce Clause, 7 .

Rate making a legislative function, 46,47 .

Rates, based on ownership of goods, 190, I9I.

both interstate and intrastate must permit return on investment, 4.

carrier required to state, in response to written request, 280 to 282.

changes in. can be ordered by Interstate Commerce Commission only after investigation. 38 f et seq.

charged for shipment, measure of carrier's liability, 475 et seq.

conclusiveness of, when published, 277 et seq.

constitutional as to one road and unconstitutional as to another road,

45.

control of, by Interstate Commerce Commission, 372 et seq.

courts may review but not fix, iqo.

depreciation of property a factor in determining, $146,147$.

determination of, by zones, 399.

different for shipments in different kinds of receptacles, I89, 190.

difficulty in determining reasonableness of, I36, I37, I39 et seq.

elements in determining reasonableness of, 46 to 48 , I 33 et seq.

equity jurisdiction affecting, 325.326 .

establishment of, evidenced by filing of schedule with Interstate Com-

merce Commission, 283, 284 .

factors to be considered in determining legality of, 40 .

filed and published, binding on carrier and shipper, 478 et seq.

for future need not be determined by Commission before issuing reparation order, 4 I 4 et seq. 
for special services, 189,190 .

in absence of filed and published, carrier may not transport property, 285 to 288.

investigation of, by Interstate Commerce Commission, 378 .

judicial review of, 35 et seq.

legality of, determined by published tariffs, 5 Io.

may not be changed by Commission if proper, 397 et seq.

must be reasonable both for company and public, 37 .

must be remunerative despite competitive conditions, 204 .

necessity for improvements a factor in determining reasonableness of, 146,147 .

on manufactured and unmanufactured articles, 217.

penalty for misstatement of, $281,282$.

posting of, in railroad stations, 282 to 285 .

posting of, not condition precedent to making them legally effective, 282 to 284 .

power of Interstate Commerce Commission to prescribe, before Hepburn Act, 378 et scq.

power of Commission to prescribe under Hepburn Act, 383 et seq. preferences and discriminations in, produced under Section 4 by lesser charge to more distant point, 240 to 243.

preliminary ruling by Commission on, before right of judicial action

for damages, 318 et seq.

presumption of fairness of, 398, 399 .

presumption of validity of, 136 .

printing, posting and filing of, 269 to 300 .

publication and posting of, distinct functions, $282,283$.

publication of, how determined, 282.

reasonableness of, 129.

reasonableness of, for intrastate traffic, i33 et seq.

reasonableness of, how determined, 45 to 48 .

reasonableness of, subject to court review, 35 et seq.

reduced to certain classes of people, 492 et seq.

regulation of, by Interstate Commerce Commission, 397, et seq.

shipper conclusively presumed to know, 282 .

standard of, under Section 2, and the Elkins Act, I80, I8I.

thirty days' notice of change in, 270 .

through or local, evidencing character of shipment, 90,91 .

where through rates do not exist carriers required to file separate rates, 286,287 .

Reasonable compensation only to be paid by carriers for services rendered, $214,215$.

Reasonable rate may yet be unlawful, 2 II to 214 .

Reasonableness of rates, 129, 139 et seq.

a relative question, 201 .

at first determined by legislatures, 32 et seq.

courts may determine, 140.

depreciation a faction in determining, I46, 147.

difficulty of determining, 136,137 . 
(The figures refer to pager.)

factors in determining, 133 et seq.

for intrastate traffic, 133 .

presumption of, $148,149$.

questions determining, 45 to 48 .

subject to court review, 35 et seq.

Rebates, forbidden by Act to Regulate Commerce, 53.

lack of intent to pay, not a defense, 519, 520 .

measure of damages for, under Section 8,305 et seq.

not legalized by competition, 183 .

payments in good faith for services rendered are not, 215.

shipper and carrier both liable to penalty for, 510 .

under Elkins Act, 505, et seq.

what may constitute, 522 et seq.

Receipt of freight, carriers must furnish adequate facilities for, 110 et seq. included under term transportation, 103 et seq.

Receptacles, freight charges for, 212.

Refrigeration charges, 123 to 126.

must be filed with the Interstate Commerce Commission, 297, 298.

Regulation of rates, powers of Interstate Commerce Commission, 397 et seq.

Regulations must be just and reasonable, 126 .

Rehearings by the Commission-Section 16a, 428 .

Reparation actions, jurisdiction in, 419 et seq.

require primary investigation by the Commsision, 408 .

Reparation order, by Commission, 364, 365.

may be combined with order for different rate, 400,408 .

not necessarily dependent on fixing of new rate for the future, $4 \mathrm{IA}$

et seq.

Reports of the Interstate Commerce Commission, 491.

how published, $37 \mathrm{I}$.

need state only findings of ultimate facts, 370 .

Reports and liabilities of carriers-Section 20,440 to 490 .

Reports of railroads, writs of mandamus for enforcement of, 457 et seq.

Reproduction of railroad, cost of, in determining reasonableness of rates, $47,143$.

Reshipping privileges under long and short haul clause, 256 to 258.

Review of decisions of the Interstate Commerce Commission by the courts, 368 .

Review of orders of the Commission by the courts, 402 et seq.

Rules of evidence in hearings on complaints, 365 .

Rules of practice before Interstate Commerce Commission, 533 et seq.

S.

Safety Appliance Law, 55 .

Salaries of Commissioners and expenses of Commission, 338, 430, 431 .

Same line or route, 247 to 249 .

Scalpers, duty of railroads to prevent sale of round trip tickets by, 496 , 497. 
Schedules, charges to be included in, 288 to 300 .

must set forth allowances to shippers for services, $298,299$.

printing, posting and filing of, 269 to 300 .

Second section, I78 to 199 .

discriminations under, 192 to 199.

distinguished from Section 3, I78, 179.

distinguished from Section 4, 229 to 233, 249, 250.

purpose of, $180,193,231$ to $233,250$.

reinforced by Elkins Act, I80, 181 .

standard of comparison under, $180, \mathbf{r} 8 \mathbf{r}$.

Seventeenth section-Practise and procedure, 429.

Seventh section-Continuous carriage, 301 to 303 .

Sherman Act, violators of, not to enter Panama Canal, 268.

Sherman Anti-Trust Act, 57.

Shipments, character of, not altered by transfer of title during transportation, $80,8 \mathrm{r}$.

within state, when part of interstate commerce, 76 to 79,82 .

Shippers, allowances to, controlled by the Commission, 392 et seq.

allowances to, only for services which carrier can be required to perform, 393 .

bound to take notice of published rate, 278, 279 .

discriminations between, in wharfage facilities, $216,217$.

liable with carrier for rebates, 510.

may be charged for services outside of mere transportation, 395 et seq. measure of allowances to, 393 .

must show injury before recovering under Section 8, 304 et seq.

right to bring suit under reparation order, 419 et seq.

right to demand switch connections, 176.

right to enjoy reasonable rates, I40, 141 .

right to recover attorney's fee in suit on award of the Commission, 423,424 .

suits against, before judicial tribunals, 3 I7 et seq.

suit based on improper charges by carrier, 3 I 8 et seq.

Shreveport case, 68 to 7 I, 208, 209.

Similar circumstances and conditions, I79, $18 \mathrm{I}$.

clause omitted from Section 4 by amendment of June 18, I910, 250, 25 I.

ocean competition a factor in determining, 234 to 238 .

under Section 2 and Section 4, 229 to 233, 249, 250.

Sixteenth section-Orders of the Commission, 4 Io to 427.

Sixteen a section-Rehearings by the Commission, 428 .

Sixth section-Printing, posting and filing of rates and schedules, 269 to 300.

contracts to pay for advertising or settle claims by transportation at less than published rates illegal, 279.

Sleeping car companies included under Act to Regulate Commerce, 93.

State legislation on carrier's liability superseded by Carmack Amendment, 469 et seq.

on long and short hauls, 258, 259.

regarding recovery of costs in suits for loss of shipments valid under

Carmack Amendment, 472, 473. 
(The figures refer to pages.)

States, can impose no restrictions upon commerce between states, 16,17 , I72, 173.

commerce in those, formerly territories, 83,84 .

intrastate traffic controlled by, 6I et seq., 72 .

may not impose burdens on interstate commerce, 172, 173.

may not legislate where non-action of Congress indicates intention to

leave subject free and untrammelled, I6, I7.

may possess concurrent jurisdiction with Congress in certain cases,

I5, 16.

police power of, ro et seq., 73 .

power of, exclusive over purely intrastate trade, 12 et seq.

power to regulate intrastate rates, I33 et seq.

power to regulate vessels in port, 20 .

power of, under Commerce Clause, i2 et seq.

State regulations, governing interchange of traffic, 225.

governing provision and delivery of cars superseded by Hepburn Act,

I06 to I Io.

of intrastate rates and charges, 209 to $2 \mathrm{I}$.

State statutes preventing discriminations prior to Act of February 4, I887, 60.

Stock ownership by railroads in producing companies under Commodities

Clause, $166,167$.

Stock yards, and facilities for handling live stock, I lo et seq.

companies engaged in interstate commerce, 120.

terminal service charges, II 8 to I 20.

when required to file tariffs with Interstate Commerce Commission,

290, 291.

Storage, carriers may make extra charges for, 105, 106.

charges for, to be stated separately under Section 6, 288 et seq.

Street railways, interurban, under Act to Regulate Commerce, 95, 96.

Stourbridge Lion, first locomotive in United States, 7.

Substantially similar circumstances and conditions, traffic under, 228

et seq.

Suits, for failure to deliver goods not based on violation of the Act to

Regulate Commerce, 33 r.

in foreign district, liability of carrier to, 488 .

in United States courts or complaint to Commission, 317 et seq.

Supplies, transportation by railroad of its own, or those of its contractors

at reduced rates, not a discrimination, 196, 197.

Switches under the Act to Regulate Commerce, I00, Ior.

Switching charges, control of, 397.

when proper, 395.

Switch connections, r7o et seq.

Interstate Commerce Commission may order, I70 et seq.

power of states to control, I 7 I to 173 .

power to order, strictly construed, I74.

right of carriers to demand, 177.

right of shippers to demand, 176 .

with lateral branch lines, 174,175 .

38 
Tap lines, $169,197,198$. allowances to, 394 .

Tariff laws, Act to Regulate Commerce not adopted to reinforce, 204.

Tariffs, purpose of filing, 291.

who must file, under Section 6, 290, 291.

Taxation, by states of property of those engaged in interstate commerce,

30,31 .

of interstate commerce by states illegal, 17,26 .

of privilege of conducting interstate commerce by states illegal, 30, 31 .

Telegraph messages as interstate commerce, 88.

Tenth section-Penalties for violations of the act, 332, 336 .

Terminal charges, I 14, I 15.

distinguished from transportation charges, IIo et seq.

must be reasonable, II 8 to 120 .

to be stated separately under Section 6, 288 ct seq.

Terminal facilities used in interstate commerce, IOO, IOI.

Terminals, state regulations governing, 225.

Territories, commerce in states formerly, 83,84 .

Testimony incriminating witness, 342 ct scq.

of witnesses under Section 9, 33I.

relevancy of testimony of witness in inquiries, 353, 354 .

Third section, complaints under, $20 \mathrm{I}$.

distinguished from Sections I and 2, 201.

distinguished from Section 4, 202, 203.

forbidding undue or unreasonable preference or advantage, 200 to 226 .

Thirteenth section-Complaints to the Commission, 362 to 365 .

Through and local traffic, $18 \mathrm{I}$ to $\mathrm{r} 83$.

Through rate, adoption of, does not make connecting carrier liable for discrimination of initial carrier, 216.

compared with local rates, 147,148 .

must be posted, 300 .

where none exists carriers required to file separate rates, $286,287$.

with competing connecting carriers, 262.

Through rates, control of, by the Interstate Commerce Commission, 389 et seq., 407 .

how evidenced, 300 .

preferences in, 222, 223.

Timber and its manufactured products excepted from Commodities Clause, 160 et seq., 169.

Track and terminal facilities, use of, 224, 225 .

Tracks used in interstate commerce, I00, IoI.

Trade centers, railroads may not complain of rates as affecting, 206.

Traffic, unlawful to prevent continuity of, 301 to 303 .

Trains, state legislation regulating stops of, 2 I to 23.

Transit charges and privileges must be extended to all on equal terms, 222 .

Trans-Missouri Freight Association Case, 260, $26 \mathrm{I}$.

Transportation, defined by Act to Regulate Commerce, Io2 et seq.

dissociated from production under Commodities Clause, I6o et seq. 
(The figures refer to pages.)

divorce of, from production purpose of Commodities Clause, I60.

includes receipt and delivery of freight, 103 et seq.

what included by term, 93 .

when begun and when ended, 103 et seq., 289.

Twelfth section-Powers of Interstate Commerce Commission to Conduct Investigations, 340 to $36 \mathrm{r}$.

Twentieth section-Reports and liabilities of carriers, 440 to 490.

Twenty-first section-Annual reports of the Interstate Commerce Commission, $49 \mathrm{r}$.

Twenty-fourth section-Qualifications and personnel of Interstate Commerce Commissioners, 338.

Twenty-third section-Jurisdiction of Federal courts to issue writs of mandamus, 501 to 504 .

Twenty-second section-Persons and property carried free or at reduced rates, 492 et seq.

U.

Undue discrimination, different charge for shipments of manufactured articles than for raw product, is not, 217 .

Undue or unreasonable preference or advantage forbidden, 200 to 226.

Undue preferences created by rates, 21 I.

V.

Validity of rates, presumption regarding, 136.

Valuation of shipments, differences in rates based on, 295, 296, 475 et seq. Value of railroads, what constitutes, in determining reasonableness of rates, $42,43$.

Violations of Act to Regulate Commerce, penalties for, 332 to 336 .

Violations of law, suit for damages based on, 308 et seq.

W.

Water carriers, commerce carried partly by, and partly by railroads under Act to Regulate Commerce, 84,89 .

commerce carried solely by, not within terms of act, 84,89 . competing, not to be owned by railroads, 266 to 268 .

Water competition under Section 4, 259.

Watered stock in determining reasonableness of rates, 46.

Wharfage rights, control of, 397.

White Slave Act, 56 .

Wholesale and retail freight rates, 186, 187.

Witnesses need not give self-incriminating testimony, 342 et seq. under Act to Regulate Commerce, immune from prosecution, 53, 342 et seq. 






TAW TIBRARY

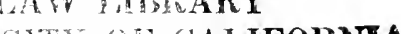


AA $000770114 \quad 7$ 
